UNIVERSIDADE DE SÃO PAULO

ESCOLA DE COMUNICAÇÕES E ARTES

MARGARIDA MARIA ADAMATTI

A crítica cinematográfica e o star system nas revistas de fãs: A Cena Muda e Cinelândia (1952 - 1955) 


\section{A crítica cinematográfica e o star system nas revistas de fãs: A Cena Muda e Cinelândia (1952 - 1955)}

Dissertação apresentada ao Programa de Pós-Graduação em Ciência da Comunicação, Área de Concentração Estudo dos Meios e da Produção Mediática, Linha de Pesquisa Comunicação Impressa e Audiovisual, da Escola de Comunicações e Artes da Universidade de São Paulo, como exigência parcial para obtenção do Título de Mestre em Ciência da Comunicação, sob a orientação do Prof. Dr. Eduardo Victorio Morettin. 
Adamatti, Margarida Maria

A crítica cinematográfica e o star system nas revistas de fãs: A Cena Muda e Cinelândia (1952-1955) / Margarida Maria Adamatti. -- São Paulo : M. M. Adamatti, 2008

327 p. : il.

Dissertação (Mestrado) Programa de Pós Graduação em Ciência da Comunicação. Área de Concentração: Estudo dos Meios e da Produção Mediática Escola de Comunicações e Artes da Universidade de São Paulo.

Orientador: Prof. Dr. Eduardo Victorio Morettin.

1. História do Cinema Brasileiro 2. Crítica Cinematográfica 3. Star System. I. Título. 


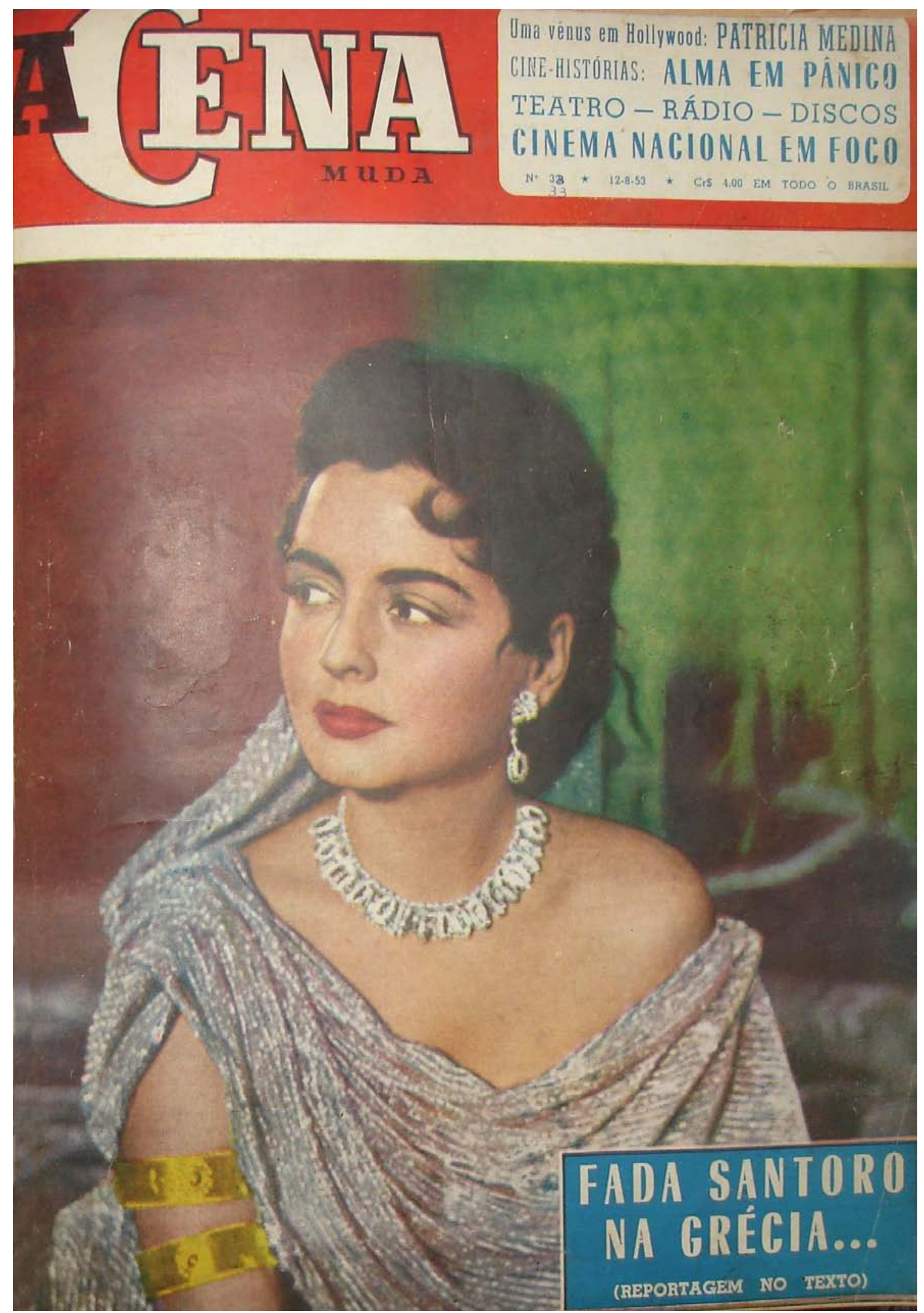




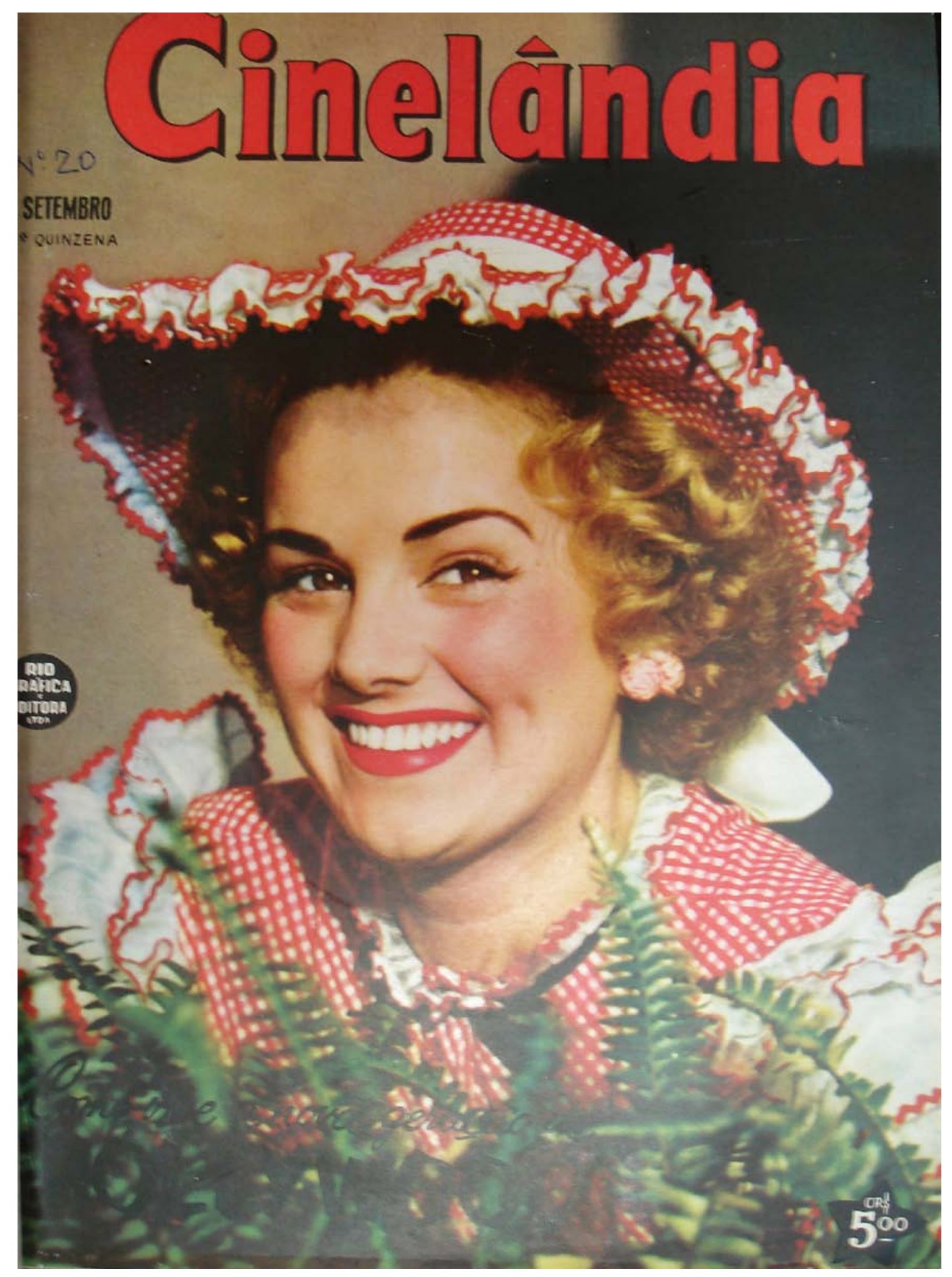


Ao Fábio Raddi Uchôa e aos meus pais 


\section{Agradecimentos}

Agradeço especialmente ao Prof. Dr. Eduardo Victorio Morettin pela orientação zelosa, atenção e pela dedicação constante nestes três anos. Pelos comentários precisos, pela paciência de ler e reler meus textos, pontuando todas as alterações necessárias, pelo saber transmitido nas aulas e pelas reuniões imprescindíveis que tornaram este trabalho possível.

À Capes pela concessão da bolsa de mestrado e pelo apoio financeiro para a realização desta pesquisa.

Ao Fábio Raddi Uchôa pela compreensão, paciência e inúmeras trocas de idéias, dicas e referências. Pela presença, segurança e calma transmitida em todos os momentos.

Aos meus pais, Maria Aparecida e Gentil, pelo apoio irrestrito e indispensável em todas as horas. Sem todo estímulo e incentivo, o trabalho não seria possível.

Agradeço ao Prof. Dr. Arthur Autran e Prof. Dr. Rubens Machado pelas preciosas contribuições e sugestões durante a qualificação, que auxiliaram a aprimorar este trabalho.

Ao Prof. Dr. Josias Abdala Duarte por ter me impulsionado a continuar a caminhada acadêmica. Pela orientação e amizade nestes anos.

Aos meus amigos pelo apoio e afeto. A Daniela Senador, Reinaldo Cardenuto, Pedro Plaza, Adilson Mendes, Fausto Corrêa Jr. e Cid Vasconcelos pelos comentários, recomendações e indicações de leituras. À Cristiane Reimberg pela amizade de mais de uma década sempre pronta a me ajudar e trocar idéias.

À Ana Maria Raddi Uchôa pelas conversas e referências sobre psicologia, além do interesse e estímulo.

À Cinemateca Brasileira, especialmente a Ana Paula, Gláucia, Carmém, Liege, Olga e Viviane pela gentileza, interesse, ajuda e bom atendimento. 
Não há nada mais simbólico da vida do que aquelas notícias dos jornais que desmentem hoje o que o próprio jornal disse ontem.

Fernando Pessoa 


\title{
Resumo
}

O objetivo desta dissertação é analisar a cobertura jornalística ao cinema brasileiro durante os anos cinquienta em duas revistas de fãs: A Cena Muda (1921-1955) e Cinelândia (1952-1967), avaliando a estrutura da crítica cinematográfica e seu papel como geradora do star system brasileiro. A análise do material de nosso estudo congrega os anos de 1952 a 1955, único período em que as duas publicações coexistiram. Através da análise comparativa com a cobertura ao cinema de Hollywood, traçamos os paralelos da configuração do estrelismo brasileiro, com especial atenção às estratégias de legitimação do sistema para aumentar o interesse dos leitores e às peculiaridades da crítica em lidar com o star system.

\begin{abstract}
This dissertation has by finality the study of the journalistic coverage to the brazilian cinema during the fifties in two fan magazines: A Cena Muda (1921-1955) and Cinelândia (1952-1967) to assess the structure of the critic cinematograph and their role as producer of brazilian star system. The material analysis of our study assembles the years of 1952 to 1955 , only period in which both publications coexisted. Through the comparative analysis with the coverage of the Hollywood cinema, we draw the parallel with the configurations of brazilian star system, with special interest to the system legitimacy strategies to increase the readers' interest and to the peculiarities of the critic to handle with the star system.
\end{abstract}

Palavras-chave:

história do cinema brasileiro, star system, revistas de fãs, crítica cinematográfica.

Keywords:

history of brazilian cinema, star system, fan mags, critic cinematographic. 


\section{Sumário}

Introdução. .13

Capítulo 1 - As estratégias de legitimação do sistema pela revista.........................27

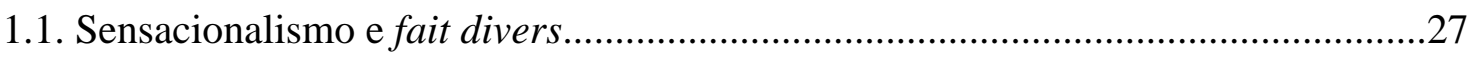

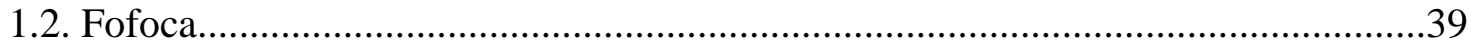

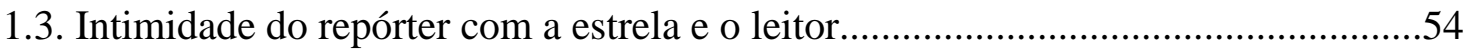

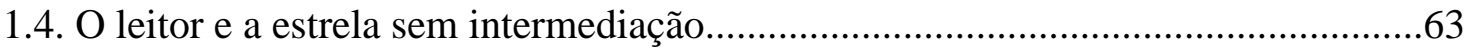

1.5. Entre a humanização da estrela e a identificação: a proximidade com o leitor.......66

1.6. A estrela como parâmetro comportamental.......................................................... 71

1.6.1. A construção da estrela como modelo de conduta...................................71

1.6.2. A propaganda como mediadora do estilo de vida.....................................75

1.6.3. As seções de conselhos e de respostas aos leitores....................................80

1.7. Estrela ou personagem? Mecanismos de transferência.............................................8

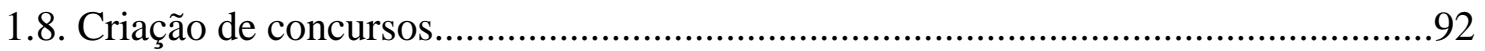

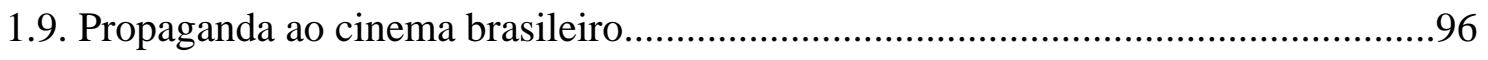

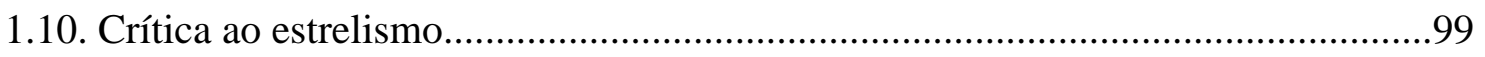

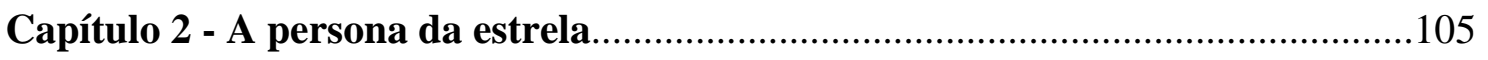

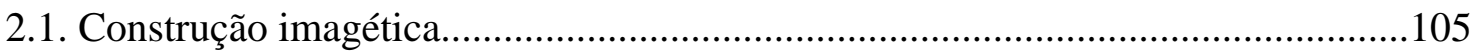

2.1.1. Construção do mito da felicidade........................................................121

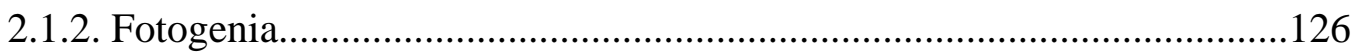

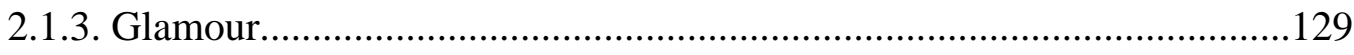

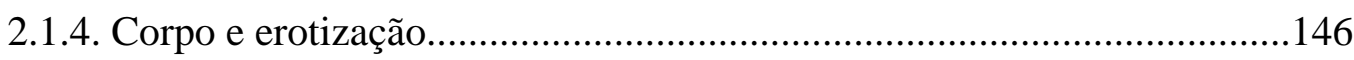

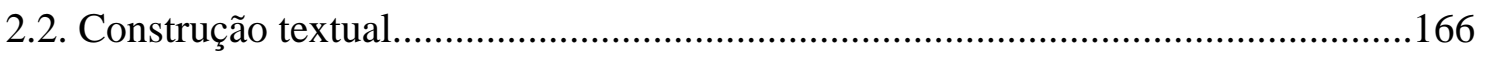

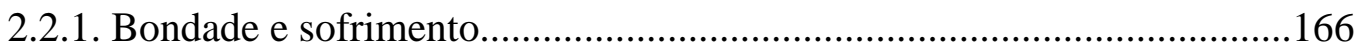

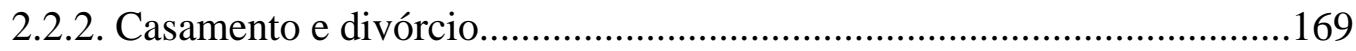

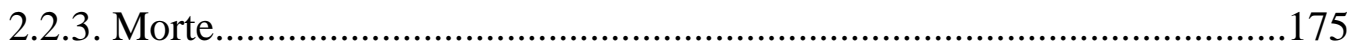

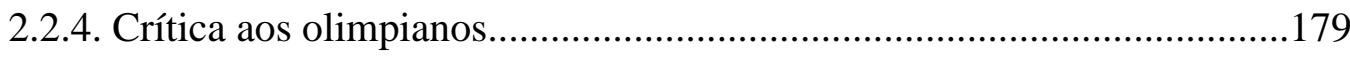

2.2.5. A transição na condenação comportamental: ambigüidade e elogio........184 


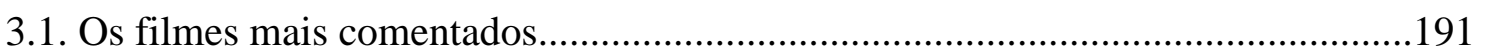

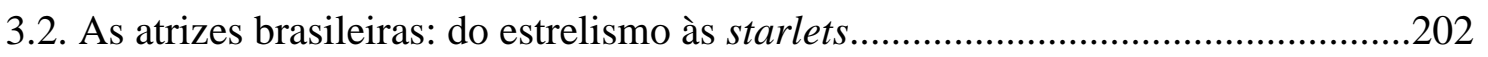

3.3. Os ausentes: a pobreza, o tema racial e as transgressões morais dos

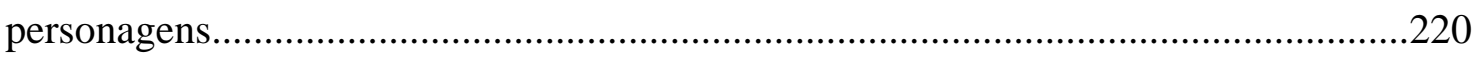

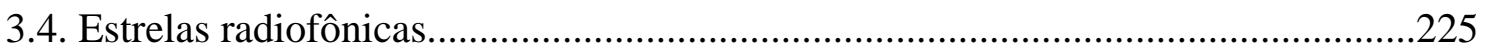

Capítulo 4 - O lugar da crítica dentro das revistas de fãs.....................................229

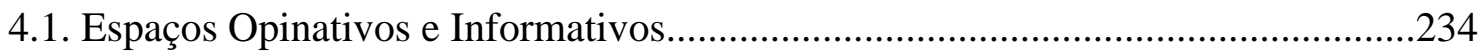

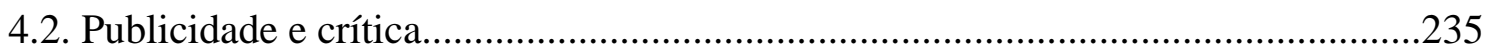

4.3. A crítica em Cinelândia como espaço da objetividade: seção de lançamento.......236

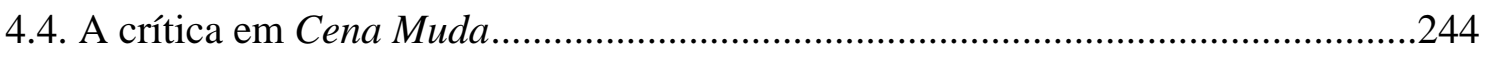

4.4.1. Salvyano Cavalcanti de Paiva: síntese da incongruência entre crítica e publicidade

4.4.2. 1952-53: Entre a diatribe, o voto de sucesso e a certeza antecipada de

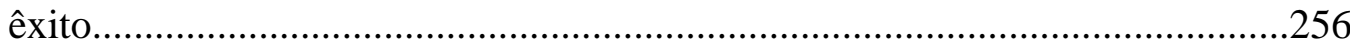

4.4.3. 1954: A crítica intelectualizada e o cinema de arte................................271

4.4.4. A cobertura ao I Festival Internacional de Cinema do Brasil.................282

4.4.5. 1954-55: Da crítica à atuação dos atores ao release ...............................295

Conclusão. .301

Bibliografia . .314

Iconografia. .326 


\section{Introdução}

O objetivo desta dissertação é analisar a cobertura jornalística ao star system e à crítica cinematográfica voltada ao cinema brasileiro durante a década de cinqüenta em duas revistas de fãs: Cena Muda ${ }^{1}$ (1921-1955) e Cinelândia (1952-1967).

As duas publicações colocavam-se ao lado dos leitores interessados no cinema nacional. Legitimavam-se como incentivadoras de nossa cinematografia, ao mesmo tempo em que eram também veículos de geração do star system hollywoodiano. Sob a égide de defender o cinema brasileiro, justificavam sua relevância em fazer publicidade aos filmes, como se o sucesso das fitas nacionais dependesse de seu auxílio. Ambas auxiliaram no processo de identificação dos leitores com os atores brasileiros, através da fabricação de estrelas e de fofocas. Através da ênfase e repetição nos filmes e atores, buscam estimular o interesse pelo cinema nacional.

A crítica cinematográfica praticada em ambas sofria as influências do star system e do material de divulgação enviado pelos estúdios. Em muitos desses artigos, mais importante do que o filme, é a presença e performance de estrela. Contudo a relação com o estrelismo não é tão simples. Coexiste a crítica condenando a baixa qualidade dos filmes de estrela e as atuações dos grandes nomes do cinema. Cena Muda, por sua vez, teve até uma fase atrelada ao cinema de arte. No caso brasileiro, os críticos viam-se geralmente como agentes do processo. Os jornalistas procuravam incentivar um tipo de cinematografia brasileira, em especial as comédias carnavalescas, geralmente desprestigiadas por parcela da crítica. Quando se condena um filme brasileiro recorrendo até às diatribes, o objetivo é possibilitar sua evolução no futuro.

A análise do material de nosso estudo congrega os anos de 1952 a 1955. A escolha do período procurou agregar o espaço de tempo de coexistência entre ambas, a partir do surgimento de Cinelândia em 1952 e o término de Cena Muda em 1955, totalizando por volta de 9.500 páginas de material consultado. Abordamos a cobertura do cinema brasileiro, a partir do parâmetro de construção do hollywoodiano, para mostrar que as diferenças não são apenas na quantidade de páginas dedicadas ao Brasil, mas também no tipo de enfoque editorial e star system existente. Contudo, não negamos

\footnotetext{
${ }^{1} \mathrm{O}$ nome completo da revista é A Cena Muda, porém, utilizaremos a nomenclatura sem o artigo por ter uso mais corrente e simplificado. A consulta ao material foi feita no site da Biblioteca do Museu Lasar Segall < http://www.bjksdigital.museusegall.org.br> e na Biblioteca da ECA. A revista Cinelândia foi consultada na Cinemateca Brasileira, na biblioteca do Museu Lasar Segall e na Biblioteca da ECA.
} 
com isso as extensas similitudes existentes entre ambas na cobertura ao cinema nacional. As dissonâncias apontadas ao longo deste trabalho apontam para o distinto parâmetro de representação destes dois cinemas nas publicações, especialmente no que tange às configurações do estrelismo. Permitem, portanto, compreender tanto as dificuldades do cinema brasileiro do período, quanto suas deficiências e diferente estrutura.

O período é privilegiado para estudar a cobertura das duas publicações em relação ao estrelismo. O final de uma "Cena" - e o começo de outra - "Cinelândia" permite analisar uma época de transição neste filão editorial. Corresponde ainda ao fim da Vera Cruz que ocupava a maior parte do noticiário brasileiro destas revistas, com consequiências para o star system praticado. Aliado a este aspecto, o I Festival Internacional de Cinema do Brasil, em 1954, foi um momento único para este nicho de mercado porque permitiu aos jornalistas a oportunidade de praticarem com os "deuses" aquilo que era sempre mediado pelos releases.

É importante ressaltar que as revistas de fãs não eram apenas divulgadoras do star system hollywoodiano, como se diz comumente. Utilizando a terminologia de Pierre Bourdieu, podemos dizer que estas revistas, assim como as demais produções da imprensa, exercem o poder de geradoras de poder simbólico. Os meios de comunicação têm o poder de predizer ou não o sucesso de um produto cultural (no caso os filmes brasileiros). Bourdieu (2001) reenfatiza sempre que o jornalista não é apenas um intermediário no processo de transmissão da informação. É agente por ser detentor de poder simbólico. Assim se ele, através de sua ação, escolheu dar ênfase ou não ao cinema nacional ou predizer seu sucesso, o crítico converte-se também em agente da construção sobre o cinema nacional no imaginário do leitor. Além disso, pode contribuir para o desenvolvimento ou não da cinematografia. Tal percepção amplia a importância das revistas de cinema no processo de produção do poder simbólico.

Os trabalhos acadêmicos sobre as revistas de cinema analisam a história do cinema nacional, a biografia de um crítico ou a cobertura jornalística com a construção do imaginário cinematográfico nos meios de comunicação. Contudo, inexiste um trabalho que relacione as revistas brasileiras de cinema com as configurações do star system nacional. Nossa contribuição, portanto, é pesquisar a relação entre a crítica cinematográfica e o star system nas revistas, porque geralmente os estudos dedicam-se a estudá-las com o intuito de pesquisar a história do cinema nacional, não a cobertura da 
imprensa. Examinamos também as fontes das teorias sobre o estrelismo, comentando sua apropriação nas revistas pesquisadas.

O principal trabalho sobre Cena Muda é a tese de Flora Bender (1979), um compêndio de extrema importância para a feitura de pesquisas sobre o periódico. Ela realizou entrevistas com os jornalistas e leitores de Cena Muda, procurando reconstituir através de registros de memória e análise dos textos a sua trajetória, além de mapear a hierarquia da redação. Utilizamos um procedimento metodológico diferente do de Bender. Voltamos nossa análise para uma abordagem teórica, colocando em questão a produção dos meios jornalísticos, a análise da crítica e do star system, acerca do cinema nacional. Bender centra sua análise nas primeiras décadas de existência da revista. Nosso foco é a relação da crítica com o star system nos anos cinqüenta, enquanto a autora realiza um panorama central das principais características da publicação, especialmente dos decênios anteriores, numa época em que a bibliografia e teoria sobre o tema eram escassas. Eliana Queiroz (1981) em sua dissertação analisa Cena Muda como fonte para a história do cinema nacional de 1921 a 1933, período que não será abordado por nós. Não encontramos artigos científicos em que a revista Cinelândia tenha sido objeto de estudo, apenas citações quando se analisa alguma outra revista da época.

Vale uma ressalva acerca dos estudos sobre o star system. Geralmente os trabalhos congregam a comparação entre a persona da estrela, a personagem contracenada e a biografia "real" da atriz, voltadas para a comparação com a análise fílmica. O livro As estrelas de Edgar Morin ${ }^{2}$ generaliza as principais características do star system por décadas e sua representação nos meios de comunicações. Os demais autores geralmente fazem análises pontuais sobre o estrelismo, seja por período, tema ou atores; dificultando o estabelecimento de pontos de contato com as estrelas brasileiras. Não encontramos pesquisas sobre a representação de várias estrelas nos meios de comunicação, nem sobre as revistas de fãs. Apesar de o trabalho de Edgar Morin ser datado do ponto de vista temporal, escrito em $1957^{3}$, ele serve como ponto

\footnotetext{
${ }^{2}$ Há também o trabalho de Roger-Gerald Schwartzenberg (1978) sobre as fases do star system, mas o trabalho foi publicado muito depois do de Edgar Morin e seu foco recai sobre o estrelismo na política, utilizando as divisões em fases do star system, como as de Morin, para comparar as estrelas de cinema com um novo tipo de político que surge.

${ }^{3}$ Utilizaremos neste trabalho o ano da primeira edição francesa do livro As estrelas que é de 1957. Apontamos a data original porque há uma diferença cronológica muito grande com a primeira edição em português de 1989.
} 
de referência para discutir e estabelecer os parâmetros na configuração do estrelismo brasileiro.

Houve uma negligência em relação ao star system nos estudos fílmicos, utilizado primeiramente como uma tentativa de justificar o cinema como arte entre 1920-1940, cegando os teóricos para a significância do star system ${ }^{4}$. Jeremy Butler (Hill, 1998) aponta que mais recentemente os métodos de semiótica, psicanálise e estudos culturais reavaliaram o star system. Para o autor, só teremos uma compreensão total do aparato cinematográfico do estrelismo, quando houver um estudo produtivo da estrela, permitindo sua compreensão quanto aos significados econômicos, os sentidos culturais e o prazer psíquico.

Não pretendemos trazer aqui o histórico do estrelismo, por ser muito extenso, mas lembramos que o star system não nasce no cinema, e sim no teatro. Por volta de 1820, os cartazes davam maior relevo aos atores do que às peças, baseado num trust coordenador de um sistema de distribuição, controlador das principais atrações. No caso do cinema, o surgimento do star system condicionou rapidamente a criação de periódicos, feitos primeiro pelos estúdios com o intuito de gerar publicidade aos filmes. As primeiras publicações voltadas a este mercado são os trade papers ${ }^{5} \mathrm{e}$ as fan magazines (lembramos que fan é o diminutivo de fanatic). Ambas surgem como um braço dos estúdios, para instigar o interesse dos leitores pelas personalidades criadas. De modo geral neste período, a vida privada da estrela não pode ser a contradição da imagem fílmica, pelo menos do ponto de vista moral. (DeCordova, 2001)

\footnotetext{
${ }^{4}$ Butler (Hill, 1998: 344-353) divide os estudos sobre o estrelismo em três vertentes interrelacionadas: 1) star production: economic and discursive structures; 2) star reception: social structures, the theory of the subject and the case of feminism; 3) star semiotics: intertextuality and structure polysemy. Na primeira vertente, há diversos trabalhos de historiadores de filmes sobre a história e evolução do star system, destacando-se o trabalho de Richard de Cordova e Janet Staiger. Entre os estudos de recepção, a imagem da estrela começa a ter uma presença social. Os modos de associação da estrela são vistos como parte do significado do sistema da sociedade de uma época particular. A estrela serviria para resolver as contradições da sociedade. Além disso, ela conforta o espectador oferecendo soluções fantasiosas para os problemas sociais que não podem ser resolvidos na sociedade. Ainda entre os estudos de recepção, há o trabalho de Laura Mulvey focado sobre a psicanálise e a imagem da mulher na sociedade. A relação do espectador com a estrela é baseada em alguns aspectos do desejo visual e o prazer na imagem, abordados mais adiante em nosso trabalho. A vertente sobre semiótica está centrada nos estudos de Richard Dyer, avaliando a estrela como uma construção da mídia, ressaltando a significação da estrela como polissêmica. Assim, deve-se procurar a identidade da estrela através do que está atrás da cobertura da mídia. Estes estudos procuram trazer os significados com os quais a imagem da estrela é contextualizada através das estruturas discursivas.

${ }_{5}^{5}$ Jornal ou revista produzido pela indústria para divulgar seus produtos tanto para o público, como para seus membros.
} 
Em 1914, as revistas de fãs já forneciam o nome dos atores porque havia uma demanda do público por esse tipo de informação ${ }^{6}$. Cedo estas publicações dependeram do prazer do público em conhecer o nome dos atores e saber se a personalidade destes possuía similitudes com a dos personagens.

As revistas de fãs ${ }^{7}$ surgiram nos Estados Unidos. Segundo Janet Staiger, Vitagraph, Lubin e Kalem foram os primeiros estúdios a adotarem a política do star system. Biograph foi forçada a aderir em 1913. Os métodos recorriam a fotografias com a marca do estúdio, slides, posters, cartões postais das estrelas e o financiamento de revistas de fãs. (Gledhill, 1991)

Surgem ainda por volta de 1910, as primeiras revistas como Motion Picture Story Magazine, Moving Picture Tales, Photoplay e a edição de domingo do Chicago Tribune. Na primeira edição da revista Motion Picture Story Magazine já estava presente a publicidade direta voltada para a vida e os amores dos atores, modelo seguido rapidamente nos números seguintes. Foi Cleveland leader em 1911 o primeiro jornal a devotar espaço para as sinopses e para os film-making (Gledhill, 1991). De todas elas, a mais famosa foi Photoplay ${ }^{8}$. Tanto Motion Pictures Magazine quanto Photoplay permaneceram no mercado até a década de oitenta, apesar de no Brasil, o nicho de mercado ter entrado em decadência na década de sessenta.

De acordo com Edward Wagenkecht, a maioria dos escritores das revistas de fãs nos Estados Unidos eram mulheres, sendo comum a utilização de pseudônimos. Não era mal visto na época um jornalista complementar sua renda atuando como representante das estrelas e diretores, enquanto escrevia para revistas sobre elas. Durante a era

\footnotetext{
${ }_{7}^{6}$ A primeira atriz que teve seu nome revelado foi Florance Lawrence, a primeira Biograph girl.

${ }^{7}$ Para maiores detalhes, consultar Slide (1985) e Gledhill (1991). No caso brasileiro Xavier (1978) e o verbete revistas escrito por Arthur Autran (Ramos; Miranda, 2000: 455-457).

${ }^{8}$ Entre as revistas mais importantes que começaram a publicar por volta de 1910-20, há Filmplay journal (1921-22), Motion Picture Classic (1915-31) e Movie Weekly (1921-25), a que mais equivale às revistas de fãs contemporâneas por ter artigos com fofocas equivalentes as de hoje. Há ainda Moving Pictures Stories (1913 - década de 30), importante por ter proporcionado uma olhar de relance fascinado sobre a idéia de que os espectadores não querem apenas ver os filmes, mas também ler as histórias de forma mais detalhada. Observamos que a maior parte das revistas citadas não permaneceu muito tempo no mercado. Surgiram no mesmo período que Cena Muda, ou seja, esta teve uma vida longa se comparada à da maior parte das similares norte-americanas, pois permaneceu na média por mais tempo que suas congêneres americanas. As mais importantes revistas de fãs da época de ouro do cinema nos Estados Unidos são: Screen (1930), Movie Action Magazine (1930-36), Movie Classic, Movie Life, Movie Mirror (1931-40), Movies Stars (1949-58), Movie Story Magazine, Movieland and TV Time (1943-58), Movies (1939-41), The New Movie (1929- 35), Screen Album, Screen Book (1928-40), Screen Guide, Screen Play (192528), Screen Book, Screen Stars, Shadowplay e Silver Screen (1930-54). Não inserimos os períodos nos quais algumas dessas revistas estiveram no mercado editorial quando estas informações não constam no livro de Anthony Slide (1985).
} 
silenciosa, aparentemente, os editores das revistas de fãs não viam como errado publicar um artigo ou entrevista com uma atriz escrito por um representante dela. (Slide, 1985)

As principais características das principais revistas de fãs foram sintetizadas e por Edward Wagenknecht, e citadas por Anthony Slide. O padrão é a revista Photoplay que em 1912 fez um design elaborado com o logo na metade superior. Abaixo havia uma cena de um filme do período ou um retrato de um ator. Padrão copiado nas revistas brasileiras e por outras tantas, como $O$ Cruzeiro, incluindo as duas publicações pesquisadas. Cada seção abria com uma seção de fotos dos atores, mas a maior parte dos espaços era devotada a ficcionalização e histórias bem ilustradas tiradas dos filmes correntes. Por volta de 1916, aparecem comentários sobre os filmes em forma de drops $^{9}$ na frente da seção de publicidade. Então as capas passaram a ser todas devotadas a retratos coloridos das estrelas. A presença de crítica de filmes aumenta enquanto os anos passam, e se torna cada vez mais importante. A circulação de Photoplay em 1950 era de 1.200.000. Em 1980 caiu para 300.000 no seu último ano.

Não sabemos ao certo qual seria a circulação de Cena Muda. Alguns entrevistados mensuraram números em torno de dez a cem mil. Já a revista Cinelândia na sua seção de Carta aos leitores ${ }^{10}$, em 1954 , diz ter ultrapassado a faixa de cem mil exemplares, número que tínhamos considerado muito alto para a tiragem de Cena Muda, mas talvez a circulação de ambas estivesse realmente neste volume, já que outras revistas do período já atingiam tiragens em volta de cem mil. Ao que consta no sumário, Cena Muda era enviada para todo o Brasil, até mesmo para alguns países da América Latina. A título de comparação, o valor da tiragem era baixo se comparado à tiragem da revista $O$ Cruzeiro, a publicação de maior circulação na América Latina no período. De acordo com Muniz Sodré (1971), entre 1950-59, a tiragem de O Cruzeiro era de 750 mil exemplares. Ana Luíza Martins explica que enquanto as revistas surgiram no século XVIII na Europa e nos Estados Unidos, no Brasil o fenômeno começou a partir de 1900 11. Muniz Sodré esclarece que até 1945, as revistas Cena Muda, Paratodos, Cinearte,

\footnotetext{
9 Drops equivalem a notas.

${ }^{10}$ Aos leitores. Cinelândia, v. 34, n. 36, p. 3, 1º quinz. maio 1954.

${ }^{11}$ Ana Luíza Martins (2001) mostra que a primeira revista em gênero e forma nasceu na Grã Bretanha em 1802, chamada Edinburgh Review. Em 1809 nasce também Quarterly Review. Porém, o gênero periódico existia desde o século XVII, mas em forma de jornal. No século XIX, as revistas tornaram-se moda e ditaram a moda, dado aos avanços tecnológicos nas gráficas, com ampliação do público leitor e devido também ao alto custo do livro. A revista possuía muitas informações num único volume. As ilustrações a enriquecem a partir do último quarto do século XIX, possibilitando a inserção de um público ou analfabeto ou que não queria ler muito. No Brasil, apenas no final do século XIX o termo revista passa a ser usado.
} 
Vida doméstica, O malho, Careta, Revista da semana "primavam pela ilustração, mas estruturalmente distinguiam-se pouco dos jornais". Elas não estiveram na tradição das lutas liberais, do abolicionismo, diferente da imprensa diária brasileira. Nasceram com as características aproximadas da revista moderna, definidas pela ilustração. (Sodré, 1971: 40)

Quando o senso comum questiona as revistas de fãs pelo seu amadorismo jornalístico, na cobertura e na disposição das páginas, não podemos perder de vista que Cena Muda nasceu junto com as revistas brasileiras. Muniz Sodré lembra que as revistas especializadas eram poucas e de qualidade sofrível. A liderança de Cruzeiro se baseava nas reportagens exclusivas de cunho sensacionalista.

A SCena Muda (1921-1955) surgiu em 31 de março de 1921. Destinada principalmente aos fãs, existiu até 1955 , semanalmente ${ }^{12}$. A revista era publicada toda terça-feira pela Companhia Editora Americana, de C. Malheiros Dias, empresa detentora de Revista da Semana, Eu sei tudo e Almanaque do eu sei tudo. Flora Bender (1979) dividiu a revista em quatro fases: a revista especializada em cinema (1921-42), a revista amiga do rádio (1942-49), a revista crítica (1949-52) e a revista decadente (1952-55).

A primeira fase é caracterizada pelo endeusamento do astro ou da estrela ${ }^{13}$. A estrutura da revista não muda muito durante esta fase: há diversos resumos de filmes, fotografias e notícias sobre a produção cinematográfica de vários países do cinema. Com o passar do tempo, a grande quantidade de resumos é substituída por um número crescente de notícias: desde fofocas à tentativas de teorização. Nessa fase não aparece o nome do redator nem da fonte. Já existe uma postura analítica, mas os comentários ocupam poucas linhas. Na primeira fase, o trabalho era artesanal. Renato de Castro, secretário de redação, e seu filho trabalhavam quase sozinhos. Recortavam e colavam matérias das revistas estrangeiras de cinema e o material das companhias cinematográficas. Pedro Lima afirmou em entrevista a Bender que também fazia Selecta sozinho. Em Cinearte, recorria-se ao mesmo esquema pela escassez de jornalistas: dois ou três traduziam o material e inventavam entrevistas. Apenas as cartas dos leitores eram verdadeiras.

\footnotetext{
${ }^{12}$ Apenas no segundo semestre de 1954 e em 1955 a revista tornou-se quinzenal.

${ }^{13}$ Bender não entra na questão, mas a fase do endeusamento a que ela refere-se concilia com a fase do star system dos anos 20, em que o artista era uma estrela distante, um ídolo marmóreo.
} 
A segunda fase chamada A revista amiga do rádio (1942-49) ${ }^{14}$, introduziu o rádio e o rádio-teatro com grande destaque. A publicação tenta criar mitos dos artistas brasileiros. A música nacional passou a ter importância, graças aos artistas radiofônicos. SCena Muda passa a publicar capítulos de rádios-novelas semanalmente.

A fase crítica da revista entre 1949-1952 ficou na cabeça dos colaboradores, mas não do público. Os leitores lembram mais da primeira fase, cheia de resumos, cineromances e fotos. Nesta fase, a publicação preocupa-se com o cinema europeu. Dirigida por Leon Eliacher, o objetivo é fazer uma revista séria: pensar cinema. Jovens críticos de cinema são convidados a trabalhar. Colaboram nessa época Moniz Viana, Alex Viany, Salvyano Cavalcanti de Paiva, Alberto Conrado.

$\mathrm{Na}$ última fase, considerada decadente (1952-55), passaram pela redação Adhemar Gonzaga e Renato de Alencar. Este último, dez anos depois da primeira passagem, volta para reformular a revista e fazê-la especializada em cinema. Renato é substituído logo depois por Levy Kleiman, que dividiu o periódico em duas: cinema e rádio. Há maior seriedade; a revista fica mais "limpa". Kleiman convida também Alberto Dines, à época um jovem jornalista, para trabalhar. Busca-se uma postura crítica mais séria. Há artigos com alguma profundidade e colaboradores de bom nível. Foi uma exceção dentro da fase decadente. Contudo Levy sai logo. Entra Luis Fernandes ${ }^{15}$. Sob sua direção, a revista constantemente interessa-se pela opinião dos leitores. Os artistas são bastante valorizados. A fase curta de um mês é marcada pela precariedade. A qualidade geral é muito mais baixa do que a das direções anteriores. Em 1954, a publicação passa a utilizar calhaus - material à disposição, sem atualidade, que pode ser aproveitada em qualquer época para encher as páginas e tapar buracos. Nesse período passa a ser quinzenal. Depois disso o periódico só piorou, até morrer. Não era só a revista que morria, a editora também estava em decadência ${ }^{16}$.

\footnotetext{
${ }^{14}$ A autora situa a fase do rádio entre 1942-49, mas entre 1952 e alguns meses de1953 metade da revista foi novamente dedicada ao rádio.

${ }^{15} \mathrm{O}$ jornalista trabalhava na revista Cinelândia.

${ }^{16}$ A revista Cena Muda foi a primeira a morrer, mas as demais publicações resistiram mais alguns anos, até que a editora foi vendida. Cena Muda teve até sucesso nacional durante um tempo, como atesta Bender, mas nunca "estourou" como revista para o grande público porque era especializada, uma restrição editorial. Já a Revista da Semana, da mesma editora, teve grande repercussão (1900-1959). Foi durante muito tempo a mais lida no país. Havia também Eu sei tudo e o Almanaque eu sei tudo. Geralmente os entrevistados culpam a falência da empresa a Gratuliano de Brito (genro do dono da empresa), que a dirigiu sem ser do ramo. Bender traz como fatores da desestruturação a decadência do parque gráfico e o surgimento de concorrentes modernas. A Companhia Editora Americana foi vendida em 1963 a um grupo, que depois se soube ligado a Brizola. Teve problemas com a ditadura. Seus antigos donos e diretores estavam em cargos de chefia nos governos militares, ou relacionados ao poder
} 
Já a concorrente, Cinelândia (1952-67) era de Roberto Marinho. A história do império da Globo começou com a compra do jornal A Noite (1911) pelo jornalista Irineu Marinho, pai de Roberto, com dinheiro emprestado. Depois de perder o jornal para seu sócio Geraldo Rocha ${ }^{17}$ em 1924, funda $O$ Globo em 1925, falecendo alguns meses depois. Roberto Marinho só assumiu o jornal como diretor em 1931. Em 1944, Roberto Marinho compra a Rádio Globo. Durante a década de cinquienta, $O$ Globo já era um jornal de grande prestígio e poder. Valério Brittos e César Bolaño (2005) lembram que o jornal $O$ Globo era o carro chefe da empresa, mas o crescimento financeiro do grupo se deu por causa da edição de Gibi (a partir de acordo com histórias em quadrinhos norte-americanas) e empreendimentos imobiliários durante a década de trinta e quarenta. Roberto Marinho soube explorar o mercado das revistas em quadrinhos, sendo a Rio Gráfica Editora uma das principais difusoras deste nicho no Brasil. Em 1939, a empresa lança gibis, com tiragem superior a cem mil exemplares. Esse investimento permitiu comprar transmissores e inaugurar a Rádio Globo no Rio de Janeiro em 1944. A TV Globo, inaugurada em 1965, só se tornou o carro chefe da empresa nos anos setenta ${ }^{18}$. Werneck Sodré (1999) conta como Roberto Marinho conseguiu cinco empréstimos diferentes entre 1950-52 para a compra de máquinas impressoras, utilizando como garantia a mesma velha rotativa Goss, em valores correspondentes a mais de um milhão de dólares. Ana Paula Goulart Ribeiro (2001) lembra que as empresas de Roberto Marinho foram uma das mais beneficiadas pelo crédito dos estabelecimentos oficiais. Obteve em todos eles condições de pagamento extremamente vantajosas ${ }^{19}$.

governamental. Durante a década de setenta, a editora passou a se especializar em livros, sob o comando de Haddad.

17 Irineu Marinho vendeu algumas ações para Geraldo Rocha, representante da firma inglesa Brasil Railways para comprar uma nova rotativa, mas continuou sendo o acionista majoritário. Contudo resolveu viajar à Europa por motivos de saúde. Geraldo Rocha comprou suas ações, mas prometeu vender de volta a Irineu assim que ele voltasse de viagem. Porém, não cumpriu o prometido. Apenas com um contrato verbal, Irineu Marinho perdeu a empresa. Na bibliografia consultada, Pedro Bial (2005) é citado nos trabalhos como fonte para narrar a história do jornal A Noite. Vale uma ressalva à fonte por se tratar de um jornalista ligado à Rede Globo escrevendo a história institucional da empresa.

${ }^{18}$ A Rede Globo é criada em 1965. A Editora Globo que era da família Bertaso, abre seu capital nos anos setenta, mantendo os herdeiros como sócios majoritários. Só em 1986, a Editora foi comprada por Roberto Marinho. Assim a Rio Gráfica passa a integrar a Editora Globo.

${ }^{19}$ Apesar de não estudar as revistas, Ana Paula Goulart Ribeiro (2001) avalia como os jornais do Rio de Janeiro dependiam tanto da publicidade, como das relações de influência, empréstimos e corrupção junto aos governos. O comentário revela indícios para analisarmos as dificuldades de Cena Muda em se adequar ao mercado pela sua insuficiência nas fontes de renda mencionadas a seguir. Ribeiro conta que havia para um jornal carioca na década de cinqüenta quatro fontes de recursos: venda avulsa ou por assinatura, publicidade comercial ou pública, empréstimos e privilégios públicos e apoio de grupos privados. Poucos veículos tinham venda avulsa e de assinatura como maior fonte de renda. Além disso, 
Cinelândia tinha acordo de exclusividade com Margood Publishing Corporation e a Dell Publishing Company. A maioria das revistas de fãs nos Estados Unidos eram controladas pelos grupos Mafadden, Dell e Fawcett Publications. Ou seja, Cinelândia tinha acordo com um dos maiores grupos controladores deste tipo de publicação, a Dell. Cena Muda teve, então, de competir com uma publicação relacionada a um oligopólio editorial internacional. $\mathrm{O}$ acordo com a Dell não era exatamente a tradução de uma revista do grupo, uma vez que a empresa possuía diversas revistas para o nicho de fãs ${ }^{20}$, algumas mais institucionais, outras voltadas às novelizações ou às fofocas. A revista brasileira copiava, por exemplo, algumas das matérias de Modern Screen, sem realizar alterações quanto à disposição da página, manchetes e das fotografias utilizadas, descartando algumas fotos e retirando parte do texto. Estas saíram com dois meses de atraso, tanto em 1952 quanto em 1954. A partir de junho de 1953, Cinelândia torna-se quinzenal. Dedicada aos aficionados pelo cinema e por suas estrelas, havia na publicação amplo material fotográfico, muitas notas e fofocas sobre os atores. As apreciações críticas sobre os filmes apareciam nas entrelinhas, geralmente para destacar a performance da estrela de cinema.

Houve no mercado brasileiro uma revista denominada Cinelândia $^{21}$, editada em espanhol a partir da década de 20 , mas sem nenhum tipo de relação com a publicação brasileira de Roberto Marinho.

Voltando à Cinelândia dos anos cinqüenta, a primeira capa dedicada ao cinema nacional saiu no número oito, em dezembro de 1952, como Josette Bertal, atriz de Amei um Bicheiro (1952), de Paulo Wanderley e Jorge Ileli. Alguns filmes como Carnaval Atlântida (1952), de Carlos Burle, e Nem Sansão nem Dalila (1954), de Carlos Manga, obtiveram até três matérias consecutivas na revista. João Luiz Vieira considera que a “Cinelândia ajudava no desenvolvimento do estrelismo da Atlântida, reforçando os estereótipos necessários para materializar a velha mas ainda sempre eficaz lei dos tipos, sustentáculo maior da redundância almejada pela Atlântida.” (Ramos, 1987: 184)

houve um aumento nos custos de produção, com crescentes despesas com pessoal, com a parte gráfica, além do aumento do preço do papel subsidiado pelo governo.

${ }^{20}$ Entre algumas das revistas da Dell Publishing há Modern Screen, Screen Álbum Magazine, Screen Stories, Screen Romances, Hollywood romances e Dell - a movie classic, esta última uma revista em quadrinhos. A empresa foi vendida, e hoje se dedica principalmente à edição de palavras cruzadas.

${ }^{21}$ A revista homônima Cinelândia circulou na América Latina com lay-out muito moderno para a época. Feita em Los Angeles/Califórnia, era publicada por Spanish-American Publishing Co, para a Espanha, e vinte países da América Latina, incluindo Porto Rico e Filipinas. A biblioteca da PUC possui uma coleção incompleta da revista entre 1927 a 1947. A Cinemateca tem apenas três números, salteados entre 1921 a 1941. Já a Biblioteca do Lasar Segall possui uma coleção mais completa. 
A revista Filmelândia (1954-63) era do mesmo grupo editorial de Cinelândia. Publicava as novelizações dos filmes ${ }^{22}$, ou seja, o enredo do filme era contado sob a forma de folhetim ${ }^{23}$. Ano a ano se amplia a quantidade de imagens com diminuição na quantidade de texto. A ilustração fotográfica passa a narrar a história e apresentar os personagens. Filmelândia parece ter surgido para competir com as novelizações de Cena Muda. Foi incorporada à Cinelândia em 1963. Por sua vez, Cena Muda eliminou o cine romance, principal foco da revista, para imitar Cinelândia ${ }^{24}$, por necessidade de sobrevivência. (Bender, 1979)

Segundo Flora Bender: "Cinelândia e Filmelândia, juntas, equivaleriam à SCena Muda: a primeira, pela informação, pela fofoca sem maiores consequiências e pela valorização do artista; a segunda, porque só apresentava resumos de filmes." (Bender, 1979: 76)

Observamos que durante a década de sessenta, Cinelândia continua com o mesmo projeto editorial e seções muito parecidas. O padrão editorial dela era mais consistente que o de Cena Muda, que enfrentava sucessivas mudanças de projeto gráfico e editorial. Cinelândia morre em 1967. Segundo o verbete da Enciclopédia do Cinema Brasileiro escrito por Arthur Autran sobre as revistas de cinema, o fato se deve a um esgotamento do filão editorial. (Ramos; Miranda, 2000: 455-457).

A estrutura das duas revistas de fãs pesquisadas é similar. Uma estrela famosa aparece na capa, com ênfase para seu rosto, geralmente sem objetos no fundo para não desviarem a atenção de seu foco. As manchetes na primeira página variam, mas nem sempre estão presentes. Conforme as observações de Ismail Xavier (1978), as capas são cópias do modelo criado pela revista Photoplay, com o logo da publicação situado acima. Boa parte das páginas é destinada às fotografias para contemplação da beleza das estrelas, com curiosidades de bastidores, seções voltadas aos leitores e artigos sobre a personalidade das estrelas, voltadas aos lançamentos. Cinelândia tinha uma vantagem sob Cena Muda na utilização de fotografias e efeitos visuais em cores, e principalmente num lay-out mais moderno ${ }^{25}$, semelhante ao de $O$ Cruzeiro. O enfoque é a vida pessoal

\footnotetext{
${ }^{22}$ As novelizações também eram comuns nos Estados Unidos e no Brasil já em décadas anteriores. No último ano de existência, Cena Muda tentou trazer para si o título de criadora do gênero no Brasil.

${ }^{23}$ Cena Muda utiliza mais de um termo para o gênero, como novelização, literatura cinematográfica, cine-romance, cine-novela, cine-literatura, cine-capítulos, os grandes romances da tela. Estes geralmente referem-se aos folhetins. Ocupam maior número de páginas. Já cine-trailer, imagens em novela, novela das imagens, enredo, são usados para sinopses, em textos curtos.

${ }^{24}$ Cf Cotrim (anexo com entrevistas). In: Bender, 1979.

${ }^{25}$ As fotografias de Cinelândia "vazam" o espaço da linha fina. Ocupam a página inteira, sobrepondo-se em ângulos diferenciados e mais modernos. O lay-out torna-se, assim, muito mais moderno do que o de
} 
das estrelas, voltada às fofocas. Quando não há fofocas para se contar, as revistas voltam-se às informações dos bastidores e lançamentos. As notícias sobre a cinematografia nacional situam-se numa seção à parte nas duas revistas, mas há também reportagens sobre a vida das atrizes brasileiras. Ambas possuem também seções de cartas destinadas aos leitores, com perguntas e dúvidas, além de colunas sobre música, rádio e teatro.

A dissertação tem como tema principal o estudo do estrelismo e da crítica cinematográfica, além da representação do cinema brasileiro a partir da comparação com a cobertura à cinematografia norte-americana. No primeiro capítulo, trazemos as estratégias pelas quais as revistas de fãs procuram se legitimar, denegar seus interesses comerciais e se aproximar dos leitores. Tais mecanismos refletem também as formas de estrutura do estrelismo na imprensa para conquistar o leitor e legitimar seus interesses. Fornecem também base para entender as dificuldades e deficiências do estrelismo brasileiro. Uma das táticas mais utilizadas é a recorrência da fofoca, sensacionalismo e fait divers para gerar interesse sobre a estrela e os filmes, a partir dos mecanismos de identificação e humanização da estrela. Abordamos também os artifícios dos jornalistas para criar intimidade com as estrelas e leitores e a construção da estrela como padrão comportamental às leitoras, vinculando uma determinada visão da mulher.

Cena Muda. Esta inseria as imagens, respeitando as delimitações da linha fina, em colunas préestabelecidas, sempre muito iguais, geralmente em molduras retangulares ou quadradas. Cena Muda também utilizava técnicas de recorte de fotografia desde os anos vinte, mas não havia um apuramento da técnica. Nas matérias compradas do exterior por Cinelândia, há uma paginação muito melhor. Pouco a pouco, Cinelândia se aprimora, trazendo o mesmo molde para a cobertura do cinema brasileiro. Em Cena Muda não havia melhoras na paginação. A foto circundava o texto, em pequenos espaços, com pouca utilização de fotografias de página inteira. Às vezes havia uma paginação melhor, mas na média havia três colunas, com fotos em seqüência respeitando as delimitações das colunas. O maior ganho de Cinelândia era permitir o acesso a fotos coloridas das estrelas, existentes somente na capa colorida e pintada de Cena Muda. As duas publicações recorriam à pintura e retoque de fotografias. Contudo não eram em todas as páginas que as duas se mostravam diferentes quanto ao lay-out. Há paginação muito semelhante nas folhas em preto e branco, com material dos estúdios. Apesar disso, ambas ainda tinham dificuldade na composição da página. Iniciavam suas matérias em páginas "casadas", mas sem conseguir preencher todo o texto neste espaço, transferiam o restante dos artigos para as últimas folhas da revista. Característica esta das publicações do período, inclusive de Cruzeiro. A técnica possibilitava um maior contato do leitor com as demais matérias, permitindo a leitura de outras reportagens. O lay-out da revista Cinelândia editada nos Estados Unidos era proporcionalmente mais moderno por ser de décadas anteriores do que o das duas revistas pesquisadas na década de cinqüenta. A paginação era mais clara e os títulos utilizavam manchetes com maior apelo. Consideramos o lay-out da Cinelândia americana mais moderno por ter características semelhantes às revistas brasileiras de 1950. O lay-out da capa das duas revistas estudadas era semelhante às publicações brasileiras da época. O padrão criado por Photoplay com fotos das atrizes centradas sob seu rosto, era comum na imprensa brasileira do período. Cruzeiro utilizava o mesmo padrão. A revista Manchete nasce em 1953 com lay-out mais moderno, sem dificuldade de paginação. As matérias começam e terminam no mesmo local, sem a necessidade de ler as continuações dos artigos nas páginas finais da revista. E até revistas prestigiadas também. Cahiers du cinéma utilizou na edição n. 42 de 1954 uma fotografia de release do estúdio da atriz Audrey Hepburn, muito semelhante às duas capas com a mesma atriz em Cena Muda e Cinelândia. 
O segundo capítulo destina-se à análise da persona ${ }^{26}$ da estrela nas revistas, a partir de duas frentes. A primeira é a análise imagética desta representação. É na imagem que a musa mostra seu sex appeal. As fotos transmitem no geral o que o texto não pode explicitar. $O$ estudo da imagem inclui também a construção do mito da felicidade dos seres sobre-humanos e o estudo da configuração do glamour e fotogenia. Procuramos exemplificar o padrão hollywoodiano para mostrar as peculiaridades e defasagens na configuração do estrelismo brasileiro. Na segunda parte deste capítulo, centramos o estudo na construção textual. De um lado há a divindade da estrela, e de outro fica patente o período de transição do estrelismo, tanto hollywoodiano quanto brasileiro. Apesar de perfeito, o ídolo sofre. Alguns tabus da sociedade têm uma representação diferenciada, como os casos de romances extraconjugais dos atores, o divórcio e as transgressões morais e comportamentais tanto dos personagens dos filmes, quanto das celebridades. Outras vezes, as revistas recorrem ainda à críticas de cunho moral como nos primeiros anos do estrelismo, quando a personalidade da atriz não podia entrar em contradição com os padrões morais.

A cobertura das revistas ao cinema brasileiro via star system é o centro de discussão do capítulo três. Trazemos a cobertura das revistas a alguns filmes do período relacionados ao estrelismo. Depois nos centramos na representação sobre as atrizes brasileiras, desde as estrelas até as starlets ${ }^{27}$. Abordamos também as estrelas radiofônicas, possuidoras de maior sedimentação quanto à audiência. Por último, trazemos o universo ausente das páginas editoriais por não se conciliar com o universo otimista do estrelismo: os casos de pobreza, o tema racial e as transgressões morais dos personagens, mesmo quando debatidos nos filmes brasileiros.

O último capítulo é dedicado à crítica. Para analisá-la é necessário lembrar sua presença não apenas nos espaços tradicionalmente vistos como opinativos, mas também nos informativos (reportagens e notas). Apenas Cena Muda utilizava a denominação de seções de crítica. Esta tem peculiaridades relacionadas aos diretores de Cena, sofrendo grandes alterações em suas características no período estudado. No geral, a crítica era voltada para a orientação do consumo, ligeira e sem pretensões de realizar um julgamento de cunho estético ou artístico. Dividida entre um discurso panegírico ou de

\footnotetext{
${ }^{26}$ Utilizamos o conceito de persona não da psicologia, mas relacionado ao estrelismo. São os casos de junção entre a personalidade da estrela com a da personagem. Como exemplo, temos a figura de Stroheim. Sua persona foi construída para imbuir as características do personagem interpretado, como um general prussiano, sádico e frio, na sua personalidade como ator e diretor.

${ }^{27}$ A starlet é uma aspirante ao estrelismo. Ainda não é estrela, mas não é uma desconhecida.
} 
diatribe, com influência do release e da publicidade. Contudo, o processo tem suas peculiaridades, coexistindo também uma crítica atrelada ao cinema de arte. 


\section{Capítulo 1 - As estratégias de legitimação do sistema pelas revistas}

O primeiro capítulo é destinado às formas encontradas pelas revistas de fãs para atrair o leitor, procurando aproximar-se dele. Tais mecanismos refletem também os formatos de estrutura textual do estrelismo na imprensa para legitimar seus interesses e conquistar público. As estratégias incluem a criação de concursos voltados aos leitores ávidos para se tornarem astros, a utilização da estrela como parâmetro comportamental a partir da composição do imaginário projetivo, entre outras. Ao mesmo tempo, as publicações buscam criar uma estrutura textual insinuando uma suposta intimidade com as estrelas para humanizá-las. Estudaremos também as formas pelas quais o sensacionalismo e a fofoca atraem a atenção dos fãs-leitores para narrativas que convertem os romances das estrelas em novelizações sob a forma de reportagens.

\subsection{Sensacionalismo e fait divers}

A raiz da palavra sensacionalismo tanto vem do que é sensacional, como da sensação. O extraordinário, insólito, divertido, original, tanto o que causa espanto por seu conteúdo fora dos padrões de normalidade, tem ainda um aspecto recorrente a atingir seu público leitor através de sensações induzidas pelo estilo de texto. O sensacionalismo busca causar interesse no leitor, mas não deve ser visto como necessariamente execrável do ponto de vista jornalístico. Todos os jornais considerados sérios ou de prestígio apelam ao sensacionalismo para atrair atenções. Muitas vezes o sensacionalismo pode ser uma forma válida quando é responsável por trazer ao leitor conteúdos que sem tal formato passariam despercebidos, como demonstrou Manuel Chaparro (2001). Sem utilizar as técnicas do sensacionalismo, dificilmente um jornal teria sucesso, sentencia o pesquisador. O sensacionalismo claramente permeia as revistas de fãs, focado sobre as particularidades das estrelas, mas qual seria a diferença do sensacionalismo das revistas de fãs com o dos veículos considerados sérios? Não é a relação entre emoção e razão que descredencia o jornalismo praticado nestas revistas. A diferença está na intencionalidade do sensacionalismo, suas formas e técnicas. A resposta tem relação com o conteúdo vinculado. O objetivo do sensacionalismo de uma revista de fã é trazer publicidade aos leitores, a partir de invenções efetuadas pelos 
departamentos de propaganda, enquanto o sensacionalismo não condenável pode trazer conteúdos eticamente corretos, denunciando problemas sociais, por exemplo.

Cinelândia como empresa jornalística moderna soube calcar suas matérias com títulos apelativos, aumentando o interesse do leitor. Cena Muda recorre a manchetes com o nome dos atores, acrescentando as palavras "sua vida e sua obra", "Os grandes vultos do presente (e do passado) III" ou ainda mostrando o filme Sinhá Moça (1953), de Tom Payne, sob a tônica da abolição da escravidão "Sinhá Moça: um instante da campanha abolicionista ${ }^{l}$. Enquanto isso, Cinelândia usava a manchete Eliane $e$ Anselmo juntos na tela ${ }^{2}$, utilizando os dois ídolos e o conseqüente par romântico do filme. Os títulos apelativos de Cinelândia pautam-se sobre a vida íntima dos atores, tais como Existe ainda amor entre Rita e Aly? Os astros de Hollywood tem medo do casamento ou do futuro?, O que a felicidade significa para mim, O coração solitário, Os corações inquietos de Hollywood, Lua de mel roubada. A revista oferece supostos flagrantes de lua-de-mel, em fotos visivelmente posadas e produzidas pelos estúdios, e imagens das atrizes após o casamento rodeadas por multidões. Ou seja, Cinelândia sabia utilizar os parâmetros modernos da cobertura jornalística, e estava mais entrosada aos novos critérios do star system, mostrando a vida íntima das estrelas, quando Cena Muda ainda pautava-se em grande parte no material que os estúdios mandavam para publicação, material este com menor sensacionalismo, conteúdo e manchetes menos atraentes.

A revista $O$ Cruzeiro no mesmo período apela aos mesmos esquemas sensacionalistas das manchetes de Cinelândia, com novelizações e títulos como $A$ Vênus oxigenada, O fotógrafo revela o segredo das estrelas diante da objetiva. Recorre-se ao mesmo tipo de novelização da vida das atrizes, contando como moças pobres tornaram-se estrelas. A empresa de Chateaubriand também publica novelizações por mais de uma edição, como em Cena Muda.

Podemos resumir o sensacionalismo de Cena Muda a uma recorrência de ambigüidade nas manchetes, mas sem revelar o conteúdo prometido. O seu uso é largamente utilizado para sugerir romances entre os atores. Nesse quesito, há uma peculiaridade na ambigüidade. Primeiro a revista utiliza uma linguagem encarregada de criar expectativas no leitor quanto a romances, com supostas provas, como descrever os

\footnotetext{
${ }^{1}$ Utilizaremos a ortografia atualizada dos textos ao longo do texto. Cena Muda, v. 33, n. 33, n. 19, p. 4-6; 34, 04/03/1953.

${ }^{2}$ Fernandes, Luis. Cinelândia, v. 1, n. 14, p. 38, $1^{\text {a }}$ quinz. julho 1953.
} 
olhares entre a estrela e o astro, os gostos em comum, para depois negar a história, declarando existir apenas uma grande amizade. Provavelmente um jogo lúdico conhecido e aceito pelo leitor, como uma linguagem instigadora de interesse, mas como resultado aquém ao esperado porque Cinelândia utiliza o sensacionalismo não só na manchete, mas como no conteúdo dos artigos. Como exemplo, temos a manchete de Cena Muda: De pintor a maconheiro ${ }^{3}$. A função da manchete é causar uma expectativa através da curiosidade sobre Emílio Castelar. Pela manchete, o leitor imaginaria uma vida pobre e o posterior envolvimento com as drogas. Contudo na matéria apenas se mescla a vida pessoal do ator, que era pintor, com o personagem do filme, usuário de drogas. Da mesma forma, Cena insinua um suposto romance entre os atores Kathryn Graysson e Howard Keen ${ }^{4}$, a partir de fotografias dos dois dançando muito próximos. Porém, a imagem revela outro conteúdo: o ambiente lotado, quase sem espaço disponível. Depois a matéria confessa tratar-se apenas de amizade, afinal de contas o astro já era casado.

Supostamente poderia haver uma decepção no conteúdo das matérias, tendo em vista o prometido na manchete. $\mathrm{Na}$ verdade, esse tipo de narrativa pode se encaixar numa das características do fait divers, chamada por Roland Barthes (1970) de causalidade perturbada. De uma frase como "de pintor a maconheiro", o leitor esperaria uma história mais ousada, mas a causalidade revelada foi mais pobre do que a esperada, porque não se prova o envolvimento com drogas. Barthes inclui neste tipo de fait divers o espetáculo da decepção. O que poderia parecer uma prova de uma estratégia mal fundamentada porque decepciona o leitor, para Barthes é a prova de que "a causalidade é tanto mais notável quanto mais é decepcionada", dando assim o efeito desejado.

Enquanto em Cena Muda o sensacionalismo das manchetes era desnudado no texto, causando "decepção" nos leitores logo nas primeiras linhas 5 , Cinelândia prometia histórias picantes e cumpria parcialmente com o trato na maior parte das vezes. O tema do divórcio aparece com recorrência. Geralmente quando há sensacionalismo no título, o romance não é negado pela publicação. Além disso, o apelo ao sensacional é justificado pelo interesse do público. Diversas vezes, os colunistas

\footnotetext{
${ }^{3}$ De pintor a maconheiro. Cena Muda, v. 32, n. 47, p. 4-5, 21/11/1952.

${ }^{4}$ Conrado, Alberto. Quatro dias com Kathryn Graysson e Howard Keen. Cena Muda, v. 32, n. 08, p. 10-3 e $28,21 / 02 / 1952$.

${ }^{5}$ Outro exemplo com certa recorrência é a utilização na contracapa de manchetes como A comediante Ema matou a sambista!, mas o conteúdo nas matérias é sempre ficcional, sobre filmes ou novelas. Cena Muda, v. 33, n. 17, p. 36, 22/04/1953.
} 
justificam as bisbilhotices na vida alheia porque os leitores querem tais fatos. Dissociam o interesse financeiro da revista, culpando os leitores pela intromissão.

As notícias mais sensacionalistas sobre a vida das estrelas em Cinelândia têm relação com o período do star system, como se Cena Muda tivesse parado no tempo no critério de veiculação do sensacionalismo. Nas décadas anteriores, na representação sobre a estrela, os ídolos eram marmóreos e distantes do público, vivendo em palacetes. A partir da década de trinta, o star system também evoluiu a partir da alteração dos enredos dos filmes, que se tornam paulatinamente mais realistas, como mostrou a pesquisa de Edgar Morin (1957). A estrela torna-se mais próxima dos leitores, aumentando assim a demanda por mais informações de sua vida pessoal. Cinelândia estava mais preparada do ponto de vista da cobertura jornalística para trazer tais detalhes aos leitores.

Há dois tipos de sensacionalismo em Cinelândia. Um é o moderado. Serve para atrair o leitor para os detalhes, porque no final da reportagem se percebe a falta de dados concretos, critério parecido com o de Cena Muda e do fait divers de efeito decepcionado, apesar de trazer mais dados com detalhes sobre a vida íntima da estrela. Nesse primeiro tipo, há notícias como a envolvendo o divórcio de John Wayne e Esperanza. Com alarde a revista comunica que os dois estavam hospitalizados quando estourou a notícia da separação. No final, somos informados que a esposa dele estava gripada, e ele fazia exames gerais de rotina ${ }^{6}$. O sensacionalismo cumpre, então, outra função. Prepara o leitor para uma notícia futura, gera expectativa que o relacionamento não esteja muito bem, afinal de contas, algo deve existir por detrás dessa história, pensará o leitor. Edições depois, a revista revela o divórcio. Entre as futilidades presentes em Cinelândia há o excesso na quantidade. Há tantos detalhes sem relevância transformados em notícias, que é difícil digerir tantas "informações".

No segundo tipo, Cinelândia faz maior alarde com os temas, geralmente em reportagens coloridas com chamadas na capa ou anunciadas para as próximas edições. Promete, por exemplo, focalizar de novo "dois novos documentos sensacionais do drama novelesco de Ingrid Bergman, que acaba de ver o seu amor materno repudiado pela filha." Ou seja, pouco importa que a revista já tenha desenvolvido o tema. O leitor quer mais detalhes, e assim, Cinelândia consegue novos dados, nem que para tal invente conteúdos, como era de costume. Este excesso de romantização se trata de uma

\footnotetext{
${ }^{6}$ Parsons, Louella. Os espiões de Cinelândia em Hollywood informam. Cinelândia, v. 1, n. 2, p. 10, junho 1952.
} 
cobertura aos olimpianos ${ }^{7}$, aumentando o interesse a partir do uso da novelização. Há uma ficcionalização da vida das atrizes, secretando "uma substância romanesca ou dramática camuflada em informação", tal como mostrou Edgar Morin (Morin, 1962: 101). Através de situações romanceadas, se fornece na imprensa uma matéria que parece real, mas cuja estrutura afetiva está calcada no imaginário. Resta saber por que o leitor se interessaria por acontecimentos claramente inventados que não informam sobre o andamento do mundo?

A resposta tem relação com o imaginário e com o fait divers. Marlyse Meyer (1996) elucida que o fait divers surgiu em 1863 no jornal Le petit journal. Antes da existência deste termo, se falava em nouvelle, canard ou chronique. São as notícias extraordinárias transmitidas em forma romanceada num registro melodramático que vai fazer concorrência ao folhetim. O conceito de fait divers surge antes da crônica do jornal, nos palanques e praças públicas onde se liam as novidades da aldeia. Daí a marca da oralidade destes textos, fruto do diálogo com os leitores. O folhetim nasce também na França no começo do século XIX, chamado de feuilleton. Por volta de 1870, ele adere ao real e ao verossímil. Enquanto que para Marlyse Meyer o folhetim é o "romance da vida", o fait divers é a "vida romanceada". Ou seja, o primeiro parte da literatura, enquanto o fait divers nasce dos "fatos", geralmente jornalísticos ${ }^{8}$. Há sempre um patético das situações, com gosto pelo excesso melodramático. Sua narrativa quer provocar uma reação subjetiva e passional, diminuindo a distância com os leitores e provocando a ilusão de participar dos eventos citados. (Meyer, 1996: 102)

Quase a totalidade do conteúdo das revistas de fãs é destinada ao fait divers e ao folhetim por sua relação com o imaginário ${ }^{9}$. Morin nos explica que tanto a informação

\footnotetext{
${ }^{7}$ Olimpianos é um termo criado por Edgar Morin para designar não só as estrelas de cinema, mas políticos, reis, esportistas, playboys, etc. No Olimpo, vivem os cinge-deuses, com dupla natureza, de deus e de mortal. Apesar de as atrizes serem mortais possuem um algo a mais, o chamado $i$, que os demais não têm (como por exemplo, beleza e talento). Os mitos são gerados no espaço do imaginário, e deles nascem os personagens dos filmes, ou a função sagrada dos reis ou presidentes. Apesar de o termo ter sido criado por Edgar Morin, Guilherme de Almeida nos anos vinte já se referia ao mesmo conceito, mas sem utilizar a designação de Morin, chegando a dizer: "A idéia que uma grande parte do mundo faz das estrelas de cinema é que elas constituem uma tribo plenamente feliz e irresponsável, acampada nas brancas tendas coloniais de Beverly Hills ou nos perfeitos apartamentos do Ambassador, dali descendo, de vez em quando, para amar e ser amada, ganhar muito dinheiro e muita fama sob as claras-bóias dos estúdios". (Almeida, 1929: 39)

${ }^{8}$ Meyer explica que o sentido da palavra fait divers é uma noção aproximativa. Há dois sentidos, o primeiro é o jornalístico, uma categoria de informação. O segundo é o costumeiro sentido pejorativo, são os fatos da realidade, uma categoria particular de acontecimento.

${ }^{9}$ Meyer mostra como o fait divers é o lugar de exercício do imaginário. Seu relato estabelece com o nosso inconsciente uma relação que reflete a nossa ambivalência. A partir do catálogo da exposição Le fait divers do Musée National des Arts et traditions populaires, Meyer traz a concepção do fait divers como "o lugar da satisfação simbólica das mais elementares frustrações (...) onde se busca o equivalente ilusório
} 
romanceada e vedetizada, além do sensacionalismo, apelam para os processos de projeção-identificação. A estrela serve como duplo. Realiza nos filmes o que os mortais não podem realizar, e os chama para realizarem com ela no imaginário, através das notícias sobre sua vida e pelas romantizações.

A relação do fait divers com o jornalismo não é apenas do século XIX. Ainda em 1690, Tobias Peucer em sua tese Os relatos jornalísticos destacou como características do texto jornalístico uma forma de caráter ameno misturado ao conceito que seria desenvolvido depois como fait divers, comuns às revistas de fãs. Os relatos periodísticos (relationes novellae) contêm, para Peucer, a notificação de "coisas diversas" acontecidas recentemente em qualquer lugar, limitando-se a uma "simples exposição" para que o leitor curioso "se sinta atraído pela variedade de caráter ameno e preste atenção”. (Peucer, 1999)

O caráter ameno descrito por Peucer pode ser facilmente transportado para as revistas de fãs. Além da função de romantizar a existência das estrelas, o sensacionalismo gerado neste nicho de mercado tem outra função, relacionada ao papel das tragédias, embora seu uso seja bem menos recorrente, porque o universo das revistas procura mostrar o lado otimista da vida. Contudo há uma banalização do sofrimento da estrela, tópico que será abordado no próximo capítulo. A banalização do sofrimento tem relação direta com a forma do consumo da imprensa. Estas notícias não são consumidas no rito cerimonial da tragédia, como nos filmes, mas à mesa, na hora do café. Assim o sensacionalismo vinculado pela imprensa, tal como mostrou Edgar Morin, é atenuado em seu conteúdo horrível, ilícito. O interesse sobre as vítimas do sensacionalismo, tanto as da tragédia, como dos jornais, cumpre sua função como projeção. Estes casos, para Morin, são ofertados em sacrifício à infelicidade e à morte: “A catarse é como que digerida no cotidiano, isto quer dizer que o grande tema do sacrifício, 'eles morrem em meu lugar', se atenua num 'são os outros que morrem, não eu’”. (Morin, 1962: 115) Dessa maneira, as esparsas tragédias da vida das atrizes são consumidas pela projeção. O objetivo é provar aos leitores como eles são felizes sem o saber, mostrando as diversas infelicidades da vida dos astros, como por exemplo, não poder ter filhos, ter dívidas ou perder amores ${ }^{10}$.

de uma experiência total do homem, através do excepcional, do atípico, do desviante, a viver ficticiamente a impossível transgressão da ordem social” (Meyer, 1996: 100)

${ }^{10}$ Há diversas matérias deste tipo, que tem como objetivo humanizar os ídolos, para gerar maior identificação. Como exemplo, temos: Conrado, Alberto. Os ídolos também sofrem - por trás da cortina da ilusão. Cena Muda, v. 32, n. 21, p. 15-17, 22/05/1952. 
Grande parte das matérias sobre a tragédia das estrelas é calcada sobre a noção de destino e fatalidade, transportando os leitores ao sonho vivido do imaginário. Assim tais textos cumprem as duas funções descritas por Morin. $\mathrm{Na}$ primeira o sensacionalismo funciona como tragédia, e na segunda "a vedetização funciona como mitologia" (Morin, 1962: 115), fechando seu ciclo.

A relação entre sensacionalismo e imaginário é útil aos meios de comunicação por infringir a ordem das coisas, violar tabus e compelir a lógica da paixão ao extremo. Morin nos mostra que o universo de sonho, tragédia e fatalidade vividos, comum às narrativas sobre as estrelas, valoriza os jornais modernos. Quanto mais espetacular é o sensacionalismo, este será mais valorizado. E para conseguir tornar as matérias mais espetaculares, a imprensa seleciona para a representação do imaginário os fatos com maior carga emocional afetiva, relacionados ao universo projetivo.

Devido à menor ocorrência de fatos sensacionalistas de cunho trágico, as revistas tentam converter brigas de casais em grandes ocorrências, às vezes insinuando agressões físicas, ora declarando ser apenas publicidade para os filmes. São raros os casos de tragédias ou agressões. As histórias que vazam são tratadas com sensacionalismo, mas não há uma repetição através de edições. Ao contrário, os temas são substituídos em pouco tempo por outros, como se estivessem velhos, diferente do que é feito com os romances. Assim, o divórcio de Susan Hayworth e Jess Barker ${ }^{11}$ é tratado com destaque em Cinelândia porque ele agrediu fisicamente a mulher, por anos a fio. Contudo pela necessidade das revistas em contaminar as histórias com um clima positivo, logo a atriz encontra outro amor, e tudo é esquecido.

O caso de maior sensacionalismo em Cena Muda foi a suposta tentativa de assassinato envolvendo a cantora Nora Ney. Ela acusou o marido de obrigá-la a tomar veneno. A denúncia tomou a forma de um box com relativo destaque na publicação. Edições depois, Nora transforma-se na vilã no início de uma nova reportagem, embora no final do texto, situado nas últimas páginas da edição, é novamente convertida em vítima ${ }^{12}$. A Justiça engavetou o caso ao considerá-lo publicidade, conta-nos a reportagem. Depois do suposto envenenamento, a cantora conseguiu lançar seu disco e alcançar sucesso. O marido a acusava de sair todos os dias às quatro da tarde e só voltar

\footnotetext{
${ }^{11}$ Parsons, Louella. O trágico fracasso do casamento de Susan Hayward. Cinelândia, v. 3, n. 28, p. 38-9; $62,1^{a}$ quinz. jan. 1954. O tema deste divórcio aparece em mais duas notas pequenas, sem uma forma de narrativa para aproximar os leitores.

${ }^{12}$ Nora Ney atacada pelo ministério público. Cena Muda, v. 32, n. 48, p. 25-6, 28/11/1952.
} 
no dia seguinte. Como furo de reportagem, a revista declara ter recebido horas antes do fechamento da edição a notícia da tentativa de suicídio do marido.

A tentativa de suicídio do marido da estrela não é retomada em outras edições, substituída por outras fofocas, o que tem relação direta com o tipo de consumo da cultura de massa na busca pelo novo.

Paradoxalmente, às vezes o culto ao sensacionalismo é visto de maneira pejorativa nas duas revistas, como característica apenas dos demais veículos de comunicação. O objetivo é se inocentar do papel desempenhado por elas mesmas. Assim, o repórter anônimo de Cinelândia condena um grupo de "megeras" que se reúnem num restaurante chique em Hollywood para discutir os boatos sobre a vida das estrelas ${ }^{13}$. A culpa recai, não para o leitor, como era comum, mas para as "megeras". Com conseqüência, o jornalista pode trazer as informações das chamadas "megeras", como se estivesse acima delas, transferindo o peso do discurso a outrem.

Há um culto ao detalhe insignificante nas duas revistas no sensacionalismo da futilidade. Era bastante comum na década de cinqüenta o jornalismo enveredar para o fait divers, devido a falta de material das fontes jornalísticas, conforme as observações de época do jornalista Manuel Chaparro. Na escassez de fatos e casos importantes intencionalmente produzidos, o inusitado, o insólito, engraçado e dramático reinavam como atributos decisivos nos critérios de agendamento e edição. O fait divers ganhou honrarias e venerações de mito. (Chaparro, 2001)

As nuances ínfimas adquirem importância para o fã preocupado em consumir a imagem de seu ídolo. As revistas convertem pormenores dos ídolos em fatos de grande relevância, copiando os critérios de noticiabilidade da grande imprensa. Entre os acontecimentos produzidos, baseados em detalhes ínfimos, há, por exemplo, a luz que em um plano reflete no batom da atriz brasileira, estragando a cena, ou detalhes sobre o hotel de beira de estrada onde Marilyn Monroe e Joe passaram sua noite de núpcias. Tais detalhes, chamados por Edgar Morin de "bobagens" a que os estudiosos se negam a estudar, estão relacionadas ao âmago do star system:

"Ninguém se atreve a estudar as estrelas. Mas nossos sábios agem pouco sabiamente ao recusar tratar seriamente as bobagens. A bobagem é também o que há de mais profundo no homem. Por trás do star system não estão apenas a imbecilidade dos fãs, a falta de criatividade dos cineastas, os acordos comerciais dos produtores. Está o coração do mundo. Está o amor, outra bobagem, outra humanidade profunda." (Morin, 1957: 71)

\footnotetext{
${ }^{13}$ Mentiras que contam sobre Liz e Mike. Cinelândia, v. 1, n. 7, p. 30-1, nov. 1952.
} 
Já em Cinearte, havia largo destaque para esse tipo de cobertura. De acordo com Ismail Xavier, "os textos de Cinearte preenchem uma larga faixa de curiosidades e interesses, das virtudes da mãe de Mary Pickford à teoria de Canudo." (Xavier, 1978: 172)

O processo de conversão do fait divers em notícia foi também estudado por Ciro Marcondes Filho (1989). Para ele, a perspectiva burguesa dispõe o mundo de maneira fragmentada ocasionando uma mentalidade fragmentada, diluída, difusa que vê o contexto social e a realidade sem um fio condutor. A fragmentação noticiosa é pertinente à mentalidade fragmentada, quebrando a lógica dos fatos entre si e perdendo a dimensão de uma totalidade que os explique. Caracterizado por uma técnica mercadológica, o fait divers destaca os aspectos sensacionalistas, desvinculando o fundo histórico e social da notícia. As notícias são vinculadas por fragmentos, descontextualizando seu sentido. Através da combinação entre o público e o privado, transformam-se todos os assuntos em objetos de consumo na forma de folhetins. Para Michel Gillet (Gillet apud Meyer, 1996), esse tipo de informação apazigua e suscita a curiosidade para quem o excesso do melodrama sempre foi natural, como se o jornal não fosse compreensível sem o código do folhetim. Talvez sem as fórmulas do melodrama, as notícias sobre os filmes e os atores não ficassem tão interessantes ao olhar dos leitores. Michel Gillet cria o termo "folhetinização da informação": o discurso do fait divers é a tônica da informação de hoje, que não separa o público do privado e tornou muito tênues as fronteiras entre imprensa marrom e imprensa "séria". As duas revistas pesquisadas transformavam os detalhes em acontecimento jornalístico pela forma do fait divers talvez porque “(...) a ficção ainda encanta o leitor, mas ela sozinha não é mais suficiente para alimentar a sua inteligência, que os acontecimentos de cada dia mantêm acessa", como afirmou Michel Gillet.

O fait divers perpassa boa parte da cobertura das duas revistas, só não maior do que a do sensacionalismo positivo romanceado. A vida pessoal dos atores torna-se mais importante que fatos de relevância cultural. Como exemplo, temos a matéria Triângulo desfeito $^{14}$, escrita pela repórter Luelinha $\operatorname{Passos}^{15}$. O nome da jornalista é um pseudônimo que procura se engrandecer através da paródia à famosa colunista americana de fofocas, Louella Parsons. O artigo narra o rompimento do noivado de Ilka

\footnotetext{
${ }^{14}$ Passos, Luelinha. Triângulo desfeito. Cena Muda, v. 32, n. 43, p. 4-5, 24/10/1952.

${ }^{15}$ Cabe uma ressalva porque boa parte dos textos sobre o cinema brasileiro que consideramos mais apelativos, sensacionalistas na revista Cena Muda são deste pseudônimo, assim como o seu congênere na revista Cinelândia era Luis Fernandes.
} 
Soares com Miro Cerni, insinuando algum interesse dele por Fada Santoro. O boato torna-se, para Luelinha, mais importantes que os debates sobre o cinema brasileiro. $\mathrm{O}$ grande acontecimento para a jornalista foi o rompimento do noivado de Ilka Soares e Miro Cerni. A repórter, inclusive, assegura a "obrigação" da revista em se preocupar com a vida alheia. A pequena fofoca ocupou duas páginas repletas de fotografias:

\footnotetext{
"No reino da Dinamarca do cinema nacional fala-se tanto sobre assuntos sobre os quais não se deve falar, que a Cena Muda foi obrigada a me trazer especialmente dos Estados Unidos para escrever os mexericos do cinema nacional. Já que ninguém se interessa com problemas outros, somos obrigados a nos preocupar da vida particular daqueles pobres coitados que só porque vivem do atuar diante da câmera, têm as suas vidas passadas, repassadas, investigadas e devassadas.

Assim para iniciar, temos um grande acontecimento. (Muito maior do que aquele deselegante congresso de cinema, onde não houve 'cocktails', nem 'partys' (sic) e onde só havia discussões e trabalhos. Imaginem que até as nossas estrelas se rebaixaram a colar cartazes e participar dos trabalhos do congresso! Que provincianas! Mas agora eu cheguei!).

$\mathrm{Bem}$, o que aconteceu foi algo verdadeiramente grandioso. Imaginem que a Ilka, aquela coisinha deliciosa, de deliciosos olhos verdes, rompeu o noivado com o Miroslau. Ora não conhecem Miroslau? Então telefonem já para a amiguinha e digam-lhe que Miroslau é sinônimo de Miro. Miro Cerni. Sim, rompeu-se o noivado. Ele é um cara pacato, que estuda na faculdade, acemista constante. Ela, por sua vez, queria continuar a ser estrela. Resultado: romperam, mas continuam a ser amigos...

Apareceu a Fada. Disseram que foi ela a causadora, por causa daquele filme 'Força do Amor', quando ela e o Miro estiveram juntos. Bem juntos, até...

-Mas somos grandes amigas, dizem as duas ao mesmo tempo...

E para provar isto, na festa do Casablanca, a Fada só falava no Cyleno (cada nome cabuloso!). Para encurtar conversas, o Cyleno é o Cyll Farney. Pois é, ela só falava no Cyll e com o Cyll. O triângulo que todos esperavam desfez-se lamentavelmente. Transformou-se num quadrilátero. Agora só falta, para o cúmulo do azar nosso, que o Cyll e o Miro se tornem grandes amigos."
}

Nesse trecho vemos boa parte dos recursos utilizados pela publicação para aproximar-se dos leitores. A todo o momento a jornalista busca dialogar com o leitor, a partir de comentários simpáticos e jocosos, como “cada nome cabuloso!". O texto não recorre somente ao espanto, como também joga com o elemento surpresa. Insinua também com ironia um triângulo amoroso no título, para, por fim, esclarecer que os três são apenas bons amigos, fórmula repetida à exaustão em Cena Muda, como já mostramos. Porém nas entrelinhas e no título cria-se a dúvida na mente do leitor sobre a veracidade dos fatos.

O congresso a que Luelinha refere-se é o I Congresso Nacional do Cinema Brasileiro, realizado em São Paulo em setembro de 1952. Segundo José Inácio de Melo Souza (1981), os congressos foram uma conseqüência do trabalho político de esquerda, sobre os problemas do cinema brasileiro. Grosso modo, era composto de três itens: 1) definição da fita nacional de curta, média e longa metragem; 2) defesa do cinema 
nacional; 3) medidas para o progresso do cinema nacional, subdividido em aspectos econômicos, culturais e legislativos. Contudo, no texto, o congresso foi reduzido a um fato sem interesse por conter discussões e trabalhos, desatrelados do estrelismo, condenando a inclusão das artistas colando cartazes a uma atitude "deselegante".

Num primeiro momento, observando as características irônicas do texto, poderíamos achar que ele se tornaria falho em termos de fait divers, sem gerar aproximação com o leitor. Na verdade, o fait divers mantém no público o hábito da intervenção, explicado por Marlyse Meyer (1996) como uma característica folhetinesca. O critério aqui não é o sensacionalismo romantizado para aproximar o leitor. O fait divers, a partir das observações de Roland Barthes (1970) ${ }^{16}$, se pauta em critérios diferentes. Não busca humanizar. Seu objetivo maior é o espanto, porque não há uma relação como se esperava entre causa e efeito, a partir de conteúdos incertos ${ }^{17}$. Há também o fait divers que traz grandes efeitos para causas pequenas, ou vice-versa. Trabalha-se sempre com o excepcional ou com o insignificante. Nesta matéria, os dois estão presentes: o excepcional como a briga entre os olimpianos, e o considerado insignificante, pautado pela continuidade na amizade, a causar espanto. É exatamente no caráter irônico, embora Barthes não use este termo, que se pauta sua descrição sobre as duas formas mais comuns de fait divers. No início desta matéria, se sobressai a causalidade decepcionada, porque se afiança que Miro Cerni rompeu o namoro, mas assim mesmo ele continua amigo da ex-noiva. Elas não brigaram, nem se desentenderam. "Como pode ser isso possível, perguntará o leitor?”, gerando o espanto previsto no fait divers. Daí reside a decepção e a força do relato. Neste caso, a causalidade revelada é mais pobre do que a causa esperada, e o fait divers se realiza em toda sua forma. Neste caso, quanto maior a causalidade decepcionada (brigaram apenas

\footnotetext{
${ }^{16}$ Para Barthes, os gestos das estrelas não são fait divers porque exigem um conhecimento anterior de sua história. Um conteúdo digno de ser chamado de fait divers é fechado em si mesmo, pode ser entendido sem remeter a nada implícito. O fait divers não exige qualquer tipo de conhecimento por parte do leitor, é uma informação total, imanente que contém em si todo seu saber. Barthes vê os gestos das estrelas como fragmentos de romance, os fatos apenas são variantes do romance. Porém, depois Barthes considera o fait divers como literatura, por existir apenas no universo da significação, do intelecto de seu criador. Contudo, acreditamos que a narrativa das revistas de fãs sobre as estrelas são fait divers, porque apresentam todas as informações necessárias ao seu entendimento, não deixando nada subentendido, mesmo que tenham estrutura de episódios através da linguagem romanceada. É possível ler uma fofoca sobre um ator que não conhecemos, e entender tudo, porque como no fait divers, é implicada uma memória curta sobre os eventos. Não há assim nada implícito, sem exigir conhecimento anterior, apesar da narrativa se estruturar sobre a forma de romance. (Barthes, 2003)

${ }^{17}$ Como exemplo de causalidade decepcionada, temos a frase de Barthes, "mulher esfaqueia o amante", enquanto se espera uma resposta sobre brigas amorosas, o fait divers revela que ela matou o amante porque discordavam em questões de política. Daí surge o espanto, a partir de um conteúdo incerto pela imprecisão entre causa e efeito.
} 
porque ela queria continuar na carreira), seus efeitos (a perpetuação da amizade e a ausência de brigas dos ex-namorados) se tornam mais notáveis ${ }^{18}$. A causalidade decepcionada da continuidade da amizade após a separação do casal é acrescida da informação sobre Ilka não ter brigado com a mulher causadora do rompimento, no caso Fada Santoro. Este segundo efeito da sentença, passa da causalidade decepcionada (o casal continua amigo) ao espetáculo espantoso porque o esperado seria $\mathrm{o}$ desentendimento entre as duas atrizes. $\mathrm{O}$ espanto da continuação da amizade entre os quatro protagonistas deixa de ser de decepção, para passar a uma surpresa de grande efeito.

Apesar de o fait divers tudo explicar, algo foge ao leitor. Há forças que constantemente lhe escapam. As causas parecem penetradas pelo acaso ou pela coincidência (as duas andam juntas, segundo Barthes). Como conseqüência, as causas fogem do entendimento do leitor, gerando uma significação que foge ao racional. Assim, o recurso cumpre a função de preservar na sociedade a ambigüidade do racional e irracional, sendo que a ambigüidade é um dos motes da configuração do star system nas duas revistas, como veremos. O sensacionalismo vinculado numa revista de fã é o positivo porque sofre, portanto, as influências dos estúdios. Seu objetivo é a publicidade dos filmes, daí o maior interesse em insinuar informações picantes. Da repetição de um acontecimento, o leitor é levado a imaginar uma causa desconhecida, que sempre escapa. A repetição dos fatos ganha, portanto, uma significação.

A possibilidade dada pelo fait divers de abordar a ambigüidade permite trazer uma alta dose de ficção sob a credencial do jornalismo às duas revistas de fãs. Enquanto o fait divers nas revistas utiliza-se mais do efeito denominado como espanto, o sensacionalismo positivo via romantização da vida das estrelas ocupa a maior parte das páginas editoriais de ambas. Já a fofoca, como parte integrante das duas estratégias descritas aqui, se reveste duplamente da novelização da vida mediática das estrelas e da surpresa contida no conteúdo incerto a partir da causalidade, como veremos no próximo tópico. Antes, porém, vale pontuar que o sensacionalismo positivo das revistas de fãs centrado sobre a vida das estrelas era confrontado por outro tipo de sensacionalismo nos Estados Unidos. Surgia em 1952 a revista Confidential, um típico veículo da imprensa marrom, que tinha como foco as celebridades. No início, seu editor Robert Harrison não checava os dados, acreditando nas fontes. O que lhe ocasionou alguns processos por

\footnotetext{
${ }^{18}$ Para Barthes, “a causalidade é tanto mais notável quanto mais é decepcionada”. (Barthes, 2003: 62)
} 
calúnia. Depois, Harrison contratou agências de detetives para seguir os famosos com reputação duvidosa, entre eles os ídolos de Hollywood. A revista conseguia informações da vida sexual dos atores, colhia depoimentos das pessoas com quem os astros tinham se envolvido sexualmente, obtinham fotos e gravações de conversas íntimas para a publicação ${ }^{19}$. Dulce Damasceno de Brito (1992) conta que a circulação da revista era de três milhões e quatrocentos mil exemplares. O senado norte-americano exigiu uma investigação sobre as agências de detetives de Hollywood, que envolviam $70 \%$ das celebridades de Hollywood. Um promotor pediu o fechamento da revista por sua imoralidade e obscenidade. Assim com o processo, os casos mais pesados vieram à tona nos tribunais. Após o julgamento, em 1958, a revista minguou até morrer, como as congêneres Whisper e Exposed. Ou seja, a representação positiva das revistas de fãs, pelo menos nos Estados Unidos, ficava cada vez mais óbvia e falseada, quando entravam em cena revistas como Confidential. (Brito, 1992)

\subsection{Fofoca}

Um dos maiores recursos do sensacionalismo nas revistas de fãs, é a utilização das fofocas, o ponto alto das duas publicações. Mais do que as escassas tragédias sobre as estrelas, as fofocas trazem um universo de sonho positivo aos leitores. A vida amorosa é seu palco, deixando em menor grau as informações sensacionalistas negativas sobre situações de trabalho, ou críticas às estrelas, como já dissemos.

Na construção textual da fofoca utilizam-se manchetes de caráter extraordinário com alta teor afetivo, como já mostramos no caso do sensacionalismo. O objetivo é criar um clima amigo entre leitores e jornalistas, característica que abordaremos no próximo item. O estilo remete ao folhetim, trazendo todo o passado das estrelas e utilizando técnicas de suspense sobre seu futuro. Transforma-se, assim, a vida mediática das estrelas em um filme para consumo. Há a retomada até de fatos antigos, como divórcios já comentados, que as revistas, principalmente Cinelândia, insistem em retomar. Trazem através do mecanismo de repetição, toda a vida amorosa pregressa. Cozinham, assim, os fatos do passado para revelar detalhes insignificantes, vistos como

\footnotetext{
${ }^{19}$ A revista procurava desvendar romances interraciais ou extraconjugais, trazia os nomes dos atores na lista negra por causa do comunismo, assim como casos de famosos que eram homossexuais ou suicidas. Confidential chegou a ir mais longe. Francesca de Scaffa, ex-esposa de Bruce Cabot, confessou seu acordo com Confidential. Tentaria seduzir sexualmente qualquer astro para obter material escandaloso para a revista. A malícia do texto estava nas entrelinhas, porque havia advogados substituindo palavras para evitar processos.
} 
segredos. Como exemplo de fofoca que se propõe a analisar quem é a verdadeira Marilyn Monroe, pautada sobre a sua dualidade, temos a reportagem de Cinelândia sob o título Os dois mundos de Marilyn ${ }^{20}$ :

"Desde que casou, Marilyn Monroe vivia em dois mundos completamente diferentes: à noite era o mundo de Joe, e o do lar; de dia o seu mundo e a sua carreira.

Esses dois mundos estavam perfeitamente separados um do outro, e Joe e Marilyn faziam interiormente a pergunta vital: Seriam esses dois mundos antagônicos ou complementares?

Poderia Marilyn ser uma pessoa durante o dia, e outra totalmente diferente à noite?"

Boa parte das fofocas utiliza esta estrutura textual. Começa com uma dúvida acerca de uma situação. Depois os agentes são vitimados e/ou acusados, com alguma dose de fatalidade e destino. No caso, o casamento não daria certo porque a carreira da atriz e sua imagem sensual atrapalharam a união do casal. A dúvida sobre o porquê da separação faz o leitor partilhar de uma angústia em não saber o destino daqueles deuses, tendo em vista a possibilidade da reconciliação. Recorre-se ao suspense, não porque se desconhece seu final, afinal, todos já sabiam que o casamento tinha fracassado, mas porque detalhes supostamente significantes são tomados como reveladores. Joga a fofoca com a mitificação para tentar desvendar se os atores seriam deuses com destino já traçado, ou humanos, com o poder de alterar sua sorte. Os atores semi-humanos conseguem mudar seu destino, mas também recaem sobre eles o destino e a fatalidade, devido a sua composição humana e divina. Volta-se, então, ao mesmo processo de mitificação. Pouco importa neste contexto, a qualidade dos filmes produzidos, ou o talento de Marilyn Monroe como atriz, tal discussão é deixada de lado, porque interessa mais a fofoca sobre a vida da estrela. Edgar Morin comentou ainda nos anos sessenta que mais importante do que o filme é a vedete, e mais importante que a participação da estrela na fita é a fofoca a respeito dela. A teorização de Morin não é exatamente uma novidade, constatada já pelas revistas de fãs do período. Certa vez, Zenaide Andrea admitindo não ter fofocas para contar, sintetiza a mesma teoria: "conformem-se, porém, os fãs nacionais, porque mesmo em Hollywood não é todo o dia que astros e estrelas dão cartaz aos mexericos dos cronistas.... E passemos aos filmes, à falta de melhor novidade." ${ }^{21}$ Assim, se revela que o cinema que era o suposto objeto de Cinelândia, na verdade, é só um meio para trazer fofocas. O boato se justifica editorialmente pelo interesse dos fãs. Não pela necessidade de vender revistas.

\footnotetext{
${ }^{20}$ Cinelândia, v. 3, n. 49, p. 19; 60; 68, 2a quinz. nov 1954.

${ }^{21}$ Andrea, Zenaide. O que eu vi nos estúdios. Cinelândia, v. 3, n. 43, p. 46-7; 57, $2^{\text {a }}$ quinz. agosto 1954.
} 
O interesse pela vida pessoal dos atores não é novo. Nasce no teatro, ainda no século XIX, como mostrou Richard DeCordova (2001). O processo tem, também, relação comprovada com o desejo dos leitores. Conhecer todas as intimidades possíveis da atriz torna-se para o leitor "um meio de apropriação mágico", descrito dessa forma por Edgar Morin, enquanto os mexericos são o "plâncton" de que se alimenta o estrelismo. Chega Morin, então, à função da fofoca, que seria não apenas transformar "a vida em mito, o mito em realidade", mas desvendar todos os detalhes, para a curiosidade insaciável dos fãs. (Morin, 1957: 60) Havia, portanto, demanda por parte dos leitores pela fofoca, num ciclo de retro-alimentação, alimentado por estas revistas.

A fofoca em Cena Muda ocupa posição de destaque no início de 1952, na página três da revista, ou seja, na primeira página textual da revista. A proeminência para os boatos não foi uma novidade em 1950. Já existia na década de vinte, numa coluna chamada Mexericos de Hollywood, constituída de notas sobre a vida privada das estrelas $^{22}$. Contudo o espaço não era assinado, composto de notas dos departamentos de publicidade, sem grande trabalho de cozinhar textos jornalísticos. Os releases eram trazidos de forma rudimentar, sem estratégias para aproximar o leitor, ou detalhar a moradia das estrelas, penteados, gostos, a partir de declarações dos atores. No período estudado, há um tratamento jornalístico à fofoca, a partir de mecanismos de autenticidade, utilizando as estratégias textuais descritas neste capítulo. Assim, sob o símbolo de uma caveira, o box escrito pelo pseudônimo de Frankie alertava em 1952, para as características da fofoca:

\footnotetext{
“esta é uma seção de venenos. O cronista não se responsabiliza pelas notícias recebidas. As pessoas atingidas podem nos esclarecer a respeito. As contestações serão publicadas, a bem da verdade. E, por favor, não troquem de mal comigo." 23
}

O rumor sobre a vida das estrelas é considerado pela própria publicação como veneno. Dessa maneira, a revista procura se engrandecer pelo suposto potencial destrutivo de suas declarações. A seção deixa claro que a fofoca não tem a intenção de se mostrar como realidade; são apenas toxinas. Venenos têm função de matar, ou intoxicar, corromper moralmente, através de interpretação textual comprometida. Não buscam espalhar uma visão monótona sobre o mundo. Os rumores nas duas revistas geram uma dúvida no leitor sobre a veracidade ou não dos casos, aumentando a

\footnotetext{
${ }^{22}$ Depois, no final de 1952, esse espaço passa a ser ocupado pelo sumário e a seção Conversa da Semana, geralmente sobre os problemas do cinema brasileiro, desviando as fofocas para as páginas seguintes, legitimando a revista como um produto cultural interessado no desenvolvimento do cinema brasileiro.

${ }^{23}$ Frankie. Vendo a caveira. Cena Muda, v. 32, n. 1, p. 4, 03/01/1952.
} 
demanda pela continuação daquelas histórias, para desvendar segredos. Pautam-se na suspeita e expectativa de que a própria fofoca possa estar errada. A dúvida é a chave.

No trecho acima descrito, como em muitos outros, o colunista não hesita em revelar não ter certeza sobre os fatos, uma das características do discurso da fofoca. Dessa maneira, se exime da culpa em caso de erro, deixando claro também que não pretende brigar com os artistas atingidos. Trata-se de um discurso válido aos leitores para provar sua boa vontade, revelando de maneira oculta que sobrevive desta função. Legitima seus venenos porque se compromete a publicar as contestações, convertidas em verdades, tentando abrandar o próprio sentido da palavra. As invenções dos departamentos de publicidade são mostradas aos leitores como verdadeiras, até que se prove o contrário. Só assim, pode-se questioná-las.

A fofoca funciona como mecanismo inverso ao preceito jurídico. O réu no Direito não tem a obrigação de provar sua inocência. $\mathrm{O}$ acusador, sim, deve comprovar a culpa do acusado. Aqui, os réus, acusados ou vítimas, devem provar as invenções dos jornalistas ou departamentos de propaganda, já que os acusadores, ou testemunhas anônimas, são sempre válidos para provar histórias, porque o sensacionalismo move as publicações. Mas provar o contrário nestas publicações não é difícil porque geralmente os discursos são aceitos sem maiores problemas. Assim, a fofoca não precisa se basear em provas realmente contundentes, para a percepção nem dos jornalistas, nem do entendimento sobre o que pensa o leitor. Afinal de conta são boatos. Vale mais a dúvida gerada do que a comprovação das teses.

Não havia nenhuma mínima preocupação com a checagem das informações ou a veracidade dos fatos, para evitar perda de credibilidade porque há interesses coincidentes entre as revistas, estúdios e astros. Mais importante era levar ao público os rumores. Esse perfil não se altera com as diversas reformas acontecidas em $1952 \mathrm{em}$ Cena Muda. E ocorre da mesma maneira com continuidade editorial na revista concorrente. É explicitado diversas vezes como algo positivo. Quando se noticia que Tom Payne teria esbravejado, porque não quiseram entregar-lhe a fita do filme Ângela (1951) de volta nos corredores do Festival de Punta Del Leste, o repórter, provavelmente o enviado especial da revista, Leon Eliachar, de Cena Muda, escreve que iria publicar, apesar de faltar ouvir o lado do diretor argentino ${ }^{24}$.

\footnotetext{
${ }^{24}$ Cena Muda, v. 32, n.8, p.8, 21/02 /1952.
} 
Os espaços para a fofoca mudam de página e passam a ser feitos por diferentes jornalistas em Cena Muda. A chamada a Louella Parsons brasileira, Dulce Damasceno de Britto, correspondente da revista $O$ Cruzeiro em Hollywood, passa a assinar a seção Hollywood Boulevard no final de 1952, em Cena Muda ${ }^{25}$. Posição antes ocupada por Gilberto Souto, então repórter de Cinearte, na época correspondente e responsável pela coluna Diretamente de Hollywood em Cena. E, por último, a seção $O$ que a tela não mostra, escrita por Lívio Dantas.

Cena Muda não encobria o material publicitário utilizado das agências americanas e se orgulhava deste aspecto, como Cinearte. Em meados de 1952, surgem algumas seções como Novidades da Universal Internacional, sem tentar esconder que se trata de material de divulgação. Copiar os releases tinha um tom positivo para Cena por se tratar de ter acesso a tais dados. Contudo estas seções não têm regularidade. Cinelândia cozinha o release para dar a impressão de furo jornalístico, insinuando que as informações obtidas foram conseguidas através da intimidade do repórter com a estrela, como veremos no próximo capítulo. A tática de Cena Muda de não transformar os boletins das empresas em furos de reportagem era usada por outros jornais da época. De acordo com Maria Rita Galvão, vários jornais e revistas, sobretudo do interior, mantém a numeração original e os títulos Últimas da Vera Cruz, ou Novidades da Vera Cruz para os releases enviados pela empresa. (Galvão, 1976)

A atriz brasileira alvo de maiores fofocas nas duas revistas é Fada Santoro. E como ela personificava o papel da boa moça de família, aguçava-se mais a curiosidade a respeito de sua vida sentimental. Durante o ano de 1953 houve diversas notas envolvendo seu suposto romance com Cyll Farney em Cena Muda, embora nenhum dos dois admitisse o relacionamento.

Além de insinuar romances, as duas revistas tentaram uma vez trabalhar com a traição no cinema nacional, criando um triângulo amoroso, quase um quadrilátero, cujos personagens foram Miro Cerni, Ilka Soares, Fada Santoro e Cyll Farney. Esta história já foi descrita no item acima para mostrar o funcionamento do fait divers. Retomamos o tema, a partir de outro artigo, para revelar os mecanismos da fofoca. Há um fato que foi antecipado de verdade nesta matéria descrita aqui que é a antecipação do rompimento do namoro de Miro e Ilka. O resto Cena Muda insinua sem nada provar, afirmando ser

\footnotetext{
${ }^{25}$ Dulce foi enviada como correspondente dos Diários Associados em 1952, assinando uma coluna diária para os 28 jornais associados, além de uma entrevista exclusiva para $O$ Cruzeiro. Dulce Damasceno de Brito admite que muitas publicações reproduziam sua coluna, provavelmente este deva ser o caso de Cena Muda. (2006)
} 
Fada a causadora do fim do relacionamento. Sob o título Fada que desmancha casamentos - é boato ou verdade? ${ }^{26}$, a fonte da reportagem é supostamente uma leitora ligada a uma empresa de São Paulo. Ela afirma ser Fada a causadora do rompimento do casal. O motivo teria sido Miro Cerni "representar muito bem com Fada". O sensacionalismo faz com que a frase venha no plural: desmancha casamentos. Apesar de o título conceder o direito à dúvida aos leitores, o texto encerra com a certeza da traição em uma legenda: "Miro Cerni em colóquio amoroso com Fada Santoro, cenas que levaram sua noiva - Ilka Soares - a acabar com o noivado". E antecipa: Ilka Soares pretende se vingar saindo com Cyll Farney.

Tal boato auxilia na divulgação do filme A força do amor (1952), de Eurides Ramos, estrelado por Fada Santoro e Miro Cerni. Certamente a história foi criada com esse intuito. As fotos da matéria são as do filme para reforçar a divulgação, uma estratégia frágil que sempre era usada por ambas as revistas, também para o cinema norte-americano.

Os supostos relacionamentos, como este, eram utilizados como estratégia de propaganda útil à divulgação dos filmes, imitando o padrão americano, que já inventava romances para vender filmes. Há uma "coincidência" altíssima de insinuar romances exatamente entre os protagonistas dos filmes, por hora de seu lançamento. A fofoca se rende aos motivos econômicos e à invenção dos departamentos de publicidade. Surge em função da divulgação dos filmes. Mecanismo este já verificado por Edgar Morin, quando o autor mostra como os jornalistas de cinema farejam, descobrem rumores, ou se apropriam deles, "e, em último caso, o inventam". (Morin, 1957, 60)

Eliane Lage conta em suas memórias ${ }^{27}$ que o departamento de publicidade da Vera Cruz queria que ela fosse "flagrada" numa boite com Anselmo Duarte para insinuar um romance entre os astros de Sinhá Moça (1953), de Tom Payne.

Obviamente a maior parte dos romances são invenções dos departamentos de publicidade. Não temos condições de averiguar a veracidade de cada fofoca, nem se faz necessário, porque ficam claro as invenções, como provaremos a partir do próprio material consultado mais tarde, a partir das fofocas sobre o cinema estrangeiro. Trabalhamos com as representações na imprensa sobre as estrelas. Por isso não importa aqui o estudo biográfico sobre as estrelas, para comprovar as invenções. Assim, não traremos a todo instante, informações como lembrar que Rock Hudson era

\footnotetext{
${ }^{26}$ Cena Muda, v. 32, n.34, p. 07-08, 15/08/1952.

${ }^{27}$ Lage, Eliane. Ilhas, veredas e buritis. São Paulo: Brasiliense, 2005.
} 
homossexual, quando as revistas vendiam seu perfil como heterossexual ${ }^{28}$. O importante aqui é o uso da fofoca como ferramenta útil à publicidade dos filmes.

Voltando à reportagem citada sobre o suposto fim do relacionamento de Miro e Ilka, o autor anônimo aproveita-se da certeza de que o valor dos boatos não é durável, teorizada por Jean-Noel Kapferer (1993). Deve ser utilizado o mais rápido possível. Tenta-se trabalhar com o conceito de instabilidade e rápidas mudanças no cinema nacional para justificar a pressa em fornecer o boato. A pressa nasce de uma tentativa de estabelecer uma atmosfera onde os atores trocavam de pares amorosos com uma constância característica do cinema hollywoodiano, em frases como a da matéria sobre Fada e Cyll, citada acima: "para ilustrar a novidade (que talvez já esteja velha quando esta reportagem sair), damos aqui várias fotos da película da Cinelândia filmes (...) para que os leitores possam ajuizar melhor." Assim, enfatizam as fotos, que são na verdade o material de divulgação que se quer vender pela invenção da fofoca.

A estratégia das revistas é utilizar uma fonte jornalística, muitas vezes anônima, para se engrandecer em dividir tal segredo com o leitor. É alguém ligada a uma empresa de São Paulo, anônima, que revela o boato sobre Fada, mas apesar de não se identificar, ninguém contesta as informações.

Entre 1952-53, o romance sobre Fada e Cyll raramente é questionado pelos jornalistas, mas os repórteres sempre trazem a negativa dos envolvidos, aumentando a dúvida sobre as informações. À medida que o tempo avança, e nada ocorre, ou seja, eles não se casam, as revistas tentam explicar os fatos aos leitores, utilizando os mecanismos que incluem a dúvida, certeza e novo questionamento. A partir de 1954, as comprovações do romance entre Fada e Cyll ficam cada vez mais frágeis. Zenaide Andrea em Cinelândia confirma que Fada a autorizou a contar que vai mesmo casar com Cyll ${ }^{29}$. Por outro lado, Cena Muda anuncia (mais de uma vez) o casamento quando o ator voltar da Europa ${ }^{30}$, mas confessa que a atriz ainda não admitiu o relacionamento. Todas estas informações são trazidas em espaços de tempo muito próximos, repetidas por meses a fio, com dados contraditórios. As fofocas ainda incluem afirmar que Cyll está magrinho porque está distante da amada ${ }^{31}$. Se o leitor acompanhasse a leitura das duas revistas, perceberia que algo estava errado. Antes mesmo desta cobertura no meio

\footnotetext{
${ }^{28} \mathrm{Na}$ verdade, Hudson compactuava com a criação, chegou a pagar a secretária de seu agente para manter um casamento de fachada por dois anos.

${ }^{29}$ Andrea, Zenaide. O que eu vi nos estúdios. Cinelândia, v. 3, n. 45, p. 50-1; 69, $2^{\text {a }}$ quinz. set. 1954.

${ }^{30}$ Cinema nacional em foco. Cena Muda, v. 34, n. 27, p. 18-9, 21/07/1954.

${ }^{31}$ Dias, Gilmar. Cinema nacional em foco. Cena Muda, v. 35, n. 4, p. 8, 2 a quinz. fev. 1955.
} 
do ano de 1954, Cinelândia confessa indiretamente as invenções da própria revista sobre o casal, mas culpa os atores. Zenaide conta que Cyll desmentiu o romance com Fada, declarando que fizeram "toda a sua novela de amor que dura já bastante tempo, como um recurso moderno de publicidade" ${ }^{32}$. Nesse texto, pode-se ver o maior recurso da fofoca na revista, através da dúvida, certeza e novo questionamento. Depois de confessar ser tudo invenção, uma declaração inédita que não voltará a se repetir no caso de Fada e Cyll, a repórter assume que não acredita nas informações. Insiste no romance, como se houvesse uma conspiração e segredo a desvendar:

\footnotetext{
“Acontece, porém, que nos não acreditamos nessas 'manifestações' de última hora, hein, leitores?... Temos visto os dois parzinhos enlaçados, de mãos dadas, olhos nos olhos, unidos o mais idilicamente que é possível neste mundo de tantos idílios - que é o da turma cinematográfica... e querem saber mais de outra? Ambos os galãs, quando longe dessas suas amadas, caem numa bruta melancolia... A respeito de Cyll, vocês todos já puderam constatar isso."
}

Para provar sua teoria sobre a veracidade do amor entre Cyll e Fada, Zenaide confessa que Carlos Alberto e Dóris Monteiro fingem um romance. Cerca-se da estratégia de se declarar uma testemunha ocular e onipresente para comprovar seu papel de desvendadora de mistérios. Assim, o leitor ficaria mais inclinado a acreditar na informação dada antes sobre Cyll. Afinal Zenaide tudo sabe; foi até honesta para desmentir um romance. A repórter declara tratar-se de uma "brincadeira" de Dóris e Carlos. Dessa maneira, confere a uma clara estratégia de propaganda o status de um jogo sem maldade. Sendo uma brincadeira, não há punidos, nem os atores, nem a publicidade, muito menos a revista.

Passa a ser cada vez mais comum narrar aos leitores que boa parte dos relacionamentos são inventados pelos departamentos de propaganda, mas sempre se tenta provar que tal história é verdadeira, ou seja, as revistas fingem não participar da publicidade dos filmes, mas usam o questionamento sobre a utilização dos departamentos de publicidade como mecanismo para aumentar a curiosidade.

Guilherme de Almeida nos anos vinte era mais sincero com seus leitores em termos de confessar a publicidade. Mostra no seu livro Gente de cinema (1929), que todos os noivados, rompimentos e uma tentativa de suicídio de um fã, fatos relacionados a Clara Bow, foram simples meio de propaganda. Revela que o resultado desejado foi alcançado. A atriz passou a receber trinta mil cartas por mês. O comentário de G. de Almeida é escrito como se o autor fosse um fã decepcionado, por constatar as

\footnotetext{
${ }^{32}$ Andrea, Zenaide. O que eu vi nos estúdios. Cinelândia, v. 3, n. 29, p. 48-9; 61, 2ª quinz. jan. 1954.
} 
invenções. Considera depois que Hollywood tudo inventa, ao se referir a Joan Crawford. Ou seja, se considerarmos o livro de Guilherme de Almeida, percebemos que houve um avanço em termos de denegação dos interesses econômicos.

No geral, as duas revistas nunca iriam desnudar dessa forma a fofoca, porque viviam dela. Apesar de tratar a fofoca como invenção dos departamentos de publicidade, Cinelândia consegue admitir certa vez, de forma indireta, pela declaração do ator Anselmo Duarte, que os que "escrevem sobre cinema" inventam histórias, culpando os leitores:

\footnotetext{
"vocês mesmos já sabem da história, e talvez sejam até um tiquinho responsáveis por isso: o diz-que-diz não pára em torno da vida deste jovem e simpaticíssimo casal da tela paulista (Ilka Soares e Anselmo Duarte)... (...) Quando (os jornalistas) não sabem mais o que dizer aos leitores, pensam com eles mesmos: e se inventássemos uma briguinha entre 'eles'?". ${ }^{33}$
}

Revela o repórter os mecanismos das fofocas, dizendo que os contos vêm bem imaginados e apresentados, porque os que escrevem sobre cinema são "mestres na arte da ficção". Jornalismo vira ficção para Cinelândia. Mostra também Werneck de Aguiar que os atores nem se irritam com as invenções, porque segundo Anselmo, "mesmo falando mal, é interessante que falam de nós, os artistas...” O jornalista embaralha a declaração do ator sobre a imprensa "falar mal" como forma de publicidade útil, para conferir a ele indiretamente participação nas invenções da mídia. Tenta-se, portanto, mostrar ao leitor que a fofoca beneficia a todos: os leitores que demandam histórias novelizadas, os jornalistas que vivem desta labuta, e os artistas com a publicidade gratuita. A veracidade dos fatos, como discurso, pouco importa, apesar de se tratar de jornalismo. Ela só serve como recurso jornalístico para se acreditar nos rumores, pela credibilidade conferida à imprensa.

O boato é alimentado em grande parte também pelo segredo que a estrela faz de sua vida sentimental, daí a importância das atrizes manterem sob sigilo seus amores. A enorme quantidade de fofocas pode ser explicada como uma necessidade do fiel/fã de consumir o seu Deus/estrela. Adentrar na vida da estrela, de acordo com Morin, significa para os leitores partilhar de alguma confidência: "toda informação traz algum segredo que permite ao leitor apropriar-se de uma parcela da intimidade da estrela (...). Daí a importância das confidências, indiscrições e entrevistas", que alimentavam na década de 50, época áurea do star system com mais de 500 jornalistas estabelecidos em Hollywood. (Morin, 1957: 61)

\footnotetext{
${ }^{33}$ Aguiar, Werneck de. Tudo em technicolor. Cinelândia, v. 3, n. 36, p. 30-1; 62, 1ª quinz. maio 1954.
} 
Não basta nas revistas de fãs apenas divulgar o modo de vida e a felicidade dos olimpianos, sua beleza, amores, vida regrada a festas, viagens e muito dinheiro, é necessário o tratamento textual transformando a informação em confissão e segredo, aumentando a curiosidade do leitor. As fofocas mantêm aceso o interesse dos espectadores. De forma geral, a estrela não pode manter sua vida pessoal em total segredo, para não ser esquecida. Nem pode tornar sua vida um livro aberto, com o perigo de não se tornar atraente ao espectador interessado em partilhar uma informação não conhecida por todos. Entre o segredo e algumas revelações, o boato se alimenta pela importância enorme dada ao fato, e uma ambigüidade considerável que cerca o segredo sobre o ídolo.

Assim, quando se descobre um novo boato, as revistas comentam em tom entusiasmado. Como exemplo, temos o casamento de Jardel Filho supostamente em segredo. A notícia entusiasma Cinelândia por ser semelhante à Hollywood: "não é que isto aqui está mesmo virando Hollywood? Nossos artistas já casam secretamente... Vai bem, não é? ${ }^{34} \mathrm{O}$ mesmo tom é apresentado também para os mexericos e briguinhas, quando Cena Muda declara que “o cinema brasileiro já está produzindo suas intriguinhas e mexericos à moda de Hollywood" ${ }^{35}$. Assim, o padrão hollywoodiano de muitas fofocas, tentava ser copiado, e geralmente inventado. O intuito é gerar nos espectadores uma demanda por fofocas sobre atores brasileiros. A tentativa de criar uma idéia de muitas fofocas e romances, cai por terra facilmente se o leitor continuar a ler com atenção as demais notícias. Certa vez, Cena Muda sem conseguir descobrir novas fofocas, reclama:

"no cinema brasileiro ninguém briga com ninguém, ninguém faz picuinhas, ninguém tem ciúmes de ninguém. Trabalha-se num ambiente de ordem e progresso. Mas, que diabo! Isso deve ser muito monótono!"36

Os boatos que permeavam as edições das duas revistas tentam fingir ter um fundo de verdade, semelhante a um vazamento de informações, mostrado já por JeanNoël Kapferer. Seu valor está na ruptura de um segredo. Quando mediatizado, o rumor adquire um critério mais elevado porque é permeado por uma aura de credibilidade. Ele incomoda por não poder ser controlado. Se fosse totalmente falso, ninguém acreditaria. O boato, como estudado por Kapferer, se caracteriza pela "emergência e circulação no

\footnotetext{
${ }^{34}$ Fernandes, Luiz. Uma voltinha pelos estúdios. Cinelândia, v. 1, n. 5, p. 24, set. 1952.

${ }^{35}$ Cena Muda, v. 32, n.33, p. 07-08, 15/08/1952.

${ }^{36}$ Dantas, Lívio. O que a tela não mostra. Cena Muda, v. 32, n. 38, p. 15, 19/09/1952.
} 
corpo social de informações que não foram ainda confirmadas publicamente pelas fontes oficiais, ou que não são desmentidas por elas." (Kapferer, 1993: 16) Embora exista também nas duas revistas as informações desmentidas pelos atores, que mesmo assim se revestem de uma aura de credibilidade, dada pelo prestígio de fontes jornalísticas, muitas vezes anônimas.

Quem nos conta os boatos geralmente é uma testemunha ocular. Seu interesse sempre parece ser altruísta, como grande parte das informações recebidas por testemunhas diretas. Ambas repousam sob a confiança. A testemunha ocular vale mais do que um "diz-se que". Sua honestidade não pode ser questionada. Os divulgadores dos boatos declaram-se sempre muito próximos da origem. Nesse aspecto, segundo Kapferer, o boato "é um veículo eficaz de coesão social" que serve para incitar a participação do grupo. (Kapferer, 1993: 48) É também uma maneira de expressar pulsões reprimidas em ambientes de rígida moral. Para garantir o recebimento da informação, sempre se eliminam os pontos obscuros. A sedução do boato é feita porque temos necessidade de ter ordem mental para as coisas quando questões importantes ficam sem resposta. Assim, numa época de conservadorismo, as fofocas sobre os romances das estrelas estrangeiras expressavam os desejos reprimidos da sociedade.

Richard Dyer (1998) explica a importância da estrela quando há valores em crise, a partir do conceito de carisma, a partir do significado desenvolvido por Max Weber. É o caráter sobre-humano e as qualidades individuais que diferenciam um indivíduo dos demais, endossando suas características excepcionais. O carisma geralmente aparece quando a ordem moral aparece incerta. Os dotados de carisma oferecem assim valores, ordem ou estabilidade. Porém, Dyer admite a dificuldade de estabelecer ao certo o potencial da estrela como gerador de valores, função ou como ideologia específica. Nem sempre é possível relacionar política e estrela, como foi feito por Charles Eckert sobre Shirley Temple. Em sua perspectiva, a atriz mirim reenfatizava nos filmes os valores sob ameaça durante a Depressão americana. (Gledhill, 1990)

Grande parte dos boatos toma as dimensões de notícias sobre a vida pessoal nas duas publicações à semelhança com o que foi dito por Kapferer porque "o boato é uma comunicação ao nível da emoção: ele incita os comentários morais, as opiniões pessoais e as reações emotivas." (Kapferer, 1993: 53) Daí grande parte das fofocas serem acompanhadas de juízos de valores, como mostraremos no próximo capítulo sobre as críticas às estrelas. 
Cena Muda certa vez foi mais longe ao admitir que a fofoca tenha relação com a constituição da celebridade com apelo popular, mostrando ao leitor que a "popularidade de um 'astro' mede-se pela soma de mexericos que se espalha a respeito" ${ }^{37}$. Cita os produtores dos estúdios para enfatizar que nenhum artista sem grande cartaz será personagem de boatos sensacionais. Admite também Cena Muda que muitos atores pagam publicistas ${ }^{38}$ para inventarem engenhosas mentiras, permanecendo na mente dos espectadores.

Pelo fato de o segredo destruir o fluxo de informações, a revista produz mais fofocas e eventos sob a forma de notícias e flagrantes, como o que aconteceu com a atriz Katharine Hepburn.

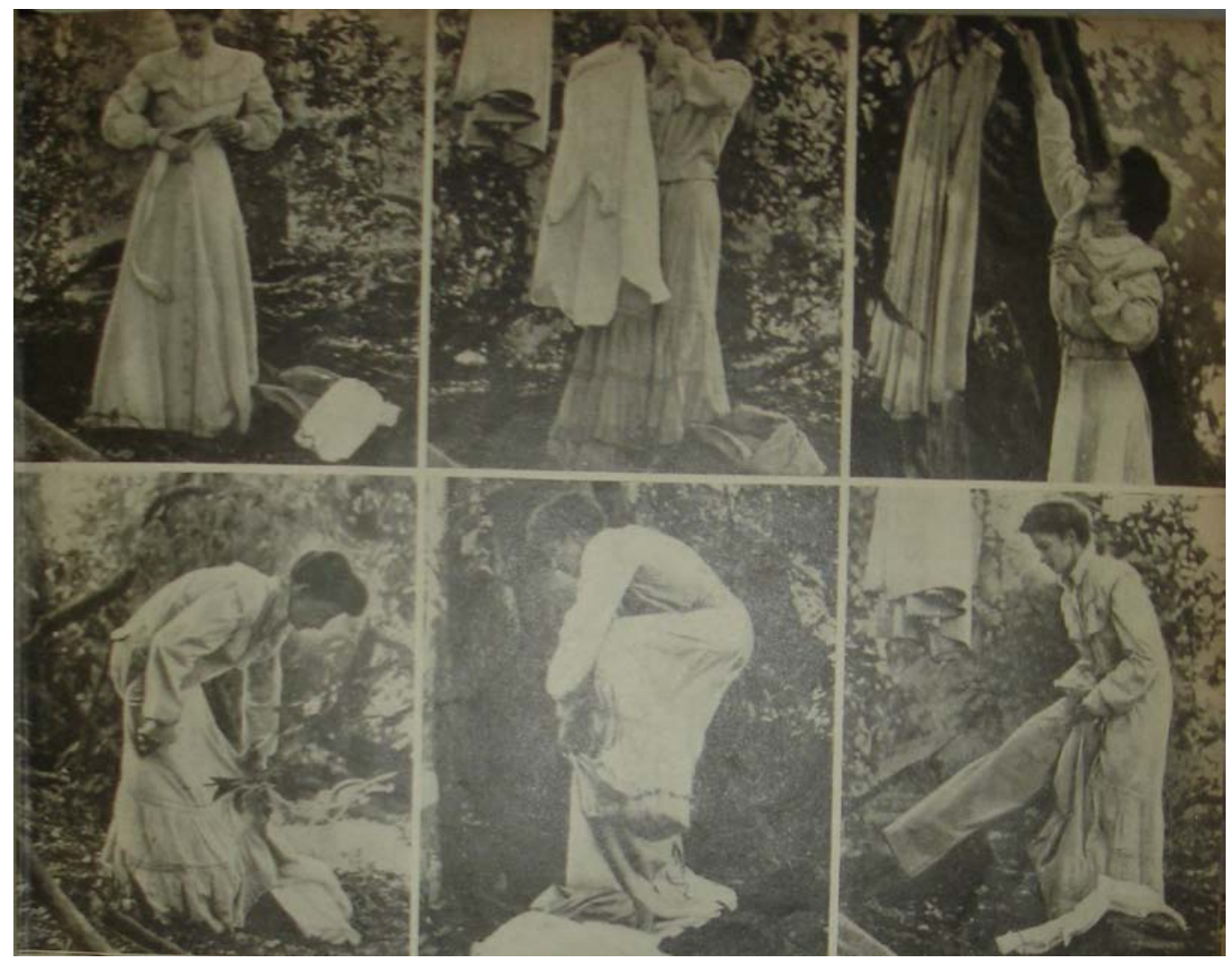

Imagem 1 - Catherine Hepburn ${ }^{39}$

\footnotetext{
${ }^{37}$ Ele detesta mexericos. Cena Muda, v. 34, n. 33, p. 23, 27/10/1954.

${ }^{38} \mathrm{Na}$ terminologia clássica, publicista é escritor público, pessoa que escreve sobre direito público ou sobre política, que ganhou notoriedade pelo grande esforço intelectual. Mas para o ambiente da produção cinematográfica e jornalística do período, a palavra caracteriza uma função que seria a do publicitário e relações públicas ao mesmo tempo, designando o trabalho dos "intelectuais de propaganda", dos redatores de reclame, dos idealizadores e realizadores dos anúncios. Trataremos do tema com maior detalhe no capítulo quatro, no item sobre Salvyano Cavalcanti de Paiva. Paulo Emilio explica a nova profissão, presente nas páginas de Cinearte, como um freelancer que escrevia e era pago pelos produtores das fitas ou pelos artistas. $\mathrm{O}$ estilo do publicista e jornalista Barros Vidal, um freelancer publicista, impregnou o estilo de escrever da revista Cinearte, caracterizado por um estilo rebuscado e um tratamento de intimidade criado com os artistas. Seus textos eram pagos pelos produtores das fitas ou pelos artistas. (Gomes, 1974)

${ }^{39}$ Dantas, Livio. O que a tela não mostra. Cena Muda, v. 32, n. 43, p. 15, 24/10/1952.
} 
Hepburn é "flagrada" supostamente trocando de roupa na selva africana durante as filmagens de Uma aventura na África, de John Huston, (1951). O texto salienta a difícil vida de estrela. O evento é totalmente produzido. Não vemos um centímetro de seu corpo. A atriz tira um vestido longo e fechado, e vemos outro por baixo, provavelmente uma combinação. Provavelmente para justificar a falta de imagem que prove a manchete, a revista confessa sua decepção e também os critérios para a fofoca:

\begin{abstract}
“(...) prosseguimos em nosso ingrato mister de bisbilhotar a vida alheia que é de bisbilhotices que vive fundamentalmente esta seção, e por derivação própria, o seu responsável que é pago para fazer semelhante trabalho. Afinal, não nos sentimos constrangidos por essa contingência, pois se sabemos que não só de bisbilhotices vive o homem, sabemos também que de pão quem vive exclusivamente é o padeiro. (...) O problema é que mesmo no cinema existem pessoas imbisbilhotáveis sobre quem temos uma vontade incontrolável de escrever algumas linhas, já que não podemos passar a vida inteira a dizer coisas sobre Yvone de Carlo, nem sobre Marilyn Monroe, que é um jornal escancarado. Precisamos de alguém inacessível como Katherine Hepburn que de tão segregada do mundo nos dá a impressão de uma monja (...). Mas infelizmente não há novidades sobre Kate, a não ser sobre sua magreza, a sua feiúra e o seu talento." 40
\end{abstract}

Em outro box chamado $\mathrm{Na}$ selva africana, o repórter comenta que as filmagens do filme foram na selva africana, e a atriz, sem camarim, teve de trocar de roupa em pleno mato, que seria o momento fotografado. Ou seja, pelo texto se conclui que haveria um flagrante, mas o box nos revela de maneira implícita que se trata de um fait divers de causalidade decepcionada, uma vez que há uma causalidade arranjada e suspeita, cujo efeito não causa surpresa. Não há revelação na fotografia, nem apelo sensual porque a atriz não personificava o ideal de juventude da revista. No primeiro texto, a revista se dirige de forma subentendida às fotos, mas só as comenta neste artigo, aparentemente sem tom sensacionalista.

A imagem de Hepburn tem relação com a diegese do filme. O departamento de publicidade antecipou o sentimento de ansiedade por ver a estrela se despindo na fita. A foto antecipa a expectativa de ver o corpo da atriz no filme, ao mesmo tempo em que antevê a decepção de não ter essa imagem. Em Uma aventura na África, a missionária tira a roupa para nadar, longe dos olhares do barqueiro. Porém, não consegue subir de volta ao barco, pedindo ajuda ao navegador, embora tema ser vista sem roupa. O personagem do ator Humphrey Bogart a ajuda a subir, supostamente sem olhar para seu corpo. Contudo na cena em que a evangelizadora sobe ao barco, ocorre o anticlímax e a

\footnotetext{
${ }^{40}$ Dantas, Livio. O que a tela não mostra. Cena Muda, v. 32, n. 43, p. 15, 24/10/1952.
} 
decepção, já antevista pela imagem da revista. A personagem está vestida com uma combinação antiga, composta por uma blusa e calça, ou seja, não há nada a ver.

O ápice das fofocas certamente não é o elenco das atrizes brasileiras. Recai sobre as estrangeiras, em longos textos narrando todos os detalhes anteriores sobre sua vida amorosa. A partir da repetição dos mesmos temas com diferentes detalhes e pontos de vista, as histórias rendem por diversas edições. Visivelmente os artigos de procedência estrangeira, comprados por Cinelândia, sabiam novelizar a vida amorosa das celebridades com maestria.

Há um amadorismo na produção de fofocas brasileiras em ambas revistas. Não se consegue inventar muitos fatos sobre as estrelas, porque nossas atrizes ainda não têm tantos casos e casamentos anteriores para comparar. A ausência destes fatos e de um número maior de estrelas tem relação intrínseca com a sociedade mais moralista. As fofocas no caso nacional buscam apenas insinuar romances. Não há diversos artigos desmentindo as informações publicadas anteriormente, como havia quanto às estrelas estrangeiras. Apesar da existência de publicistas do cinema nacional, as fofocas se mostram com conteúdo simplificado, sem grandes desdobramentos. Faltava muito para atingir o grau profissional na criação de fofocas estrangeiras. Os boatos sobre as estrelas estrangeiras trazem declarações da esposa dizendo-se preocupada ou não com os rumores sobre seu marido estar envolvido com outra mulher, frases dos atores sobre as inúmeras qualidades de suas amadas, histórico amoroso do casal, explicando separações anteriores, o que eles buscam, porque se amam, o que há de especial em cada um deles, enfim, toda uma novelização sobre a vida mediática das estrelas. A ficção sobre a fofoca da estrela estrangeira mostra-se completa, enquanto o boato sobre a brasileira ainda engatinha, apenas com duas ou três fases insinuando que há um romance, com fotos de divulgação do filme. O amadorismo textual na invenção na fofoca brasileira facilita perceber que se trata de publicidade. Pouco se denega com eficiência.

Como exemplo do diferente mecanismo de fofoca, temos o romance entre Lana Turner e Fernando Lamas. No final de 1952, as duas revistas anunciam o rompimento do namoro, Lamas a teria trocado por Arlene Dahl. No ano seguinte, Cena Muda continua a anunciar o rompimento do namoro, enquanto Cinelândia vende que os dois continuam juntos, perguntando inclusive quando será o casamento com Lana. Ignora a memória do leitor e embaralha os fatos, estratégia útil para incentivar o interesse em obter informações verdadeiras sobre o romance, gerando a dúvida descrita antes. Depois, Cinelândia narra a briga do casal numa festa. A causa teria sido Lana dançar 
diversas vezes com outro homem. Ele teria terminado o namoro sem mais palavras. Este pequeno fato dá margem para muitas discussões, porque a revista julga existir algum motivo oculto, novamente como se houvesse um segredo, ou conspiração a revelar, como no mecanismo do fait divers. Assim, a cada nova edição de Cinelândia há diversas versões sobre os motivos da separação, totalmente contraditórias. Há colunas de diversos jornalistas que não só descrevem sua opinião, como narram eventos para justificar a separação, episódios que supostamente só eles conhecem. Todos os colunistas inventam histórias, principalmente a famosa Louella Parsons, que a cada edição se contradiz. No caso de conflito como neste ${ }^{41}$, um dos envolvidos deve ser vitimado e o outro é quase demonizado. A teoria conspiratória, maior a cada edição, congrega tantas contradições que as invenções ficam altamente explícitas, quando acompanhamos o desenrolar da história por mais meses (às vezes até na mesma edição). Há certo humor nas revelações, porque numa matéria Lana aparece como a "devoradora de homens", que não pode ver um desconhecido interessante, indo logo se apresentar, como uma oferecida, e em outro momento, ela é uma vítima, imatura, enganada por Lamas; quer apenas alguém para dividir a vida. Lamas aparece como grande amoroso, um homem apaixonado, com medo das exigências dela. Depois como um latino que não respeita os direitos das mulheres, ou como alguém que usa as estrelas para ascender na carreira. Outras vezes, o ídolo quer mesmo é voltar com sua esposa. Na verdade, os dois conspiraram juntos os romances com atrizes famosas, e sua esposa ainda o aguarda. Depois, se nega o romance entre os dois, como se este tivesse sido apenas uma forma de publicidade para o filme. Não só as versões mudam, como também a descrição sobre a personalidade dos dois, e os fatos. A folhetinização destrói qualquer tipo de insinuação de veracidade quando se pretende relatar "fatos" não ficcionais.

Até que numa edição de Cinelândia é anunciado que foi Lana Turner quem desprezou Lamas, não o contrário. Ela o deixou em lugar secundário, sugerindo que de uma simples briga não se pode terminar um relacionamento. Afinal Lamas é o maior apaixonado de Hollywood, e homens para Lana, não valem mais do que vestidos usados uma única vez. Assim, uma suposta verdade, como a briga do casal numa festa passa a ser negada.

O leitor pode escolher a variação da realidade que mais gostar. Cinelândia tem mais talento para inventar, mas perde o controle sobre suas fofocas, de tantas mentiras

\footnotetext{
${ }^{41}$ Nos casos de separação de namorados sem traição, a responsabilidade recai sobre um dos dois, embora nos casos de traição no casamento, o enfoque mude. O tema será retomado no capítulo dois.
} 
que inventa. Cena Muda, pelo menos, não cria tantas versões ao mesmo tempo, embora esse fato se deva a seus parcos recursos para comprar tais matérias. Assim, Cinelândia cria no espectador uma expectativa em não saber o que aconteceu realmente, fornecendo várias versões sobre os fatos.

Os boatos se convertem em grandes novelizações de romances, supostamente não ficcionais. A linguagem de folhetim utilizada, sob a égide da dúvida, fornece material constante, até mesmo quando não há mais novidades a se contar. Assim, a base da fofoca nas revistas é revelar o binômio verdade/mentira, a partir de uma testemunha ocular, ou jornalista amigo, onipresente, trazendo sempre discursos questionáveis, que são desnudados pelos próprios jornalistas. É sobre a verdade e mentira dos romances que se pauta a cobertura das duas revistas. A forma de divulgar a fofoca é a partir das versões da realidade. Esse é o ápice da fofoca, estratégia útil a agregar diferentes públicos, com interesses diversos. Há versões para todos os gostos. O discurso da publicidade utiliza as versões para não impor apenas uma disposição sobre o mundo. Serve-se assim da possibilidade de acesso a diversas opiniões dos jornalistas para trazer discursos opostos. Afirmar numa página que a estrela é boa ou ruim, instiga na verdade o mecanismo de ambigüidade, ambigüidade esta que é útil para os assuntos que não podem ser mensurados, como as fofocas.

Para tornar a fofoca crível, as revistas de fãs recorriam a outros critérios, que analisaremos no próximo item, como o estabelecimento de vínculos a partir da suposta intimidade do jornalista com os ídolos. Ao mesmo tempo, as publicações buscam estabelecer formas de contato a partir da intimidade concomitante com os leitores.

\subsection{Intimidade do repórter com a estrela e o leitor}

Durante os anos cinqüenta no Brasil, ainda não imperava completamente o lead no jornalismo. Os textos não começavam com as seis perguntas mais famosas do jornalismo: quem fez o que, quando, onde, por que e como. Havia uma maior influência do chamado nariz de cera, ou seja, semelhante à estrutura do romance, as informações novas apareciam geralmente no final do texto, após uma longa apresentação com detalhes, geralmente de pouca relevância em relação à manchete. Apesar de ultrapassada, a técnica do nariz de cera quando bem utilizada é útil pela estratégia criada 
para atrair a atenção do leitor até o final do texto. As duas revistas pesquisadas utilizavam esta técnica em demasia.

Além disso, o texto de Cena Muda e Cinelândia é permeado de muitos adjetivos. Cinelândia exagera nesse atributo e às vezes utiliza até quatro para descrever alguém, como: "pessoa inteligente, culta, natural e simpaticíssima" ${ }^{42}$. Em Cena Muda, esse exagero, embora diminuto, também existe. Assim em cada nova matéria, todas as atrizes são consideradas as maiores, melhores, as preferidas pelo público. Este último transforma-se em juiz e responsável pelo estrelismo. Pouco importa a eleição nas páginas seguintes de outra atriz, porque a natureza do produto cultural reclama continuamente um produto sempre novo e individualizado. A utilização dos adjetivos não era apenas comum nas revistas de fãs, mas também na imprensa do período. Durante o final da década de cinqüenta e início de sessenta, ocorreram diversas reformas editoriais, especialmente nos jornais. Carlos Eduardo Lins da Silva (1990) explica que a influência era dada pelo padrão dos jornais americanos, interiorizado pelos profissionais brasileiros que voltavam de estágios no continente americano. A partir desse estágio, o lead ${ }^{43}$ passa a ser a fórmula hegemônica para abertura dos textos.

A ampla utilização dos adjetivos nas revistas de fãs vinha acompanhada da folhetinização da informação (Gillet apud Meyer, 1996), explicitados no tópico sobre sensacionalismo e fait divers. Ambas caminhavam junto a outra estratégia empregada por estas publicações que é a intimidade do jornalista com o leitor, acrescida da simulação de intimidade do repórter com a estrela.

O recurso não é uma novidade deste nicho editorial. Edgar Morin (1962) já mostrou a necessidade da cultura de massa se aproximar dos leitores para criar um ambiente de amizade e clube de amigos, num clima simpático. Destacamos esta técnica porque nela se pauta uma das principais estratégias de nosso objeto de estudo para atrair os leitores, com textos leves, de fácil entendimento, simulando conversas. Mesmo dentre as revistas de cinema, a técnica já tinha sido copiada pelo freelancer Barros Vidal na revista Cinearte, como mostrou Paulo Emilio Salles Gomes (1974). Nos jornais a técnica também já era usada no mesmo período. O citado publicista lançava mão de informações sobre a vida pessoal das estrelas, com terminologia rebuscada. Os jornalistas, principalmente Barros Vidal, utilizavam recursos folhetinescos, narrando

\footnotetext{
${ }^{42}$ Adjetivos empregados para definir a cantora Carmélia Alves, uma das intérpretes no filme Agulha no palheiro (1953), de Alex Viany. Fernandes, Luis. Cinema brasileiro. Cinelândia, v. 1, n. 8, p. $26 ; 55$.

${ }^{43}$ São as informações mais importantes que respondem às perguntas quem fez o quê, quando, como, onde e porque, situadas nos dois primeiros parágrafos do texto.
} 
como era a estrela em casa ou na rua, apelando também para os sentimentos do leitor, como num diálogo. Também já Guilherme de Almeida recorria, ainda nos anos vinte, à mesma estratégia para se aproximar dos leitores, além de procurar criar intimidade com as estrelas.

A tática do estrelismo cinematográfico de concentrar o interesse na vida dos atores, mais do que nos filmes, foi adotada muito antes, no século XIX, pelos atores e pelos políticos. A necessidade de agregar uma crescente intimidade foi inserida por Richard Sennet (1991) na chamada "tirania da intimidade". Em meados do século XIX, há o estabelecimento de fundamentos alterando os critérios para as relações interpessoais. A personalidade entra para o domínio público, preparando a estrutura para a sociedade intimista. A crença nas relações humanas seduz cada vez mais, como se a aproximação entre as pessoas fosse um bem moral, enquanto que a impessoalidade passou a ser tratada como um defeito, num panorama de perda e ausência de relacionamentos humanos. Os líderes precisam se mostrar na intimidade, como se as relações de poder tivessem maior sentido quanto mais intimista fosse a escala.

Embora as técnicas apresentadas tenham progredido muito no tom íntimo criado, por outro lado, decaíram mais ainda quanto às apropriações da literatura do tipo folhetinesca. Os textos estão longe do requinte ensaístico de um Guilherme de Almeida. Possuem vocabulário cada vez mais simplificado. Com o desenvolvimento da linguagem coloquial na imprensa do período, há uma transição entre uma linguagem requintada para a cotidiana em Cena Muda. Ao invés de se calcar no tom cerimonial, Cinelândia busca agregar um público leitor mais jovem, com dúvidas e questionamentos adolescentes, embora Cena nem sempre esteja preocupada com esse nicho editorial. Cinelândia já nasce usando gírias, enquanto Cena Muda ainda tinha um linguajar mais cerimonioso, que provavelmente diminuía o interesse por parte dos mais jovens.

A intimidade sugerida com as estrelas inclui o emprego de recursos do folhetim, trazendo uma narrativa romanceada e melodramática, acrescentando ainda trazer os pensamentos da estrelas e seus sentimentos, mas sem recorrer diretamente às entrevistas, como na matéria sobre Lana Turner. Nela, busca-se mostrar o repórter como um narrador onisciente dos fatos, que tudo sabe, trazendo inclusive os contextos, para os desconhecedores das intrigas: 


\begin{abstract}
"Largando os remos, Lana reclinou-se no barco e deixou-se levar pelo suave balanço das águas. O lago era calmo, o dia sereno, a temperatura agradável. Um dia propício à meditação. $\mathrm{E}$ a atitude de Lana era, de fato, de quem recordava e pensava. Em seu quarto, no hotel à beira do lago, ficara um jornal onde se lia, na primeira página, a notícia de que Mrs. Fernando Lamas concedera o divórcio ao marido, e que decerto Lana Turner não tardaria a procurar o tribunal que tratava de seu divórcio de Bob Topping, autorizando-o a concluir o caso, e ficando livre para dar o 'sim' a Fernando. Um passo muito simples na aparência (...). Para Lana, entretanto, o passo é mais sério do que parece. Porque, embora pareça de fato apaixonada por Fernando, quer, antes de tudo, ser sensata. (...) ${ }^{44}$
\end{abstract}

Este é o tom folhetinesco de Cinelândia, que inclui partilhar das angústias das estrelas. As matérias jornalísticas na maior parte do tempo utilizam este critério a partir do nariz de cera. O formato esconde o pouco conteúdo existente. Não há novidade no caso entre Lana Turner e Fernando Lamas, os leitores já sabiam do romance. Exatamente por não ter novidade a contar, supostas intenções e pensamentos são novelizados, como aqui.

Nos casos em que há a intermediação do repórter com a estrela, a linguagem das duas revistas mantém um tom de diálogo em primeira pessoa do jornalista com o leitor, geralmente como se fossem velhos amigos. Essa familiaridade é acompanhada de uma suposta intimidade também do repórter com todas as estrelas, simulando ter estado com as atrizes. As notícias enviadas pelos estúdios são convertidas em furos de reportagem, como se tivessem sido reveladas devido à intimidade entre jornalista e estrela.

Os textos de Gilberto Souto já em Cena Muda na década de cinqüenta são permeados de intimidade, principalmente com as estrelas brasileiras. Ele é o grande amigo de Carmem Miranda. Souto chega a afirmar que a atriz não tem segredos com ele $^{45}$. Também Walt Disney pedia sua opinião quando ele trabalhou em sua empresa.

No geral, Cena Muda ainda engatinha no recurso de conversar com o leitor, se comparada à revista concorrente. Tem mais talento para dialogar com seu público para debater os problemas do cinema nacional. Consegue gerar intimidade em tom folhetinesco, nos artigos escritos pelo pseudônimo de Luelinha Passos, com na matéria anteriormente citada sobre o suposto romance entre Miro Cerni e Fada Santoro. Embora muitas vezes Cena recorra à estrutura tradicional da notícia, narrando gostos e fatos recentes da vida das atrizes, mas sem romantizar em exagero suas vidas, ao contrário do trecho citado acima sobre Cinelândia.

Já Cinelândia tem maestria no recurso. Não só Zenaide Andrea, como Luis Fernandes também sabia conversar com o leitor, num tom muito próximo ao do rádio, e

\footnotetext{
${ }^{44}$ Henaghan, Jim. Lana e o amor. Cinelândia, v. 2, n. 9, p. 38, jan. 1953.

45 Souto, Gilberto. Posso marcar a minha viagem ao Rio. Cena Muda, v. 33, n. 11, p. 8-9 e 34, 13/03/1952.
} 
semelhante à linguagem da televisão. Fernandes conta em que rua se situa o estúdio, como foi tomar o ônibus para chegar ao local, quanto esperaram para ser atendidos, como foram tratados pelas estrelas, etc. Quando Luis Fernandes dirige Cena Muda no final de 1953, traz consigo o estilo textual de Cinelândia, mas este tom não perdura depois de sua saída, como no trecho abaixo, publicado em Cena:

"Vou levá-los ao estúdio da 'Sacra Filmes, lá em São Cristovão, onde terão oportunidade de assistir à primeira cena de 'Nobreza Gaúcha' a ser filmada. Gostaram? Então, vamos, pois a caminhada não é brincadeira!...

O que é isto? Aonde vão? É aqui mesmo, nesta casa velha. O quê? Não tem pinta de estúdio? Não tem mesmo... mas é. Os barracões, contendo os palcos de filmagem, estão lá atrás, vocês vão ver. Entremos... sabem quem é aquela garota alta que vem vindo ali, de bombacha gaúchas, chicote, lenço no pescoço, e tudo mais? Ora, ora, é a Patrícia Lacerda! (...) Vocês sabem?... Silêncio, silêncio, que esse toque da campainha significa que a câmera vai rodar. Aliás, vocês já deviam saber disso, pois já estiveram presentes a muitas filmagens!...

(...) O que é que você aí está perguntando, garota? O Emílio Castelar? Não, não trabalha hoje, mas... - não precisa fazer essa expressão de decepção! (...) Aí vem ele entrando! O que? É verdade, ele é um dos mais altos galãs, se não for o 'mais' alto. E vocês, rapazes? O que acharam da Patrícia? O que há? Perderam a voz? Está bem, está bem, não precisam responder, pois sei exatamente o que estão pensando.

Como é? O que eu ia perguntar quando a campainha pediu silêncio? Ah, é verdade, quase me esquecia. Ia perguntar se conheciam aquele outro ator que está sentado ali, também vestido de gaúcho, a espera de ser chamado para alguma cena. Não? É o Jece Valadão. Vocês sabem, sim... É o ex-noivo de Rosangela Maldonado. Romperam o compromisso às vésperas do casório (...)". outro dia." $" 46$

E com isso, vamos tratar de sair, que está ficando tarde. Cada um para a sua casa, e até

Luis Fernandes escreve como se estivesse trazendo seu público de Cinelândia para Cena. O jornalista não compõe um parágrafo sem inserir um ponto de exclamação ou reticências, buscando trazer seu suposto leitor ao texto, como se estivessem realmente conversando. O clima de amizade nesta coluna atinge níveis exagerados, típicos de Cinelândia. Por isso, o repórter feito diretor em Cena Muda não continuou no cargo. Não era esta a linguagem da revista anciã de 34 anos no mercado. Fernandes tenta gerar um clima fantasioso, onde os leitores já estão familiarizados com a dinâmica e funcionamento dos estúdios, porque acompanham a coluna. Tenta mostrar uma suposta instantaneidade, impossível ao veículo impresso. Essa tática, geralmente é utilizada nas matérias sobre o cinema brasileiro. O jornalista procura transpor a conversa para o ambiente de filmagem, uma estratégia para atrair o espectador ao filme nacional, apresentando atores, que na verdade, não eram tão conhecidos, como Jece Valadão ou Emílio Castelar. Claramente se vê a tentativa de gerar uma curiosidade pelo cinema nacional, porque o maior interesse era pelo produto hollywoodiano. Trazer o

\footnotetext{
${ }^{46}$ Uma voltinha pelos estúdios. Cena Muda, v. 33, n. 45, p. 16, 04/11/1953.
} 
leitor através do texto para o ambiente dos estúdios brasileiros tornava-se um passo para conseguir incutir o desejo de ver os filmes.

Em Cinelândia, as celebridades de Hollywood são chamadas pelos jornalistas pelo primeiro nome, sem o sobrenome, como se fossem velhos amigos. Os repórteres são íntimos de todas elas. As atrizes supostamente ligam para os jornalistas contando as novidades, desde nascimentos, divórcios até os novos romances. São elas que supostamente procuram os repórteres para revelar todas as informações, inclusive os convidam para visitar seus palacetes: "abrindo seu coração". Assim, o leitor pode se projetar no jornalista, sonhando estar em seu lugar, para ser requisitado por elas. Há uma criação dos jornalistas em personas, buscando sua transformação em semiolimpianos, acima dos leitores, ao mesmo tempo em que os repórteres partilham o sentimento de admiração pelas estrelas, como os fãs. Tais jornalistas são vizinhos das estrelas, sabem como elas se vestem no dia a dia, freqüentam as mesmas festas, explicam em detalhes os vestidos e os assuntos discutidos nas festas, sentam em mesas próximas e ouvem os dizeres dos namorados, têm acesso à supostas cartas de amor. São, portanto, não só referência, mas profundos conhecedores de todos os temas, onipresentes. Contudo, esta característica está presente apenas em Cinelândia.

Não basta apenas contar ao leitor da sua amizade, Louella Parsons se coloca em duas ou três fotografias ao longo de 1952 com as estrelas ${ }^{47}$. Depois o processo passa a ser comum. Parsons era uma colunista de fofocas muito famosa no ramo das revistas de fãs nos Estados Unidos. Participou de três filmes interpretando a si mesma. Estreou como repórter de fofocas ainda na década de vinte, sempre atrelada ao império de William Hearst, tanto que a primeira exibição do filme Cidadão Kane (1941), de Welles, para uma jornalista foi feita para ela ${ }^{48}$. Seus artigos eram transcritos para muitos jornais ao redor do mundo. Sua principal concorrente era a ex-atriz Hedda Hopper $^{49}$. As colunas das duas eram traduzidas para Cinelândia. Os artigos de Louella muitas vezes têm um tom folhetinesco, enquanto Hopper parece mais sarcástica e realista em suas descrições (sem recorrer tanto à romantização), mas não podemos

\footnotetext{
${ }^{47}$ Em uma delas, a repórter aparece abraçando Judy Garland depois de sua estréia Parsons, Louella. $O S$ espiões de Cinelândia em Hollywood informam. Cinelândia, v. 1, n. 5, p. 10, set. de 1952.

${ }^{48}$ Laura Mulvey (1996) conta que Parsons foi a primeira jornalista a atacar o filme diretamente, logicamente por trabalhar para Hearst, o magnata que deu margem à composição do personagem do filme. Apenas na década de sessenta, a coluna da jornalista começa a apresentar sinais de decadência.

${ }^{49}$ Hedda Hopper aparece na cena final do filme Crepúsculo dos deuses (1950), de Billy Wilder, também se interpretando como colunista de fofoca. Na cena, ela consegue entrar no quarto da atriz Norma Desmond, narrando em tom folhetinesco e sensacionalista os devaneios da estrela, através do telefone, dando uma idéia de instantaneidade da informação e da profissão.
} 
afirmar ao certo a diferença textual entre elas porque provavelmente os textos sofressem algum tipo de edição por Cinelândia.

No caso brasileiro, a correspondente em Hollywood, Dulce Damasceno de Brito se converte na estrela brasileira, a jornalista que conseguiu se tornar correspondente em Hollywood. Como Louella, Dulce não só está em meio às celebridades, mas participa do Olimpo na qualidade de amiga, como se fosse uma igual. Depois, passa a usar o mesmo mecanismo de Parsons. Para provar sua grande amizade com as estrelas, sua coluna passa a ser acompanhada de fotos dela abraçada às celebridades. A repórter conta as novidades em Cena Muda, mas não utiliza tamanha novelização, nem recorre a pontos de exclamação ou penetra no pensamento das estrelas, como se as informações visuais por si só já fossem suficientes. Usa critérios mais jornalísticos na estrutura textual.

O cotidiano dos jornalistas das revistas de fãs era bem diferente da representação presente nas páginas editoriais. A ex-escritora das revistas de fãs Motion Picture, Photoplay, Modern Screen, Jane Wilkie (1981) narra a difícil relação entre jornalistas e publicistas. Os repórteres não podiam ficar um minuto sequer sozinhos nos estúdios ${ }^{50}$. Os publicistas estavam presentes todo o tempo, para evitar perguntas inoportunas dos repórteres, e respostas inconvenientes dos atores. As entrevistas duravam apenas uma hora, mas tinham de render doze páginas. Conforme o relato de Wilkie, nenhum artigo em revista de fã era publicado sem o aval do publicista do estúdio e a estrela. Os publicistas faziam as correções, alterando palavras e títulos, para permitir a publicação. O objetivo era evitar uma representação pouco atraente do ídolo ${ }^{51}$. Atividade sexual, comportamento desonesto ou homens que abandonaram a família eram itens banidos. Os estúdios conseguiam, inclusive, impedir a publicação de escândalos nos jornais ${ }^{52}$. Apesar de confessar os mecanismos de controle, Wilkie garante que as entrevistas em sua grande maioria realmente ocorriam.

São muitas as matérias em Cinelândia em que o jornalista, como suposto conhecedor profundo do pensamento da estrela, descreve ao leitor conteúdos de cartas, que ele supõe terem sido escritas. O objetivo é mostrar como o astro continua amando

\footnotetext{
${ }^{50}$ Ao contrário dela, Dulce Damasceno de Brito declara que podia assistir a qualquer filmagem todos os dias. (Brito, 1992)

${ }^{51}$ Wilkie conta que certa vez não foi possível alterar o título como queria o publicista. O resultado foi que a publicista não falou mais com ela. Para ela, os publicistas (dos estúdios) e os press agents (agentes das estrelas depois do final da verticalidade do studio system) eram arrogantes com os jornalistas. (Wilkie, 1981)

${ }^{52}$ Como exemplo, Wilkie lembra o caso do ator Walter Pidgeon, pego pela polícia num bordel. A MGM conseguiu sufocar o caso, impedindo a publicação. (Wilkie, 1981)
} 
sua mulher. As cartas, novelizações de amores, são escritas com aspas, tentando sugerir ao leitor o acesso a uma documentação, que o próprio jornalista deixa claro não existir. Porém, o conteúdo é tratado como verdadeiro, revelando a conexão importante para as revistas de fãs entre o sensacionalismo e romantização. Assim, a suposta intimidade transcrita nos textos de Cinelândia chega à total inverossimilhança. Em muitos casos, a esposa ou marido não sabem o que vem na cabeça do cônjuge, mas o repórter sabe. Como exemplo, temos a carta que Aly Khan escreveu para Rita, quando ela o deixou:

\footnotetext{
"Não desejo tornar a casar-me, nem existe, em meu coração, outra mulher, além de ti... És incapaz de imaginar quanto sinto a tua falta. Enquanto houver uma partícula de esperança, não serei eu quem irá deitá-la a perder. Em qualquer momento que voltes o pensamento para mim, estarei à tua espera, de braços abertos, com o amor que sempre tive e tenho por ti”. ${ }^{53}$
}

A revista não explica como teve acesso à carta, além de ocultar nessa matéria, os diversos casos do príncipe, mostrados em outras edições, nem que rapidamente ele se envolveu publicamente com outras mulheres. Nada disso importa à novelização. Vale trazer cartas de amor às leitoras, para que elas se imaginem como destinatárias de um romance como o da estrela, a partir dos mecanismos de projeção e identificação, que veremos depois.

A onisciência da jornalista, às vezes funciona também para questões de trabalho. Parsons conta que "num longo bate-papo" numa festa, "o meu amigo Gregory" (Peck) ${ }^{54}$ disse que pretendia ficar um ano na Europa, caso conseguisse emprego. Em seguida, Parsons informa aos leitores o desconhecimento de Gregory sobre seu próprio futuro. Afinal, ele vai gravar o filme A princesa e o plebeu (1953), de William Wyler. Certamente a informação do release do estúdio é tratada por Louella como furo de reportagem, usando a suposta intimidade com todos os atores para provar a veracidade dos fatos.

No ano de 1952, as atenções de Cinelândia se concentraram sobre as estrelas: Elisabeth Taylor, Rita Hayworth e Ingrid Bergman. E é exatamente sobre essas três que as repórteres alegam possuir maior intimidade, como uma forma de prender a atenção dos leitores. As matérias de Cinelândia eram compradas, e a maior parte dos jornalistas estrangeiros supostamente eram mulheres, em oposição ao que existia no Brasil na

\footnotetext{
${ }^{53}$ Miller, Cynthia. Existe ainda amor entre Rita e Aly. Cinelândia, v. 1, n. 2, p. 12-13; 40, junho 1952.

${ }^{54}$ Parsons, Louella. Os espiões de Cinelândia em Hollywood informam. Cinelândia, v. 1, n. 4, p. 10, agosto de 1952.
} 
revista Cena Muda, numa época em que poucas mulheres trabalhavam em redações em nosso país ${ }^{55}$.

O teor geral do texto de Cinelândia, semelhante ao de Louella Parsons, é pautado por um estilo folhetinesco. Depois da separação de Rita Hayworth com o príncipe Aly Khan, a atriz não concedeu mais entrevistas. Louella publica uma longa entrevista, com grande destaque, como a primeira concedida pela estrela, chamada "As primeiras revelações da ex-princesa" ${ }^{56}$. Utilizando a intimidade da jornalista como mote das revelações conseguidas, admite que apesar do gelo inicial, assim que Rita sentou, confessou tudo a Louella, porque já foram grandes amigas:

\begin{abstract}
“é tão bom, Louella, tão bom estarmos juntos outra vez. Nossas mãos se juntaram, naquela compreensão que supera as palavras, e todos os mal-entendidos que nos tinham separado anteriormente desapareceram. Conversamos durante duas horas. A luz do dia foi sumindo lá fora, mas nós não nos preocupamos em acender o abajur. Rita se tem sentido extremamente infeliz desde que deixou Aly Khan. Fôra por isto que se escondera, que procurava não ver os amigos mais chegados. (...) não tivera coragem de falar contra o homem a quem ela tanto amou, e que talvez ainda ame, embora não possa viver com ele."
\end{abstract}

A intimidade com a estrela inclui também ser recepcionada pela princesa Yasmin, que faz sala para ela. A mãe zelosa chega depois, abraça a filha e a joga para o alto, intimidade não revelada na revista concorrente. São estes detalhes de novelização e intimidade com a estrela que Cena não tem, em razão da aliança com a empresa americana que garante matérias como as de Parsons.

O contato íntimo do repórter ainda permite dar conselhos únicos às celebridades. A repórter induz o leitor a acreditar que as atrizes precisam dos jornalistas. Louella Parsons ao comentar o distanciamento de Rita Hayworth da imprensa e de seus amigos, declara: "à Rita, que já foi minha amiga, eu digo como alguém que ainda a estima: pense bastante antes de fazer as coisas.... Mas, pelo amor de Deus, não seja você mesma

\footnotetext{
${ }^{55}$ Apesar de ser verdadeiro afirmar que poucas mulheres eram jornalistas no período estudado, conforme atestou a pesquisa de Alex Criado: Repórteres pioneiras: resgate da trajetória de três jornalistas através da história oral (Dissertação, Escola de Comunicações e Artes, 2000), Ana Luíza Martins (2001) mostra que ainda em meados de 1800 havia algumas mulheres no Brasil escrevendo em revistas. A passagem da mulher leitora para colaboradora foi rápida, porque a partir desses artigos em revistas, geralmente artesanais, o papel feminino de mulher, mãe, esposa e rainha do lar era reiterado. Há uma tímida participação feminina da mulher na imprensa na metade do século XIX em temas como moda e ensaios literários, entre eles no $O$ Jornal das Senhoras (1852) e $O$ Bello Sexo (1862). São periódicos artesanais, feitos por uma ou duas pessoas. Surge depois na virada do século em São Paulo, algumas revistas com reivindicações, defendendo o sufrágio feminino, o divórcio, o movimento feminista, assim como reprovando a dominação masculina. Ainda no começo de 1900 surgem algumas revistas feministas. Contudo, o enfoque na produção paulista era a educação da mulher com ênfase na higiene, levando o comportamento moralizante, o investimento na escolaridade, abordando também as atividades filantrópicas, além de moda, decoração e literatura.

${ }^{56}$ Parsons, Louella. Cinelândia, v. 1, n. 3, p. 14-15 e 61, julho 1952.
} 
a sua pior amiga." ${ }^{57}$. Nas notícias do cinema brasileiro, não havia tal intimidade, tudo o que se tenta é inventar fofocas que ocupam um parágrafo.

Em outras matérias, os jornalistas divulgam as perguntas indiscretas feitas às estrelas e as reações negativas delas, mostrando que conseguem as matérias a custa de muito esforço, como ouvir as conversas alheias das celebridades sentando em lugares próximos nos restaurantes. Cinelândia cai, assim, em uma contradição com a imagem construída de amizade entre jornalistas e atrizes. A impressão dada ao leitor é a do sacrifício, como se dissesse "perguntei só para poder contar a você, leitor".

Enquanto o máximo de intimidade que Cena tentava insinuar eram frases sobre a suposta intimidade, recorrendo no máximo às novelizações sobre os filmes, a revista concorrente conseguia atingir mais de perto os leitores por lançar mão de colunistas famosas de Hollywood, especialistas em romantizar a vida dos atores. Em Cinelândia há novelizações da vida amorosa das estrelas, mas não dos filmes. Assim, sua estratégia tinha todos os ingredientes para dar mais certo que as de Cena. Uma novidade no recurso da intimidade, utilizada em Cinelândia, será abordada no próximo item, centrada na suposta amizade da estrela com os leitores, em textos escritos hipoteticamente pelos atores.

\subsection{O leitor e a estrela sem intermediação}

Um passo além no quesito da intimidade é um outro tipo de recurso largamente utilizado em Cinelândia, que nasce a partir do apagamento da figura do jornalista, como se não houvesse um intermediário, tática inexistente na revista concorrente. Artigos supostamente escritos pelas estrelas tornam-se ponto central do interesse editorial porque contêm os supostos discursos das atrizes. A aproximação se serve, então, da certeza em partilhar de uma confissão, por menor que seja. O apagamento da figura do jornalista do artigo pode ser entendido como um meio de aproximar a imagem da estrela, humanizando-a através da linguagem em primeira pessoa. A ocultação da figura do repórter ocorre também quando mortais que partilharam da vida da celebridade antes do sucesso, escrevem artigos para mostrar quão especial é a atriz ${ }^{58}$. Há ainda descrições

\footnotetext{
${ }^{57}$ Parsons, Louella. Os espiões de Cinelândia em Hollywood informam. Cinelândia, v. 1, n. 1, p. 30-31 e 46, maio de 1952.

${ }^{58}$ Como exemplo, temos a narrativa da ex-cunhada de Marilyn Monroe, mostrando quão especial já era a garota antes de se tornar famosa, construindo um mito de amor em torno do ex-marido, supostamente
} 
de pessoas que presenciaram o it ${ }^{59}$ da estrela antes da fama. São relatos de homens comuns, convertidos em fontes jornalísticas, muitas vezes com diálogos na primeira pessoa. O objetivo é ou simular uma longa amizade com a deusa, ou conversar de igual para igual com o leitor.

No caso destes últimos artigos, há sempre a mesma fórmula: uma pessoa comum ficou impressionada ante a beleza de uma moça vista de relance, ou admirada numa fotografia. Afinal a estrela é especial. Anos mais tarde, a musa inspiradora transformouse numa atriz famosa. Este primeiro admirador da então desconhecida serve como um observador da história, como um vidente. A abertura dos textos a partir do relato de uma testemunha ocular possibilita discorrer sobre os atributos da celebridade, sem intermediação. Mais importante do que a opinião do jornalista enfatizando as qualidades da estrela, é o discurso de um indivíduo isento a provar que a atriz já possuía o it. Esta fonte prediz de forma retroativa o sucesso, e aproxima o leitor do ídolo, às vezes deixando clara a impossibilidade do sucesso a qualquer mortal. Foi um empregado do comércio o primeiro a vislumbrar o it de Ava Gardner:

"Certo dia, em 1940, o empregado do comércio, Barney Duhan parou diante da vitrine de um fotógrafo em Nova York para admirar o retrato da garota mais linda que já vira em toda a sua vida.

Deu-lhe então uma vontade doida de conhecer 'aquele fenômeno', e entrou no fotógrafo para perguntar quem era ela, dizendo-se agente dos estúdios da Metro.

- A garota é Ava, minha cunhada - explicou o fotógrafo Larry Tarr. - E ela vive na roça, na Carolina do Norte. Eu poderia telegrafar...

- Não! Não precisa! - interrompeu Barney em pânico. - Não é preciso chamá-la! Basta mandar as fotografias dela para o estúdio da Metro, aos cuidados de Marvin Schenk!

- Mas quem me garante que ele verá as fotografias? - perguntou Larry.

- Ponha uma marca vermelha no envelope - disse Barney rapidamente, procurando escapulir do apuro em que se metera.

E o rapaz, que hoje é detetive da companhia de trens subterrâneos, não mais pensou no caso durante alguns anos, e já se tinha esquecido completamente da moça do retrato, quando viu novamente aquele rosto lindo na capa de uma revista...

- Quem sabe o que teria acontecido se ela estivesse em Nova York quando eu inventei aquela história? - pergunta Barney. - Mas assim foi melhor, embora eu nunca a tivesse encontrado... Como pode um humilde detetive particular de Nova Iorque sonhar em conhecer pessoalmente a mais famosa estrela do cinema da atualidade?" 60

Estes casos são menos recorrentes do que a narrativa escrita diretamente pela atriz aos leitores. Um exemplo da intimidade da estrela com o leitor, aparentemente sem a intermediação do jornalista, é o texto creditado à atriz Jan Sterling, na seção Eu sou

nunca esquecido pela estrela. Nelson, Elyda (ex-cunhada de Marilyn). Pela primeira vez é contada a verdadeira história do casamento de Marilyn Monroe. Cinelândia, v. 2, n. 10, p. 38-41, fev. 1953.

${ }^{59}$ Foi a escritora e roteirista inglesa Elinor Glyn a primeira a definir o it como uma magia da sedução feminina. (Holanda, 1991)

${ }^{60}$ A rainha do glamour: Ava Gardner. Cinelândia, v.1, n. 1, p. 16-7, maio 1952. 
assim. Ela chega a sugerir que o leitor puxe sua cadeira para "bater um papo", prometendo, inclusive, dizer toda a verdade:

\begin{abstract}
"Não peço desculpas a ninguém pelo que venho a dizer nesta seção. Puxe a cadeira, leitor, e conversemos um pouco. Sinceramente falando, acho que os artistas de cinema têm todo o direito de manifestar publicamente suas opiniões. (...) estou disposta a dizer o que penso e o que sinto e o mesmo farão (...) todas as que por aqui aparecerem." 61
\end{abstract}

Essa aproximação da diva antes de se tornar estrela pode ser sentida mais de perto quando ela conversa diretamente com os leitores. Supostamente os atores querem saber como o público procederia se estivesse em seu lugar, porque não sabe como agir para não decepcionar seus fãs. Não há temas realmente íntimos, apenas se discute a representação mediática das estrelas, como por exemplo, questionar se o público confunde ator e personagem, se almeja histórias fantasiosas sobre seus ídolos ou se quer uma profunda identificação entre ator e personagem ${ }^{62}$. No final do texto, sempre se escreve:

"É esse o meu problema, prezados fãs, e acreditem que não é nada fácil de resolver. Escrevam-me dando sugestões, através das páginas de Cinelândia. (...) Eu dou aqui a minha opinião, e espero a de vocês". (...) Que pensam vocês do problema (...)? Escrevam dizendo." 63

No ano de 1952, este recurso torna-se comum em todas as edições, mas quase some nos anos seguintes. Há um tom muito artificial na suposição do artista pedir ajuda aos leitores, talvez por isso a tática tenha sido abandonada. Continua a existir a conversa com os leitores, ou as confissões de erros ${ }^{64}$, mas não os pedidos explícitos de ajuda. $\mathrm{O}$ objetivo é trazer uma dimensão menos marmórea dos atores, ressaltando seu lado humano.

A partir dos artigos onde a estrela pede a opinião dos fãs, nasce um pressuposto diferente. Não é mais o fã que se intromete sem ser chamado na vida da estrela; é ela

\footnotetext{
${ }^{61}$ Eu sou assim. Cinelândia, v. 1, n. 3, p. 19, julho 1952.

${ }^{62}$ Como exemplo, temos o artigo de Kirk Douglas perguntando às leitoras se as mulheres ainda não cansaram de ver os papéis de protagonistas submissas e masoquistas. Diz temer que as mulheres tenham medo dele, o achando semelhante aos papéis interpretados. Douglas, Kirk. As mulheres gostam de brutalidade nos filmes? Cinelândia, v. 1, n. 2, p. 41, junho 1952.

${ }^{63}$ Skelton, Red. Alô fãs, os problemas de um cômico. Cinelândia, v. 1, n. 1, p. 6; 41, maio 1952.

${ }^{64}$ Abordaremos os erros das estrelas no próximo capítulo, mas citamos aqui dois exemplos para situar o tema. Joan Crawford admite ter sido mal educada com alguém no telefone. Contudo, a atriz retornou a ligação para pedir desculpas, ensinando as regras do bom viver aos leitores para chegar à formula da felicidade. Crawford, Joan. O que a felicidade significa para mim. Cinelândia, v. 1, n. 2, p. 8-9; 44, junho 1952. Já Mário Lanza confessa sua desilusão com o sucesso porque estranhos lhe pedem dinheiro, como se o conhecessem. Além disso, tem de sustentar diversas pessoas por estar em melhor situação financeira. Além dessas "infelicidades", mal tem tempo para gastar seu próprio dinheiro, porque trabalha demais. Nem tudo são flores. Cinelândia, v. 1, n. 5, p. 26-7; 52, set. 1952.
} 
quem pede a aproximação com seu público, mas logicamente sobre sua vida mediática. Há um aumento na intimidade quando o leitor sente verdadeiramente partilhar dos segredos da estrela, porque ela assim o pediu, não o inverso. Cria-se um mito de dependência da estrela aos desejos dos fãs extremamente útil aos valores difundidos por este veículo. Esta subordinação da estrela ao leitor gera uma inversão mitológica da forma mais pura do estrelismo, na qual o fã depende da concessão do ídolo em fornecer informações. A inversão mostra ao leitor que o estrelismo precisa dele para sua continuidade.

Para atrair o leitor recorre-se a uma conversa íntima entre amigos. Contudo este processo não aconteceria de forma efetiva, se a representação da estrela não tivesse sido alterada para a humanização crescente dos ídolos. Os pressupostos entre humanização e intimidade serão analisados no próximo item. As estratégias descritas até aqui se pautam também sobre o conhecimento do jornalista dos processos de projeção e identificação, que veremos no tópico a seguir. Sem a humanização e os mecanismos projetivos inter-relacionados, os processos descritos aqui não atingiriam tão bem seus fins.

\subsection{Entre a humanização da estrela e a identificação: a proximidade com o leitor}

Quando as estrelas pedem ajuda ao leitor, ou quando abrem "seu coração" sobre seus problemas, confessando sua natureza mortal, são humanizadas porque revelam algum segredo. Humanizadas parecem mais perto do público, como mortais, e não como deusas. Ou seja, a geração da intimidade entre o ídolo e leitor está focada no processo de humanização da atriz. Lembramos novamente que esta nova configuração do estrelismo é muito mais presente em Cinelândia.

Para entender porque a crescente humanização da estrela é uma novidade, precisamos voltar às primeiras configurações do star system, ainda nos anos vinte. Nesse período, as estrelas pareciam mais distantes de seu público. Habitavam castelos e mansões, sozinhas. Eram inacessíveis e inimitáveis. Com a evolução do star system e do realismo no cinema, a partir dos anos 30, a veneração dos seres supra-humanos se converte em admiração, processo analisado por Edgar Morin (1957). A estrela aproxima-se de nós. Não é uma heroína distante. Esta aproximação acentua o culto ao invés de eliminá-lo. Mais presente e familiar, a celebridade está quase à disposição de 
seus admiradores: daí o florescimento de fãs-clubes, revistas, fotografias, correspondências.

Assim, a admiração nasce com o processo de humanização da estrela. Morin lembra que as estrelas passam a morar em casas ou apartamentos ${ }^{65}$, casadas, com filhos. Só falta o cachorro. Do ponto de vista teórico, há uma diferença na percepção desse movimento. Para Edgar Morin, as estrelas continuam a ser deusas para os leitores, só mais próximas deles, enquanto que para Roger-Gerard Schwartzenberg (1978), mais preocupado com o estrelismo na política, as estrelas se aproximam do homem comum, como se nos representasse. Processo descrito como de dessacralização. O ídolo deixa de ser motivo de fascinação, e passa a ser modelo comportamental. Entre semiexcepcional e semi-cotidiana, a estrela é agora um modelo imitável, como um líder charmoso. Encerrara-se, para Schwartzenberg, a era mitológica dos ídolos inacessíveis com o advento do cinema sonoro, porque o imaginário cinematográfico aproximou-se do real.

Alexander Walker (1970) revela o aspecto econômico por detrás da humanização dos atores nos anos trinta. Depois da crise de 1929, com cortes de custos, os estúdios pagavam menos aos atores. As estrelas queriam mostrar sua popularidade para impressionar seus chefes, aumentando as informações sobre as suas personalidades. Para isso, queriam ter contato com o público. Alguns atores apelavam para leituras públicas para provar que eram tão bons quanto os atores do teatro legítimo. Assim, segundo Walker, o povo sentia que as estrelas eram semelhantes a ele. Os filmes fechariam o ciclo, confirmando a estrela como representante do público. O autor mostra que nos anos trinta, o papel popular dos atores é mais presente do que nos decênios anteriores. $\mathrm{O}$ medo de que a maternidade atrapalhasse a imagem romântica da estrela mudava. Temia-se, por exemplo, que o nascimento do bebê de Norma Shearer atrapalhasse a imagem de seus personagens. Contudo a maternidade aumentou o interesse sobre ela. Os fãs gostaram de ver seus ídolos humanizados, iniciando um ciclo de filmes sobre maternidade e paternidade.

A mesma humanização foi descrita por Guilherme de Almeida décadas antes. Ele escreveu que procurava a realidade no cinema, não a fotogenia. Então, quando viu George Bancroft, encontrou o homem a representar "a verdade americana", porque o

\footnotetext{
${ }^{65}$ Guilherme de Almeida (1929) ainda nos anos vinte, cita os apartamentos das estrelas, sendo, portanto, relativo afirmar que apenas em idos de 1930-40 houvesse tal mudança. Mas como esta nova morada passa a ser mais comum nos decênios subsequientes, por isso não desconsideramos as apropriações de Morin.
} 
ator é como um amigo seu. O crítico cita Bancroft para renegar os rostos fotogênicos falsos porque estes não existem na vida real. Portanto, o tema da representação do estrelismo do common men descrita por Schwartzenberg já podia ser encontrada em estrado bruto na frase do colunista brasileiro. (Almeida, 1929: 143-44)

Deusa ou modelo comportamental, as teorias encontram consonância porque explicam a dupla natureza dos olimpianos, mortal e divina. Morin fala em modelo de vida, enquanto Schwartzenberg usa o termo modelo comportamental. Ambos percebem o processo de humanização e aproximação com os leitores.

Voltando da digressão necessária para compreender o histórico da humanização, no período estudado por nossa pesquisa há uma ampliação da intimidade com a estrela, além da descrita por Morin e Schwartzenberg ${ }^{66}$. Nas reportagens de Cinelândia, as celebridades erram, e esta é uma novidade que altera a configuração clássica do estrelismo, porque amplia o processo de conversão da estrela em um ser mais humano que divino. $\mathrm{O}$ intuito das revistas de fãs em mostrar pedidos de ajuda (ou erros dos ídolos, como veremos adiante), é proporcionar ao leitor a experiência de partilhar da vida do ídolo a partir do sentimento de igualdade.

A humanização está calcada sobre os mecanismos de projeção, identificação e transferência, vitais para aproximar o leitor de seu ídolo. O interesse em relação à estrela surge quando o espectador, através do duplo, realiza o que não pode fazer em sua vida. A percepção da função do duplo não foi percebida só por Morin. Duas décadas antes, quando era crítico de $O$ Estado de S. Paulo, Guilherme de Almeida (1929) narrou a a forma por meio da qual, imaginariamente, o personagem do filme abandona a tela, e sai com ele, para tomarem um drink ${ }^{67}$. Brinca já com a possibilidade de projeção do leitor a partir do duplo.

Exatamente por ter uma natureza humana e divina, o duplo realiza a circulação entre projeção e identificação. Morin (1956) explica o processo de funcionamento do duplo por três mecanismos imaginários. O primeiro deles é a identificação. Esta nasce quando o leitor compartilha sobre sua auto-imagem um paralelo com a vida da atriz ou com o personagem interpretado. Sente, a partir do duplo, viver emoções fora de seu

\footnotetext{
66 Porém não podemos precisar ao certo quando esta ampliação da intimidade se iniciou cronologicamente em Cena Muda.

${ }^{67}$ No trecho citado, Guilherme de Almeida escreve: "George despede-se de mim. Volta para a tela. O filme trepida nos seus últimos lampejos. A sala acendeu-se. E, ao passar pela cortina de veludo ou ao abotoar o meu sobretudo, tenho a impressão de que George passa o seu braço pelo meu - e vamos juntos, George, um homem tão verdadeiro, e eu, um homem tão mentiroso, tomar um drink bem seco por aí..." (Almeida, 1929: 147)
} 
corpo. A identificação pode ser com um alter ego, do mesmo sexo, ou com um parceiro do sexo oposto, numa identificação apaixonada. Já a projeção funciona como expulsão para fora de si do obscuro, proporcionando libertação psíquica, embora os processos de projeção e identificação estejam interligados, através do suporte da transferência ${ }^{68}$. Quando a estrela se humaniza, o processo de identificação e de projeção se torna ainda mais presente para o leitor ${ }^{69}$, servindo como um sistema de legitimação para os novos padrões do star system, onde é importante a atriz ser como os mortais. Transferem-se desejos e anseios para ela.

Os leitores consomem a vida da atriz porque na cultura de massa existe um duplo movimento do real arremedando o imaginário e vice-versa. O setor imaginário, tal como analisado por Morin, procura se parecer com o realismo, e o real procura ter as cores do imaginário. As intrigas romanescas dos ídolos passam a ter a aparência de realidade. $\mathrm{Na}$ verdade, é o imaginário que permite ao homem moderno a projeção e identificação, daí a importância dos amores das celebridades, porque estes permitem tirar uma substância romanceada que a imprensa e leitores necessitam. Isso porque as estrelas são, segundo Morin, "heróis modernos que encarnam os mitos de autorealização da vida pessoal”, ligando assim o duplo à projeção. (Morin, 1962: 106-7)

Para existir intimidade é preciso gerar uma continuidade nos mecanismos imaginários que transformam o ídolo em modelo comportamental para o fã. As estratégias de legitimação criaram mecanismos para incutir a curiosidade pela vida pessoal. Este interesse surge quando o espectador vê nos famosos as características, almejadas por ele, a partir dos mecanismos projetivos explicados aqui. Além disso, o duplo gera no espectador o desejo de encontrar o grande amor de sua vida, concretizado no mundo do sonho, ou de se tornar conhecido, pelo menos no imaginário. Toda a

\footnotetext{
${ }^{68}$ Aprofundando o tema, explica Edgar Morin que "na identificação, o sujeito, em vez de se projetar no mundo, absorve-o. A identificação 'incorpora o meio ambiente no próprio eu' e integra-o afetivamente. A mais banal 'projeção' sobre outrem - o 'eu ponho-me no seu lugar' - é já uma identificação de mim com o outro, identificação esta que facilita e convida a uma identificação do outro comigo: esse outro tornou-se assimilável. Não basta, pois, isolar a projeção de um lado, a identificação do outro (...). É o complexo projeção-identificação-transferência que comanda todos os chamados fenômenos psicológicos subjetivos, ou seja, os que traem ou deformam a realidade objetiva das coisas, ou então se situam, deliberadamente, fora desta realidade, como os estados da alma, e os devaneios". (Morin, 1956, 82-5)

${ }^{69}$ Não pretendemos aqui estudar a audiência relacionada ao estrelismo. Para maiores detalhes, consultar Andrew Tudor e Leon Handel que estabeleceram quatro categorias para separar os tipos de percepção da estrela pelos espectadores, como fenômeno de consumo. (Tudor; Handel apud Dyer, 1998). Há a afinidade emocional (sentimento forte pelo protagonista), auto-identificação (colocar-se no lugar da estrela), imitação (modelo para a audiência, geralmente jovens) e projeção (imitação não só de vestuário e acessórios, mas imitar a forma de vida da estrela). Neste último, a estrela ensina como lidar com a realidade.
} 
estratégia das revistas de fãs está calcada na função do duplo. Os jornalistas e/ou publicistas que escreviam sobre a intimidade da estrela conheciam bem a função de duplo. Daí o surgimento do nicho de mercado das revistas de fãs.

A proximidade criada entre o repórter e o ídolo criou espaço para uma nova demanda. O próximo passo foi o suposto contato direto com as estrelas, presente em Cinelândia, e para tal, era necessário gerar um tipo de star system mais humano. Só que as bases desse novo estrelismo são diferentes das descritas por Edgar Morin. O processo de aproximação com os leitores, tal como descrito por Morin, gera um tipo de deusa humanizada, mas que não erra em nada grave, nem precisa pedir ajuda.

O período estudado pode ser pensado como momento de transição para uma humanização calcada sobre erros, dificuldades e problemas, sempre com o objetivo de se parecer cada vez mais com o real. Essa característica humana das estrelas está presente nas duas revistas, em todas as edições, em matérias como Iguais a todos nós ${ }^{70}$ :

\footnotetext{
"faz-se tanta ressonância em torno da personalidade do artista que se chega a impressão de que ele é um ser a parte, para o qual não há o cotidiano nem o sentimento comum a cada um de nós. Vai-se ver (...) são todos iguais a nós e aos nossos vizinhos. Com a diferença de que nós e nossos vizinhos não andamos nos telegramas nem nas manchetes. A propósito, vale a pena mostrar estes 'skils' colhidos na intimidade de alguns 'big names'?'
}

A matéria fotografa os atores em atividades comuns como pintar xícaras ou fazer tapetes. As revistas tentam vender a idéia de que os próprios ídolos passam a narrar suas vidas. Através da humanização e dos processos projetivos, as celebridades surgem como modelo comportamental, e sem esses mecanismos, as revistas de fãs não teriam tido a abrangência cultural que tiveram. No próximo item, mostraremos através de exemplos os processos descritos aqui. A partir dos mecanismos projetivos, a estrela surge como parâmetro comportamental, especialmente para as mulheres. Focalizamos a construção como modelo comportamental e o ensejo dos leitores em se tornarem olimpianos. Por outro lado, humanizadas, as atrizes estão mais aptas a dar conselhos. Assim, a análise recai também sobre as seções de cartas e espaços destinados aos leitores, além dos artigos escritos supostamente pelas celebridades aconselhando de forma direta $o$ público.

\footnotetext{
${ }^{70}$ Iguais a todos nós. Cena Muda, v. 32, n. 18, p. 27, 01/05/1952.
} 


\subsection{A estrela como parâmetro comportamental}

$\mathrm{O}$ culto à personalidade da estrela não revela o aspecto irracional dos fãs em consumir atributos geralmente inventados. Através delas, os leitores realizam no imaginário seus sonhos. Por meio dos mecanismos projetivos, as atrizes transmitem parâmetros comportamentais, lembrando que são elas as mensageiras do mito da felicidade, e também de parte dos ideais da sociedade. Os departamentos de publicidade utilizam o padrão de comportamento para centrar o interesse sobre o consumo do filme. Porém, o modelo de conduta era escolhido a partir de um imaginário favorável aos ídolos de cinema, sintonizado com as demandas sociais da sociedade. No geral, não se devia contrariar a regra vigente ainda na década de cinqüenta: a estrela deveria ser boa, acima dos mortais.

Assim, a partir de detalhes, como saber o perfume preferido da estrela, o seu novo penteado, ou a forma de lidar com a tríade carreira/casamento/filhos, o leitor se vê imbuído de informações úteis para lidar com seu mundo, a partir de parâmetros de comportamento dos mitos, daqueles que possuem talento, carreira, dinheiro e principalmente amor conjugal. Este último é o ponto mais importante para as revistas de fãs. A principal busca dos leitores será para imitar e conseguir encontrar um amor matrimonial como o das estrelas.

Discutiremos como se opera esta construção de modelo comportamental, a partir de três itens principais: 1.6.1) como se dá a construção da estrela como modelo de conduta; 1.6.2) o papel da propaganda como mediadora do estilo de vida e 1.6.3) as seções de conselhos e de respostas aos leitores.

\subsubsection{A construção da estrela como modelo de conduta}

A base para transformar as atrizes em modelo de conduta é trazer diversas reportagens mostrando como elas agem, para servirem de exemplo comportamental às leitoras. A partir de matérias, entrevistas, fofocas e fotos congeladas de momentos de enlevo amoroso, há uma idéia clara da perfeição da celebridade. Outra forma de sugerir um padrão comportamental, apesar de pouco utilizada, é censurar os escassos e pontuais erros das estrelas, aspecto este revelador de como a mulher não se deve portar ${ }^{71}$.

\footnotetext{
${ }^{71}$ Não só nos elogios se constrói o modelo comportamental, mas também nas críticas às estrelas, e indiretamente às mulheres com o mesmo perfil. São menos comuns porque a representação da estrela nas
} 
Vale lembrar que os parâmetros de comportamento visam especialmente às mulheres, principal público alvo das revistas Cena Muda e Cinelândia durante 1950, num universo comum que congrega cinema, revista feminina e conselhos. A perspectiva do exemplo ideal de mulher para o comportamento das leitoras é a esposa dedicada ao lar, a partir dos diversos relatos dos astros. São inúmeros os textos em Cinelândia narrando a maneira correta e idealizada pelos homens da conduta feminina, mas nenhum do contraponto desejado pelas mulheres. Os galãs de Hollywood elucidam seu tipo preferido, mostrando indiretamente como conquistar um marido. Às vezes apontam os principais erros femininos neste quesito. O ideal descrito por Farley Granger é uma "clássica mulherzinha carinhosa. Nada de mulheres vitoriosas em sua carreira", porque ele não se "daria bem com uma esposa mais preocupada com a carreira do que com o resto das coisas" 72 . Depois para abrandar a opinião de Granger, o repórter anônimo declara que o casamento será para ele a coisa mais importante em sua vida, por isso o ator espera o mesmo da futura e desconhecida amada. Apesar de Cinelândia questionar a descrição, porque não acredita na cena idílica, alega que o ator precisa amadurecer. Assim, não se condena o machismo da declaração, mas a falta de maturidade do astro. Também Ava Gardner depois de ver o fracasso do seu casamento, tem uma postura diferente: tudo o que ela quer é ter uma vida simples, no lar e para o lar ${ }^{73}$. O exemplo da dona de casa cabe exatamente a uma atriz muito ligada à esfera do desejo e do sex appeal. Ava serve de exemplo à Cinelândia, embora não tenha deixado a carreira para se dedicar ao casamento.

Para os atores de Hollywood ${ }^{74}$, a mulher ideal é a bela com "algo a mais". A beleza não é suficiente sozinha. A mulher amada deve estar acima das outras, admirada, no fundo, como a estrela. Nesse sentido, volta-se indiretamente à celebridade como síntese da perfeição, porque só ela possui todas estes pressupostos. Isso fica subentendido no texto, quando se descrevem as características excepcionais desta mulher ideal. $\mathrm{O}$ que os atores buscam descrever na verdade é o it, um algo a mais

revistas possuía no período apenas alguns erros pontuais. As mulheres criticadas são as que amam boites, usam maquiagem pesada, falam alto, criticam os homens em público, tentam dominar a conversa para atrair a atenção. De modo geral, para Cena Muda, um atributo sem igual é a simpatia. As atrizes consideradas antipáticas são vistas de maneira bastante negativa, anulando qualquer qualidade ou talento. Tony Curtis chega a dizer: "a mulher que faz qualquer tipo de crítica é uma mulher que merece a minha antipatia”. Mac Kay, Margareth. O meu tipo feminino. Cinelândia, v. 1, n. 1, p. 8; 48, maio 1952. Não ampliaremos este conceito porque ele será retomado no item sobre as críticas aos olimpianos.

72 Às vezes sou feliz. Cinelândia, v. 1, n.6, p. 18-9; 59, out. 1952.

${ }^{73}$ A rainha do glamour: Ava Gardner. Cinelândia, v.1, n. 1, p. 16-7, maio 1952.

${ }^{74}$ Mac Kay, Margareth. O meu tipo feminino. Cinelândia, v. 1, n. 1, p. 8; 48, maio 1952. 
inexplicável, que só a diva de cinema tem. As apenas belas acabam por ceder o lugar às outras. Importa para os atores a força de caráter, simpatia, inteligência, meiguice. Na maioria dos textos se vende a idéia de que nem todas são belas, nem todas têm atrativos físicos, mas todas podem ser bonitas. Além disso, "não existe mulher bela que não seja boa e compassiva". A beleza surge também como consequiência dos atributos interiores. Entre os predicados necessários os atores destacam: a alegria de viver, as mulheres compreensivas, moças interessadas por uma variedade maior de divertimentos (são citados apenas esportes masculinos), as amantes da natureza e do ar livre, as interessadas pelos outros, principalmente atentas a ouvir seus namorados e maridos. Não é citado textualmente que a leitora deve seguir aquele modelo, mas ela perceberá que a descrição é das esposas dos galãs, porque todos se dizem felizes no casamento. Depois, para não haver dúvidas, a revista declara que eles encontraram a mulher ideal: "o que prova que não sonharam com o impossível". Assim, o modelo de mulher para alcançar a felicidade é a estrela. Para fechar o ciclo, estas esposas escrevem seções de conselhos às leitoras.

Os valores positivos numa mulher, seja estrela ou leitora, é o da mulher submissa, criada para viver em função do lar. A carreira pode existir como ponte para conseguir um casamento, mas não pode de modo algum atrapalhar o amor conjugal, significação maior da vida feminina, mas não da masculina. A esposa ideal como modelo de conduta pode ser personificada em Betsy Drake, mulher de Cary Grant.

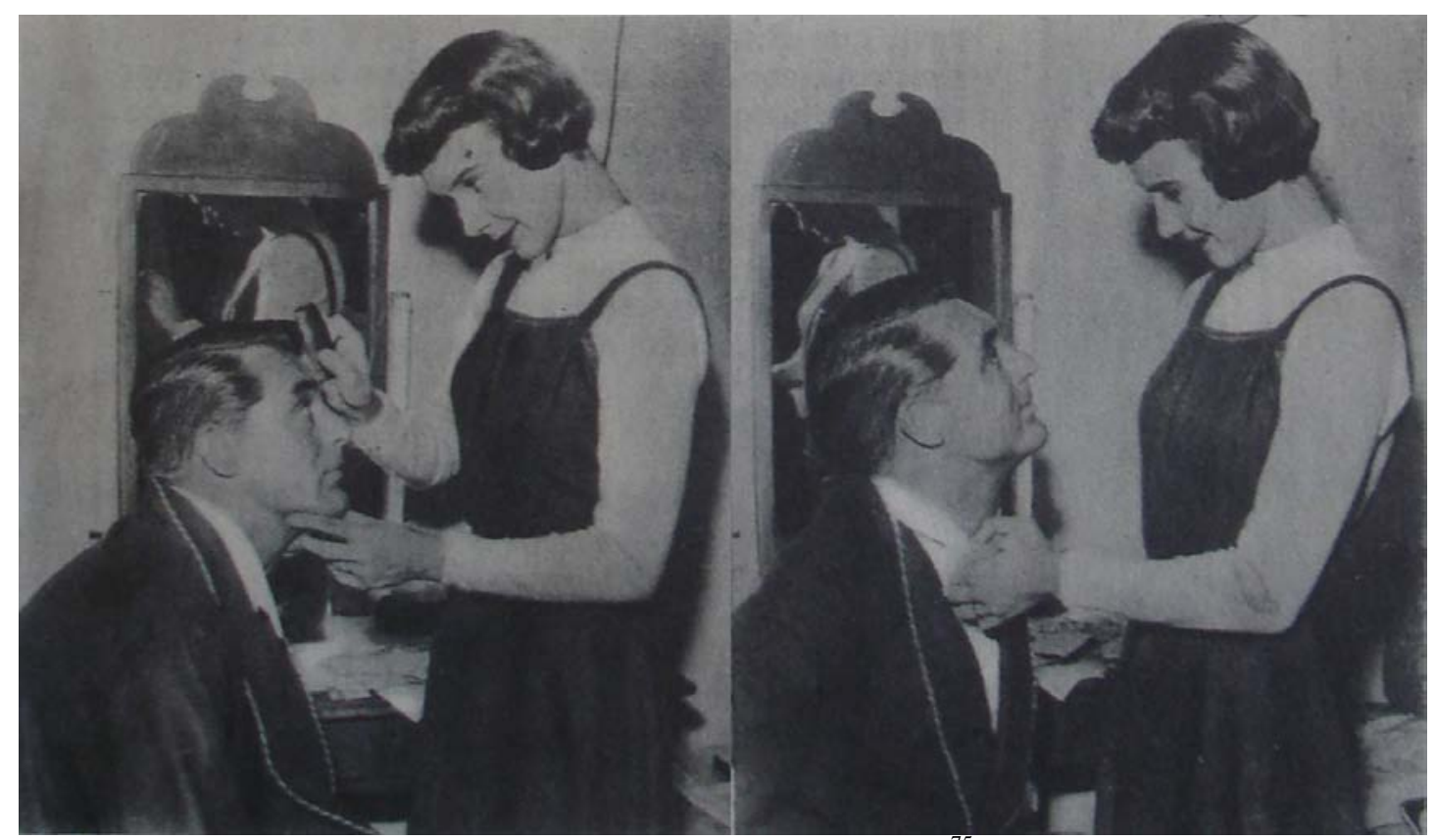

Imagem 2 - Betsy Grable

\footnotetext{
${ }^{75}$ Cinelândia, v. 1, n. 1, p. 11, maio 1952.
} 
De acordo com um texto claramente de divulgação do estúdio, todos os dias Betsy vai ao set de filmagem para fazer café, arrumar a gravada, pentear seus cabelos, passar o texto com o marido. Tarefa muito apreciada pelo ator, de acordo com o artigo e a expressão dele na fotografia. Além de cumprir as funções domésticas dentro e fora de casa, ela ainda co-estrela o filme com Grant. O título da matéria A babá do gala $^{76}$ é considerado positivo. As fotos, além de artificiais pelo olhar congelado entre os dois, não escondem sua função direta de release do próximo filme deles, Lugar para mais um (1952), de Norman Taurog.

Betsy trabalha fora e cumpre as funções domésticas até no set de filmagem, mas as estrelas que desistem da carreira pelo casamento são bastante elogiadas. Este modelo induzido do comportamento da esposa voltada apenas ao lar tentava tornar-se próximo das leitoras, a partir da mitificação e das novas formas de criação da identidade pelo consumo simbólico. Isso ocorre porque os símbolos de Hollywood, como analisou Néstor Garcia-Canclini (1995), são formas de consumo de bens simbólicos, que se tornam mais poderosos na configuração da identidade do que os tradicionais, como família, religião ou partidos políticos.

Dessa forma, a estratégia de transmitir a vida da estrela visando ao consumo do filme converte-se também numa determinada visão da mulher. As revistas de fãs como geradoras de poder simbólico autenticam também uma construção conservadora, moralista e submissa do papel feminino, corroborando com o domínio exercido no campo das ações materiais.

Nossas observações sobre o papel da mulher atrelado ao lar nas revistas pesquisadas coincidem com a tese de Dulcília Buitoni (1980) sobre a representação da mulher na imprensa feminina. Buitoni divide a representação dos valores femininos por décadas, designando os anos cinqüenta como a da garota moderna ${ }^{77}$. Apesar do termo, a autora confirma que o amor só existe por vias do casamento. Amar e casar são sinônimos. Através do amor todos os problemas se resolvem, e a felicidade suprema só se realiza no lar. A mulher esperta deve ser ela mesma para conseguir prender o namorado. Jamais deve ofuscar ou cansar o amado. A perspectiva do querer é sempre dos homens. Na imprensa, nunca se indaga às mulheres o que elas querem dos homens, assim a mulher se vê através de outros olhos que não os seus. Há ainda no final da

\footnotetext{
${ }^{76}$ Cinelândia, v. 1, n. 1, p. 11, maio 1952.

${ }^{77}$ Segundo Buitoni (1980), na década de 1930-40, a mulher bonita era chamada de girl, passando para garota na década de cinqüenta, para depois se tornar a jovem, além de nova.
} 
década de cinqüenta uma conotação negativa quanto à inovações e movimentos de vanguarda $^{78}$.

No geral, não há sugestões explícitas nas reportagens de como a leitora deve proceder. Os artigos trazem apenas a conduta perfeita, tendo por base as estrelas. São transmitidos geralmente modelos imitáveis de comportamento. As alusões diretas à forma de se portar estão mais presentes na incitação do consumo pela publicidade e nas seções destinadas às indagações das missivistas, com as particularidades que veremos agora.

\subsubsection{A propaganda como mediadora do estilo de vida}

O consumo de um modo de vida nas revistas visa logicamente ao consumo dos filmes. Mas nesse meio termo, a propaganda se une ao moralismo numa representação tradicional do papel da mulher. Os anúncios de Cinelândia mostram uma revista essencialmente feminina ${ }^{79}$. As estrelas de cinema passaram a integrar os anúncios a partir dos decênios 1910-20, processo analisado por Richard DeCordova (2001).

\footnotetext{
${ }^{78}$ Só na década de sessenta, a representação da mulher mostra a insatisfação no casamento, falando da liberdade. Embora apenas em 1970, temas tabus são descritos; o sexo passa a ser o principal produto vinculado. A representação da mulher em 1970 não precisa passar necessariamente pelo casamento. O mais importante é amar e consumir. (Buitoni, 1980)

${ }^{79}$ Há muitos anúncios de cosméticos, cintas modeladoras, absorventes, eletrodomésticos para a casa, roupas para bebês, tecidos, leite de rosas, sabonetes embelezadores. Em Cena Muda há escassas páginas de propaganda, no máximo três, voltadas ao público feminino, mas com possibilidades mais neutras, como lojas de sapatos. Não se pode dizer que a revista não tivesse propaganda devido a sua decadência, porque havia um modelo pouco profissional na relação com a publicidade. Não era a quantidade de páginas de propaganda que diminuía. Em décadas anteriores já havia poucas folhas dedicadas ao tema. Para Salvyano Cavalcanti de Paiva, um dos motivos da decadência editorial de Cena Muda era sua relação atrasada com a publicidade. Ele contou a Flora Bender (1979) que não havia uma agência de propaganda encarregada de programar os números do periódico. Cena Muda estava atrasada em relação à publicidade da época. Bender mostra que a publicidade da revista era feita por Severino Lopes Guimaraes. Só em 1954, a revista passa a citar o nome de J.M. Costa, S.L. Guimaraes, A. Mendes e S. Sant'Anna. Contudo, não era mais eficiente procurar anúncios em lojas nas esquinas, como ela fazia. O atraso parece ser grande quanto à publicidade feita no período. Ana Luíza Martins (2001) narra depois do final da Primeira Guerra Mundial, surgiram cinco agências de publicidade, encarregadas também de realizar assinaturas para os jornais e revistas. A consolidação das agências de publicidade ocorre ainda na década de trinta. Já Cinelândia nasce com média de treze páginas de propaganda, conseguindo anúncios de grandes empresas, não do pequeno comércio. Ana Paula Goulart Ribeiro (2001) explica que após a Segunda Guerra Mundial, a publicidade ganhou impulso no país em decorrência do crescimento industrial, com grande aumento no orçamento de publicidade durante os anos cinqüenta. As agências de publicidade cresciam, apesar de muitos jornais terem departamentos de publicidade. Os anúncios eram distribuídos através do pagamento de uma taxa sobre o volume das verbas. As agências eram autônomas, não meras intermediárias, além de realizaram as campanhas com redação e ilustração. Já faziam estudos de mercado rigorosos sobre a circulação dos jornais para decidir onde anunciar. Em 1950, metade do volume total de publicidade despendido no Brasil foi distribuído através das agências, com porcentagem maior ainda nas grandes cidades. A publicidade favoreceu o movimento de concentração das empresas
} 
Durante a década de trinta, as revistas publicavam as fotos das estrelas com as roupas que iriam usar nos próximos filmes. Charles Eckert (Gledhill, 1991) ressalta que esta associação tomou a liderança na forma da publicidade e se tornou lugar comum naquele decênio. As fotos eram distribuídas gratuitamente com texto apropriado para centenas de órgãos da imprensa. A venda das roupas foi tremendamente auxiliada pelos releases e fotos nos jornais e das revistas de fãs. Tentou-se evitar o surgimento de linhas mais baratas com as roupas das atrizes, mas pouco a pouco elas também foram surgindo. A partir dos anos trinta, os cosméticos tornam-se símbolo de Hollywood. Antes ficavam em segundo lugar no volume de publicidade, depois dos produtos alimentícios. Nesta mesma década, há um esforço para criar roteiros escritos com as menções à publicidade para a futura venda. Charles Wolfe (Gledhill, 1991) acrescenta que em 1936, as roupas das estrelas de Hollywood eram tratadas como itens regulares nas principais revistas norte-americanas. A publicidade adquiria assim uma nova dimensão social.

Paul McDonald (2000) conta que em 1930 foi criado o Modern Merchandising Bureau, de Bernard Waldman. Os estúdios mandavam cenas e fotos do estilo dos filmes antes do lançamento para se produzir roupas a partir desses modelos. A rede enviava as peças de roupa para os vendedores com o material de publicidade da estrela no filme. Sua rede Cinema Fashion Shop tinha 400 lojas em 1937, além de produzir para mais 1400 pontos de venda. O autor lembra também a importância do glamour das celebridades nos anos da depressão econômica quando na Inglaterra, durante a guerra, as mulheres copiavam os figurinos dos filmes, indicando uma escapatória das condições reais de vida. As linhas de vestuário prontas ofereciam a imagem do glamour a preços módicos.

No caso das revistas americanas, a assimilação do nome das atrizes ocorria meses ou até um ano antes de seu aparecimento nas telas. Thomas Haris (Gledhill,

jornalísticas. Os veículos maiores concentravam as maiores receitas publicitárias. As principais publicações cariocas batiam recordes de faturamento nesse quesito, aumentando a dependência dos jornais em relação à publicidade com o aumento dos custos de produção. As reformas gráficas e editoriais foram um fator importante para atrair a publicidade comercial. Ainda em 1949, O Globo faturou mais de dez milhões de cruzeiros através das agências. Em 1956, o mesmo jornal declarava que os anúncios de um ano geraram 92 milhões de cruzeiros, $920 \%$ a mais do que em 1949. Werneck Sodré (1999) lembra que as empresas jornalísticas eram pressionadas pelas agências de publicidade, representante dos monopólios estrangeiros. Em 1953, o total de publicidade paga e distribuída por companhias americanas aos jornais, rádios e outros veículos de propaganda foi da ordem de 3 bilhões e 500 mil cruzeiros. Werneck Sodré cita um estudo do período que indicou as empresas, geralmente americanas, que mais gastavam em publicidade, entre elas duas empresas que eram anunciantes constantes na revista Cinelândia, a Antártica e a Cia. Cigarros Souza Cruz, esta última também constante em Cena Muda. 
1991) lembra que a publicidade ainda se encarregava de interpretar o papel do novo filme da estrela para pré-estabelecer um estereótipo. Existia uma funcionária encarregada de plantar itens sobre a personalidade da celebridade nos jornais e revistas, além de assegurar que o material publicitário fosse convertido em penteados, estilo de roupa e figurino.

No Brasil, antes de 1922, havia dois tipos de representação paralela da mulher nas revistas. Ana Luíza Martins (2001) mostra que no texto havia a vinculação como esposa e mãe. Nas imagens, como consumidora, para vender os produtos em voga. Até nas publicações masculinas havia seções destinadas a este nicho. As ilustrações já mostravam uma mulher esportiva, liberada, moderna, que fumava e dirigia, explicando que esta imagem moderna era destinada às camadas de maior poder aquisitivo, nas revistas de elite. O discurso do recato e economia era voltado às leitoras de classe média. Estas últimas copiavam os figurinos. Cena Muda e Cinelândia já trabalham a dicotomia destes dois discursos paralelos: geralmente no texto, a idéia do recato, e na imagem o símbolo do consumo.

Nas revistas pesquisadas, a propaganda tem duas vertentes. A primeira é a direta, focada na incitação explícita ao consumo, ligada às preferências das estrelas, vistas como modelo para a leitora ficar tão bonita quanto à atriz. Presentes particularmente em Cinelândia, de forma aparentemente inocente, a propaganda sobre o universo dos ídolos adentra nos desejos do público ${ }^{80}$. Na seção Eu sou assim, em Cinelândia, as olimpianas descreviam seus gostos. A maior parte dos textos começa com as predileções delas por determinados perfumes e artigos de luxo. Não aparecem somente os nomes dos

\footnotetext{
${ }^{80}$ Para entendermos como se opera o consumo da publicidade nos espaços de conselho, vistos de maneira neutra, trazemos o conceito de denegação de Pierre Bourdieu. Esta funciona através da negação real do interesse econômico. A partir do irreconhecimento coletivo, as manifestações culturais coletivamente irreconhecidas são reconhecidas. Os interesses publicitários são denegados através da cobertura aos estilos de vida, as dicas amorosas e a aproximação e conseqüente identificação entre a estrela e o público. A publicidade dos filmes fica oculta através da cumplicidade dos leitores interessados em consumir o ídolo como seu Deus. A denegação do interesse econômico serve para legitimar as publicações voltadas ao star system como desprovidas de interesses e vantagens comerciais, a partir da neutralidade e do discurso de incentivo ao cinema brasileiro. Resta lembrar que o processo ocorre quando estudamos as instâncias institucionais, não em nível individual. Obviamente não era o objetivo explícito por parte dos jornalistas denegar os interesses econômicos. Longe disso, porque se o processo é reconhecido pelos indivíduos, perde seu efeito porque cai por terra o irreconhecimento coletivo. É importante ressaltar que o irreconhecimento coletivo funciona a partir da aceitação da violência simbólica por parte de todos. Existe uma alquimia social entre o grupo. Um empreendimento bem sucedido depende de interesses bem sublimados e eufemizados para serem satisfeitos pela dissimulação. Os excluídos ajudam a produzir e reproduzir as propriedades distintivas que conferem aos detentores destas ações/produtos simbólicos sua raridade aparentemente intrínseca, porque contribuem para sustentar continuamente a tensão do mercado de bens simbólicos. "A imposição da legitimidade é a forma acabada da violência simbólica, violência atenuada, que só pode ser exercida com a cumplicidade de suas vítimas (...), a violência simbólica é tanto mais presente quanto mais mascarada" (Bourdieu, 2001: 183; 205).
} 
produtos, mas também citações a lojas e cosméticos. Joan Crawford conta que sonhou ter roubado uma grande quantidade de seu perfume preferido (citando o nome), novelizando uma história ${ }^{81}$. Jan Sterling vai mais longe e declara: "se os fabricantes gostaram do anúncio, podem mandar-me um bom carregamento de perfumes..." ${ }^{82}$. Os produtos são assim estimulados pelas atrizes, mas de uma forma denegada, porque o produto visa a deixar a mulher mais bonita, invertendo a razão da propaganda. Fixa-se, assim, de maneira sutil, o nome de um produto, a partir do desejo de partilhar os encantos estrelares. Estas incitações diretas ao consumo minguam em alguns meses.

A segunda vertente é a da propaganda indireta nas matérias com dicas de maquiagem e tipos de roupas, explicando como se tornar glamourosa. As estrelas em Cinelândia sempre dão dicas de maquiagem e roupas ${ }^{83}$. As seções com os vestidos das atrizes são constantes nas duas publicações. Em cada número de Cinelândia, há fotos coloridas para divulgar em minúcias a casa de um ídolo, além de seu estilo de vida. Contudo, se incita nesse último tipo de propaganda de maneira indireta o consumo ${ }^{84}$, não se diz qual produto consumir, mas estes nomes aparecerão em outras matérias. Estas imagens das casas dos atores também não são novidade. Richard DeCordova (2001) as encontrou em Photoplay ainda em meados da década de 1910. Porém, o interesse pelo lar dos atores já não era na época para propagar valores familiares, mas sim para incitar ao consumo, já consolidado na sociedade norte-americana nos anos 1910-20. Em Cinelândia, as fotos da fachada das mansões, com os atores em alguns cômodos internos, eram acompanhadas de imagens idílicas do amor do casal. Às vezes os filhos apareciam, tema que abordaremos no item sobre a construção da felicidade.

A vertente da propaganda indireta é sem dúvida a mais eficiente, lembrando que a publicidade é estimulada nos espaços do conselho aparentemente sem interesse, como indicou Morin (1962). Torna-se parte integrante da cultura de massa. São conselhos que dizem respeito à saúde, ao conforto, à beleza e à sedução. Os produtos de consumo são instigados no estágio dos temas imaginários de ordem prática, onde se exerce a pressão da indústria.

\footnotetext{
${ }^{81}$ Crawford, Joan. Eu sou assim. Cinelândia, v. 1, n. 4, p. 7-8, agosto 1952.

${ }^{82}$ Eu sou assim. Cinelândia, v. 1, n. 3, p. 19, julho 1952.

${ }^{83}$ A revista $O$ Cruzeiro possuía seções semelhantes, com dicas de roupas e maquiagem das estrelas de cinema. Havia geralmente oito colunas especiais dedicadas às mulheres.

${ }^{84}$ Nas primeiras edições de Cinelândia estes artigos citavam os nomes dos decoradores. Rapidamente o nome das grifes somem, talvez por serem uma propaganda pouco eficiente pela distância geográfica, para o público específico e para o período.
} 
Contudo, nenhuma das duas revistas teve coragem de explicitar a relação entre moda e cinema, como o fez Guilherme de Almeida ainda nos anos vinte. O cronista, com um quê de fã encantado, mas irônico, admite o enraizamento da moda no cinema, e vice-versa. Declara ser impossível separar os dois: "duas divindades distintas numa só verdadeira. Porque elas tanto se fundem, tanto se correspondem, tanto se completam, que chegam a formar só um ídolo com um só poder e um só culto" (Almeida, 1929, 206). Além de analisar a conexão, G. de Almeida explica que a moda gera grande parte do sucesso das estrelas, muito mais do que pelas qualidades e talento das atrizes:

\begin{abstract}
“(...) se, aquela estrelinha ligeira daquele filme leviano agrada tanto, atrai, como um imã imagético, toda a miúda limalha humana - e o cinema enche-se de gente, e os jornais enchem-se de notícias, e os empresários enchem-se de dinheiro e os lares enchem-se de discórdias... -, se aquela estrelinha faz assim tanto sucesso, produz assim tanto ouro, promove assim tantos divórcios, engendra assim tantos suicídios, indubitavelmente é porque ela é moderna, porque ela se veste como Paris quer que se vista, porque ela sabe ilustrar, na tela viva, a página morta do último, precioso Vogue...” (Almeida, 1929: 206)
\end{abstract}

Cinelândia sabia com destreza utilizar a propaganda de produtos diretos a se consumir através das estrelas, Cena Muda tentou em 1952, mas abrandou sua utilização no ano seguinte. Não se fecha completamente, portanto o ciclo do consumo pela propaganda nesta última. Apesar de a empresa tentar desnudar o estrelismo em todos os anos, Cena não teve a coragem de admitir que as páginas com os vestidos das celebridades eram uma estratégia explícita para o sucesso dos filmes, como o fez Guilherme de Almeida. Cinelândia, por outro lado, não tentava esconder a relação com a publicidade, considerada extremamente positiva. Chega a declarar que os leitores modernos não prescindem dela ${ }^{85}$, mostrando de forma implícita o papel da propaganda como mediadora para atingir atributos estrelares.

\footnotetext{
${ }^{85}$ Aos leitores. Cinelândia, v. 1, n. 3, p. 3, julho 1952.
} 


\subsubsection{As seções de conselhos e respostas aos leitores}

O último ponto analisado neste subitem refere-se à representação do parâmetro comportamental sugerido de maneira direta como ideal às leitoras em duas frentes: na primeira, os conselhos das estrelas às leitoras ensinando como manter o marido ou conquistar um, e por último, as seções com respostas às cartas dos missivistas. Os conselhos, dados por atrizes ou especialistas, na maior parte dos casos referem-se à esfera sentimental. Ao examinar tais seções podemos compreender como este modelo comportamental gerado nas reportagens, agora direcionadas diretamente às leitoras, era retomado para instruir formas de se portar frente aos homens. Os conselhos não fogem ao ideal da mulher voltada ao lar, como nas reportagens. Além disso, de maneira mais direta ainda, as colunas destinadas às leitoras consideram que as mulheres sozinhas são culpadas de sua situação, caso prefiram ler livros em casa ou assistir a filmes ${ }^{86}$.

Dulcília Buitoni (1980) percebeu uma representação subjacente do feminino na imprensa feminina, sempre como mito. O primeiro periódico destinado às mulheres surgiu na Grã Bretanha ainda em 1693, chamado Lady’s Mercury. Neste veículo já havia a seção de consultório sentimental. No Brasil, a imprensa feminina surge no século XIX, com dois tipos de representação da mulher, a tradicional com a mulher sem ação fora do lar, engrandecendo as virtudes domésticas e as qualidades femininas, e a progressista, defendendo os direitos femininos e a educação, esta última obviamente ausente nas revistas pesquisadas.

Uma revista de cinema com seção destinada à mulher não era novidade na década de cinquienta. Também os jornais de prestígio, como $O$ Estado de $S$. Paulo e $A$ Folha de S.Paulo dedicavam seções às mulheres. O Suplemento Feminino do Estadão surge em 1953. Na década de cinqüenta há um aumento nas publicações destinadas ao público feminino. Buitoni lembra que a revista Capricho surgia em 1952, com tiragem muito superior à das publicações pesquisadas ${ }^{87}$.

As colunas de Cinelândia voltadas ao contato entre estrela e leitora se mantêm temporalmente, diferente das da revista concorrente. A apresentação das atrizes como

\footnotetext{
${ }^{86}$ Para resolver o problema a mulher deve aceitar convites até dos homens com quem jamais sairia, nem casaria, para através deles conhecer outros. Miller, Ann. Dez mulheres para um homem. Cinelândia, v.1, n. 1, p. 34-5, maio 1952 .

${ }^{87}$ Na primeira edição, Capricho teve tiragem de 26 mil exemplares, passando a ter uma média de 90 mil. No final da década a tiragem era de 500 mil. Na França, a revista Marie Claire já tinha tiragem de 800 mil exemplares ainda em 1937.
} 
modelo de conduta em Cinelândia é mais detalhada porque a publicação é acima de tudo uma publicação feminina. Cena possui esta faceta especialmente entre 1952-3, mas o enfoque feminino não é tão evidente em todas as edições. Não negamos, com isso, o apelo destas mesmas revistas ao público masculino, mas o alvo principal é a mulher. As celebridades continuavam a ser modelos a se seguir porque não havia problematização do star system em sua estrutura. Os problemas e infelicidades destes eram passageiros. Os ídolos podiam, assim, aconselhar os leitores. Em 1952, as estrelas conselheiras em Cena Muda são as estrangeiras, mas há colunas escritas por jornalistas e supostos psicanalistas do Brasil. No final de 1953, surge a coluna Querida Marlene, em que a cantora Marlene dava conselhos amorosos ${ }^{88}$. Em Cinelândia, apenas as atrizes estrangeiras dão conselhos; como se as brasileiras não tivessem autenticidade simbólica suficiente para a empreitada. Segundo Morin, a estrela deve ajudar seus admiradores sempre. (Ela) "é constantemente solicitada a dar conselhos íntimos, sentimentais e morais". (Morin, 1957: 32)

Cinelândia nasce com uma representação mais real de suas leitoras, enquanto Cena abordava apenas o perfil de beleza perfeita das olimpianas. Atrelada a um periódico feminino, Cinelândia propõe a resolução de todos os problemas através da "arte do glamour" em artigos com linguagem extremamente publicitária. Parte da premissa de que é a mulher quem precisa do produto para ficar bonita, negando a necessidade comercial dos produtos. Na seção Para sua beleza, atribuída à atriz Joan Bennett, há inúmeras dicas de maquiagem para ajudar as que se sentem feias:

\footnotetext{
"para se transformar uma pequena sem grandes atrativos numa criatura encantadora será preciso recorrer à feitiçaria ou a golpes de magia? Em absoluto! Leia o que Joan Bennett tem a dizer a esse respeito e verá que bastam, para consegui-lo, certa dose de sensatez e o conhecimento de alguns segredos. (...) Você é uma pequena comum, sem atrativos? Se é, não se desespere. Muitas das nossas mais lindas mulheres eram iguais a você ante de se iniciarem na arte do 'glamour'." 89
}

Apesar de os textos se proporem a auxiliar padrões fora do ideal das páginas editoriais, como "uma pequena de pele ruim, cabelo castanho claro e gorducha", as soluções propostas são paliativas. Não há informações para emagrecer ou tratar da pele, apenas a transformação da aparência via maquiagem, acessórios e roupas para parecer mais magra. Há uma condenação ao excesso (de maquiagem ou de acessórios) em total dissonância com a representação do belo nas fotografias da revista.

\footnotetext{
${ }^{88}$ A seção surgiu primeiro para informar sobre a vida profissional da cantora.

${ }^{89}$ Cinelândia, v. 1, n. 1, p. 39, maio 1952.
} 
Os conselhos para o amor buscam geralmente evitar o divórcio ou ensinar como conquistar um marido. Esther Williams fornece dicas machistas de como a mulher deve se comportar. Na entrevista chamado Prenda seu homem $^{90}$, declara a atriz que os defeitos dos maridos não valem nada se ele for um bom pai, "mas o que nossos maridos gostariam de mudar em nós mesmas, merece uma transformação”. A mulher deve ser organizada, manter tudo limpo em casa, ter senso de humor, ser esportiva e nunca falar dos aborrecimentos de casa, quando o cônjuge chegar. Deve ainda ajudar a economizar, não gastar todas as economias e evitar longas separações. O mais importante numa mulher é ser limpa. Glamour não importa, o essencial é usar vestidos limpos ${ }^{91}$. O marido lhe deu uma grande lição quando pediu que ela não tivesse opinião, porque Esther o interrompia sempre, sem deixá-lo terminar suas frases. Com esses pressupostos, o marido ensinou a ela a fórmula da felicidade, partilhada com as leitoras:

"ouço conscientemente, espero que ele peça a minha opinião, antes de falar sem ser chamada - e nem sempre tenho uma opinião. O poder sobre um marido depende muito dessa palavra: conscientemente".

Em caso de o marido estar enamorado de outra mulher, o conselho de Esther é grudar nele como se estivesse acometido por uma doença até sarar. Ela não deixaria o "investimento" de tantos anos para outra. E termina com um conselho: "um bom homem é difícil de encontrar, então se encontrar (um), não o deixe escapar".

Se a matéria citada acima constrói Esther Williams como a esposa ideal como parâmetro direto de comportamento, pelas citações explícitas de como as leitoras devem se portar, há outro tipo de representação ao público, voltada aos atributos de beleza das estrelas. A beleza é o pressuposto necessário para se discutir a personalidade, nascendo daí o conselho sentimental. Cena propõe analisar os formatos dos lábios para saber a personalidade das moças, a partir do modelo de Lana Turner. O conselho do profissional de beleza é observar os lábios sem batom antes de casar: "o homem que desposa uma mulher sem a ver sem batom põe em sério risco a sua felicidade" porque

\footnotetext{
${ }^{90}$ Prenda seu homem. Cena Muda, v. 32, n. 14, p. 22-3; 34, 03/04/1952.

${ }^{91}$ Mais do que o glamour, quando as matérias se dirigem às leitoras, há uma insistência em ensinar que a higiene é importante, deve-se lavar os cabelos todos os dias, passar as roupas, usar vestidos limpos, como se as duas revistas estivessem se imbuindo de instruir (com grande atraso) as normas do novo tempo. Dessa forma entram os produtos para a higiene pessoal. As indústrias norte-americanas de limpeza e higiene pessoal, como a Colgate-Palmolive e Gessy Lever, produziram e patrocinaram as primeiras radionovelas, tendo por público-alvo a dona de casa. (Hamburger, 1998)
} 
"a disposição de uma mulher está revelada em seus lábios" 92 . A matéria é um teste de personalidade, com dicas aos homens, e como sugestão comportamental às mulheres via o conhecimento da arte do glamour:

\footnotetext{
"Se quiserem ganhar uma discussão não se casem com a garota de lábios, finos, retos e apertados. (...) As mulheres com boca do tipo botão de rosa sempre levam a melhor na briga. Se o sujeito quer se impor não deve casar com esse tipo de moça."
}

Contudo o objetivo da matéria não era auxiliar ninguém, uma vez que todos os formatos labiais possuem mais defeitos do que qualidades. Há uma análise da configuração da personalidade através dos traços físicos ${ }^{93}$. O artigo de duas páginas tem em Lana Turner a perfeição do contorno labial, embora não esclareça qual era seu formato, para evitar creditar à atriz algum defeito ou concretizá-la apenas como um tipo de mulher. Afinal, Lana Turner não pode ter defeitos. A idéia do amor e do beijo eufemizado adquire também funções de conselho sentimental às moças, dissimuladas no aprendizado da maquiagem, sem ensinar a técnica utilizada por Lana Turner para não ocultar a curva natural dos lábios. Há sempre o movimento de conceder e de manter o segredo, incitando a curiosidade do leitor para mantê-lo insaciado porque não se revela o prometido. O estudo e reconhecimento de cada parte do rosto da atriz era uma constante para os fãs. Eles deveriam saber distinguir o formato do nariz, da boca, da sobrancelha das estrelas. $\mathrm{O}$ apelo à perfeição dos lábios de Lana serve de publicidade ao filme A viúva alegre (1952), de Curtis Bernhardt, presente na imagem de Lana na iminência de ser beijada por Fernando Lamas na primeira página da publicação. Embora a atriz tivesse os lábios mais beijáveis do mundo (título da matéria), Fernando Lamas a traiu com outra, justamente na época desta edição. Um pequeno símbolo não aproveitado do declínio do mito da felicidade na revista, usado apenas para fins publicitários.

Na seção Respostas de Jeanne Crain, em Cinelândia, as leitoras, inclusive as brasileiras, podiam enviar cartas à atriz-conselheira. A coluna inclui a publicidade do

\footnotetext{
${ }^{92}$ Williams, Penélope. Lana Turner, os lábios mais beijáveis do mundo. Cena Muda, v. 32, n. 47, p.18-9; $34,21 / 11 / 1952$.

${ }^{93}$ Assim como nesta reportagem sobre a perfeição dos lábios, Dulcília Buitoni (1980) observou na imprensa feminina durante a década de quarenta textos semelhantes a este, no qual o corpo determina a personalidade, minimizando o contexto familiar e social. Entre diversas citações de Sérgio Augusto (1989) para contextualizar a época em que as chanchadas foram produzidas, ele relembra diversos fatos sem situá-los temporalmente. Cita um concurso realizado pelo jornal O Estado de S. Paulo "quem tem lábios parecidos com o de Hedy Lammar?" Não eram apenas as revistas de fãs que incentivam os leitores a reconhecerem cada detalhe do rosto das estrelas, ou eleger como modelo os lábios de Lana Turner, também o jornal de prestígio utilizava os mesmos métodos.
} 
próximo filme. Um dos casos narrados é o de uma viúva. Ela teve de voltar a ser dançarina numa boite, deixando o filho com uma família. Vê a criança apenas no final de semana ${ }^{94}$. Um tema moderno e fora dos tabus como esse de uma dançarina de boite não apareceria em Cena Muda. Jeanne Crain aconselha um curso de datilografia para no futuro a mãe poder ficar com seu filho.

A carreira da mulher nestas seções não tem importância alguma, embora em mais de uma matéria, provavelmente de procedência estrangeira, se fale no número crescente de mulheres trabalhando fora, realidade considerada longe do ideal ${ }^{95}$. Assim, a estrela condena uma moça por não entender como ela pode ficar em dúvida entre casar e ter uma carreira ${ }^{96}$. Entre ter uma vida melhor com os pais e se tornar bailarina, ou ter um cotidiano difícil com um moço pobre, Jeanne Crain a condena pela hesitação: "não sei como uma mulher pode hesitar entre uma carreira e o amor de um homem de quem gosta imensamente e quer casar com ela". Cabe às estrelas em nível discursivo reafirmarem a preferência pelo lar frente à carreira, embora elas não deixem seu trabalho para casar.

Concordar com a obediência da mulher ao marido não combina com a aceitação dos divórcios das estrelas. Os olimpianos têm direito a uma existência que seria condenável aos mortais, principalmente os brasileiros. Na seção Problemas humanos à luz da psicanálise, em Cena Muda, a relação extraconjugal é criticada com sutileza na carta de uma leitora analisada pelo suposto psicanalista Dr. Fraga. Uma moça "inexperiente nas questões do amor" ${ }^{97}$ confessa ter um relacionamento com um homem “comprometido". Não se fala em nenhum momento em se tornar amante, mas que a “decisão de ir para o apartamento é perigosa”. Ela não "deve resvalar”. Em outro texto, Fraga afirma que "os homens nasceram para o prazer e para a dor e as mulheres para o amor de Deus e para a humanidade". 98

Em outra edição, uma suposta estudante de Filosofia é aconselhada a não se preocupar com os problemas sociais brasileiros. Afinal a questão racial está morta, preterida pela questão espiritual. Ela deve apenas pensar na sua vida porque tudo se

\footnotetext{
${ }^{94}$ Crain, Jeanne. Respostas de Jeanne Crain. Cinelândia, v. 1, n. 1, p. 36; 47, maio 1952.

95 Dulcília Buitoni mostra que na década de quarenta na imprensa feminina, a representação da mulher não permitia a existência de uma profissão. Já em 1950, há um contexto a levando para trabalhar fora, mas a pressão para ficar em casa ainda é maior. (Buitoni, 1980)

${ }^{96}$ Crain, Jeanne. Respostas de Jeanne Crain. Cinelândia, v. 1, n. 4, p. 50, agosto 1952.

${ }^{97}$ Fraga. Problemas humanos a luz da psicanálise. Cena Muda, v. 32, n. 01, p. 29, 03/01/1952.

${ }^{98}$ Fraga. Problemas humanos a luz da psicanálise. Cena Muda, v. 32, n. 06, p. 22, 07/02/1952.
} 
resolverá no mundo sem sua ajuda. O texto foi transformado em diálogo. A paciente apenas repete diversas vezes a frase: "continue doutor, está me fazendo bem.”:

“(...) os substratos raciais formam apenas a soma estagnante. E a função dos homens superiores? Deles depende a grandeza da nação. Um estadista é tão superior quanto um capitão de indústria, num regime trabalhista. Os artistas, os poetas e os religiosos formam igualmente a equipe desses homens. - (...) O senhor falou em poetas, mas nessa época, na era trabalhista? - O mundo não dispensa a contribuição dos poetas. Eles despertam os espíritos que se podem despertar na mecanização progressista. Eles estimulam os tímidos e eternizam as glórias. Vá, Heloisa, continue os estudos. Pesquise, leia, mas não se preocupe com o destinos dos povos. A evolução se fará certamente. Tudo acabará bem." 99

A seção do suposto Dr. Fraga permanece nos dois primeiros meses de 1952, voltada tanto ao público feminino quanto masculino. É substituída pela coluna de Grafologia, anunciada com destaque quando Cena passou por algumas reformas. A utilização da grafologia relacionada ao potencial das leitoras tornarem-se estrelas não era novidade. Já em 1929, Guilherme de Almeida, em seu livro Gente de cinema, recorreu à grafologia para destrinchar a personalidade das atrizes ${ }^{100}$. Admite mais de uma vez inventar fatos porque os fãs querem ouvir tais histórias ${ }^{101}$. Comparativamente, nenhuma das duas revistas chegaria à sinceridade discursiva de G. de Almeida.

Em Cena Muda, os leitores eram convidados a escrever missivas a um famoso grafologista e astrólogo (não identificado) analisar suas potencialidade para atender aos pré-requisitos das artes e para se tornar uma estrela. Os dois tipos de talento são convertidos em sinônimos. O missivista envia o nome do ídolo preferido, e o grafólogo indica se a personalidade dos dois possui pontos de contato. Quando há coincidências, os fãs estariam mais próximos do conceito de estrela, vista como aquela possuidora de todas as qualidades importantes desenvolvidas:

“de modo geral, todos os fãs se julgam portadores de predicados atribuídos ao artista de sua
preferência. As afinidades eletivas, nós o sabemos, geram as afeições. Nada mais interessante,
portanto, do que a constatação desses predicados, dessas qualidades que, existindo em cada um

${ }^{99}$ Fraga. Problemas humanos a luz da psicanálise. Cena Muda, v. 32, n. 02, p. 23, 10/01/1952.

${ }^{100}$ Descrevendo ter encontrado um punhado de retratos de artistas em sua gaveta, passa a se ater à letra, não na imagem. Declara com ironia que começou "a comparar aquelas letras com o espírito e com a vida daquelas mulheres". Declarando depois com ar dúbio: "E acabei acreditando inabalavelmente na grafologia”. (Almeida, 1929: 184)

101 À carta de Vivian, perguntando se Coleen Moore é mesmo igual na vida como é no cinema, G. de Almeida responde: "Eu sei, Vivian, que se respondesse não a essa interrogação assustada, eu levaria a sua pequena alma, toda lilac time (...), talvez a primeira tristeza, a primeira desilusão de sua vida. Deus me livre desse pecado! Por isso, Vivian, e também porque é verdade, eu respondo sim a sua pergunta. Sim: Coleen é igual, é a mesma, na arte e na realidade." Mais adiante na resposta a outra leitora, claramente inventada, chamada Annie Laurie, perguntando se Ramón Novarro vai mesmo entrar para o seminário, ele declara: “"Acho. Preciso, devo achar que sim. O melhor, único sonho dos que já sonharam consiste em alimentar o sonho dos outros..."” (Almeida, 1929: 91-2; 116). 
de nós, nos aproxima irresistivelmente daqueles que têm a felicidade de possuí-las totalmente desenvolvidas." 102

A revista explora o conceito de projeção e o desejo do leitor de possuir as mesmas características da estrela. Ser feliz é parecer-se com seu ídolo. Ao invés de apenas se projetar via duplo, o leitor acredita possuir as mesmas qualidades dela, então a felicidade pode estar dentro dele, deixando de ser mera imitação. $\mathrm{O}$ fã pode se tornar famoso caso desenvolva suas qualidades. Como Cena confere ao estrelato o merecimento pela luta, fica subentendido que através do esforço, um dia um reles mortal poderá se tornar um astro. A luta tem como objetivo alcançar a vida de prazeres dos famosos.

Os mecanismos de projeção e a incitação no leitor a partir do sonho de ter as mesmas características que seu ídolo já estavam presentes também no livro já citado de Guilherme de Almeida. O cronista responde a uma leitora, que se ela admira a atriz Coleen Moore, as duas devem ser muito parecidas, vendo a personalidade da missivista semelhante à da estrela:

"nós não nos conhecemos, talvez; no entanto, sei que você deve ser muito parecida com Coleen. Adivinho isso pelo entusiasmo infantil de sua carta, pela simpatia espontânea, pela fascinação inconsciente que você sentiu por Coleen. Nunca ninguém lhe disse isso? Só uma grande semelhança, só uma grande afinidade poderiam explicar o coup-de-foudre de você pela estrela de franjinha. E justamente por isso, porque vocês se parecem muito de corpo e de alma, é que sei que o meu sim será muito bem aceito pela Coleen que me escreve.” (Almeida, 1929: 95)

A técnica de Guilherme de Almeida era utilizada para incentivar os leitores a entrarem para o cinema. O incentivo aparece de modo evidente:

\footnotetext{
"A história muito esquisita que você vai ler daqui a pouco, meu esperançoso leitor, tem um único fim: animar você a entrar para o cinema. Qualquer que seja a sua atual situação social ou financeira (...), você ainda pode perfeitamente vir a ser uma estrela de primeira grandeza no céu do celulóide. O mundo dá voltas: mas a manivela de uma câmera dá mais voltas ainda..." (Almeida, 1929: 61)
}

Ao invés de a seção incentivar os leitores, como o fazia Guilherme de Almeida, o grafólogo de Cena faz severas críticas a seu público. Um missivista, segundo ele, é tão tímido e inseguro (por causa da forma como corta a letra " $t$ "), que projeta seu desejo de aparecer e de se projetar numa existência extrovertida de galã. De outros, relata o baixo preparo intelectual pela letra ou sinais de descontrole. Quando um leitor tem

${ }^{102}$ Cena Grafológica. Cena Muda, v. 32, n. 29, p. 23, 03/07/1952. 
vocação artística, chega a dizer qual área deve seguir: "se tentar o teatro ou cinema tente o gênero ligeiro, não o drama por sua personalidade ágil". Ao considerar a letra de um missivista sem pendor artístico nenhum, aconselha-o a fazer apenas duas coisas na vida: plantar uma árvore e ter um filho. Outro deve conseguir um emprego público porque "há dois tipos de homens, os empresários e os empresados - os tímidos que tem falha de iniciativa”. Uma contadora, de acordo com o astrólogo, não tem vocação para seu trabalho, "no seu caso, a melhor profissão seria um bom casamento com pessoa de maior idade, economicamente equilibrada, tolerante e sadia" ${ }^{103}$. Não há sequer um caso de fã considerado plenamente apto a se tornar célebre, nem elogiado ao máximo. Ou seja, as estrelas são elevadas ao ápice de um modelo inimitável.

Apesar de as seções destinarem-se aos fãs, não há transcrição das dúvidas ou perguntas. O foco recai nas respostas das estrelas. As perguntas dos missivistas só aparecem quando há dúvidas pontuais sobre a vida das atrizes ${ }^{104}$, no caso de Cinelândia, ou em Cena nos espaços destinados às críticas dos leitores.

O star system difundido nos anos cinqüenta pelas duas publicações aproximava a atriz dos leitores como um ser igual, não como uma deusa longínqua. Quando a estrela dá conselhos, o discurso implícito é de um modelo de conduta imitável, o mesmo vale para os padrões de comportamento e felicidade no dia-a-dia das atrizes através das reportagens. Porém, nas seções de cartas e consultório sentimental de Cena Muda, de forma geral, o ídolo torna-se um modelo de comportamento inimitável porque tem o it, algo faltante a todos os mortais. Nestes casos, ela passa a ser perfeita, completa. Assim fecha-se um jogo lúdico com os fãs, e a partir dessa antinomia se fortalece o mito, denegado quando necessário, e engrandecido de forma indireta no contato com os mortais incompletos. O padrão comportamental se fecha sob a impossibilidade de atingir o patamar dos olimpianos, aumentando ainda mais a projeção e identificação. Assim só resta ao leitor alcançar a total realização no imaginário projetivo, pela felicidade via duplo.

Para se realizar, além do duplo, o público pode recorrer à identificação com os personagens interpretados pela atriz. Através dos mecanismos de transferência, resta ao fã-leitor retornar aos personagens dos filmes para concretizar seu desejo de ser famoso

\footnotetext{
${ }^{103}$ Os exemplos citados foram retirados da seção Cena Grafológica nas edições n. 29 e 32. Cena Muda, v. 32, n. 29 e 32 , p. 30 e 6, 18/07/1952 e 08/08/1952.

${ }^{104}$ Cinelândia mantém uma seção para tirar dúvidas dos leitores sobre a vida das atrizes, ou fornecer os endereços dos estúdios, chamada Indiscrições de Cinelândia.
} 
ou conseguir encontrar um amor. Abaixo trazemos o funcionamento nas revistas da transferência da personalidade da personagem para a persona da estrela, e vice-versa.

\subsection{Estrela ou personagem? Mecanismos de transferência}

Como a estrela é chamada para encarnar personagens, ao mesmo tempo em que os personagens também se encarnam nela, já há na raiz do estrelismo uma “interpretação recíproca" entre artistas e heróis do filme, analisada por Morin (1957). A cada edição as consonâncias entre as personalidades das personagens e da artista são mostradas nas duas publicações, porém a estratégia não foi criada pelas revistas de fãs. É apenas um prolongamento do processo fílmico dos filmes de estrela.

A personificação e união entre a vida privada do ídolo e seu personagem são utilizadas ainda como estratégia para ampliar a curiosidade a respeito das consonâncias entre as duas personalidades. O processo é largamente utilizado até os dias atuais. Assim quando Fada Santoro estrela o filme Nem Sansão nem Dalila (1954), de Carlos Manga, a capa e manchete da edição de Cena assinala Fada Santoro na Grécia ${ }^{105}$. A primeira página poderia dar a impressão de viagem à Grécia, mas há uma ambigüidade que pode ser apreendida pelo leitor. Fada usa uma vestimenta típica da Grécia antiga, revelando, assim, o local da trama. O entrelaçamento entre o papel interpretado e a atriz faz parte de um mecanismo lúdico conhecido pelo público. Não chega a ser uma novidade porque esta utilização é repetida diversas vezes.

Cristina Meneguello acredita que as revistas utilizavam a "confusão" entre realidade e fantasia, misturando a personalidade do astro e do personagem, para mostrar depois as diferenças entre os dois. As contradições entre ambas servem, segundo Meneguello, como um mecanismo importante por ter papel contraditório. A estrela é boa e perigosa ao mesmo tempo. Há sempre, portanto, uma possibilidade de conversão: cada uma pode ser outra. Como exemplo, Meneguello lembra a atriz Jane Russel. Ela usa roupas provocantes nos filmes, mas no lar veste-se com recato. Cabe ao fã perceber os paralelos entre a vida real e a representação. (Meneguello, 1996:110-1)

Acreditamos que esta suposta "confusão", descrita pela autora, faz parte de um jogo lúdico, no qual o leitor não é vítima, mas participante e conhecedor das regras. Porém, mais importante do que apontar a personificação do ídolo é entender porque ela

${ }^{105}$ Fada Santoro na Grécia. Cena Muda, v. 32, n. 33, p. 5-7, 12/08/1953. 
é utilizada. O processo tem relação com a configuração do melodrama e com os filmes de estrela.

A personificação do olimpiano é importante ao melodrama. Este trabalha com a recognição da identidade, mas de forma planificada, diferente da tragédia. Esta recognição está presente também nos filmes de estrela, como mostrou Christine Gledhill (1991). A atriz é encarregada de trazer um universo moral a ser questionado ou sedimentado. Por este motivo o entrelaçamento entre intérprete e personagem é desejado, porque a personalidade do papel interpretado é transferida ao artista. O processo de recognição da identidade em tais filmes é reforçado pela personalidade da atriz, ou seja, fechando-se o ciclo de retro-alimentação. Passa a ser o ídolo, o responsável também por mostrar valores novos ou sob ameaça, contidos nos filmes. Portanto, a definição da identidade passa da vida ficcional da personagem para a persona da estrela.

Nesta passagem para a vida do ídolo há uma vantagem em termos de autenticação, tal qual mostrada por Richard Dyer, porque se refere a um drama moral da pessoa real fora da tela. A autenticação é mais eficiente quando se mostra com destaque a personalidade da atriz do que a do papel interpretado. Mais importante nos filmes de estrela do que trazer uma performance boa (quando a celebridade interpreta bem o sofrimento do personagem a partir de técnicas cênicas e talento), é mostrar uma performance verdadeira, ou seja, quando a intérprete interioriza o sofrimento, trazendo seu sentimento pessoal à atuação. Assim, o olimpiano encarna na personagem, e viceversa. Está aí uma das chaves do estrelismo, fechando a reciprocidade entre as duas personalidades. Não é nosso objetivo adentrar na relação da performance verdadeira com o estrelismo. Só queremos lembrar que o processo não surgiu no cinema, e sim no teatro, a partir das teorias de Stanislavski, na qual, grosso modo, não é preciso representar; mais importante é o ator ser ele mesmo no palco. Esse pressuposto possibilitou um campo fértil para o surgimento do estrelismo. (Gledhill, 1991)

A personificação é usada com freqüência para causar espanto nas revistas de fãs, estratégia muito recorrente no caso do cinema brasileiro, mas sem grande sutileza em seu uso. Muitas sentenças estabelecem que apesar de vilão nos filmes, José Lewgoy é "boa praça". O fato de o eterno personagem do mal ser um dos mais queridos atores brasileiros "não deixa de ser paradoxal" para Cena Muda ${ }^{106}$. Já no cinema

\footnotetext{
${ }^{106}$ Dines, Alberto. O vilão Lewgoy é boa praça. Cena Muda, v. 32, n. 42, p. 04-5; 34, 17/10/1952.
} 
hollywoodiano, há um trabalho mais bem elaborado nas dissonâncias entre as personalidades. Quando Cena cita diversas vezes o filme Nasce uma estrela (1954), de George Cukor, estabelece uma relação entre a decadência do personagem Norman Maine (interpretado por James Mason) com a da intérprete Judy Garland. No filme, o astro Norman Maine, em decadência devido ao alcoolismo, descobre uma desconhecida, com talento e a transforma na estrela Vicki Lester. Depois de casados, enquanto sua esposa consegue maior sucesso, ele continua a decair. O filme não é novelizado, mas há algumas reportagens em Cena realçando como Judy Garland superou seus problemas, dando a volta por cima. Na vida real, Garland estava decadente, havia tentado o suicídio, como o personagem do filme, Norman Maine. Aqui há uma transição diferente, de um personagem que a atriz não interpreta (vivido por James Mason), para a vida mediática de Garland. A vida dela é novelizada, e a partir desta história romantizada, o leitor pode se interessar mais pelo filme. A representação da trajetória de Judy Garland será retomada no tópico sobre a morte dos olimpianos.

A ambigüidade entre a personagem e a estrela está presente em toda representação do estrelismo nas duas publicações. Mais do que indicar as similitudes entre ídolo e papel interpretado, busca-se mostrar um ínfimo segredo. Porque o olimpiano não se revela por inteiro. É necessário tentar descobrir nuances de sua personalidade em doses homeopáticas. O jogo programado pelas revistas é um quebracabeça através das reportagens sobre as personalidades mediáticas e interpretadas. A cada artigo, o leitor descobre um novo detalhe. O papel da ambigüidade é aumentar a curiosidade. No caso do estrelismo brasileiro, a coincidência entre a personalidade da atriz com o papel interpretado será retomada no capítulo três, mas adiantamos que o processo de similitudes ocorre também em paralelo ao da ambigüidade.

Lembramos também que durante os anos vinte, era preciso existir uma coincidência entre o personagem interpretado e o ator. Rodolfo Valentino tinha de ser na vida real um amoroso, como na tela. Nos artigos dos anos cinqüenta, observamos nas revistas de fãs um alargamento, através da ambigüidade, entre ator e personagem, que permite uma não-reciprocidade entre os dois. A estrela torna-se mais densa, ampliando a complexidade sobre seu modo de ser. Ressalta-se assim seu caráter divino que não pode ser facilmente entendido. Cada personalidade interpretada surge como uma das mil nuances possíveis da dos famosos. Resta ao leitor-mortal não apreender a complexidade de seu ídolo. A ambigüidade trazer esta constatação de forma agradável, aumentando mais ainda o processo de mitificação. Quando uma estrela interpreta um papel 
totalmente diferente de sua personalidade ou com consonância com seu modo de agir, as revistas aproveitam o ensejo para incutir no leitor a dúvida sobre a "verdadeira" personalidade da atriz. Porém, a totalidade do caráter das celebridades nunca é exemplificada nas matérias. Esta curiosidade será infinita porque nunca se revela toda a individualidade do artista nas reportagens, através da utilização do mecanismo de versões, já explicado antes.

Afirmar a existência de uma relação contraditória entre estrela e personagem não dá conta da complexidade da associação da personificação porque a contradição explica a diferença pela planificação, como se fosse possível vislumbrar as divergências entre dois opostos. $\mathrm{O}$ entrelaçamento entre personagem e atriz só pode ser explicada pela ambigüidade, porque não fica claro ao leitor qual é a personalidade do ídolo, sobrando um enigma a ser decifrado apenas parcialmente.

Nossa observação sobre o enigma presente na estrela, sendo impossível conhecêla por inteiro, foi também descrita por Richard DeCordova (2001). Não podemos deixar de trazer a similitude com a pesquisa dele, voltada ao surgimento do estrelismo. $\mathrm{O}$ autor não estuda as relações entre a personalidade da estrela e o papel interpretado, como aqui enfocado, mas a identidade do ator. Utiliza o mesmo termo usado por nós: há um "enigma" que mantém o segredo sobre a identidade do ator. Para ele, com o estrelismo, o público passa a pagar para ter acesso à identidade do intérprete. Contudo, esta não pode ser revelada por inteiro a partir de uma fita. É preciso ter o hábito regular de ir ao cinema, porque o consumo repetitivo segue a aparência do ator de filme para filme. DeCordova mostra que esta constituição da identidade é feita também pela publicidade e pelas revistas de fãs. Ambas prometem não só repetir, mas elaborar a identidade da estrela.

A constituição do enigma da estrela foi explicada por Richard Sennet como uma impossibilidade em compreender por completo a percepção da personalidade dos outros. E é exatamente essa dificuldade que engaja os homens numa busca de pistas obsessivas e infindáveis para descobrir como os outros e eles mesmos são realmente. "O fato da revelação é o que incita; nada de claro ou de controle é revelado." (Sennet: 1988, 330)

Um exemplo da personificação entre as identidades ocorre quando se anuncia que os papéis dos filmes são feitos a partir da personalidade dos atores. Cena anuncia 
que a Republic escolheu os astros John Wayne e Anna Neagle ${ }^{107}$, para depois escrever um argumento de acordo com a personalidade deles. O leitor tentará descobrir a partir do personagem interpretado, quem é o ídolo, uma vez que foi revelada na matéria uma relação entre os dois, na verdade calcada sobre a lei dos tipos.

O desejo de conhecer por completo a estrela se calca não só nas leituras sobre as coincidências entre as personalidades, aqui descritas, mas também sobre a possibilidade de conseguir no futuro tornar-se uma delas. As publicações procuram promover a criação de concursos, voltados à descoberta de talentos anônimos, calcados na fotogenia. Alimentam o sonho do leitor em consumir a revista como escada para seu sucesso, tema detalhado no próximo tópico.

\subsection{Criação de concursos}

A partir de 1953, Cinelândia organiza um concurso chamado Miss Cinelândia, destinado a encontrar uma atriz para um filme da Atlântida. Auxiliaram no certame o jornal $O$ Globo e a Rádio Globo. A Atlântida participou diretamente do júri do concurso em 1954, representada por Carlos Manga ${ }^{108}$, Cyll Farney, e seu principal acionista, Luis Severiano Ribeiro. O jurado era composto ainda do crítico Salvyano Cavalcanti de Paiva, da repórter da mesma revista Zenaide Andrea, e do cineasta Humberto Mauro.

Cinelândia não admite ganhar popularidade com a empreitada. Declara diversas vezes que criou o concurso para dar uma oportunidade às moças sem experiência de entrar para o cinema ${ }^{109}$. A publicação se prontificava a procurar estúdios interessados em destinar uma vaga à ganhadora. Depois cita a participação da Atlântida. Para atrair as leitoras, declara que os estúdios já consultam o catálogo da revista, frisando com freqüência a contratação antecipada de algumas inscritas. Pede fotos bem tiradas das candidatas, para comprovar beleza. Não está em jogo o talento artístico, mas a fotogenia. O concurso teve duzentas inscritas, segundo o último dado publicado no seu primeiro ano ${ }^{110}$.

\footnotetext{
${ }^{107}$ Herbert Wilcox e Anna Neagle produzirão filmes na Inglaterra para serem distribuídos pela Republic. Cena Muda, v. 33, n. 24, p. 16, 12/06/1953.

${ }^{108}$ Um dos testes era um skech com Cyll Farney, avaliado por Jorge Ileli. Carlos Manga teria oferecido oportunidade de trabalho em seu próximo filme a nove finalistas. Eleição de miss Cinelândia. Cinelândia, v. 4 , n. 52 , p. 20-1; 58, $1^{\text {a }}$ quinz. jan. 1955.

${ }^{109}$ Cinelândia, v. 2, n. 18, p. $3,1^{\circ}$ quinz. agosto 1953.

${ }^{110}$ A revista Manchete anuncia a inscrição de trezentas candidatas. Manchete, n. 90, p. 1, 09/01/1954.
} 
A competição começava em maio e terminava apenas em janeiro do ano seguinte, incluindo divulgação das novidades com destaque a cada edição. No primeiro ano, a ganhadora, Inalda de Carvalho, adquire enorme publicidade nas páginas da revista em 1954 e nos anos consecutivos. Em toda edição, se planta matéria sobre ela, nem que seja para algum ator famoso ficar encantado com sua beleza. A cobertura exagerada de Cinelândia à novata conseguiu agendar seu nome em outros veículos. O nome de Inalda chega até ao Boletim do Festival Internacional de Cinema do Brasil, anunciando com direito a fotografia, a participação diária de Miss Cinelândia em todas as seções do evento de São Paulo ${ }^{111}$. A revista Manchete apresenta Inalda na capa ${ }^{112}$ quando ela ganhou o concurso, enquanto $O$ Cruzeiro citou também sua presença na $2^{\text {a }}$ Semana do Cinema Brasileiro ${ }^{113}$.

Inalda fez A outra face do homem (1954), de J. B. Tanko. Além deste filme, Carlos Manga utilizou a primeira recém-eleita Miss Cinelândia, para a mocinha do filme Matar ou correr (1954) porque a estrela Eliana Macedo estava em viagem ${ }^{114}$. Segundo matéria de Cinelândia, $O$ Globo e a Rádio Globo divulgaram o concurso todos os dias.

Apesar de citar Inalda como grande estrela, ou futura grande estrela, uma vez Cinelândia não escondeu nas entrelinhas o baixo preparo da novata. Apontando a seriedade de intenções de seu trabalho, admite que ao lado do brilho de sua vocação, aparece também "a sua natural falta de experiência, também" ${ }^{115}$. Já Cena Muda, como concorrente, não perde tempo. Em sua coluna de crítica, afirma que Inalda é a "criatura mais estática que se pode desejar ver no cinema" ${ }^{116}$, sugerindo que o diretor Carlos Manga, de Matar ou correr, precisa adquirir maior autoridade sobre o elenco, porque muitas primeiras figuras agem em todos os instantes do filme da mesma forma. No final, simplifica: “(Inalda) irrita de tão indiferente!”.

\footnotetext{
${ }^{111}$ Boletim número seis, de 17/02/1954.

${ }^{112}$ Manchete, n. 90, p. 1, 09/01/1954.

$1132^{a}$ semana do Cinema Brasileiro. O Cruzeiro, v. XXVI, n. 41, p. 100-5, 24/07/54.

114 Inalda de Carvalho afirma no documentário Assim era a Atlântida (1975), de Carlos Manga, que trabalhar na Atlântida era seu sonho, assim como o de Terezinha Morango, Adalgisa Colombo, Miriam Persa e Norma Bengell, como se todas elas tivessem começado no concurso Cinelândia. Mas Norma Bengell já tinha uma carreira como vedete. Bengell concorreu em 1954, mas perdeu para Avany Maura, sendo escalada por um integrante do júri, Carlos Manga, anos depois para participar do filme $O$ homem do Sputnik (1961). Segundo Sérgio Augusto, Inalda de Carvalho aparece com destaque no documentário por ser esposa de Manga, apesar de ter feito apenas quatro filmes na Atlântida, em oposição a Wilson Gray que não foi convidado para participar do documentário, apesar de ter trabalhado em oito fitas da companhia carioca. (Augusto, 1989)

${ }^{115}$ Nova estrela do cinema brasileiro. Cinelândia, v. 3, n. 42, p. 34-5; 61, $1^{\text {a }}$ quinz. agosto 1954.

${ }^{116}$ Bello, Alberto Simoens. Filmes em revista. Cena Muda, v. 34, n. 35-6, p. 68-9, dez. 1954.
} 
Não só a ganhadora de 1953 aparece bastante, como as semifinalistas Julie Bardot (parafraseando Brigitte Bardot) e Ana Beatriz também. As duas saíram antes do final do certame porque já tinham conseguido um contrato para estrear um filme ${ }^{117}$. As duas também aparecem em quase todas as edições de Cinelândia durante os demais anos analisados. Porém, o quadro muda no ano seguinte. A ganhadora de 1954, Avany Maura, aparece apenas na edição de janeiro de 1955. Permanece até maio sem aparecer nas edições ${ }^{118}$. Contudo, o concurso não foi garantia de uma longa carreira no cinema para as finalistas. Avany Maura participou apenas de dois filmes, assim como Julie Bardot. Ana Beatriz teve carreira mais longa, fez cinco filmes ${ }^{119}$.

No período analisado, Cena Muda não promoveu concurso, mas pensou em fazê-lo para dar espaço aos novatos entrarem para o cinema nacional. Porém na seção de cartas, justifica a ausência da competição a uma leitora porque as companhias não gostam de encontrar alguém com a ajuda de terceiros ${ }^{120}$. Mesmo assim, Cena passa a publicar a seção Um lugar ao sol com duas ou três fotos de leitores interessados na carreira cinematográfica.

Tentando se conectar ao universo dos leitores, Cena Muda declara receber muitas cartas questionando como entrar para o ramo. O conselho dado é esperar uma chance. Todavia, sem dar muitas esperanças, explica: “esse esperar uma 'oportunidade' é muito vago, não decide nem contribui em favor do candidato. Os concursos para revelar 'astros' e 'estrelas', por sua vez, são viciados". Como se indiretamente criticasse o concurso da Cinelândia e os estúdios, escreve: "escondem protecionismos, simpatia pessoal e apadrinhamentos." Lança Cena uma pergunta aos produtores de cinema: “vamos abrir as portas dos estúdios a gente nova?" Questiona se nesse momento um leitor com o tipo de uma estrela (cita algumas), "um possível Oscarito não estaria lendo a revista”. Otimista, declara inocentemente: no futuro não será mais problema encontrar a estrela para um filme, será só escolher entre vários excelentes atores.

\footnotetext{
${ }^{117}$ Ana Beatriz fez Toda uma vida em quinze minutos (1954), de Vanoly Pereira Dias. Julie Bardot foi trabalhar no estúdio dos Latini. Regina Moreira foi contratada pela Multifilmes.

${ }^{118}$ A nova Miss Cinelândia não aparecia em todas as fotos da revista tão bela quanto a primeira. Talvez este pudesse ser um critério para a primeira eleita ser mais presente na revista.

${ }^{119}$ Avany Maura participou de dois filmes, ambos de Carlos Manga: Vamos com calma (1955) e Colégio de Brotos (1956). Julie Bardot participou de Matar ou correr (1954), de Carlos Manga e Malandros em quarta dimensão (1954), de Luiz de Barros. Ana Beatriz fez Toda vida em quinze minutos (1954), de Vanoly Pereira Dias. Ela já tinha participado do filme Quando a noite acaba (1950), de Fernando de Barros, antes do concurso Miss Cinelândia. Depois fez ainda: Tira a mão daí (1955), de Ruy Costa, sobre moças que desejam se tornar Miss em algum concurso e $O$ primo do Cangaceiro (1955), de Mário Brasini. Participou também do filme Rio quarenta graus (1955), de Nelson Pereira dos Santos.

${ }^{120}$ Cena Muda, v. 2, n. 33, p. 32, 02/09/1953.
} 
As duas concorrentes tiveram seus donos aliados três décadas antes num concurso semelhante. Em 1923, o jornal de Irineu Marinho, A Noite, se aliou à Revista da Semana, do mesmo grupo editorial de Cena Muda, lançando um concurso popular para encontrar a mulher mais linda do Brasil. O longo processo de competição já nascia ali. Depois de 24 meses, com mais de trezentas finalistas, Zezé Leone foi eleita, tornando-se logo depois atriz de cinema. Tais certames já eram muito comuns nos Estados Unidos ${ }^{121}$, mas a idéia do sucesso deste concurso antigo pode ter motivado Roberto Marinho a lançar Miss Cinelândia décadas depois. (Morais, 1994)

A melhor parte de Miss Cinelândia é quando o jogo por detrás dele é aberto ao leitor, trazendo as estratégias da publicidade. Numa entrevista, Inalda revela um pouco da dinâmica destas novatas ${ }^{122}$. Ela se apresentou a Leon Eliachar, antes diretor de Cena Muda, para arranjar trabalho, por suas relações com o meio cinematográfico. Eliachar a apresentou a Moacyr Fenelon e a Salomão Scliar. Ambos lhe prometeram trabalho. Scliar a levou ao coquetel de comemoração de um ano de Cinelândia. Foi ele quem sugeriu o concurso "por motivo de publicidade". Assim que Moacyr Fenelon começasse seu filme, Inalda se retiraria da competição, como se tivesse sido descoberta via Cinelândia. Porém, Fenelon morreu neste meio tempo. Por isso, Inalda ficou até o final. A fala dela de como seu sonho de "ser Cinderela" se "cumpriu" fecha o desejo projetivo das leitoras. O desejo de parecer influir no campo cinematográfico não se manifesta somente na criação destes concursos às novatas. Ambas revistas realizam a propaganda direta da nossa cinematografia nos artigos, como se o sucesso do cinema nacional estivesse atrelado ao auxílio destas publicações.

\footnotetext{
${ }^{121}$ Paulo Emilio Salles Gomes (1974) mostra que nos últimos anos da Republica Velha os concursos de beleza se tornaram um dos temas básicos de nossa propaganda no exterior.

${ }^{122}$ Lee, Fred. Nasce uma estrela. Cinelândia, v. 3, n. 29, p. 46-7, 2a quinz. jan. 1954.
} 


\subsection{Propaganda ao cinema brasileiro}

Tanto Cena Muda quanto Cinelândia concediam espaço ao cinema brasileiro, ocultando seus interesses comerciais. De outro lado, não negamos a existência de forma concomitante de uma preocupação por parte de alguns jornalistas em auxiliar o cinema brasileiro, por ser incipiente, conforme explicitado em diversas declarações dadas pelos repórteres de Cena a Flora Bender (1979).

O que contamina o jornalismo é a propaganda. Já a publicidade situa-se no espaço dos anúncios. Esta última já teve relações muito mais promíscuas com o jornalismo há três ou quatro décadas, segundo as observações de Manuel Chaparro como repórter no período (2001). No caso das revistas de cinema estudadas, a situação é bem diferente da descrita por ele sobre os anos cinqüenta ${ }^{123}$. O star system institucionalizou as fontes vinculadas à publicidade dos estúdios décadas antes. Lembramos ainda que o processo de utilização dos releases ${ }^{124}$ era comum em todo o jornalismo. Durante os anos 20, em Cena Muda, era comum a utilização de colagens dos materiais enviados pelas agências estrangeiras. Esse dado contido na tese de Flora Bender é visto como parte do cunho amadorístico e da falta de recursos da revista. Porém, a dificuldade de se transformar um jornal ou revista em um negócio na época era grande. Ainda durante os anos 40, os secretários dos jornais no Brasil buscavam material para ilustração nas revistas e jornais dos Estados Unidos porque a imprensa não podia fazer frente a tais gastos. Segundo Carlos Eduardo Lins da Silva (1990), até $O$ Estado de S. Paulo nos anos cinqüenta publicava informações, transmitidas à redação, que parecessem dignas de publicação, como informações do governo, de agências e de pessoas amigas.

A propaganda nos artigos informativos continuava a ser vista pelas duas revistas como a melhor forma para divulgar as películas brasileiras, tal qual era feito em

\footnotetext{
${ }^{123}$ Segundo Chaparro, as fontes durante a década de cinqüenta eram passivas, defensivas. Precisavam ser conquistadas. Hoje são entidades organizadas, produtoras competentes de acontecimentos e saberes que interessam ao jornalista.

${ }^{124}$ Vale lembrar que o release não deve ser visto obrigatoriamente como uma degradação da ação jornalística. Estes boletins são sempre utilizados nas redações, em todos os períodos. São úteis por trazer discursos das fontes, que nem sempre os jornalistas têm acesso e tempo para procurar. Manuel Chaparro confere uma atribuição positiva aos releases, pois eles assumem e repassam por inteiro os interesses das agentes com informações úteis ou interessantes sob o ponto de vista da atualidade e do acesso aos bens ou serviços divulgados. (Chaparro, 1997) Porém, no caso das revistas pesquisadas, o problema é a forma de utilizar tais materiais. Cena Muda e Cinelândia nos espaços das reportagens geralmente não realizavam nenhum tipo de alteração ou checagem das fontes e dados, sem acrescentar outros pontos de vista. Na maior parte do tempo, compram nos espaços informativos as informações dos releases sem checar, muitas vezes incluindo a adesão à visão das companhias cinematográficas.
} 
Cinearte. Esta última se orgulhava de sua competência publicitária na divulgação do cinema norte-americano, acreditando na legitimidade do gênero, como aponta Ismail Xavier (1978) e Paulo Emilio Salles Gomes (1974).

No período pesquisado, Cena Muda não iria declarar de forma tão contundente seu orgulho de ser publicista do cinema norte-americano, porque durante a década de cinqüienta há uma tomada de consciência dos problemas do cinema brasileiro. Contudo, poucas vezes o papel da cinematografia hollywoodiana é percebido como negativo em Cena Muda. Em Cinelândia, esta consciência e preocupação são ausentes. Quanto ao cinema brasileiro, Cena continuava a se orgulhar de ser um veículo de propaganda do cinema brasileiro, como se não ganhasse nada com isso. Surge por esse motivo sua legitimidade como bem simbólico, via denegação. Em julho de 1952, Cena esclarece o caráter de incentivadora de nossa cinematografia:

\footnotetext{
“esta revista sempre manteve páginas e mais páginas sobre o cinema brasileiro, mesmo quando este era considerado insuportável, especialmente por exibidores que já foram conquistados por nossos estúdios e nossos artistas." 125
}

Em oposição à informação de que a Vera Cruz enviava inúmeros boletins para a maior parte dos jornais, Cena reclama mais à frente no mesmo artigo que os estúdios não mandam matérias, impedindo uma boa cobertura do cinema brasileiro:

"Mas, é doloroso, declarar que os departamentos de propaganda do nosso cinema se mantêm inativos, insuficientes, negligentes, apáticos, como que indiferentes aos veículos de publicidade da categoria de A Cena Muda, a mais antiga revista do gênero neste país. Para que possamos divulgar notícias, cenas e descrições de filmes nacionais de longa metragem, é preciso que percamos tempo a mendigar de estúdio a estúdio, alguma coisa para publicar. Que deveria fazer o departamento de publicidade de cada produtora nacional? Mandar-nos, normalmente, tudo o que fosse interessante ao leitor, com o que poderíamos dar maior divulgação ao cinema nacional."

Dessa forma, Cena Muda admite ser um "veículo de publicidade", além de fabricar a idéia da existência de departamentos de publicidade em todos os estúdios. Produz uma imagem do cinema nacional falseada. A reclamação era antiga, Pedro Lima escrevia o mesmo em Cinearte. Na edição seguinte de Cena Muda, Renato de Alencar 126 assegura que a revista causou grande repercussão com o artigo. A coluna surtiu efeito e companhias mandaram material.

\footnotetext{
${ }^{125}$ Cinema brasileiro. Cena Muda, v. 32, n. 27, p. 20, 03/07/1952.

${ }^{126}$ Alencar, Renato. Ciranda cirandinha. Cena Muda, v. 32, n. 31, p. 3, 01/08/1952.
} 
Enquanto Cena Muda tenta construir uma imagem do cinema nacional pouco pautada na realidade, Cinelândia declara ainda no seu primeiro número ${ }^{127}$, que os estúdios devem fornecer material inédito e interessante às revistas, incluindo fotos das residências das estrelas. Edições depois, afirma ter conseguido sanar boa parte do problema, querendo trazer para si as glórias de um feito não realizado, igualando-se à Cena Muda na estratégia de autopromoção:

\begin{abstract}
"na parte jornalística, também cobrimos setores que se achavam desguarnecidos, sobretudo no que se refere aos cinemas nacional e europeu. Insistimos em dizer que o cinema nacional, que tanto tem progredido na qualidade dos filmes, precisa organizar-se melhor. Não há kodackromes das estrelas para serem publicadas nas capas e nas páginas internas de cores. Não há serviço informativo organizado, não há material inteligente de publicidade dos 'astros', que os focalize sob os aspectos que o público mais gosta de conhecer, na vida real, fora das telas. Tudo isso necessita de ser urgentemente sanado. (...) Aqui estaremos para proporcionar a um grande público a revista que o nosso país bem merecia. O Brasil tem progredido muito, nestes últimos tempos. Não seria crível que somente no setor jornalístico continuássemos num padrão medíocre, à espera de que qualquer organização estrangeira aqui viesse fazer o que nós não éramos capazes de realizar." 128
\end{abstract}

No ano de 1952, enquanto Cena pedia aos estúdios materiais de divulgação, como se estes existissem, Cinelândia confessou por cinco vezes a sua inexistência, além da desorganização e ineficiência dos departamentos. É relevante notar que Cinelândia não mentiu ao revelar a inexistência de tais materiais, mas exagerou porque Cena Muda conseguia algumas fotos e cobria muito melhor o cinema brasileiro neste mesmo período.

Se há benevolência de Cena para com o cinema brasileiro, o tom em relação aos atores, especialmente os do rádio, passava às vezes para um teor condenatório. Afirmou, certa vez, que os atores nada seriam se não houvesse a publicidade das revistas, que no Brasil é gratuita, denegando assim seu interesse e necessidade na confecção de um estrelismo brasileiro:

\footnotetext{
"Adoramos imensamente fazer reportagens com artistas que realmente sabem dar valor e atenção ao trabalho do cronista especializado. Detestamos - é o termo mais adequado - ter que falar com astros - e que astros, leitores! (...) O que nos deixa mais embasbacado (sic) ainda, é a falta de senso de alguns que se intitulam de PRODUTORES RADIOFÔNICOS e que, ao final da contas, não sabem equiparar as funções respectivamente, ou seja imprensa-rádio. Eles precisavam saber que cada um é rei na sua profissão: se ele consegue fazer o rádio-ouvinte rir durante alguns minutos, nós o prendemos às suas fotos e a fatos de sua vida que, temos que dizer, não fossemos nós, nunca viriam à publicidade. (...) Se eles estivessem em um país estrangeiro, nem todos, é verdade, não teriam a publicidade que lhes dispensam os nossos órgãos especializados, posto que lá teriam que chegar ao balcão e deixar algumas notinhas de mil pela publicidade em torno de seus nomes: mas cremos que talvez não o fizessem, porque são
}

${ }^{127}$ Aos leitores. Cinelândia, v. 1, n. 1, p. 3, maio 1952.
${ }^{128}$ Aos leitores. Cinelândia, v. 1, n. 2, p. 3, junho 1952. 
verdadeiros rochedos, dos quais nem pobre arranja níquel. Mas, infelizmente, tudo no Brasil é de graça. Não somos reis de nenhum país, ainda não estamos com o rei atravessado à garganta, mas, que diabo, devemos ser tratados e correspondidos como amigos e como sinceros propagadores do valor artístico dos que, graciosamente, focalizamos em nossas páginas. Vamos esperar que as flores brotem das pedras." 129

Com este artigo, Cena confere o sucesso da cinematografia nacional a seu trabalho, como se a propaganda gratuita fosse paga só com gratidão. $\mathrm{O}$ artigo é revelador da morte editorial da revista. Trata da deficiência na geração de publicidade. Cena divulgava as cinematografias hollywoodiana e brasileira, mas não conseguia ter os estúdios ou exibidores como anunciantes. A relação com as empresas propiciava apenas material gratuito de publicação. Há uma personificação da ineficiência, transformada em arrogância e desdém de alguns produtores. Ocultando sua relação de dependência para com os produtores criticados, a publicação confere a si o papel de guardiã do sucesso da cinematografia. A responsabilidade pelo insucesso, caso ocorresse, recairia à arrogância de alguns, no caso os produtores radiofônicos. Assim, a revista se autocelebra como componente importante ao sucesso, mas se exime da culpa em caso de fracasso, porque declara fazer sua parte. Aponta para o perigo de os produtores não contribuírem com a imprensa, e resolve o impasse na base do elogio à simpatia. Além deste tipo de condenação à arrogância de alguns ou à falta de matérias sobre o cinema brasileiro, Cena e Cinelândia utilizam a estratégia de censurar o formato do estrelismo, abordadas a seguir.

\subsection{Crítica ao estrelismo}

Quando as revistas condenam os romances inventados pelos departamentos de publicidade, buscam transmitir aos leitores sua credibilidade. O discurso é simples: "todos mentem, menos eu, caro leitor". Paralela à estratégia de legitimação via denegação da propaganda, por outro lado, há uma peculiaridade que é a crítica ao próprio sistema gerado pelas publicações. Esta foge ao controle total do estrelismo em sua forma mais comum. Cinelândia não questiona o sistema, apenas narra as invenções dos departamentos de publicidade. Vale-se desta estratégia apenas para se legitimar. Contudo o processo em Cena Muda tem nuances.

${ }^{129}$ Correa, Otton. Cena Muda. v. 33, n. 10, p. 3, 04/03/1953. 
No primeiro caso, a estratégia serve como legitimação. Certa vez, Luelinha Passos questiona se os leitores sabem que os atores são meros joguetes nas mãos dos diretores. Vivem da exposição de sua vida íntima, como uma "sina" ${ }^{130}$. Ela disseca o star system em tom lúdico, constatando que os intérpretes são mera fabricação dos estúdios. Contudo, o objetivo é conseguir fofocas:

Por que, afinal dar tanto valor a estes seres cuja sina é se deixar devassar pela massa ávida e curiosa para conhecer os detalhes de sua existência? Será que vocês ainda não descobriram que, quem faz filmes bem ou mal, é o diretor, o realizador? Será que vocês não sabem que o ator (estes que vocês chamam de "artistas de cinema") é um mero joguete nas mãos deste mesmo realizador? Sabem? Então porque divinizar estas criaturas simpáticas e atraentes mas tão auxiliadas e amparadas pelo 'make-up', pelas luzes e pelas lentes?... Mas já que insistem, aí vai alguma coisa que eu consegui apurar sobre os salários dos nossos atores de cinema."

$\mathrm{O}$ artigo procura criar confiança no leitor para trazer depois a fofoca, como exigência deste público. Há uma ironia latente em atribuir o desnudamento do sistema exatamente à Louella Parsons brasileira, sob o pseudônimo de Luelinha Passos. O tom jocoso do artigo faz parte das estratégias das revistas para balancear a dose de irrealidade do estrelismo.

Outra estratégia comum era atribuir a responsabilidade das invenções aos atores. Duvidando da quantidade de esportes praticados pelas estrelas todos os dias de manhã, o veículo propõe a pergunta, tornada título do artigo: Você acredita nisso? Elas dizem que fazem ${ }^{131}$. No início, a matéria disseca as informações como falsas. Contudo, no final nega o comprometimento dos departamentos de publicidade, culpando os atores pelas invenções:

\footnotetext{
“Todos nós gostamos de contar vantagens. É um defeito tão humano como qualquer outro defeito. Os ídolos da tela também são humanos, e por isso mesmo, têm os mesmos defeitos que nós na vida real. Uma vez que fora do alcance da objetiva e de seus truques eles não possam ser os heróis imaginários que a ficção idealiza. Ainda assim eles querem ser. E dizem coisas do arco da velha aos amigos. Alguns acreditam, outros não. E você?”
}

A invenção não recai sobre os departamentos de publicidade, mas sim sob os próprios atores, ansiosos por tirarem vantagem. A ausência de responsabilidade ao estúdio está presente no filme A embriaguez do sucesso (1957). Alexander Mackendrick disseca a relação desonesta entre publicista e colunista de fofoca, mas não explicita a relação destes com os estúdios. Além de centrar a culpa sobre os colunistas e publicistas, motivados muitas vezes por interesses pessoais, são as próprias estrelas, as

\footnotetext{
${ }^{130}$ Passos, Luelinha. Desvendando mistérios. Cena Muda, v. 32, n. 48, p. 4, 28/11/1952.

${ }^{131}$ Cena Muda, v. 32, n. 23, p. 29, 05/06/1952.
} 
interessadas na propaganda. A responsabilidade dos atores mostrada na fita talvez seja reflexo da época de transformação do studio system, na qual os agentes dos ídolos adquiriram maior força. No filme, não há limite para as invenções dos colunistas e publicistas, destruindo carreiras por motivos pessoais.

No segundo caso de crítica ao estrelismo, Cena criticava a falta de talento das atrizes e o grande espaço dedicado à plástica nos estúdios hollywodianos, exatamente os valores difundidos na maior parte de suas páginas. Assim, a crítica ao sistema avançava e retrocedia em Cena. Apenas em 1954, há alguns artigos da repórter Maria Luíza dedicados a desnudar o sistema, explicando seu surgimento e estratégias. A jornalista lembra que estrelismo não significa talento, mas apenas plástica, uma vez que muitos artistas talentosos não obtêm sucesso. A representação do star system traz apenas a perfeição dos atores. Lembra que o objetivo é receber a simpatia dos leitores, porque o mais importante é o lucro certo. Explica Maria Luíza que para ser estrela, não é necessário ter dotes artísticos, porque a propaganda se encarrega de tudo:

"o ator é estimulado pela vaidade, o povo pela propaganda. $\mathrm{O}$ industrial pelo lucro criando um ambiente de falsidade, e para a estrela, uma auréola de artificialismo, que só pode ser prejudicial ao cinema quando se tem em vista o fator qualidade." 132

A repórter explica que os astros têm de se mostrar como originais, usar meias vermelhas com smoking ou comer flores, para chamar a atenção ${ }^{133}$, para a publicidade o mostrar como alguém com horror às convenções. Além disso, a jornalista condena Hollywood por ter regras morais tão elásticas. Se os escândalos ou a censura despertam a curiosidade do espectador, os filmes não são cortados. Por outro lado, se há censura com boicote por parte do público, Hollywood se volta ao puritanismo. Maria Luíza esclarece: "o motivo disso é muito facilmente explicável: numa indústria, até mesmo a moral é função das vantagens financeiras" ${ }^{134}$. Considera que já terminou a época na qual os escândalos repercutiam de maneira negativa na carreira dos artistas, trazendo como exemplo a irritação dos puritanos contra Marilyn Monroe. Esta só aumentou o cartaz dela.

A condenação ao estrelismo em Cena Muda voltou-se à crítica ferrenha às revistas de fãs também em 1954. A repórter Marien mostra a cobertura a um mesmo fato por diversos colunistas. Quer revelar aos leitores a mentira por detrás destas

\footnotetext{
${ }^{132}$ Luíza, Maria. Escândalos de Hollywood. Cena Muda, v. 34, n. 20, p. 18-20, 19/5/54.

${ }^{133}$ Luíza, Maria. Ídolos da terra em escala crescente. Cena Muda, v. 34, n. 11, p. 12-3, 17/3/54.

${ }^{134}$ Luíza, Maria. Escândalos de Hollywood. Cena Muda, v. 34, n. 20, p. 18-20, 19/5/54.
} 
publicações ${ }^{135}$. O artigo destina-se a censurar Louella Parsons e Hedda Hopper, sem citar Cinelândia. Para Marien, Louella conta mais de suas próprias emoções do que vida das estrelas, em sua coluna "xaroposa". O apelido dado pelos críticos menos "generosos" a Parsons seria o de uma "caldeira de mel a ferver". Já Hedda Hopper é tida como um "ferrão armado para matar", uma vespa zumbindo nervosa, em suas mais "magníficas inventivas". A jornalista compara dois artigos da mesma edição de uma revista, focada sobre o namoro de Jane Powell e Gene Nelson para revelar as inventivas. Louella teria escrito com ironia que "os dois continuam a sair juntos, mas quase não conversam". Depois Louella questiona o relacionamento: "Será que o amor, tão esperado, não deu certo? Será dor de dentes ou enfarto?". O enfoque de Parsons foi oposto ao da "não menos canastrona" Pamela Morgan. Esta deu como título à matéria "Como nós nos amamos". Sem meias palavras, Marien prova que as colunistas de Cinelândia inventam histórias:

\footnotetext{
"Que coisa meu Deus! Todos esses colunistas afirmam, categoricamente, que foram os primeiros a entrevistar fulano ou fulana depois do divórcio; os primeiros a falar no apartamento dos dois; entrevista especial etc. Logo à frente, um seu colega afirma que foi o primeiro a receber telefonema, informações, etc, etc!"
}

Concentrando-se nas invenções da publicidade, o texto se destina a uma campanha contra Cinelândia, desenvolvida por Cena Muda de forma sutil. Contudo, quando cita os nomes das colunistas da revista de Roberto Marinho, revela por inteiro seus intuitos. Visto de outra maneira, é no mínimo inusitado o fato de Cena Muda, uma revista também destinada a inventar romances, desvendar seus próprios critérios. Tratase da característica de uma publicação que congregava publicistas e críticos intelectualizados.

A mesma repórter tenta provar depois a capacidade crítica do leitor que o isenta de acreditar nos mecanismos da fofoca. Aborda ${ }^{136}$ duas notícias sobre acidentes com estrelas para mostrar a diferença entre fantasia e realidade. A primeira sobre a perfuração no pescoço de Judy Garland por um caco. Segundo a revista, a história verdadeira foi vista como uma tentativa falsa de suicídio. Sete milhões de leitores acompanharam e vibraram tristemente com "o sensacionalismo". Por outro lado, a notícia falsa de Bette Davis ter caído sob um cacto, além de ter tirado 49 espinhos da silhueta foi considerada verdadeira. Contudo a reação do público narrada por Marien

\footnotetext{
${ }^{135}$ Marien. Curiosidades e closes ups. Cena Muda, v. 34, n. 15, p. 12, 14/04/1954.

${ }^{136}$ Marien. Curiosidades e close-ups - mistificações da publicidade. Cena Muda, v. 34, n. 14, p. 9, 07/04/1954.
} 
não prova a capacidade crítica dos leitores, mas o poder das revistas de fãs. Depois, a repórter transfere o tema para a invenção e conseqüente responsabilidade destas revistas de "gênero de publicidade que constitui um fenômeno social bem recente" no reino da "burla". Afirma que há menos de dez anos estas publicações eram sub-ramos dos departamentos de publicidade dos estúdios. Nesse período, as biografias não "passavam de mal disfarçados truques de publicidade", com fotos glamourosas enviadas pelas mesmas empresas. Depois Marien reitera o grande poder das revistas da época, que "avultam como poderosa força", "fazem e destroem "astros"” os submetendo "à mais corrosiva das críticas". Em tom paradoxal à conclusão anterior do poder destas publicações, o artigo declara que a era da "futilidade açucarada" nas revistas para fãs já havia passado, porque os fãs da época eram muito "espertos", capazes de descobrir um tópico mentiroso quase à primeira leitura. Exigiam honestidade. Queriam ver os 'astros' como seres humanos com quem pudessem se identificar, e não como ídolos.

Apesar de creditar uma esperteza aos leitores, o artigo mostra também como o público quer e aprecia a invenção e folhetinização. Descreve, então, a pesquisa de uma empresa de anúncio para descobrir o público leitor das revistas de fãs. O modelo seria o de uma estudante de ginásio com 19 anos, ou a detentora de emprego inferior ao de estenógrafa, datilógrafa ou encarregada de mesa telefônica. Os peritos apelidaram-na de 'Judy'. A repórter termina o texto lembrando que os editores destes veículos amam com sinceridade este tipo porque "Judy é a pequena que considera o realistamento de Audie Murphy no exército uma tragédia maior que a Guerra da Coréia". O leitor é visto como "esperto" por não cair nos truques da publicidade, embora os exemplos mostrem o contrário. Ao mesmo tempo, o público aparece como um ser ávido por informações de pouca relevância sobre a vida das estrelas. O referido texto revela como o fã poderia perceber as invenções das fofocas, mas ao mesmo tempo desejá-las. Com estes artigos fica evidente que neste período Cena Muda percebia suas deficiências enquanto revista de fã, mas não queria participar do modelo proposto por Cinelândia. A preocupação de Cena Muda em 1954 era debater se o estrelismo estaria em seu fim, ou se o vedetismo iria ressurgir com mais força.

O preconceito contra as revistas de fãs não vinha só de Cena por seu caráter antagônico na cobertura ao estrelismo. Jane Wilkie trabalhou durante muitos anos em revistas de fãs, entre elas Motion Picture, Photoplay, Modern Screen. Relembra que seus amigos jamais admitiam ler as revistas onde ela trabalhava. Os conhecidos afirmavam que tinham lido os artigos dela apenas quando encontravam as publicações 
no cabeleireiro. O preconceito não era apenas dos amigos. A própria Wilkie confessa que se eles tinham vergonha, que diria ela? Quando questionada sobre sua profissão, declarava ser escritora, aprendendo a esconder “a horrível verdade". (Wilkie, 1981: 2)

O processo de desnudamento de algumas características do star system, como mostramos acima, expunha os pontos frágeis não aceitos pelos leitores, trazendo a necessidade de nova denegação da publicidade. Acima de tudo, este desnudamento parcial da estrutura do estrelismo indica uma época transitória para o estabelecimento de novas estratégias. No próximo capítulo, destrincharemos como se dava a construção do estrelismo do período e suas transições. 


\section{Capítulo 2 - A persona da estrela}

Voltamos nosso foco agora ao tipo de construção sob a persona da estrela, atentos a traçar paralelos à configuração do estrelismo brasileiro com o hollywoodiano. Na primeira parte deste capítulo, analisamos a construção imagética. A partir das fotos, o espectador-leitor armazena a imagem das atrizes para ter o sentimento de partilhar a posse delas. Tratamos também da representação da ética do lazer, a partir dos momentos de felicidade da vida da estrela, da fotogenia, do glamour, e do sex appeal das atrizes, um dos recursos visuais mais importantes ao sistema, via potencial do prazer visual. $\mathrm{Na}$ segunda parte focada sobre a construção textual, trazemos de um lado a divindade da estrela, sua bondade, e de outro, o processo de transição para uma humanização crescente, na qual a estrela pode sofrer, se divorciar e até errar. A representação inclui ainda os casos de transgressões da moralidade predominante no período e as conseqüentes críticas aos que fugiam ao padrão.

\subsection{Construção imagética}

As fotos trazendo a fotogenia da estrela ou o enlevo amoroso tornam-se presentes em todas as edições das duas revistas. Cumprem a primeira função de possibilitar a contemplação da beleza da artista. Além disso, propiciam vislumbrar os "momentos mágicos", ou seja, na iminência do beijo, designados dessa forma em Cena Muda. Tais ilustrações são muito semelhantes. As fotografias na iminência do beijo em Cena Muda são sempre semelhantes, beiram a simulacros mudando apenas os atores. Privilegiam o rosto da estrela em close up, ou suas pernas, em estado de graça e por meio da exibição da aura da musa. Por outro lado possuem forte apelo para exibição dos atributos físicos. Geralmente a estrela cintila sozinha na imagem. Embora muitas vezes ela esteja acompanhada do par romântico do filme.

Em muitas das capas de Cena Muda, as artistas permanecem marmorizadas, congeladas de forma bastante estática. As mulheres costumam não sorrir. Estão com ar aquém da realidade, em seu Olimpo pessoal. Lana Turner parece uma atriz dos anos vinte, de tão distante e fria. A seu lado, o galã Fernando Lamas não sorri. Está absorto em seu amor. Há nestas capas uma representação contida da felicidade. Os momentos 
de amor ou de beijo são congelados na menção de acontecer, deixando o leitor na impossibilidade de ver a concretização da felicidade. Esta está bem próxima, mas nunca se torna efetiva. Já a imagem do casal Tony Curtis e Janet Leigh mostra como as imagens são simulacros de um formato sempre repetido.
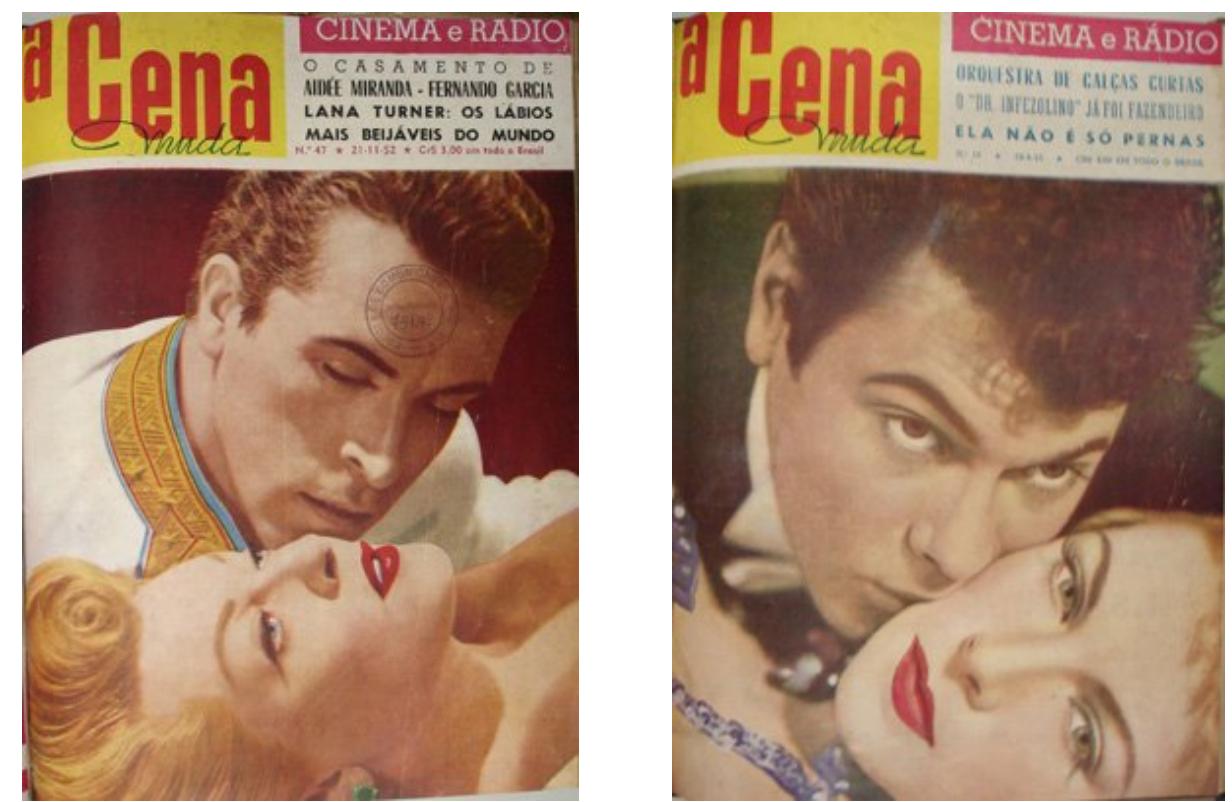

Imagem 3 a 4 - Capas de Lana Turner/Fernando Lamas ${ }^{1}$ e Tony Curtis/ Janet Leigh ${ }^{2}$

Uma vez que contemplar a estrela também significa admirar seu modo de vida, multiplicando-se também as fotografias das atrizes com a família ou em momentos de hobby, presentes apenas sob a forma de fotos posadas ou posadas simulando flagrante, estudadas de forma mais detida no tópico sobre a construção da felicidade.

Pouco importa o local escolhido para as fotos. Não vemos imagens das atrizes em países, cidades ou pontos turísticos identificáveis. A exceção são as fotos no convívio familiar. Geralmente não há fundo (apenas cores fortes e contrastantes como vermelho e amarelo), nem objetos. A estrela é única, deve cintilar sozinha, em especial seu rosto. Raramente há fotos com duas ou três artistas juntas, embora haja diversos pares amorosos (reais ou dos filmes) ${ }^{3}$. Nestes casos não há destaque para as intérpretes

\footnotetext{
${ }^{1}$ Cena Muda, v. 32, n. 47, 28/11/1952.

${ }^{2}$ Cena Muda, v. 33, n. 18, 29/04/1953.

${ }^{3}$ Fotos com duas estrelas ocorrem quando o tema permite, como no encontro entre as estrelas do rádio Dircinha Batista e Camélia Alves (Cena Muda, v. 32, n. 50, 12/12/1952), ou para pontuar que as três estrelas Marilyn Monroe, Lauren Bacall e Bette Grable são da 20th Century Fox (Cinelândia, v. 2, n. 25, $2^{a}$ quinz. nov. 1953). Esta última imagem cumpre a função de realizar a publicidade do filme Como agarrar um milionário (1953) de Jean Negulesco, mas sem citá-lo. Há ainda as imagens de lançamento, como do filme The I don't care girls (1953), de Lloyd Bacon, com Seymour Felix, Bette Onge, Jane Howorth e Meredith Leads na capa de Cena Muda (v. 32, n. 16, 17/04/1952).
} 
de forma unitária. Suas dimensões são diminuídas para compartilhar o espaço visual, quase na fronteira da representação imagética do star system.

As capas são para os grandes galãs, não para os comediantes, com algumas exceções, como Oscarito em Cena Muda. Durante os primeiros meses de 1952 não havia a indicação do nome da estrela na capa, como se o fã conhecesse a todas, ou tivesse tal obrigação, como acontecia durante a década de vinte.

Em Cena Muda, nem sempre as estrelas da capa apareciam nas reportagens ou notas. Às vezes sequer apareciam nas folhas internas. Depois de alguns meses de existência, Cinelândia passa a relacionar as primeiras páginas com as principais reportagens, padrão copiado na publicação concorrente nos anos seguintes. Algumas vezes a atriz da capa aparecia numa na edição seguinte de Cena Muda em alguma reportagem. Em todos estes casos, a primeira página cumpria a função de publicidade das próximas estréias ou de vitrine do próximo número.

A maior quantidade de capas é dedicada de longe às atrizes. Para Edgar Morin, o rosto da mulher reina sobre as capas das revistas porque não existem setores especificamente masculinos na cultura de massa. A imprensa não-feminina também não é masculina, ela é feminino-masculina porque o essencial é o modelo identificador da mulher sedutora. Os valores projetivos não-femininos envolvendo violência não podem se realizar na vida. Por isso, são afastados para a projeção devido a sua polaridade negativa. (Morin, 1962)

Quanto à vestimenta, as mudanças são lentas e graduais. Em Cena Muda, grande parte dos atores veste terno. As mulheres usam vestidos ou saias, mas com grande incidência de maiôs. Em Cinelândia o padrão já é um pouco diferente desde seu nascimento, com roupas menos sociais, refletindo a nova tendência da moda ${ }^{4}$. Pouco a pouco, aumenta a quantidade de roupas esportes, assim como a de jeans. As camisetas continuam raras, apenas para os transgressores de regras, como Marlon Brando e Montgomery Clift, abordados em outro tópico.

\footnotetext{
${ }^{4}$ James Laver (1989) mostra que a moda da década de cinqüenta foi a época da sofisticação. A idéia era se contrapor ao racionamento de tecidos e estilo militar dos anos 40 . A sofisticação tinha por motivo indicar que as mulheres gastaram muito tempo para ter um aspecto perfeitamente cuidado. Fora de Paris, as mulheres faziam uma revolução jovem. Muitas delas queriam criar sua própria roupa, ao contrário do luxo vigente. Contudo, a grande demanda de roupas jovens não foi atendida de imediato. A indústria do prêt-à-porter tornava-se forte, mas só nos Estados Unidos ela avançava no sportwear. O look esportivo não tinha se firmado na Europa, apesar de ser popular nos Estados Unidos. Só em 1960, a moda passa a ter como modelo para composição os adolescentes.
} 
No geral, os dois veículos não se preocupavam em veicular fotos que não envolvessem o glamour. Quando uma atriz teve o vestido rasgado, torceu o pé e quase quebrou o dente durante filmagens de um beijo, a foto de Cinelândia não revelou o momento exato, ou a atriz enfaixada, porque contrariaria as regras da fotogenia. A foto utilizada é de divulgação. Não há imagens do que é dito, porque apenas o mundo do glamour é relevante.

Podemos dividir as categorias de construção imagética da estrela em quatro categorias: as fotos de cena e/ou os posters, as fotografias posadas, as posadas simulando flagrantes, e por último, os instantâneos. Essas categorias sofrem ainda a diferença na composição entre Cena Muda e Cinelândia, não só de lay-out, mas do tipo de construção de um determinado estrelismo, condicionando uma percepção mais ou menos próxima do ídolo.

Nas fotos de cena, são escolhidos em geral os momentos com o par romântico. Há ainda as fotos do elenco em tableau, prevalecendo os momentos de maior dramaticidade. A maioria privilegia o close up, mas algumas delas estão em plano geral. Já os posters prescrevem os mesmos momentos das capas, porém utilizam mais os planos gerais para mostrar a estrela em sua totalidade visual. Os posters de Cena não são para qualquer ator, em cada edição há no máximo dois, mesmo no caso de aspirantes à estrela. Em Cinelândia não há tamanha preocupação em publicá-los porque há diversas fotografias coloridas vazando os espaços delimitados, cumprindo a mesma função. Poucos atores brasileiros são contemplados com posters em Cena.

Nas fotos visivelmente posadas, não há preocupação de denegar os fins publicitários. Nas fotos de publicidade, a estrela fita a câmera, faz poses e sorrisos, insinua olhares para a câmera. Neste tipo, a estrela se mostra gratuitamente aos fãs.

Já as posadas simulando flagrantes sempre se propõem a revelar um pequeno, mas relevante segredo ou intimidade da estrela. Este tipo de imagem é facilmente percebido como construído nos estúdios. São imagens muito recorrentes em ambas revistas. 

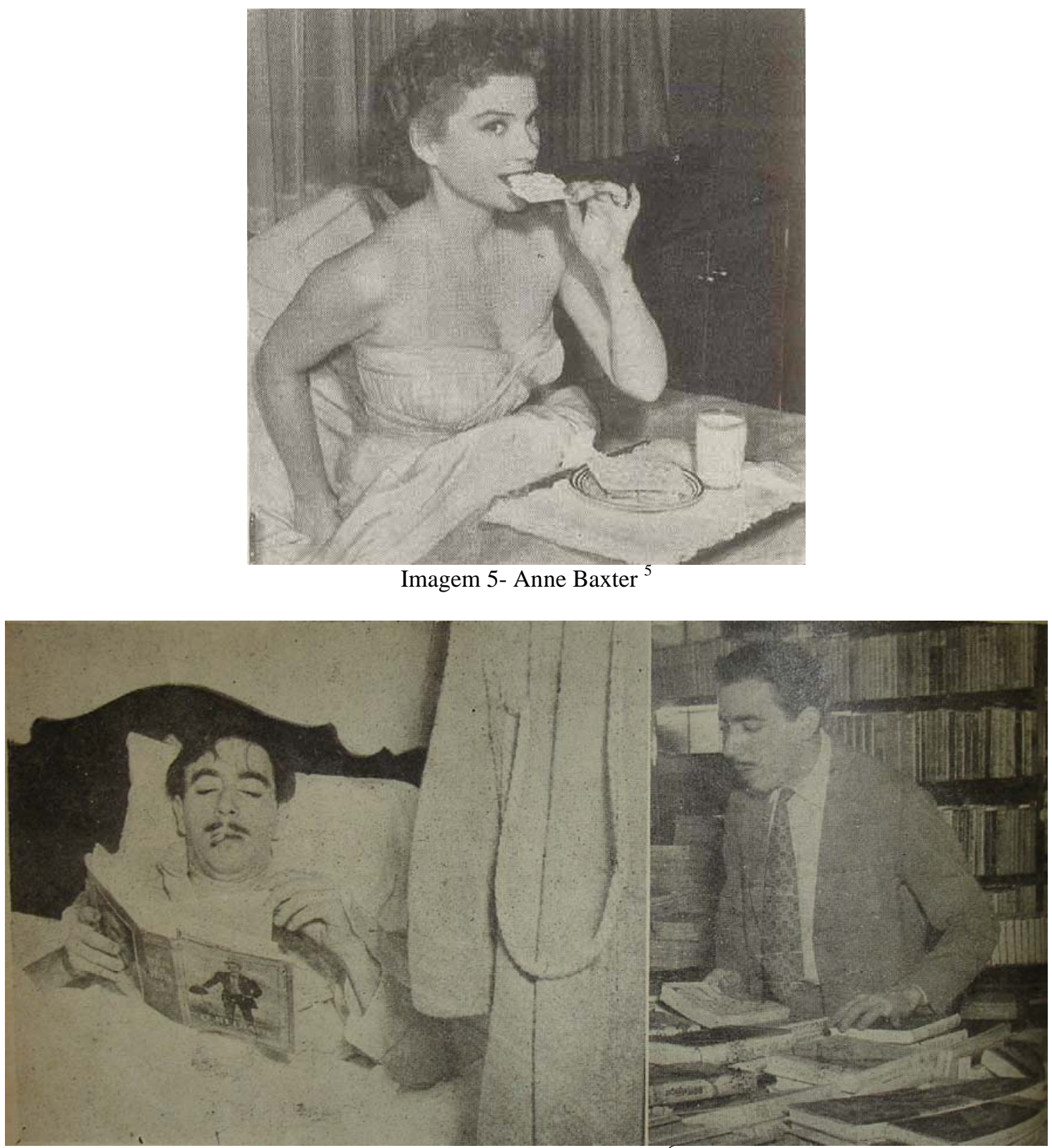

Imagem 6 a 7 - José Lewgoy ${ }^{6}$

Estas são típicas imagens de simulação de flagrante. A legenda da primeira imagem tenta provar um flagrante. Anne Baxter ${ }^{7}$ tomava café na cama de camisola, com uma torrada na mão, quando foi chamada para substituir a atriz do filme $A$ tortura do silêncio (1953), de Alfred Hitchcock. A ilustração funciona como uma novelização daquele momento apreendido pela simulação. Por outro lado, existe também o apelo do corpo que se mostra para um público masculino. No cinema brasileiro há diversas destas fotos, como a imagem acima de Lewgoy na cama ou escolhendo um livro.

\footnotetext{
${ }^{5}$ Cena Muda, v. 32, n. 41, p. 13, 10/10/1952. Esta foto foi coletada na internet do site do Lasar Segall, por este motivo está com resolução mais baixa. O mesmo ocorreu com as imagens n. 28, 31, 42, 47 e 49.

${ }^{6}$ Dines, Alberto. O vilão Lewgoy é boa praça. Cena Muda, v. 32, n. 42, p. 4-5; 34, 17/10/1952.

${ }^{7}$ Cena Muda, v. 32, n. 41, p. 13, 10/10/1952.
} 
Apesar de ficar clara a simulação, o interesse dos leitores certamente não iria diminuir porque o ídolo representa a si mesmo nos detalhes diários. A partir destas simulações, o público pode imaginar como seria a realidade íntima da estrela, fazendo os mesmos gestos sem a presença do fotógrafo. Dentro desta categoria, há também as representações das estrelas supostamente distraídas ou olhando em direção do infinito. Apresentadas também como flagrantes. Imagens estas também bastante comuns, especialmente em Cena, por usar material de release.

Não há dúvida que a categoria de fotografia mais utilizada em ambas as revistas são as posadas, ou as posadas simulando flagrante, porque as revistas de fãs não deixam de ser órgãos de geração do star system. A diferença é que Cinelândia recorre mais a outro esquema, raro em Cena Muda: os momentos de instantaneidade, tratados como flagrantes reveladores.

Cena Muda não contava com um grande acordo internacional para publicar fofocas sobre as estrelas estrangeiras. Utilizava geralmente material dos estúdios. Raramente conseguia alguns instantâneos. Geralmente estas fotos são as da coluna da correspondente brasileira de $O$ Cruzeiro, Dulce Damasceno de Brito. Contudo as ilustrações geralmente têm tamanho pequeno ou médio, provavelmente uma opção da publicação para encaixar uma quantidade maior de fotos, uma vez que o lay-out da mesma coluna em $O$ Cruzeiro era diferente. Cena conseguia alguns instantâneos na cobertura aos assuntos brasileiros, atores nas festas, premiações, como a de Emilinha como Rainha do Rádio.

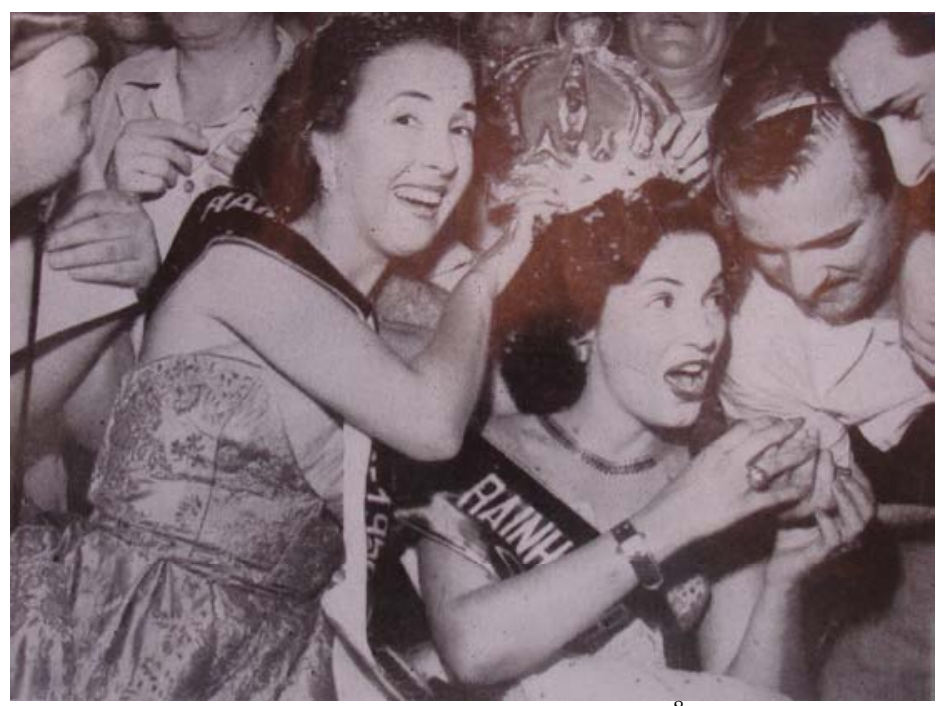

Imagem 8 - Mary e Emilinha ${ }^{8}$

\footnotetext{
${ }^{8}$ Correa, Otton. O rádio paga uma dívida a Emilinha. Cena Muda, v. 33, n. 8, p. 22-4, 18/02/1953.
} 


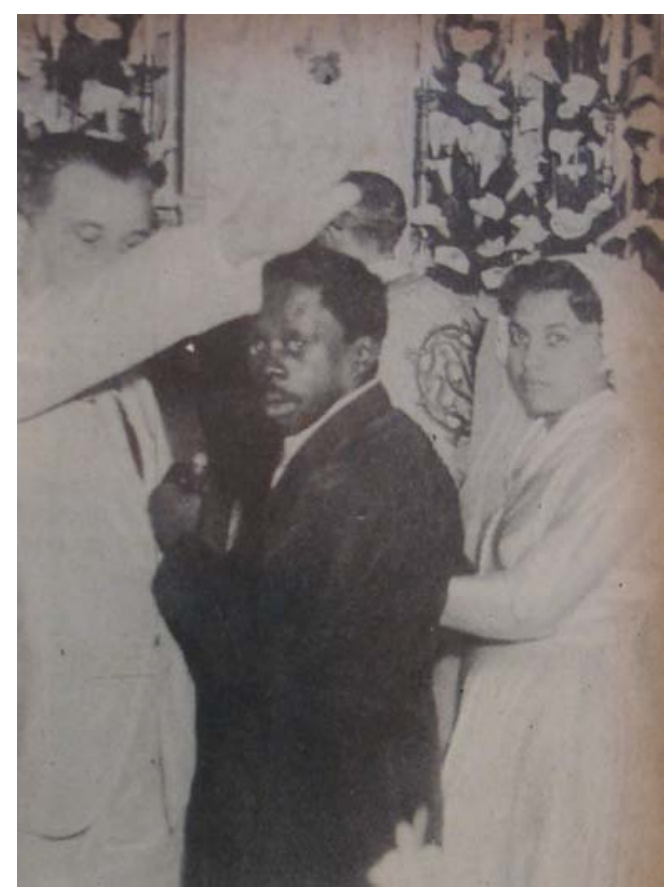

Imagem 9 - Grande Otelo ${ }^{9}$

O número de instantâneos não era grande, concentrava-se na cobertura institucional de festas ou de estréias. No cinema estrangeiro, era raríssimo, porque a revista utilizava em demasia material de divulgação dos estúdios. Um dos raros momentos de flagrante de Cena Muda é o casamento de Grande Otelo, com os noivos olhando para trás espantados e um pouco irritados.

$\mathrm{Na}$ instantaneidade sobre as estrelas estrangeiras reside a maior diferença da cobertura de Cinelândia. Os instantâneos são batidos em restaurantes, boites ou nas estréias de filmes. Supostamente as fotografias teriam sido tiradas à revelia dos atores ou sem que estes o percebessem. Na verdade, estas imagens são mais instantâneos do que flagrantes, porque nem sempre há algo revelador. Contudo, são tratados como flagrantes porque revelam as estrelas em sua vida mediática. Há quantidade bem menor de flagrantes do que de instantâneos. De fato, os instantâneos vistos como flagrantes referem-se a pequenos acontecimentos, importantes para os fãs, como os dois abaixo:

\footnotetext{
${ }^{9}$ Grande Otelo casou de surpresa! Cena Muda, v. 34, n. 33, p. 21-22, 27/10/1954.
} 


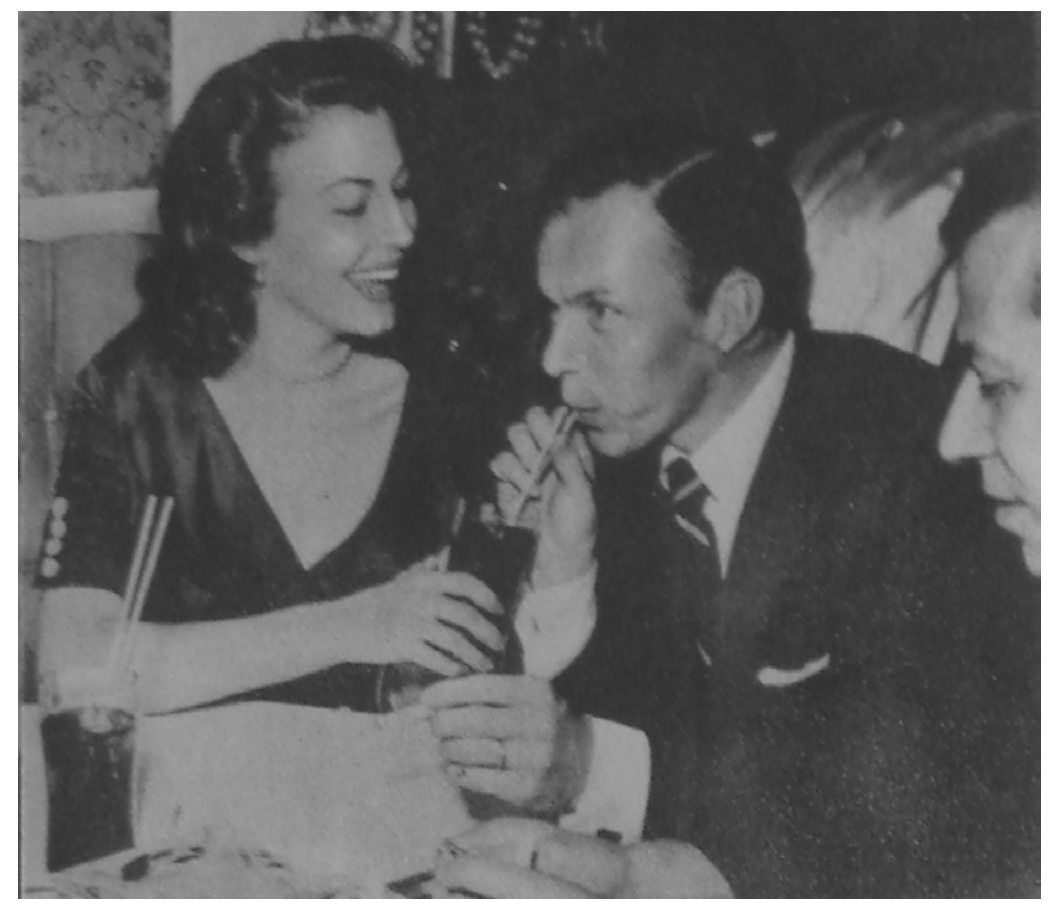

Imagem 10 - Frank Sinatra e Ava Gardner ${ }^{10}$

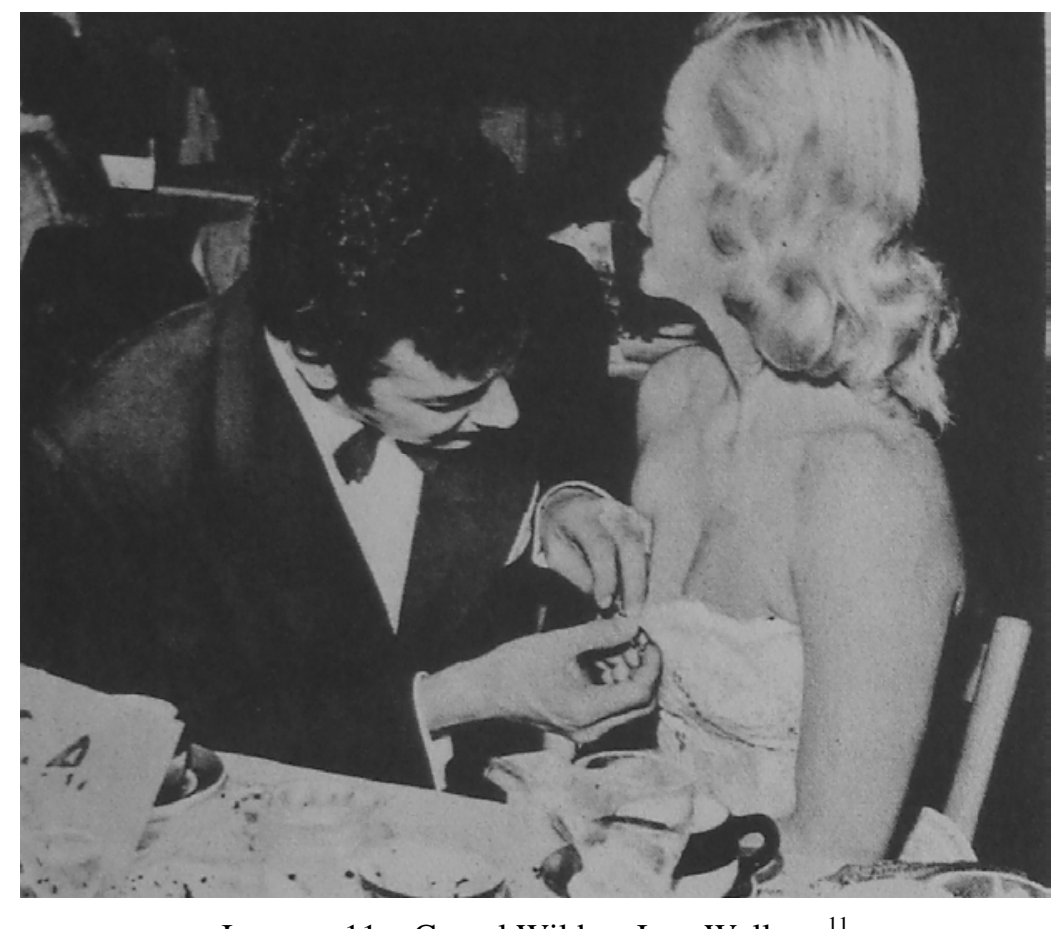

Imagem 11 - Cornel Wilde e Jean Wallace ${ }^{11}$

As fotos acima pertencem à seção de fofocas. Há centenas deste tipo. Elas congelam momentos importantes para saciar a curiosidade dos leitores. Na maior parte, os atores estão sentados à mesa ou conversando em festas, fazendo gestos, mímicas ou

\footnotetext{
${ }^{10}$ Parsons, Louella. Os espiões de Cinelândia em Hollywood informam. Cinelândia, v. 1, n. 2, p. 38, junho 1952.

${ }^{11}$ Parsons, Louella. Os espiões de Cinelândia em Hollywood informam. Cinelândia, v. 1, n. 4, p. 18, agosto 1952.
} 
rindo. É evidente o acordo entre fotógrafos e artistas, porque se tratam de locais badalados, notoriamente cheios de repórteres. Embora haja um pré-acordo em aceitar se expor aos fotógrafos, estas imagens possuem um tom de flagrante e instantaneidade, diferente das fotos das festas brasileiras. Isso porque se consegue apreender momentos como os da foto acima, de Frank Sinatra bebendo num canudinho, ou Cornel Wilde consertando o vestido da esposa Jean Wallace. No caso brasileiro, os famosos apenas conversam. A diferença aqui é um flagrante não num momento institucional de estréia, como havia em Cena, mas em festas particulares, boites ou restaurantes.

A impressão dada é de adentrar na intimidade das celebridades. Não se consome um segredo, mas mesmo que a foto nada revele, é possível ver o suposto sorriso "verdadeiro" da atriz, não o da interpretação da personagem ou do material de estúdio. Era muito difícil o acesso pelo público de imagens que revelassem como a atriz fotografa sem muitos flashes, como olha as pessoas a sua volta ou como estava vestida no cotidiano. Tais fotos permitem partilhar de um momento que se perderia para sempre, não fosse o trabalho do fotógrafo. Para Cinelândia, esta cobertura dos instantâneos fez toda a diferença em relação a sua concorrente. Há uma diferença patente nesta revista. Por um lado, as fotos de flagrantes e/ou de instantâneo nas seções de fofocas. De outro, as imagens posadas ou simulando flagrantes nas reportagens. Há uma defasagem deste tipo de instantâneo na cobertura ao cinema brasileiro, em relação ao grande número de imagens das atrizes em Hollywood.

Comparando-se os instantâneos das duas publicações com a de $O$ Cruzeiro e Manchete há um claro desnível pelo grau de insistência. Na cobertura das estrelas estrangeiras nas duas maiores revistas de atualidade do período, há imagens de Marilyn Monroe não em festas particulares, mas em shows. É possível vê-la em movimento, às vezes em poses comuns, pega de surpresa, abrindo a boca ou se movendo ${ }^{12}$. Em Cinelândia raramente havia destas imagens. No cinema brasileiro vale o mesmo pressuposto, embora em número diminuto. Em Cruzeiro, há, por exemplo, uma imagem de Fada Santoro dançando capoeira com José Lewgoy ${ }^{13}$.

A cobertura jornalística copiada por Cinelândia nascia nos Estados Unidos nos anos trinta. Alexander Walker (1970) mostra que os jornalistas americanos nos anos vinte não tinham sensibilidade para tratar de algumas questões; perspectiva diferente dos ingleses. Há um aumento na quantidade de repórteres cobrindo a meca do cinema

\footnotetext{
${ }^{12}$ Manchete, v. 103, p. 28-9, 10/04/1954.

${ }^{13} 2^{a}$ semana do Cinema Brasileiro. O Cruzeiro, v. XXVI, n. 41, p. 100-5, 24/07/54.
} 
na nova década. Em 1920, não eram mais do que algumas dezenas. Em 1930, havia 300 jornalistas para 150 estrelas, além de 80 correspondentes estrangeiros. Estes novos repórteres alteram a configuração da cobertura de Hollywood. Acreditavam que as pessoas não queriam mais as histórias e fofocas plantadas pelos estúdios. A ordem era sair das redações para competir pelas histórias desconhecidas e sensacionalistas. Uma das principais ordens era tirar muitas candid pictures, ou seja, as fotos sem permissão da pessoa fotografada. Os estúdios logo reclamaram daqueles que os invadiam e utilizavam o transporte interno, na tentativa de obter favores, adentrar e parar os sets de filmagem e usando de chantagem contra as estrelas para evitar possíveis publicações. Num primeiro momento, logo com a chegada do som, os repórteres foram banidos dos estúdios. Os contratos impediam os atores de conceder entrevistas para evitar trazer a baila um comportamento ruim ou indesejado por parte dos mesmos. A publicidade teve assim, papel de censor em 1930.

O último ponto a ser observado na diferença entre as categorias fotográficas é a comparação dos instantâneos de Cinelândia e as imagens posadas de Cena Muda focadas sobre os mesmos atores é que se estabelece o maior disparate entre as duas representações do estrelismo.

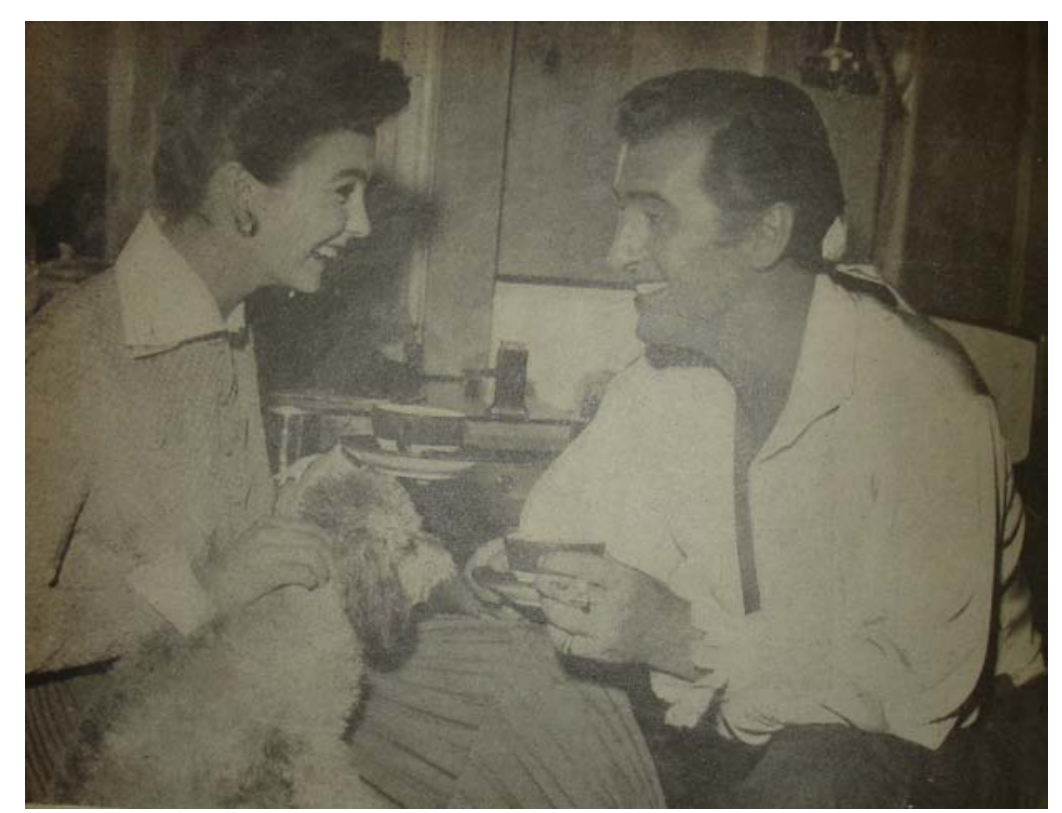

Imagem 12 - Casal Stewart Granger/Jean Simmons no camarim em Cena Muda ${ }^{14}$

\footnotetext{
${ }^{14}$ Cine mundial. Cena Muda, v. 32, n. 37, p. 14, 12/09/1952.
} 


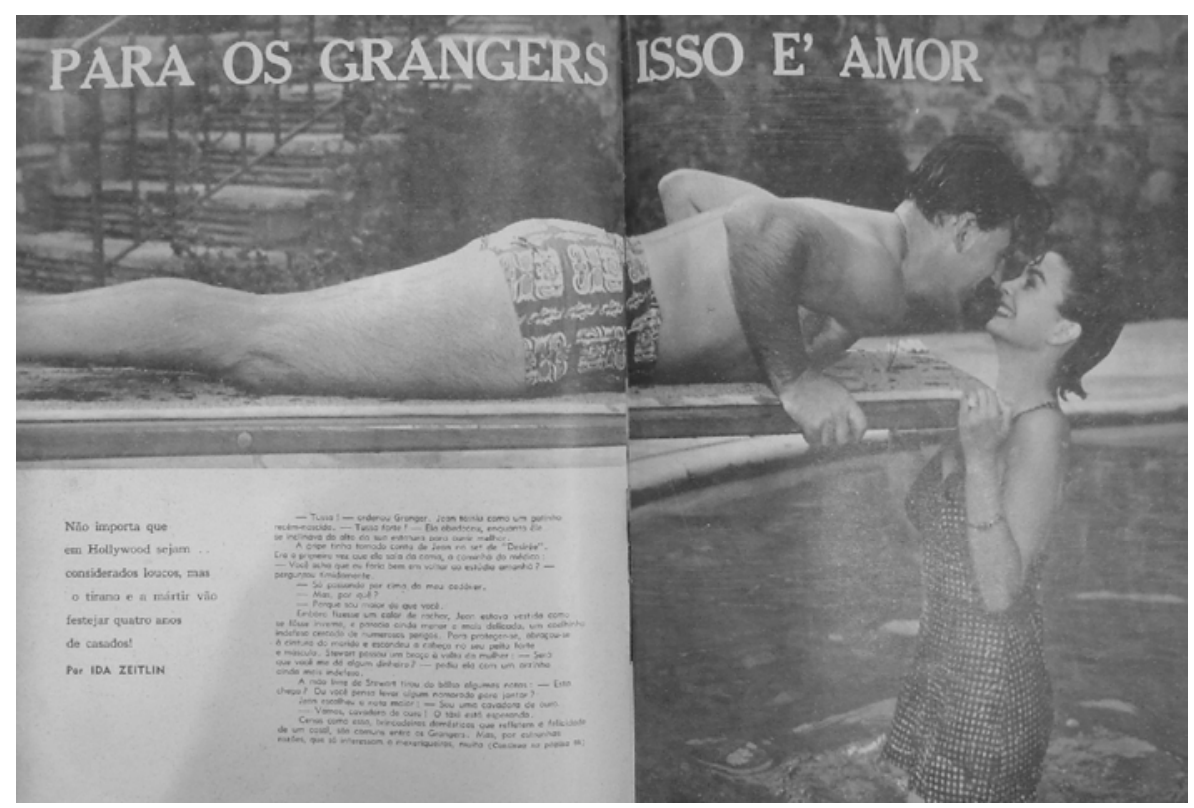

Imagem 13 - Casal Stewart Granger/Jean Simmons na piscina em Cinelândia ${ }^{15}$
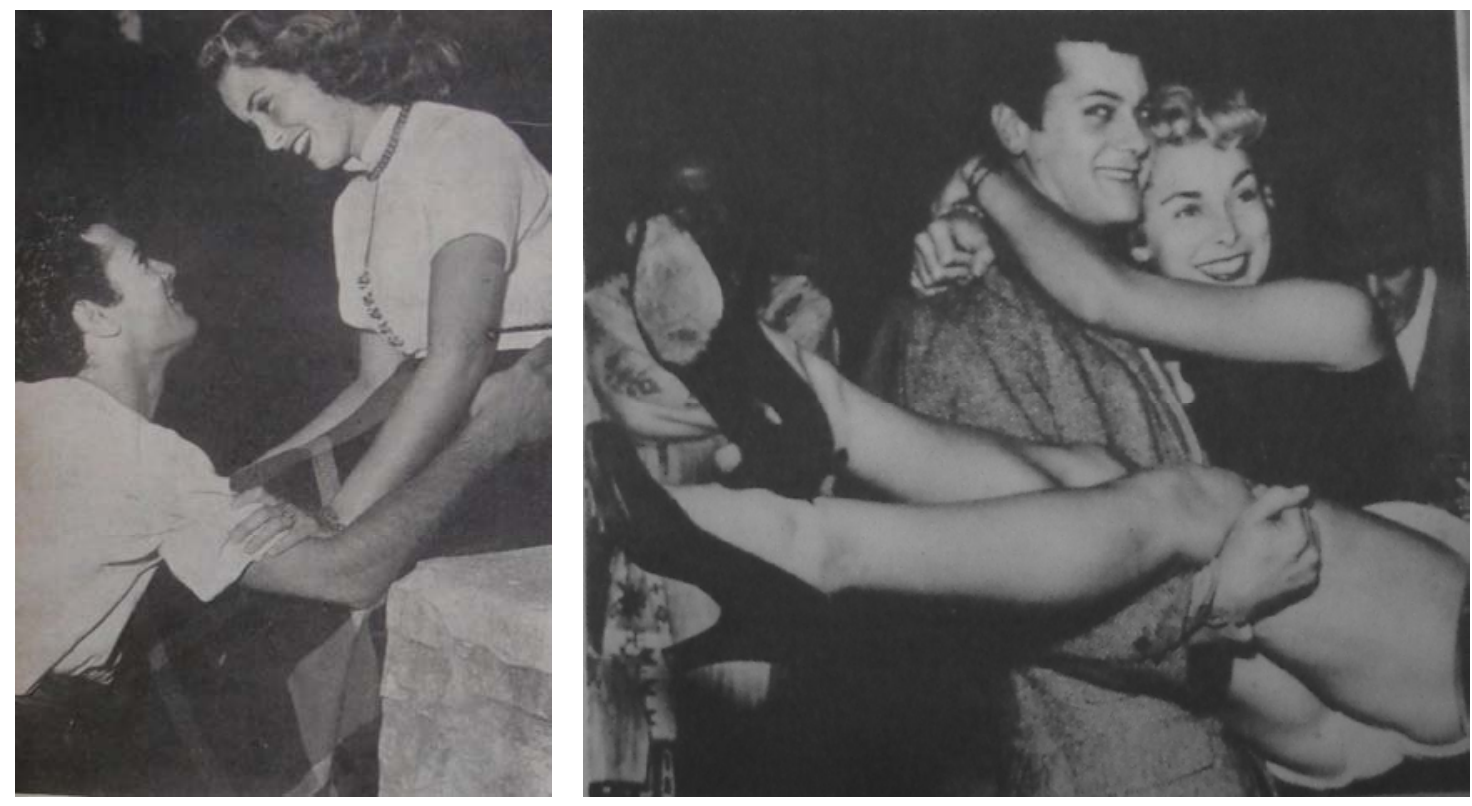

Imagem 14 a 15 -Tony Curtis/Janet Leigh ${ }^{16}$ e Tony Curtis segura Janet Leigh no colo ${ }^{17}$.

Em Cena Muda, os momentos de enlevo amoroso são constantes e produzidos de maneira artificial em cada detalhe, como se vê na foto abaixo em que Jean Simmons vai visitar seu marido Stewart Granger no set de filmagem ${ }^{18}$. Os dois se entreolham de forma apaixonada com xícaras na mão, no espaço minúsculo do camarim móvel. O

\footnotetext{
${ }^{15}$ Para os Grangers isso é amor. Cinelândia, v. 3, n. 51, p. 40-1, 2a quinz. dez. 1954.

${ }^{16}$ O mais doce romance de Hollywood de todos os tempos. Cena Muda, v. 33, n. 18, p. 4-5, 29/04/1953.

${ }^{17}$ Parsons, Louella. Os espiões de Cinelândia em Hollywood informam. Cinelândia, v. 2, n. 10, p. 8-9, fev. 1953.

${ }^{18}$ Cine mundial. Cena Muda, v. 32, n. 37, p. 14, 12/09/1952.
} 
sorriso soa artificial, assim como o gesto da esposa sorrir para o marido e acariciar o cachorro ao mesmo tempo. Um instante difícil de se fotografar, supostamente apreendido por um fotógrafo num "flagrante".

Essa imagem mostra quanto o amor em Cena Muda é doce e idílico. Pode ser sintetizado na outra fotografia em que Tony Curtis olha de maneira apaixonada e romântica para sua esposa Janet Leigh ${ }^{19}$. Os dois estão distantes um do outro. O título é sugestivo: O mais doce romance de Hollywood de todos os tempos. A fotografia é de release. A encontramos numa outra publicação americana ${ }^{20}$. É exatamente esse tipo de representação que a cobertura de Cinelândia altera.

$\mathrm{Na}$ primeira imagem de Cinelândia, o mesmo casal Granger diverte-se na piscina. Stewart na prancha beija Jean Simmons dentro da água ${ }^{21}$. Um instante posado sob a forma de flagrante. Contudo o lay-out é moderno. A imagem ocupa a maior parte da página. O texto apenas é acompanhamento. A foto seguinte é a de Tony Curtis segurando sua esposa Janet Leigh no colo ${ }^{22}$. Esta imagem é fundamental para entendermos a diferença entre a representação visual do estrelismo das duas revistas. Há aqui um momento que se mostra como real; apreendido em alguma festa. Apesar de ser uma foto posada simulando flagrante como a de Cena, há uma sutil diferença. A esposa parece entretida na situação, enquanto Tony Curtis não se preocupa com a fotografia, certamente por estar num local lotado de fotógrafos. Ao contrário, fita a câmera. A revista não esconde na legenda trata-se de um evento plantado quando explica a situação: "Tony Curtis carregava no colo a sua esposa, Janet Leigh, quando entrou no palco para bancar o mágico numa festa a que os dois compareceram." Mesmo com a confissão do interesse por parte da revista, há uma diferença. A imagem tem mais peso do que a explicitação da publicidade da legenda. Há um movimento de instantaneidade na fotografia, mostrando como o ator realmente carregou sua esposa, deixando transpassar até um detalhe indiscreto. Ao levantar Janet Leigh, permite ao leitor vislumbrar grande parte de seu corpo.

Esta cobertura aos instantâneos de Cinelândia fez a diferença porque Cena Muda não tinha como ter acesso a estes instantes. E é exatamente este tipo de

\footnotetext{
${ }^{19}$ O mais doce romance de Hollywood de todos os tempos. Cena Muda, v. 33, n. 18, p. 4-5, 29/04/1953.

${ }^{20}$ Encontramos a mesma fotografia na revista Picturegoer: film annual for 1954-55. Chappell, Connely. Picturegoer: film annual for 1954-55. Picturegoer: Londes, 1955. A cobertura fotográfica deste anuário (dedicada a fotonovelas e sinopses) utiliza fotos muito semelhantes às de Cena Muda, claramente de release, diferente dos momentos de intimidade conseguidos por Cinelândia.

${ }^{21}$ Para os Grangers isso é amor. Cinelândia, v. 3, n. 51, p. 40-1, 2a quinz. dez. 1954.

${ }^{22}$ Parsons, Louella. Os espiões de Cinelândia em Hollywood informam. Cinelândia, v. 2, n. 10, p. 8-9, fev. 1953 .
} 
instantâneo o mais precioso ao fã. A necessidade do leitor de possuir algo do ídolo ou apreender e congelar estes momentos descritos acima tem relação com a experiência efêmera do cinema. Este dificulta aprisionar as imagens e os ídolos. O espectador que se relaciona aos filmes de estrela é considerado por Laura Mulvey como possessive ${ }^{23}$. Para ele, a imagem da atriz está sempre perdida, devido ao movimento do cinema. Nunca há satisfação completa no cinema porque não há tempo para apreender as imagens; diferente da fotografia que possibilita a posse. Para sanar esse desejo de deter a imagem do astro, a indústria fílmica criou dois mecanismos. O primeiro é chamado de delayed cinema. Trata-se de uma técnica utilizada especialmente pelos filmes melodramáticos norte-americanos para congelar por alguns segundos a imagem da intérprete para contemplação. É um atraso proposital na seqüência fílmica. Nestes instantes, a estrela faz pose para ser admirada por seus espectadores. Aliado ao congelamento, a contemplação torna-se mais presente porque também é focada nos close ups, na performance e na capacidade da intérprete de fazer poses para a câmera. Daí a importância das fotografias congeladas das atrizes, cartazes de filmes e dos posters, presentes também nas revistas de fãs. É este o segundo mecanismo que cumpre a mesma função de permitir ao espectador congelar a imagem perdida na memória.

Para tornar mais clara a teoria do delayed cinema, trazemos um exemplo citado por Mulvey. A cena inicial de Imitação da Vida (1959), de Douglas Sirk. A personagem vivida por Lana Turner é uma mulher divorciada com uma filha para criar. No início do filme, a mãe procura a filha desaparecida em uma grande multidão. Está muito apreensiva numa escadaria, sem se preocupar com sua aparência física. Usa roupas comuns. No discurso, a mulher pouco liga para seu apelo sensual, mas as imagens revelam o contrário, misturando a personalidade atribuída à atriz, como mulher elegante e glamourosa. Num plano muito rápido, um homem a fotografa, mas aparentemente a mãe zelosa nada percebe. Contudo, se a cena for revista em baixa velocidade, fica evidente que a personagem não só congelou seu movimento para ser contemplada pelo fotógrafo e espectadores, como fez uma pose para a fotografia. São estes momentos de contemplação a que Mulvey se refere.

A imagem da estrela, como a da personagem de Lana Turner, possui uma existência interna e externa à performance porque existe uma ambivalência entre elas:

\footnotetext{
${ }^{23}$ Para Laura Mulvey, o desejo de posse do espectador possessivo faz com que ele assista ao filme dezenas de vezes. Fato relacionado à teoria de Freud no prazer da repetição, como, por exemplo, o da criança que relê a mesma história diversas vezes. A diferença entre o possessive spectator e o pensive é a postura ou fruição que o espectador resolve ter diante de um filme.
} 
no filme se contempla ao mesmo tempo não só a personagem, mas principalmente a artista. O delayed cinema se encarrega deste jogo quando possibilita uma ampliação do status iconográfico da estrela, misturando a performance ficcional interna e externa, porque quem faz a pose para contemplação é a atriz e a personagem.

No caso do cinema brasileiro do período, A dupla do barulho (1953), de Carlos Manga utilizou o delayed cinema sob a forma de paródia ao universo das estrelas de cinema e das revistas de fãs. Na trama, Oscarito e Grande Otelo após algum tempo de sucesso, entram num hotel. Há diversos jornalistas esperando alguém. Os dois, deslumbrados com a fama recente, supõem que sejam eles.

Os jornalistas se levantam com máquinas fotográficas em punho, quando a dupla entra. Um deles exclama: “pessoal, será que é ele?”. A frase é suficiente para Oscarito e Grande Otelo, acompanhados de suas namoradas, pararem como "estátuas", fazendo uma pose congelada para a imprensa; como aspirantes a starlets. Grande Otelo empolgado, diz "a imprensa!" e Oscarito completa "olha o passarinho".

Este congelamento na imagem, referente ao delayed cinema, em que cada um deles fez uma pose cômica diferente, como um tableau, foi aqui ironizado no que de mais característico há sobre a pose da estrela.

Contudo, os jornalistas passam por eles para fotografarem o hóspede ilustre; recém chegado. Como um aspirante ao estrelato, Grande Otelo tenta ainda atrair a atenção dos jornalistas: “o negócio é aqui”, frase nem sequer ouvida pelos repórteres. Otelo considera o fato uma falta de consideração, enquanto Oscarito pensa ter chegado Getúlio Vargas, tal o agitamento.

Já no filme É proibido beijar (1954), de Ugo Lombardi, a parodia ironiza também as revistas de fãs. A personagem de Tônia Carrero finge no começo da trama ser uma atriz norte-americana, rival de Rita Hayworth. Um jovem repórter (Mário Sérgio) encarregado de cobrir o desembarque da verdadeira estrela, por acaso entra em contato com a farsante. Cai na enrascada da moça, e a leva embora do aeroporto pensando ter dado um grande furo de reportagem. Para conseguir hospedagem, a suposta atriz concorda em conceder uma entrevista a ele, apesar de declarar odiar jornalistas ${ }^{24}$. A confusão toda se instala porque o repórter "da coluna elegante" mal

\footnotetext{
${ }^{24} \mathrm{O}$ ódio aos jornalistas é manifestado diversas vezes pelas estrelas estrangeiras nas revistas consultadas. No universo representativo dos filmes brasileiros do período, os astros e os mortais também não gostam de entrevistas e da imprensa. No filme Apassionata (1952), de Fernando de Barros, a famosa pianista odeia os textos publicados na imprensa sobre sua vida. Em Uma pulga na balança (1953), de Luciano Salce, os ricaços fogem da imprensa para não serem fotografados pela imprensa na festa promovida pelo
} 
reconhece a fisionomia das grandes estrelas. Despreza seu trabalho. Quer se dedicar a um jornalismo mais sério, o da "crônica negra", ou seja, a reportagem policial. Há um desmerecimento evidente em relação aos jornalistas que cobrem fofocas ou colunas sociais. A legitimidade da profissão não é alcançada por estas vias do jornalismo. Porém, o repórter não sabe conduzir uma entrevista. Comete algumas gafes e sem ver utilidade para o seu precioso Manual do perfeito entrevistador, o coloca de lado. A suposta estrela June Lindsay, vendo a inexperiência do rapaz, resolve ajudá-lo. Propõe ditar as perguntas e as respostas. Neste momento, ela se transveste de duas personagens. A primeira, da entrevistadora, em tom sério e obsequioso. A segunda, da estrela, em tom afetado, zombeteiro, que os espectadores percebem mentirosa, menos o protagonista. As perguntas feitas referem-se justamente ao universo das entrevistas das revistas de fãs. A farsante afirma ter entrado para o cinema por "vocação", rindo bastante ao proferir esta palavra. Pergunta a si mesma como ganhou seu primeiro "Ôscar" (sic) e no tom comum às entrevistas da época, afirma ter sido aos dezoito anos, dizendo ter sido muito fácil ganhar o famoso prêmio da Academia. "Foi um imprevisto", conta em tom de desdém, como se pouco importasse a estatueta. Teria ido substituir a atriz principal, acometida por uma doença.

O filme de Ugo Lombardi faz então uma referência a uma das perguntas mais presentes nas entrevistas das revistas de fãs sobre os inúmeros atributos das estrelas. Na cena do filme, quando questionada sobre suas preferências, a farsante responde: "ah, eu adoro verde, a vida doméstica, as arrumações da casa, (??? ${ }^{25}$, sei cozinhar. Gary Cooper e Charles Boyer acham que eu sou a melhor dona de casa de Hollywood."

Uma das últimas perguntas que a falsa atriz faz a si mesma se refere à prática de esportes, muito citadas nas revistas de fãs, como parte da perfeição das estrelas. Em tom de deboche despercebido pelo jornalista, a personagem declara fazer "patinação, muito passeio a pé, muita ginástica pela manhã, corrida, equitação, automobilismo, patinação e alpinismo três vezes ao ano, basketball também, jui jitsu..." A protagonista iria continuar a lista, mas o repórter afirmou já ter o bastante, sem se questionar sobre a veracidade das palavras. Age como uma máquina de escrever. Enquanto profere essas frases, podemos contemplar a beleza da diva despindo-se enquanto fala, com destaque especial às pernas. Há dois movimentos concomitantes. Ao mesmo tempo ridiculariza-

chantagista na prisão. E finalmente em Nadando em dinheiro (1952), de Abílio Pereira de Almeida, o repórter chantagista quer dinheiro para publicar matéria sobre Izidoro (Mazzaroppi) que ficou rico.

${ }^{25}$ Inaudível na versão consultada. 
se na fala o star system vinculado às revistas, mas nas imagens se apela para a lei dos tipos, fotogenia e contemplação do corpo da estrela.

A entrevista é publicada e a farsa, revelada porque a verdadeira estrela nem tinha desembarcado no Brasil. Cenas depois, Lindsay inventa estar em perigo para justificar a invenção. Chega a dizer que a falsa entrevista foi uma forma de ajudar o repórter a não perder o emprego. Por fim, declara: "as entrevistas são todas iguais", como se o jornalista tivesse a obrigação de conhecer os métodos de sua profissão. A visitante se instala no apartamento porque não tem para onde ir. Com fome, o repórter pede que ela cozinhe, mas a intrusa mal sabe abrir uma lata. Quando o repórter questiona seus dotes culinários ausentes, ela retruca não ter dito saber cozinhar. Era a atriz estrangeira que sabia cozinhar, mas enfatiza: "talvez ela também tenha mentido". Ao professar estas palavras, condena de forma mais direta as falsas entrevistas divulgadas nas revistas de fãs. Ou seja, até o universo da paródia dos filmes brasileiros da época ridicularizava o material de publicidade das publicações de fãs.

As revistas de fãs podiam apenas trazer as fotografias para possibilitar ao leitor possuir a imagem da estrela, mas não tinham como apreender o delayed cinema em sua totalidade ${ }^{26}$. A tentativa de transmitir estes momentos de congelamento nas duas publicações ocorria nas fotografias com cenas dos filmes em série, principalmente nos momentos românticos. Certa vez Cena Muda tentou apreender na matéria $O$ beijo e a censura $^{27}$ fotos na menção e concretização do beijo entre Elisabeth Taylor e Montgomery Clift no filme Um lugar ao sol (1951), de George Stevens. Os beijos vêm em série, cronometrados por segundos que aproximam a estrela e o astro, como para trazer ao leitor as imagens perdidas do filme. Refletem a vontade de rever a cena. Assim, o instante do happy end tão rápido nos filmes era congelado ao leitor.

Estas imagens de momentos de beijos, as quais os espectadores querem ver à exaustão, se unem à representação da estrela com outra categoria de fotografia. São os instantes de concretização da felicidade, agora das estrelas, que transferem a vida ficcional de felicidade da personagem para a vida mediática das atrizes. Focaremos no próximo item os modos de construção da felicidade por via da ética do lazer. Apesar de as estrelas serem as mensageiras da felicidade, os instantes de felicidade dos filmes e a

\footnotetext{
${ }^{26}$ Nas novelizações de Filmelândia mais à frente fica cada vez mais comum congelar cenas do filme para realizar sinopses.

${ }^{27}$ O beijo e a censura. Cena Muda, v. 32, n. 3, p.22, 17/01/1952.
} 
contemplação da beleza da estrela não são suficientes para provar este pressuposto. É preciso mostrar a felicidades no Olimpo.

\subsubsection{Construção do mito da felicidade}
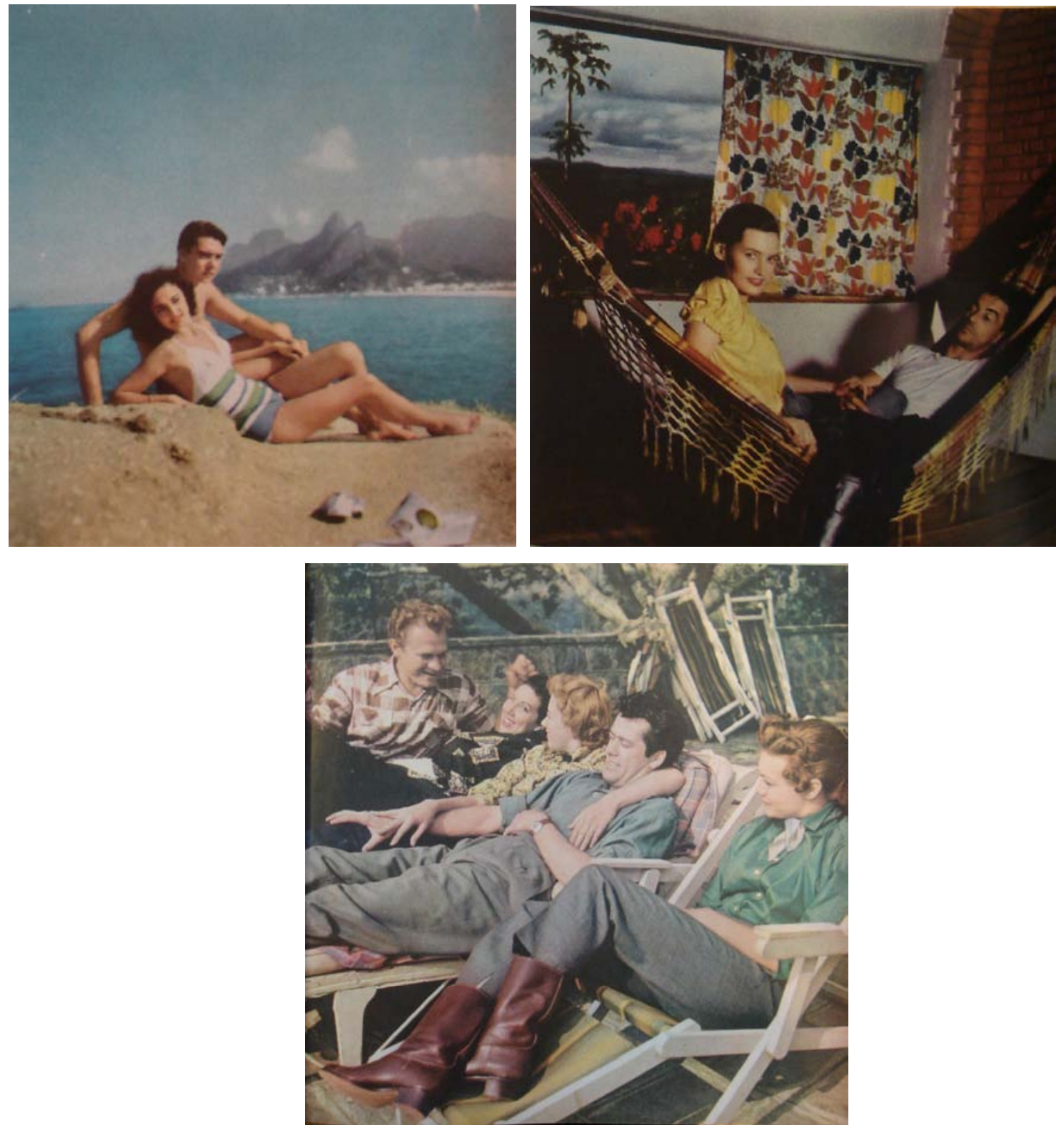

Imagem 16 a 18: Eva Wilma/John Herbert ${ }^{28}$, casal Eliane Lage e Tom Payne ${ }^{29}$ e atores de Floradas na Serra ${ }^{30}$

A vida do ídolo é constituída de prazeres, símbolo mor da felicidade. Assim, em Cinelândia multiplicam-se os momentos para provar aos leitores o quão maravilhosa é a vida da estrela, concretizando os desejos dos leitores de alcançarem esse patamar pelo

\footnotetext{
${ }^{28}$ Idílio no Arpoador. Cinelândia, v. 3, n. 47, p. 34-5; 67, 2a quinz. out. 1954.

${ }^{29}$ Aguiar, R. Werneck de. A fortaleza dos Paynes. Cinelândia, v. 3, n. 32, p. 30-1; 66, 1a março 1954.

${ }^{30}$ Andrea, Zenaide. Um simples caso de crise. Cinelândia, v. 3, n. 41, p. 38-9; 58, $2^{\text {a }}$ julho 1954.
} 
duplo. Os momentos de irrupção da felicidade acentuam-se em Cinelândia a cada ano. As fotos dos atores em praias ou jardins, brincando ou rindo entre amigos, ocupam boa parte das fotos. Geralmente há as fotos para contemplar a beleza da artista, acompanhadas dos momentos de felicidade. Nos casos citados acima, os fotógrafos conseguiram reproduzir os momentos de felicidade sobre as atrizes estrangeiras para o cenário brasileiro, em momentos de instantâneos e/ou posados bem feitos.

Eva Wilma, a primeira da fotografia, ainda era uma novata no ramo, ao lado de seu futuro marido John Herbert, também em início de carreira. Na época de crise da Vera Cruz, Cinelândia passa a cobrir com maior destaque os momentos de prazer dos atores brasileiros. Afinal há muito tempo disponível. Assim a crise patente do cinema nacional é convertida em felicidade idílica. Vale o mesmo para o amor de Eliane Lage com o diretor Tom Payne. A imagem mostrada acima é um exemplo da concretização da felicidade. Com Eliane fitando o fotógrafo, temos uma foto visivelmente posada centrada sob o ócio de uma vida idílica num sítio. A paisagem não poderia ser mais bucólica: na rede a esposa meiga e idealizada vive a felicidade conjugal com o marido.

A terceira foto é mais reveladora porque está centrada sob o ambiente de trabalho. Nesta fotografia se opera a transformação dos momentos de trabalho para os de prazer. A imagem é das filmagens de Floradas na serra (1954), de Luciano Salce. Os atores conversam de maneira animada. Outros estão contemplativos. Há o amor conjugal de Ilka Soares e Anselmo Duarte, as conversas entre amigos de Cacilda Becker, Jardel Filho e a mesma Ilka. Apesar de a imagem remeter à diegese do filme, no caso as cadeiras onde os tuberculosos se sentam, o momento é de alegria. O mais importante é a felicidade dos atores, já que a falência da Vera Cruz é tratada na manchete como Um simples caso de crise. Não se vê nenhum tipo de apreensão dos atores nas fotografias, só bons momentos da filmagem, mostrando a insignificância da dita crise, chamada de simples "caso", sem remeter à situação da cinematografia. A matéria está totalmente distante da realidade da empresa. Afinal o filme foi retomado. Dessa forma, Cinelândia desvia os temas não otimistas de seu universo imagético, não frisa a paralisação anterior da filmagem do filme, nem o ambiente de incerteza quanto a finalização.

A construção imagética da felicidade é feita de momentos possíveis ao leitor, como conversas entre amigos, amor conjugal, filhos, em jardins. Contudo, a impossibilidade de felicidade surgiria no momento da concepção do ambiente de trabalho como prazer. Mas isto também não é problema para a representação das 
revistas, porque ninguém trabalha nas fotografias. A vida dos atores é uma constante hora do café. Até na crise do cinema brasileiro, eles se divertem, aproveitando a paralisação das filmagens.

Estas matérias vendem a idéia de que são os pequenos momentos cotidianos os importantes. Por isso, há a necessidade de congelar essas ocasiões com fotos dos instantes para aprisioná-los.

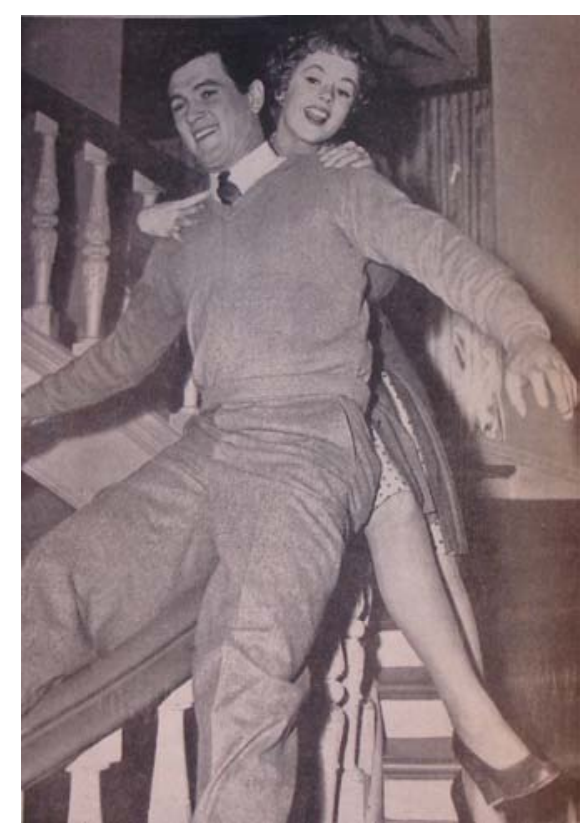

Imagem 19 - Piper Laurie e Rock Hudson ${ }^{31}$

Já na imagem sobre o cinema estrangeiro, a legenda de Cena sugere que Rock Hudson e Piper Laurie parecem duas crianças grandes. Apesar da pouca idade, vale a forma adulta de se vestir. Não há grandes contravenções na vestimenta. Rock Hudson veste um terno, Piper usa salto alto, mas mesmo assim eles descem pelo corrimão da escada. A comparação ao universo infantil deve-se à "espontaneidade" dos astros. A foto de publicidade nos transpõe ao universo da projeção, de ser feliz brincando como eles. Mas tudo se passa num set de filmagem, induzindo assim à vontade no espectador de assistir ao filme para aprisionar momentos como aqueles. Fecha-se o ciclo da projeção via consumo publicitário.

Apesar de afirmar diversas vezes as dificuldades da vida dos atores, nas fotografias ninguém parece fatigado. $\mathrm{O}$ maior volume de imagens em momentos de lazer pode ser explicado pela necessidade da cultura de massa de ignorar os problemas do trabalho e se interessar muito mais pelo bem estar do lar. Edgar Morin compara a

${ }^{31}$ Cena Muda, v. 32, n. 24, p. 06, 12/06/1952. 
cultura de massa a uma ética do lazer, da felicidade e do espetáculo, porque o lazer é a suprema aspiração da vida e o local onde "a aspiração à felicidade individual se torna exigência". (Morin, 1962: 69; 75)

Acreditamos que a representação do trabalho das estrelas pode ser descrito pela ética do lazer de Morin. Contudo, Richard DeCordova (2001) tem diferente opinião, analisando o surgimento do estrelismo nos Estados Unidos. Segundo ele, a estrela mostra que a satisfação não vem do trabalho, mas fora dele, a partir do prazer e consumo. Por isso há imagens da família. As matérias da década de vinte citadas pelo autor mostram como os atores se divertem, e como gastam seus salários. $\mathrm{O}$ autor observou também um incitamento ao consumo de carros. Como a gasolina era cara em 1920, as estrelas possuíam os modelos mais exóticos de automóveis. Por isso, o principal hobby geralmente era dirigir. Já para Richard Dyer (1998), as imagens do estrelismo podem ser vistas como versões do sonho americano, organizadas em volta de consumo, sucesso e de homens comuns.

Nas revistas pesquisadas, a irrupção da felicidade é mostrada no happy end dos filmes. Porém para sanar o vazio da falta de acesso à continuação nos filmes, as publicações deslocam o tema para a felicidade conjugal das estrelas, eternizando tanto na ficção quanto na reportagem, o grande momento da felicidade: o beijo.

As fotos das estrelas com seus filhos são abundantes nas duas publicações. Tal tipo de imagem parece ir contra a afirmação de Morin. Quando o tema é o imaginário projetivo dos filmes, segundo ele, os pais, as crianças, o Estado e a religião são exilados, assim como os temas familiares. O mais importante, de acordo com o autor, é a relação do casal, a implicação entre os namorados: "O casal surge da dissolução da família, mas como fundamento do casamento". (Morin, 1962:135) Contudo, na transferência para a vida mediática das celebridades nas revistas, a família é reabilitada como signo da felicidade. Assim, as crianças parecem tão especiais quanto seus pais. Visitam as mães nos sets de filmagem. Usando como recurso um fait divers para causar efeito cômico, Cena Muda chega ao absurdo de certa vez afirmar que um bebê fez "cara de quem quer dar palpite" ${ }^{32}$. Por genética, os filhos dos olimpianos são tão especiais quanto seus pais. Estão destinados ao sucesso. Há mais de uma matéria ou poster com os irmãos estreantes dos famosos, convertidos em astros pela aproximação familiar.

\footnotetext{
${ }^{32}$ Crianças entre estrelas. Cena Muda. v. 32, n. 35, p. 7, 29/08/1952.
} 
Embora o espaço visual para tais fotografias seja menor, secundário como a presença das crianças.

Os textos que discorrem sobre a felicidade tematizam atores hollywoodianos. Pouco a pouco, Cinelândia copia o padrão para os atores brasileiros. Nos artigos, ao lado da aura do ócio, existe também uma noção de merecimento, através do trabalho e da luta anteriores, necessários para alcançar o estrelato. Grande parte dos atores tiveram uma vida de privações, enfrentadas com grande coragem. Eles merecem a felicidade porque lutaram por ela. Ao contrário deles, as atrizes entram para o cinema por acaso. Foram descobertas. Porque são especiais não precisaram procurar trabalho. Alguém teve de pedir sua grande contribuição, fato repetido na representação do estrelismo brasileiro. Já os astros admitem ter feito testes. As estrelas não imploram por emprego, fazem testes por acaso, como uma denegação do interesse descrita por Bourdieu para legitimar seu conteúdo simbólico (Bourdieu, 2001).

Porém, em oposição, quando os atores tiveram uma infância abastada, ou melhor ainda, quando possuem ascendência aristocrática, a revista os exalta: nobres que preferiram se dedicar ao cinema ${ }^{33}$. Esta característica é reflexo da imprensa como um todo, tal como analisou Muniz Sodré. A luta tendo a fama por resultado transforma-se em uma mensagem para os leitores.

O uso de fotografias e textos para convencer os leitores da felicidade dos atores não era apenas uma necessidade do star system, mas também uma das características das revistas. Muniz Sodré resumiu as características das revistas a três: sensação, sucesso e relaxamento, através da técnica do encantamento do redator. O relaxamento do leitor visa ao entretenimento, libertando os leitores de assuntos intelectuais. Assim, a "logosfera do jornalismo de luxo é sempre exageradamente otimista ou idealizada". Esse otimismo é logicamente publicitário, não só pelas demandas da propaganda, mas pela preferência das publicações em ser um bom suporte publicitário a um bom transmissor de informações, valorizando, a partir da denominação de Sodré, os ângulos “publicísticos da informação”. (Sodré, 1971: 44-52)

A construção da felicidade dos olimpianos tem um pressuposto importante: o it. As atrizes são felizes porque possuem algo a mais: talento, dinheiro, simpatia, amor conjugal, e especialmente beleza. A construção da fotogenia é de extrema importância

\footnotetext{
33 Segundo Muniz Sodré, pessoas de famílias ilustres ou com laço aristocrático são notícia certa, a qualquer pretexto. "A monarquia acabou-se há muito tempo, mas o sangue azul é um venerado coágulo social.” (Sodré, 1971: 50)
} 
para justificar o Olimpo de felicidades em que vivem. Geralmente só podem ser felizes as mulheres tão belas, como uma forma de merecimento. A fotogenia é, portanto, um dos principais ingredientes para a criação de um universo mágico e de encantamento acerca do star system, mostrado no próximo item.

\subsubsection{Fotogenia}

Tanto em Cena Muda quanto em Cinelândia, a noção indicadora da fotogenia é reduzida à beleza das atrizes, a partir do esvaziamento de seu significado. Há uma redundância na terminologia, porque um dos pressupostos para ser estrela é possuir uma beleza acima das mortais, o it. Fotogenia confunde-se, portanto, com o conceito de estrela, sendo seu principal atributo.

As imagens fotogênicas das atrizes em close up ${ }^{34}$ se encarregam de trazer o mecanismo do delayed cinema para a representação das revistas de fãs. Ou seja, a partir dessas imagens congeladas há a contemplação da face humana. Mary Ann Doane mostrou que a chave da fotogenia é o close up: "the estatic contemplation of cinema in its uniqueness, (...)." (Doane apud Mulvey, 2006: 164) Na verdade, a fotogenia envolve uma fusão entre estética e fetichismo. A raiz destes filmes, tal como explicada por Laura Mulvey, traz a fotogenia voltada à contemplação. O motivador do processo é possibilitar prazer visual, uma vez que a atriz é apreendida como um ícone sexual. A erotização da estrela a partir de critérios fotogênicos será mostrada apenas mais à frente.

Nas revistas de fãs, a fotogenia, tal como pensada pelas vanguardas européias que viam nela uma forma do específico cinematográfico, é reduzida à beleza, luxo e juventude, como foi apontado por Ismail Xavier. Contudo, esta simplificação não foi único nas duas revistas pesquisadas. Já estava presente em Cinearte. (Xavier, 1978)

A noção da fotogenia nasce ainda com os primeiros estudiosos de cinema. Ismail Xavier mostra como os teóricos tentaram provar a capacidade da imagem

\footnotetext{
${ }^{34} \mathrm{O}$ close up traz o desejo do leitor de parar o filme, porque ele quer apenas trazer o momento sincrônico, rejeitando a estrutura narrativa diacrônica. O close up tratado como êxtase para Mary Ann Doane é uma resistência à linearidade da narrativa. Traz a contemplação da estrela. Já Alexander Walker (1970) frisa a importância do close up para o estabelecimento do estrelismo. O close up é uma quebra na representação tradicional do palco, um jeito poderoso de estabelecer a unicidade do ator. É responsável por suscitar uma interpretação psicológica por parte do público e transmitir a emoção dos atores. De acordo com Richard Dyer (1998), Bela Belazs considerava o close up parte fundamental do film medium, porque este revela a vida e personalidade do indivíduo através da face humana. Dyer aponta que o close up não é apenas um conceito transparente, mas social e cultural, relembrando as experiências com a face de Kuleschov.
} 
cinematográfica dizer algo além da evidência denotativa. O objetivo era defender o cinema como arte e provar sua autonomia, a partir da originalidade do novo código cinematográfico. Teóricos franceses como Canudo, Delluc e Moussinac prenderam-se ao conceito da fotogenia para provar o específico do cinema na revelação das imagens. Abria-se um novo problema, a partir do questionamento se a fotogenia estava na própria coisa ou era produzida através da projeção da imagem. Os elementos fundamentais não estariam no objeto filmado, mas nas operações de filmagem. Canudo, por exemplo, defendia a fotogenia não como uma propriedade naturalmente visível das coisas. Não é o rosto que é fotogênico, mas a partir do tratamento da luz, a fotogenia se acrescenta à imagem ${ }^{35}$. Ricciotto Canudo, Louis Delluc e Léon Moussinac lutaram contra o deslumbramento de uma fotogenia, onde o importante é "ficar bonito". Temia-se também o domínio da vedete no cinema porque o principal não era a aparência do ator, mas o modo de iluminá-lo e enquadrá-lo.

E o temor se concretizou, trazendo não só o domínio da vedete, mas da confusão entre beleza e fotogenia. A contaminação da fotogenia pela beleza da estrela nasce porque a fotogenia é uma qualidade de "sombra, reflexo e duplo", analisada já por Edgar Morin ${ }^{36}$. A fotogenia da personagem na tela vaza para a da atriz, permitindo que as potências afetivas da imagem mental se fixem na imagem da reprodução fotográfica. O processo se conclui porque há uma transferência das qualidades da imagem mental para a imagem fotografada. (Morin, 1956: 38)

Assim, a fotogenia embute-se no processo de transferência via duplo. A carga afetiva da personagem do filme se transfere para a reprodução fotográfica da imagem, apreendida como a vida "real" da estrela, trazendo consigo não só o duplo, mas como os processos de transferência e de projeção, úteis às estratégias de aproximação com o leitor.

A fotogenia traz um universo projetivo propício à concretização do sonho de ser bela como a estrela. Por isso, ela continua a ser divulgada à exaustão em ambas as revistas, mas como atributo relevante. A possibilidade da felicidade passa principalmente pela necessidade de ser fotogênica e/ou bela. A beleza acima dos mortais, o it, leva o indivíduo a conseguir alcançar a felicidade. Assim, a fotogenia é um dos atributos mais importantes e invejáveis a se ter. A beleza e a felicidade se imbuem de tal maneira, dificultando afiançar ao leitor se ela é feliz porque, além de todas as

\footnotetext{
${ }^{35}$ Para ver maiores detalhes, ler: Xavier (1978).

${ }^{36}$ Para maiores detalhes, consultar Edgar (1956).
} 
qualidades, é bonita; ou se por ser bela, é feliz. Bondade e talento são importantes para as revistas, mas a beleza é o primeiro pressuposto para alcançar o estrelato.

Contudo, para as intérpretes não belas, nem jovens, ressuscita-se como critério o talento. Porém, nestes casos, as fotos e o espaço textual diminuem bastante, caso de Bette Davis e Katharine Hepburn, consideradas feias. Quase a totalidade das capas é para jovens belas. Embora a feiúra possa também ser um ingrediente para a reportagem, como foi o caso da matéria William Bendick, ator por casualidade ${ }^{37}$. O título mostra como só a causalidade pode explicar o sucesso sem o ingrediente da fotogenia. Ele se tornou ator por acaso, porque é feio. A feiúra, neste caso, reforça o sistema do star system. Quando o leitor se depara com a foto de Bendick, confirma como a beleza é um atributo importante para os ídolos.

A fotogenia das brasileiras tem outra função primordial nas revistas de fãs: fazer "progredir" o cinema nacional. A beleza das atrizes nacionais deve estar no mesmo padrão que as estrangeiras. Tão importante como ter bons técnicos, o cinema brasileiro precisa de estrelas à altura de Hollywood. Remetendo, na verdade, ao conceito da importância da fotogenia e da publicidade para o sucesso dos filmes já presente na revista Cinearte nos anos vinte, como atestam os trabalhos de Paulo Emilio Salles Gomes (1974) e Ismail Xavier (1978). A fotogenia, assim como Ismail Xavier demonstrou, presume a necessidade de um modelo aristocrático de perfeição racial e estética, elogiando-se a produção de Hollywood. Ainda em 1925, Adhemar Gonzaga acreditava em sua utilização para a criação de estrelas brasileiras. Para Pedro Lima, a beleza seria a base do cinema. Paulo Emilio Salles Gomes explica que a fotogenia se ligava à publicidade, cuja base era o estrelismo. Cinearte procurava publicar fotos para inspirar cartas dos leitores.

Cena Muda explicitou certa vez a necessidade da fotogenia para alcançar o sucesso do filme brasileiro. Segundo o Juiz Bonzê, deve-se aproveitar a beleza física congregada ao valor artístico. Sobre a heroína do filme brasileiro Destino (1952), de Samuel Murkenson, vaticina a publicação que ela não deveria ter sido escolhida para o papel devido a sua feiúra:

"Nem todas as atrizes feias, angulosas e até antipáticas podem competir com Katherine Hepburn. Esta é feia de doer nos gorgomilos de uma tartaruga; mas compensa a feiúra com o talento artístico. Por ora, meus senhores, vamos fazer o que os americanos fizeram no começo de Hollywood: aproveitemos a beleza física adaptada ao valor artístico, ou este aquela. Somente

\footnotetext{
${ }^{37}$ Araújo, Lionel. William Bendick, ator por casualidade. Cena Muda, v. 32, n. 24, p. 08, 12/06/1952.
} 
depois de estarmos donos do assunto, com uma indústria firme e próspera daremos chance às feias geniais. E atualmente todas as nossas feias são medíocres. Nota dois bolos." 38

Continuamente nas matérias sobre as atrizes brasileiras tenta-se provar quanto são belas, criando-se uma idéia de paridade quanto à beleza entre artistas nacionais e norte-americanas, num Olimpo comum. Algumas vezes Cena tenta afirmar a superioridade das estrelas brasileiras, tal a beleza.

Não discutiremos a configuração imagética da fotogenia nas revistas de fãs, dado que a mesma é pensada nestes veículos como o principal atributo do glamour, tema do próximo tópico.

\subsubsection{Glamour}

O glamour num sentido popular tem uma conotação de sofisticação, elegância, charme, luxo. A palavra nasceu ainda por volta de 1800, designando originalmente o encantamento e aspecto mágico, usado primeiramente pelos escoceses. Até nas definições do dicionário, os exemplos para definir o termo remetem às estrelas de Hollywood. O sentido exato da palavra contém diversas nuances, tendo em comum a sofisticação e, principalmente a atração exercida por esta pessoa ou objeto. Trata-se de uma qualidade especial a causar fascinação, deslumbramento, encantamento porque se transmite status, saúde, sucesso, prestígio, ou beleza física. Todos esses atributos conjugados transformam esse sujeito de atração em alguém especial. Ou seja, o conceito se confunde com todas as qualidades criadas para a estrela de cinema, calcada nos atributos da fotogenia. A estrela é especial, bela e tem sucesso. Afirmar que uma estrela é glamourosa no fundo é um pleonasmo, porque ela tem de ser o glamour em pessoa; sua personificação.

Em primeiro lugar, glamour designa num sentido popular a sofisticação, mas o conceito se amplia nas duas revistas estudadas porque há uma transição entre o artificial e o natural nas fotografias. As fotos parecem situadas num momento de transição entre a sofisticação e a simplicidade. A simplicidade aliada à naturalidade é considerada mais um atributo da estrela: as belas por natureza não precisam de truques ou maquiagem, embora não seja o que acontece na maior parte das imagens. Nas imagens, as atrizes

\footnotetext{
${ }^{38}$ Juiz Bonzê. Tribuna da crítica. Cena Muda, v. 32, n. 28, p. 5, 11/7/1952.
} 
vestem shorts ou maiôs, mas em saltos altíssimos. Batom e unhas costumam ser em vermelho. Nenhum fio de cabelo deve estar desalinhado.

Com o glamour se mistura com o conceito de estrela, a cada página virada, as duas publicações definem a exaustão todas as atrizes como as mais glamourosas de Hollywood ou do Brasil. Ter glamour é uma exigência editorial. O conceito não está atrelado apenas a casacos de vison, altos saltos e brilhantes. Ainda há muitas fotos das estrelas revestidas em peles, mas no geral esse tipo de imagem cede lugar a um novo patamar de representação do belo, mais atrelado ao conceito de sensualidade, com as pernas cada vez mais a mostra, em maiôs. Assim o glamour se mistura cada vez mais com o conceito de atração física da estrela e sua capacidade de produzir sex appeal.

Lana Turner geralmente aparece envolta em peles, jóias (geralmente brilhantes), com os cabelos loiros perfeitamente penteados. Já as fotografias das atrizes de maiôs ou com roupas simples mostram ao leitor de maneira mais incisiva o it da estrela, porque quando se fotografa uma mulher simplesmente vestida, sem luxo, e mesmo assim ela parece especial, o fato serve com prova para a revista de todo seu glamour. Nestes casos, é possível ver a atriz como um modelo de beleza a ser imitado, porque não há excesso de luxo. Um exemplo disso é uma matéria de Cena Muda, feita pelo estúdio para provar a beleza de Marilyn Monroe. A atriz veste um saco de batatas ${ }^{39}$. O texto busca causar espanto, como um fait divers de efeito de decepção porque logicamente a atriz não usa um saco de batatas largo, apenas o tecido do saco de batata, transformado num vestido justo, permitindo ver seu corpo, sem nenhuma deficiência quanto ao efeito de beleza reproduzido. Isso porque o glamour não tem a ver necessariamente com as roupas chiques, mas com a dimensão da beleza e do $i t$.

As imagens das estrelas desprovidas do excesso de luxo tornam o glamour um conceito cada vez mais ambíguo no entendimento de seu significado. Geralmente as atrizes glamourosas ainda são modestas, negando o atributo que as distingue. Contudo nas fotografias fica evidente a atração física, beleza e a sofisticação, provando o contrário ao leitor. A ambigüidade torna-se necessária para que a leitora reflita sobre o conceito, comparando imagem e texto. Há dois tipos de estrelas quanto à admissão do glamour. As primeiras negam tê-lo. Afirmam apenas sua natureza mortal cheia de afazeres. Ava Gardner ${ }^{40}$ nega ter glamour porque trabalha 13 horas, além de ter

\footnotetext{
${ }^{39}$ A vida é melhor assim. Cena Muda, v. 34, n. 16, p. 15, 17/04/1954.

${ }^{40}$ O fascínio de Hollywood - o glamour por Ava Gardner. Cena Muda, v. 32, n. 22, p. 4-5; 30, 29/05/1952.
} 
obrigações domésticas. As segundas tomam para si o papel de conselheiras das leitoras para o aprimoramento de seus dotes. Convertem o significado do glamour para outras bases. Zsa Zsa Garbo ${ }^{41}$ adquire esta posição: dá conselhos de como os homens devem se vestir. Em nível discursivo se configura um total disparate entre as declarações e a representação das roupas nas fotografias. Como regra geral, as atrizes desmentem o fato de serem belas, glamourosas ou com sex appeal, quando as imagens mostram o contrário. É necessária esta contradição para evitar a arrogância. Para Zsa Zsa, glamour é sinônimo de simplicidade e o dom de saber combinar as cores, na verdade, usar somente uma cor. Assim, ela desmonta o sentido primeiro do glamour porque simplicidade não é glamour, embora o glamour exista na simplicidade. Através da negação, ela se fortalece como glamourosa porque os leitores poderão observar seus diversos atributos físicos. Então, ocorre o inimaginável. Entre as profissões enumeradas por Zsa Zsa como modelos do padrão cromático do bem vestir, ela cita os frentistas, carteiros e leiteiros. Mistura antônimos: glamour e simplicidade, autenticando exatamente os uniformes dos empregos com menor remuneração. $\mathrm{O}$ leitor podia seguir seus conselhos e comprar a quantidade e a cor de ternos recomendados pela atriz. A matéria fazia parte da divulgação do seu próximo filme. Está implícito que o leitor não pode seguir o mesmo modelo de luxo das estrelas, então quando a diva dá conselhos de glamour, deve rebaixar seus conceitos, invertendo as bases do luxo de Hollywood para realizar um tipo de "inclusão social".

Por outro lado, quando uma estrela afirma não ter glamour, pode atingir a curiosidade do leitor, que talvez fique tentando concluir a existência ou não do atributo. Grace Kelly declara não ter sex appeal ${ }^{42}$. Este surge como um atributo a completar o glamour, porque é mais uma característica da atração física produzida no leitor. A fotogenia está estritamente ligada a ele. Segundo Grace Kelly, em Hollywood misturase a atração com a sensualidade. A ambigüidade da sua declaração aparece nas duas fotografias sobre ela, publicadas em Cinelândia.

\footnotetext{
${ }^{41}$ Zsa Zsa Garbo e seu parecer sobre os trajes masculinos. Cena Muda, v. 32, n. 50, p. 11, 12/12/1952.

${ }^{42}$ Eu não tenho sex appeal. Cinelândia, v. 4, n. 57, p. 29-30; 65, 2a quinz. março 1955.
} 

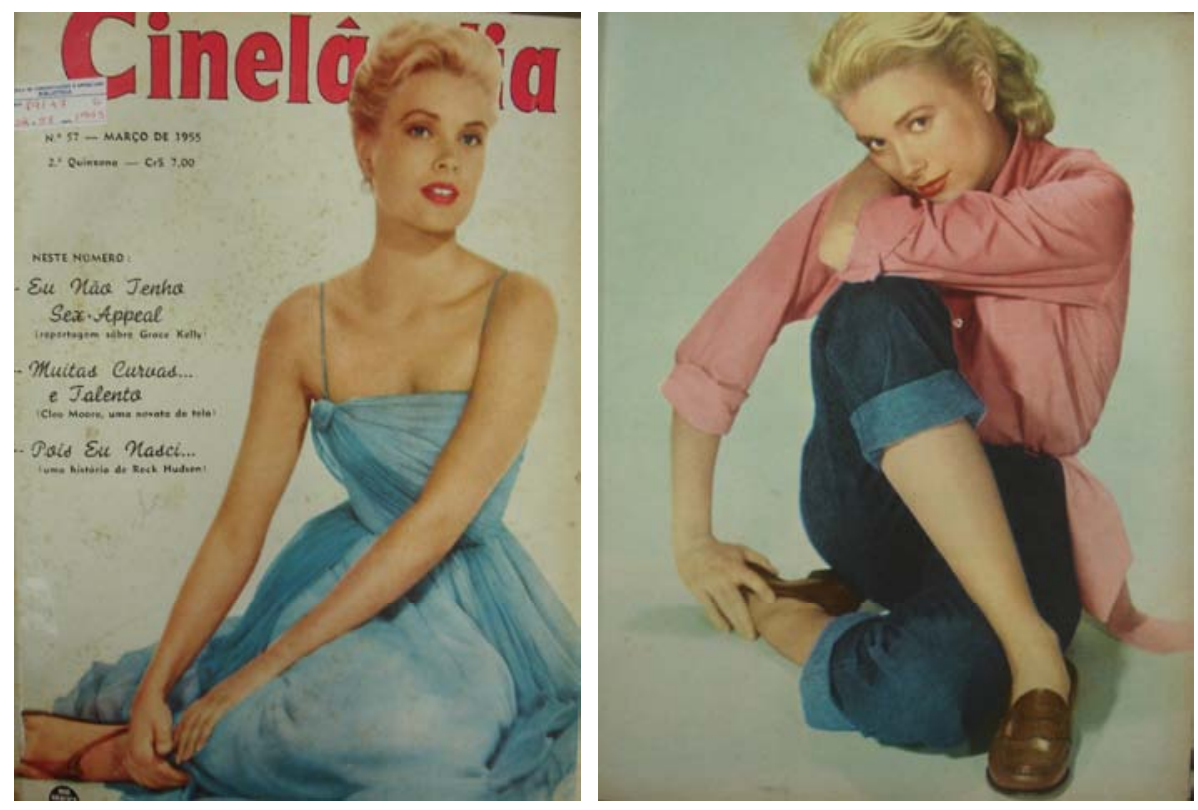

Imagem 20 a 21 - Grace Kelly ${ }^{43}$

A fotografia da matéria traz a atriz vestida de jeans e camisa, sob pesados sapatos tipo mocassim, um tipo de calçado inexistente para mulheres na representação da revista. Na capa, Kelly aparece glamourizada no vestido, embora utilize sandálias, tendo ar menos artificial, o que não era comum. A escolha de Grace Kelly para discutir a dualidade glamour $\mathrm{x}$ simplicidade não foi à toa. Tinha relação evidente com a personagem interpretada na fita de lançamento. O filme era Janela indiscreta (1954), de Alfred Hitchcock, tratando também desta dualidade na protagonista. Na história, Grace Kelly é uma milionária sofisticada. Aparece com um vestido diferente a cada cena. $\mathrm{O}$ excesso de sofisticação é criticado por seu par romântico, James Stewart, porque o estilo de vida dos dois é muito diferente. Ele interpreta um fotógrafo com remuneração moderada para os padrões da namorada, desprovido de ambições financeiras. Na cena final, para parecer concretizar os desejos do amado, ela supostamente se transforma. Usa a calça jeans, camisa rosa com o mocassim desta matéria. $\mathrm{O}$ artigo aproveita as imagens da atriz, extremamente sofisticada, para afirmar o oposto: ela não acredita ser detentora de sex appeal. Dessa forma, cria-se uma ambivalência entre personagem e estrela. Ambas não admitem a sofisticação, mas a possuem. Contudo, a negação do glamour é tratada como característica apenas da atriz, quando há uma transferência

\footnotetext{
${ }^{43}$ Eu não tenho sex appeal. Cinelândia, v. 4, n. 57, p. 29-30; 65, 2ª quinz. março 1955.
} 
porque a discussão nasce do filme ${ }^{44}$. Como a protagonista é glamourosa, mas nega este atributo na cena final, há a possibilidade de o leitor acreditar na semelhança com a artista. Ou seja, Grace tem glamour, o que é evidente nas fotos, mas o nega, assim como sua personagem. Certamente o filme estava em cartaz ou estaria para entrar, porque a data do artigo é próxima a do ano de produção. A ambigüidade se faz presente quando se declara que uma atriz glamourosa não acredita ter sex appeal, misturando fotogenia, sofisticação e sensualidade.

A estrela se fortalece nesta ambigüidade. Soaria esnobe admitir o próprio glamour, porque a autopromoção ocasiona uma perda de credibilidade ${ }^{45}$. O glamour deve se mostrar como algo normal. O intuito é indicar nas fotos algo que resplandece de dentro da atriz: o glamour, a fotogenia e a estirpe. Ter estirpe para usar aquelas roupas demonstra que o glamour não é construído, deve ser nato. Em síntese, é uma qualidade inerente à atriz. A estrela resplandece glamour, não precisa reafirmar tê-lo; a fotografia existe para isso. O objetivo não é somente a publicidade, mas também criar a estrela como parâmetro comportamental. Não é possível dizer que o glamour é esvaziado de conteúdo no texto, porque ele se mostra nas fotografias. No texto, há apenas a afirmação do glamour por meio de diversos adjetivos.

No caso do cinema pátrio, a diferença do glamour entre a estrela nacional e estrangeira aparece centrada nas imagens. O glamour nas fotos sobre as brasileiras tem qualidade inferior ao das norte-americanas, pela dificuldade em produzir tais matérias de conselho, e principalmente na composição imagética. Busca-se instigar os leitores a ver modelos do bem vestir no elenco brasileiro. Assim, o vestuário serve de modelo e sugestão às leitoras. Nos anos vinte, Cena além de apresentar os modelitos das atrizes, fornecia a metragem necessária para copiar o figurino com sugestões de adaptações. Já na década de cinqüenta, na matéria Edith Morel apresenta: elegância no cinema nacional $^{46}$, o jornalista anônimo declara de que já se foi a época das estrelas brasileiras serem figuras apagadas nos filmes. "Agora o cinema nacional traz estrelas que podem

\footnotetext{
${ }^{44}$ Além desta publicidade indireta, a matéria trata do suposto esnobismo da atriz, bastante comentado na imprensa do período. A discussão é pertinente porque as características da intérprete vazam para a personalidade da personagem, uma moça rica, e por isso vista como esnobe.

${ }^{45}$ Pierre Bourdieu esclarece que há um gasto muito alto de energia quando o próprio falante tenta provar suas qualidades. $\mathrm{O}$ reconhecimento da legitimidade é mais completo quanto mais longo for o ciclo da consagração. A autocelebração produz um rendimento da consagração muito fraco para um dispêndio de energia social igualmente fraco. "A legitimação só pode ser operada por procuração." O primeiro interessado é o menos indicado para levar o interesse que ele próprio tem por sua celebração. Este é por sinal o limite da eficácia da publicidade. O rendimento simbólico é maior, quanto menos aparente é a relação entre os parceiros. (Bourdieu, 2001: 170)

${ }^{46}$ Cena Muda. v. 33, n. 36, p. 9, 02/09/1953.
} 
ocupar páginas e páginas de revistas. As atrizes do cinema brasileiro lançam moda!" Os vestidos da estreante argentina Edith no filme A Dupla do barulho (1953), de Carlos Manga, são "dignos de registro" para a publicação: "Reparem no bom gosto e na saia que ela mesma ajudou a desenhar". A estrela é tão especial que até ajudou a desenhar o vestido. Provavelmente os trajes serão "copiados pelas leitoras, sempre desejosas de seguir a moda das "estrelas"”, antevê o autor do artigo para sugerir a cópia dos modelos. Apesar de garantir a possibilidade de o figurino ocupar diversas páginas das revistas, isto não é feito em Cena. Vale só como discurso.

Edith Morel revelou anos mais tarde que os atores tinham de comprar as roupas ou emprestá-las com alguém porque a Atlântida pagava muito mal. Segundo seu depoimento, a companhia utilizava roupas de papel crepom porque não havia dinheiro para criar figurinos. A entrevista de Adelaide Chiozzo ao MIS relatou a mesma situação descrita por Edith Morel. Chiozzo confirmou as improvisações durante as filmagens de Aviso aos navegantes (1950), de Watson Macedo, por razões econômicas. "No vestuário dos atores, por exemplo. Por mais de uma vez, as atrizes da Atlântida entraram em cena vestindo roupas de papel crepom, praticamente costuradas no corpo." Segundo Sérgio Augusto, Lewgoy sofreu mais com a pobreza orçamentária do figurino da Atlântida. Se não fosse um traje a rigor emprestado por Bené Nunes, ele não teria conseguido trabalho no filme Aí vem o barão (1951), de Watson Macedo. (Augusto, 1989: 118)

Estes depoimentos destoam da construção de Cena sobre o luxo das vestimentas das estrelas, supostamente bancadas pela Atlântida. Contradizem também a tentativa de converter as atrizes brasileiras em criaturas dotadas de glamour, como as estrangeiras. No geral, as fotos para demonstrar glamour são focadas sobre o rosto das estrelas em primeiro plano, ou em plano geral, para mostrar o corpo. Neste formato não há grandes alterações quanto ao glamour norte-americano. A contradição aparece mais quando as revistas procuravam reafirmar o glamour das brasileiras nas imagens e nos artigos, ao mesmo tempo em que apontavam a árida situação do cinema brasileiro.

O star system brasileiro tinha características peculiares na composição imagética. Tentava imitar o padrão das fotos dos estúdios americanos, mas na maior parte das vezes a empreitada falhava nos detalhes pela dificuldade financeira e de ambientação das ilustrações. As fotos das atrizes brasileiras aparecem com alguma freqüência ao lado de plantas, como se as revistas buscassem enfeitar ou tornar mais atraente as imagens, mostrando quanto o star system brasileiro não lidava tão bem com o glamour importado dos Estados Unidos. A estrela é única e deve cintilar sozinha nas 
fotografias. Não se deve desviar a atenção sobre ela para mostrar uma planta. Substituir um casaco de vison com brilhantes por uma planta não era, portanto, uma estratégia das mais eficientes para o público das revistas de fãs.
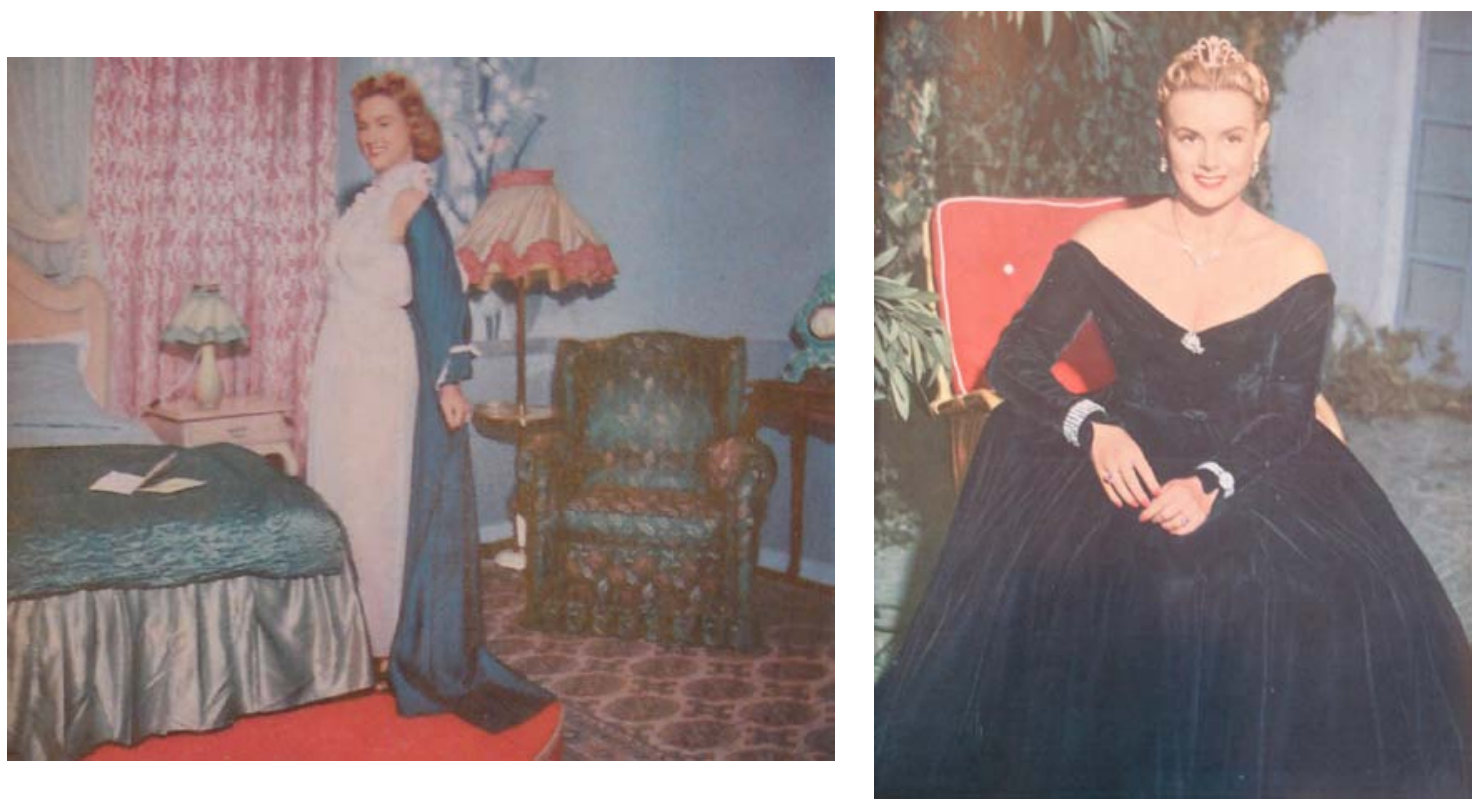

Imagem 22 a 24 - Eliana Macedo acima ${ }^{47}$ e Terry Moore ${ }^{48}$ abaixo.

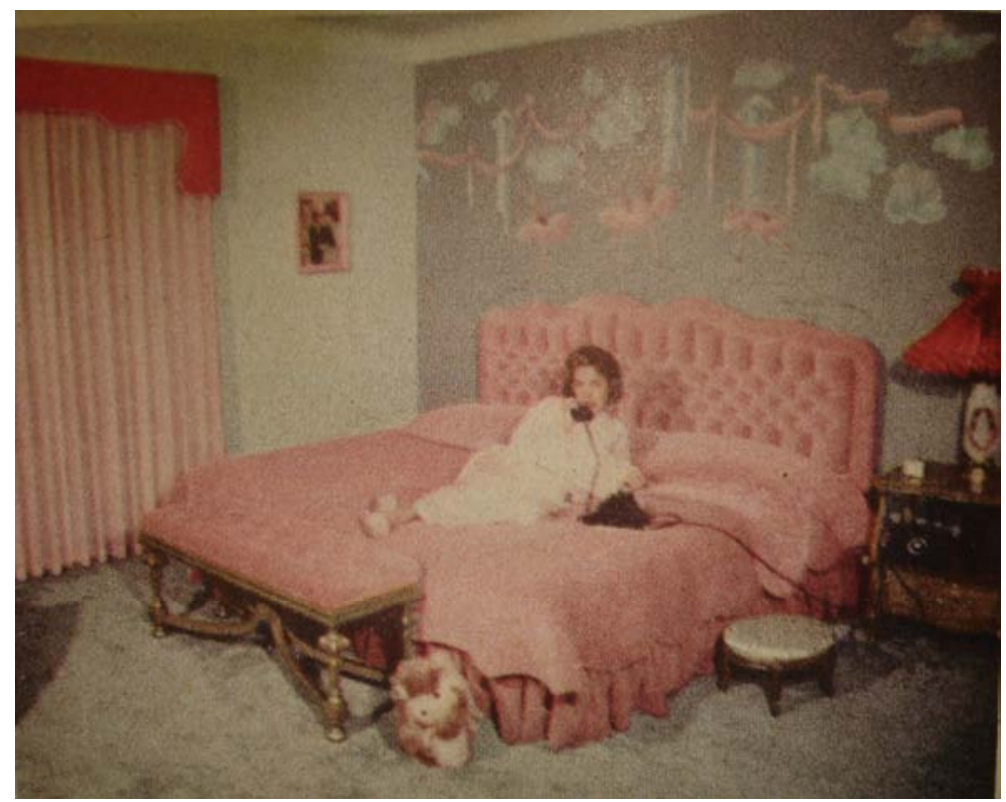

O título da reportagem sobre Eliana Macedo realmente é verdadeiro, Glamour só na tela ${ }^{49}$, porque as fotografias fogem ao conceito de glamour propagado por

${ }^{47}$ Glamour só na tela. Cinelândia, v. 3, n. 41, p. 30-1; 64, 2ª quinz. julho 1954.

${ }^{48}$ Terry Moore: pode uma glamour girl viver feliz em casa dos pais? Cinelândia, v. 3, n. 44, p. 38-9; 66, $1^{a}$ quinz. set. 1954. 
Cinelândia. O repórter queria induzir o leitor a perceber a sofisticação de Eliana pelas imagens dela em sua casa, apesar de afirmar textualmente a negação do glamour da atriz. O modelo seguido eram as matérias sobre as atrizes hollywoodianas. Estas negavam em nível discursivo o glamour da artista americana para enfatizá-lo nas imagens. Contudo, aqui há uma contradição entre o textual e o imagético, porque este último não consegue dar conta de provar a sofisticação. Nas três fotografias da casa de Eliana se tenta confirmar o glamour da artista, não apenas o de suas personagens. Assim, Eliana senta-se como princesa, num vestido de galã, com brilhantes em excesso, cabelo perfeitamente alinhado, adornado até com uma tiara real. A pose é de rainha, ereta e sorridente, mas dizendo não gostar de aparecer. A denegação da simplicidade fica muito frágil ao leitor. Porém, a fotografia tem um erro crucial: é o décor. Eliana não está sentada em seu trono real, num cenário de palácio, mas numa poltrona simples, em um jardim de sua residência. Ao fundo vemos plantas. É a típica moça bonita com seu melhor vestido, mas em casa. Na outra foto, há a mesma contradição. Eliana em seu pegnoir pronta para dormir, mas o quarto não é o aposento de sonho dos filmes de Hollywood. As cores não têm a harmonia ${ }^{50}$ exigidas em 1950 , o pegnoir não é glamouroso, assim como a poltrona, a cama, colcha e cortinas. Há no geral um tom fake. Para aquele ambiente, a atriz está arrumada demais para ir dormir, arrumada demais para ficar em casa porque as atrizes estrangeiras cada vez mais apareciam com roupas menos sociais em casa. Pode ser bem representada a classe média ou alta do Brasil no quarto, mas não se consegue compor com esse tipo de imagem a imitação da perfeição de sofisticação do quarto de Terry Moore, todo em rosa, com a estrelinha falando ao telefone. Tenta-se imitar o padrão do american way of life de Hollywood, não só nos cenários dos filmes, mas na representação da vida das estrelas. Contudo a conseqüência é a construção de um ideal de vida ausente para o caso brasileiro, como se vê nestas imagens. A foto é representativa das contradições da realidade brasileira, e da configuração do glamour nacional. Busca-se mostrar um modelo inatingível de beleza e sofisticação, mas não se consegue comprovar nas fotos. Que adianta aprimorar o penteado da estrela, se a casa não é uma mansão de Hollywood? Teria sido melhor ocultar tais detalhes, mostrando apenas a atriz. Vale lembrar que as fotografias das

\footnotetext{
${ }^{49}$ Glamour só na tela. Cinelândia, v. 3, n. 41, p. 30-1; 64, 2a quinz. julho 1954.

${ }^{50}$ Apesar de a moda em 1950 considerar positiva a harmonia entre as cores para as roupas, em muitas das casas dos atores de Hollywood há um entrelaçamento de tons diferentes e muito fortes.
} 
estrelas brasileiras em casa, presentes apenas em Cinelândia, não apareciam com freqüência, embora a partir de 1954, elas melhorem muito em qualidade.

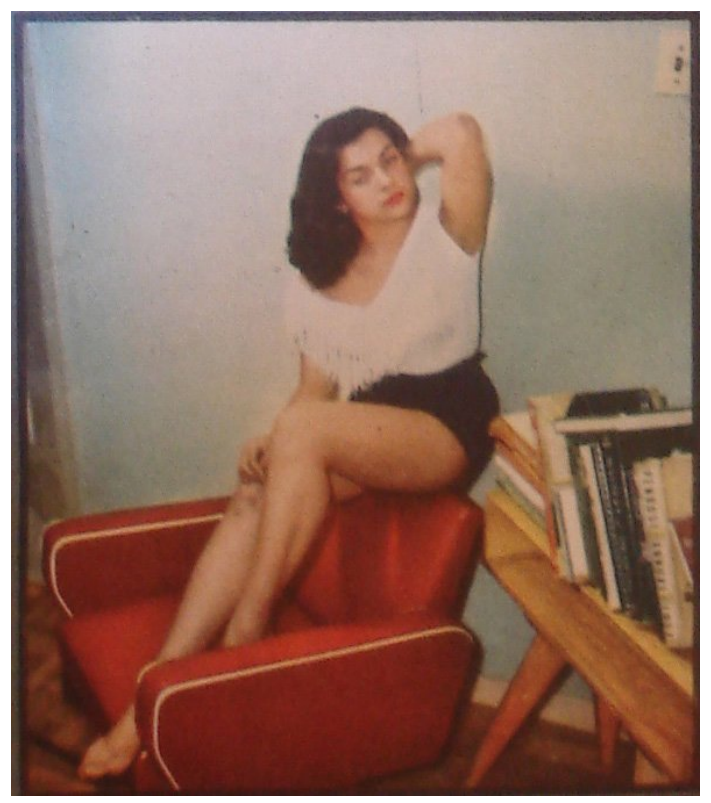

Imagem 25 - Miss Cinelândia Inalda de Carvalho ${ }^{51}$

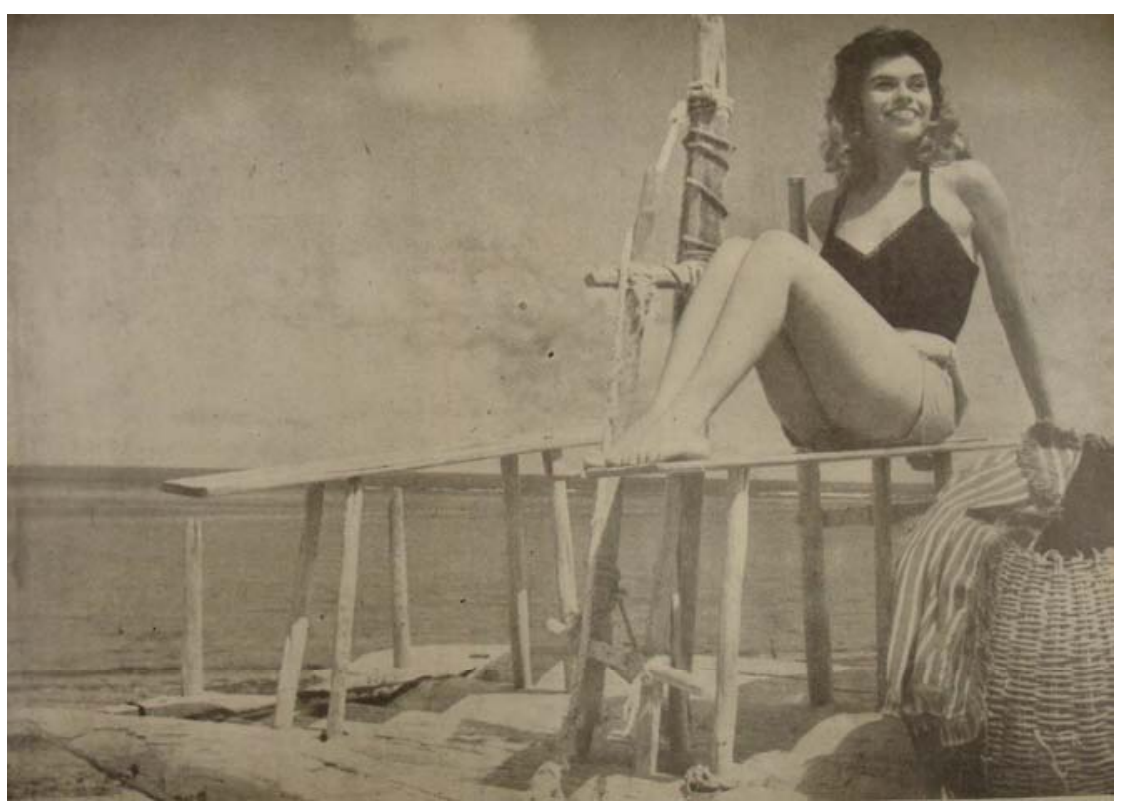

Imagem 26 - Cacilda Lanuzza ${ }^{52}$

Grande parte das estrelas brasileiras aparecem nas fotografias sentadas em cadeiras, geralmente vestidas com shorts. Imitam as atrizes de Hollywood. Contudo, o efeito nunca sai em paridade com o modelo estrangeiro. Até o apelo de mostrar o corpo em detalhes diminui porque as fotos acima mencionadas do cinema brasileiro são

\footnotetext{
${ }^{51}$ Poster Miss Cinelândia. Cinelândia, v. 3, n. 31, p. 34-5, 2a quinz. fev. 1954.

52 Cinema Nacional. Cena Muda, v. 33, n. 18, p. 7, 29/04/1953.
} 
exemplos desta dificuldade em trabalhar toda a dimensão do décor. Inalda de Carvalho, Miss Cinelândia, sai pouco atraente nesta fotografia, embora na mesma página houvesse imagens de melhor qualidade. Há o mesmo erro da ilustração da casa de Eliana. Vemos um sofá simples, uma roupa pouco atraente e uma pilha de livros sem contexto com o tema do estrelismo.

Já a fotografia da atriz Cacilda Lanuzza, em Cena Muda, é menos eficiente na transmissão do glamour. O ambiente lembra um canteiro de obras. Talvez o objetivo fosse relacionar a imagem com o tema do filme $O$ Canto do Mar (1953), de Alberto Cavalcanti, retratando a pobreza dos habitantes do Recife. O erro é, numa revista de geração de estrelismo, trazer fotos desglamourizadas destas mesmas atrizes.
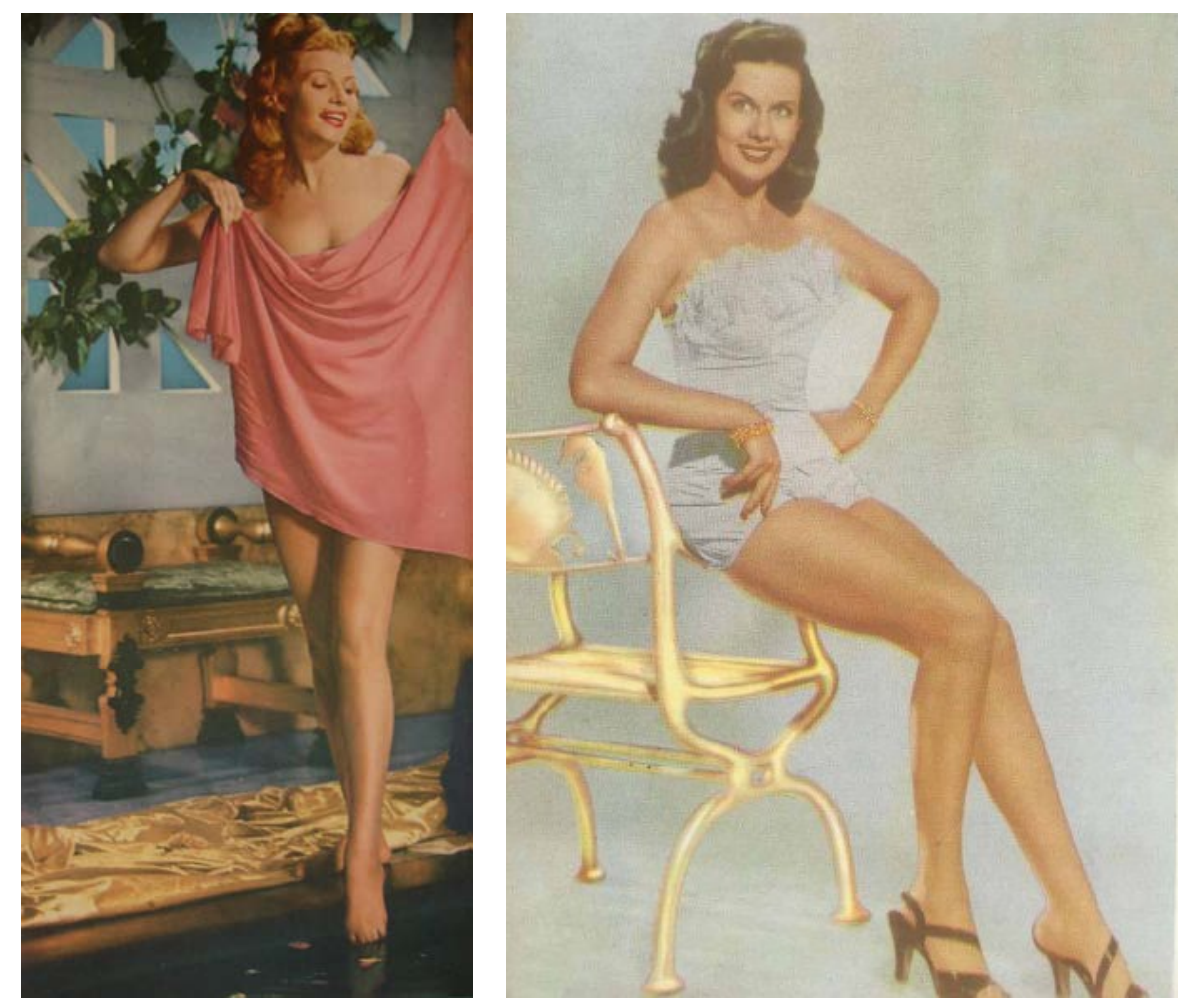

Imagem 27 a 28 - Rita Hayworth ${ }^{53}$ e Ellen Westcott ${ }^{54}$

Há inúmeros exemplos de fotos das estrelas brasileiras em cadeiras e sofás, mas nunca se conseguiu a qualidade de uma imagem, de dimensões reduzidas por sinal, como a da atriz Ellen Westcott. A roupa se ajusta perfeitamente ao corpo, o sorriso parece perfeito, assim como o brilho sobre as pernas e a cadeira dourada ao fundo. Tudo

\footnotetext{
${ }^{53}$ Uma estrela no céu de Allah. Cinelândia, v. 3, n. 37, p. 39; 60, 2ª quinz. maio 1954.

${ }^{54}$ A porção superior desta fotografia estava sobreposta à outra imagem, por isso selecionamos apenas esta que nos interessava, cortando parte da outra imagem sobreposta, e preenchendo com o mesmo fundo o espaço vazio. As boas também descansam. Cena Muda, v. 35, n. 4, p. 24, $2^{\text {a }}$ quinz. fev. 1955.
} 
é glamour na imagem. Há uma aura resplandecente no retrato. Do mesmo modo, a imagem de Rita Hayworth sob um véu, insinuando nudez sem nada revelar, com o detalhe dos pés sob a água não tem nenhum elemento externo ao glamour. O ambiente criado está em sintonia com a manchete da matéria Uma estrela sob o céu de Allah porque aproveita o tema oriental relacionado ao ex-marido da atriz, o príncipe Alli Khan.

Além da dificuldade de alcançar um equilíbrio no décor das fotografias, Cinelândia envereda por uma representação das atrizes brasileiras, junto a animais exóticos, quando esta representação inexistia entre as estrelas norte-americanas. Nem com animais de estimação, as artistas de Hollywood apareciam.
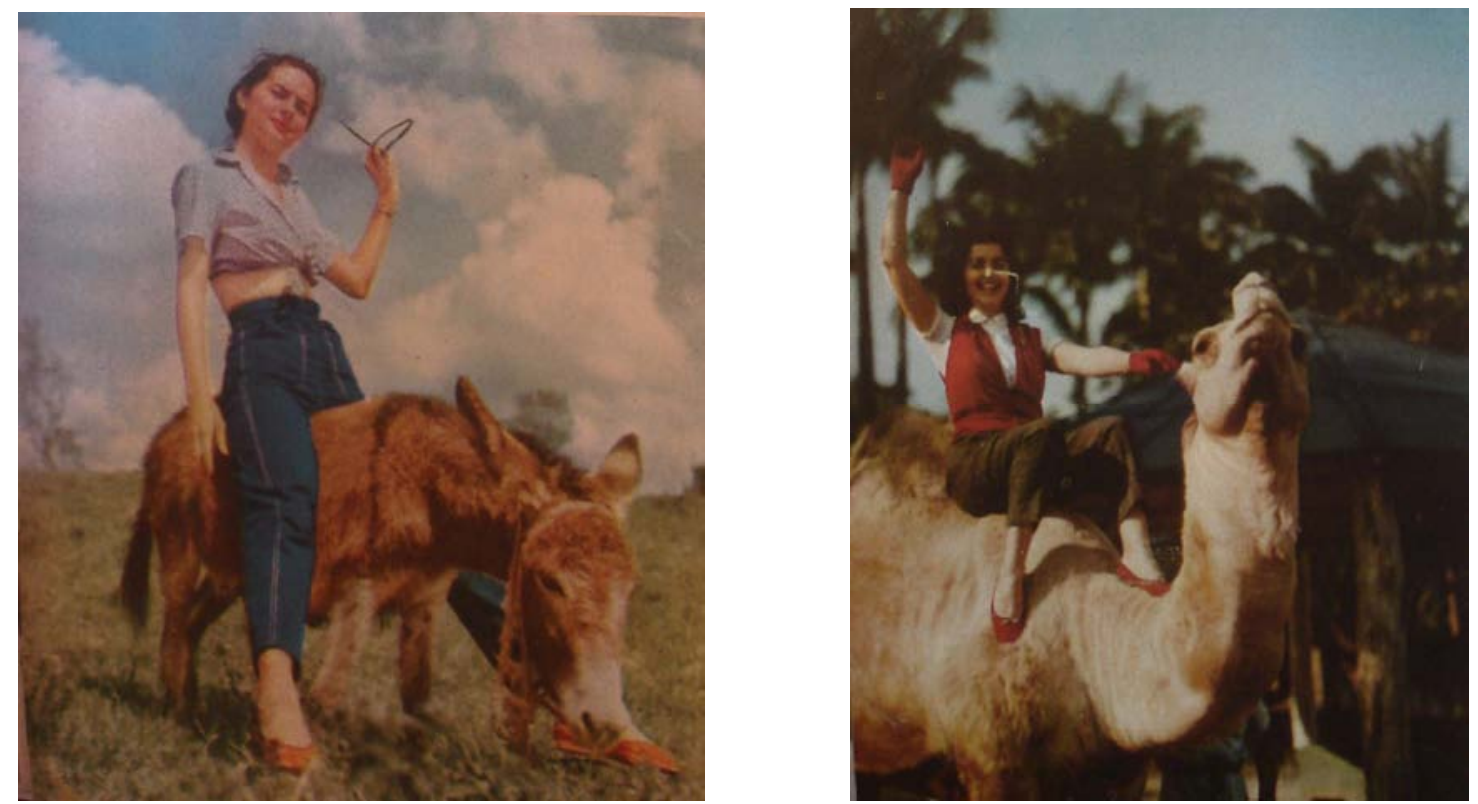

Imagem 29 a 30 - Marisa Prado ${ }^{55}$ e Fada Santoro ${ }^{56}$

As duas imagens acima, principalmente a de Marisa Prado montada numa mula contraria as regras do star system de Hollywood no período. Uma estrela deve ter glamour, deve ser mostrada num ambiente luxuoso, ou pelo menos considerado atraente ao espectador. Não deve aparecer exatamente montada numa mula, ou num camelo. No caso de Marisa Prado, há uma relação um tanto indireta com a personagem interpretada por ela em Candinho (1953), de Abílio Pereira de Almeida. Apesar de Filoca viver na fazenda de seus pais, a relação afetuosa com o animal é do personagem Candinho,

\footnotetext{
${ }^{55}$ Andrea, Zenaide. A caipirinha que virou estrela. Cinelândia, v. 3, n. 30, p. 34-5; 64, $1^{\text {a }}$ quinz. fev. 1954.

${ }^{56}$ Andrea, Zenaide. A fada entre as feras. Cinelândia, v. 3, n. 50, p. 30-1; 80, $1^{\text {a }}$ quinz. dez. 1954.
} 
interpretado por Mazzaroppi. Expulso da fazenda, Candinho vai embora montado no burrinho Policarpo. Assim, há um entrelaçamento indireto entre a vida da atriz, a da personagem Filoca e do protagonista Candinho. Maria Rita Galvão (1976) conta que Marisa Prado era chamada de a Cinderela da companhia. De datilógrafa da empresa virou estrela. Porém, em Cinelândia, ela foi transformada na "caipirinha que virou estrela". A roupa muito larga da artista também é desglamourizada, diferente dos trajes das norte-americanas, justos para mostrar a silhueta. Na última foto da matéria, Marisa Prado aparece sem maquiagem, com roupas muito simples, ao lado de um papagaio. A imagem espanta, se é de espanto que vive o fait divers, pois é exatamente Marisa quem aparece ao lado do papagaio, tal o destaque que o animalzinho ganha.

Já na foto de Fada Santoro, a repórter de Cinelândia tem a ousadia de afirmar que encontrou a atriz montada num camelo em pleno jardim botânico ${ }^{57}$. Não podia deixar de fotografar, declara Zenaide. Talvez a matéria quisesse imitar as diversas matérias dos atores conhecendo pela primeira vez parques de diversão, mas a denegação do interesse, tal como descrita por Pierre Bourdieu, ficou altamente frágil neste caso. Afinal, nem uma criança acreditaria na tal coincidência.

A dificuldade de reproduzir com perfeição o décor nas fotografias permite outra leitura. Em sintonia com os comentários de Paulo Emilio Salles Gomes (1973), a respeito da incompetência criativa em copiar por parte do filme brasileiro, pode-se falar de uma incapacidade de imitar as imagens de glamour norte-americano, uma vez que muitas das fotos publicadas decorrem do processo de produção das fitas. A tentativa de Cinelândia de ser criativa colocando uma atriz em cima de uma mula ou um camelo provavelmente não rendesse muitos frutos ao glamour e estrelismo brasileiro para o público destas revistas, interessado no padrão criado pelo star system hollywoodiano. Contudo, estes simulacros do estrelismo revelam o artificialismo do décor e poses perfeitas, com todos os elementos alinhados. Desvendam ao leitor o esquema de produção das imagens de publicidade e a dificuldade brasileira na feitura e competição desnivelada com as fotos estrangeiras, embora não fosse o objetivo dos produtores expor tais questões, principalmente aos leitores-espectadores amantes de Hollywood.

\footnotetext{
57 “Ora, direis, não se deve surpreender uma estrela entre feras e outros bichos enjauláveis, ou o que, em última instância, devam viver a maior parte dos seus dias longe dos homens (e, portanto, também das mulheres), como é o caso desse dromedário (...). E o caso dessa estrela chamar-se Fada talvez nos leve a achar ainda mais estranha a nossa atitude. Resistir, quem há de, porém ao gosto de vos servir, amigos leitores, quando se tem, por acaso, diante dos olhos e da nossa câmera fotográfica, um quadro como este que aqui publicamos (...). Acreditem ou não, tudo aconteceu por acaso (...)."
} 
Esta dificuldade em imitação o décor raramente ocorria nas fotos do cinema estrangeiro. Apesar disso, nem todas as imagens das atrizes norte-americanas utilizadas por Cena Muda conseguiam transmitir instantes de rara beleza, glamourizados, com uma aura transcendental. Como exemplo, temos o poster de Vera Ralston. A fisionomia dela não parece muito estimulante.

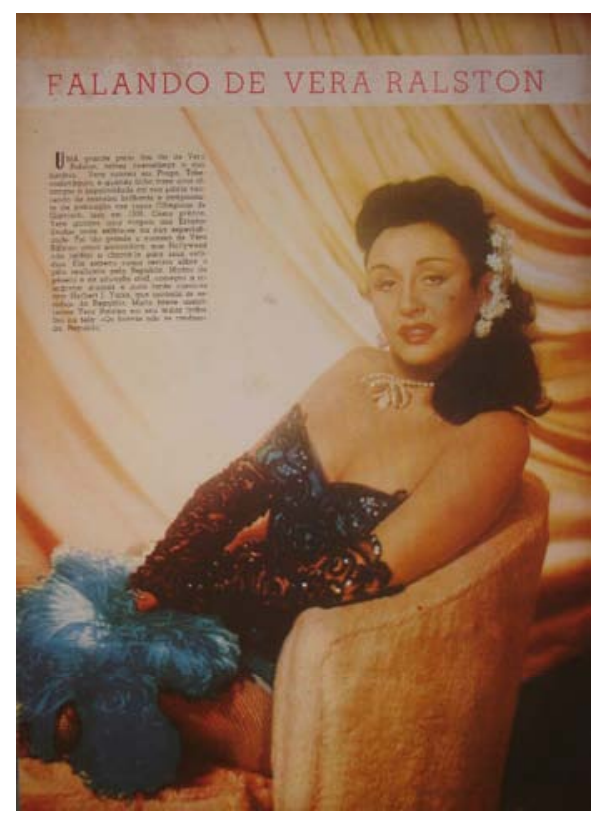

Imagem 31 - Vera Ralston ${ }^{58}$

Nas últimas edições de Cena Muda, a revista parece nem mais se importar com os critérios do estrelismo. Assim, publica uma fotografia de Violeta Ferraz, a atriz cômica das chanchadas da Atlântida. Uma revista de geração de star system nos moldes da época jamais traria com destaques as imagens da comediante, a fazer caretas, com grandes laços. Estes eram um dos aspectos mais relevantes para acentuar seu lado cômico, a partir da análise de João Luis Vieira (1977). Todavia, nem os cômicos saiam nas revistas fazendo tantas caretas. Trazer uma foto de Violeta Ferraz interpretando seus personagens cômicos era a concretização do anti star system hollywoodiano de Cena. Estas imagens podiam ser adequadas ao público da chanchada, mas provavelmente não o eram aos leitores das revistas de fãs, interessados na disseminação dos padrões de glamour de Hollywood.

\footnotetext{
${ }^{58}$ Falando de Vera Ralston. Cena Muda, v. 35, n. 2, p. 23, 2ª jan. 1955.
} 


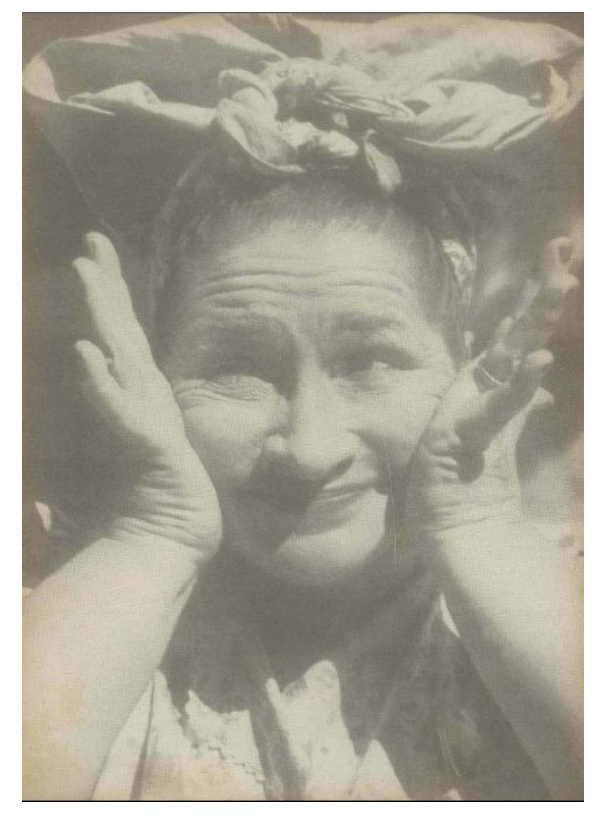

Imagem 32 - Violeta Ferraz ${ }^{59}$

Não diremos que só de contradições com o padrão imagético de Hollywood vivia o estrelismo brasileiro. Não, muitas vezes Cinelândia conseguia acertar a composição do glamour nas imagens das brasileiras, como nas três fotos a seguir:

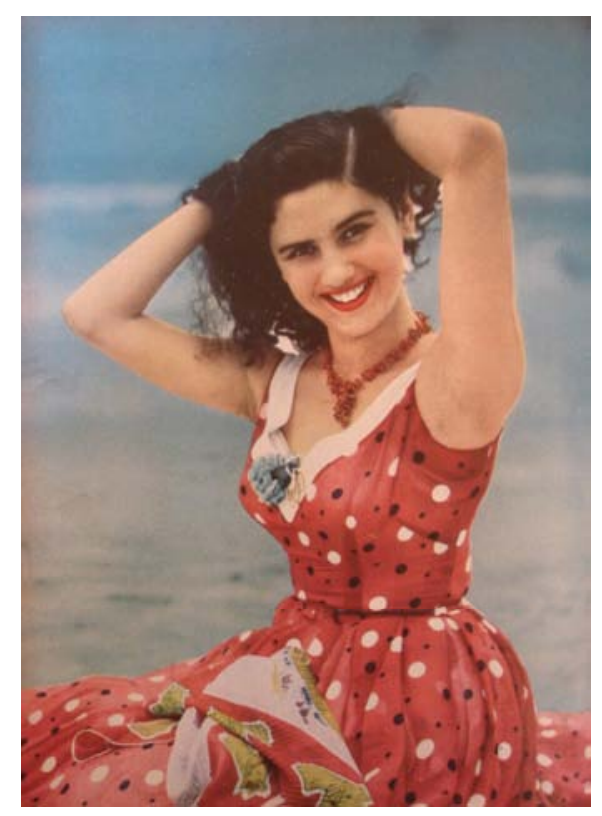

Imagem 33 - Aurora Duarte ${ }^{60}$

${ }^{59}$ A caricatura do cinema brasileiro. Cena Muda, v. 35, n. 4, p. 18-9, $2^{\text {a }}$ fev. 1955.

${ }^{60}$ Andrea, Zenaide. Aurora do Recife. Cinelândia, v. 3, n. 32, p. 42-3; 61, 1ª quinz. março 1954. 

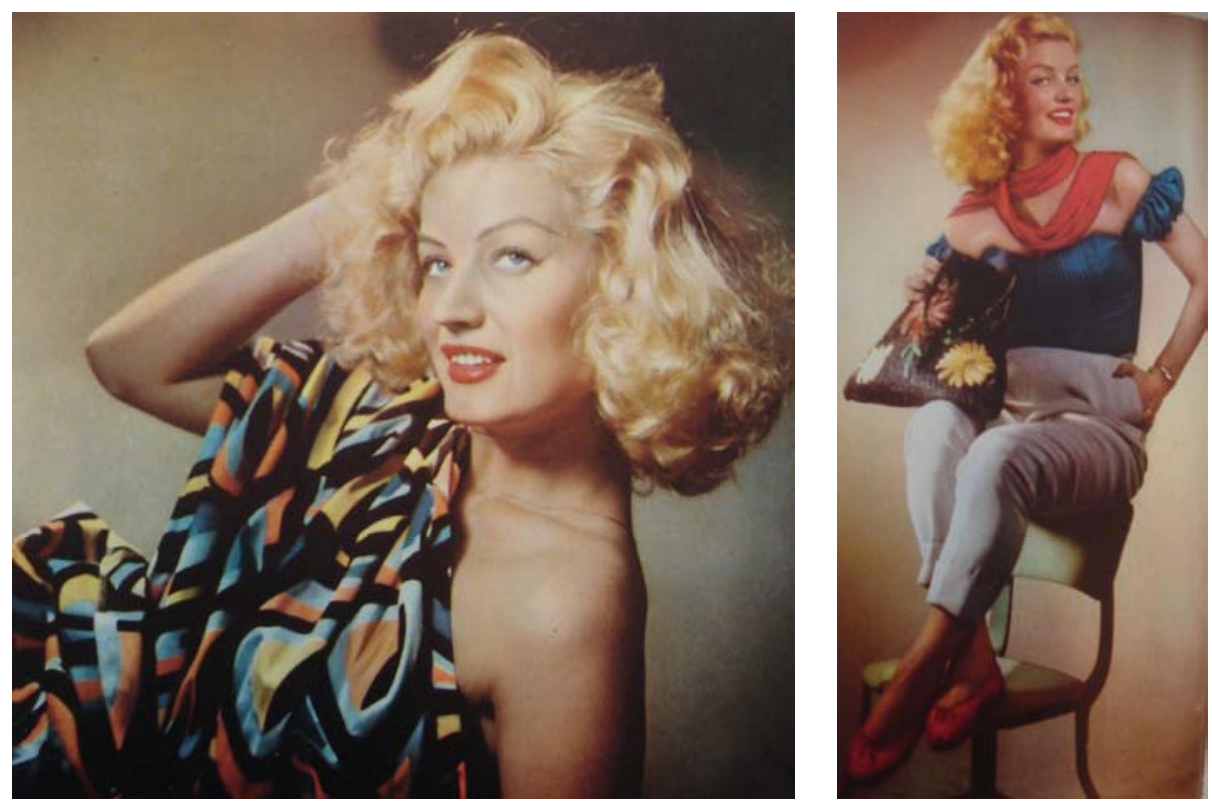

Imagem 34 a 35 - Julie Bardot ${ }^{61}$

Na primeira imagem, vemos Aurora Duarte, a atriz inexperiente convertida em estrela do filme $O$ Canto do Mar (1953), de Alberto Cavalcanti, com os cabelos ao vento, graciosa. A técnica de mostrar as brasileiras segurando o cabelo para cima não dava sempre certo, mas nesta conseguiu transmitir um bom efeito. Resultado muito melhor do que o da fotografia já analisada de Cacilda Lanuzza em Cena Muda no tablado de obra. Ambas buscam vender o mesmo filme, mas com uso diferente quanto ao glamour.

Já na matéria sobre de Julie Bardot, vemos claramente uma época transitória, com algumas fotos bem feitas, ao lado de outras, ainda deficientes. Na primeira, a candidata ao concurso Miss Cinelândia, revela uma aura envolvente de beleza. Os cabelos soltos têm ar de frescor, diferente das atrizes estrangeiras que apareciam com os cabelos extremamente bem alinhados. A iluminação acentuou o brilho de seus olhos. Contudo, a técnica não deu nada certo na outra fotografia, também mostrada aqui. Julie aparece numa cadeira sem sofisticação, assim como sua roupa com cores "descombinantes" para o padrão da época. Para piorar, a novata aparece com uma bolsa com temas florais, sabe-se lá com que intuito. Certo é que as estrelas estrangeiras não apareciam de bolsas. Estes acessórios aparecem apenas para mostrar os modelos da nova estação em seções específicas.

\footnotetext{
${ }^{61}$ Andrea, Zenaide. Uma loira dos pampas. Cinelândia, v. 3, n. 40, p. 30-1; 62, $1^{\text {a }}$ quinz. julho 1954.
} 
Muitas vezes Cinelândia conseguia trazer glamour via fotogenia às fotografias das estrelas brasileiras. Como exemplo, temos a capa de Eliane Lage para a divulgação do filme Sinhá Moça (1953), de Tom Payne.
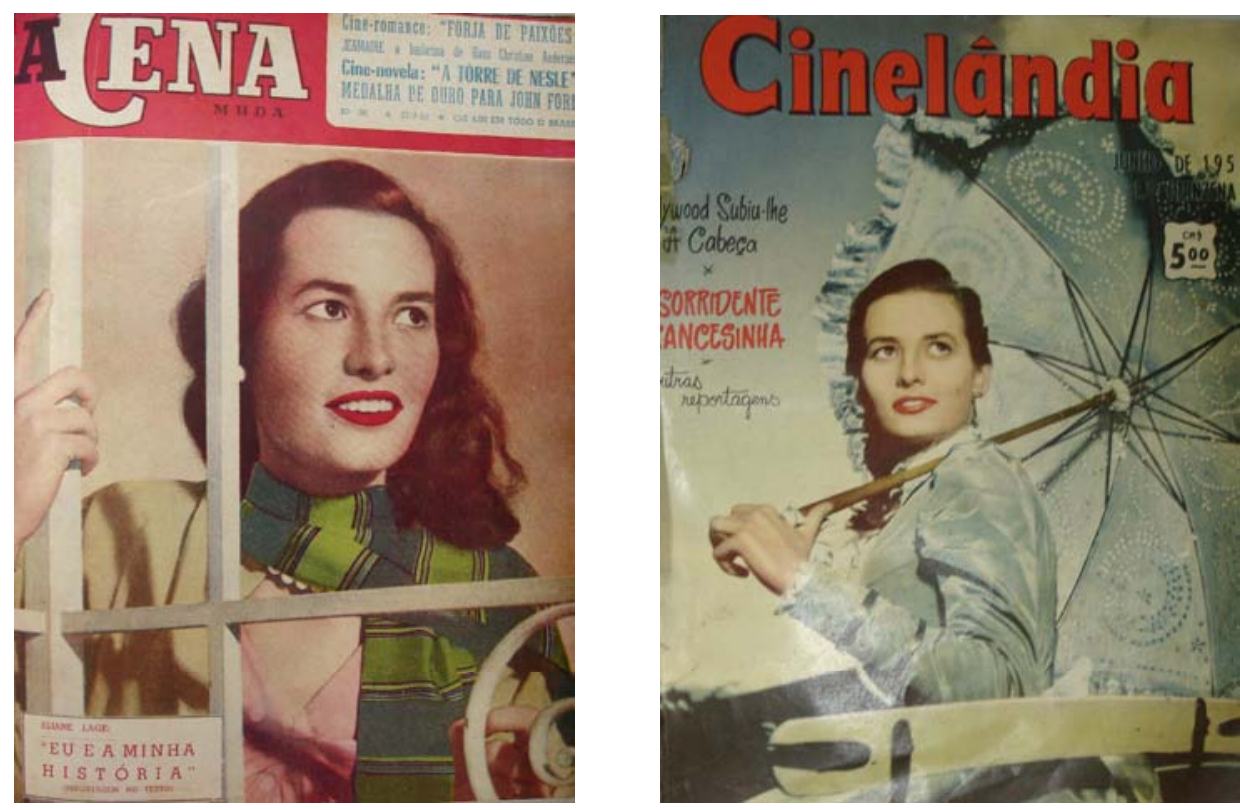

Imagem 36 a 37 - Eliane Lage em Cena Muda ${ }^{62}$ e Cinelândia ${ }^{63}$

$\mathrm{Na}$ comparação entre as primeiras páginas das duas revistas fica evidente a deficiência maior de Cena na composição das fotos. Esta utiliza uma fotografia de Lage com roupas pouco atraentes. Mistura cores díspares e pinta muito mal os lábios da estrela da Vera Cruz. Enquanto isso, Cinelândia usa o figurino de época do filme para suscitar a curiosidade do leitor. A capa de Cena sai um mês depois da de Cinelândia. Mas nem por isso, Cena produziu uma fotografia atraente de Lage para competir com a da concorrente.

Apesar de a representação do glamour das atrizes brasileiras em Cena Muda parecer abaixo da comparação com a da revista concorrente, como no exemplo sobre Eliane Lage, em muitas das fotos das atrizes norte-americanas em Cena há boa utilização dos recursos do glamour. Porém, perdem um pouco no conceito de glamour pela composição plástica. São sempre imagens em preto e branco, mais congeladas quanto à beleza das atrizes, com lay-out ${ }^{64}$ inferior. Muito parecidas entre si, as fotos focalizam mais o rosto em close up, sem inovações no padrão.

\footnotetext{
${ }^{62}$ Cena Muda, v. 33, n. 30, 22/07/1953.

${ }^{63}$ Cinelândia, v. 2, n. 14, $1^{\text {a }}$ quinz. junho 1953.

${ }^{64}$ Não pretendemos nos prolongar no tema do estudo de lay-out ou paginação, mas trazemos a análise de Muniz Sodré ainda na década de setenta sobre o modelo de jornalismo do período. As fotografias das
} 
Embora não possamos negar a maior estrutura de produção de fotografias da Vera Cruz, não é possível estabelecer uma diferença no glamour entre as matérias de divulgação das atrizes da Vera Cruz e da Atlântida. Em Cena Muda havia um padrão de fotografias trazendo as atrizes brasileiras sem grandes alterações. O fato indica certamente um material de release. A alteração se dá nas imagens captadas por Cinelândia, a partir de seu corpo de jornalistas. Afinal, se Cena Muda tivesse acesso ao mesmo tipo de fotografia publicada pelos estúdios, porque sempre escolheria as imagens que menos contribuiriam para o consolidar o estrelismo nas bases hollywoodianas, como no caso da capa de Eliana Lage? Fica evidente que as fotografias de Cinelândia não estavam disponíveis a todos os órgãos de imprensa. Não eram de release. Assim, a configuração do estrelismo passa por dois filtros, o primeiro é a divulgação do material dos estúdios. O segundo, a cobertura e geração deste mesmo estrelismo pelos veículos da imprensa. No caso de Cinelândia, o produto final contribuía mais com uma construção do star system mais parecido com o padrão norteamericano do período. Isso ocorria, mesmo que esta revista ainda não conseguisse atingir todo o nível de detalhamento e perfeição do décor.

Não tivemos acesso às fotos de divulgação da Vera Cruz para realizar um estudo comparativo da apropriação deste material por parte das revistas. Das fotos de cena do arquivo da Cinemateca Brasileira e do Museu da Imagem e do Som fica patente a boa qualidade fotográfica das imagens desta companhia. Contudo, as fotos são de cena, não de publicidade. Nas duas revistas, as imagens dos filmes eram pintadas em cores, processo comum na imprensa brasileira e estrangeira da época, inclusive em Cinelândia. Contudo, o processo diminuía muito o nível de detalhamento das ilustrações. Por exemplo, encontramos uma imagem de Anselmo Duarte e Leonora Amar de roupa de dormir na cama, provavelmente uma foto de divulgação do filme Veneno (1952), de Gianni Pons. A cena foi reproduzida na capa de Cena Muda ${ }^{65}$, mas a pintura em cores tornou o rosto dos atores falseado para os padrões atuais. Além disso, excluiu detalhes do cenário. Ou seja, muitas vezes as ilustrações dos estúdios sofriam

revistas até 1945 no Brasil eram estáticas e a paginação era rudimentar - geralmente feita pelo próprio secretário da revista. Foi $O$ Cruzeiro a grande lançadora, no Brasil, da reportagem ilustrada, dinâmica. Para Sodré, as revistas especializadas eram poucas e de qualidade sofrível. Apenas em 1960, mudaram, com o desenvolvimento das agências noticiosas e o aprimoramento da notícia, do serviço fotográfico e do segundo caderno dos jornais, com a multiplicação das revistas especializadas, com o grande boom da televisão, em suma, com o bombardeio pelos veículos de massa. (Sodré, 1971: 40)

${ }^{65}$ Cena Muda, v. 32, n. 43, 24/10/1952. A imagem se encontra no MIS n. 90 (Bra07). 
uma seleção das revistas, numa estética diferente do que consideramos hoje como "melhor".

As imagens encarregadas de perpassar glamour e fotogenia das atrizes geralmente são acrescidas de outro tipo de apelo imagético, a erotização dos atributos sexuais secundários, como lábios, olhos, cabelo, e especialmente as pernas. A beleza a partir do sex appeal e da perfeição dos corpos mostra quão especial é a estrela, temas abordados a seguir.

\subsubsection{Corpo e erotização}

Já citamos o glamour, a fotogenia e a construção da felicidade pelos momentos de instantaneidade como reveladores da representação da estrela em toda sua dimensão de perfeição. Falta ainda abordar um dos maiores apelos fotográficos do ídolo, ou seja, a exposição de seu corpo, atributo sem igual para a configuração do estrelismo. O glamour e a fotogenia estão intimamente ligados ao conceito de erotização. Por isso, grande parte das imagens mostram as atrizes de maiôs, mais do que com belos vestidos e casacos de pele. Edgar Morin (1957) já apontou como não há um centímetro do corpo da estrela que não seja uma mercadoria a ser lançada no mercado, por isso a "estrelamercadoria" sabe que deve ter uma vida pública. Conhece a conversão de seu corpo e alma em consumo.

A erotização do corpo da celebridade cria uma fascinação com o corpo e com a face humana, essência do fetichismo do espectador, já apontada por Laura Mulvey. Responsável por criar uma estética de extremo antropocentrismo, Hollywood investiu pesado na erotização via culto à estrela. (Mulvey, 2006)

Mulvey explica que a imagem da mulher se torna um signo de sexualidade, convertida em imagem, devido a inúmeros fatores como a censura, o discurso da liberdade sexual e da representação da mulher transfigurada em espetáculo. A base para os filmes e para as revistas de fãs é o discurso de sexualidade. Este discurso constrói uma "retórica do não-movimento", ou seja, induz ao stasis. A partir desse êxtase, o espectador ou leitor retém a excitação do movimento num instante de "prazer visual erotizado". (Xavier, 1996:126)

A erotização dos corpos tem como chave o prazer visual erotizado, mas o processo relaciona-se com a psicanálise porque esta explica os meios pelos quais a fascinação do cinema é reforçada. Mulvey estabelece uma relação entre o inconsciente 
ligado ao patriarcalismo na composição dos modos de estruturação do cinema com o passivo/mulher e o ativo/homem. O cinema corporifica dois movimentos. O primeiro é o escopofílico (prazer em usar uma outra pessoa como um objeto de estímulo sensual e/ou sexual através do olhar) e o segundo o narcisismo e a constituição do ego pela identificação com a imagem vista.

A escopofilia se relacionada diretamente com a erotização dos corpos. O cinema satisfaz a necessidade da escopofilia, proporcionando ao espectador o prazer visual de contemplar uma pessoa como objeto erótico. Possibilita também espionar o mundo privado. De um lado há uma separação entre a identidade erótica do sujeito e o objeto na tela. Já no narcisismo é preciso ter a identificação do ego com o objeto através da fascinação e do reconhecimento do espectador com seu semelhante. O primeiro processo (escopofilia) é uma função dos instintos sexuais, enquanto o segundo relaciona-se com a libido e com o ego, a partir da teoria de Lacan, apropriadas por Laura Mulvey. (Xavier, 1983)

O narcisismo na constituição do ego surge no estágio do espelho para Lacan. O reconhecimento que a criança tem de si mesma a deixa feliz, sem ter consciência de que sua ambição física seja menor que a motora. Esse reconhecimento que a criança faz de si mesma, apesar de ter como ponto de partida um reconhecimento falso de suas dimensões, coloca seu corpo para fora de si, como ego ideal, o mesmo ego que dará origem aos processos de identificação. De acordo com Mulvey, é a partir de uma imagem que se constitui a matriz do imaginário, do reconhecimento/falso reconhecimento e da identificação, e, portanto, da primeira articulação do 'Eu', da subjetividade. Este processo permite entender o surgimento do estrelismo.

Astros e estrelas surgem através da construção de um ego ideal, nos diz Mulvey. E é através do estrelismo que o cinema produz egos ideais. Os ídolos centralizam presença na tela e na história "na medida em que representam um processo complexo de semelhança e de diferença, como por exemplo, o glamouroso personificar o comum." (Xavier, 1983: 442-3)

$\mathrm{O}$ estrelismo relaciona-se com a imagem que o indivíduo acredita ter quando observa a estrela. Ele constitui seu $e u$ a partir da imagem do outro, sonhando possuir, ter semelhanças e/ou incorporar o $e u$ do outro. Essa constituição entre a imagem de si e do outro é gerada via mecanismo de identificação.

A partir da teoria de Mulvey podemos pensar o papel da estrela na consolidação da identidade. Só que a constituição desse $e g o$ a partir das revistas de fãs não tem por 
público a primeira constituição do ego, e sim a do adolescente em diante, trazendo, portanto, uma sedimentação ou consolidação da identidade ${ }^{66}$ através da identificação, tendo por base os ídolos da tela. A partir da personalidade da estrela, o leitor poderia se reafirmar como sujeito de sua personalidade. É possível coexistir dois processos: olhar a personalidade modelo da estrela para sonhar-se semelhante, ou buscar imitar o ídolo a partir dos parâmetros comportamentais por meio das dicas das revistas e do conteúdo dos filmes.

É relevante realçar que a representação das revistas de fãs quanto ao corpo das estrelas está sempre aquém quanto a dos filmes. O corpo da estrela podia estar mais exposto na fita, mas não era desejável congelar por muito tempo as mesmas imagens nas revistas. A erotização de cenas rápidas congeladas nas imagens tornar-se-iam pesadas para o nicho editorial das revistas de fãs. Há uma contenção da erotização em Cena Muda e Cinelândia. Um dos maiores exemplos disso é a foto de Marilyn Monroe nua. Nos primeiros anos de nossa análise, Cena Muda e Cinelândia citam diversas vezes a foto, referindo-se a uma imagem em que a estrela aparece "do jeito que veio ao mundo". O termo nudez é incorporado pouco a pouco. Contudo, a foto sempre citada nunca aparece de fato. Esse abrandamento das imagens mais erotizadas é uma característica das duas revistas. Cobertura diferente de Manchete, que publica a foto com destaque em $1954^{67}$.

A configuração da erotização sofre mudanças lentas e graduais, sempre impulsionadas pelo fator estrangeiro. Quando as fotos dos estúdios de Hollywood mostram as atrizes com o corpo um pouco mais à mostra, a composição será imitada no modelo brasileiro, mas de maneira vagarosa. No primeiro ano de pesquisa, 1952, o corpo das atrizes estrangeiras e brasileiras aparecia menos descoberto. Eram raras as fotos de homens sem camisa. Contudo, a cada ano, o processo vai se ampliando. Nas imagens do cinema estrangeiro, as mudanças são um pouco mais rápidas. Em 1952, quando as artistas posavam para fotos em maiôs, estavam de frente. Nos anos subseqüentes, há uma inclinação nesta posição, voltando-se quase ao perfil de todo o corpo, para marcar a silhueta, mas ainda sem mostrar a anca. Pouco a pouco, as fotos transformam-se. Algumas delas mostram a silhueta de forma mais evidente, com o

\footnotetext{
${ }^{66}$ Não esquecendo que há constituição de identidade pelo consumo de bens simbólicos. Canclini (2005) mostra que os partidos políticos, religião e família perdem espaço para os bens de consumo, como o cinema e a televisão. O consumo não é mais visto como lugar do irracional, mas de configuração da identidade.

${ }^{67}$ Vaitsman, Maurício. Marilyn Monroe nua a meio dólar. Manchete, n. 93, p. 32-3, 30/01/1954.
} 
contorno dos quadris. A estrela é um ícone sexual, seu corpo existe para ser visto. Só há variação em maior ou menor grau, como veremos.

A erotização das celebridades é difícil de mensurar como um todo homogêneo, porque há contradições aparentes. Não é possível dizer que as estrelas mostram menos o corpo, ou que as starlets e pin ups são sempre muito erotizadas.

O termo pin up vem do ato de colocar um alfinete para vislumbrar uma fotografia de uma mulher bela, desconhecida, que mostra seu corpo. Nas revistas pesquisadas, o termo também é usado para designar uma qualidade plástica das estrelas ou uma pose específica, dotada de sex appeal. A estrela precisa ter qualidade de pin up. Bertrand Mary (1983) conta que durante a segunda guerra mundial, as imagens das mulheres começam a ser conhecidas como pin ups. O ano exato seria 1942, surgindo na Europa e nos Estados Unidos ao mesmo tempo. A palavra apareceu para designar as imagens femininas e o hábito dos combatentes ingleses e americanos de cortar ou de tirar os grampos das páginas das revistas para pendurar as fotos nos muros e divisórias de seus territórios. Bette Grable tornou-se a primeira pin up dos soldados, fazendo um filme consagrado a seu personagem nesta função, chamado Pin up girl (1944) de H. Bruce Humberstone.

Fechando este parêntese sobre a significação da pin up, a afirmação de Edgar Morin (1957) sobre a estrela expor o corpo apenas em situações excepcionais, enquanto as starlets e pin ups o mostrarem sempre, soa seletiva demais para o universo das revistas de fãs estudadas. Afinal de contas, Morin mesmo afirmou que não há nenhum centímetro do corpo da estrela que não seja vendável. Por isso, a diferença entre mostrar ou não o corpo não pode ser mensurada apenas pela fama das atrizes. Todas as atrizes mostram seu corpo, afinal trata-se de revistas de divulgação do star system via sex appeal. Apenas se altera a forma e quantidade. Concomitante a este fenômeno, há também um processo de transição e liberação da sexualidade. Molly Haskell (1973) analisando a representação da mulher durante a década de cinqüenta, mostra que as personagens rondavam o tema sexo, mas sem ousar dizer. Segundo ela, o período já mascarava uma rebelião futura. Havia uma perda de credibilidade e um fosso crescente com os espectadores, dada a representação aquém da desejada.

O corpo da estrela se revela cada vez mais nas revistas. Por outro lado, o contraponto visual entre as desconhecidas que mostram o corpo e as starlets, novatas em busca de fama, parece muito pequeno nos dois periódicos. 
A divisão entre a erotização das imagens estabelecida abaixo busca trabalhar com todas estas nuances, a partir da diferença entre fotos mais secas e cruas mostrando o corpo, e imagens com uma aura de sensualidade e glamour, insinuando sem mostrar.

A primeira forma de imagem encontrada é a exposição dos corpos das atrizes sem glamour ou aura. São ilustrações secas, em maiôs ou shorts, sem grande apelo sensual e sem erotização via glamour. As pernas aparecem, mas sem aura de beleza ou sex appeal. Embora seja mais comum fotos assim para atrizes de baixo renome, há também fotografias de estrelas.
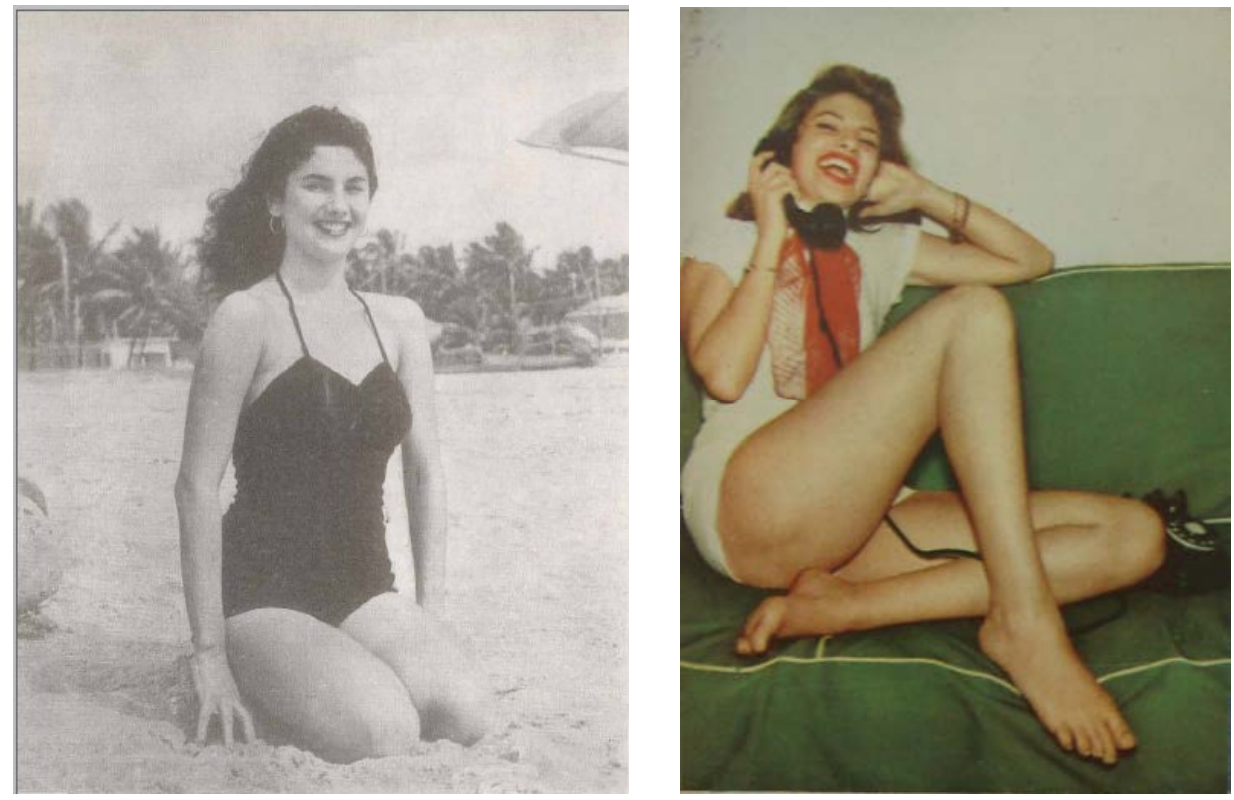

Imagem 38 a 39 - Aurora Duarte ${ }^{68}$ e Patrícia Lacerda ${ }^{69}$

Na primeira foto vemos Aurora Duarte em maiô, mas não há apelo sensual forte. A segunda mostra de forma crua o corpo da novata, considerada estrela, Patrícia Lacerda. Há uma representação seca de seu corpo.

Depois há as imagens secas dissecando o corpo das atrizes, insinuando nudez ou semi-nudez, mais comuns quando se trata de starlets ou pin ups brasileiras ou estrangeiras. Geralmente são fotos pequenas. Falta uma aura de glamour a insinuar sem mostrar. Essas imagens são pouco comuns, e aparecem apenas em Cena Muda:

\footnotetext{
${ }^{68}$ Brandão, Paulo. En rade (em versão brasileira) O famoso filme de Cavalcanti $O$ canto do mar. Cinelândia, v. 33, n. 6, p. 4-6, 04/02/1953.

${ }^{69}$ Sex appeal no cinema brasileiro. Cinelândia, v. 2, n. 24, p. 34-5, $1^{\text {o }}$ quinz. set. 1953.
} 

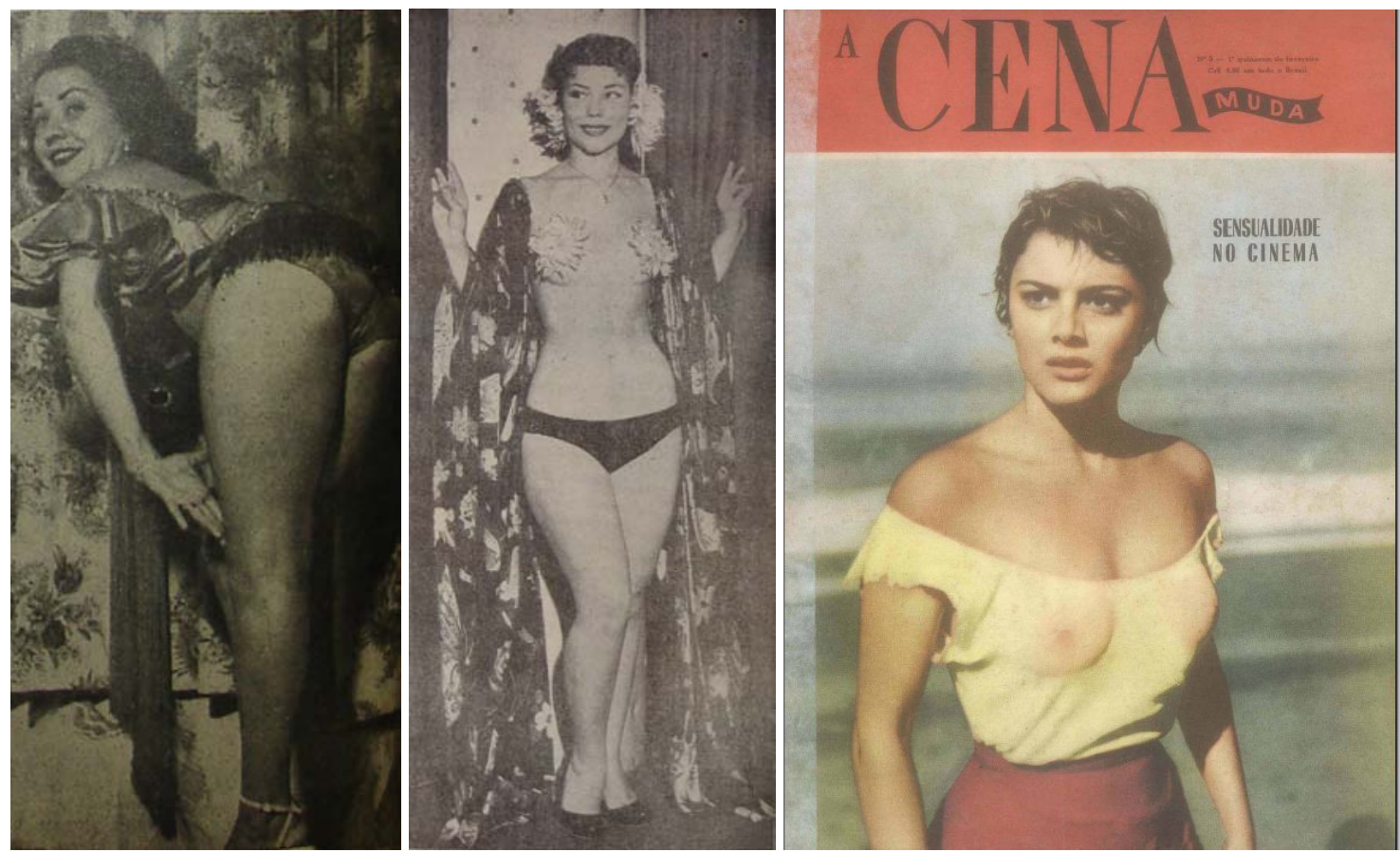

Imagem 40 a 42 - Cuquita Carballo ${ }^{70}$, Yolanda Glacomo ${ }^{71}$ e Rossana Podestá ${ }^{72}$

No cinema nacional, principalmente em 1952, havia maior erotização das atrizes estrangeiras residentes no Brasil do que das estrelas brasileiras. Depois, as brasileiras passarão a mostrar o corpo, assim como as de Hollywood, mas jamais de forma tão evidente, como nas fotos acima. Um dos exemplos de starlet é Cuquita Carballo, nesta imagem em que se mostra de forma direta seu quadril, de forma crua, seca, sem aura. Cuquita participou do filme Carnaval Atlântida (1952), de Carlos Burle, num pequeno papel de secretária. A representação do corpo da mulher de forma bastante explícita era mais comum nas imagens de Cena sobre o teatro de revista.

Há ainda outro tipo de imagem, com sensualidade, mas mostrando partes do corpo feminino, ou um pequeno detalhe do corpo com maior realce, geralmente para atrizes não muito conhecidas, embora haja também atrizes famosas pelo sex appeal, como Silvana Pampanini.

\footnotetext{
${ }^{70}$ Cena Muda, v. 32, n. 18, p. 10, 01/05/1952.

${ }^{71}$ A vida começa à meia noite. Cena Muda, v. 32, n. 14, p. 29, 03/04/1952.

${ }^{72}$ Cena Muda, v 35, n. 3, $1^{\text {a }}$ quinz. fev. 1955.
} 

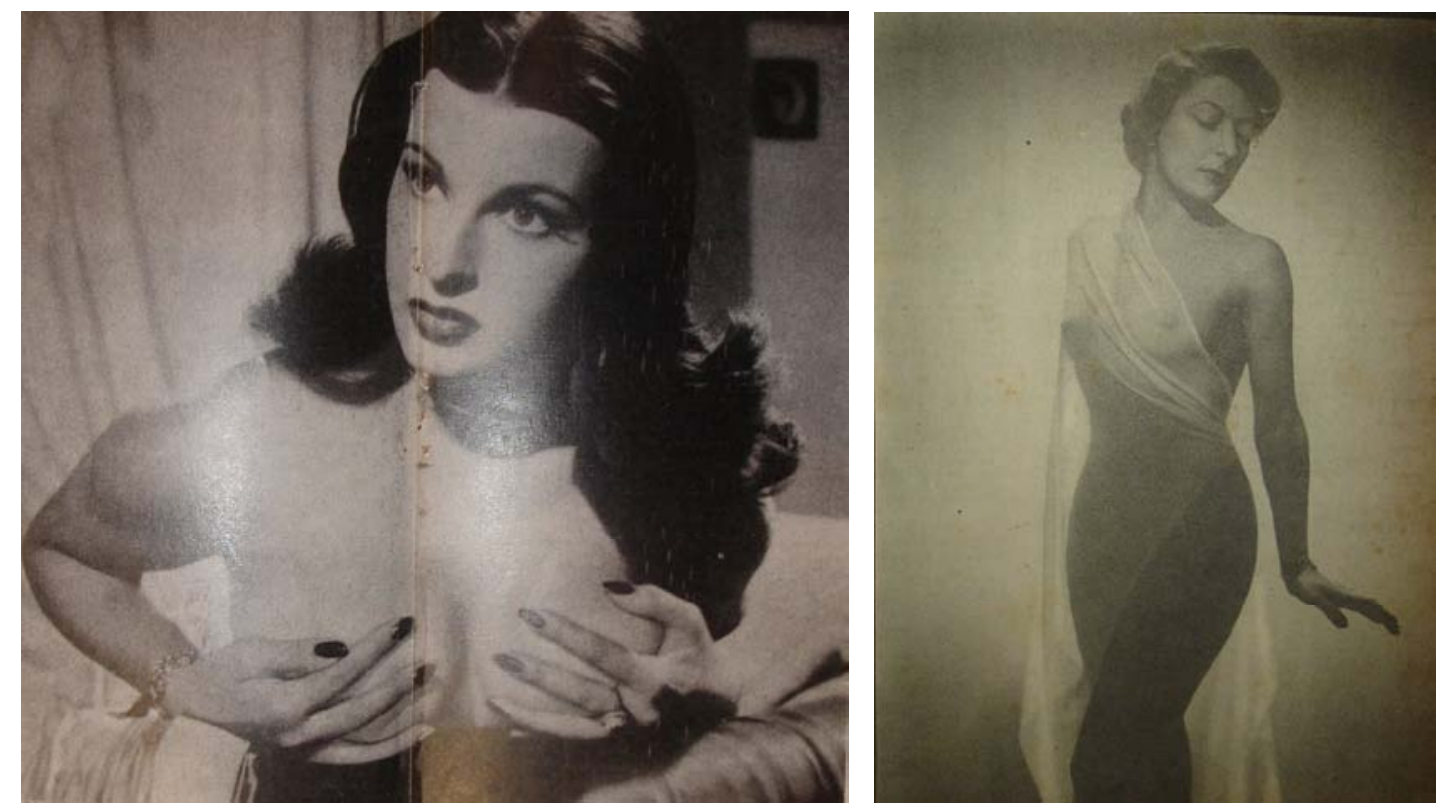

Imagem 43 a 44 - Silvana Pampanini ${ }^{73}$ e Regine ${ }^{74}$

Depois há a erotização dos atributos sexuais secundários, mais freqüentes em ambas as revistas. Devido ao conservadorismo, a erotização, vista como glamour e apelo quanto à atração física, é mostrada na apresentação das pernas, num decote sem revelar muito. A diferença é mostrar o corpo com sensualidade, não de forma explícita e seca, como no exemplo anterior. Dentro desse tipo de erotização um pouco além dos atributos sexuais secundários, há também as insinuações de nudez, mas com maior requinte na composição fotográfica, afinal nada é exposto. Estrelas aparecem enroladas em tecidos, peles, ou em banheiras. Como exemplo da amplitude desta categoria há desde estrelas como Marilyn e Tônia Carrero, como a starlet Liana Durval, vista abaixo:

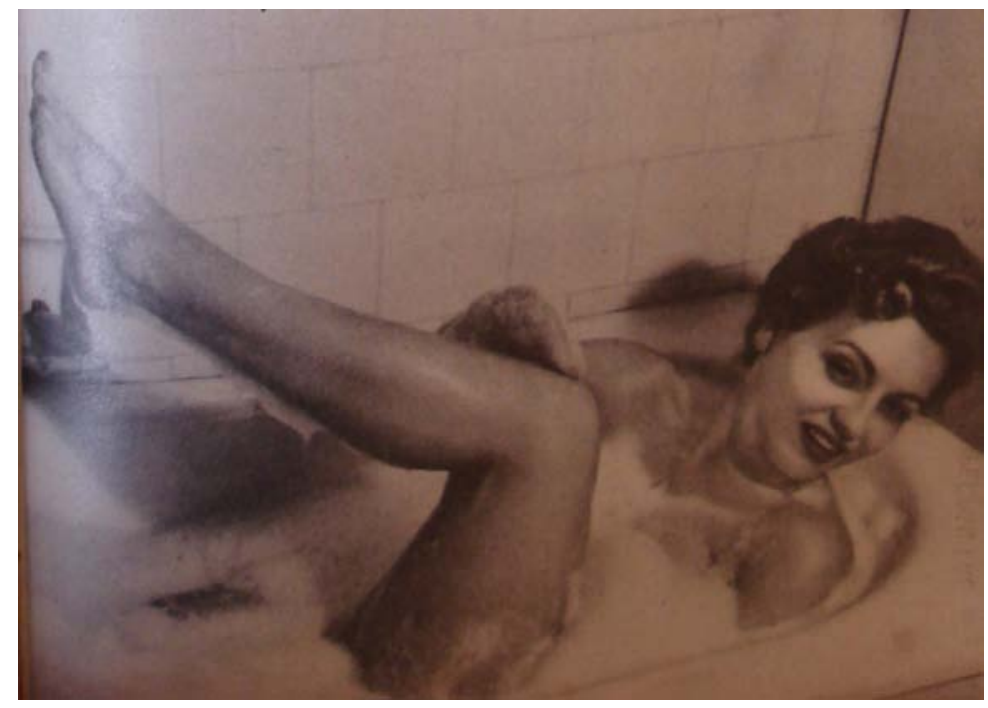

Imagem 45- Liana Durval ${ }^{75}$

\footnotetext{
${ }^{73}$ Silvia Pampanini cansou apenas de ser mulher bonita. Cena Muda, v. 32, n. 17, p. 18, 22/04/1953.

${ }^{74}$ Regine quer trabalhar em boites. Cena Muda, v. 33, n. 48, p. 29, 25/11/1953.
} 

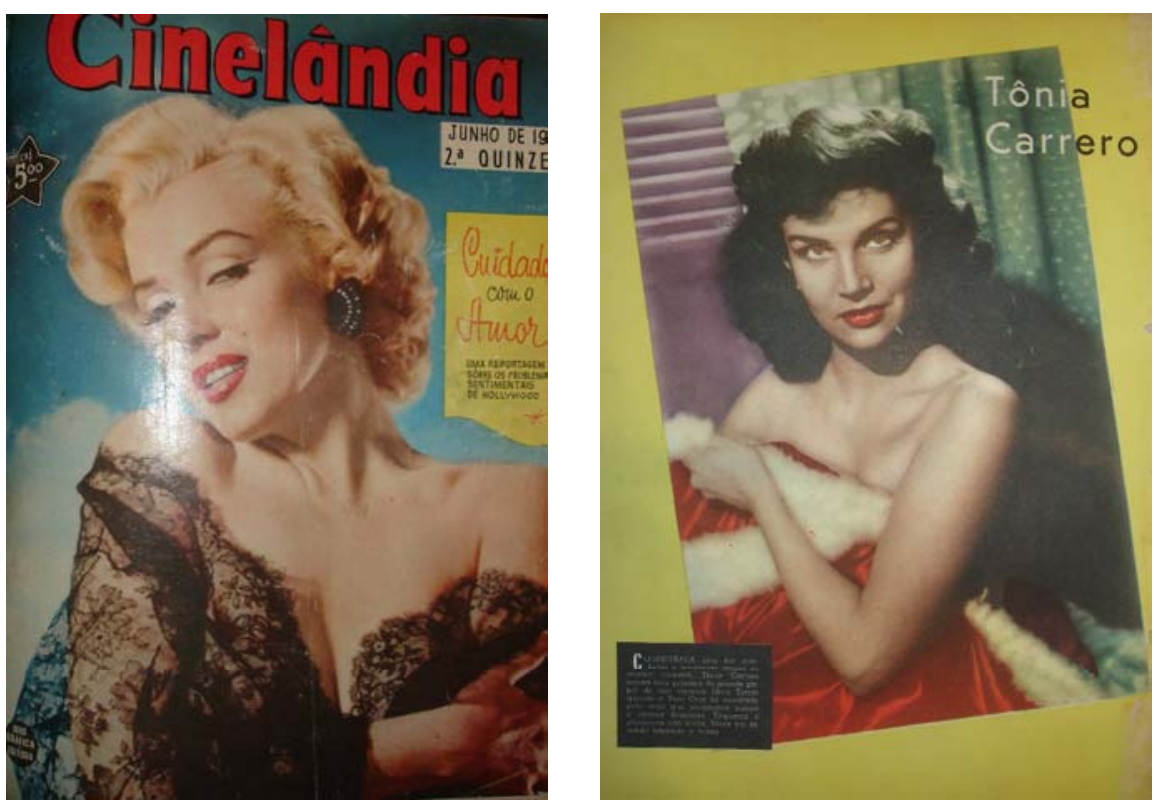

Imagem 46 a 47 - Marilyn Monroe ${ }^{76}$ e Tônia Carrero ${ }^{77}$

Há que se considerar também que a diferença entre o grau de erotização depende da construção a respeito do papel interpretado. Há maior erotização por se tratar de imagens dos filmes de personagens de vamp ${ }^{78}$, por exemplo. Eliana Macedo aparece em reportagens de meia liga por causa do filme A outra face do homem. Embora estas fotografias sejam sempre pequenas, tentando se diferenciar tratar da personagem, não da atriz.

\footnotetext{
${ }^{75}$ Andrea, Zenaide. O que eu vi nos estúdios. Cinelândia, v. 2, n. 25, p. 46-7; 51, 2a quinz. nov. 1953.

${ }^{76}$ Cinelândia, v. 2, n. 15, $2^{\mathrm{a}}$ quinz. junho 1953.

${ }^{77}$ Cena Muda, v. 34, n. 33, p. 2, 27/10/1954.
}

${ }^{78}$ A vamp condensa grande carga erótica, mas seu objetivo não é encontrar um amor. Ela não é a mocinha em busca de seu príncipe encantado. Bela e sedutora, mostra-se como uma ameaça, porque não se deixa levar por romantismo. A vamp surge ambientada na figura da dinamarquesa Theda Bara. $\mathrm{O}$ termo surgiu a partir de um poema sobre uma mulher vampiro que sugava através do beijo a alma dos homens, apontando já para uma relação entre o erotismo como algo perigoso. O filme era A fool there was (1915), de Frak Powell, e a atriz escolhida Theodosia Goodman, convertida pela Metro Goldmeyer em Theda Bara. A publicidade da companhia criou uma persona para a atriz a partir de sua personagem. Theda seria a filha de um sheik com uma egípcia, conhecedora de feitiçaria. A mãe teria ensinado à filha e atriz Theda tais conhecimentos, além da clarividência. Com poderes sobrenaturais, estaria acostumada a beber sangue de serpente desde a infância, além de ser insaciável sexualmente. O nome escolhido era um anagrama de Arab Death, simbolizando assim todo o poder oriental desta mulher. Theda era o diminutivo de Theodosia, e Bara as primeiras iniciais do sobrenome da avó, Barangers. A atriz se apresentava em público nas coletivas de imprensa vestindo peles quando a temperatura era muito alta, como se estivesse acostumada com o calor excessivo. Sentia apenas frio. A publicidade criada para Theda foi feita um ano antes deste primeiro filme. Mostrou aos produtores que se podia criar uma estrela sem ter feito filme algum, apenas aproveitando uma audiência interessada em sex appeal. Numa carreira curta, Theda caiu logo no esquecimento. (Walker, 1970) Foi ela a introduzir o beijo na boca, não o teatral, sugando a alma do amante. Durante os anos 20 e 30, o arquétipo da vamp se confundiu com o da femme fatale. Após 1930, os filmes tornaram-se mais realistas e a vamp entrou em decadência, por parecer burlesca. Tornouse personagem secundária. Depois as vamps se humanizam, mas neste processo, ela distribuiu sua carga erótica para todos os outros tipos de estrelas. (Morin, 1957) 
Deve-se estabelecer uma outra categoria que deriva desta primeira, que é a reciprocidade entre personagem interpretada e personalidade da estrela, ou apenas sobre a representação desta última. Claramente, Marilyn Monroe sai em fotos de maneira mais sensual que Debbie Reynolds ${ }^{79}$, assim como Tônia Carrero aparece com maior sex appeal que Fada Santoro. As que personificam os papéis de ingênuas são bem menos erotizadas nas imagens. Mesmo em imagem de shorts, não há apelo sensual para Fada, embora nos papéis interpretados, como em Nem Sansão nem Dalila, ela apareça com maior sensualidade. Geralmente as atrizes se apresentam na média entre esses dois modelos. Ocorre também que numa foto, as atrizes aparecem de forma mais sensual, e na outra como ingênuas. Isso ocorre porque é necessário mostrar um pouco e ocultar, conceito defendido por Morin. O autor mostra que a nudez era ainda um tabu, mas precisa haver sempre uma licença a corroê-lo. Como a nudez total continuava proibida, todo o corpo era erotizado, a partir dos atributos sexuais secundários. Essas características fazem parte do reino do novo ídolo da cultura de massa, pontuado por Morin na figura da vedete: "não a deusa nua das religiões antigas, não a madona de corpo dissimulado do cristianismo, mas a mulher seminua, em pudor impudico, a provocadora permanente". (Morin, 1962: 122)

Grosso modo, as fotos das grandes estrelas estrangeiras possuem maior insinuação e sensualidade, mas não de maneira crua. As brasileiras aparecem ainda de forma menos sensual em quantidade, provavelmente devido ao maior controle no país.

É necessário também frisar a diferença na erotização das fotografias em Cena Muda e Cinelândia. Esta última erotiza mais os atributos sexuais secundários, geralmente com aura e glamour. A referida revista, pouco a pouco aumenta o apelo sensual das imagens, citando com maior freqüência a nudez e o sexo. As fotos pouco a pouco se aprimoram neste quesito, revelando cada vez mais partes do corpo das atrizes. Cena Muda utiliza extremos, como vimos.

A construção da erotização dos corpos focava a imagem da mulher. Raramente havia a presença de um homem na foto. Esta representação da relação entre os corpos é desconstruída apenas numa imagem de Kirk Douglas concedendo um autógrafo:

\footnotetext{
79 Molly Haskell (1973) relaciona Marilyn Monroe a uma sexualidade artificial, repudiada pelas mulheres. Já Debbie Reinolds possuía uma sexualidade mais inocente, mas calculada. Nesse sentido, Doris Day perderia muito, por não ter sex appeal junto aos homens, embora fosse adorada pelas mulheres por não parecer perigosa. Durante os anos cinqüenta, a divisão entre personalidade e a "verdadeira" atriz eram mais explicitadas por diversos cineastas. Segundo ela, a separação entre persona e mulher foi um tema central na década.
} 


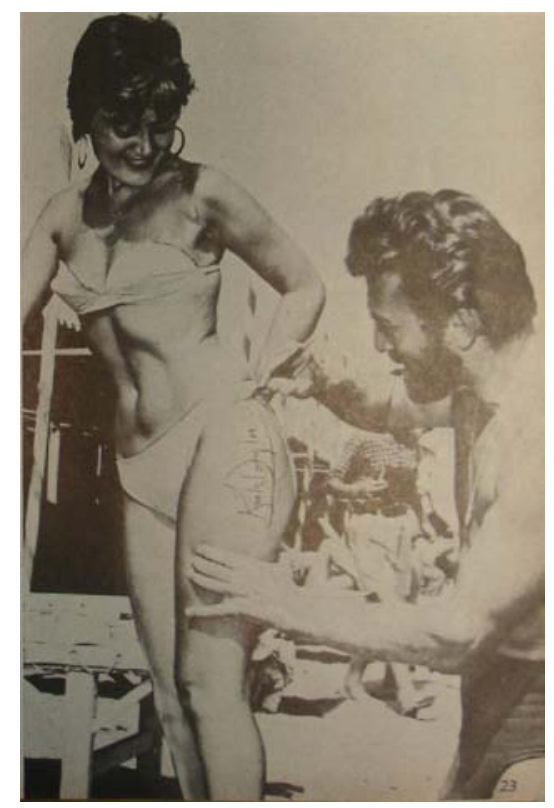

Imagem 48 - Kirk Douglas ${ }^{80}$

Tanto a legenda quanto o texto reafirmam o enorme prazer com que o ator assinou o autógrafo nas pernas da atriz italiana Novelli Parigini. A representação do astro foge dos parâmetros das fotografias divulgadas em Cinelândia. Kirk Douglas aparece com barba, cigarro na boca, com aparência de bad boy, semelhante aos papéis interpretados, mas muito diferente das fotos de divulgação ou das imagens dos atores em festas. Procurando trazer o ambiente de naturalidade das cidades européias, diferente da "moral pública" dos Estados Unidos, o artigo termina por dizer que fatos como estes corroboraram com o conceito de extravagância na estadia do ator na Europa.

Cena Muda recorria à insinuação da sensualidade e da nudez para vender os lançamentos em manchetes, mas sempre sob a forma de fait divers decepcionado, porque prometia mais do que cumpria. Certa vez anunciou reportagem fotográfica na capa: "Jane Russel e Bob Hope tomando banho" ${ }^{81}$. Depois de mostrar diversas fotos dos banhos dos atores em separado, o texto explica que Hope quis tomar um banho como o da atriz, após a filmagem da cena de Russel na tina, do filme $O$ Filho do Treme Treme (1952), de Frank Tashlin.

Cena tinha um menor poder de erotização via glamour. Contudo, a revista é contraditória. Às vezes, publica imagens mais cruas das atrizes com os seios a mostra, depois condena a exposição total do corpo feminino, especialmente quando se trata de

\footnotetext{
${ }^{80}$ Garrison, Omar. Roma...sucursal de Hollywood. Cinelândia, v. 4, n. 52, p. 22-3, 60, $1^{\text {a }}$ quinz. jan. 1955.

${ }^{81}$ Nada num banho de espuma/ Surge uma nova rainha das cenas de banho. Cena Muda, v. 32, n. 49, p. $18-19,05 / 12 / 1952$.
} 
atrizes brasileiras consagradas. Leon Eliachar escreve o editorial Revista ou imoralidade ${ }^{82}$, condenando o teatro de revista. Segundo ele, a censura deveria fazer algo antes que fosse tarde. A nudez é mais aceita quando se trata das estrelas vindas do exterior, mas quando situada no Brasil, o tom da discussão muda. Marilyn Monroe é elogiada pela coragem de admitir ter pousado nua porque passava fome ${ }^{83}$, mas o teatro de revista é combatido, eis uma clara diferença dada às questões brasileiras.

Por não haver muitos casos de nudez no cinema brasileiro em 1952, o tema recai sobre o teatro de revista ou sobre as dançarinas das boites. A relação da revista Cena Muda é contraditória. Revela um preconceito. No decorrer de 1952, Cena Muda dedica duas páginas às seções para cobrir os espetáculos do Rio de Janeiro, principalmente as boites. Traz até as programações. Dançarinas desconhecidas são fotografadas em biquínis minúsculos, como a imagem de Yolanda Glacomo, já mencionada. Não há fotos desse tipo em Cinelândia, nem destaque para estas atrações.

A relação de Cena Muda com a nudez varia. Segundo César Ladeira ${ }^{84}$, a pornografia é aceitável apenas em anedotas para rodas masculinas e espetáculos de gênero livre. Já Leonel Araújo condena o nu, mas considera que a nudez artística deve aparecer ${ }^{85}$. A revista utiliza o termo pornografia, com certa freqüência, como sinônimo de erotização. A palavra é associada às pernas das atrizes nos filmes, o que reflete também o discurso da época sobre as chanchadas.

Virgínia Lane ora é condenada, ora elogiada nas edições da revista de acordo com o autor do texto. Geralmente aparece em pequenas fotos e notas. No ano de 1952, Lane foi citada seis vezes, mas sem destaque visual. Seus amores são chamados de "casos", entre aspas. A letra de sua música de carnaval é considerada "condenável" ${ }^{86}$. Cena Muda publica a canção somente por ter tido "êxito no gosto do povo", condenando a população de forma indireta. Apenas uma vez Virgínia Lane foi objeto de reportagem. Seu nome aparece como chamada numa capa, numa reportagem intitulada Oscarito e Virgínia Lane abafaram na festa de Alô, alô, Carnaval ${ }^{87}$. Ela distribuía beijos aos maiores lances para arrematar uma célula de um cruzeiro autografada por

\footnotetext{
${ }^{82}$ Eliachar, Leon. Revista ou imoralidade. Cena Muda, v. 32, n. 01, p. 03; 32, 03/01/1952.

${ }^{83}$ Só a mulher peca? Cena Muda, v. 32, n. 31, p. 15; 32, 01/08/1952.

${ }^{84}$ Ladeira, César. Palco Giratório. Cena Muda, v. 32, n. 19, p. 16-7, 08/05/1952.

${ }^{85}$ Araújo, Leonel. A cena noturna. Cena Muda, v. 32, n. 30, p. 07, 25/07/1952.

${ }^{86}$ Cena Muda, v. 32, n. 05, p. 31, 31/01/1952.

${ }^{87}$ A festa do congresso referido é o I Congresso Nacional do Cinema Brasileiro, ocorrido em setembro de 1952. Houve realmente o leilão da célula pelo presidente Café Filho, mas a seleção da revista, ao destacar tal ato, deixou de lado a cobertura a outros temas, como as teses apresentadas. Dines, Alberto. Oscarito e Virgínia Lane abafaram na festa de 'Alô Alô Carnaval. Cena Muda, v. 32, n. 39, p. 04-6, 26/09/1952.
} 
Café Filho e um cartaz do Congresso de Cinema assinado por vários atores. Porém, em todas as imagens, não vemos o rosto da vedete em destaque, como era comum com as demais atrizes do cinema brasileiro. Ela é fotografada de lado, beijando o público, no colo de um espectador, ou de longe com os artistas no palco. Em Cinelândia, Virgínia Lane mal era citada.

Quando o assunto é sexo, o tema é tratado em meio a eufemismos em Cena Muda. A personagem Ponina (Cacilda Lanuzza) do filme O Canto do Mar (1953), de Alberto Cavalcanti, prefere tornar-se prostituta a viver a vida de lavadeira no Recife. Apesar da clareza no tratamento do filme, Cena oculta até a palavra, chamando uma prostituta de "dona de pensão" 88 . O processo de ocultação da prostituição era comum em 1952. Pouco a pouca, Cena passa a tocar no assunto, falando depois em nudez e sexo. Cinelândia já nasce mais aberta ao tema.

Pode-se estabelecer uma clara diferença entre as estrelas brasileiras e as atrizes estrangeiras trabalhando por aqui. O apelo sensual das brasileiras é bem menor, como já dissemos. Contudo nos anos seguintes, lentamente se inicia uma maior erotização nas imagens também delas. Se nos primeiros anos, Tônia Carrero raramente aparecia mostrando as pernas nas duas revistas, o processo se altera. Logicamente havia apelo sensual nos personagens interpretados por Tônia Carrero. Contudo, estas imagens não eram congeladas nas duas publicações, apenas presentes na memória. Em 1954, já parcialmente desligada da Vera Cruz, Tônia Carrero é fotografada numa insinuação de nudez, como um embrulho de natal, num pano vermelho, como vimos. Para mostrá-la como mulher desejável, Tônia Carrero não aparece como mãe. Apenas uma vez, já em 1954, Cinelândia a fotografa com seu filho ${ }^{89}$. A atriz aparece também numa fotografia deitada na cama, numa cena do filme Mãos sangrentas (1954), de Carlos Hugo Christensen ${ }^{90}$.

É difícil estabelecer uma diferença entre a erotização das estrelas da Vera Cruz e da Atlântida. Num primeiro momento as fotografias da Vera Cruz não utilizam tanto o quesito sensual das estrelas, num suposto tom de recato, que distingue a companhia das demais empresas. Certo é que havia ainda um receio em conferir bastante sex appeal às atrizes brasileiras, num primeiro momento. Contudo, as grandes estrelas americanas se mostravam com incidência cada vez maior em insinuações de nudez, em biquínis ou

\footnotetext{
${ }^{88}$ Cena Muda, v. 33, n. 21, p. 31, 20/05/1953.

${ }^{89}$ Liberdade provisória. Cinelândia, v. 3, n. 48, p. 30-1; 74, $1^{\text {a }}$ quinz. nov. 1954.

${ }^{90}$ Andrea, Zenaide. O que eu vi nos estúdios. Cinelândia, v. 3, n. 50, p. 62-3, 74, 1 a quinz. dez. 1954.
} 
roupas transparentes, representação copiada pouco a pouco. Em 1954, as pin ups ou starlets do cinema nacional aparecem em Cinelândia em insinuações de nudez freqüentes, geralmente em banheiras ou deitadas em camas, com as pernas para o alto.

O discurso implícito da Vera Cruz contra o teatro de revista ou o rádio, descrito por Maria Rita Galvão, servia como uma ação para legitimar a diferença de suas atrizes. Nos boletins da companhia, anuncia-se que Inezita Barroso recusa-se a aparecer em programas radiofônicos. Aceitou apenas participar de Ângela (1951), de Tom Payne. O mesmo para Tônia Carrero. Ela não se deixou convencer a aparecer num teatro de revista. Recusou altos salários. Também Eliana Lage nunca teria pensado em fazer cinema antes da Vera Cruz, porque não participaria de atividades vulgares de outras companhias. (Galvão, 1976) Contudo não encontramos este discurso nas revistas contra o rádio, porque este tinha papel importante para estas publicações. Ao contrário, ele é muito elogiado em Cena Muda por produzir tantas estrelas.

Porém, Maria Rita Galvão observa uma mudança no comportamento da Vera Cruz a partir de 1952 com apelo publicitário voltado ao sexo, através de uma "vulgaridade inadmissível" (grifo da autora) de se relacionar com a companhia de até pouco tempo atrás. O artigo é transcrito por Maria Rita Galvão:

"No céu do Brasil há mais uma estrela, uma pin-up girl: Liana Durval, recentemente contratada pela Vera Cruz, e que deverá estrear em 'Nadando em dinheiro'. (Liana) é o tipo da pequena que valoriza um anúncio de refrigerante, porque ao mesmo tempo chama a atenção para o cartaz e provoca o necessário calor e respectiva sede... (...) Liana levanta a venda de qualquer maiô, seja ele 'tomara que caia', duas peças e principalmente bikini...” (Galvão, 1976: 210)

O boletim da Vera Cruz depois tenta legitimar a atriz do ponto de vista cultural: ela estudou canto, dança, dicção, mímica e história do teatro. O texto é acompanhado de fotos dela deitada em diferentes posições, vestindo maiô e depois um negligê semitransparente, e também envolta em toalha de banho. (Galvão, 1976)

$\mathrm{O}$ artigo acima citado foi aproveitado pela revista Cena Muda sem alterações ${ }^{91}$. Apesar do relativo destaque recebido pelo filme Nadando em dinheiro (1952), de Abílio Pereira de Almeida e Carlos Thiré, no mesmo ano de produção, Cena utiliza boa parte do release, incluindo a citação acima.

A tentativa de construir Liana Durval como nova estrela, levada a cabo em Cena Muda e Cinelândia, não se sustenta nem mesmo dentro da estrutura fílmica, dada a insignificante aparição da atriz. Liana aparece em pequenas pontas para mostrar seu

\footnotetext{
${ }^{91}$ A "pin up girl" de Presidente Prudente. Cena Muda, v. 32, n. 17, p. 27, 24/04/1952.
} 
corpo no papel de empregada insinuante. A personagem mal tem falas na história. Para ser convertida em estrela só mesmo através do sex appeal.

Quando as atrizes tiram a roupa ou abusam da sensualidade para fins publicitários, não em fotos feitas pelos estúdios, há tom de censura nestes dois periódicos. É o caso das atrizes Simone Silva e Terry Moore. A primeira tirou um lenço que cobria seu busto, e se deixou fotografar de topless em Cannes. Depois disse tratarse de um acidente, o lenço teria caído. Contudo, as imagens mostram o contrário. A segunda aceitou ser fotografada de maneira bastante insinuante com um ator. Além disso, foi convidada pelo exército a se retirar do segundo show feito na Coréia, por ter usado um maiô de arminho. Negou o potencial erotizado da imagem. Declarou ter usado a roupa porque se achou parecida com Papai Noel. Ambas são bastante criticadas em Cinelândia, dando origem às mais diversas versões da realidade.

A relação com a erotização dos corpos em Manchete era bastante avançada em comparação com as revistas estudadas. Manchete publicava em 1954 fotos com maior apelo sensual. Há muitas fotos de atrizes com os quadris a mostra, bem diferente do que Salvyano dizia ser o correto, quando estava em Cena, como veremos no último capítulo.

Enquanto a revista Manchete em 1954 apresentava fotos dos foliões com roupas bastante curtas, dois anos antes, Cena concordou com um decreto de um delegado proibindo roupas curtas e transparentes no carnaval, além da ingestão de bebida alcoólica nas festas ${ }^{92}$. Ao concordar com o decreto, Cena entra numa grande contradição, porque também apresenta como modelo vestes curtas e transparentes das estrelas estrangeiras. Surge um universo à parte na qual a representação das celebridades por meio da erotização dos corpos é positiva, permitindo apenas uma possibilidade projetiva ao público leitor. Num ambiente recalcado e conservador, as pulsões reprimidas vazam através da representação das estrelas. Forma-se, assim, um paradoxo entre o comportamento feminino quanto às estrelas, porque a exposição dos corpos seria reprovável às leitoras.

Em 1952, as fotos dos homens sem camisa ou de shorts eram raras e sempre pequenas, em preto e branco. Pouco a pouco a quantidade aumenta. O processo foi bem mais lento do que a representação do corpo feminino no mesmo nicho. Lidava-se melhor com o desejo de consumir a imagem do corpo das estrelas, não dos astros. Cinelândia começa com um número um pouco maior de fotos dos astros sem camisa,

\footnotetext{
${ }^{92}$ Carnaval. Cena Muda, v. 32, n. 8, p. 31, 21/02/1952.
} 
mas geralmente sem grande espaço visual. Rock Hudson é o ator que obteve maior destaque como galã em 1952, nas duas revistas, considerado o novo Rodolfo Valentino $^{93}$ por Cena Muda. A comparação é importante porque foi Valentino o primeiro ator a ser visto num discurso sexual explícito da beleza masculina, segundo Miriam Hansen. (Gledhill, 1991) Entre as fotos, vemos Hudson cozinhando na lareira. As ilustrações de homens cozinhando são quase sempre na lareira, ou em lugares improvisados. Talvez uma adaptação para fugir do ambiente feminino, conferindo um caráter de improvisação e talento. Como disse Laura Mulvey, deve haver alguma compensação pela exposição do astro como objeto passivo para o olhar do espectador, através dos atributos de controle e atividade ${ }^{94}$. Além desses atributos, para compensar a exposição ao olhar, procura-se mostrar os atores como grandes amorosos. Para construir a imagem de sedutor, Cena publica uma imagem de Fernando Lamas fitando a atriz Esther Williams, vestida com o maiô que ela usará no filme estrelado pelos dois ${ }^{95}$. Como num suposto flagrante, Lamas não observa a colega de trabalho, mas a estrela com seu corpo muito a mostra. O objetivo era provar tratar-se do novo latin lover, tendo por base também a transferência da personalidade atribuída a Rodolfo Valentino. Aqui, a estrela faz pose para ter seu corpo contemplado. Induz ao desejo:

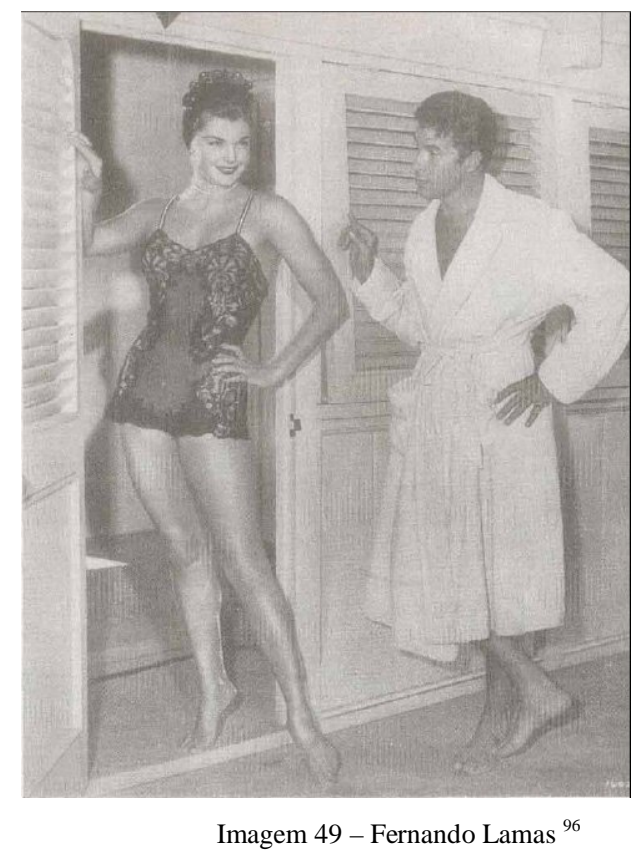

\footnotetext{
${ }^{93}$ O bonitão Rock Hudson. Cena Muda, v. 32, n. 24, p. 10-1, 12/06/1952.

94 "The female star was, I argued, streamlined as erotic spectacle while the male star's attributes of control and activity provided some compensation for his exposure as a potentially passive object of the spectator's look". (Mulvey, 2006: 165-6)

95 Brito, Dulce Damasceno. O 'sex appel' (sic) de um casanova argentino. Cena Muda, v. 33, n. 14, p. 18-9, 01/04/1953.

${ }^{96}$ Brito, Dulce Damasceno. O 'sex appel' (sic) de um casanova argentino. Cena Muda, v. 33, n. 14, p. $18-9,01 / 04 / 1953$.
} 
Entre os atores brasileiros, no primeiro ano de análise raramente havia imagens de atores sem camisa. Quando havia, eram fotos minúsculas ${ }^{97}$. Nos anos seguintes, há um grande aumento das imagens em cores de homens sem camisa em Cinelândia, geralmente tomando banho (aparece somente o rosto e os ombros) ou praticando esportes. Farley Granger aparece de shorts com grande destaque para seu tronco e músculos, assim como Jardel Filho é mostrado num pequeno calção levantando peso.

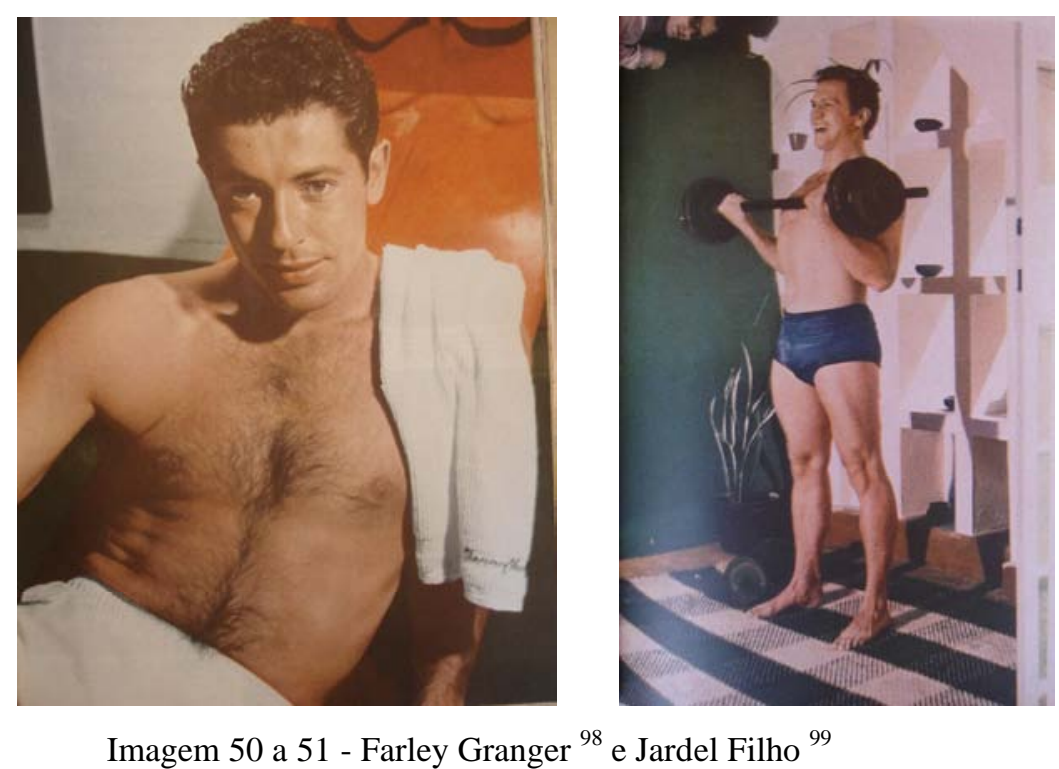

Voltando à erotização da mulher, há um antagonismo entre o discurso da imagem e do texto. Em geral, a erotização do corpo da estrela é negada textualmente, ressaltando os atributos de dona de casa, ou de bondade extrema. A imagem traz a estrela como um ícone sexual, mas o texto deve abrandar esta mensagem. No geral, esta é a base para a representação imagética das estrelas, principalmente das estrangeiras.

Dessa forma, o traço mais importante para se entender a configuração da erotização nas revistas de fãs é a ambigüidade:

\footnotetext{
${ }^{97}$ Oscarito foi fotografado sem camisa, mas o tom era humorístico. Paulo Monte aparece de calção na praia, como publicidade de seu último filme, Fatalidade (1953), de Jacques Maret. Cinema nacional em foco. Cena Muda, v. 33, n. 42, p. 8, 14/10/1953.

${ }_{98}$ Connoly, Mike. Ele consegue tudo o que deseja. Cinelândia, v. 2, n. 13, p. 26-7; 52, maio 1953.

${ }^{99}$ Werneck, R. Um atleta no cinema. Cinelândia, v. 3, n. 34, p. 30-1, 1ª quinz. abril 1954.
} 

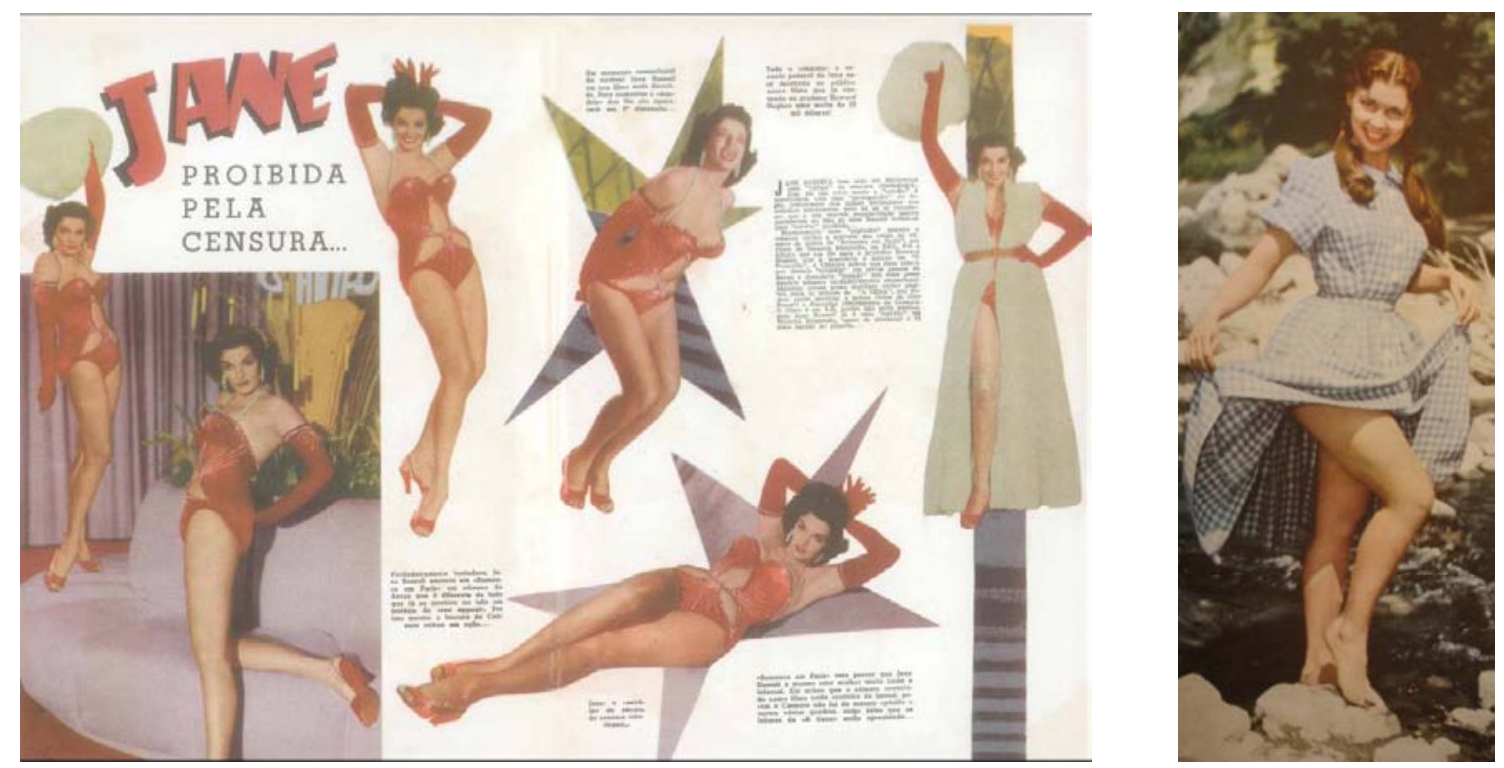

Imagem 52 a 53 - Jane Russel ${ }^{100}$ e Mitzi Gaynor ${ }^{101}$

As ilustrações acima se referem aos dois tipos de ambigüidades presentes nas duas revistas. No primeiro, a ambigüidade se processa na relação entre imagem e texto, mais comum. Jane Russel foi questionada pelo sex appeal presente nas cenas do filme Romance em Paris (1954), de Lloyd Bacon. A atriz desabafa (verbo a indicar intimidade com o leitor) a Cinelândia porque se considera inocente ${ }^{102}$. Transfere a culpa ao diretor. Não quer mais papéis extravagantes e escandalosos, por ser muito devota. Fará tudo para não ficar mal com a igreja. A partir da constatação de que a estrela tem religião, se diminui o aspecto negativo do apelo erotizado, visto ainda de forma pecaminosa ${ }^{103}$. Por ser uma atriz religiosa e aparecer vestida a ressaltar o corpo nos filmes, se incita um novo tipo de moralidade, na qual a relação com o corpo vai se moldando a um novo padrão de normalidade. Supostamente, os atores argumentam que fazem o ordenado pelos diretores, mas não sabem com vai sair o resultado. Não se sabe o que a câmera fixa, não dá para controlar os movimentos, declara Russel. A culpa recai sobre o cineasta. Este não cortou os planos prometidos.

Em Cena Muda vemos claramente a estratégia publicitária da revista concorrente, uma vez que fica clara a utilização das mesmas fotos de Jane Russel apenas citadas em Cinelândia. As posições das imagens são insinuantes. A roupa

\footnotetext{
${ }^{100}$ Jane proibida pela censura. Cena Muda, v. 34, n. 37, p. 24-5, 2a quinz. dez. 1954.

101 Trent, Susan. Mitzi não chorou. Cinelândia, v. 2, n. 13, p. 39; 66, maio 1953.

${ }^{102}$ Serrano, Louis. O desabafo de uma estrela. Cinelândia, v. 3, n. 42, p. 20-1; 57, 1ª quinz. agost. 1954.

${ }^{103}$ Paulo Emilio Salles Gomes já apontou a relação entre o erotismo, o prazer sensual, ao mal, pecado e vício. Gomes, Paulo Emilio Salles. "Erotismo e humanismo". IN: Crítica de cinema no suplemento literário. Rio de Janeiro, Paz e Terra, 1981. v. 2.
} 
acentuar as marcas de seu corpo. O discurso é da linguagem maliciosa ${ }^{104}$. Incita-se algo, para se negar depois, com ar inocente. Na verdade, Peter Lev (2003) mostra que a campanha negativa feita beneficiou o filme.

O segundo exemplo é menos comum por ter a ambigüidade presente na estrutura da imagem. A atriz Mitzi Gaynor aparece caracterizada como uma moça inocente, cabelos divididos, vestido aparentemente recatado, comprido, quadriculado e fechado, com grandes botões. Tudo isso na paisagem de um rio de águas borbulhantes. Contudo seu sorriso é malicioso. Ela levanta a saia para mostrar as pernas. Há intenção consentida de forma explícita através da pose artificial. As fitinhas no cabelo opõem-se o ar de enfrentamento da atriz frente à câmera. A imagem representa a síntese da ambigüidade, o discurso da erotização junto à ingenuidade, características das imagens das revistas de fãs.

Paulo Emilio Salles Gomes analisou a relação entre a sinceridade da personagem interpretada e a representação da estrela em sua vida nos meios de comunicação para compreender o mecanismo de funcionamento da criação do mito, calcado sobre Theda Bara e Rodolfo Valentino. A diferença entre os dois era uma sinceridade, que chamaremos aqui de conciliação, entre os papéis interpretados por Valentino e Theda com suas supostas personalidades mediáticas. Realmente o ator era/sentia-se um grande amoroso. Por sua vez Paulo Emilio mostra que Theda Bara foi uma criação artificial dos estúdios. Ninguém acreditou se tratar da filha de um sheik com uma egípcia, conhecedora de feitiços. A relação entre a vamp sugadora da alma dos homens através do beijo era vista com interesse nos primeiros filmes por ser exótica ${ }^{105}$, mais do que por sua carga de erotismo. Depois o interesse mingou. Theda tornou-se, então, ridícula. O trabalho de publicidade não pode quebrar a autenticidade entre estrela e personagem. Para Salles Gomes, precisa existir uma sinceridade entre a personalidade da personagem e da atriz. A conciliação entre as duas personalidades seria a responsável pela criação do mito. (Salles Gomes, 1981)

\footnotetext{
${ }^{104}$ Dino Prete trata apenas da questão da linguagem, mas aqui fazemos um paralelo entre linguagem e imagem. O autor esclarece que há um significante escondido no vocabulário, com as manipulações que o falante realiza para passar e não passar, dizer e não dizer ao ouvinte, eximindo-se de uma responsabilidade na comunicação. Deve haver um comprometimento entre autor e leitor. Prete, Dino. "Algumas peculiaridades da linguagem maliciosa". In: A gíria e outros temas. São Paulo: T. A. Queiroz, 1984", p. 51-68.

${ }^{105}$ A posição de Paulo Emilio é totalmente diferente da de Edgar Morin. Segundo Morin, com o tempo as vamps caem no ridículo pela evolução do cinema. Morin não analisa o espectador como alguém apenas curioso pela novidade, mas acreditando nos mitos criados.
} 
Abrimos um parêntese para trazer uma opinião diferente sobre Theda Bara. A contradição na persona de Bara não está somente na falta de autenticidade entre a personalidade da artista e da personagem, como nos levaria a supor Paulo Emilio Salles Gomes, mas na incongruência entre a moralidade da atriz e o papel por ela estrelado. Para Richard DeCordova (2001) a imagem da vamp, perigosa para os homens, entrava em contradição com o discurso da moralidade dos atores. Ela parecia normal na vida real, mas havia o perigo da sexualidade de seus papéis. Os escândalos dos anos vinte, analisados mais à frente no item sobre Crítica aos olimpianos, alteram a representação da moralidade do ídolo. Há uma mudança no local da sexualidade naquela década. DeCordova aponta que o último segredo a ser revelado sobre a vida privada calca-se na sexualidade, último refúgio para adentrar na identidade da estrela. Considera DeCordova que apenas o discurso sobre os escândalos sexuais promete satisfazer por completo a chave da identidade, como se os segredos vinculados nas revistas de fãs e na imprensa nunca estivessem dissociados da sexualidade. Em nossa pesquisa sobre a década de cinqüenta, a sexualidade continua a ser um componente importante, mas continua muito eufemizada nas revistas pesquisadas. Acreditamos que nem mesmo o discurso sobre a sexualidade da estrela a revele por inteiro. $\mathrm{O}$ ídolo tem de permanecer como enigma até o fim, como já pontuamos. Embora existam também similitudes nas nossas conclusões com as descrições de DeCordova sobre o tema da sexualidade e moralidade, como veremos agora.

A tese de Paulo Emilio pode ser repensada para as estrelas da década de cinqüenta, com uma diferença: o papel da ambigüidade a representar a confusão entre atriz/personagem. Não há necessariamente uma sinceridade/conciliação entre personagem e atriz, mas uma demanda por se checar os pontos de contato, porque elas são divergentes e convergentes ao mesmo tempo. Cada vez que se buscam similitudes, encontram-se diferenças. Não se pretende mais encontrar uma total aderência entre personagem e atriz. A ambigüidade incita a curiosidade no leitor-espectador sobre a personagem interpretada e a das estrelas. São as good bad girl representadas por Marilyn Monroe. O apelo exagerado das roupas justas e do olhar sensual devem ser minimizados por declarações de que Marilyn é uma boa moça, interessada em casar e ter filhos. Não gosta de festas, prefere cozinhar macarrão para Joe Di Maggio. No papel interpretado nos filmes, Marilyn aparentemente tem uma vida reprovável, moralmente 
maleável, mas tem bom coração ${ }^{106}$. É vista de maneira errada pelos outros. A ambigüidade já está no papel interpretado, compondo o quadro com a vida mediática da atriz.

A ambigüidade lida com o sensacional, com o que esta fora do padrão de normalidade. A incerteza aumenta o interesse. A ambigüidade rege a relação da sexualidade. Algo precisava estar subentendido; por pudor não se podia revelar tudo. Já as ingênuas possuíam uma relação menos ambígua entre papéis interpretados e vida mediática, mas se procura germinar a dúvida sobre sua "real" personalidade. Veja-se o exemplo de Fada Santoro. Cria-se uma certa dose de ambigüidade nos papéis interpretados de mulher com mais sex appeal em filmes como Nem Sansão nem Dalila (1954), de Carlos Manga, ou Barnabé tu és meu (1951), de José Carlos Burle. Porém, na vida real não há ambigüidade, puxando a incerteza da diegese. O importante é nunca revelar totalmente quem é a estrela. Deve existir ambigüidade, especialmente nas vamps, pois esta é a chave da sexualidade. As vamps possuem uma carga erótica muito maior, mas há sempre um tratamento ambíguo, uma vez que a erotização total mata a aura de perfeição moral conservadora da estrela. E são exatamente as atrizes com maior carga de ambigüidade os mitos de primeira grandeza, que perpassam as décadas, como Marilyn Monroe.

A dicotomia presente nas estrelas é a do ser e parecer. Não importa o ser (talentosa, linda, boa) se não estiver acompanhado do parecer ser tudo isso ao leitor, por meio das imagens. Porém a foto sempre revela algo a mais. $\mathrm{O}$ que o leitor quer realmente é desvendar o segredo da estrela. É a ambigüidade que gera o interesse pelo segredo. A personalidade total da estrela é o segredo que não pode ser revelado. A ambigüidade é a chave do estrelismo do período estudado, reflexo do mundo em transição. A estrela mostra o certo e errado, deixa pistas que dão segurança, mas também confunde para fazer pensar no padrão da normalidade, do ser e parecer. E Cinelândia sabia se cercar e utilizar a ambigüidade com maestria, uma das razões de sua permanência no mercado.

A exposição do corpo feminino, utilizada como atração aos leitores, era geralmente feita a partir de organizações textuais focalizando a estrela de forma não

\footnotetext{
${ }^{106}$ Richard Dyer acredita que Marilyn Monroe conseguia ter sex appeal sem ser ameaçadora, daí o protótipo de mulher não muito inteligente. Sua persona inocente quebra a barreira entre sexo e culpa (Dyer apud Lev, 2003). O autor relaciona ainda a atriz com a disseminação das idéias de Freud no pós segunda guerra mundial (Dyer, 1998)
} 
erotizada, diferente dos exemplos acima citados. A seguir, concentramos nossa análise na composição textual da persona.

\subsection{Construção textual:}

Por meio da construção textual, se busca realçar principalmente as qualidades morais da estrela. Tais valores trazem a bondade do ídolo e a concretização da felicidade via casamento, mas devido a um universo já em transição para uma incapacidade da estrela em continuar no papel de transmissora da felicidade, as revistas trazem também críticas de cunho moral às atrizes, problemas no casamento, mortes prematuras e sofrimento, causados em grande parte pelo insucesso no amor. Iniciamos este bloco de estudo pela dicotomia bondade versus sofrimento, porque esta pontua os demais itens.

\subsubsection{Bondade e sofrimento}

No período estudado há uma transição. A estrela é sempre boa, mas mesmo assim sofre. A conseqüência é uma concepção de destino e fatalidade. Este antagonismo precisa ser continuamente explicado aos leitores. Por outro lado, o ídolo passa a errar, mas jamais com dolo. As falhas formam uma base para o leitor não cair nas mesmas armadilhas. Neste tópico, nos concentraremos apenas nos casos de sofrimento da estrela, deixando os erros para o último subitem deste capítulo.

A bondade deve manifestar-se não só nos papéis interpretados, mas também na vida privada. A estrela, como descrita por Edgar Morin (1957), não pode ser apressada, desatenta e descuidada com seus admiradores. Por exemplo, mesmo ante um acidente causado por outrem, Eliane Lage socorreu as vítimas ${ }^{107}$. Um caminhão desgovernado atingiu seu jeep. Na tentativa de desviar, a atriz atingiu uma carrocinha de frutas, mas não deixou de prestar atendimento ao vendedor. Afinal, ela não poderia ser modelo de comportamento se não fosse boa com todos. $\mathrm{O}$ infortúnio foi convertido em ganhos à atriz, porque a vítima deu parecer favorável a ela no processo.

Nos casos de sofrimento, quase sempre de ordem amorosa, há dois tipos. Os sofrimentos de amores passageiros são vistos de forma romantizada porque são uma

${ }^{107}$ Kalamar, Paulo. Eliane não foi julgada. Cena Muda, v. 32, n. 03, p. 08, 17/01/1952. 
forma de busca da felicidade. Depois há os casos mais sérios, que terão outro desfecho nas revistas, abordados no tópico sobre a morte dos olimpianos.

A atriz Maria Felix é chamada em Cena Muda de eterna prisioneira ${ }^{108}$ porque declarou viver num cativeiro. Supostamente seu empresário bloquearia seus encontros com seu amado, Rossano Brazzi, numa situação inverossímil da estrela ser submissa ao agente. Paradoxalmente, cria-se uma demanda para provar que também o agente a ama, daí o comportamento autoritário. Como era comum nas duas revistas de fãs estudadas, depois de fazer a apologia à estrela, nas últimas linhas o autor lança o verdadeiro motivo. Maria Felix admite ter tido alguns romances na Itália, apenas "para se distrair" e esquecer, descompondo a imagem da diva sofredora, construída antes. Um ano depois, a atriz casa, mas com outro homem.

Há um duplo movimento. As revistas buscam convencer os leitores da felicidade completa dos olimpianos, depois decretam o sofrimento dos ídolos. O objetivo de mostrar as vicissitudes é humanizar os deuses para aproximá-los dos leitores, através da simpatia com apelo melodramático. O objetivo é conscientizar os leitores que mesmo os que têm tudo, sofrem. A consternação é causada pelo componente amoroso. Uns não podem ter filhos, há os calvos, os com doença contagiosa, os que perderam amores ou se divorciaram. Por causa do sofrimento amoroso, a estrela passa a ter às vezes problemas no seu trabalho. Fica implícito que ao resolver os problemas de amor, tudo se resolverá.

Observamos também a obrigação de ser feliz e a concepção de fatalidade num texto escrito pela atriz Joan Crawford: "ou a gente merece a felicidade e consegue ser feliz ou não merece, e ela foge de nós" ${ }^{109}$. O artista de cinema tem de ser feliz, "porque do contrário a sua infelicidade se refletirá no seu trabalho e lhe prejudicará toda a carreira." Em casa, se os filhos estiverem zangados, devem voltar para o quarto, até melhorarem de humor, dispostos a sorrir. A obrigação de parecer feliz é exigência para a convivência em grupo. Há uma novidade no artigo: a incompletude da felicidade: “ainda não encontrei a felicidade completa, mas quem foi que já a encontrou?"

A felicidade continua extremamente atrelada à noção de merecimento, principalmente aos batalhadores. Em Cinelândia, há uma alteração: as menções à falta de dinheiro dos astros, a competição desleal com os freelancers novatos e a conseqüente

\footnotetext{
${ }^{108}$ Conrado, Alberto. Maria Felix continua sofrendo - a eterna prisioneira. Cena Muda, v. 32, n. 09, p. $16-8 ; 32,28 / 02 / 1952$.

${ }^{109}$ Crawford, Joan. O que a felicidade significa para mim. Cinelândia, v. 1, n. 2, p. 8-9; 44, junho 1952.
} 
falta de trabalho em virtude da idade mais avançada. Outra transição na representação do star system são algumas imagens de apartamentos bastante simples para o padrão hollywoodiano, com a explicação de que nem todos ganham bem ${ }^{110}$. Há também a desilusão com o sucesso, porque existe inveja ou se trabalha demais, sem aproveitar a vida, perspectiva não explorada na revista concorrente.

Em Cinelândia, as estrelas começam a abrir sua vida pessoal para a mídia. Em alguns momentos, são vistas como vítimas do ambiente em que vivem (Hollywood). Chegam a pedir ajuda, como vimos no capítulo anterior. Cinelândia começa a se abrir para um tipo de problematização do mito da felicidade, descrito por Edgar Morin, mas de forma lenta, porque a grande maioria dos problemas são temporários. Afinal, não se deseja comprometer em sua totalidade o mito da felicidade abordando temas sérios.

O sofrimento da estrela abordado neste item é acrescido em Cinelândia de uma narrativa sobre novos temas. Estes serão a abertura para o questionamento posterior dos

\footnotetext{
${ }^{110}$ O processo descrito por Cinelândia tem relação com o declínio do studio system, alterando também a configuração do estrelismo. Os salários caíram e a estabilidade nos estúdios terminou. O sistema gerador do estrelismo estava em declínio de suas características originais da década de quarenta, observação atestada por Peter Lev (2003). O studio system das décadas anteriores congregava uma integração vertical que incluía não só a produção, distribuição, como principalmente a exibição. O sistema possibilitava lucro certo, mesmo se as empresas perdessem numa etapa de produção, pois elas retomavam os gastos com o lucro da exibição e vice-versa. No final dos anos quarenta, o governo considerou as relações entre as oito maiores empresas cinematográficas como um trust, exigindo o desmembramento da exibição. Os exibidores ficariam obrigados a transmitir filmes não só das grandes empresas, das quais eram participantes diretos. A nova regra queria aumentar a competição entre as companhias, possibilitando acesso ao mercado às demais empresas. O montante do lucro caiu bastante, e as novas empresas tiveram de se adaptar às novas regras. Nasce um modelo transitório chamado de individually packaged films, já utilizado pelos produtores independentes, que passa a ser cada vez mais usado. De acordo com Janet Staiger (Staiger apud Lev, 2003), a chave desta nova organização é a produção individual, mas continua a existir a produção do estúdio de antes. O filme de estúdio continuou a ter presença, porque apesar de não controlar todas as etapas da produção, as empresas podiam propiciar os elementos cruciais para financiar as exibições. No novo modelo, a contratação era feita por filme, diminuindo os longos contratos com atores, diretores e roteiristas. O novo sistema não era totalmente independente, porque com a falta de sucesso de muitos filmes da década, os bancos passaram a exigir financiamentos com garantias. Assim, os produtores independentes precisavam negociar com as produtoras. A mudança alterou também os critérios do estrelismo. Surgiam os atores freelancer contratados para filmes específicos. As agências de talento ganharam proeminência neste período. Antes tinham poderes diminutos frente às produtoras. Havia agências destinadas a criar roteiros de filmes a partir do perfil de determinado ator. O elenco passa a ser feito a partir dos atores disponíveis, não obrigatoriamente do casting dos estúdios. Muitos atores e diretores criaram suas próprias companhias. A principal parte dos problemas enfrentados pelas principais companhias norte americanas de cinema com a queda nas fortunas de 80 a 90 milhões de dólares na década de quarenta para 60 milhões em 1950 era também um reflexo do papel preponderante da televisão. Contudo, Thomas Schatz (1991) lembra que com a reformulação do studio system para a operação filmepor-filme, o critério mais confiável para se julgar o valor de um projeto era o apelo comercial da estrela. Os bancos não faziam mais financiamentos para a produção anual dos estúdios, mas para projetos individuais. Invariavelmente os projetos giravam em torno das estrelas, e eram pacotes preparados por agentes. Os estúdios não estavam interessados mais na carreira de uma atriz a longo prazo. Enquanto isso, as agências, como a Music Corporation of América, ocupavam o espaços das companhias. Lew Wasserman foi o mais famoso agente desses tempos. No início dos anos cinqüenta, a MCA tinha mais artistas sob contrato do que qualquer outro estúdio. Wasserman organizava mais projetos e star vehicles que qualquer outro produtor de Hollywood.
} 
cânones do star system: a questão do divórcio e da morte, indícios de algum tipo de crise na representação do universo dos olimpianos. Traremos a seguir a abordagem destes temas e o grau de conscientização na construção destes problemas.

\subsubsection{Casamento e divórcio}

Discutir os casamentos de Hollywood é tema recorrente em Cinelândia. Mais do que a felicidade a revista aborda os diversos problemas surgidos no relacionamento. Esta representação do matrimônio pode ser classificada em seis tipos: 1) os textos de conselho sentimental com os depoimentos das estrelas narrando como superaram as crises do casamento, detalhando também como deve ser a relação do casal; 2) as discussões sobre casar cedo ou não; 3) os recorrentes casamentos de última hora em Hollywood ${ }^{111}$; 4) as dificuldades do casamento, inclusive a questão econômica; 5) esposas em melhor situação econômica do que seus cônjuges; 6) as críticas às esposas. Logicamente, todas estas matérias são acompanhadas da publicidade dos próximos filmes dos atores citados.

O casamento é visto em Cinelândia como algo arriscado, por isso a revista busca debater de forma aparentemente aberta as causas da separação. Os motivos são entrados na mulher: desde o excesso delas no mundo, as autoritárias, as esbanjadoras e as com maiores salários, um dos maiores temores dos homens, de acordo com a publicação.

Às vezes a culpa pelo insucesso do casamento recai sobre a tribulação da vida em Hollywood. Marilyn Monroe declara ser impossível a felicidade na Meca do cinema. Se o casamento é descrito como plena felicidade, o divórcio também passa a ser uma possível concretização de felicidade ao lado de outrem. O divórcio abre espaço para viver outros amores. Possibilita ao leitor ler novas novelizações de sonhos possíveis. A disponibilidade das atrizes aumenta as possibilidades projetivas do leitor sonhar com ela. Assim, depois de enfatizar por edições a fio o sofrimento de Marilyn Monroe, as fotos a mostram feliz e sorridente, quase se lançando para fora de um vagão de trem, dando a sensação de liberdade ${ }^{112}$. A imagem da felicidade nesta pausa do amor possibilita o relaxamento da tensão após acompanhar o sofrimento do ídolo por tanto tempo. Agora sem o marido, ela não reclama mais das locações fora da cidade. A atriz parece se rejubilar nas imagens, com os braços abertos.

\footnotetext{
${ }^{111}$ A maior parte das estrelas casa de improviso. As filmagens em locais distantes vão demorar alguns meses, mas o casal apaixonado não consegue ficar tanto tempo longe, então se casam de última hora.

${ }^{112}$ Marilyn Monroe ferroviária. Cena Muda, v. 35, n. 4, p. 46, 2ª quinz. fev. 1955.
} 
A revista encontra a solução para atingir a ausência de problemas dos olimpianos: a estratificação social. Os dois devem ganhar bem. Outra forma de manter o casamento é a mulher abandonar a carreira, escolha muito elogiada. As esposas espertas deixam os maridos pensarem que estão no comando. Jeff Chandler ${ }^{113}$ viu seu lar desmoronar, até entender a necessidade de dividir as tarefas domésticas. Não considera mais a mulher má esposa, caso ela atrase o jantar. O mais importante é manter a aparência do homem estar no comando:

\begin{abstract}
"E é só para manter as aparências que, depois de bem discutida uma questão, diz-se a todo o mundo que fui eu que assim deliberei, pois Marge acha que devemos respeitar as regras do meio em que vivemos e fazer as nossas filhas acreditarem que são os homens que mandam no mundo. Mais tarde, elas compreenderão que não se trata de nenhum mito de superioridade masculina, mas simplesmente da necessidade de que o homem execute e faça cumprir as deliberações tomadas de comum acordo."
\end{abstract}

A fórmula de Cinelândia é admitir o distanciamento do casal para debater a possibilidade da reconciliação. Quando raramente a culpa é do homem, como no caso de Stewart Granger, tudo se resolverá porque os dois se amam ${ }^{114}$. Granger contraria sempre a esposa, que está "somatizando" (termo nosso) os problemas. O artigo alerta os leitores para não deixarem os problemas aumentarem de tamanho.

A visão das revistas é a da normalidade dos divórcios em Hollywood. Cena mostra que "colecionar" esposas ou maridos "é o passatempo predileto de muitos" da terra do cinema ${ }^{115}$. Liga-se o conceito de estrelismo exatamente ao excesso de divórcios: “Todo ídolo deve ter, pelo menos, um 'ex'. É o complemento imprescindível, sem o qual uma estrela não é estrela de verdade."

Há uma diferença muito grande entre a realidade brasileira e a representação do matrimônio nas duas revistas. Numa época na qual os divórcios não estavam legalizados no Brasil ${ }^{116}$, as estrelas estrangeiras terminam casamentos em alguns meses. Passam geralmente da terceira união. Em Cena Muda, a quantidade anterior de matrimônios das americanas geralmente é ocultada. Narrar a opção por casar no Uruguai é a forma utilizada por Cena Muda para deixar subentendido uma união envolvendo desquitados. Raras vezes há um tom de elogio, indicando transição, quando, por exemplo, se anuncia o casamento de Anselmo Duarte e Ilka Soares no Uruguai porque a união para ambos

\footnotetext{
${ }^{113}$ O meu lar estava desmoronando. Cinelândia, v. 1, n. 1, p. 22-3; 44, maio 1952.

${ }^{114}$ Seis perigos ameaçam Stewart e Jean. Cena Muda, v. 32, n. 15, p. 20-1; 33, 10/04/1952.

${ }_{115}$ Maria Luíza. Por que trocar de esposa? Cena Muda, v. 33, n. 52, p. 4-5, 23/12/1953.

${ }^{116}$ O divórcio no Brasil só foi legalizado em 1977.
} 
não deveria "significar um laço indissolúvel” 117. São descritos como “criaturas modernas" porque entendem o casamento como um acordo que não pode subsistir se infringido, deixando a possibilidade aberta para a não durabilidade da relação.

Em Cinelândia, os casamentos anteriores são enfatizados, quase num tom de elogio pela busca da felicidade. A normalidade no tratamento do divórcio mostra um mundo em transição, preparando terreno para a alteração no Brasil. Cinelândia tenta incentivar uma representação sobre a normalidade no divórcio e nova união. Afirma que as pessoas do cinema brasileiro solucionam seus problemas amorosos, sem "lágrimas amargas", "recriminações românticas" ou vinganças ${ }^{118}$. Estão compatíveis com a evolução dos tempos.

Quando não há ainda um compromisso, as revistas falam em "amizade masculina" para se referir aos romances. Quando há separação, os títulos costumam ser: “Quando não existe amor”. O mundo dos divórcios é apresentado geralmente sem culpados, quando se trata de traição masculina. Cinelândia enfatiza diversas vezes com normalidade os "romances" (alguns deles, extraconjugais). Sobre Gregory Peck, Cinelândia declara que as mulheres européias entendem a transgressão no casamento, e aconselham a paciência e perdão como melhor antídoto ${ }^{119}$. Busca-se vender um padrão comportamental diferente, onde trair é normal, mas só para os homens. Aliás, a infidelidade geralmente é dissimulada, para não atrapalhar a imagem de perfeição e bondade dos ídolos. Porém, quando o assunto é a traição feminina, o enfoque muda um pouco, como veremos no tópico Crítica aos olimpianos.

Quando as estrelas se separam, sempre alegam divórcio por crueldade mental do marido. Há um tom irônico na descrição, como um "exagero feminino", porque nenhum astro usa o termo. O divórcio por crueldade mental é o motivo clássico em Hollywood. O termo só poderia ser utilizada na meca do cinema. Ser cruel, além do sadismo, é não amar, abrindo um contra senso. Como seria possível não amar estrelas perfeitas? Os agentes da crueldade mental fazem sofrer às deusas. Contudo, eles também são astros. São insensíveis, causando danos psicológicos. Não se pode fazer sofrer uma estrela ou deusa. O curioso é que o termo aparece como uma brecha para uma condenação mais direta sempre ausente, porque os galãs são inocentados.

\footnotetext{
${ }^{117}$ Lua de mel: Ilka Soares-Anselmo Duarte. Cena Muda, v. 33, n. 28, p. 5-7, 08/07/1953.

118 O caso citado é o de Carlos Thiré, ex de Tônia Carrero. Thiré iria se casar com Maria Luíza, mas trocou alianças com Maria Pedroso D’Horta. A última é inclusive amiga de Tônia. Dessa forma, se enfatiza um clima de amizade coletiva no Olimpo brasileiro. Aconteceu no Brasil. Cinelândia, v. 3, n. 46, p. $48-9,1^{\text {a }}$ quinz. out. 1954.

${ }^{119}$ Maurier, Colette. Ele há de voltar. Cinelândia, v. 3, n. 33, p. 28-9, 64, 2a quinz. março 1954.
} 
Há que se destacar também um antagonismo de Cinelândia na representação dos namoros entre estrelas divorciadas. Às vezes Cinelândia toma um tom de normalidade quando as atrizes viajam com seus namorados, como Lana Turner, Ava Gardner, Gene Tierney, Rita Hayworth. Às vezes há uma nuance de censura. Lembrando o caráter especial destas deusas feito mulheres, elas concordaram com uma exceção, porque se trata de alguém também especial. A publicação censura quando um pretendente não se porta com a devida reverência em relação a uma deusa. Teme-se sua reputação.

Edgar Morin (1957) tem uma visão de ruptura histórica causando a alteração do mundo de encantos de Hollywood. A partir da morte prematura de James Dean e do suicídio de Marilyn Monroe, segundo ele, há uma crescente desmitificação. Os casamentos, brigas, o excesso de bebida, festas e internações, antes vistos como busca pela felicidade, passam a mostrar aos leitores apenas a atmosfera vazia da meca do cinema. A teoria de Morin busca padronizar um universo em contradições, mas a partir de nossas observações sobre a construção dos meios de comunicação, observamos alterações quanto a este modelo proposto, numa época anterior ao processo de ruptura descrito por ele. Ainda nos anos vinte, havia em Cena Muda uma ironia crescente em relação ao alto índice de casamentos das estrelas, processo abrandado nas décadas seguintes. Segundo, já há um tom irônico em relação ao casamento nas revistas. Apesar de o matrimônio ser tratado como o bem mais precioso e desejado da vida, há em Cinelândia paulatinamente um tom de condenação, mostrando a relação do casamento com o dinheiro, em artigos de procedência estrangeira:

\footnotetext{
"Às vezes somos a favor da comunhão de bens, quando a mulher ajudou o marido a ficar milionário e ele a trocou por outra, ela tem o direito de ficar com metade da fortuna dele. Mas como pode receber um centavo se não contribuiu em nada? Por essas e por outras, muitas pequenas já casam pensando na partilha dos bens quando chegar a hora do divórcio." ${ }^{120}$
}

Há uma simplificação dos problemas que geram o divórcio. Cinelândia repete frases do tipo: "não era apenas a distância que os separava. Era muito mais do que isso, era o orgulho". Apesar de abordar nos artigos as dificuldades de relacionamento dos casais, nas fotografias a união é apresentada sempre de maneira perfeita.

Acreditamos que a época de nossa pesquisa seja uma etapa transitória, onde os valores estavam sob processo de declínio, ampliando o debate sobre as questões

${ }^{120}$ Canfield, Alyce. Mexericos de Hollywood. Cinelândia, v. 1, n. 1, p. 12-3, maio 1952. 
relativas ao casamento e ao divórcio. Em Cinelândia, alguns matrimônios são vistos como fadados ao fracasso de antemão.

Há uma alteração na representação do casamento em meados dos anos vinte. Antes se buscava criar uma representação dos atores do cinema a partir do discurso da moralidade, além da vida saudável proporcionada pelo cinema. $\mathrm{O}$ ingrediente familiar entrava em cena. Richard DeCordova mostra que a representação sobre os atores do teatro envolvia escândalos e instabilidade. No cinema, o aparato da publicidade alterou a representação sobre a vida amorosa das estrelas. Antes de 1913, Photoplay se negava a responder perguntas sobre a vida dos atores. O casamento era mostrado primeiro a partir da felicidade conjugal, mas os problemas domésticos das estrelas começam a aparecer na imprensa entre 1920-21, alterando a representação da felicidade. DeCordova cita o primeiro caso de repercussão envolvendo a separação de Mary Pickford. Antes os divórcios até apareciam, mas ganhavam apenas algumas linhas, cobertura semelhante a de cidadãos importantes de outras áreas. Quando Pickford se divorciou, as revistas revelaram a separação física do casal muito tempo antes. Trouxeram como causa a brutalidade e alcoolismo do marido. Pickford declarou que não iria mais se casar, dedicando-se exclusivamente ao cinema. Meses depois, casou-se com Douglas Fairbanks. Como os dois casaram em pouco espaço de tempo, comentouse o relacionamento deles antes da separação dela. Contudo o adultério não foi citado. Sem culpados, a reputação do casal não foi abalada. Ao contrário, os dois transformaram-se em modelos da felicidade matrimonial e do bem viver. A representação de uma das maiores histórias de amor já vistas era acompanhada de menções à infelicidade anterior ${ }^{121}$. Os divórcios e transgressões tornaram-se depois a fórmula para escrever sobre as estrelas. Segundo DeCordova, apesar de se realçar o patamar de beleza e saúde dos olimpianos acima dos demais, o comportamento das estrelas quanto ao casamento era visto como semelhante ao de qualquer mortal. Nos anos vinte, fica evidente a diferença dos astros neste quesito, devido ao seu potencial ao escândalo. Contudo o que a estrela perdia em integridade moral, ganhava em termos de glamour nos anos vinte. Muitas conseguiram transformar as revelações em vantagens. Os casos de escândalos mostrando a alteração do discurso sobre a estrela nos anos cinqüenta serão retomados mais à frente no item Crítica aos olimpianos. (DeCordova, 2001)

\footnotetext{
${ }^{121}$ DeCordova mostra que a revista Photoplay e Motion Picture World não cobriram o caso, por suas
} ligações de cooperação com a indústria. 
O grande escândalo da separação de Ingrid Bergman acendeu na imprensa o componente da culpa da atriz, mas também foi reportado como uma grande história de amor. Acreditamos que a estrela ainda fosse uma guardiã da moralidade nos anos cinqüenta. Houve alteração e transição na moralidade aceita, mas sem grande mudança no papel de perfeição comportamental conferido à estrela. Este último tornou-se mais flexível em relação aos divórcios. Como já apontamos, os erros das estrelas são vistos de maneira passageira, como formas de se buscar a felicidade. Não alteram a visão positiva delas. Richard DeCordova (2001) mostra que não houve uma quebra na representação da moralidade do ator dos anos dez para os vinte, mas uma evolução. Os leitores almejavam por informações dos pontos obscuros, assim como das transgressões.

Voltando desse parêntese, os casamentos entre olimpianos são realçados, diferente do que é feito quando uma estrela casa com um simples mortal, não famoso, como foi o caso de Rita Hayworth e Dick Haymes ou Lana Turner com Lex Baxter, um ator de pouco prestígio. Por não ter dinheiro, Haymes é tratado em Cinelândia como um gigolô.

Embora os casamentos entre olimpianos sejam anunciados com destaque, quando a estrela casa várias vezes seguidas, a cobertura das duas revistas diminui bastante. Há uma alteração em relação à descrição de Morin. Ele aponta que eventos normais para os mortais, como casamentos, divórcios, nascimentos, são convertidos em grandes acontecimentos quando se trata de astros. Além disso, a vida idílica, sem grandes problemas não interessa muito. $\mathrm{O}$ nascimento de um bebê ocupa apenas uma matéria em cada revista, mas os problemas amorosos são repetidos à exaustão. $\mathrm{O}$ casamento não é tão importante quanto as fofocas sobre a infelicidade, como na estrutura do melodrama.

Como vimos, há uma transição para uma constatação futura de questionamento do sistema mágico do estrelismo, a partir do tema do divórcio e do casamento, embora no geral ainda prevaleça a imagem da busca da felicidade. No tema proposto a seguir, a morte é tratada com espanto e estranhamento pela perda dos olimpianos. Abordaremos nos casos a seguir o quanto havia, por parte das duas publicações, de questionamento e consciência de que as estrelas têm a sua finitude. 


\subsubsection{Morte}

A cobertura das revistas sobre casos de falecimento ou tentativas de suicídio dependia do grau de estrelismo dos agentes envolvidos. Há os casos de morte natural, como aquelas de Carmem Santos e de Moacyr Fenelon. Através de tributos curtos, ambos são relembrados apenas pelo trabalho e dedicação ao cinema nacional. A cobertura às mortes lentas por doença dos atores tem o mesmo tratamento dos não olimpianos, como Carmem Santos e Fenelon. Apenas desfrutam de um realce um pouco maior. No caso de olimpianos, há uma novelização enfatizando o grande amor entre os atores, como foi o caso da morte de Dixie Lee, esposa de Bing Crosby ${ }^{122}$. Como o fim já era esperado devido à doença, o objetivo é mostrar os erros do casamento. A história ocupa apenas uma matéria em Cinelândia. Depois, as publicações buscam desvendar se o ator já está interessado em outra mulher, constatação tratada com alegria.

Certa vez o tom do tributo caiu por terra em Cinelândia para mostrar os caçadores de autógrafos. Foi o caso do enterro de John Garfiel, interrompido a todo instante "pela desrespeitosa algazarra das mulheres que queriam autógrafos das estrelas e astros" ${ }^{123}$. No caso de falecimento em decorrência do alcoolismo, há o mesmo tom novelizado para demonstrar aos leitores os perigos da bebida, como no caso de Robert Walker ${ }^{124}$.

Quando o tema é o suicídio, a cobertura das duas revistas também não se volta ao sensacionalismo, caso da atriz tcheco-eslovaca Miroslava Stern ${ }^{125}$, que se matou porque seu namorado a trocou por outra, ou a do diretor Herbert Leeds ${ }^{126}$. Ambos são apenas citados em notas. O caso da esposa de Grande Otelo que se suicidou, levando junto a filha adotiva do casal, aparece de maneira discreta apenas no final de uma matéria ${ }^{127}$. Quando Cena fala da internação do ator, não é por causa da bebida alcoólica, e sim por cansaço do trabalho. Se a publicação quisesse ser sensacionalista, ressuscitaria o caso, apesar dos longos anos passados. Contudo, optou pela omissão, talvez em algum tipo de respeito à dor de Otelo.

\footnotetext{
${ }^{122}$ Charles, Arthur. E a última página de um romance de amor. Cinelândia, v. 1, n. 8, p. 20-1; 66, dez. 1952.

${ }^{123}$ Connolly, Mike. Mexericos de Hollywood. Cinelândia, v. 1, n. 6, p. 20, out. 1952.

${ }^{124}$ O adeus de Robert Walker. Cena Muda, v. 33, n. 35, p. 10, 26/08/1953.

${ }^{125}$ O que há de novo. Cinelândia, v. 4, n. 58, p. 16-7, $1^{\mathrm{a}}$ quinz. abril 1955.

${ }^{126}$ O que há de novo. Cinelândia, v. 3, n. 39, p. 18-9, $2^{\mathrm{a}}$ quinz. junho 1954.

${ }^{127}$ To aí de novo, macacada! Cena Muda, v. 32, n. 49, p. 26; 34, 05/12/1952.
} 
Não se novelizam os motivos do suicídio para os não-olimpianos. O pequeno destaque pode também ser explicado como um cuidado da imprensa em evitar noticiar atentados contra a própria vida. Quando não é possível omitir o fato, do ponto de vista ético, os jornais devem minimizar seu destaque para evitar que o ato seja imitado. Porém, como o forte destas revistas é a novelização e sensacionalismo, acreditamos que a razão esteja relacionada a outro fator, já explicado por Edgar Morin: os "núcleos obscuros da vida", assim como as críticas radicais e o "sentimento de absurdo" são atirados para a periferia projetiva, abafados pelo "mito da felicidade". (Morin, 1962: 129)

Além desse fator, há outro: as revistas criam uma visão otimista do mundo, como já vimos. A conversão dos problemas em felicidade é tão grande nas revistas, que até a tentativa de suicídio da atriz Judy Garland é transformada em um exemplo de "dar a volta por cima". O objetivo é mostrar quão especial e forte é Garland. Neste caso, Cena noveliza a tentativa de suicídio por dizer respeito a uma celebridade. A morte em si não é fator de sensacionalismo, depende de quem se trata. A tentativa de suicídio foi causada pelo declínio na carreira (a atriz estava com 39 anos), não por um amor, um caso único na representação da revista. Apesar de versar sobre a única história de desespero por causa da carreira, no final, a solução foi encontrada via amor conjugal de seu agente, Sid Luft. Este se tornou seu marido. O tema da matéria não podia ser outro; é a felicidade de ser mãe novamente ${ }^{128}$.

Nas demais matérias sobre a atriz, o declínio da carreira perde espaço para o fracasso do casamento e a relação ruim com a mãe ${ }^{129}$. Novamente, o tom é positivo em Cena Muda. Agora curada, Judy Garland fará sucesso no filme Nasce uma estrela (1954), de George Cukor. Há um mimetismo com a situação de vida da estrela. Apenas Cinelândia toca diretamente na tentativa de suicídio, com uma visão menos amena da realidade ${ }^{130}$. Aqui há uma novidade, a não certeza da felicidade futura, porque a natureza dela "é vulcânica". A morte não é questionada, mas sim a personalidade da estrela. Garland é considerada infeliz, insatisfeita. Enfim, não sabe o que quer. Não tem saúde, segurança. Os casamentos foram desastrosos. Ela não teve amores correspondidos. Além de tudo isso, não é bela. Não há tom de piedade, porque a culpa

\footnotetext{
${ }^{128}$ Anos mais tarde, a atriz morreu devido a uma overdose de medicamentos.

129 Parker, Russ. Judy Garland, a estrela que nasceu outra vez... Cena Muda, v. 34, n. 29, p. 22-3, 18/08/1954.

${ }^{130}$ Barbour, William. O retorno de Judy... Cinelândia, v. 3, n. 48, p. 36-7, 74, $1^{\text {a }}$ quinz. nov. 1954.
} 
recai sobre a personalidade dela. O sofrimento serve de publicidade indireta ao filme Nasce uma estrela.

Enquanto as revistas procuravam ocultar os problemas dos atores, no universo dos filmes o tema da decadência em Hollywood era retratado, em fitas como Nasce uma estrela $^{131}$ (1954), de George Cukor, Crepúsculo dos deuses (1950) de Billy Wilder ou Lágrimas amargas (1952), de Stuart Heisler. A desmitificação do ambiente de Hollywood, em Assim estava escrito (1952), de Vincente Minnelli, é ocultada em Cena Muda. Numa reportagem ${ }^{132}$, a única crise é a da atriz que se percebe joguete nas mãos do diretor. Porém, isso lhe dá forças para se transformar numa grande estrela. A reportagem é feita a partir dos ídolos presentes, sem revelar a densidade da trama de Minelli.

Durante o período pesquisado, não houve mortes trágicas de olimpianos. Apenas em casos de falecimentos trágicos há sensacionalismo e largo destaque. A história que causou comoção em Cena foi a do acidente automobilístico fatal do cantor Francisco Alves. Cena Muda deu destaque por mais de uma edição ${ }^{133}$ ao tema, incluindo uma reportagem de sete páginas fartamente ilustrada ${ }^{134}$, com uma multidão acompanhando o cortejo fúnebre.

Como as notícias envolvendo mortes de forma geral não chegam a causar a problematização da felicidade propagada pela cultura de massa no período estudado, rememorar a morte de um astro do passado, em Cena Muda, fortalece o mito a respeito da divindade dos atores. Aumenta também a nostalgia, criando comparações com os galãs atuais que seriam seus substitutos. Cultuar as celebridades do passado é enfatizar mais ainda o mito acerca de Hollywood, creditando-lhes uma grandiosidade a respeito de fatos pessoais construídos como acontecimentos históricos. A atriz que trabalhou com Rodolfo Valentino, Nita Naldi ${ }^{135}$, narra em primeira pessoa a "história do maior amante de todos os tempos". A morte dele levou à comoção coletiva de centenas de mulheres, além de influenciar dois suicídios. Nita passa a ser testemunha ocular de fatos desconhecidos do público e convertidos em acontecimentos históricos porque enumeram segredos concedidos aos fãs. O texto é romantizado por uma mulher apaixonada, não só pelo ator, mas principalmente pelo personagem. Nita salienta a

\footnotetext{
${ }^{131}$ O filme foi um remake da versão original de William Wellman de 1937. Portanto, o tema já era anterior.

${ }^{132}$ Assim estava escrito, um retrato de Hollywood. Cena Muda, v. 33, n. 12, p. 18-9, 18/03/1953.

${ }^{133}$ Edição n. 41-42 de 1952.

${ }^{134}$ Francisco Alves, imortal! Cena Muda, v. 32, n. 41, o. 21-28; 34, 10/10/1952.

${ }^{135}$ Naldi, Nita. Eu fui estrela de Rodolfo Valentino. Cena Muda, v. 32, n. 27, p. 16-19; 31, 03/07/1952.
} 
ambivalência entre os dois. De um lado o personagem, um amante felino com fúria selvagem. De outro, o ator, caracterizado pela suave carícia. Ambivalência esta percebida até por sua mulher. Ela só sentia a paixão ardente ao ver os filmes do marido, porque com ela, Valentino era sempre suave.

Assim o leitor terá a impressão de conhecer o ídolo em sua intimidade, sem considerar o testemunho como relativo. Talvez nem mesmo questione os fatos, porque a atriz é elevada à qualidade de autoridade histórica na construção da mitologia da estrela. Nita Naldi torna-se testemunha histórica porque estava com a esposa dele quando Valentino morreu, além de ter ouvido um vidente predizer sua morte três anos antes. Conhecia-o melhor que a esposa, provando sua inserção como testemunha. O ídolo, portanto, não se livra da divindade e, em especial, de seu destino fatídico.

O depoimento tem o estilo de um grande folhetim. Realça como Valentino era especial, e como Nita apaixonou-se por ele à primeira vista. $\mathrm{O}$ amor não correspondido nem frustrado era. Fica implícito que Nita não se achava digna de ser amada por um Deus. Escondia seus sentimentos através da amizade de muitos anos. Por meio destas revelações, ela converte a leitora em amiga, como uma confidente a compartilhar seus sentimentos. Ao mesmo tempo, busca se mostrar como figura generosa e altruísta por dividir seus segredos publicamente.

A personalidade de Valentino como felino não corresponde à forma com que os galãs do cinema da década de cinqüenta são idealizados nestas revistas. Eles são sempre transformados em bons moços, recalcando mais a erotização. Não há nenhum ator personificando as qualidades de sedutor de Valentino nas páginas de Cena Muda. Ele é comparado sempre a um felino ou selvagem: "sempre uma sugestão em seus abraços, como um selvagem que houvesse aprendido a arte de amar com uma deusa", descreve Nita Naldi. O beijo do astro com a mortal sempre parece um último adeus para Nita porque olimpianos não amam mortais.

Valentino é um deus que sofre, humanizado através do texto, de acordo com os cânones do star system da década de cinqüenta. Ser Rodolfo Valentino era ter uma "vida solitária e infeliz". Ele teria perguntado a Nita: "porque devo estar sempre tendo que provar aos outros que sou humano também?", numa época em que o astro de cinema parecia marmóreo e distante, sobre-humano; humanizado aqui numa matéria escrita segundo os moldes da década de cinqüenta. O mote principal é o publicitário por causa do lançamento de um filme sobre a vida do ídolo. 
Este depoimento vale como um suposto testamento ou diário de Valentino, antecederia o sofrimento das estrelas cujo ápice seria o suicídio de Marilyn Monroe e a morte prematura de James Dean. A estrela é humanizada a tal ponto que se enfatiza mais ainda sua divindade ante tamanho sofrimento. O texto serve como precursor da problematização da felicidade, descrita por Morin, porque não eram comum matérias como esta, embora o tempo do sofrimento esteja situado no passado.

O depoimento de Nita Naldi pode ser facilmente contextualizado através do trabalho de Miriam Hansen. Ela nos conta que Valentino incentivava a audiência feminina ${ }^{136}$. As mulheres mandavam peças de roupas para ele beijar e mandar de volta, tarefa executada pelo ator. Desconstrói-se também assim a imagem ingênua de Valentino como uma vítima da publicidade. (Gledhill, 1991)

Apesar de não existir um questionamento aprofundado sobre as questões de morte em Hollywood, porque a perspectiva das publicações é a da busca da felicidade, as revistas questionam em certos momentos algumas posturas comportamentais condenáveis dos astros, abordadas melhor no próximo tópico.

\subsubsection{Crítica aos olimpianos}

Deuses não erram, mas semideuses cometem pequenas falhas, passageiras, decerto. Assim é a representação das revistas de fãs quanto às falhas dos olimpianos. Há que se apontar um avanço na representação humanizada do estrelismo. Em décadas anteriores, os estudos indicam uma intolerância em relação a desvios quanto à moralidade predominante, sem grandes possibilidades de extrapolar as regras vigentes. As personalidades da tela e da vida mediática da atriz não podiam divergir demais. Observamos um período de transição neste protótipo. Esse processo estava em abertura nas revistas de fãs. É possível contrariar certas normas sem receber uma condenação explícita. As estrelas ainda deviam estar dentro de um padrão de moralidade razoavelmente conservador. Os romances em grande quantidade não são vistos de

\footnotetext{
${ }^{136}$ Miriam Hansen afirma que Hollywood criou o mito sobre Rodolfo Valentino, promovendo a fusão entre a sua vida e os personagens interpretados por ele na tela. Valentino foi o primeiro ator herói a ser visto num discurso sexual explícito de beleza masculina. Antes dele, a mulher era apenas fruto do olhar do homem sobre ela. Com Valentino, a mulher às vezes passa a sujeito do olhar. Estas mulheres, tratadas como vamps, às vezes sofrem algum tipo de condenação pela primazia no olhar. O que também tinha relação direta com a necessidade da época de quebrar a imagem da mulher restrita ao âmbito doméstico e maternal. (Gledhill, 1991: 259)
} 
maneira negativa, mas ainda é inexistente admitir manter romances só para passar o tempo. Se os atores não estivessem dentro deste modelo, pelo menos na aparência devia-se manter o padrão de perfeição nas revistas de fãs. Quando os ídolos não o faziam, eram criticados pelas mesmas publicações encarregadas de sua veneração, como um mecanismo de válvula de escape pronto a mostrar o problema latente.

Estas críticas, censuras ou reprimendas raramente são tratadas como de cunho moral, porque se trata de um período transitório, sem grandes alterações. As transgressões morais são abrandadas na maior parte dos casos para alterações comportamentais. Há dois casos de censura: o primeiro refere-se à antipatia, e o segundo, à vida sentimental.

O pior dos defeitos presentes nas revistas de fãs eram os casos de antipatia, principalmente em Cena Muda, porque este pressuposto anula as qualidades plásticas e artísticas. No cinema brasileiro, as críticas às estrelas antipáticas são mais raras, talvez porque elas pudessem revidar as acusações. Em Cena Muda, Luis Fernandes se propôs a condenar os atores brasileiros a cata de publicidade, os com complexo de Don Juan ou os que interpretam mal ${ }^{137}$. Todavia a coluna não vinga. $O$ repórter tenta se imbuir de poder. Em tom de ameaça, explica que a coluna é destinada à má publicidade. Tenta criar uma imagem aos leitores de ser temido pelos ídolos, como era supostamente Louella Parsons. Esta publicava às vezes uma coluna chamada de lista negra, condenando em Cinelândia geralmente os alcoólatras.

As condenações de antipatia aos atores estrangeiros eram mais comuns. Vale a mesma premissa: demonstrar ao público o poder da imprensa sob os olimpianos. Os dois casos mais comentados referem-se ao casal Frank Sinatra e Ava Gardner. No primeiro caso, busca-se mostrar a importância das revistas de fãs para o sucesso das estrelas. Frank Sinatra é considerado o inimigo número da imprensa porque desdenha jornalistas ${ }^{138}$. Tenta-se provar que a partir da condenação da imprensa e menor destaque ao astro nas publicações, a popularidade de Sinatra decaía. Como se fosse atingido por uma praga dos jornalistas, sua voz sumia, num acaso tornado destino. Apenas com o auxílio de jornalistas amigos, teria retomado o sucesso. Depois as

\footnotetext{
${ }^{137}$ Luis Fernandes escreve: por falar em cinema nacional. Cena Muda, v. 33, n. 4, p. 18-9, 04/11/1953.

${ }^{138} O$ casamento diminuirá a popularidade de Ava Gardner? Cena Muda, v. 32, n. 18, p. 16; 32, 01/05/1952.
} 
publicações mostram uma alteração comportamental no ator, tratando os repórteres de maneira gentil ${ }^{139}$.

O segundo caso ocorreu no Brasil. Ava Gardner foi condenada pela imprensa local, quando participou do Festival Internacional de Cinema do Brasil em 1954. Tanto Cena Muda quanto Cinelândia dão largo destaque ao tema, tentando apreender quem é verdadeiramente a estrela. $\mathrm{O}$ tema da censura foi o comportamento de Ava Gardner no aeroporto, reclamando do contato com o público, comparando o povo a selvagens. Depois teria quebrado móveis no hotel, sendo expulsa. A atriz se defendeu criticando o tratamento inconveniente dos fãs. Admitiu apenas ter quebrado um copo para aliviar a tensão, trocando de hotel por livre e espontânea vontade. No geral, Cena Muda toma uma postura mais dura, condenando mais a atriz porque bebeu whisky e falou palavrões. Afiança a expulsão do hotel, mostrando fotos dos móveis quebrados ${ }^{140}$. Este foi o único caso de crítica da imprensa brasileira a uma estrela estrangeira, porque sempre no contato com os jornalistas brasileiros o processo de mitificação aumentava. Por meio de uma publicidade negativa, se garante espaço ao seu último filme $A$ condessa descalça (1954), de Joseph Mankiewicz.

A censura aos atores antipáticos já estava presente nos textos de Guilherme de Almeida. O colunista se refere a John Barrymore como dotado de mau humor, tratando mal os entrevistadores. (Almeida, 1929)

Uma peculiaridade de Cena Muda em 1952 eram as críticas em tom pessoal, especialmente aos cantores do rádio. Na coluna social Quando fala o coração da "Tia Laura”, a colunista chega a citar nominalmente o nome dos cantores brasileiros que enganam moças, fingindo-se de solteiros.

O segundo tema de críticas são os romances, alguns deles extraconjugais. Cinelândia tem um tom de normalidade nestes casos quando os atores passam longos períodos na Europa trabalhando. A culpa recai na distância. Os casos são sempre de homens. Para abrandar o tema, não se fala em traição, mas em romances. Mesmo quando Clark Gable assume não querer compromisso, é desculpado. Não há condenação porque a revista tenta provar que interiormente o astro quer amar, trazendo exemplos de quão alegre estava em companhia de tais atrizes. Para Cinelândia, só falta o ator admitir publicamente o desejo de amar.

\footnotetext{
${ }^{139}$ Ava contra ataca. Cinelândia, v. 1, n. 3, p. 34-5; 54, julho 1952.

${ }^{140}$ A matéria foi publicada muitos meses após o final do Festival. Ava um show! Cena Muda, v. 34, n. 31, p. $8-11,42,21 / 9 / 54$.
} 
Porém, quando o assunto é a infidelidade feminina, o enfoque muda um pouco. Ingrid Bergman recebe num texto a nomenclatura de ré, citando o termo do processo pela guarda da filha ${ }^{141}$. O texto busca a suposta neutralidade ao trazer as duas cartas, a do esposo de Ingrid, chamado sempre de Dr. Lindstrom (as estrelas são sempre chamadas pelo primeiro nome), e a dela. A união com Rossellini é denominada de "casamento ilegal". No final, o texto explicita as razões da atriz, e a considera uma boa mãe. Afinal, não se podia vilanizar totalmente a estrela.

Apesar de considerar normais os romances extraconjugais, as atrizes muito "namoradeiras", como Rita Hayworth e Lana Turner, são criticadas. Mal tem tipo preferido de homem, porque saem com todos. Contudo os homens que namoram demais são vistos como sofredores de alguma decepção anterior, como Farley Granger ${ }^{142}$. Apenas Jacques Sernas ${ }^{143}$ foi realmente criticado em Cena Muda por ser um aventureiro e não querer casar. Aí estava o limite para não ser censurado. Independente da vontade, os ídolos devem admitir desejar casar ou encontrar o parceiro ideal. Procurar o amor conjugal é um imperativo.

Uma estrela sozinha por livre e espontânea vontade também era motivo de censura para ambas revistas. A explicação é simplista: estão sozinhas porque são muito exigentes. Outras são tratadas com piedade, porque já ficaram para “titia”. O sofrimento é explicado por uma psicologia banalizada. As causas são: narcisismo, problemas no relacionamento com a mãe, infantilidade, traumas de infância, não se desligar do passado, ou querer um romance como o dos livros.

Como as estrelas são olimpianas e modelos comportamentais, nos casos de crítica há sempre um movimento de remissão. O ídolo não pode ser visto de maneira totalmente negativa. Numa matéria se condena Shelley Winters por ser explosiva e querer o principal papel no filme Um lugar ao sol (1951), de George Stevens. Indiretamente se transfere a personalidade do papel interpretado à atriz. Depois, seu comportamento é explicado por um trauma de infância ${ }^{144}$. Quando criança, num acesso de birra, o pai ameaçou deixá-la sozinha. A partir daí, ela passou a achar que ninguém gostava dela.

\footnotetext{
${ }^{141}$ Howard Hughes quis usar a união do casal Ingrid Bergman e Roberto Rossellini e o nascimento do primeiro filho como publicidade para o lançamento de Stromboli (1950), de Rossellini. Este caso foi um dos que envolveu os escândalos do homem à frente da RKO. (Lev, 2003) A luta de Ingrid pelo amor de sua filha. Cinelândia, v. 1, n. 3, p.8-9; 56; 50, julho 1952.

142 Vida de artista - Farley Granger dos amores falhos. Cena Muda, v. 32, n. 38, p. 24-5, 19/09/1952.

143 Jacques Sernas trocou o cinema de sua terra natal pelo italiano. Cena Muda, v. 32, n. 35, p. 24-5, 29/08/1952.

${ }^{144}$ Para Shelley ou tudo ou nada. Cinelândia, v. 1, n. 5, p. 30, set. 1952.
} 
Em algumas notas, Cinelândia nomeia os atores que fazem de tudo para aparecer na imprensa. O tom é de reprovação e escárnio. A revista denega seu proveito porque vive numa relação de simbiose com estes mesmos astros. Esse tom de desmitificação e ironia é uma das diferenças do star system vinculado em Cinelândia.

Muito antes disso, o discurso sobre a moral perfeita dos atores tinha sido alterado nos anos vinte. Já mostramos como o ator de cinema era visto num discurso de moralidade, diferente dos escândalos dos atores de teatro. As primeiras críticas aos artistas surgem com os primeiros escândalos em 1920-21. Com eles, a estrela torna-se exemplo da transgressão e inconveniência social. Richard DeCordova (2001) enumera três casos principais que contribuíram com a mudança: William Desmond Taylor encontrado morto em 1922, Wallace Reid morto em decorrência de overdose de drogas em 1923, e o mais famoso dos casos, o falecimento de Virgínia Rappe numa festa do ator Roscoe "Fatty" Arbuckle em 1921. Estes escândalos iniciais não eram nada se comparados aos das décadas seguintes, mas trouxeram uma mudança. Não alteraram obrigatoriamente a reputação dos ídolos ou impediram carreiras ${ }^{145}$, mas mudaram o tipo de conhecimento acerca da celebridade. O sucesso não era mais a melhor forma de levar a vida da estrela. As transgressões passam a ser a forma dramática de transmitir sua existência, a partir do debate feito pela imprensa sobre a imoralidade dos atores. A partir de 1922, há uma inclusão de cláusulas nos contratos dos artistas sobre a moralidade, com risco de demissão ${ }^{146}$.

As contravenções são moderadas nas representações das revistas de fãs. O único grande escândalo representado é a união de Ingrid Bergman com Rossellini, que já tinha sido apaziguado pelo tempo. Portanto, as condenações leves dos supostos erros das celebridades situam o estrelismo destas duas publicações em linhas diferentes das

145 No caso de Roscoe "Fatty" Arbuckle houve prejuízo à carreira. Seus filmes foram banidos por Will Hays, da Motion Picture Producers and Distributors of América (MMPDA), apesar de ter sido inocentado no processo, composto de três júris diferentes. Arbuckle foi trabalhar no vaudeville. Anos depois Hollywood aceitou o seu retorno como diretor de pequenas comédias. Morreu em 1932.

146 Alexander Walker (1970) mostra que antes desses casos, já havia cláusulas contratuais sobre a moralidade, como o de Mary Miles Minter ainda em 1919 que a proibia de ser vista com freqüência em público. Devia viver só para o trabalho. Além disso, estava proibida de se casar. Havia outros casos mais extremos, como Dorothy Cumming, proibida de se separar do marido pela produção do filme de Cecil de Mille. Isso porque ela realizava o filme épico-religioso O rei dos reis (1927). Havia o temor da contradição com a imagem pessoal, como se o público aceitasse a personalidade interpretada na fita como a real. Este último foi um exemplo extremo porque infringiu a liberdade da atriz. Walker afirma que os casos extremos envolveram papéis sacros. Mas a relação com o estúdio não era só de condenação. No caso de Clara Bown, aproveitou-se sua reputação ruim (de perdulária e flapper) para realizar o filme No limit (1931), de Frank Tuttle. O termo flapper designa um estereótipo usado somente para os anos vinte. São as jovens independentes sintonizadas sempre com a moda. O estereótipo incluía mulheres que bebem álcool, fumam e gostam de dançar, sempre com cabelo e saias curtas. Além disso, eram desprovidas de preconceitos. Muitos na época as consideravam imorais. 
descritas por Edgar Morin e de DeCordova. A estrela comete erros, se comporta mal. Morin aponta uma condenação quando o astro não se porta bem, mas não explica as novas configurações sobre suas falhas. A seguir focaremos estes casos de transição dos padrões comportamentais através das alterações graduais do estrelismo.

\subsubsection{A transição na condenação comportamental: ambigüidade e elogio}

Os casos de transgressão de ordem moral são abafados, como traições e homossexualismo. Ainda em 1929, Guilherme de Almeida narra a seus leitores como Mary Nolan posou nua mais de uma vez, além de ter se apaixonado por um homem casado. Apesar da "tragédia", a atriz declarou que faria tudo de novo. Assim, um tema tabu aparecia ainda na década de vinte, menos subentendido que nos anos cinqüenta.

A proibição não existia apenas nas revistas. Era reflexo da produção dos estúdios, e principalmente de proibições legais. De um lado havia a Liga da Decência, coordenada pela Igreja Católica. Esta teve poder diminuto durante a década de cinqüenta, porque as objeções não atrapalhavam os filmes. Até ajudavam, como foi o caso do filme Romance em Paris (1954), de Lloyd Bacon. No final da década de cinqüenta, a Legião se tornou mais flexível em sua crítica à indústria, como mostrou Peter Lev (2003). Havia uma autocensura de Hollywood em temas sobre o comunismo, por exemplo. Elia Kazan foi convocado para depor porque realizava o filme Viva Zapata (1952) e porque tinha sido simpatizante do comunismo no passado. Os produtores temiam que o filme fosse visto como apologia ao comunismo. Assim, há em Cena fotos do filme, uma delas com Marlon Brando em estado de fúria ${ }^{147}$, mas os artigos apenas falam do ator, não da fita. Temas sociais também tinham tratamento cuidadoso para não infringir normas. O novo Código de Produção ${ }^{148}$ da indústria, de

\footnotetext{
${ }^{147}$ Marlon Brando - um talento excêntrico. Cena Muda, v. 32, n. 32, p. 4-5, 08/08/1952.

${ }^{148}$ A censura nos anos cinqüenta aos filmes da indústria americana é vista por Peter Lev como uma série de negociações. O Production Code Administration (PCA) era parte da autocensura da indústria fílmica, voltada a assegurar padrões morais aos filmes. O PCA foi estabelecido em 1934 para minimizar os perigos de uma censura externa. O governo estava envolvido em diversos níveis, via estado e censores locais, além da pressão exercida pelo congresso norte-americano. O primeiro código foi escrito em 1929, pelo padre Daniel Lord. A influência da Igreja Católica teve mais a ver com decisões políticas do que com o Código, que agradava também aos protestantes e judeus, estes últimos eram maioria entre os chefes dos estúdios. A regulamentação foi adotada no ano seguinte, trazendo a necessidade de não se ridicularizar a lei, divina ou humana, e nem mostrar personagens do crime de forma simpática ao público, além de determinar os princípios para se mostrar sexo, obscenidade, costumes, religião, crimes e brutalidade. Foi primeiro um alerta, que se tornou uma parte do Código Hays de 1934. Os produtores e
} 
1956, continuava a proibir cenas de violência física, abuso ou tortura, assim como de homossexualismo, tratado ainda como perversão sexual. O adultério devia ser mostrado como moralmente errado. Havia restrições para cenas de abortos, nascimentos de crianças e dependência de drogas. A miscigenação nem sequer era citada. No filme Chá e Simpatia ${ }^{149}$ (1956), de Vincente Minnelli, a inclinação homossexual do marido foi cortada do roteiro original. Houve três anos de negociações para a adaptação ser aprovada, além das negociações com a Liga da Decência. A atriz Debora Kerr teve de gravar uma nova versão da carta de sua personagem, enfatizando que o adultério era errado. Na década de cinqüenta, o código entrou em conflito com a audiência e as condições da indústria porque já havia uma grande ênfase à sexualidade. Com o número de espectadores caindo, as empresas queriam reavivar o interesse do público ${ }^{150}$. (Lev, 2003)

Richard Dyer (1998) lembra que a decadência dos atores já era mostrada nos anos trinta, mas apenas na década de cinqüenta a representação esteve presente de maneira maciça não só nas revistas, como nos filmes, incluindo também a possibilidade de uma maior liberdade sexual e extravagâncias dos atores.

Nas revistas de fãs pesquisadas, as discussões sobre a corrupção de Howard Hughes na RKO, os problemas do filme Viva Zapata e os questionamentos da imprensa sobre o Código de Produção não apareciam. Os temas ficavam escondidos sob o enfoque da vida íntima das estrelas na representação positiva de Hollywood. Por exemplo o caso de Walter Wanger que sabendo-se traído por Joan Bennet com o agente Jennings Lang, o alvejou. O caso é discutido em notas, apenas em Cinelândia, mas como se Wanger sofresse de um "acesso de ciúmes". Para evitar problemas, Louella Parsons se eximiu de entrar em detalhes ${ }^{151}$.

Os assuntos tabus da vida dos atores continuavam ocultos, mas se abria pouco a pouco licença para tratar de contravenções, consideradas apenas comportamentais. Os

diretores concordaram em submeter os scripts ao Código de Produção. A igreja católica dava suporte ao Código de Produção, em oposição aos censores do governo, mas em troca queria acesso e influência. Para maiores detalhes, consultar Peter Lev (2003)

${ }^{149}$ A peça de Roberto Anderson, dirigida por Elia Kazan, foi um sucesso na Broadway em 1953.

${ }^{150}$ Peter Lev (2003) inclui entre os filmes que discutiam assuntos tabus: Romance em Paris (1954) de Lloyd Bacon, pela releitura dos hábitos das mulheres, A um passo da eternidade (1953), de Fred Zinnemann, por tratar de adultério, O homem do braço de ouro (1955), de Otto Preminger, sobre drogas, Chá e simpatia sobre o homossexualismo, Baby Doll (1956), de Elia Kazan, sobre um triângulo amoroso, e Ingênuo até certo ponto (1953), de Otto Preminger que envolvia conversas sobre sexo, sedução, virgindade e casamento. A recepção deste último foi um misto de choque e triunfo. O filme quase não foi aprovado pelo Código de Produção. Tornou-se um sucesso, devido à censura.

${ }^{151}$ Parsons, Louella. Os espiões de Cinelândia em Hollywood informam. Cinelândia, v. 1, n. 1 p. 30-1; 46, maio 1952. 
dois principais temas tratados são: a representação das vamps e os jovens rebeldes ou com comportamento transgressor.

Impregnando-se na personalidade da estrela a do tipo que costuma encarnar, a vamp dos filmes é confundida com as atrizes. Há uma abertura na ausência de condenação moral no quesito de artistas consideradas vamps, simplificado a uma alteração comportamental diferente, mas não ruim. Porém nas imagens, Cena não mostra vamps ou mulheres fatais, e sim a personificação de ingênuas. Busca-se amenizar sua carga erótica. No máximo há algum tipo de apelo sensual, mas sem trazer alusão a um comportamento que pudesse ser considerado agressivo às mulheres. Não há um grande número de reportagens sobre femmes fatales porque prevalece o destaque às protagonistas dos filmes, sempre heroínas ou moçinhas. Uma exceção é a matéria Françoise Arnoud está mal acostumada ${ }^{152}$. A atriz admite ganhar a antipatia das mulheres por ser o tipo que rouba o marido da outra. Só vai descansar quando se apaixonar mesmo. Utiliza-se aqui o mesmo argumento para os homens, nesse quesito a vamp se assemelha a eles por ter maior poder de decidir o que fazer. Marlene Dietrich, considerada a maior vamp de todos os tempos, é mostrada como a "vovó" amorosa. Não há transgressão em tratar dela porque a vamp situa-se no passado, na história do cinema. Não se fala em transgressões no comportamento moral ou amoroso, apenas no modo de se vestir. A "fabulosa" ${ }^{153}$ Dietrich infringiu as regras sociais trajando calças. Contudo, sofreu as penalidades por esta "transgressão".

Uma das maiores transgressões a rondar a vida de Dietrich era o suposto lesbianismo. Apesar de Cena não abordar o tema de maneira direta, uma das fotos vai contra o conservadorismo da revista. Trata-se da imagem de um beijo em vias de ser concretizado entre Dietrich e Hedy Lamarr, sob o olhar ambíguo de Billy Wilder, talvez cômico, enojado ou assustado. O olhar polissêmico do diretor é proposital, aberto a permitir diferentes leituras. A fotografia é claramente de release. Cena tenta pontuar uma leitura lúdica: (ele) "que não pode deixar de estar pensando que Marlene está desperdiçando seus beijos com Hedy Lamarr, que a foi visitar durante uma filmagem". A cena é teatral. Marlene se abaixa para beijar Lamarr. Esta está mais inclinada ainda, quase torta. Não é uma foto de enlevo amoroso, certamente uma citação do filme Marrocos (1930), de Joseph Sternberg, na qual a personagem de Marlene Dietrich, vestida de homem num cabaré, beija uma mulher, rouba-lhe uma flor e a entrega a Gary

${ }^{152}$ Françoise Arnoud esta mal acostumada. Cena Muda, v. 32, n. 47, p. 07, 21/11/1952.
${ }^{153}$ Dietrich, a fabulosa! Cena Muda, v. 34, n. 50, p. 8-10; 33, 09/12/1953. 
Cooper ${ }^{154}$. A atriz Hedy Lammar também não foi escolhida à toa. Tinha causado polêmica décadas antes ao aparecer nua numa cena dentro de águas límpidas de um rio, no filme Extase (1933), de Gustav Machatý.

A ambigüidade possibilita uma transição na avaliação das personas não só pelas qualidades, mas ao mesmo tempo pelos defeitos. O mote é atiçar a curiosidade do leitor. Cria-se um imaginário diferente para estes atores, numa nova forma de criação do estrelismo. Ainda não surge como fenômeno Brigitte Bardot nas revistas pesquisadas, mas Marlon Brando e Montgomery Clift criam espaço para um novo tipo de demanda, calcada em valores díspares ao do conceito de glamour vinculado.

A cobertura a estes dois astros é baseada na ambigüidade e nas versões. Num primeiro momento, os artigos assinalam textualmente a preferência por um tipo de vestimenta que raramente aparece nas revistas em 1952: camisetas, calça jeans e "sapatos de tênis". Marlon Brando prefere usar camisetas para não ter de abotoar a camisa. É um nômade. Não dá valor ao dinheiro, nem ao glamour. Nas imagens em 1952, tanto Marlon quanto Montgomery personificam galãs sorridentes, nunca transgressores. Porém, nas fotos os dois atores vestem roupas sociais, geralmente camisas. Ou seja, não existe transgressão nas imagens, só no texto. Estas primeiras ilustrações procuram ocultar os casos de contravenções. Por isso, quando a revista descreve Uma rua chamada pecado, aborda o intenso realismo da fita e os tipos reais, excluindo as características negativas do personagem de Marlon Brando. Em outro momento ${ }^{155}$, Brando surge como o excêntrico, mas ao mesmo tempo melancólico, trazendo mecanismos projetivos positivos aos leitores. Peter Lev conta que o filme sofreu importantes cortes pela censura (o rapto fica apenas implícito), assim como Um lugar ao sol (1952), de George Stevens.

O grande destaque ao ator se deve ao lançamento não só de Uma rua chamada pecado (1951), de Elia Kazan, mas de Viva Zapata! (1952), do mesmo diretor. Pouco a pouco há uma transformação nas roupas dos atores. Primeiro com jeans e camisas esportivas, depois camisetas. Processo este iniciado em 1953. Na fisionomia não se vê mais o sorriso a indicar uma felicidade transbordante. No final de 1953, Marlon Brando

\footnotetext{
${ }^{154} \mathrm{O}$ cartaz da Paramount anunciava na época, uma campanha supostamente voltada ao tema do lesbianismo: "Marlene Dietrich, a mulher que toda mulher quer ver". Promovia-se a intriga, prevenindo escândalos. Segundo Andréa Weiss, a publicidade do filme utilizava termos dúbios, menos para atrair uma audiência lésbica, visando o interesse voyeurístico dos homens no lesbianismo. A justificativa do estúdio foi uma cena para aumentar o desejo do personagem por ela, a partir do exotismo. (Gledhill, 1991)

${ }^{155}$ Marlon Brando - da Broadway para Hollywood. Cena Muda, v. 32, n. 22, p. 11, 29/05/1952.
} 
foi capa de Cena vestido à moda romana. Aparece sem camisa ${ }^{156}$ por conta de Júlio César (1953), de Joseph Mankiewicz. Sua fisionomia é de poucos amigos. Diferente dos astros sorridentes ou contemplativos nas capas. Num entrelaçamento entre personagem interpretado e ator, Marlon aparece em geral com aparência fechada e agressiva, Montgomery como o melancólico.

Há uma postura supostamente ríspida de alguns colunistas porque supostamente os dois atores não se vestem bem e não ligam para Hollywood. As matérias indicam as esquisitices e pequenas transgressões deles para atiçar o interesse dos leitores. No caso de Marlon Brando, ele usa sandálias, parece sempre maltrapilho. Não tem residência fixa, plantou bananeira para um repórter. Consulta com freqüência um psiquiatra. Montgomery veste-se como um mecânico. Mora em pensão de terceira categoria, não gosta da vida e detesta Hollywood. Quando se aponta o jeans com roupa favorita, a motivação é logicamente publicitária, voltada aos personagens. Grande parte das reportagens visam descobrir o intuito ou não de casar, não os motivos das transgressões. As campanhas prós e contra se misturam. Acusados de não ligar para Hollywood, interessados apenas em dinheiro, alguns colunistas conferem a eles o poder de causar a ruína do sistema, matando o glamour ${ }^{157}$.

O tom de condenação é acompanhado de um misto de encantamento com os violadores de regras, daí a importância dada aos rebeldes. Continuam a ser olimpianos, porque além de belos e bons atores, não ligam para fama nem para o dinheiro. Acima de tudo, não são superficiais. Fecha-se, portanto, um ciclo de condenações, ambigüidades e encantos, visando fins publicitários.

A partir das versões da realidade, Cinelândia traz depois a campanha a favor dos dois atores. Revela que Monty come nos melhores restaurantes, usa roupas de grife. No processo de normalização dos atores, Marlon Brando é fotografado com um gatinho no ombro ${ }^{158}$, como na época em que os heróis de Griffith eram mostrados em sintonia com os animais, diferente dos vilões a maltratar os indefesos. $\mathrm{O}$ namoro teria transformado seu gênio selvagem. Num momento, Marlon veste roupas sociais, depois Cinelândia fixa seu gosto por roupas esportes. Preferência também de boa parte dos americanos, lembra a revista. O problema é que os deuses devem se diferenciar dos mortais, a partir do conceito de it do período; não simplesmente representar um tipo comum. Daí a

\footnotetext{
${ }^{156}$ Marlon Brando elogia os extras. Cena Muda, v. 33, n. 50, 09/12/1953.

${ }^{157}$ Os cavadores de ouro de Hollywood. Cinelândia, v. 2, n. 12, p. 32-33; 64, abril 1953.

${ }^{158}$ Croni, Steve. Como Marlon Brando noivou. Cinelândia, v. 4, n. 56, p. 32-3, 65, 1'a quinz. março 1955.
} 
transição para outro modelo de star system, processo iniciado pelos filmes. Começa a passagem para um tipo novo de glamour, focado nos atributos físicos, não na sofisticação. Do ponto de vista da personalidade, há uma alteração na representação da felicidade absoluta, entra a melancolia e infelicidade do ator/personagem de forma mais incisiva nas revistas, embora o processo esteja só no início.

Por último, alguns artigos desvendam as campanhas publicitárias, com novo enfoque, a partir das imperfeições dos galãs. Primeiro, as reportagens garantem que a vergonha e timidez de Clift foram inventadas. Depois, afiançam não se tratar de publicidade porque realmente o ator tem estas características, afinal o verdadeiro Monty e o inventado têm muito em comum, processo que facilitou a mitificação ${ }^{159}$. Esta afirmação auxilia na transferência da personalidade do personagem para o ator. Ao lançar a dúvida sobre a veracidade de seu comportamento de maneira continuada, se aumenta a demanda para comprová-la. Assim tudo recomeça. Cada detalhe insignificante é transformado em reportagem, divinizando e condenando ao mesmo tempo.

Nas revistas pesquisadas, o tom de condenação cada vez mais é esvaziado de teor conservador. Volta-se apenas a cumprir sua primeira utilidade: os fins sensacionalistas e publicitários. No capítulo três, abordamos a constituição da persona das atrizes brasileiras na inter-relação do estrelismo com os filmes nacionais, dando especial atenção às dificuldades de estruturação do nosso star system.

${ }^{159}$ Collins, Imogene. O ermitão da tela. Cinelândia, v. 4, n. 58, 54-5; 60, $1^{\text {a }}$ quinz. abril 1955. 


\section{Capítulo 3 - $\mathrm{O}$ cinema brasileiro dentro da perspectiva do star system}

A cobertura ao cinema brasileiro nas duas revistas teve um resultado quantitativo semelhante, por volta de $20 \%$ das páginas editoriais ${ }^{1}$. Cena Muda se atém não só às produtoras independentes, mas também ao rádio e outros espetáculos da cidade. Durante alguns meses de 1952-1953, esta dedicou metade de suas páginas editoriais ao rádio. A média entre as capas voltadas ao cinema brasileiro nos dois veículos revela números semelhantes, também por volta de $20 \%{ }^{2}$. Atores ou cantores brasileiros dominaram as primeiras capas do ano de 1952 em Cena. Nos meses seguintes, houve um grande período de ausência de brasileiros. Quando o Brasil volta a ser capa é com os cantores do rádio. Segundo o trabalho de Catani e Melo (1983), o espaço para o cinema brasileiro, no caso a chanchada, era privilegiado nos meses de dezembro a março. A observação explica a grande quantidade de capas para os atores do rádio nos primeiros e últimos meses do ano. Havia mais capas para os cantores no final do ano do que no começo, o que pode ser explicado também pela tentativa de Cena em procurar agendar o interesse dos leitores com meses de antecedência.

Nos próximos tópicos abordamos os filmes brasileiros mais comentados nas revistas. Este subitem analisa a cobertura ao cinema nacional nas reportagens, deixando para avaliar as características das seções de críticas no próximo capítulo. Depois discutimos as peculiaridades do estrelismo brasileiro a partir do enfoque dado às atrizes. Em seguida, aparecem os temas ocultos pela dinâmica do estrelismo: a pobreza, o tema étnico e as transgressões morais dos personagens. $\mathrm{O}$ último tópico pondera a participação do rádio na representação do star system nacional nos dois veículos.

\footnotetext{
${ }^{1}$ Em termos exatos em 1953, Cena Muda dedicou 17\% de suas páginas ao cinema nacional, enquanto Cinelândia teve $19 \%$ da cobertura voltada ao cinema brasileiro.

${ }^{2}$ A relação entre os anos revela que Cena Muda em 1952 dedicava maior espaço ao tema brasileiro, principalmente ao rádio. Das quinze capas dedicadas ao Brasil, apenas 4 eram para o cinema. Em 1953, os valores para o cinema e rádio quase se igualam, seis para o cinema, e cinco para o rádio, atingindo $20 \%$ das capas. A crise da Vera Cruz atinge a cobertura ao cinema nacional em 1954, sem falar do declínio da própria revista. Das 37 capas de Cena, apenas uma foi dedicada a Brasil, no caso a Carmem Miranda (2,7\%). O último ano da revista teve apenas oito edições, duas delas ao cinema brasileiro, totalizando $25 \%$. Cinelândia nasce com um pífio destaque às atrizes brasileiras. No primeiro ano, de oito capas, apenas uma foi para a estreante Josette Bertall, de Amei um bicheiro (1952), de Paulo Wanderley e Jorge Ileli. Ou seja, 12,5\%. O apelo ao cinema brasileiro aumenta no ano seguinte, em 1953, com quase 40\% das capas. Cai em 1954 para 26\%, talvez reflexo também da crise do cinema brasileiro. Em 1955, das nove capas analisadas até maio (mês da morte de Cena Muda), apenas uma foi para uma atriz brasileira, totalizando $11 \%$.
} 


\subsection{Os filmes mais comentados}

Voltamos nossa análise aos filmes nacionais mais comentados do período, a maior parte deles da Vera Cruz. Grande parte da comparação entre a cobertura das revistas e o material de release da Vera Cruz foi realizada a partir das observações da tese de Maria Rita Galvão. Os demais comentários foram feitos a partir de uma pesquisa parcial a alguns boletins da companhia. Nosso foco aqui não é realizar um estudo comparativo entre os dois universos. Por este motivo, este subitem não inclui a comparação com os boletins da Atlântida, porque desconhecemos um trabalho centrado sobre este material.

Em 1952, os filmes mais comentados foram: Sinhá Moça (1953), de Tom Payne, O Cangaceiro (1953), de Lima Barreto, e Apassionata (1952), de Fernando de Barros. O maior destaque para as fitas se dava meses antes de sua estréia, durante as filmagens, produzindo também fofocas e expectativas. Tico Tico no Fubá (1951), de Adolfo Celi, teve baixa cobertura nas duas revistas durante seu lançamento, apesar de muito comentado nos boletins da companhia. Sua estréia, comparada às estréias de Hollywood, recebeu apenas uma página em Cena Muda. O filme é relegado a segundo plano no texto de apenas três parágrafos. A ênfase, totalmente visual, recai sobre as estrelas presentes na première, com sete fotos em uma página:

\footnotetext{
"Teria agradado o novo filme da Vera Cruz que levou mais de um ano para ser terminado e custou oito milhões de cruzeiros? As opiniões se dividiam. O cinema brasileiro está cumprindo o seu programa. Restam aos exibidores inaugurar mais e melhores casas para garantia das nossas produções, aqui mesmo dentro de nosso mercado." 3
}

Questiona-se no final a idéia de tentar levar os filmes ao exterior. Não há uma crítica propriamente dita. Não há análise sobre o filme, apenas esta citação. Outros artigos centraram-se na personalidade das duas estrelas, visando já os próximos filmes, como Apassionata (1952), de Fernando de Barros, e Veneno (1952), de Gianni Pons. Segundo Maria Rita Galvão (1976), a companhia aproveitou o sucesso inesperado de Tônia Carrero para vender Apassionata.

Em 1952, Cinelândia cobriu muito pouco o cinema brasileiro, mas comentou o grande orçamento do filme Tico Tico no Fubá na seção de perguntas dos leitores:

\footnotetext{
${ }^{3}$ Avant-première de Tico Tico no Fubá. Cena Muda, v. 32, n. 18, p. 06, 01/05/1952.
} 
“É verdade que a Vera Cruz deverá perder uma fortuna com o filme ‘Tico Tico no Fubá'?” J. C. de S.P. (resposta) “'Tico Tico no Fubá' é o filme mais caro que já se filmou no Brasil, e dificilmente conseguirá compensar os gastos. O filme será todavia transcrito para o inglês, e a Vera Cruz espera exibi-lo nos Estados Unidos, que é um mercado bem mais remunerador do que o nosso." 4

As duas publicações não comentaram o filme, nem fizeram sua divulgação. Apenas se quer anunciar com esse trecho um padrão semelhante ao de Hollywood. Não analisamos, contudo, se no ano anterior durante as filmagens a fita recebeu maior cobertura. Quando Cinelândia informa a participação de Tico Tico no Fubá no Festival de Cannes, se exime de comentá-lo de forma prolongada por já estar em cartaz:

"além do êxito inegável que a película alcançou, causou impressão o desempenho de Tônia Carrero e Anselmo Duarte. Todos sabem, agora que o filme já foi estreado no Brasil, o que ele é, sendo inúteis, portanto, quaisquer outros comentários de nossa parte." 5

A frase é bastante significativa do padrão de cobertura de Cinelândia. Diz respeito à ausência de espaço destinado à crítica na revista em forma de seção, sintetizado na frase desta reportagem, consciente de seu projeto editorial voltado aos fãs. Abordaremos melhor o tema no próximo capítulo.

A baixa cobertura ao filme não se concentrou apenas nas duas revistas estudadas. De acordo com Maria Rita Galvão (1976), os jornais ${ }^{6}$ comentavam com freqüência os altos custos de produção. $O$ Estado de $S$. Paulo passou a noticiar secamente as informações sem comentá-las. Alguns jornais abriram campanhas contra a empresa, como $O$ correio da manhã. As observações sobre os altos custos de produção tornaram-se cada vez mais freqüentes nos periódicos. Galvão faz alusão inclusive à Cena Muda em 1951, entre as que faziam críticas. Não analisamos o ano citado por ela por não fazer parte do período de nossa pesquisa. Contudo, em 1952, só houve o questionamento descrito acima. Há aqui uma alteração na representação porque Cena geralmente elogiava as grandes somas gastas num filme, por enxergar nisso uma semelhança com os padrões de Hollywood.

Houve ainda outro ingrediente a causar a baixa cobertura da imprensa em relação à Vera Cruz, revelado por Maria Rita Galvão. O mal estar com os críticos começou na estréia de Caiçara (1950), de Adolfo Celi. Alberto Cavalcanti havia prometido uma apresentação do filme ao Círculo de Estudos Cinematográficos. A Vera

\footnotetext{
${ }^{4}$ Indiscrições de Cinelândia. Cinelândia, v. 1, n. 2, p. 51, junho 1952

${ }^{5}$ Festival de Cannes. Cinelândia, v. 1, n. 2. p. 14-17; 48, junho 1952.

${ }^{6} \mathrm{O}$ tom varia da apreensão de B. J. Duarte, à ironia de Salvyano Cavalcanti de Paiva e à irritação de Walter George Durst. (Galvão, 1976)
} 
Cruz ignorou o compromisso. Excluiu do lançamento na capital carioca a imprensa e os críticos desse grupo. Houve apenas uma festa para a alta sociedade. Os jornais comentaram em tom rancoroso o evento porque tinham dado seu apoio à Vera Cruz durante meses. Quando houve uma segunda première para os críticos, muitos deles se negaram a ir. Como conseqüência, a simpatia dos jornais cariocas diminuiu bastante.

A publicidade sob a forma de reportagens dos filmes brasileiros em 1952 nas duas revistas era centrada na produção da Vera Cruz. O departamento de publicidade desta companhia era uma verdadeira redação de jornal, conforme narra Maria Rita Galvão. Havia datilógrafos, redatores, fotógrafos, arquivistas e tradutores. Cerca de 700 jornais e revistas de todo o país recebiam o noticiário da empresa, muitos no exterior. Investiu-se pesado na propaganda, considerada pela empresa como a alma do negócio. De acordo com o diretor de publicidade, Cavalheiro Lima, não havia uma única publicação regular brasileira, conhecida em São Paulo, que não recebesse os boletins. Havia fotografias de todos os tipos e tamanhos, apropriados para cada tipo de publicação e inúmeras para cada filme. Segundo Lima: "com tudo isso, se a Vera Cruz não funcionou, não foi por falta de propaganda”. (Galvão, 1976: 179)

A Vera Cruz atendia, dessa forma, às reclamações dos críticos desde os anos vinte de que os produtores não abasteciam com material a redação. No ano de 1953, por exemplo, entre maio a setembro, a Vera Cruz produziu dez a doze comunicados por mês. Contudo, a fórmula da empresa para resumir seus enredos, de acordo com Galvão, frequentemente criava "na publicidade um mundo à parte" que pouco tinha "a ver com os filmes propriamente ditos." (Galvão, 1976: 134)

As revistas procuravam não explicitar a relação dos filmes novelizados e das reportagens sobre as estrelas do cinema estrangeiro com a divulgação direta das estréias. Havia também matérias sobre estréias, mas eram menos comuns. O objetivo era dar a impressão de furo de reportagem e denegar a publicidade. No cinema brasileiro, o foco preponderante é sobre os lançamentos. Há menor denegação dos objetivos publicitários nestes casos. Uma significativa dificuldade em produzir conteúdos vinculados a fofocas e dicas das estrelas sobre o cinema nacional.

Cena Muda se apropria dos releases muitas vezes sem alterá-los. Às vezes aproveita as frases consideradas melhores, em outros momentos utiliza os boletins da Vera Cruz em sua totalidade. Um exemplo da utilização dos releases da Vera Cruz ${ }^{7}$

\footnotetext{
${ }^{7}$ O mesmo artigo do Boletim da Vera Cruz é citado por: Maria Rita Galvão (Galvão, 1976: 215); Cena Muda, v. 32, n. 35, p. 29, 29/08/1952 e Cena Muda, v. 32, n. 39, p. 18-19; 34, 26/09/1952.
} 
refere-se à Tônia Carrero, citado em duas edições diferentes. As palavras do boletim da Vera Cruz: "para a beleza de Tônia Carreiro foram criados os mais belos cenários feitos no Brasil" ou ainda, ela aparece "em meio aos maiores 'sets' já montados no cinema brasileiro", os ambientes com "luxuosa decoração e mobiliário", são copiados por Cena sem nenhuma alteração.

Depois Cena passa a noticiar o lançamento dos filmes, agendando as estréias com mais de um mês de antecedência no caso dos brasileiros. Por certo a divulgação das fitas americanas era mais apurada. Sempre havia matérias mais detalhadas com biografias sobre os atores. A utilização de anúncios sobre os filmes brasileiros ou estrangeiros tem pequena frequiência, diferente do que se esperaria numa revista de divulgação.

Comparando a cobertura realizada pelo boletim da Vera Cruz sobre Anselmo Duarte a partir da análise de Maria Rita Galvão, observamos que muito do exagero dos releases era filtrado pelas duas revistas. Nos diversos boletins, há menção aos "cabelos despenteados" do galã (que aparecem bastante no filme Tico Tico no Fubá), ausentes nas revistas. Um dos destes releases é citado por Galvão: é a primeira vez que o cinema brasileiro tem um galã, “os cabelos parecem arranjados só com as mãos e não com o pente", e o desalinho, longe de prejudicá-lo, "lhe empresta um certo quê muito apreciado pelo elemento feminino". (Galvão, 1976: 157) Acreditamos que a idéia de se destacar o cabelo do galã se trate de algum tipo de cópia da publicidade de algum ator estrangeiro. Cena Muda anuncia (em data posterior) que Tony Curtis é o belo rapaz de "cachinhos caídos na testa" ${ }^{8}$. A moda teria sido lançada por Farley Granger e Guy Madson, mas estes não conseguiram tamanha repercussão nesse quesito quanto a de Curtis. Contudo, estes detalhes sobre Anselmo repetidos a exaustão nos boletins não aparecem nas duas revistas.

Em 1952, outros exageros e adjetivações são empregados pelos boletins da Vera Cruz para definir Anselmo, tais como: "um tipo exemplar de beleza masculina", "moreno, de pele muito clara contrastando com os cabelos muito negros e lisos que lhe caem sobre a testa, e que, num gesto habitual, ele ajeita com os dedos para trás", além de seus olhos castanhos e um "porte viril". Nenhum deles aparece nas duas publicações pesquisadas. Os excessos folhetinescos do release ressaltando Anselmo como um moço do interior que teve um começo duro em São Paulo, mas que enfrentando a vida, "lutou

\footnotetext{
${ }^{8}$ Das sarjetas de Manhattan, aos pináculos da fama! O rei dos cachinhos. Cena Muda, v. 34, n. 27, p. 12-3, 21/07/1954.
} 
e venceu", não são citados também. Há apenas a consagração, ficando implícito o passado pobre. As revistas ressaltam que Anselmo tem seu próprio carro, comprado com seu trabalho. Contudo o esquema descrito por Galvão não é aproveitado. As revistas o filtram, colocando na periferia os sacrifícios. (Galvão, 1976: 169)

Muitas vezes Cena melhora os textos dos boletins. Estes tinham uma forma muito rudimentar de texto jornalístico, tentando gerar o sucesso dos filmes à força. Como exemplo, temos uma matéria sobre a governanta do filme Apassionata (1952), de Fernando de Barros. $\mathrm{O}$ artigo procura aproximar e colocar no mesmo patamar a atriz Edith Helou com Judith Anderson, a famosa governanta Miss Danvers do filme Rebecca (1941), de Alfred Hitchcock ${ }^{9}$. Afirma ser ela a "Judith Andersen do cinema brasileiro". No filme, também fica patente a tentativa de imitar a personagem, uma citação empobrecida. Contudo a construção desta persona não convence, e Cena nem sequer faz referência à atriz. Portanto, boa parte dos excessos da construção do estrelismo da Vera Cruz não são aproveitados nos textos das duas revistas. Certamente a proximidade com o contexto de produção acarretasse numa leitura mais crítica destes releases, diferente da relação existente com o material norte-americano.

Também os boletins sobre Alberto Ruschel não foram aplicados. Pouco se fala sobre ele como um galã nas revistas. De acordo com Galvão, os textos sobre Ruschel são menos numerosos, mas "igualmente elaborados". O tipo de apelo da campanha publicitária foi totalmente diverso porque não havia nobre origem ou fina educação a ser ressaltada. "Tenta-se fazer do ator um futuro Anselmo Duarte, salientando as 'qualidades inatas' do rapaz talentoso e perseverante que sobe na vida, sabe o que quer e luta por alcançar seu objetivo" (Galvão, 1976: 185)

Durante o ano de 1953, os filmes da Atlântida tiveram grande destaque nas duas revistas ${ }^{10}$. O cômico é a receita infalível de sucesso para a película e para o entretenimento do público, segundo as duas publicações. Em 1952, os filmes da Atlântida são divulgados apenas com notas na revista Cena Muda. A Vera Cruz obtém maior destaque, mas nem todos os filmes são bastante anunciados, à exceção de Sinhá Moça (1953), de Tom Payne. As pequenas produtoras independentes como Oceania e Jaraguá filmes recebem grandes aclamações por parte de Cena, algumas com direito a

\footnotetext{
${ }^{9}$ Edith Helou, a "Judith Andersen do cinema brasileiro". Noticiário da Vera Cruz, n. 87, junho de 1953.

${ }^{10}$ Cena Muda auxiliou na fundação da Atlântida. A constituição do capital da Atlântida se fez em boa parte por meio de vendas de ações populares, oferecidas de porta em porta, com um exemplar da revista Cena Muda e o apoio do Jornal do Brasil. (Leite, 2005)
} 
sinopses e tentativa de criação de um star system ${ }^{11}$. Da produção da Maristela ${ }^{12}$, as revistas comentam os filmes produzidos no período, como $O$ comprador de fazendas (1951) de Alberto Pieralisi e Simão, o caolho (1952) de Alberto Cavalcanti, com algum tipo de repetição, voltando o foco aos diretores. Podemos incluir neste rol e $O$ canto do mar (1953), de Alberto Cavalcanti, da Kino Filmes. Entre os filmes de produção independente produzidos nos estúdios da Maristela, Areião (1952) de Camilo Mastrocinque, e Mãos Sangrentas (1954) de Carlos Hugo Christensen são bastante citados em notas e algumas sinopses de Cena. Por outro houve pouco espaço para $O$ Saci (1953), de Rodolfo Nanni, e Três garimpeiros (1954), de Gianni Pons, ambas produções independentes feitas na mesma empresa. As fitas da Multifilmes, como $A$ Sogra (1954) de Armando Couto, O craque (1953) de José Carlos Burle, Fatalidade (1953) de Jacques Maret, e Chamas do Cafezal (1954) de José Carlos Burle, são citadas no máximo em uma matéria. Aparecem em raras notas. A diferença é que não há repetição sobre os filmes das pequenas companhias em mais de duas ou três matérias. Sem a repetição, a estratégia de agendamento junto aos leitores provavelmente não se completasse por completo.

Em 1952, a cobertura escassa ao cinema brasileiro em Cinelândia voltou-se ao release e ao incentivo às chanchadas. $\mathrm{O}$ tom de release é encontrado na matéria sobre $\mathrm{o}$ filme Carnaval Atlântida (1952) ainda sob o título anterior da fita como Pegando fogo, descrito como um filme onde:

“o comandante desse barco é José Carlos Burle, que parece ter injetado na história, no elenco, no
celulóide, em tudo - gás hilariante... quando a gente passa por perto do estúdio onde está sendo

\footnotetext{
${ }^{11}$ Talvez a tática fizesse parte do discurso de incentivar a produção nacional, ou porque estas companhias tivessem mandado material para publicação.

${ }^{12}$ A Maristela surgiu do desejo de Mário Audrá Jr. em realizar filmes a exemplo do cinema italiano neorealista. Contudo, o projeto inicial de realizar filmes em locação com baixo orçamento em um curto período de tempo foi logo substituído pela grande produção, a exemplo do que era feito com a Vera Cruz. Na primeira fase (1950-51), a empresa produziu quatro filmes, mas sem conseguir retorno, demitiu uma centena de empregados. A Maristela não paralisou suas atividades totalmente, mas o chamado "fechamento" da empresa foi muito comentado em 1951 nos jornais. A companhia passou a alugar seus estúdios e equipamentos, recorrendo às co-produções para não precisar acarretar com todas as despesas. Na segunda fase (final de 1951-1952), a empresa fez apenas Simão, o caolho. Sem conseguir cobrir os prejuízos, a família Audrá vendeu os estúdios e equipamentos para a Kino Filmes, empresa que tinha à frente Alberto Cavancanti. Contudo, a Kino não conseguiu quitar a dívida e devolveu os estúdios para a Maristela. Na terceira fase (1954-56), a companhia teve sua fase mais dinâmica, realizando sete filmes. Entre 1957-58, fez duas co-produções com a Columbia e encerrou suas atividades. Para maiores detalhes, consultar a dissertação de Catani (1983) e a tese de Maria Rita Galvão (1976).
} 
filmada essa bola carnavalesca da Atlântida, parece que está passando por um manicômio onde todos os loucos estão com mania de rir a bandeiras despregadas... se não fosse a música (e que música!) dos sambas e marchinhas, do melhor que vai sair no carnaval, a gente juraria que era hospício mesmo, com malucos do gargalheiro ininterrupto. Assistimos a algumas tomadas de cenas e tivemos que sair de perto, chorando, de tanto rir..." 13

No geral, o tom de Cinelândia volta-se mais ao elogio, embora houvesse um tom mais analítico em alguns momentos, como veremos no último capítulo. Já o filme $O$ Cangaceiro (1953), de Lima Barreto, recebeu uma cobertura razoável em Cena Muda, ao contrário do que ocorreu em Cinelândia. Durante 1952, Cena anuncia em pequenas notas Alberto Ruschel como protagonista. Fotos grandes agendam o lançamento, mas não há reportagens. Porém, se analisarmos os quatro anos, O Cangaceiro torna-se o filme mais comentado, mas a cobertura é feita por meio de notas, não de reportagens.

Em 1953, a cobertura de Cena Muda varia muito. Passa a ser mais calcada em materiais de propaganda dos estúdios. Assim é a principal matéria ${ }^{14}$ sobre o filme $O$ Cangaceiro, semelhante a um release da Vera Cruz. O jornalista anuncia o sucesso antes de assistir ao filme: "a película destinada a obter a mais ampla repercussão no mundo cultural e junto às grandes platéias." O texto é fartamente ilustrado. Em uma única página há cinco fotos.

Quando o filme é lançado, a cobertura de Cena Muda passa para o lado negativo. Na crítica da seção Telas da cidade ${ }^{15}$, escrita por Livio Dantas, a fita é desaprovada por passar ao largo das fontes históricas, das causas sociais e sociológicas do banditismo. Para Cena, a trama deveria ser histórica. O crítico elogiou apenas a inegável presença do cangaço, através da ambientação e personificação muito convincentes. Porém, considerou o filme condenado a exibir um romance pobremente articulado, a mostrar cenas de ação e violência, limitando os fatos em si mesmos. Tudo isso porque não há explicação para onde vai o dinheiro saqueado. O erro estaria em confiar tão somente na valorização dos elementos - como corte, fotografia, música, movimento de câmera e desempenho: "pois foi isso que aconteceu com 'O Cangaceiro' que teve praticamente tudo para ser um grande filme, menos o essencial que seria uma história." Dantas analisa também a atuação dos atores, mas apenas na base da adjetivação. Considera os protagonistas abaixo de qualquer apreciação pela falta de capacidade interpretativa. Há uma divisão salutar entre a opinião da crítica e as matérias para vincular o estrelismo.

\footnotetext{
${ }^{13}$ Valle, Ronald. Pegando fogo. Cinelândia, v. 1, n. 8, p. 10-11, dez. 1952.

${ }^{14}$ O cangaceiro vem aí. Cena Muda, v. 33, n. 3, p. 7, 14/01/1953.

${ }^{15}$ Dantas, Livio. Telas da cidade. Cena Muda, v. 33, n. 16, p. 9, 14/04/1953.
} 
Cena cita $O$ Cangaceiro mais de uma vez em notas, mas sem conferir maior destaque. Uma semana depois, chega a notícia de seu sucesso no festival de Cannes, laureado com o prêmio de melhor filme de aventura, além de uma menção honrosa à música. O Comentário da semana ${ }^{16}$ é sobre o Festival, mas provavelmente por falta de tempo para produzir algum artigo, apenas se diz: "O cangaceiro arranca aplausos no Festival de Cannes, revelando ao mundo que o cinema no Brasil já é uma realidade”. O artigo esteve em sintonia com a cobertura de Cinelândia. Esta apenas citou a premiação.

$\mathrm{Na}$ edição de maio, Cena elogia largamente a fita: "a fotografia e a música constituem verdadeiras obras primas do cinema brasileiro" ${ }^{17}$. Depois, condena os que desacreditam no cinema brasileiro: "não podemos deixar de registrar também, os prognósticos por parte de alguns 'entendidos', de que a fita brasileira é séria candidata a um dos prêmios secundários da competição". Oculta as suas apreciações negativas nas edições anteriores. Talvez $O$ Cangaceiro não seja mais comentado pela dificuldade em transformar os atores em astros. Ao contrário do que era feito com outros filmes, os protagonistas não se convertem em ídolos. A atenção se concentra em Vanja Orico. Apenas em 1954, a película é mais comentada a partir dos atores, porque Ruschel e Marisa Prado foram convidados para fazer um filme na Europa.

Apesar dos comentários negativos da crítica de Cena Muda ao Cangaceiro, um crítico vislumbrou o potencial da fita ${ }^{18}$. Por meio da análise fílmica, Alberto Dines considera o filme a maior realização do cinema brasileiro. Contudo, o comentário não significou apenas elogios. Dines censura diversos pontos, como a atuação negativa dos protagonistas, a falta de ligação entre os planos, dificuldade de construir tensão entre os grupos no desfecho do filme, além da fala fraca, falsa, requintada e pretensiosa.

A cobertura de Cinelândia ao filme foi ainda menor. A fita de Lima Barreto aparecia apenas em notas. Na seção Por falar em cinema brasileiro, Luis Fernandes

\footnotetext{
${ }^{16}$ Kleimann, Levy. E o espetáculo continua. Cena Muda, v. 33, n. 17, p. 3, 22/04/1953.

${ }^{17} \mathrm{O}$ texto parece ter sido escrito antes do recebimento do prêmio. Cita o bom recebimento do filme na segunda noite de exibição: "Estamos, pois, bem situados no campo do cinema internacional e, mesmo que não consigamos um prêmio no Festival de Cannes, não devemos esmorecer em nossos esforços no sentido de elevar (...) as qualidades do cinema de nossa terra”. Provavelmente um artigo anterior à premiação, publicado sem ser relido, porque edições a revista já havia anunciado o prêmio. Averbach, Samuel. O cangaceiro. Cena Muda, v. 33, n. 19, p. 3, 06/05/1953.

${ }_{18}$ Elogia apenas alguns momentos de linguagem cinematográfica, considerada excelente. Louva a fotografia de Chick Fowle, o contraste "cuidadoso", além da composição e enquadramento "cuidadíssimos", tratamento plástico, entrosamento com as canções, ótimo ritmo, excelente uso do primeiro plano e dos planos dentro do shot. Dines exagera quando compara a fita a No tempo das diligências (1939), de John Ford, pela profundidade teórica. Dines, Alberto. O Cangaceiro, a maior realização do cinema brasileiro. Cena Muda, v. 32, n. 8, p. 7, 18/02/1952.
} 
afirma que $O$ Cangaceiro é um belo espetáculo para os olhos e para os ouvidos, mas Lima Barreto se perdeu ao lidar com o elemento humano:

"Os personagens estão mal delineados e mal interpretados, com raras exceções. Mas está perdoado, pois é responsável pela mais arrojada e melhor de nossas realizações até hoje. Lima Barreto, como ator, dá um show de estrelismo, numa cena que de tão inverossímil, chega a ser grotesca. Mas está perdoado, pois é responsável pela mais arrojada e melhor de nossas realizações até hoje." 19

Quando a película ganha o Festival, Cinelândia não critica mais os mesmos defeitos. A coluna Aos leitores destaca a vitória do filme. Dá os parabéns a Vera Cruz e Lima Barreto. Segundo o artigo, os brasileiros não deram tanto destaque à fita, considerando-a fora do páreo, sem admitir a possibilidade de um filme da Vera Cruz, conseguir um prêmio em Cannes. A condenação da postura dos brasileiros não inclui a própria revista. Esta não tinha destacado sequer que o filme de Lima Barreto iria participar do certame. No final do artigo, há uma mea culpa indireta quando afirmam a baixa expectativa anterior da revista:

\begin{abstract}
"sem dúvida o grande acontecimento cinematográfico do momento é a vitória de ' $O$ Cangaceiro', no Festival de Cannes. A película de Lima Barreto, embora a sua larga repercussão no Brasil, com um público jamais alcançado com nenhum outro celulóide nacional, saiu para o certame internacional da Costa Azul cercado de desconfiança. O agudo espírito crítico dos brasileiros não admitia que o filme da Vera Cruz, embora com qualidades marcantes, levantasse um dos prêmios em Cannes, onde se encontra a nata do cinema do mundo inteiro e onde o júri, em geral, não se deixa influenciar pela política das marcas ou por qualquer outra política. (...) Acontece, entretanto, que ' $O$ Cangaceiro' fez maior sucesso em Cannes, do que no Brasil! E desde o primeiro momento, ficou sendo considerado do páreo. Finalmente, mereceu o 'Grande prêmio do filme de aventura', como menção especial para a música (...). Não foi pouco. Antes, foi muito mais do que esperávamos." (...) ganhar um prêmio internacional nos enche de júbilo. (...) Lima Barreto e a Vera Cruz estão de parabéns." 20
\end{abstract}

Em maio de 1953, Lima Barreto concede uma entrevista à imprensa. Afirma ter feito $O$ Cangaceiro exclusivamente com o auxílio de Caio Pinto Guimarães, (ex) vicepresidente da Vera Cruz. Segundo ele, o filme ficou abaixo de suas expectativas. Além disso, declara que não apreciou as atuações de Marisa Prado e Alberto Ruschel, ambos "horríveis". Ele procura justificar-se dizendo que os atores foram impingidos pela Vera Cruz. A entrevista bombástica não é citada nas duas revistas, apesar dos desentendimentos entre Lima Barreto e a Vera Cruz terem rendido várias semanas nos jornais. A imprensa fez inúmeras referências à luta de Lima Barreto na Vera Cruz para fazer seu filme, tal como foi analisado por Maria Rita Galvão. (Galvão, 1976: 267-9)

\footnotetext{
${ }^{19}$ Fernandes, Luiz. Por falar em cinema nacional. Cinelândia, v. 2, n. 11, p. 18, março 1953.

${ }^{20}$ Aos leitores. Cinelândia, v. 2, n. 14, p. 3, $1^{\circ}$ quinz. junho 1953.
} 
Nos boletins da Vera Cruz de 1952, os filmes mais citados são O Cangaceiro (1953), de Lima Barreto, Sai da Frente (1952), de Abílio Pereira de Almeida, e Tico Tico no Fubá (1951), de Adolfo Celi. Nos meses de fevereiro e março, o noticiário da companhia concentrou-se na propaganda de Tico Tico no Fubá com grande estardalhaço, com diversas reportagens sobre Marisa Prado, Tônia Carrero e Anselmo Duarte. $O$ Cangaceiro também teve um impressionante volume de publicidade nos boletins. Comparando com a cobertura de Cena Muda, observamos que exatamente estes três filmes tiveram o menor destaque. Em 1952, a fita da Vera Cruz mais comentada em Cena é de longe Apassionata (1952), de Fernando de Barros. A repercussão deste filme poderia explicar um interesse maior da publicação quando houvesse protagonistas femininas. Além disso, a maior cobertura ocorria durante as filmagens.

A cobertura de Cinelândia ao cinema brasileiro no seu primeiro ano de vida é tão precária que não cabe um comentário sobre os filmes mais destacados. Como exemplo, temos Apassionata. Enquanto Cena Muda fez diversas reportagens sobre Tônia Carrero, o filme e a estrela apareceram somente em uma página de Cinelândia com apenas quatro fotos de close up para a contemplação da beleza da atriz. As legendas nada informam sobre o enredo. O título da matéria $A$ falsa pianista ${ }^{21}$ vem de uma suposta pergunta de um curioso questionando se Carrero sabe tocar piano. A resposta dela foi: "sou a falsa pianista, fique certo".

Ambas as publicações centram as reportagens sobre os filmes do gênero melodramático. O fato tem relação com o vínculo entre o estrelismo e o melodrama, analisado por Christine Gledhill. A estrela funciona como símbolo num sistema que trabalha com o melodrama. $\mathrm{O}$ desenvolvimento de Hollywood não pode se entendido sem fazer referência ao melodrama, aprimorado por estes mesmos estúdios. (Gledhill, 1991).

Há ainda uma subdivisão no critério do estrelismo brasileiro e estrangeiro que é a questão do gênero. Os filmes com protagonistas masculinos obtêm um realce bem menor, como $O$ cangaceiro e Tico Tico no Fubá. Entre $O$ Cangaceiro e Sinhá Moça, os dois maiores sucessos da Vera Cruz, o de Tom Payne aparece muito mais pela presença de Eliane Lage. Em 1953, Sinhá Moça aparece à exaustão nas revistas, principalmente em Cinelândia, assim como suas duas estrelas, Anselmo Duarte e Eliane Lage. Foi o

\footnotetext{
${ }^{21}$ Cinelândia, v. 1, n. 1, p. 7, maio 1952.
} 
único filme que recebeu diversas críticas dos leitores em Cena, além de novelizações, fotos de Lage, algumas delas centradas em sua vida pessoal. Já o diretor de $O$ cangaceiro era mais citado que os protagonistas do filme.

$\mathrm{O}$ interesse centrado no melodrama com protagonistas femininas explica o pequeno destaque aos filmes, cujo gênero dominante é outro, tais como Uma pulga na balança (1953), de Luciano Salce; Família Lero Lero (1953), de Alberto Pieralisi; A dupla do barulho (1953), de Carlos Manga; O canto do mar (1953), de Alberto Cavalcanti, e os dois filmes de Abílio Pereira de Almeida: Nadando em dinheiro (1952) e Sai da frente (1952). Alguns destes filmes até aparecem em uma reportagem ou duas, ou em notas, mas não houve a transformação dos atores em estrelas. Mazzaroppi bastante citado nos boletins da Vera Cruz pouco aparece nas revistas.

Havia, sem dúvida, uma maior cobertura quando se tratava dos filmes da Vera Cruz. Durante 1953, as revistas ocultam os problemas da companhia, a paralisação dos estúdios em novembro não aparece. Só em 1954, quando finalmente as duas revistas comentam a crise, as notícias sobre o cinema brasileiro despencam em quantidade, tanto as fofocas quanto os lançamentos. Por esse motivo, as revistas focam mais a produção da Atlântida e das pequenas companhias. Em 1954, as revistas voltam a comentar com ênfase $O$ Cangaceiro. Neste ano, Alberto Ruschel e Marisa Prado passam a ser capa, citados em reportagens. Portanto, diferente do que costumava acontecer, o maior destaque concentrou-se depois da estréia, não na produção. O Cangaceiro foi, assim, o filme mais comentado durante os quatro anos de analise de Cena Muda.

Abaixo enfocamos a representação das estrelas brasileiras, procurando sintetizar o tratamento geral dado a cada atriz a partir da comparação com a análise dos papéis desempenhados no período. 


\subsection{As atrizes brasileiras: do estrelismo às starlets}

Nas revistas de geração do estrelismo, o foco deve ser a estrela, não exatamente os filmes ou os diretores. Eis uma das dificuldades na vinculação da cobertura ao cinema brasileiro, especialmente em Cena. Pouco a pouco, a quantidade de matérias sobre as atrizes aumenta, especialmente em Cinelândia. Contudo, a orientação ao estrelismo brasileiro é frágil em muitos aspectos. Calcada nas predileções das estrelas nacionais, a maioria das matérias envolviam mais o lançamento dos filmes. No cinema de Hollywood, a maior parte das estréias apareciam sob a publicidade dissimulada focada sobre os astros.

Enquanto há fotos das estrelas hollywoodianas em festas ou com os filhos, no cinema brasileiro as imagens são institucionais ou de publicidade. No cinema norteamericano, há novelizações sobre as divas estrangeiras, trazendo o histórico amoroso, os sofrimentos. A ausência de novelização sobre a vida amorosa das brasileiras pontua uma defasagem considerável na geração do estrelismo nacional.

A grande deficiência em produzir fofocas sobre as estrelas brasileiras falha no ponto mais importante, que é o apelo ao público leitor. As fofocas sobre as atrizes brasileiras são mais frágeis porque sedimentadas apenas no interesse amoroso entre os protagonistas de filmes. Não há os divórcios e casamentos rápidos, ou a incitação da curiosidade sobre possíveis separações. O processo de mitificação das brasileiras é incompleto porque apesar de considerá-las grandes estrelas, não se prova a divindade com fofocas.

O caso da separação de Tônia Carrero, por exemplo, não foi aproveitado para gerar sensacionalismo, como era feito em Hollywood. A atriz separou-se de Carlos Thiré e se casou com Adolfo Celi. Os colunistas ávidos de Cinelândia não tocam no assunto. Apenas insinuam que uma atriz famosa iria se separar e casar com um famoso diretor. Não há cobertura ao fato. Apenas se constata meses depois o relacionamento. Caso se tratasse de uma atriz de Hollywood, a revista comentaria com várias reportagens o caso. Contudo, o tema no Brasil era ainda um tabu por ser tratado como uma questão moral.

A diferença provém na verdade da produção empresarial dos departamentos de publicidade dos Estados Unidos. Este mesmo material da Vera Cruz e da Maristela tem uma estrutura amadora nos artigos. Falta estrutura empresarial moderna aos escassos 
departamentos brasileiros porque a estrutura de produção não é industrial. A presença de alguns roteiristas ou jornalistas para produzir boletins não configura a existência de um setor destinado à publicidade como os de Hollywood. Na capital do cinema, existiam funcionários encarregados de conseguir contatos com as revistas de fãs para plantar matérias, fofocas e penteados, como já abordamos. O figurino dos filmes já era voltado para a divulgação e venda de produtos, ainda nos anos trinta. Produzir releases não significa existir um departamento de publicidade eficiente. Há uma deficiência na produção de conteúdos como os de Hollywood. Enquanto os artigos sobre as estrelas estrangeiras novelizavam sua vida pessoal, deixando os filmes em segundo plano, os boletins da Vera Cruz centralizam seus artigos sobre as fitas, com comentários sobre a biografia dos atores, mas falta conteúdo sobre a personalidade dos artistas. Não há uma narrativa de folhetim. Os artigos são divididos geralmente em pequenos tópicos, sobre o elenco com biografia, consagração dos atores, enredo, recepção e próximos lançamentos. Ao contrário de destacar a importância das estrelas, os boletins vendem a importância dos filmes da companhia para a consagração dos atores:

"Um trio de ouro:

"Apassionata", o filme que consagrará definitivamente Tônia Carrero, tem um "cast" em que desde as primeiras figuras até as "pontas" trabalham os melhores artistas que se poderia exigir. Tônia Carrero contracena com "astros" como Anselmo Duarte, Alberto Ruschel e Ziembinski. Alberto Ruschel, grande revelação de "galã" do cinema nacional surgido com o filme "Ângela", num papel de extraordinária dramaticidade em "Apassionata", e Ziembinski, o famoso ator europeu, agora definitivamente integrado na Vera Cruz, vive um dos grandes papéis de sua carreira. Secundam esse verdadeiro "trio de ouro" (...)" 22

Aqui há apenas uma narrativa sobre o elenco do filme, sem tentar aproximar a personalidade da estrela com a do papel, nem anunciando detalhes sobre figurino, penteados ou fofocas. O artigo cita apenas a beleza de Tônia Carrero, os belos cenários feitos para ela e os filmes feitos antes.

Já o departamento de publicidade da MGM durante os anos trinta e quarenta possuía em média sessenta pessoas. Paul McDonald (2000) conta que cada funcionário era responsável por duas ou três estrelas, além de realizar contatos com um grupo de correspondentes nacionais da imprensa. Durante a feitura do filme, o estúdio deixava um único publicista criar e manter a publicidade em volta de uma produção individual. Além de preparar o lançamento e preview, o departamento organizava histórias sobre as

\footnotetext{
${ }^{22}$ Boletim da Vera Cruz n. 26, p. 3, agosto de 1952.
} 
estrelas e sobre a produção. Os casos eram plantados na imprensa e nos veículos de divulgação da indústria, chamados de trade.

Além dos publicistas dos estúdios, as estrelas tinham também agentes de publicidade, embora o estúdio desencorajasse a mediação, vendo com maus olhos a função. As atrizes pouco conhecidas contratavam o serviço para atingir o status de estrela. Os astros já conhecidos também usavam os agentes para cultivar sua imagem junto ao público e para aumentar o interesse interno da indústria por sua pessoa.

Havia ainda um serviço de medição da popularidade dos atores a partir do volume de cartas recebidas, além de estatísticas de lucro dos filmes relacionadas às atrizes e entrevistas com frequientadores de cinema para indicar os nomes conhecidos. As companhias contavam ainda com estudos para comparar a aparência das atrizes nos últimos filmes com sua popularidade.

Apesar das matérias plantadas nas revistas, Paul McDonald lembra a importância para os estúdios da publicidade primária realizada pelos press books de cada filme. $\mathrm{O}$ material era enviado aos exibidores, mas também à imprensa. Contava com lista de elenco, biografia dos atores, sinopse do filme, críticas para os jornais, além de inúmeras fotografias, consideradas a parte central nas campanhas publicitárias. $\mathrm{O}$ objetivo primeiro dos press books era enviar aos exibidores informações úteis com conselhos para realizar a publicidade dos filmes. O livro incluía os anúncios e posters disponíveis para colocar nas ante-salas dos cinemas, a partir do tipo de público alvo. Esta publicidade indicava as possíveis divulgações voltadas para as características dos estabelecimentos. A propaganda ao filme incluía também a aparição das atrizes nos previews e lançamentos, além das previews em diferentes cidades, chamadas de road shows. A presença da intérprete era muito efetiva para a vinculação da publicidade. Quando se tratava de um musical, as estrelas podiam exibir seus dotes cantando e dançando. Em casos de papéis dramáticos, o departamento criava uma pequena cena a partir de uma versão do filme. O objetivo era avivar a performance.

No caso brasileiro, não existia nem um terço dessa estrutura. Nas reportagens sobre as estrelas brasileiras, há geralmente apenas informações sobre as preferências de cor, comida, livros, estatura, peso e hobbies dos ídolos. As matérias são curtas. As brasileiras não dão conselhos às leitoras, não falam sobre sua grande felicidade, não ensinam o leitor a ser feliz. Tampouco sofrem com intensidade. Não mostram a 
decoração da casa ${ }^{23}$. A mitificação falha em muitos aspectos. Falta também repetição de matérias sobre as mesmas atrizes, assim como não há grande volume de fotografias e número exacerbado nas qualidades descritas dos olimpianos. As atrizes são lembradas apenas por causa do lançamento, não durante o ano todo, como ocorria com as divas hollywoodianas. Podemos encontrar notas sobre algumas estrelas na maioria das edições, mas não há novelizações sobre sua divindade, problemas, romances. Estes são os indícios dessa ausência do cinema brasileiro como um todo nas publicações.

Nas comédias carnavalescas, a atenção volta-se às estrelas radiofônicas e ao par amoroso. Outras vezes é feito estrelismo de Oscarito, mas centrado sobre seus dotes humorísticos, não sobre sua vida pessoal. Grande Otelo aparece pouco, razão citada mais adiante. Outros humoristas como Mesquitinha e Ankito aparecem de forma discreta, em uma ou duas matérias.

A deficiência do cinema brasileiro em produzir seu estrelismo aparece quando se legitima as atrizes nacionais pela comparação com as estrangeiras. Para provar que a atriz é mesmo uma deusa, deve ter os mesmos atributos das divas hollywoodianas, especialmente quanto à fotogenia. Assim, o star system brasileiro confessa textualmente que não existe sem a comparação com o norte-americano. Outro problema é a negação das estrelas brasileiras em algumas reportagens. Depois de afirmar a divindade das atrizes, numa sentença os repórteres admitem sua condição de novatas, ou relembram o desempenho anterior muito ruim. Diversas matérias revelam que só a partir do último filme, os atores tiveram seu primeiro grande papel.

A maior parte das manchetes tem a mesma denominação Nasce uma estrela ${ }^{24}$. A principal diferença no caso brasileiro entre estrelas e aspirantes é a composição textual. As starlets são apresentadas em artigos bem mais curtos, ou apenas em notas. Descritas com menos atributos, as matérias enfocam as suas preferências pessoais e hobbies. As fotos são geralmente em preto e branco com dimensões reduzidas. O mais importante para se distinguir uma estrela de uma novata é a ausência de fofocas a respeito destas últimas. Não namoram, nem se envolveram com nenhum astro. Apesar das revistas realizarem alarde com pequenos papéis dos coadjuvantes para ampliar a noticiabilidade do estrelismo, apenas se narra a vida pessoal, sem interesse por experiências sentimentais. Não há tom de fofoca. $\mathrm{O}$ estrelato chega quando há interesse

\footnotetext{
${ }^{23}$ Entre 1954-55, Cinelândia mostra a decoração da casa dos atores, como a do casal Anselmo Duarte e Ilka Soares, embora estes casos sejam raros.

${ }^{24}$ A manchete passa a ser mais usada ainda depois das notícias sobre o remake de Nasce uma estrela (1954), de George Cukor.
} 
crescente por parte das publicações pela personalidade da estrela e na verificação de similitudes com seus personagens.

A configuração do estrelismo brasileiro nas revistas de fãs tinha avançado bastante da época em que Eva Nil ou Carmem Santos apareciam em Cinearte sem terem feito filme algum (Gomes, 1974). Não é possível alegar a total fabricação de estrelas no caso do cinema nacional, porque as norte-americanas também eram criadas e geradas na produção.

A definição da revista Cena Muda da estrela como a possuidora de boatos ${ }^{25}$, pode ser acrescida de outra nomenclatura, desta vez utilizada por Cinelândia. Ser estrela é garantir o sucesso e/ou bilheteria do filme apenas com seu nome. Esta é a justificativa do diretor da Paramount para explicar que Audrey Hepburn ainda não é estrela ${ }^{26}$. A declaração confessa o estrelismo como estratégia para garantir lucro aos filmes. Apesar de o critério estar em total desacordo com a representação das publicações, e com o peso do nome da atriz no período, podemos utilizá-lo para discutir a falta de parâmetros das duas revistas para discutir a diferença entre estrelas e starlets. Tenta-se criar aqui patamares para o estrelismo, para ter o que se noticiar. Procura-se apontar o poder das revistas de fãs na conversão de estrelas. O processo é diferente do caso brasileiro, pois neste caso único sobre Audrey Hepburn apenas se criou um patamar mais alto às atrizes. No caso brasileiro se condenam as interpretações anteriores com freqüência.

Depois da crise da Vera Cruz, há um salto na quantidade de pin ups e starlets do cinema brasileiro ${ }^{27}$. Pela dificuldade de conseguir matérias, as duas revistas citam em demasia as novatas e aspirantes em notas com pequenas fotografias. Algumas delas aparecem muito nas notas, aumentando a fixação de seus nomes pela repetição.

No caso dos novatos, por não ter it ou um atributo a causar distinção, recorre-se à especificações como: Paulo Geraldo é o astro mais alto do cinema brasileiro ${ }^{28}$. Esse é seu único diferencial. Cena Muda fez durante esse período matérias sobre os atores da Oceânia Filmes, tentando criar o star system do cast de filmes como Conflito ${ }^{29}$ e Custa

\footnotetext{
${ }^{25}$ Ele detesta mexericos. Cena Muda, v. 34, n. 33, p. 23, 27/10/1954.

${ }^{26}$ Audrey Hepburn ainda não é estrela? Cinelândia, v. 3, n. 42, p. 23, $1^{\text {a }}$ quinz. agosto 1954.

27 Alguns dos nomes que passam a aparecer com freqüência são as participantes do Concurso Miss Cinelândia como Ana Beatriz, Inalda de Carvalho, Julie Bardot, Agnes Fontoura. Há ainda Cleo Tereza, Lia Cortese. Nos anos anteriores se divulgava atrizes como Regina Laura, Luis Jorge, Jane Martins, Nadia de Lucena, D’Andrea Netto, Margo Bittencourt, Cuquita Carballo. Havia também Eva Wilma, Nathália Timberg entre as novas artistas anunciadas.

${ }^{28}$ Paulo Geraldo - novo galã brasileiro. Cena Muda, v. 32, n. 35, p. 17; 30, 29/08/1952.

29 Não encontramos referência ao filme no site da Cinemateca Brasileira.
} 
pouco a felicidade (1952), de Geraldo Vietri. As fitas são enaltecidas na base da participação das aspirantes, convertidas em estrelas.

Nem todos novatos são citados. O star system da Maristela era composto de Antonieta Morineau, uma segunda Eliane Lage pelos releases da companhia, Procópio Ferreira, Hélio Souto, Orlando Vilar, Vera Nunes, Henriette Morineau, Jackson de Souza, Zilah Maria, Dina Lisboa, Margot Bittencour e Jaime Barcelos. (Galvão, 1976) Contudo nas duas revistas aparecem apenas com algum realce em notas de maior dimensão Margot Bittencourt, Jackson de Souza e, é claro, Procópio Ferreira. Maria Rita Galvão (1976) verificou que desde 1951 havia informações sobre a situação ruim da Maristela nos jornais. Até 1951 o fato foi muito comentado. Embora nem Cena Muda, nem Cinelândia comentam a crise nos anos analisados, sem contextualizar as dificuldades da companhia, as duas revistas buscam incentivá-la, citando a possibilidade de realizar novos filmes. Contudo, a Maristela como empresa não é muito citada, se comparada com o noticiário da Atlântida e da Vera Cruz nas duas revistas, tanto em termos de atores quanto de filmes produzidos.

Enquanto Cena Muda fazia a divulgação dos estreantes das pequenas companhias, convertendo-os em estrelas, Cinelândia no seu primeiro ano relatou certa vez o "ostracismo" dos atores. Depois da fama, acabam fora do meio cinematográfico:

\footnotetext{
"é interessante notar como, em geral, não é ainda forte o cartaz dos nossos artistas. Conseguem certa notoriedade, para logo depois caírem no ostracismo ou empregarem suas atividades em outros setores que não o cinematográfico. Por exemplo, quem vai ao 'Monte Carlo' assistir ao bonito e divertido 'show' intitulado 'O terceiro homem', tem a surpresa de encontrar Mary Gonçalves como uma das cantoras da orquestra e Margot Bittencourt, a estrela de 'O comprador de fazendas', integrando o corpo de coristas ! O que é que há?" 30
}

Apesar de a revista confessar a dificuldade de geração de estrelismo brasileiro, continua a tentar divulgar pin ups. Além disso, grande parte das maiores estrelas brasileiras também tinham sido apresentadas pouco tempo antes como desconhecidas com grande potencial. As musas da Vera Cruz também eram chamadas de futuras estrelas, quando ainda eram desconhecidas. Segundo a análise de Maria Rita Galvão, em março de 1950, os boletins da Vera Cruz afirmavam que Eliane Lage está "destinada a se tornar uma das nossas maiores "estrelas"”. O release admitia tratar-se de "um nome ontem desconhecido e que dentro de poucas semanas será consagrado pelo público brasileiro como o de uma das nossas maiores revelações artísticas de todos os tempos."

\footnotetext{
${ }^{30}$ Fernandes, Luiz. Cinema brasileiro. Cinelândia, v. 1, n. 8, p. 26; 55, dez. 1952.
} 
O noticiário da companhia fez o mesmo ao se referir ao seu par romântico na fita, o ator Mário Sérgio, considerado "o jovem galã” possuidor de todas as qualidades necessárias para se tornar um dos maiores atores do "écran nacional". Também Marisa Prado foi descrita como "a nova descoberta da Vera Cruz". A companhia espalhou várias matérias sobre ela na imprensa. (Galvão, 1976: 4; 133).

Para difundir o mito da Hollywood brasileira, Cena Muda cria boatos sobre os salários dos atores, a partir de dados irreais. Ao contrário do prometido, a repórter Luelinha Passos não traz os valores dos ordenados. Justifica a ausência de números porque alguns atores são ricos e não precisam ganhar bem ${ }^{31}$. Oscarito teria até seis milhões guardados. No Rio de Janeiro, o salário é bem mais baixo. Luelinha deixa em aberto que os atores são também piores.

Contudo a realidade era outra. Para se sustentar, Oscarito trabalhava no teatro, além de fazer excursões pelo Brasil, de onde tirava seu lucro. O renome conseguido com os filmes auxiliava a criar a sua imagem. Watson Macedo confessou anos mais tarde ter trabalhado como diretor na Atlântida sem ganhar pelo cargo. Por sete anos seu salário foi o de um montador. Nos dois últimos anos recebeu a soma de mais dez contos de réis pela função de cineasta. Burle também revelou ter trabalhado de graça até seu quinto filme, pelo qual recebeu também dez mil cruzeiros. (Augusto, 1989)

Dado ao exagero na conversão de aspirantes em celebridades nas revistas de fãs, é importante pontuar quais eram as maiores estrelas de acordo com a repetição em capas e matérias sobre a vida pessoal. A maior parte dos estudos sobre o star system fazem um paralelo da vida mediática com os papéis interpretados, ou seja, estudam as atrizes a partir de análises fílmicas. Fazemos uma análise apenas da representação dos famosos nos meios de comunicação. Porém, alguns pressupostos da personalidade dos personagens são importantes para tentar compreender a estrutura do star system nas revistas de fãs ${ }^{32}$, dado o mecanismo de transferência. No geral, a lei dos tipos, necessária à adequação do ator ao personagem, é convertida no cinema brasileiro em atributo ao estrelismo, como foi mostrado por Paulo Emilio Salles Gomes sobre a revista Cinearte:

“A 'lei dos tipos', originalmente ligada à necessidade de adequação do ator à personagem e às regras de verossimilhança que apontavam para uma representatividade

\footnotetext{
${ }^{31}$ Passos, Luelinha. Desvendando mistérios. Cena Muda, v. 32, n. 48, p. 4, 28/11/1952.

${ }^{32}$ Trazemos apenas as atuações feitas durante os primeiros anos da década de cinqüenta. Contudo os dados sobre muitas personagens estão incompletos porque diversos filmes do período estão indisponíveis. De outras atrizes só tivemos acesso a uma ou duas fitas, sendo difícil estabelecer um perfil mais certeiro.
} 
sociológica, transforma-se em critério de estrelismo, reduzida a parâmetros estéticos-sexuais. Para exercer atração sobre o espectador, a mulher deve ser um 'tipo de beleza' e o homem um 'tipo de virilidade"'. (Salles Gomes, 1974: 336)

Voltando dessa comparação com Cinearte, este esvaziamento da lei dos tipos, transvertido numa planificação da fotogenia, condiciona uma cobertura apenas aos protagonistas fotogênicos.

A fronteira entre starlets e estrelas na representação do cinema nacional é bastante tênue, como veremos aqui. Entre as estrelas com maior enfoque textual e imagético há Tônia Carrero, Eliane Lage e Fada Santoro. Apesar de estas estrelas serem sempre citadas nas matérias internas, poucas vezes foram capas das revistas. A maior evidência não se deve às fofocas, mas aos lançamentos. Fada Santoro recebeu duas capas, uma em Cena Muda e outra em Cinelândia, devido ao lançamento de Nem Sansão nem Dalila (1954), de Carlos Manga. Eliane Lage aparece duas vezes na primeira página, uma em cada revista por causa de Sinhá Moça (1953), de Tom Payne. Tônia Carrero aparece só uma vez na capa pelo filme Apassionata (1952), de Fernando de Barros. Eliana Macedo recebe apenas numa capa de Cinelândia em 1953. Comparativamente, a cantora Marlene ganhou quatro capas em Cena Muda, por causa do destaque desta revista ao rádio. Nos anos posteriores e depois destes lançamentos, o número de capas com brasileiras cai bastante. Faltava agendar a presença dessas estrelas via repetição na mente dos espectadores durante todo o ano. No cinema estrangeiro, havia infindáveis capas nas duas revistas com Marilyn Monroe, Lana Turner ou Ava Gardner. Estrela de primeira grandeza deve ter apelo para vender capa. As brasileiras raramente cumpriam este fim para as revistas de fãs analisadas.

Havia um aproveitamento da persona da estrela e de sua representação social quando se creditava determinado tipo de papel nos filmes. Nesse sentido, as protagonistas interpretadas por Eliane Lage ${ }^{33}$ combinavam com o papel nobre atribuído a sua família: a sinhá na era escravocrata em Sinhá moça (1953), a nobre falida, em Ângela (1951), ou a filha de um rico industrial em Terra é sempre terra (1950). Contudo este paralelo não explica o caso da personagem de Lage em Caiçara (1950), de Adolfo Celi. Trata-se de uma moça pobre, filha de pais leprosos, embora mesmo assim ela seja tratada como superior em relação ao seu marido pescador.

\footnotetext{
${ }^{33}$ Sobre Eliane Lage, existe a tese de Ana Carolina Maciel. Yes nós temos bananas: cinema industrial paulista: a Companhia Cinematográfica Vera Cruz, atrizes de cinema e Eliane Lage. Brasil, anos 1950. Tese (doutorado em História) - Instituto de Filosofia e Ciências Humanas, Universidade Estadual de Campinas, Campinas.
} 
Em oposição ao universo de riquezas de algumas de suas protagonistas, Cinelândia narra a vida humilde da atriz, durante as filmagens de Sinhá Moça. Eliane Lage mora num sítio, sem empregada, longe do luxo da casa da família: “em Nuporanga ela 'pega no pesado' e tem de costurar, cozinhar e lavar a louça”. Para provar a descrição, a atriz é fotografada em outras matérias ao lado de uma vassoura na varanda ${ }^{34}$, com um pato no colo ${ }^{35}$, ou com pano na cabeça estendendo fraldas ${ }^{36}$. O texto vende a concepção de felicidade campestre, em oposição aos textos majoritários da revista com fotos de apartamentos luxuosos, permeados pelo glamour. O objetivo é elogiar a atriz, desinteressada dos bens mundanos: "Eliane Lage vive fora da tela uma vida simples, despida do 'glamour' com que as outras artistas procuram se cercar', declara Cinelândia.

Já o aparecimento do nome de Fada Santoro nas duas revistas estava mais vinculado às fofocas sobre sua vida amorosa do que aos filmes estrelados. Em 1953, seu nome está atrelado ao filme Nem Sansão nem Dalila (1954), de Carlos Manga. No ano anterior, a atriz aparece por causa dos supostos relacionamentos com Cyll Farney e Miro Cerni. No caso do filme A força do amor (1952), de Eurides Ramos, o nome de Fada está ligado a uma pequena companhia, a Cinelândia Filmes, o que ocasiona uma diminuição considerável na cobertura das revistas.

Entre as três maiores estrelas para as duas revistas: Tônia Carrero, Eliane Lage e Fada Santoro, a última atrai maior número de fofocas porque estava solteira e personificava mais o estereótipo da boa moça, ingênua e prendada. Seu nome verdadeiro era Mafalda. Convertido para Fada dizia bastante sobre o papel desempenhado por ela nos filmes. Em uma foto, a atriz aparecia tocando violão, ao fundo estava a figura da mãe-modelo, tricotando num ambiente estritamente familiar $^{37}$.Tônia Carrero era uma atriz casada, diminuindo em parte as fofocas a seu respeito. Nesse período, Eliane Lage também estava casada. As duas revistas de fãs procuravam apenas conseguir fotos dos momentos de intimidade do casal Payne, as fofocas eram para as solteiras.

Num paralelo entre os filmes contracenados por Fada e seu perfil divulgado nas revistas, podemos dizer que as personagens da atriz têm muito a ver com a persona construída a seu respeito: uma moça de família, com papéis de ingênua ou sofredora.

\footnotetext{
${ }^{34}$ A casinha pequenina lá no alto da colina. Cinelândia, v. 1, n. 6, p. 30-1, out. 1952.

${ }^{35}$ Aconteceu no Brasil. Cinelândia, v. 3, n. 42, p. 46-7, $1^{\text {a }}$ quinz. agosto 1954.

${ }^{36}$ Aconteceu no Brasil. Cinelândia, v. 2, n. 25, p. 48-9, $2^{\mathrm{a}}$ quinz. nov. 1953.

${ }^{37}$ A fada que não quer ser mais ingênua. Cinelândia, v. 2, n. 22, p. 42-3, $1^{\text {o }}$ quinz. out. 1953.
} 
Fada não fazia papéis de moça rica, era sempre de classe média ou pobre. Em Nem Sansão nem Dalila, interpreta uma manicure. No tempo diegético onírico, situado no Reino de Gaza, Fada é a irmã de um rico aristocrata, mas não a privilegiada entre as filhas. Em Escrava Isaura (1949), de Eurides Ramos, a atriz novamente interpreta a sofredora, assim como em Agulha no palheiro (1953), de Alex Viany. Neste último, Fada vive uma moça ingênua, romântica, enganada e abandonada pelo namorado porque ficou grávida. Fada não assume nas reportagens o papel de mulher com sensualidade, como no filme Nem Sansão nem Dalila. Procura separar personagem e atriz. Por esse motivo, o discurso de Santoro no documentário de Carlos Manga, Assim era a Atlântida (1975), é negar ter sido vedete, quando começou dançando e cantando em um cassino do Rio de Janeiro. Quando ela oculta o trabalho exercido, atribui a ele uma conotação negativa.

As personagens de Tônia Carreiro geralmente congregam mulheres independentes. Não ligam para convenções sociais e até com um "que" de vamp em alguns momentos. Assim é a personagem Branca em Tico Tico no Fubá (1951), de Adolfo Celi. Uma atriz circense sem lar. Apaixonada, decide levar consigo o homem que conheceu aquela semana. Em É proibido beijar (1954), de Ugo Lombardi, Tônia desempenha papel semelhante em nível de independência feminina porque aceita fazer parte de uma aposta, envolvendo viver uma semana na casa de um homem à custa dele, sem beijá-lo nenhuma vez. Em Apassionata (1952), de Fernando de Barros, Carrero personifica a pequena seduzida pelo professor pianista. Anos depois, vivendo uma vida de inferno com o marido, se divorcia, sem se importar com os boatos, nem com as acusações de ter feito sucesso a custa do renome do marido. Sem se importar com as convenções sociais pelo pouco tempo de luto, encontra um novo amor. Esta imagem de mulher moderna se concilia mais com a vida da atriz.

Tônia Carrero é a grande atriz para Cena: tem beleza e talento, embora os atributos físicos pesem mais. Já Fada Santoro encarna os estereótipos que a revista vende como ideais comportamentais, a boa moça de família, enfatizando mais os dotes morais que a beleza.

A categoria seguinte refere-se às estrelas, protagonistas dos filmes das grandes empresas cinematográficas do período, mas citadas sem realce, entre elas Ilka Soares, Marisa Prado e Eliana Macedo.

Ilka Soares aparece bem menos. Apesar de ser citada como estrela, não há cobertura fotográfica abundante. Ela está nas revistas devido a dois acontecimentos de 
sua vida pessoal: o rompimento do noivado com Miro Cerni e o casamento com Anselmo Duarte. As fofocas são pontuais e sem repetição, diferente do caso de Fada Santoro. Ilka foi a protagonista do filme Esquina da ilusão (1953) de Ruggero Jacobbi, mas sua participação na fita foi pouco comentada. A fita aparece mais em notas sobre a produção. A publicidade deste filme nas revistas não se concentrou sobre os atores.

Talvez no caso de Marisa Prado, o maior destaque tivesse sido no seu surgimento, como é o caso da maior parte das atrizes lançadas. Apesar de Marisa Prado ser a protagonista do filme $O$ Cangaceiro (1953), de Lima Barreto, a atriz só recebeu apreciações negativas nas seções de crítica de Cena. A starlet Vanja Orico com pequena participação, apareceu muito mais nas revistas. O fato pode ser explicado por uma necessidade do star system, das publicações e da cultura de massa em dar ao público sempre o novo. Vanja Orico é transformada em Cinelândia na nova estrela do cinema nacional. A protagonista interpretada por Marisa Prado nem sequer ganhou uma matéria em 1953. No ano seguinte, convidada a fazer o filme Orgulho (1955), de Manoel Mur Oti, na Espanha, recebeu maior cobertura. Talvez as fofocas diminuíssem porque Marisa era casada. Por outro lado, Vanja além de solteira, era uma cantora lírica residente havia três anos na Itália. Apesar disso, ambas as revistas não citam sua participação no filme Mulheres e luzes (1950), de Alberto Lattuada e Federico Fellini, em que ela cantou Meu limão, meu limoeiro. Vanja tinha ainda um programa de rádio na Europa ${ }^{38}$, mas não era propriamente uma atriz na época.

Os papéis interpretados por Marisa Prado são os de moças simplórias. A comparação induzida dos releases com Cinderela não se fechava na trama dos filmes. Em Terra é sempre terra (1950), de Tom Payne, interpreta seu primeiro papel no cinema como Lina, a ex-amante do dono da fazenda, entregue como esposa ao capataz corrupto. Depois, tem um romance com o filho do proprietário (Mário Sérgio), engravidando. $\mathrm{O}$ filme termina em aberto, com a personagem carregando seu filho, simbolizando um possível retorno da propriedade para a mesma aristocracia. Em Tico Tico no Fubá (1951), de Adolfo Celi, a personagem Durvalina apesar de conseguir casar, vive infeliz porque seu marido Zequinha de Abreu (Anselmo Duarte) não consegue esquecer Branca (Tônia Carrero). O destino da professora Olivia não é mais feliz em O Cangaceiro (1953), de Lima Barreto, após a morte de seu amado Teodoro (Alberto Ruschel). Apenas em Candinho (1953), de Abílio Pereira de Almeida, como a

\footnotetext{
${ }^{38}$ Vanja continuou carreira e fez diversos filmes em produções estrangeiras.
} 
caipira Filoca alcança um final feliz, mas a alegria parece um sonho impossível. O final do filme tem um tom fábula. Antes tinha sido deserdada, tornando-se taxi girl, ou seja, dançarina avulsa de cabaret. Passado este que apenas o caipira Candinho (Mazzaroppi) iria relevar por sua ingenuidade. Há uma falta de completude no final feliz, sem a transformação em Cinderela nem das personagens, nem da atriz.

Em 1952, a grande ausente de Cena é Eliana Macedo. Ela aparece pouco nas reportagens. As matérias sobre Amei um bicheiro (1952), de Paulo Wanderley e Jorge Ileli a colocam em segundo plano. A atriz não obteve maior espaço em Cinelândia também, mas foi tema de duas reportagens. Em 1953, ganha capa e matéria de uma página em Cinelândia. Neste texto, podemos encontrar o porquê do menor destaque à Eliana. Ela é considerada uma atriz com potencial não aproveitado, sob expectativa de melhora com a direção de Carlos Manga em Nem Sansão nem Dalila. Segundo o autor anônimo de Cinelândia:

\footnotetext{
"até agora Eliana tem sido desajustada de direção. Quando trabalhava sob o comando de Watson Macedo, (..) seu rendimento era apreciável. Contudo, sentimos que, mesmo naqueles papéis e com um diretor de pulso mais forte, ela renderia muito mais. (...) Eliana precisa de argumentos melhores, de papéis mais ricos de conteúdo, de diretores que consigam tirar desta artistazinha tão querida o que ela é capaz de dar ao cinema." ${ }^{39}$
}

Provavelmente por Eliana já ser uma estrela consagrada, as revistas preferissem enfocar as estreantes. É improvável que Cena a ignorasse porque Eliana era uma atriz da chanchada, porque a publicação destacava atrizes como Fada Santoro. Talvez a Atlântida não mandasse um largo material de divulgação. Certamente as revistas estavam mais interessadas sobre a vida pessoal de Fada, batalhando mais para conseguir fotos e matérias. Nem o casamento dela com o radialista Renato Murce obtém reportagens, apenas notas e uma foto de pequenas dimensões. Segundo Sérgio Augusto, em 1956, Eliana já estava em fase de decadência, mas assim mesmo seu tio Watson Macedo insistiu em fazer seis filmes com ela na sua produtora, onde os dois foram ganhar muito mais do que recebiam na Atlântida. O descompasso deste caso é importante porque revela também um distanciamento em relação ao modelo criado pelas revistas de divulgação do star system das companhias brasileiras.

Em 1954, a atriz volta a aparecer no noticiário, mas de maneira discreta devido ao filme A outra face do homem (1954), de J. B. Tanko. As duas revistas a citam como uma vamp. Cinelândia afirma ser difícil penetrar em seu mundo. Eliana é "condenada a

\footnotetext{
${ }^{39}$ Eliana. Cinelândia, v. 2, n. 20, p. 27, $1^{\text {o }}$ quinz. set. 1953.
} 
interpretar papéis de mulher perversa e fatal", declara ${ }^{40}$. Por isso a estrela faz questão de não se revelar, porque sua persona de vamp volta e meia ressurge no cinema. A fita não é anunciada pela presença da atriz. Há apenas algumas frases sobre seu papel de vamp, tentando provar a coincidência entre a personalidade da intérprete e da personagem. Contudo a divulgação de Eliana como vamp torna-se muito frágil, porque a atriz não personificava este estereótipo. Eliana vez por outra possuía uma dualidade nos papéis interpretados. Mostrava seu corpo, com apelo sensual mais forte, como uma vedete, mas interpretava o tipo de ingênua romântica ou ainda mulheres destemidas, corajosas ou independentes.

Poderíamos acrescentar também entre as ausentes Maria Fernanda, protagonista do filme Luz apagada (1953), de Carlos Thiré. Acreditamos que a menor evidência tenha sido causada pela crise da Vera Cruz, que diminuiu bastante a cobertura às fitas desta companhia. Quando as revistas não mais ocultam os problemas da empresa (muito depois da grande imprensa), o noticiário da companhia despencou. Até Tônia Carrero, protagonista do filme É proibido beijar (1954), de Ugo Lombardi, não teve evidência nas duas publicações. Maria Fernanda é citada em Cinelândia com continuidade, mas apenas em notas ou em pequenas fotografias.

Já os boletins da Vera Cruz em 1953 enfatizaram Maria Fernanda e Mário Sérgio do filme Luz apagada, ou Gilda Nery e Waldemar Wey de Uma pulga na balança (1953), de Luciano Salce. Estes releases citados por Maria Rita Galvão (1976) não aparecem. Não há conversão dos atores em astros, apenas citações deles em notas. O caso de Uma pulga na balança pode ser explicado pelo gênero cômico do filme. No geral, as duas publicações informam mais sobre as superproduções, como Sinhá Moça, porque se pode compará-las a Hollywood. Talvez a cobertura das revistas em busca de filmes com altos custos para permitir a comparação com Hollywood tenha colocado de lado Luz apagada pelo conteúdo do próprio boletim da Vera Cruz que se desculpava pelos erros, alardeando o baixo custo da fita.

Os últimos filmes da Vera Cruz, como Floradas na serra (1954), de Luciano Salce, Na Senda do Crime (1954), de Flaminio Bollini Cerri, Candinho (1953), de Abílio Pereira de Almeida, É proibido beijar (1954), de Ugo Lombardi, e Luz apagada (1953), de Carlos Thiré, tiveram sua produção e edição durante a crise, abalando bastante a

\footnotetext{
${ }^{40}$ Glamour só na tela. Cinelândia, v. 3, n. 41, p. 30-1; 64, 2ª quinz. julho 1954.
} 
representação das revistas sobre a Vera Cruz. Não se anuncia mais uma super-produção, mas filmes de uma empresa falindo.

Entre as estrelas cinematográficas produzidas naquele período, que passam a ser citadas com freqüência, mas não se perpetuam como ídolos como as primeiras, há a cantora Dóris Monteiro, Aurora Duarte e Patrícia Lacerda. As matérias sobre a vida pessoal não são constantes, não há muitas fofocas. Não existe tanta repetição na aparição delas em diversas reportagens. Estão numa categoria abaixo das primeiras. Patrícia Lacerda e Dóris Monteiro são aclamadas como grandes revelações, mas são novatas, como fica claro nas duas revistas. Há uma insistência em seus nomes, em notas com fotografias, embora Dóris tenha uma incidência nas revistas maior que as demais deste grupo. Por outro lado, Paulo Paranagua (1987) lembra que os atores do teatro, como Cacilda Becker, Eva Todor, entre outros, ficaram reduzidos a aparições episódicas nos filmes do período.

Em outra categoria, há as atrizes que aparecem com frequiência ainda menor por não estrelarem um filme no período, por serem coadjuvantes ou por estarem fora do conceito de fotogenia das publicações. Há também os casos das que não interpretam as protagonistas ingênuas nem heroínas. Entre elas há Adelaide Chiozzo, Violeta Ferraz, Inezita Barroso. Isso porque os atores ou atrizes secundários não aparecem com freqüência. No máximo são tema de duas matérias. Adelaide costumava fazer o papel da melhor amiga de Eliana Macedo. Participou de filmes com um destaque um pouco maior em Aviso aos navegantes (1950), de Watson Macedo, É fogo na roupa (1952), de Watson Macedo, O petróleo é nosso (1954), de Watson Macedo e Barnabé, tu és meu (1951), de José Carlos Burle. Para se tornar uma estrela para as duas revistas pesquisadas lhe faltava a extrema beleza nas imagens difundidas. Adelaide era citada em notas, ou pelas músicas nas seções de rádio. Talvez as revistas estivessem mais interessadas em produzir novas estrelas do que noticiar os trabalhos das coadjuvantes. $\mathrm{O}$ critério neste caso não foi a ausência da atriz nos estúdios, nem a falta de fama no rádio, onde Chiozzo tocava acordeão.

A atriz Aurora Duarte, considerada portadora de uma beleza nordestina, é aceita como uma beldade exótica. Contudo os traços são europeus ${ }^{41}$. O nome da personagem, chamada de Aurora no filme $O$ canto do mar (1953), de Alberto Cavalcanti, transformou-se no seu nome artístico. Aurora Duarte é o maior exemplo de

\footnotetext{
${ }^{41}$ Já a atriz Cacilda Lanuzza, com traços mais brasileiros e atuando no mesmo filme, não é convertida em estrela.
} 
transferência das características da atriz à personagem. As duas revistas questionam se ela irá se adaptar ao mundo chique da metrópole, como se sua personalidade fosse a do papel interpretado. Não há notícias sobre sua vida pessoal ou fofocas. Depois do filme de Cavalcanti, a intérprete é denominada nas revistas como a Aurora do Canto do Mar. Há diversas citações à atriz em Cinelândia, embora o filme não tenha sido objeto de interesse da publicação.

O critério para o maior ou menor interesse das publicações passa claramente pela fotogenia convertida em atributo de beleza. Glauce Rocha ${ }^{42}$, mesmo como protagonista do filme Rua sem sol (1953), de Alex Viany, aparece apenas em notas em ambas revistas. A ênfase fica para a cantora do rádio Dóris Monteiro. Na única matéria sobre Glauce, Cena Muda explicita os critérios deste conceito de fotogenia ao declarar que apesar de não ser uma pin up, Glauce é simpática e "ótimo papo" 43 . A manchete utiliza a palavra estrela entre aspas, uma clara referência ao desvio padrão de perfeição física da atriz. Sanin explica que não gostaria de chamá-la de estrela, porque Glauce é simplesmente atriz. O motivo vem logo depois: a ausência de traços geometricamente regulares.

Há ainda atrizes em foco por conta de um filme, mas que somem depois, como Josette Bertall, a femme fatale de Amei um bicheiro (1952), de Paulo Wanderley e Jorge Ileli. Ou ainda Maria Della Costa, Maria Antonieta Pons, Edith Morel, Mara Abrantes. Estas starlets para as revistas são tratadas como estrelas, mas em apenas poucos textos. Entre as estrelas condenadas devido ao moralismo está sem dúvida Virginia Lane, citada apenas em notas, mas sem fotografias grandes, como já mostramos.

Entre as starlets comentadas apenas de maneira visual, já abordamos o caso de Liana Durval no capítulo anterior. A atriz é uma pin up no filme Nadando em dinheiro (1952), de Abílio Pereira de Almeida e Carlos Thiré. Durante 1954, a atriz ganha destaque nas duas revistas em pequenas fotos com notas. É considerada a Marilyn Monroe do cinema brasileiro ${ }^{44}$ e a principal atriz do gênero malicioso no Brasil ${ }^{45}$. Ela é o maior exemplo no caso brasileiro de conversão de uma pin up em starlet.

O maior astro e galã de longe é Anselmo Duarte. Ninguém o alcança, embora cresça aos olhos das revistas Cyll Farney. Quando Cena Muda tenta explicar a formação

\footnotetext{
${ }^{42}$ Glauce Rocha se consagrou depois como o modelo da anti-estrela. Não usava roupas caras, morava num pequeno apartamento, nem alcançou grandes salários. Segundo o verbete escrito por Silvia Oroz, seu rosto foi "desglamourizado" no filme Rua sem sol. (Ramos; Miranda, 2004: 467-468)

${ }^{43}$ Sanin. Cinema brasileiro - a trajetória de uma 'estrela'. Cena Muda, v. 34, n. 23, p. 20-1, 09/06/1954.

${ }^{44}$ Liana Durval opina sobre os homens. Cinelândia, v. 3, n. 34, p. 48, $1^{\mathrm{a}}$ quinz. abril 1954.

${ }^{45}$ Cinema nacional em foco. Cena Muda, v. 34, n. 32, p. 13-4, 13/10/1954.
} 
do mito de Anselmo, confere papel primordial à distância entre astro e público. Hollywood seria mito porque está a milhares de quilômetros dos fãs. A partir dessa distância, os galãs são convertidos a "alturas jamais sonhadas". Fica implícita a diminuição do potencial de conversão em ídolo quando há maior contato com o ator. A prova para Cena é que quando Anselmo Duarte vivia no Rio de Janeiro, "disponível” e acessível aos fãs, era um "artista fácil". O artigo aponta também a geração do estrelismo pelas invenções dos departamentos de publicidade:

\footnotetext{
“(...) as fantasias que se criam em torno dele, é que levam o público a assistir seus filmes. As lendas que se contam a respeito de sua vida; os boatos de seus romances; os seus hábitos fora dos estúdios são responsáveis pela enorme correspondência que o artista recebe." 19
}

Desconsidera-se a ascensão da carreira do galã para conferir peso à impossibilidade de contato em São Paulo, diferente da grande metrópole do Rio de Janeiro. O texto explicita, portanto, a maior capacidade da Vera Cruz em gerar mitos.

Vale um comentário sobre a aparição deste galã nas capas. Anselmo Duarte não é fotografado sozinho em nenhuma capa das duas revistas. Em Cena Muda, ele aparece três vezes nos anos de 1952-3, mas sempre acompanhado de alguma atriz. A explicação pode ser dada a partir de Edgar Morin (1962): a cultura de massa propaga mais os valores femininos, assim a maioria das capas é destinada às mulheres. Os protagonistas masculinos para as duas revistas têm peso muito menor.

Cyll Farney não foi capa no período estudado. A ausência na primeira página desvenda recente fabricação dele em astro. Farney é bastante comentado pelo suposto envolvimento com Fada Santoro, e pelo seu papel de galã nos filmes. Contudo foi pequena a quantidade de reportagens sobre ele. Por ser o galã de Amei um bicheiro, aparece mais na matéria de Cena sobre o filme do que Grande Otelo ${ }^{46}$.

Anselmo Duarte é sempre o galã, mas não um personagem comunicativo ou bem articulado nos filmes. Interpreta geralmente homens muito tímidos, introspectivos e submissos, que depois se revelam heróis com poder de decisão. Em Sinhá Moça (1953), de Tom Payne, Anselmo Duarte aparece como um acanhado advogado, mas depois surge como herói e advogado bem articulado na luta contra a escravidão. Em Apassionata (1952), de Fernando de Barros, e Tico Tico no Fubá (1951), de Adolfo Celi, Anselmo personifica o sofredor, esquecido pela sociedade, de genialidade e/ou qualidades não percebidas pelo seu meio. Até mesmo quando interpreta um assassino

\footnotetext{
${ }^{46}$ Cinema brasileiro - o jogo do bicho ainda em rodagem. Cena Muda, v. 32, n. 27, p. 28, 03/07/1952.
} 
em Veneno (1952), de Gianni Pons, a chave é a do homem que enlouqueceu. A esposa, o trabalho maçante e o ambiente torturante com o barulho dos trilhos tiveram peso sobre sua personalidade e o desenvolvimento de sua doença. O protagonista mata a esposa e coloca no seu lugar uma prostituta. Com ela, Anselmo é dócil, gentil. Quer ser feliz com o duplo da mulher, porque a esposa era fria, calculista, enfim, o usava. Porém, transtornado, tenta matá-la. A punição final vem com a morte. Em Aviso aos navegantes (1950), de Watson Macedo, o ator também interpreta um contínuo, se faz passar por comandante para conquistar uma atriz famosa. Nos textos sobre sua personalidade não se fala nesse excesso de submissão dos protagonistas, nem na transformação para herói. Ele é transformado apenas em galã pela beleza. Em alguns artigos fica implícita a necessidade do ator de trabalhar para seu sustento, quando este dado permanecia oculto nas revistas, mas não há referência à infância pobre de Anselmo.

Em comparação, Cyll Farney congrega também o papel de bom moço, mas não tão submisso quanto Anselmo. Mesmo quando interpreta um bicheiro em Amei um bicheiro (1952), de Jorge Ileli e Paulo Wanderley, há uma justificativa: a falta de oportunidade de trabalho. Penalizado por seus atos, ele é preso, mas não por muito tempo porque foi uma vítima de uma enrascada feita pelo patrão corrupto. No filme Nem Sansão nem Dalila (1954), de Carlos Manga, Cyll desempenha o papel de herói, sem profissão definida no enredo. Aparece apenas como um freguês do cabeleireiro, apaixonado pela manicure, vivida por Eliana Macedo. O personagem de Cyll é quem toma as decisões. Em Carnaval Atlântida (1952), de Carlos Burle, Farney também é um mero trabalhador da empresa do pai da moça por quem está apaixonado. Tem idéias geniais, não é compreendido pelo chefe. Na vida real, as revistas relembram mais de uma vez sua posição social de integrante da classe média. Possui até carro. Não precisa trabalhar no cinema com tão baixos salários, profissão escolhida por amor.

Alberto Ruschel é pouco focado como o protagonista do filme $O$ Cangaceiro durante as filmagens. Não há matérias tentando convencer o público que se trata de um grande astro. Apenas em 1954, Ruschel volta ao noticiário devido a um convite para estrelar Orgulho (1955), de Manoel Mur Oti, na Espanha. A partir do reconhecimento dele no exterior, as duas revistas realizam matérias sobre ele e Marisa Prado. Publica-se uma foto dele com sua filha ${ }^{47}$. Talvez um dos motivos para não se vender o ator como grande galã seja sua situação de homem casado com uma não-olimpiana.

\footnotetext{
${ }^{47}$ Aconteceu no Brasil. Cinelândia, v. 3, n. 37, p. 46-7, 2ª quinz. maio 1954.
} 
Alberto Ruschel fez quatro filmes na Vera Cruz. Em Ângela (1951), de Tom Payne, interpretou o jogador viciado Dinarte, apaixonado por Ângela (Eliane Lage). Já no filme Apassionata (1952), de Fernando de Barros, atuou como Luis Marcos, o segundo marido da personagem interpretada por Tônia Carrero. Seu trabalho como pintor é subestimado porque a sociedade considera que ele vive a sombra do renome da esposa pianista. Depois Ruschel viveu o cangaceiro-mocinho Teodoro em $O$ Cangaceiro (1953), de Lima Barreto. Por último, em Esquina da ilusão (1953) de Ruggero Jacobbi, o ator interpretou Alberto, um chofer. Ele ajuda um imigrante pobre a se fingir de rico para impressionar o irmão da Itália.

Outro ausente é o ator Mário Sérgio, que foi protagonista em quatro filmes da Vera Cruz. Seus personagens vão desde personagens com profissões menos conceituadas como o pescador-galã Alberto de Caiçara (1950), de Adolfo Celi, passando pelo marinheiro Tião de Luz Apagada (1953), de Carlos Thiré, até homens de maiores posses. Nestes papéis interpretou José Carlos, o filho de um fazendeiro, em Terra é sempre terra (1950), de Tom Payne, e o herdeiro esportista Juvenal, um dos filhos de um rico banqueiro em Uma pulga na balança (1953), de Luciano Salce. Viveu também o papel de Eduardo, o jornalista com pouca experiência profissional em $E$ proibido beijar (1954), de Ugo Lombardi, além de ter participado em Ângela, como Jango, o apaixonado não correspondido. O ator não tem nem o mínimo realce. É citado em notas. A pequena cobertura talvez seja um indício da falta de critérios das revistas na abordagem ao estrelismo brasileiro.

Entre os atores é dado relativo destaque ao cômico e ao vilão. Oscarito é considerado astro de primeira grandeza, mas a chave não é a do galã. Por este motivo recebe poucas matérias. A cobertura a Oscarito é sempre positiva. Há Procópio Ferreira com relativo destaque. Entre a tentativa das revistas em fabricar estrelas, mas sem realce, colocamos Dick Farney, Alberto Ruschel, Hélio Souto, Miro Cerni, Orlando Vilar, Roberto Batalin. Entre os atores com cobertura moderada estaria Grande Otelo. Entre os vilões, apenas José Lewgoy é mencionado com freqüência. Os demais são esquecidos. Ziembinsky não é sequer citado em matéria, apenas nas legendas das fotografias e por ter participado dos elencos. Zé Trindade não aparece. Entre os cômicos há Ankito, Walter D’Ávilla, Mesquitinha, mas nenhum deles em evidência. Ganham apenas uma matéria por conta de um filme estrelado. Renato Restier é tema de apenas uma matéria sem estrelismo nem exagero. 
Há também inversões devido ao papel da fotogenia com atributo de beleza. Procópio Ferreira é o grande astro de $O$ comprador de fazendas (1951), de Alberto Pieralisi. O filme é citado diversas vezes em 1952, mas o nome de Procópio é relegado. Cena Muda divulga apenas as "novas estrelas" como Margot Bittencourt e Hélio Souto. Segundo outro artigo ${ }^{48}$, Procópio Ferreira só se consagrou como astro cinematográfico após ter feito $O$ comprador de fazendas. $\mathrm{O}$ objetivo é enfatizar a realização do último filme feito como escada para o sucesso, ocultando os sucessos anteriores.

Nas duas publicações, em oposição ao universo das atrizes aclamadas, formas de representação da realidade que fugissem da fotogenia estabelecida ou da visão de mundo idealizadas eram mitigadas. Assim o universo da pobreza nos filmes e os atores negros são ocultados, tema analisado abaixo.

\subsection{Os ausentes: a pobreza, o tema racial e as transgressões morais dos personagens}

A realidade social brasileira ficava distante nas páginas editoriais das duas revistas, mesmo quando era focada em alguns filmes. A representação da pobreza para as publicações atrapalhava a construção do glamour do padrão hollywoodiano. Cinelândia não selecionava fotos relativas à pobreza das fitas brasileiras. Cena teve duas exceções neste quesito: $O$ canto do mar (1953), de Alberto Cavalcanti e Balança mas não cai (1953), de Paulo Wanderley. Neste último, as imagens mostram um casebre com pouquíssimos móveis. O cenário lembra o décor do teatro. Já a divulgação de $O$ canto do mar voltou-se ao estrelismo de Aurora Duarte em ambas as revistas. Apenas a reportagem En rade (a versão brasileira) do famoso filme de Cavalcanti $O$ Canto do $\mathrm{Mar}^{49}$ trouxe fotos representativas da pobreza do sertão nordestino. Só que os dois pares de imagens da miséria, com casebres e retirantes em fuga, coexistem com a foto de Aurora Duarte de maiô. A legenda de uma delas contextualiza a pobreza do retirante: "uma cena tipicamente nordestina. Um casebre, palmeiras e uma jangada que vai e não se sabe se volta". O artigo tenta poetizar a pobreza. A outra ilustração remete ao trabalho incansável dos nordestinos: "a tragédia do labor quotidiano dos 'pau de arara"”. Cena Muda não busca comover com a reportagem. Não transforma a história

\footnotetext{
${ }^{48}$ Lopes, Landa. Alberto Pieralisi o melhor diretor de 1951 conta sua história. Cena Muda, v. 32, n. 41, p. 4-5, 10/10/1952.

${ }^{49}$ Brandão, Paulo. Cena Muda v. 33, n.6, p. 4-6, 04 fev. 1953
} 
em cine romance. $\mathrm{O}$ enfoque foi transviado para a beleza do Recife, contudo foi um avanço para a revista cobrir um filme sobre a miséria.

Cena considera as condições de vida dos nordestinos com um "bizarro cenário de um subúrbio da Veneza brasileira" ${ }^{50}$. A pobreza produz estranheza para a publicação. Em outra nota na seção Sete dias em revista, a miséria nordestina é tratada com tom jocoso, mostrando o preconceito implícito sofrido por seu tema:

\footnotetext{
"O calor continua intenso e a gente se refugia num refrigerado para ver $O$ Canto do Mar. Ficamos sabendo que o tempo lá no nordeste é mais quente e triste que o próprio $O$ Canto do Mar, aquecido pela graciosa Aurora Duarte." 51
}

Certa vez, Cena trouxe as fotos de Heleninha Costa no morro. Ela desce as escadas da favela para sentir o ambiente do barracão, diz a revista ${ }^{52}$. Estas são as únicas imagens de uma estrela na favela, cercada de crianças. Há uma romantização na representação da pobreza nas duas publicações e nos filmes.

O segundo tema é uma consequiência do primeiro: a representação dos atores negros nas publicações. Eles não aparecem nas capas. Fato comum também nos primeiros anos da revista Cena Muda, como pontuou Flora Bender (1979).

Grande Otelo é convertido neste "valor indígena que dispensa adjetivos" 53. Entrelaçando o nome de seu personagem em Moleque Tião (1943), de José Carlos Burle, Cena chama o ator de Menino Tião ${ }^{54}$. Não encontramos no período analisado nenhum pôster ou foto de grandes dimensões para recortar e colar porque o intérprete é negro. $\mathrm{O}$ ator não tem evidência na revista como teve Oscarito, exclusão evidenciada também em A dupla do barulho (1953), de Carlos Manga. No filme, Grande Otelo era escada para o astro interpretado por Oscarito. Na estréia de Amei um bicheiro (1952), de Paulo Wanderley e Jorge Ileli, o nome de Grande Otelo aparece apenas no final da reportagem de Cena ${ }^{55}$. Em Cinelândia, a omissão nas imagens e artigos é ainda maior. O ator só aparece nas fotos se acompanhado do elenco. Nos artigos só é citado quando se tem por tema os filmes, não sua pessoa.

\footnotetext{
${ }^{50}$ Cena Muda v. 33, n.33, p. 28-29, 12 ago. 1953.

${ }^{51}$ Cena Muda v.34, n.5, p. 17, 03 fev. 1954

52 O barracão de Heleninha. Cena Muda, v. 33, n. 6, p. 21, 04/02/1953.

53 Brandão, Paulo. Pegando fogo, o filme de carnaval da Atlântida. Cena Muda, v. 32, n. 49, p. 04-5, 05/12/1952.

${ }^{54}$ To aí de novo, macacada! Cena Muda, v. 32, n. 49, p. 26; 34, 05/12/1952. Também no filme A dupla do barulho (1953), de Carlos Manga, o nome do personagem de Grande Otelo é Tião, uma citação ao seu personagem.

${ }^{55}$ Cinema brasileiro - o jogo do bicho ainda em rodagem. Cena Muda, v. 32, n. 27, p. 28, 03/07/1952.
} 
Quando Grande Otelo trabalhava no Cassino da Urca, não podia se sentar como cliente ${ }^{56}$. Essa exclusão é retomada de maneira indireta no filme Vou te contá (1958), de Alfredo Palácios. O personagem Chocolate salva uma criança seqüestrada. Tenta ir a um restaurante dar comida ao bebê, mas o garçom não quer servi-lo por causa de sua tez. O personagem indignado diz ter dinheiro para pagar. Além disso, responde que não é pior que qualquer branco. A cena não é representada no filme, apenas narrada pelo personagem revoltado com a situação.

A mesma omissão acontecia com Ruth de Souza durante a cobertura ao filme Sinhá Moça (1953), de Tom Payne. A atriz, considerada de talento, é lembrada apenas em notas. Ganha só uma pequena fotografia em Cinelândia. Há mais de uma citação nas duas publicações sobre sua grande atuação em Sinhá Moça. Contudo estas sentenças encontram-se no final das matérias, situadas nas últimas páginas ou na continuação dos artigos sobre os protagonistas da fita.

De acordo com a pesquisa realizada por Maria Rita Galvão nos boletins da Vera Cruz e do TBC, Ruth de Souza é apresentada com ênfase por conta de sua contratação para Terra é sempre terra (1950), de Tom Payne. É descrita como a "a grande atriz negra". Nas duas revistas, não há semelhante evidência à atriz, embora tenhamos estudado um período posterior ao lançamento da atriz na Vera Cruz.

Quando Sinhá Moça ganha o leão de bronze no Festival de Veneza em outubro, Cinelândia destaca o desempenho de Ruth de Souza, esquecendo de elogiar as estrelas do filme. O texto localizado nas últimas páginas de Cinelândia esclarece que os repórteres estrangeiros elogiaram as atuações dos atores negros, provavelmente tirando daí o enfoque diferente ${ }^{57}$.

Até na categoria do estrelismo há uma subdivisão para as atrizes negras. Não são apenas estrelas. Pertencem a outra categoria. São estrelas do tipo colored. Quando se descreve Mara Abrantes ${ }^{58}$ como "estrelinha colored", Cena Muda cita apenas sua beleza "mestiça" 59 .

Certa vez, Cena trouxe à tona a discussão sobre os atores negros no cinema brasileiro. Considerou sua representação "superficial" e "plástica", mas "não negativa".

\footnotetext{
56 Informação citada por Stam, Robert. Tropical Multiculturalism: a comparative history of race in Brasilian cinema and culture. Durkam, Duke University Press, 1997.

${ }^{57}$ Festival de Veneza. Cinelândia, v. 2, n. 23, p. 22-3, 45; 54, 2ª quinz. out. 1953.

${ }^{58}$ Mara Abrantes interpretava o par romântico de Grande Otelo no filme A Dupla do barulho (1953), de Carlos Manga.

59 Valle, Ronald. Lugar par os novos entre os mais prestigiosos veteranos em 'Dupla do barulho'. Cinelândia, v. 2, n. 12, p. 52-3, abril 1953.
} 
Os negros aparecem apenas em cenas de macumba, de pescadores, carregadores ou "mulatinhas de linhas insinuantes". Sanin condena o cinema norte-americano pelo tom de chacota e lugar comum, mas lembra que os próprios atores se prestam às caçoadas da sua gente ${ }^{60}$.

Apesar do ar simpático em relação aos atores negros da matéria acima citada, um ano antes, Cena Muda não tinha o mesmo tom ao tratar de um casamento interracial entre famosos. Apesar de aceitar as diversas separações dos atores, a revista não viu com bons olhos a união da "estrela colored" Pearl Bailey, com o baterista Louis Bellson. A cantora já tinha tido quatro casamentos. Além de tudo era mais velha. Samuel Averbarch vê nos casamentos anteriores uma mostra da inconstância de Pearl no matrimônio, condenação não citada para as atrizes brancas. Cena Muda chega a alegar: "Em nossa neutralidade, este tipo de união está fadada ao insucesso, tanto pela separação constante em que ficarão, como que pela diferença de cor (que, mais dia, menos dia, sempre se faz presente) e de ascendência (...)." ${ }^{61}$.

Assim, a ausência de negros nas capas de Cena era exemplificada de maneira mais explícita, sob o tom da suposta "neutralidade" que a publicação confere a si mesma. No caso brasileiro, uma repórter de Cinelândia confessou seu "medo" quando foi buscar a concorrente a Miss Universo Marta Rocha. Temia que tivessem mandado uma "baiana típica, queimada pelo sol causticante do norte, o que causaria má impressão ao público americano." 62

Já no caso das representações sobre as transgressões dos atores, não encontramos nenhum astro brasileiro que personifique características semelhantes às de Marlon Brando ou de Montygomery Clift. Há em nível diegético, o caso do personagem de Miro Cerni em Na senda do crime (1954), de Flaminio Bollini Cerri. Interpretando o sobrinho rico de um banqueiro, é a cabeça de um grupo de ladrões, imagem oposta a de bom moço construída em volta dele nas revistas dois anos antes. O mesmo aconteceu com Cyll Farney no filme Amei um bicheiro (1952), de Paulo Wanderley e Jorge Ileli. Numa reportagem de Cena, o repórter avisa aos fãs que o personagem de Farney é diferente de todos os papéis feitos anteriormente, mas nada revela sobre ele encarnar um bicheiro. Ou seja, os temas escusos da periferia projetiva são descartados nas revistas. Assim, em Cena Muda, é também deixado de lado o fato de a personagem de Glauce

\footnotetext{
${ }^{60}$ Sanin. Cinema brasileiro - Os interpretes de cor em nosso cinema. Cena Muda,v. 34, n. 13, p. 8, 31/03/1954.

${ }^{61}$ Averbach, Samuel. O eterno conflito. Cena Muda, v. 33, n. 21, p. 3, 20/05/1953.

${ }^{62}$ Brito, Célia. Marta conquistou Hollywood. Cinelândia, v. 3, n. 29, p. 38-41, 18/08/1954.
} 
Rocha no filme Rua sem sol (1953), de Alex Viany, ser a suposta amante do dono de um salão de dança, na verdade, um bordel disfarçado. $O$ interesse recai sobre a irmã cega que Glauce tenta salvar da pobreza. Possivelmente pelo fato de a cantora Dóris Monteiro, intérprete da cega, ser mais conhecida no período. No caso da personagem de Glauce Rocha, a imagem da amante no filme é aparente. Mantém aceso o interesse do espectador por se tratar de uma suposta assassina, para no final descobrirmos sua inocência, além de castidade. A protagonista só trabalhava no local inadequado para sobreviver. Quando ia tornar-se amante do dono do local, a providência divina fez com que ele fosse assassinado.

O mesmo ocorre com Fada Santoro em Agulha no palheiro (1953), de Alex Viany. Na primeira sinopse realizada por Cena Muda, a personagem encontra o namorado e tem de se decidir entre dois amores ${ }^{63}$. Só na novelização ${ }^{64}$, edições depois, o artigo explica que a personagem estava grávida. Nos demais artigos, a gravidez era ocultada, talvez para não revelar o final da história.

A personagem Ivone, interpretada por Josette Bertall no filme Amei um bicheiro, aparece em Cena como amante, mas o relacionamento com o bicheiro é citado apenas na legenda. Na novelização, Ivone entregava o dinheiro do banqueiro a Carlos por amor, "e ao mesmo tempo leva este a descuidar-se de suas obrigações no lar" ${ }^{65}$. Assim não se revela que Ivone foi amante dos dois personagens.

Dessa forma, os poucos temas desestabilizadores do cinema nacional eram ocultos em sua maioria. Quando não podiam ser excluídos de todo, eram amenizados. O último tópico deste capítulo aborda a questão das estrelas radiofônicas, de grande importância para o star system do período. Tais atrizes já estavam sedimentadas por anos de contato com o público, em oposição à fabricação de estrelas brasileiras.

\footnotetext{
${ }^{63}$ Jorge, Luis. Fada Santoro e Dóris Monteiro disputam as honras do elenco em 'Agulha no palheiro'. Cena Muda, v. 33, n. 8, p. 4, 18/02/1953.

${ }^{64}$ Agulha no palheiro. Cena Muda, v. 33, n. 16, p. 16-7, 14/04/1953.

${ }^{65}$ Amei um bicheiro. Cena Muda, v. 34, n. 2, p. 12, 09/01/1954.
} 


\subsection{Estrelas radiofônicas}

O star system brasileiro não existiria sem a participação dos cantores do rádio e também dos atores do teatro. Grande parte da cobertura ao rádio era feita em pequenas notas, em tom bastante opinativo em Cena Muda. Durante alguns meses de 1952-53, a revista confere metade de suas páginas ao rádio. Muitas vezes afirmava em tom de deboche a falta de voz de uma cantora ou considerava péssimos os substitutos dos cantores das emissoras de rádio. $\mathrm{O}$ tom pejorativo ao rádio inexiste na cobertura ao cinema porque os atores são divinizados.

Cada novo artista do rádio ou do teatro cotado para fazer um filme era recebido com alarde pelas duas revistas. Por certo os cantores do rádio auxiliavam na legitimação e garantia de sucesso dos filmes, uma estratégia utilizada também nos demais países, como nos Estados Unidos e na Argentina. (Augusto, 1989)

O processo não era novidade. Nos Estados Unidos, de 1934 em diante, uma quantidade crescente de filmes já empregava as personalidades do rádio. Havia uma simbiose e cooptação entre o rádio e Hollywood. As empresas faziam uma associação entre os nomes e vozes do rádio com os produtos ligados às estrelas dos filmes. Charles Eckert (Gledhill, 1991) lembra que o poder dos dois em fazer anúncios parecia ilimitado nos anos trinta.

No Brasil, Octávio Gabus Mendes conseguia os roteiros dos filmes com as agências norte-americanas e os adaptava para o rádio. $\mathrm{O}$ rádio-teatro semanal era apresentado no programa Cinema em casa. David José Lessa Mattos confere a ele a introdução de uma nova linguagem no rádio-teatro, libertando o texto da pesada influência da tradicional escrita. A mudança repercutiu no modo de atuar dos radioatores. A influência de Gabus Mendes era de roteiristas norte-americanos como Michel Curtiz, Ben Hecht, Paddy Chayefsky e Herman Mankiewicz. (Mattos, 2002)

Paulo Paranagua (1987) nomeia a segunda fase do estrelismo brasileiro na época da conexão deste com o rádio tão subdesenvolvido quanto o primeiro, mas com representação menos artificial do que o da época de Cinearte. Contudo, analisa que apenas o rádio teve repercussão na tela, e não o contrário. Mesmo os músicos de repertório muito típico ou limitado para os padrões do cinema tiveram sua aparição com benefícios para a popularidade. Paranagua considera esta fase do estrelismo nacional uma das mais fecundas, por meio dos filmes da Atlântida. A companhia se beneficiou da evolução do humor radiofônico. 
Certa vez o cantor Francisco Carlos propôs a Carlos Manga uma comédia ambientada no interior de uma escola. $\mathrm{O}$ diretor sugeriu inserir as fugas de um aluno da escola para ir cantar numa rádio. Pensou principalmente "na pitada de show business que esse gênero de comédia não costumava dispensar." (Augusto, 1989: 138)

A conexão com o rádio também foi tema do filme É a maior (1958), de Carlos Manga. Uma paródia à história de Emilinha Borba e Marlene. O título foi retirado do grito de guerra das fãs de Emilinha e Marlene. O enredo inclui ainda um patrocinador e um fã clube.

Também a tentativa de transformar o pianista Bené Nunes em personalidade nos filmes da Atlântida gerou alguma repercussão em Cena Muda anos depois do lançamento do filme Carnaval no fogo (1949), de Watson Macedo. No filme, o pianista senta-se ao piano, quando uma espectadora interrompe o barulho causado pelos presentes. Exclama “Psss! Bené Nunes” porque quer ouvir a música. Segundo Sérgio Augusto, a técnica pode ter sido usada para apresentar o pianista aos espectadores de uma chanchada, artifício usado em diversos filmes no exterior. O tom da fala soa falso. Credita Bené como uma celebridade. De acordo com Sérgio Augusto, os que o conheciam acharam graça, pois julgaram a "reverência descabida". (Augusto, 1989: 148-9).

Três anos depois deste filme, Bené Nunes vira capa de Cena Muda, mas sem sequer ser mencionado no interior da revista ${ }^{66}$. Três edições mais tarde, a publicação apresenta a novelização do filme $O$ rei do samba $(1952){ }^{67}$, de Luis de Barros, da qual ele participa. Talvez a capa fosse uma estratégia de venda posterior do filme, agendando junto aos leitores as personas criadas.

Não há por certo tantas fofocas sobre os atores brasileiros quanto sobre os estrangeiros, exceto quando o tema era o rádio. Nesse caso, o noticiário ficava mais "apimentado". Houve até a suposta tentativa de assassinato de Nora Ney, já comentada aqui. Além disso, a revista dava os nomes dos cantores que se fingiam de solteiros. As notas incluem também comentários discutindo se Dóris Monteiro deve ou não cortar o cabelo. A cantora é um dos exemplos mais presentes entre 1952-53 das estrelas do rádio migrando para o cinema.

\footnotetext{
${ }^{66}$ Bené Nunes aparece também tocando no filme Aviso aos navegantes (1950), de Watson Macedo, em que uma música de Tchaikovsky vira um samba. (Augusto, 1989)

${ }^{67}$ Cena Muda, v. 32, n. 08, p. 09, 21/02/1952.
} 
Quando Cena Muda tem por tema os cantores ou cantoras do rádio, não mensura os termos utilizados. Exagera nas diatribes. É o caso da reportagem Nem todos os anjos são bons, Dóris Monteiro prejudicada pela própria mãe ${ }^{68}$. O artigo conta que Dona Mariquinha, mãe da cantora, a acompanha em todos os lugares. "Pode levar Dóris ao fracasso (...) com o seu desvelo que já esta se tornando cacete”. A mãe intromete-se na carreira artística da filha, coage Dóris a cantar sempre as mesmas músicas, sem variar o repertório. Cena aconselha uma mudança comportamental, condenando os passeios da progenitora com os seus "quilos de gordura pelas dependências da rádio".

Em 1952, a cobertura ao rádio de Cinelândia foi infinitamente menor que a da revista concorrente. A cobertura ao rádio era feita na seção Radiolândia com pequenas notas e pequenas reportagens coloridas sobre os artistas. O foco era a vida íntima dos ídolos. Contudo, o nível geral destes textos estava bem abaixo dos artigos estrangeiros comprados.

Em oposição ao mundo encantado de Hollywood, a cobertura aos cantores do rádio pontua o abismo existente do ponto de vista financeiro. Jair da Silva, locutor da Rádio Tamoio, conta ter passado fome. Chegou a dormir debaixo da ponte ${ }^{69}$. Ao contrário da ambientação das casas dos atores brasileiros, nas reportagens sobre o rádio em Cena aparecem as casas simples dos cantores. Do ponto de vista visual, o leitor poderia medir a simplicidade da casa de Araci de Almeida e sua cozinha sem aparelhos modernos, com paredes velhas, adornadas com recortes de jornal ${ }^{70}$.

Apesar de as revistas citarem sempre o interesse dos fãs pelas estrelas do cinema brasileiro, não há imagens para provar este contato mais próximo. Ao contrário, na cobertura ao rádio há fotos das cantoras rodeadas por seus fãs. Encontramos uma imagem única em Cena Muda representativa do sentimento de posse do leitor em relação à estrela do rádio. Dalva de Oliveira teve sua roupa rasgada pelos fãs ${ }^{71}$ quando retornou ao Brasil depois de uma tournée pela Europa. O artigo procura trilhar o contato ardoroso dos fãs como fruto dos "muitos abraços" recebidos. A imagem é indicativa do apelo popular mais sedimentado no rádio de uma cantora muito consagrada, diferente da maior parte das estreantes no cinema nacional que cintilavam por pouco tempo.

\footnotetext{
${ }^{68}$ Nem todos os anjos são bons, Dóris Monteiro prejudicada pela própria mãe. Cena Muda, v. 32, n. 38, p. 22, 19/09/1952.

${ }^{69}$ Rádio flashes. Cinelândia, v. 1, n. 8, p. 48, dez. 1952.

${ }^{70}$ Henrique, Waldemar; Kasmer. Cinelândia, v. 1, n. 7, p. 46-7, nov. 1952.

${ }^{71}$ Cena Muda, v. 32, n. 37, p. 26-7, 12/09/1952.
} 


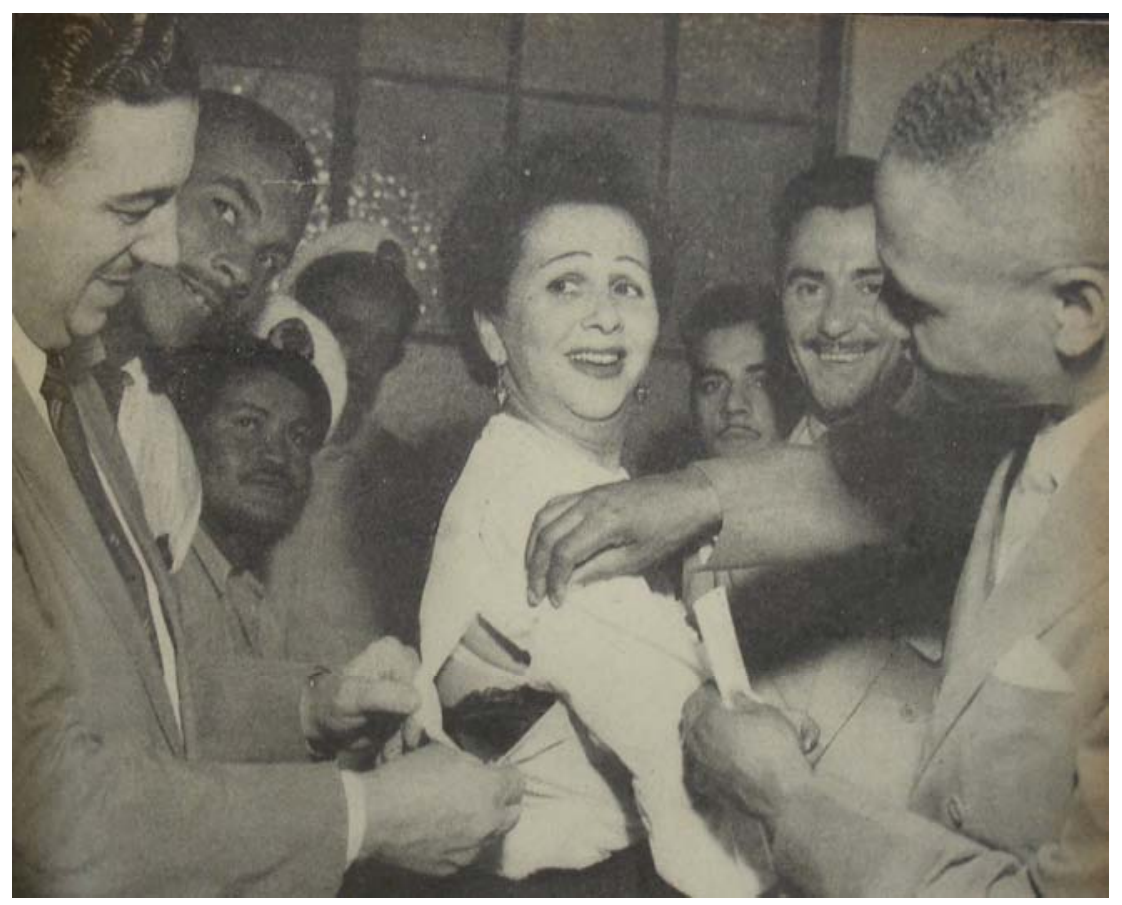

Imagem 54 - Dalva de Oliveira ${ }^{72}$

No próximo capítulo, nos voltamos às seções de crítica, nas quais o enfoque dado ao cinema brasileiro sofre alterações em relação ao padrão estabelecido nas reportagens, já analisadas aqui. Procuramos destrinchar quais são as suas características e a maneira de lidar com o cinema hollywoodiano e nacional, com especial atenção à cobertura do I Festival Internacional de Cinema do Brasil, que foi responsável por uma alteração nas configurações da crítica praticada. Cena Muda neste período possui evidente preferência pelo cinema de cunho estético, modificando sua abordagem sobre o cinema brasileiro, anteriormente feita a partir dos votos de sucesso, da certeza antecipada de êxito e das diatribes.

${ }^{72}$ Cena Muda, v. 32, n. 37, p. 26-7, 12/09/1952. 


\section{Capítulo 4 - O lugar da crítica nas revistas de fãs}

Neste último capítulo, voltamos nosso foco especialmente às seções de crítica de Cena Muda. A publicação concorrente não possui um local destinado a este fim, embora exista análise dos filmes na Seção de Lançamentos, nas colunas, especialmente sobre o cinema nacional. Com o estudo dedicado a tais espaços, não queremos negar as ponderações dos capítulos anteriores como exemplos, uma vez que os comentários opinativos vazam os espaços tradicionalmente destinados a eles. Porém, as seções de crítica têm peculiaridades e uma maneira diferente de lidar com o star system.

Devido às mudanças de direção em Cena Muda, optamos por dividir suas fases por um critério cronológico. Em 1952, Cena Muda teve quatro diretores, número que se repetiu no ano seguinte, com mais quatro secretários de redação. Em 1954, o número caiu para dois. Totalizando dez diretores em apenas quatro anos. Tais mudanças ocasionam uma heterogeneidade na postura editorial, com grandes desníveis quanto ao conceito de crônica praticada. Contudo a divisão feita aqui é plausível porque há continuidade editorial dentro de cada período delimitado.

Não pretendemos nos prolongar discutindo o histórico da crítica nas revistas brasileiras de cinema, nem seu conceito, campo muito vasto que merece uma análise mais detalhada. Mas é pertinente apenas trazer o entendimento do tema nos anos cinqüenta, a partir das considerações de Arthur Autran (2003) e de Jean Claude Bernardet (1979).

Os críticos dos anos cinqüenta dividiam a crítica cinematográfica no Brasil em duas. Segundo Alex Viany, de um lado ficavam os favoráveis ao cinema europeu, e de outro, os admiradores de Hollywood. A oposição também era dividida entre os partidários do conteúdo e os formalistas; ou ainda os de esquerda contra os de direita. A classificação baseia-se em artigo de Flavio Lucas, publicado na Revista de Cinema em setembro de 1955. (Autran, 2003)

Para Flavio Lucas, o campo era dividido entre "críticos historiadores" e "esteticistas". Os esteticistas consideravam o cinema como realidade artística regida por leis peculiares. Para estes, devia-se extirpar qualquer fio ligando a arte do cinema às concepções sócio-políticas ou aos conceitos estéticos de outros gêneros artísticos. Já os 
críticos-historiadores acreditavam que o que interessava no filme era a mensagem implícita ou explícita. (Autran, 2003)

Entre os esteticistas estariam Almeida Salles, Moniz Vianna e B.J. Duarte. Entre os críticos-historiadores: Salvyano Cavalcanti de Paiva (crítico de Cena Muda), Carlos Ortiz e Walter da Silveira. Não nos prolongaremos no tema porque a crítica de Cena não pode ser descrita por nenhuma dessas metodologias, embora tenda mais para os críticos-historiadores. Em alguns momentos pontuais, há uma preocupação com a história do cinema, mas raramente se configura como uma crítica-histórica.

Para compreender a crítica de Cena, o principal critério é entender tais seções como espaços de orientação para o consumo dos leitores. Neste sentido, os comentários de Jean Claude Bernardet são fundamentais porque mostram a função do crítico como reforço de um gosto sedimentado pelos leitores. Duas conseqüências desse processo têm relação com a crítica de Cena. A primeira é a dificuldade de o comentarista condenar um filme que o público ou redatores gostaram. A segunda decorrência permite entender o contexto da crítica no período. Muitos cronistas foram afastados dos cargos por pressões de exibidores e distribuidores ${ }^{1}$. Apesar de não termos notícias de críticos afastados por estas pressões em Cena Muda, vale a pena vislumbrar esta atmosfera, porque muitos publicistas tinham exercido ou exerciam a crítica nas duas revistas, entre eles Salvyano Cavalcanti de Paiva e Zenaide Andréa.

\footnotetext{
${ }^{1}$ Muitos críticos que se opuseram ao processo de orientar o público para o consumo, atrelado ao gosto médio, foram afastados de seus cargos nas décadas de 1940-50, por pressões de exibidores e distribuidores (Bernardet, 1979: 20). A irmã de Vinícius de Moraes contou na biografia dele que as distribuidoras e produtoras de filmes estrangeiros ameaçaram retirar anúncios dos jornais, caso Vinícius não os elogiasse de vez em quando. Depois de sua saída, o jornal se reformulou, abrindo as páginas para anúncios de cinema. (Souza, 1995: 18-19) Para José Inácio de Melo Souza, com o aparecimento da revista Clima e das críticas nos jornais criou-se uma liberdade de escrita limitada pela censura direta do Estado Novo, pelo autocontrole e pelas pressões econômicas. O mesmo motivo casou a demissão de B. J. Duarte do jornal $O$ Estado de S. Paulo em 1950. O grupo de Severiano Ribeiro fez uma queixa em tom de ameaça porque as críticas dele atrapalhariam na bilheteria dos filmes. O diretor administrativo do jornal pediu que o crítico fosse mais brando com os filmes dele, que era anunciante diário do jornal. B. J. Duarte contou que teve um problema no mesmo jornal por causa de Stromboli (1950), de Roberto Rossellini. Depois da publicação de sua crítica, a bilheteria teria tido uma queda considerável. Um gerente da empresa exigiu a cabeça do crítico ao diretor administrativo do jornal, ameaçando de cancelar as grandes verbas de publicidade. $\mathrm{O}$ diretor do jornal o teria ameaçado, gerando um clima de animosidade. (Catani, 1991) O mesmo aconteceu com Tito Batini, crítico de cinema despedido das Folhas na época de Nabantino Ramos (1945-52), devido à defesa que realizava do cinema nacional e pelo combate contra os filmes americanos e a ideologia de Hollywood, contrariando assim o interesse dos anunciantes. (Galvão, 1976: 204-5) Também Walter George Durst sofreu com retaliações, mas por suas críticas ao cinema brasileiro. Apesar da posição de discórdia de B. J. Duarte para com ele, uma vez o crítico da revista Anhembi saiu em sua defesa. A direção do jornal $O$ tempo recebeu no ano de 1952 uma representação assinada por vários cineastas pedindo a demissão do cronista, por ser ele um sabotador do cinema nacional, com ação funesta aos interesses artísticos e financeiros do Brasil. (Catani, 1991)
} 
Zenaide Andrea foi publicista primeiro. Depois se tornou jornalista, processo oposto ao de Salvyano. É importante ter a dimensão da pressão comercial exercida sobre a crítica, ainda mais numa revista de geração do star system hollywoodiano. Contudo esta relação não impedia que os críticos censurassem o cinema norteamericano, ou negassem a postura de bajulação.

Como referência ao contexto de 1950, é importante lembrar a situação difícil dos críticos. A maior parte deles possuía dois empregos porque não era possível viver apenas com a função de comentarista. Ainda na década de cinqüenta, Paulo Emilio Salles Gomes ${ }^{2}$ lamentou que ainda fosse praticamente impossível aos críticos, mesmo nos casos mais privilegiados, viver apenas do exercício da profissão. Todos exerciam ainda atividades paralelas na imprensa, no cinema, no funcionalismo, nas profissões liberais, ou mesmo na publicidade.

A conjunção entre a atividade de publicidade e jornalismo é latente em Cena Muda, por exemplo, no comentário detalhado às novelizações das distribuidoras. Como exemplo, temos o grande destaque aos filmes da Art filmes, empresa para a qual Salvyano Cavalcanti de Paiva tinha sido publicista. Por outro lado, talvez algumas distribuidoras enviassem mais materiais, resultando daí um noticiário mais volumoso. Não podemos mensurar se havia algum tipo de pressão na crítica de Cena pelos publicistas ou pelas agências, mas é possível que existisse alguma, talvez centrada numa auto-censura a partir do receio de perder os poucos anúncios das agências de publicidade dos filmes estrangeiros. Por outro lado, a maior liberdade da crítica em Cena Muda talvez se deva à dificuldade de conseguir anúncios de agências de publicidade das empresas de cinema. A maior parte das propagandas era de pequenas lojas ou de produtos voltados à mulher. A falta de anúncio que enfraqueceu a revista a longo prazo pode ter sido uma propulsora para uma maior isenção da crítica. Por certo é também que a maior publicidade para as companhias era a própria matéria da revista, como dizia seu dono Gratuliano de Brito (Bender, 1979) Lembramos que o cinema era visto nos jornais como assunto secundário. Daí a menor preocupação ética de muitos dirigentes da imprensa na relação entre crítica e publicidade.

Por último, trazemos as considerações de Bernardet sobre a crítica praticada em 1950, que estão presentes em boa parte dos períodos da crítica em Cena Muda. O filme

\footnotetext{
${ }^{2}$ GOMES, Paulo Emilio Salles. "Antes da Primeira Convenção”. IN: Crítica de cinema no suplemento literário. Rio de Janeiro: Paz e Terra, 1981. v. 2.
} 
era analisado a partir de critérios em separado, como a fotografia, argumento e interpretação. A qualidade do filme derivava, então, da média entre estes fatores.

Bernardet mostra como a crítica costumava adotar duas posturas para o filme brasileiro ou estrangeiro, critério que será utilizado como parâmetro neste capítulo. O comentarista conhecia os esquemas de produção do filme brasileiro. Em geral, quando analisava o filme, discutia tais problemas ou os meios de produção. A postura mudava quando se tratava do filme estrangeiro. Desconhecendo o contexto social, cultural e cinematográfico das fitas, ela se tornava uma eventual obra de arte. Bernardet trata sua divisão como uma generalização, porque há exceções. No contexto, persistia um ideal cinematográfico de proveniência estrangeira, isolando as fitas de sua situação histórica. Algumas vezes o crítico se tornava condescendente porque o cinema brasileiro era considerado precário, como se não fosse justo aplicar as mesmas normas rígidas usadas para analisar a produção estrangeira ${ }^{3}$.

A metodologia crítica, para Bernardet, é a afirmação de um gosto (que não é questionado) e a aceitação de uma estética normativa (por exemplo, um estilo cinematográfico erguido como ideal e verdadeiro). Os filmes são avaliados como melhores ou piores conforme mais se afastam ou se aproximam deste padrão. Apenas no caso da Vera Cruz e especialmente do Cinema Novo, a crítica assumiu seu papel de participante no processo. Porém, só com o Cinema Novo, os melhores comentaristas perceberam que não era mais possível dar notas e tirar a média.

A crônica praticada em Cena Muda tentava se fortalecer como participante do processo de produção. Não analisamos as seções de crítica antes do surgimento da Vera Cruz, mas acreditamos que esta postura tenha uma maior relação com uma estratégia de legitimação da revista, do que com o surgimento da companhia. O objetivo seria se tornar um referencial de credibilidade aos leitores, através da auto-promoção de ser um agente consultado pelos diretores. Assim, os críticos sugeriam melhoras e cortes no

\footnotetext{
${ }^{3}$ Bernardet lembra que a relação do público com os filmes brasileiros é totalmente diferente, porque a cinematografia brasileira trata da realidade social e cultural em que vivemos. Sempre a película nacional oferece uma determinada imagem da sociedade. Já as fitas estrangeiras não exigem angústia em verificar se filmes consagrados são ou não bons, porque os meios de comunicação já as consideraram arte suprema. Porém, diante de um filme brasileiro, a decisão se o filme vale a pena ainda não foi tomada porque tal produção mexe com a imagem que temos de nós mesmos. Esclarece Bernardet: "A má qualidade que este público atribui ao cinema brasileiro não é apenas um julgamento de valor sobre determinada obra cinematográfica, mas me parece ser um julgamento sobre a má qualidade da realidade brasileira. É também uma maneira de reafirmar e consolidar o complexo de inferioridade, portanto de nos instalar no amargo, porém confortável estado de irresponsabilidade: fazemos mau cinema, somos dominados, dependentes, inferiores, logo não podemos nos assumir e criar nossa perspectiva histórica. Em última instância, temos que rejeitar, não digo os filmes, mas a própria realidade: e argumento do tipo 'brasileiro não presta para fazer cinema'." (Bernardet, 1979: 19)
} 
filmes. Essa característica tem uma relação clara com as discussões durante a década de cinqüenta sobre o papel da crítica. Para o crítico baiano Walter da Silveira ${ }^{4}$, a crítica ao filme brasileiro deveria analisar os fatores internos e externos que atrasam a formação autônoma de nossa cinematografia. Deveria ainda definir as características da nossa produção e assumir um papel de vanguarda revelando os fundamentos estéticos do cinema brasileiro. A crítica de Cena Muda era influenciada indiretamente com estas discussões de época, embora com profundidade teórica muito menor.

Resta estabelecer ainda uma diferença entre crítica e resenha, para determinar qual o termo seria mais exato para dar conta das especificidades das revistas de fãs. Esta terminologia seria a resenha, mas usaremos a palavra crítica por ser mais utilizada. Dentro da teoria do jornalismo descrita por José Marques de Melo (1985), o termo crítica estaria ligado à era amadora do jornalismo brasileiro, realizada por intelectuais. No período profissionalizante, os intelectuais recusaram-se a fazer as simplificações almejadas pela indústria cultural para ampliar seu público. Os que insistiram em realizar exercícios críticos refugiaram-se nos periódicos acadêmicos e especializados e se autodenominaram críticos.

Os artigos com apreciações de lançamentos artísticos feitos pelos que continuaram a trabalhar nos meios de comunicação coletiva passaram a se chamar resenhas (review). Quando o jornalismo adquiriu escala industrial na década de trinta, aumentou o público leitor (classe média e operária) e abriu um novo caminho. Mudou também seu conteúdo: não era mais a obra de arte sob análise de padrão estético refinado para as elites, mas sim novos produtos da indústria cultural para o grande consumo. A resenha distinguiu-se pela forma mais simplificada e despojada, enquanto que a crítica estética virou ocupou menor espaço na grande imprensa.

Melo cita Afrânio Coutinho para quem a resenha é um comentário breve, a margem da obra para consumo popular. Enquanto a crítica exige métodos e critérios que tornariam o resultado incompatível com o jornal ${ }^{5}$, a resenha não tem intenção de fazer julgamento estético. Faz apreciação ligeira, sem entrar na sua essência enquanto bem cultural. É uma atividade utilitária. Quando há muita opção no mercado cultural, o

\footnotetext{
${ }^{4}$ Silveira, Walter da. “O papel vanguardista da crítica cinematográfica no Brasil”. Salvador, s.d., 4 pp. Pasta D 54 da Cinemateca Brasileira.

5 Utilizamos aqui o termo crônica e comentário como sinônimo de crítica, embora exista uma simplificação nesta opção, porque como observado por alguns autores, como Mariano del Pozo (1970) e Tim Bywater (1989), o comentário/crônica teria o mesmo sentido descrito da review. Feito após o lançamento do filme, não há espaço para análises mais densas. Já a crítica seria praticada nas revistas, quando o jornalista pode dedicar mais tempo aprofundando as questões. Contudo, no Brasil ocorreu o inverso, os críticos intelectualizados escreviam em jornais, não nas revistas.
} 
consumidor quer dispor de informações e juízos de valor para ajudar na decisão da compra. (Coutinho apud Melo, 1985)

O estilo textual das revistas de fãs estaria ligado a um gênero jornalístico que recebe diversas nomenclaturas, resumidas por José Marques de Melo: jornalismo de entretenimento, diversional ou estilo ameno. São os textos que fincados no real, procuram dar uma aparência romanesca aos fatos e personagens captados pelo repórter. (Melo, 1985)

Como referencial metodológico para embasar as discussões sobre a crítica nas revistas de fãs trazemos mais duas discussões pertinentes nos próximos dois tópicos: a separação entre espaços opinativos e informativos e a relação entre publicidade e crítica.

\subsection{Espaços opinativos e informativos}

Abordaremos de forma sucinta a discussão sobre os espaços opinativos, mas deixaremos de lado uma teorização mais aprofundada da ação jornalística em seus gêneros, uma vez que o assunto já foi analisado por Manuel Chaparro, do qual utilizamos os principais conceitos.

Não é possível noticiar um fato sem o componente opinativo, principalmente no caso de lançamentos da indústria cultural. Sempre há valoração e subjetivismo na ação jornalística, ao destacar ou não uma manchete e ao abordar determinado tema, entre outros. Sempre o agente opina sobre o mundo que o cerca. Toda afirmação depende do valor atribuído pelo sujeito na valoração, julgamento e opinião, a partir de cada época. Para Chaparro, se as fronteiras opinião/informação "alguma vez existiram, foram distribuídas pela inevitabilidade da valoração jornalística” (Chaparro, 1997: 27)

Há sempre intenção nos gêneros, assim também a função valorativa é própria e específica em todos os níveis do exercício do jornalismo, sintetizada na frase de Chaparro: "não existem, pois, espaços exclusivos e excludentes para a opinião e a informação." (Chaparro, 1997: 10). Martinez Alberto (1983) vai mais longe ao afirmar que sem a intervenção valorativa não há ação jornalística”.

Essa característica da opinião embutida no suposto gênero apenas informativo é característica de Cinelândia e Cena Muda, como estratégia para transmitir opiniões com suposta neutralidade. O conceito de não separar de forma excludente opinião e informação nos é de grande valia porque a crítica cinematográfica nas revistas não estava restrita às seções assim denominadas. Estava ampliada em toda publicação: nas 
notas, nas reportagens e nas cartas aos leitores. Desconsiderar a crítica em Cinelândia devido ao escasso espaço dedicado é um conceito muito frágil porque se desconsidera as opiniões expressas em suas páginas de Carta ao leitor e nas colunas. O veículo exige uma teorização diferente para analisar a crítica.

Depois de sintetizar a interseção entre crítica e reportagem, vale a pena antecipar que em Cinelândia os dois espaços estavam muito mais conectados, provavelmente uma estratégia para agregar um público a. Os espaços opinativos em Cena Muda aparecem também em seções destinadas a este fim, o que não impedia também a existência de opinião do jornalista nas notas e reportagens. No próximo tópico, resumiremos a relação intertextual presente na crítica e as influências da publicidade.

\subsection{Publicidade e crítica}

Utilizamos novamente a pesquisa de Manuel Chaparro sobre as conexões entre crítica e publicidade como referencial metodológico. Ao invés de procurar um jornalismo totalmente dissociado da publicidade, o autor esclarece que não existe jornalismo só com propaganda, mas também não há jornalismo em sua forma pura. É impossível separar "a informação jornalística dos efeitos propagandísticos, porque os acontecimentos relevantes sempre envolvem interesses particulares". (Chaparro, 2001:127)

A novidade não é considerar de maneira maléfica a conexão com os interesses propagandístico. No campo do cinema, Chaparro mostra que o realizador de cinema quer publicidade para seu filme, mas tal postura não empobrece a ação jornalística. Mesmo no caso de interferência no conteúdo jornalístico pelas fontes, tal ação não invalida o jornalismo, nem o enfraquece. Ao contrário, valoriza a informação por trazer tais discursos, mas expõe as fragilidades da prática jornalística.

As revistas de fãs são vistas de forma pejorativa por esta ligação com a publicidade, por isso o trabalho de Chaparro nos interessa porque permite pensar em diferentes bases a questão com os estúdios. O jornalismo não deve ser visto como uma tentativa de excluir a publicidade para purificar sua ação. Isso porque o jornalismo é um território de conflito. Não há nenhum acontecimento, segundo Chaparro, que não esteja vinculado a vários desses conflitos. Ou seja, os interesses dos estúdios iriam de qualquer maneira aflorar nos artigos porque as notícias envolvem sempre conflitos que dizem respeito a estes agentes. 
A questão do conflito no campo jornalístico não é novidade, já descrita por Pierre Bourdieu no funcionamento dos campos de saber. Dentro de qualquer campo há disputas. As lutas são necessárias e caracterizam não só a configuração do campo, como todo o seu desenvolvimento. Não há um campo sem lutas ou disputas. O campo está em permanente construção e tais disputas são necessárias.

Bourdieu enfatiza que de todos os campos, o jornalístico possui maior influência e sanções do pólo comercial e do mercado, além da influência do índice de audiência. As pressões do mercado modificam as relações de força no interior dos campos. "O campo jornalístico tem uma particularidade: é muito mais dependente das forças externas que todos os outros campos". (Bourdieu, 1997: 76)

Se os interesses das fontes ou dos estúdios não aparecem, deve-se suspeitar. É melhor quando os interesses se tornam visíveis no texto, como é o caso de Cena Muda e de Cinelândia. De acordo com Chaparro, o maior perigo reside nos casos em que o discurso jornalístico perde autonomia ou é agendado por acontecimentos já elaborados para o relato jornalístico.

\subsection{A crítica em Cinelândia como espaço da objetividade: seção de lançamento}

Não há designação de nenhum tipo de seção de crítica em Cinelândia no sumário. Contudo, a afirmação da inexistência do gênero opinativo não é verdadeira. Vale apenas como discurso da publicação. Para entendê-lo, os tópicos anteriores sobre publicidade/crítica e gênero opinativo/informativo são úteis para podermos discutir as razões editoriais por mascarar as valorações opinativas. A inexistência de "seções de crítica" em Cinelândia busca difundir a imagem da neutralidade pela ausência de tal gênero. A revista procura se distinguir de um de seus alvos, os críticos intelectualizados. Estes, a partir do discurso de Cinelândia, censuram os filmes que os fãs gostam. Supostamente Cinelândia traz aos leitores apenas informações com artigos de fácil entendimento, voltados ao divertimento.

A posição de Cinelândia é uma estratégia eficiente para conquistar a simpatia de um determinado público leitor, provavelmente adolescente ${ }^{6}$. A falta de seções de crítica

\footnotetext{
${ }^{6}$ Folheando Cinelândia é fácil perceber seu perfil voltado às mulheres mais jovens ou adolescentes. Há posters, seções de conselho sentimental, matérias sobre romance e amor com linguagem coloquial e uso de gírias. As histórias de amor dos filmes e das atrizes são novelizadas recorrendo à narrativa melodramática. Algumas sinopses são contadas com recursos da fotonovela, principalmente em
} 
tem relação direta com este pressuposto, como se permitisse ao leitor escolher sozinho o que assistir. Embora a publicação procure orientar para o consumo dos filmes nas reportagens. A ausência destas seções quer mostrar uma revista democrática, sem a hierarquia de um crítico acima dos leitores, dizendo quais os melhores filmes. Estaria então o gosto dos jornalistas totalmente atrelado e semelhante ao dos leitores. Assim sendo, uma seção de crítica para Cinelândia não tem utilidade em nível discursivo. Ou seja, atrela-se o cinema apenas ao divertimento. Os filmes não valem a pena ser pensados, apenas consumidos pela presença da estrela. No fundo trata-se de uma difusão do star system de Hollywood. Como o aspecto mais importante dos filmes citados é a presença de estrela, todos são bons para Cinelândia. A experiência do cinema vale pela oportunidade em consumir a imagem da estrela. Estas observações se referem ao discurso de Cinelândia que procuramos esmiuçar. Tal postura em seu âmago tem estreita relação com a publicidade. Não se reprovam as fitas para não atrapalhar o acordo com os estúdios.

A posição anti-crítica intelectualizada é evidente quando se mostra ao leitor a diferença do gosto da crítica, considerado como sinônimo de "arte pura". O objetivo é justificar os comentários negativos feitos no Festival de Veneza aos filmes elogiados pela revista ${ }^{7}$. Cinelândia avisa que muitos das fitas desclassificadas poderão agradar ao público:

\footnotetext{
"a crítica rigorosa dos juizes de Veneza desclassificou muitos filmes que agradarão ao grande público e premiou outros que talvez não alcancem êxito nas bilheterias, mas é preciso notar que o ângulo em que se colocam os juízes desses festivais internacionais é o da arte pura, sem concessões ao gosto do público em geral."
}

Cinelândia mostra aos leitores que os filmes apreciados por eles não são arte. Fica implícito que os críticos de renome não se interessam pelo gosto do público, ou melhor, o desprezam. Assim, a publicação afirma ser a única a ter esta preocupação com seus leitores. Uma relação afetuosa, de amigos. Além deste caso, há algumas censuras

Filmelândia. Cinelândia também explica como as jovens devem se portar em questões de namoro, partindo na maior parte do tempo de perguntas feitas por supostas leitoras que se dizem pouco experientes. Não negamos com isso o potencial editorial da revista ao público masculino pelo apelo dos corpos à mostra. Christine Meneguello (1996) analisou como boa parte das revistas desta época, incluindo as duas publicações pesquisadas, adentram no tema da adolescência, a partir das estrelas da mesma faixa etária. Segundo ela, a figura da adolescente sofreu grandes investimentos por parte da mídia a partir de 1940. Cabe ao amor, foco das revistas, ser o mediador para a entrada no mundo da mulher.

${ }^{7}$ Há um outro tipo de artigo, de teor crítico mais elevado, claramente comprado do exterior para se cobrir uma lacuna da cobertura de algum festival internacional, num enfoque em total dissonância com o tipo de texto da publicação. Mas é algo pontual de ano de 1952, com poucos exemplos. Depois tais textos somem. Por isso não nos deteremos a este tema. 
diretas aos críticos para provar aos leitores sua não participação no meio dos intelectuais, como na sentença seguinte: “os críticos talvez achem a história inverossímil demais, mas as crianças de todas as idades, dos cinco aos noventa anos, adorarão Príncipe Valente" ${ }^{8}$. Ou seja, os críticos estão aquém do gosto de todo o público. Não gostam de nada. O tom de condenação aos críticos continua quando a revista declara: "há tantas coisas de novo que não sabemos como escolhê-las para os leitores (...). Há os debates do Grupo de Crítica, semanalmente, para esclarecer naturalmente aos próprios críticos". 9

Em geral, a seção de filmes novos não apresenta comentários opinativos explícitos, apenas traz sinopses, resumos, com a preocupação de pontuar o nome da personagem e a estrela a interpretá-la, além do estúdio, ocultando na maior parte das vezes o nome dos diretores. Porém, é patente a utilização de adjetivos e textos visivelmente feitos pelos departamentos de publicidade das empresas estrangeiras. Raríssima é a presença de filmes brasileiros na seção de lançamentos, como se este espaço somente fosse dedicado ao cinema americano, ou como se apenas o cinema de Hollywood levasse o público da revista ao cinema. A filmografia brasileira ocupa seções específicas, como um mundo a parte. $\mathrm{O}$ tratamento diferenciado mostra como Cinelândia considera a cinematografia brasileira inferior à estrangeira, deduzindo que as duas não devem compartilhar o mesmo espaço.

O tom dos textos geralmente é laudatório, provavelmente pelo perfil de ser uma revista de incentivo ao consumo de filmes. Para não explicitar a má qualidade de uma fita, utiliza-se a expressão "um filme de segunda classe", ou seja, a película ainda é boa porque tem "classe". Conceito este relacionado à concepção de fotogenia e glamour da publicação. Com o passar dos primeiros meses de existência em 1952, Cinelândia começa a fazer comentários negativos aos filmes. Diretores célebres como John Huston não são mencionados, sugerindo ao leitor assistir a Uma aventura na África (1951) para observar como os cabelos da atriz Katharine Hepburn vão se tornando mais ruivos a medida que o filme avança ${ }^{10}$. Esse é o perfil de Cinelândia, bastante diferente da concorrente.

Entre os diretores citados há Hitchcock, Cecil de Mille, Rossellini, mas sem realce. Hitchcock, por exemplo, aparece só uma vez numa foto, lendo a mão de Ruth

\footnotetext{
${ }^{8}$ Filmes novos. Cinelândia, v. 3, n. 42, p. 24, 2 a quinz. agost. 1954.

${ }^{9}$ O que há de novo. Cinelândia, v. 2, n. 17, p. 23, $2^{\text {o }}$ quinz. julho 1953.

${ }^{10}$ Mexericos de Hollywood. Cinelândia, v. 1, n. 3, p. 53, julho 1952.
} 
Roman. Finge ser um vidente, prevendo um futuro brilhante à atriz ${ }^{11}$. Não há comentários sobre seus filmes, diferente de Cena Muda.

Geralmente os artigos sintetizam se o filme é de qualidade quando os atores são considerados excelentes, situando o leitor para o gênero de cada fita: "se você aprecia esses números arriscados em que artistas desafiam a morte certamente gostará desse filme" 12 .

Em raros momentos, durante o ano de 1953, há comentários negativos explícitos aos filmes, denotando talvez um interesse futuro em desenvolver uma seção de crítica. O critério da censura recai sobre fitas enfadonhas, consideradas "chatas". O tom é bastante coloquial. O inventor da mocidade (1952) de Howard Hawks, não é bem visto porque pela metade da fita "a coisa vai ficando cacete e o filme que tanto prometia, termina bastante enfadonho. Poderia ser muito melhor se tivesse um pouco de sátira" ${ }^{13}$. O importante é o cinema como divertimento. Quando não se prende a atenção do espectador, o filme não é bom. Por esse motivo, o filme Os saltimbancos (1953), de Elia Kazan, não é recomendado por ser estranho "todo cinzento, indeciso, como se não passasse de um pesadelo. E de fato é" 14 .

O final feliz das fitas é elogiado, com algumas exceções nos casos da falta de fidelidade ao material original.

Raras vezes se procura realçar aos leitores características positivas e negativas ao mesmo tempo, como foi feito no caso do filme Ivanhoé (1952), de Richard Thorpe, elogiado como uma das "mais felizes adaptações dos romances de Walter Scott", por satisfazer a todos os gostos ${ }^{15}$. Os pequenos defeitos, como a "pálida atuação de Elisabeth Taylor", são compensados. Talvez o objetivo fosse levar ao leitor uma visão clara de orientação para distinguir se a fita mereceria ou não ser consumida. Levantar os pontos positivos e negativos confundiria o leitor, talvez por isso a técnica seja pouco usada.

Algumas vezes se reprovam as interpretações dos atores, creditando apenas aos fãs de determinado ator a possibilidade (não a certeza) de gostar do filme, como no caso de $O$ filho de Ali Baba (1952), de Kurt Neumann: "ninguém, nem os próprios

\footnotetext{
${ }^{11}$ Parsons, Louella. Os espiões de Cinelândia em Hollywood informam. Cinelândia, v. 1, n. 4, p. 10, agosto 1952.

${ }^{12}$ Filmes novos. Cinelândia, v. 1, n. 3, p. 18, julho 1952.

${ }^{13}$ Filmes novos. Cinelândia, v. 2, n. 9, p. 48, jan. 1953.

${ }^{14}$ Filmes novos. Cinelândia, v. 2, n. 17, p. 52, 2a quinz. julho 1953.

${ }^{15}$ Filmes novos. Cinelândia, v. 1, n. 7, p. 57, nov. 1952.
} 
intérpretes levam a sério esta história, que talvez agrade aos fãs de Tony Curtis e Piper Laurie" 16 .

Por ser uma revista de fã com um projeto editorial mais coerente, Cinelândia geralmente elogia os atores. Às vezes, a revista desgosta das atuações, mas não fornece maiores explicações. Quando não gosta de um filme, a publicação recorre aos mesmos termos de Cena Muda. Não falam do filme. Trazem apenas duas ou três qualidades. Declaram que nada mais de bom se pode falar do filme por ter "lugares comuns" e "absurdos na história". A base é o "achismo" e o poder de nomeação da revista. Se a publicação não gostou, não é necessário dar maiores explicações.

A primeira crítica negativa a um filme americano em Cinelândia saiu em setembro de 1952 sobre a fita Entre duas lágrimas (1952), de William Wyler, porque a transferência de amor da personagem parece "muito súbita e bastante cínica para uma garota do interior." A história trágica virou sórdida. O desempenho dos atores é recriminado porque eles dificultam a decifração dos personagens ${ }^{17}$, ou seja, o critério precisa ser a simplicidade. Laurence Olivier teria feito um de "seus piores papéis". A história humana virou sórdida no filme. O problema da película para Cinelândia tem tons moralistas. Há uma condenação ao comportamento da personagem, que se associa a um homem casado. Ou seja, se os protagonistas com os quais deveríamos nos identificar não são heróis não são bons em sua totalidade, a crítica toma um tom maquiavélico, como se não pudesse haver ambigüidade nem disparidade de estrelas em papéis de vilania. Lembramos que na maior parte das reportagens há uma grande ambigüidade entre a estrela e personagem, incluindo até mesmo aspectos nem sempre elogiáveis do comportamento, mas quando se aconselha uma fita, o critério muda.

Porém no final do ano de 1953, os comentários explícitos aos filmes na seção Filmes novos somem, característica perpetuada durante os dois anos consecutivos. A partir desse ponto, há apenas sinopses, algumas vezes com elogios. A revista torna-se, então, mais dependente das fontes (no caso, os estúdios). Fica evidente que os jornalistas ainda não assistiram a grande parte dos filmes porque trazem as expectativas da qualidade das fitas. Apenas reproduzem releases. O espaço aos filmes novos também diminui para uma página neste período, com maior espacejamento entre as linhas. $\mathrm{O}$ objetivo dos comentários não é apontar fitas artísticas, mas divertimento ao leitor, sintetizado em frases do tipo "felizmente não pretende ser mais do que um agradável

\footnotetext{
${ }^{16}$ Filmes novos. Cinelândia, v. 1, n. 8, p. 24, dez. 1952.

${ }^{17}$ Filmes novos. Cinelândia, v. 1, n. 5, p. 16, set. 1952.
} 
passatempo" ${ }^{18}$. Uma censura implícita ao conteúdo artístico, de películas com pretensões além do entretenimento.

Em 1953, também o tom de elogio vem acompanhado de frases do tipo "o filme é um absoluto sucesso", ou "o resultado foi excelente". Comenta-se, neste período, a qualidade do colorido da película. Os artigos incluem sempre elogios à atuação e beleza dos atores, um sinal de adesão completa aos objetivos propagandísticos dos estúdios, que não eram tão comuns no ano anterior. Em 1954, o elogio se converte na certeza de sucesso junto ao público: "vocês certamente adorarão", "faz a gente desmaiar de tanto rir" ou ainda uma "estupenda interpretação". Todavia em alguns momentos, a revista critica o sentimentalismo. Aconselha os melodramas ou filmes de piratas apenas para os apreciadores do gênero. No geral Cinelândia elogiava o gênero melodramático, dando maior atenção ao seu público alvo. Declara como positivo "o filme que vai direto ao coração".

Contudo, durante 1953, há uma condenação dos “filmes para mulheres", que são o ponto alto das reportagens. Nestes comentários, há um tom irônico em relação aos leitores que aceitam filmes sem conteúdo nenhum.

O tom geral das críticas aos filmes brasileiros nas reportagens e colunas em 1952 era copioso. Continha apenas informações como: "Dóris Monteiro novamente, numa cena emocionante no hospital. É uma grande vocação de atriz" ${ }^{19}$. Mas em algumas reportagens, mesmo tentando incentivar as produções, os jornalistas reclamam do baixo nível de qualidade dos filmes ou de seu artificialismo. Às vezes o tom é de desânimo:

\footnotetext{
"não foi de todo mal em 1952, mas poderia ter sido ainda pior. E o que adianta agora chegarmos a conclusão de que poderia ter sido melhor? O que interesse agora é olhar para a frente (...). Os cineastas tem 365 dias para fazer bons filmes: só assim teremos consciência de que caminhamos para a frente, nem que seja a passos de tartaruga. Isso nos dará a esperança de alcançarmos um dia a nossa meta, e, até podermos concorrer a festivais internacionais de cinema sem nos envergonharmos de ser brasileiros. Se porém ao entrarmos no ano de 1954, não pudermos constatar algum progresso, então... então é porque não é mesmo possível. O único jeito é desistir!..." 20
}

\footnotetext{
${ }^{18}$ Filmes novos. Cinelândia, v. 3, n. 38, p. 24, $1^{\text {a }}$ quinz. junho 1954.

${ }^{19}$ Ronald Valle ignora o enredo de Agulha no palheiro (1953), de Alex Viany na matéria. Segundo ele, a personagem de Fada Santoro, "a mocinha chorona de nosso cinema romântico-melodramático" vai surgir na comédia, "em um filme para rir, em um celulóide realista! (...) ver aqueles bonitos e doces olhos negros, sem lágrimas - de fato valerá a pena." Quando na verdade, a atriz desempenha o mesmo papel de ingênua, mas agora grávida e abandonada, chorando e sofrendo quase no filme inteiro. Agulha no palheiro. Cinelândia, v. 1, n. 8, p. 38-9, dez. 1952.

${ }^{20}$ O que eles esperam conseguir. Cinelândia, v. 2, n. 9, p. 26, jan. 1953.
} 
Geralmente o tom de desânimo visa elogiar um novo filme. Assim se condenam o sentimentalismo fácil, vulgarizado da rádio-novela e os clichês do cinema norte americano para provar a necessidade de elevar o padrão, a partir do que está sendo feito com tal filme. Provavelmente a tática buscasse causar simpatia nos leitores que não gostassem do cinema nacional, mostrando o desânimo da própria revista, mas ressaltando as melhoras no quadro. Cinelândia não se propunha a discutir as causas da situação do cinema brasileiro, como era feito em Cena Muda. Apenas apontou o quadro de crise da Vera Cruz em 1954-55. O maior problema para a revista foi a falta de fofocas do cinema brasileiro.

Em relação à chanchada, a posição de Cinelândia em geral é de louvor, mas isso não impede de às vezes censurar os filmes, ou admitir a grande quantidade de "abacaxis" lançados. Algumas vezes a revista fornece duas coberturas diferentes ao mesmo filme. Na reportagem, o release corre solto, nas colunas, o critério varia. Considera-se Guerra ao Samba (1954), de Carlos Manga, na reportagem, como um "verdadeiro acontecimento". Tudo o que se pode desejar de um filme de carnaval, está presente nesse ${ }^{21}$, declara a revista. Nas colunas opinativas, pouco a pouco o tom vai se tornando menos copioso. Em 1955, Zenaide Andréa afirma que há muito a se declarar negativamente contra os filmes carnavalescos ${ }^{22}$. Não elogia sua qualidade, mas invoca o gosto do público: "devemos reconhecer que se trata de um gênero muito estimado pelo público e o único gênero cinematográfico que criamos no Brasil."

Entre 1952 e 1953, Cinelândia chama a Vera Cruz a todo o momento de $a$ Hollywood brasileira, reflexo do projeto de cinema que a própria empresa possui. $\mathrm{O}$ tom é muito lisonjeiro. A comparação busca aumentar o interesse do leitor pela paridade do estúdio brasileiro a Hollywood. Raras reportagens conseguem balancear os elementos positivos e os negativos de uma película brasileira, como no caso dos filmes estrangeiros. Contudo há aqui uma diferença, ou se elogia tudo, ou se condena em exagero. Uma exceção foi a crítica ao filme Com o diabo no corpo (1952), de Mario del Rio, em que se enumerava pontos positivos e negativos:

\footnotetext{
“... estreou com relativo agrado. Pontos altos do filme: bela fotografia de (...), o trabalho em geral correto de (...)." Os pontos fracos para o repórter são: "o argumento muito frágil e forçado, a personagem encarnada por Patrícia, mal definida (..) e o excesso de cenas de 'boite'. E aqui vai um conselho a Oscar Juarez, maquiador do estúdio: menos pintura nos olhos de suas estrelas, 'seu' Oscar (..)." 23
}

\footnotetext{
${ }^{21}$ Guerra ao samba. Cinelândia, v. 4, n. 55, p. 52-3; 65, 2a quinz. fev. 1955.

${ }^{22}$ Andréa, Zenaide. Guerra ao samba. Cinelândia, v. 4, n. 53, p. 52-3, $2^{\mathrm{a}}$ quinz. jan. 1955.

${ }^{23}$ Cinema brasileiro. Cinelândia, v. 1, n. 8, p. 55, dez. 1952.
} 
No texto acima, o repórter busca aconselhar o maquiador a se aprimorar em sua técnica. Esse tom de aconselhamento apareceu algumas vezes nos dois primeiros anos analisados. Sobre o filme Destino em apuros (1953), de Ernesto Remani, da Multifilmes, lançado como o primeiro filme inteiramente em cores, Cinelândia declara que o dono da companhia em um almoço oferecido à imprensa teria deixado livre o caminho para criticarem a fita. O repórter então segue a risca a sugestão de Civelli. Aconselha o diretor a cortar as cenas de valsa, sem afinidade com uma comédia de carnaval. Além disso, condena os trechos em que as roupas são como as de western e o modo de dançar é artificial. "Deixo aqui consignada uma grande VAIA à Multifilme e a todos os responsáveis por algumas cenas de 'Destino em apuros', que apresentam erros tão grotescos, quanto imperdoáveis." ${ }^{24}$ Cinelândia busca nestes artigos pontuais se firmar como espaço de análise antecipada dos filmes brasileiros, tentando se autopromover como agente no campo cinematográfico, antevendo como deve agir o cineasta; postura semelhante a da revista concorrente.

Apesar de a revista tentar provar sua postura neutra, há claras afirmações de um gosto estético afinado com os padrões de Hollywood, além do desprezo pelo filme artístico. O suposto tom benevolente ao cinema brasileiro coexiste com censuras a sua baixa qualidade, com algum tipo de preocupação em analisar a interpretação dos atores. Raramente há algum tipo de preocupação em dividir filmes para análise. O máximo que encontramos são comentários na base do gosto dos jornalistas, anônimos nos espaços da seção Filmes novos. Assim a crítica em Cinelândia dificilmente pode ser vista como produto do pensamento individual, mas da publicação. Esta postura não sofreu alterações durante a década de sessenta; no sumário encontramos as mesmas seções, com manchetes semelhantes. A repetição dos mesmos critérios serviu por dezessete anos. Geralmente as técnicas de ocultação da opinião no jornalismo causam uma sedimentação das publicações como veículos confiáveis aos leitores, e ao que parece, Cinelândia estava mais de acordo com esses novos cânones da imprensa do que a sua concorrente Cena Muda.

\footnotetext{
${ }^{24}$ Cinema brasileiro em technicolor. Cinelândia, v. 2, n. 18, p. 66, $1^{\circ}$ quinz. agosto 1953.
} 


\subsection{A crítica em Cena Muda}

Se Cinelândia pautava-se por uma crítica em espaços supostamente informativos, Cena Muda não buscava ocultar suas opiniões. Estas recebiam um espaço privilegiado nas seções de crítica e nos editoriais sobre a situação do cinema brasileiro. Reflexo do jornalismo da década de cinqüenta, Cena Muda praticava o jornalismo opinativo, polêmico, missionário e pessoal. A crítica da publicação também sofria influência das relações com os estúdios e com o star system. Neste tópico, trilharemos as principais características da crítica a partir de um critério cronológico, voltado a detalhar as mudanças editoriais derivadas da grande sucessão de diretores. De maneira geral, a revista estava em crise, mas o mesmo não se efetuava com a qualidade da crítica estabelecida, com diversas alterações ao longo dos quatro anos. Iniciamos a discussão pelas críticas de Salvyano Cavalcanti de Paiva por se tratar de um crítico de Cena, também reconhecido pela história da crítica cinematográfica, e que possibilita discutir a relação entre crítica e publicidade na publicação.

\subsubsection{Salvyano Cavalcanti de Paiva: síntese da incongruência entre crítica e publicidade}

A tentativa de incentivar o cinema nacional por via do estrelismo não estava presente em Cena Muda apenas nos artigos vinculados ao material de release dos estúdios, mas também em alguns artigos de Salvyano Cavalcanti de Paiva. A postura deste cronista é semelhante à da crítica da revista voltada às diatribes e ao discurso panegírico. É importante frisar que na maior parte dos textos o posicionamento de Salvyano em relação ao estrelismo é antagônico. Há desde análises voltadas para a conscientização dos leitores sobre o tema até a utilização de adjetivação excessiva, incluindo a análise da atuação e performance dos atores. Na verdade, Salvyano congrega o paradoxo de ter desempenhado a função de crítico de cinema e de publicista da Art Films. Para compreender a produção textual de Salvyano em Cena é preciso dividir seus artigos em duas frentes: o discurso do jornalista e do publicista.

Há um tom sensacionalista, inflamado, com frases apelativas nos artigos de Salvyano em Cena Muda, embora haja também uma postura de estudioso do tema, informativa. Não podemos transpor tais observações para seu trabalho em outros 
veículos de comunicação. Talvez essa dualidade tenha sido uma adaptação ao trabalho em uma revista de fã. Acreditamos que a necessidade de adequação ao veículo tenha sido o principal responsável pela dualidade, embora não descartemos a influência da publicidade sob seus comentários.

Os artigos em tom laudatório podem ser explicados pelo depoimento do crítico à Flora Bender (1979). Salvyano admitiu ter produzido várias starlets em Cena, comentário narrado em tom positivo, porque ele teria conseguido lançar muita gente, ao lado da crítica séria. O cronista confessou também a necessidade de fazer tal "badalação" para sobreviver "porque tinha interesse em fantasiar a revista daquele aspecto esfuziante, que é o da vedetinha". Acrescenta que as moças "imploravam para aparecer". Apresenta sua relação com as estrelas como desprovida de interesses comerciais.

Nossas observações sobre Salvyano diferem dos textos publicados por ele posteriormente. Maria Rita Galvão e Jean Claude Bernardet citam um artigo seu denominado $O$ Problema da revisão do método crítico, publicado na revista Manchete. Nele, Salvyano explica que a crítica não deve jamais se submeter ao "gosto da multidão não-esclarecida e embotada pelo produto de segunda classe feito pelos capitães-deindústria com o objetivo de anular a consciência social". Mais importante do que a forma é o conteúdo do cinema. (Galvão; Bernardet, 1981: 71)

As observações de Salvyano na revista Manchete sobre a crítica diferem radicalmente de sua prática em Cena Muda. Arthur Autran declara que Salvyano Cavalcanti de Paiva era um crítico comunista, como Carlos Ortiz. Pode ser considerado um crítico-historiador. Não era um crítico esteta como Moniz Vianna e Almeida Salles, preocupados em analisar o cinema como arte. Seu capital social era menor se comparado ao dos esteticistas.

Salvyano foi crítico de a Cena Muda, crítico e redator-chefe de Manchete, publicista da Art Filmes, repórter e redator da imprensa carioca. Chefiou no final dos anos sessenta o Departamento de Fomento do Filme Nacional do INC. (Autran, 2003)

A observação de Autran sobre o crítico não ter sido um esteta foi confirmada pelo próprio Salvyano em Cena Muda. Ele admitiu nunca ter tentado fazer teoria do cinema, apenas "resenhas críticas" ${ }^{25}$. Cavalcanti de Paiva declarou a Flora Bender (1979) que fazia parte do clube de fãs de Cena Muda quando criança. Todo o grupo,

\footnotetext{
${ }^{25}$ Paiva, Salvyano Cavalcanti. Antologia dos cronistas cariocas. Cena Muda, v. 31, n. 20, p. 14; 23-24; $30,17 / 05 / 1951$.
} 
fascinado pelo cinema, tinha ambições intelectuais. Quando passaram para a adolescência, perceberam o kitsch que representava Cena Muda e as revistas similares, inclusive Cinearte. A partir daí, começaram a atuar de forma diversa, verificando as fraquezas teóricas dos que escreviam sobre cinema nas revistas de fãs. Porém, quando Salvyano foi trabalhar em Cena Muda, utilizou boa parte dos esquemas anteriormente condenados.

O cronista fazia publicidade para cinema. Começou na função de crítico em Cena Muda. Peri Ribas o convidou para assinar uma coluna semanal na publicação. Descobriu sua "vocação" ao ler seus artigos enviados como leitor. Salvyano entendia Cena Muda como uma leitura de distração, embora alguns leitores participassem, reagindo e contribuindo para o enriquecimento da crítica. Salvyano ficou em Cena Muda de 1944-48, embora tenha colaborado outras vezes por mais dois ou três anos de 1950-52. Trabalhou também na revista Manchete, na Rádio Jornal do Brasil e no Correio da Manhã, Diário de Notícias, Última Hora e na Revista Senhor.

Conforme João Carlos Rodrigues, Salvyano era um crítico da "velha estirpe": “jornalista de bom texto, sanguíneo e frequentemente injusto" ${ }^{26}$. Em Cena Muda, ele não se eximia de expressar sua opinião, com uso excessivo de adjetivos. É necessário também pontuar a existência de algumas matérias de sua autoria que são meros releases, cumprindo a função de lançar estrelas. Nestes casos, o jornalista eleva as atrizes ao Olimpo por suas qualidades, postura diferente dos textos elogiando as brasileiras, com menor grau de qualidades descritas e diminuto detalhamento sobre a vida pessoal.

A crítica feita por Salvyano em Cena era voltada a uma análise sociológica do cinema. Coexistiam também comentários ligados à publicidade dos filmes, largo uso do sensacionalismo e frases bombásticas, em estilo peculiar. Os seus textos no período analisado estão em espaços informativos, sob a forma de reportagem ou de artigos sobre a produção do cinema brasileiro, não nas seções de crítica, embora sejam claramente opinativos em sua essência. Avaliam muito mais a situação do cinema brasileiro do que os filmes. Algumas vezes ele escrevia sobre as fitas, analisando a produção brasileira com o objetivo de compreender a nossa produção cinematográfica. Baseando seu critério num certo gosto e não gosto, Salvyano nomeava aspectos positivos e negativos dos filmes, centrados na figura do diretor e na atuação dos atores.

\footnotetext{
${ }^{26}$ Rodrigues, João Carlos. A metralhadora de Salvyano. Cine Imaginário, v. 4, n. 39, p. 16, fev. 1989.
} 
A utilização de estilo bombástico nos textos tem como principal motivação chamar a atenção sobre suas opiniões e artigos, via sensacionalismo, não porque Salvyano realmente estivesse "furioso" com o cinema brasileiro, como gostava de vender aos leitores. O caráter de irritação com o cinema nacional, como o de um juiz, confere poder de nomeação ao crítico. Ao se declarar indignado com nosso cinema, ele quer provar seu interesse pela cinematografia, almejando seu desenvolvimento porque era politicamente correto se colocar a favor de nossa produção na revista. Com tal postura, ele divide sua posição de censor apenas em relação às obras produzidas; não em relação ao cinema nacional. Como se coubesse ao crítico reclamar, censurar, ou seja, controlar a qualidade da produção. Muitas vezes, seus textos centram-se sobre filmes em processo de produção para que suas sugestões modifiquem o resultado final, em similitude com o modelo da crítica teatral. O objetivo parece ser o de se destacar no meio, tanto no campo da crítica cinematográfica quanto em relação aos leitores.

Há uma preocupação discursiva com a produção e melhora do cinema brasileiro, mas não com a teorização do mesmo, nem com uma análise fílmica mais apurada. Porém fora do discurso, na porção prática, ele não encontra melhora nos filmes nacionais. Acaba por enveredar para as diatribes. Por outro lado, para se justificar, busca fazer "sua parte" sobre o cinema brasileiro. Ou seja, o elogiar no único ponto positivo encontrado: a qualidade e beleza das estrelas, como se a função do crítico fosse o incentivo, a partir de um tom laudativo. Assim Salvyano torna-se publicista do cinema brasileiro, pedindo melhoras. Consequentemente prediz o êxito de muitos filmes, sem economizar louvores. Todavia, nada o impede de censurar depois as mesmas fitas depois de prontas. A postura de sua crítica pode ser descrita como extremista: de amor e ódio, louvor ou censura.

Muitas vezes há uma postura de elogio à plástica, citando a beleza corporal das estrelas de forma muito rudimentar. Certa vez o crítico pontuou com destaque as "curvas, curvas, curvas" de Margot Bittencourt. Recorreu também a um tom lúdico e humorístico. Afirmou que só uma mulher não era fã dela: "uma senhora surda, cega e muda." ${ }^{27}$ Essa é em síntese a cobertura positiva dele ao estrelismo brasileiro.

Os demais textos publicados do cronista nos primeiros meses de 1952 eram de críticas ao estrelismo e ao estado do cinema nacional. Debruçamo-nos agora sobre esta produção. Muitos dos artigos com postura mais analítica de Cena durante 1952 são de

\footnotetext{
${ }^{27}$ Paiva, Salvyano Cavalcanti. Caras novas no cinema brasileiro - astros de amanhã. Cena Muda, v. 32, n. 7 , p. $11-13 ; 23,14 / 02 / 1952$.
} 
Salvyano Cavalcanti de Paiva. Apesar de o colunista lutar para construir um estrelismo nacional, o cronista critica o cinema existente no país, principalmente o nudismo, a macumba e a malandragem, temas com certa constância em seu nível discursivo. Ou seja, sua preocupação é com o conteúdo dos filmes. A visão é extremista, geralmente pessimista, como se não houvesse mais solução. Certa vez, ele criticou o filme Com o diabo no corpo (1952), de Mario del Rio, por conter mulheres com "roupas transparentes, portanto, praticamente nuas":

\begin{abstract}
"nada de novo no cinema brasileiro. Nada de novo, exceto sexo, misticismo e policialismo, que se traduzem melhor por NUDISMO, MACUMBA E MALANDRAGEM. Nada de novo na forma, nem no conteúdo, nem tampouco no sentido. Estrutura capenga: o progresso foi apenas da técnica; a estética continua na estaca zero. O conteúdo é cada vez mais cosmopolita, cada vez menos brasileiro, nacionalista, típico. O colorido verde amarelo desaparece diluído, (?) ${ }^{28}$, universalhado... pior para os adeptos do cinema nacional." 29
\end{abstract}

Cavalcanti de Paiva é contra o exagero do tema sexo não só nos filmes brasileiros, como no dos americanos que abusam das cenas "nos quartos de dormir". Entretanto, segundo ele, são os brasileiros os transformadores do sexo numa indústria de cinema. Comentário despropositado, uma vez que tal produção questionada é na verdade a chanchada ou filmes de produtoras independentes, pouco pautados nos critérios de sex appeal, em relação à produção estrangeira ${ }^{30}$.

Considera Salvyano a nudez feminina "coisa muito séria, muito digna em certo sentido, para andar sendo explorada de maneira tão baixa como nos filmes nacionais dos últimos anos", especialmente quando o sexo mistura-se com as crendices populares e a imitação servil dos modelos de exploração de gângsteres americanos, dos gigolôs franceses. Surge então no mesmo texto citado acima o medo da imagem negativa do Brasil no exterior como durante a década de vinte, analisada por Ismail Xavier (1978) ${ }^{31}$ já na revista Cinearte, que reaparece em Cena Muda:

\footnotetext{
${ }^{28}$ Palavra ilegível na cópia digitalizada consultada no site do Museu Lasar Segall.

29 Paiva, Salvyano Cavalcanti. Nada de novo no cinema brasileiro, exceto... nudismo, macumba $e$ malandragem. Cena Muda, v. 32, n. 5, p. 10-13; 26, 21/01/1952.

30 Salvyano elogia a nudez com dignidade de Heddy Lammar no filme Êxtase (1933), de Gustav Machatý, película muito criticada no período de exibição, devido à aparição da atriz totalmente nua num rio de águas transparentes. Nudismo sem dignidade aparece, conforme seu artigo, não só em filmes brasileiros, como mexicanos e franceses. O cronista consegue aceitar que certos filmes admitem e precisam de cenas de nudez, tal como Presença de Anita (1951) de Ruggero Jacobbi.

31 Segundo Ismail Xavier, para a revista Cinearte, os filmes brasileiros não deveriam mostrar imagens negativas do país, para não abalar nossa imagem no exterior, porque o parâmetro do progresso é o cinema: "seria nas telas e não nas ruas que se deveria produzir a imagem do progresso do país". (Xavier, 1978: 176)
} 
“o que pode aparecer lá fora, senão que somos uma raça de malandros, (...) que vivemos de capoeiras, (...) que nossa religião é o baixo espiritismo e os mitos afro-americanos, apenas, e que vivemos aluados com a visão fixa de sexo, sexo, sexo???"

O cronista censura diversos filmes brasileiros, entre eles $\mathrm{Meu}$ destino é pecar (1952), de Manuel Peluffo, na cena que Antonieta Morineau despe-se. Este último é considerado um filme "completamente tarado." Ele não poupa Virgínia Lane e Fada Santoro. Esta última por ter se despido no filme Escrava Isaura (1949) de Eurides Ramos. Segundo ele, Marisa Prado também teria caído nua no rio numa cena do filme Terra é sempre terra (1950), de Tom Payne, com Mario Sérgio junto. Vale aqui uma ressalva, pois no filme a nudez é sugerida. Apenas vemos as roupas da personagem no mato. Quem se despiu numa cena foi o personagem masculino. Ele começa a tirar a roupa num plano geral, rapidamente o vemos saltar na água e mergulhar, nada se pode enxergar. Na verdade, o argumento foi moderno para os padrões conservadores da revista em relação ao cinema brasileiro, porque na cena os protagonistas nadam juntos. Salvyano mistura a sugestão de nudez da trama com o ato de tirar a roupa das estrelas nas filmagens, utilizando um dos recursos do estrelismo pautado sobre a interseção da vida e personalidade da atriz e de seu personagem. Mistura diegese e estrelismo.

Salvyano consegue ver nudismo, macumba, malandragem, cenas na alcova e excesso de sexo em quase todos os filmes brasileiros neste artigo citado. Conforme sua análise, dos estúdios brasileiros, grandes ou pequenos "só sai droga (mortíferas ou analgésicas)". O padrão das fitas nacionais é baixo do ponto de vista estético, sociológico, moral e psicológico. Portanto, os personagens tipicamente brasileiros tornam-se artificiais, pressuposto para se censurar o cinema da época, considerado ainda de cavação:

\footnotetext{
"O cinema nacional de cavação é um tóxico tão perigoso para a nação quanto à cachaça, a maconha ou as aguardentes (...). O malandro e o cafajeste perdem sua afeição natural nos filmes, ficam afrancesados, americanizados. O nudismo precisa de um motivo para se despir e no cinema brasileiro não precisa. Há uma razão comandando, a renda, a bilheteria. $\mathrm{O}$ nudismo supera as deficiências técnicas e artísticas das fitas, atrai público, serve para despistar a falta de imaginação dos realizadores."
}

Nessa parte do texto, Salvyano admite a responsabilidade de tal processo ao imperativo da bilheteria. Pontua também o apelo junto ao público, embora o forte do artigo seja culpar os realizadores e atores pela empreitada. 
Um mês depois, Cena publicou o direito de resposta ${ }^{32}$ de Fada Santoro. Ela alegou ter usado um maiô, o qual aparece numa cena do filme Escrava Isaura. De acordo com ela, deste detalhe foi condenado pelos críticos como um erro de filmagem. Salvyano, então, escreve outro artigo reprovando novamente a nudez. Contudo elogia o comportamento de Fada Santoro, por não ter se despido. Ou seja, como crítico, ele hesitava, com uma certa falta de parâmetros e de firmeza na argüição.

Em menos de dois meses, Salvyano muda totalmente de argumento. Como se fosse um publicista do cinema brasileiro, declara que a forma do cinema brasileiro representar a alcova é muito digna, de "uma sobriedade elogiável", apesar do despreparo no elemento técnico ${ }^{33}$. As diatribes somem neste artigo. $\mathrm{O}$ tom panegírico está acompanhado de uma foto de Fada Santoro no filme Areias ardentes (1952) de J. B. Tanko, como "convite ao mais", vista agora de maneira positiva.

Há uma incoerência muito grande na postura de Salvyano quanto ao tema da erotização crescente dos corpos, considerada ao mesmo tempo vulgar ou excessivamente valorizada em outros artigos. Há volatilidade em sua opinião. Dois anos antes, em 1950, ele publicou um texto em Cena Muda intitulado Vitaminas dando sopa... ${ }^{34}$. Utilizando um apelo à erotização das belas estrelas brasileiras, recorre aos critérios que ele mesmo condenaria nos textos anteriormente descritos. Não sabemos ao certo quem fez a seleção das fotos, mas as ilustrações apelam muito para as pernas e decotes das novas estrelas. Numa das fotos, a silhueta nua da vedete Luz del Fuego, aparece coberta na frente por uma toalha. A aparição da atriz contraria as normas conservadoras da revista. Luz del Fuego ${ }^{35}$ era uma vedete bastante polêmica. Criou posteriormente até uma praia de nudismo. A foto é bastante ousada para os parâmetros da publicação na cobertura às celebridades brasileiras, embora o critério para as vedetes do teatro de revista seja diverso, como já mostramos. A legenda apelativa diz: "Luz del Fuego. A vida por um fio...de (?) ${ }^{36}$ pano." Vale lembrar que no artigo anterior, Salvyano havia condenado o "nudismo da exibicionista Luz del Fuego". Este último texto começa com grande ironia e trocadilhos maliciosos comparando as atrizes à frutas:

\footnotetext{
${ }^{32}$ Cena Muda, v. 32, n. 8, p. 14, 21/02/1952.

${ }^{33}$ Paiva, Salvyano Cavalcanti. Um elemento dramático importante: o cinema brasileiro e a alcova. Cena Muda, v. 32, n. 10, p. 32-33, 06/03/1952.

${ }^{34}$ Paiva, Salvyano Cavalcanti. Vitaminas dando sopa... Cena Muda, v. 30, n. 36, p. 5-7, 05/09/1950.

${ }^{35}$ Luz del Fuego participou dos seguintes filmes: Nativa solitária (1954), fita da qual não consta nem o nome do diretor, Curucu, best of the amazon (Curuçu, o terror do amazonas, 1956) de Curt Siodmak; Comendo de colher (1959) de Alcebíades Ghui e Franz Eichor; Tarzan e o grande rio (1969) de Robert Day.

${ }^{36}$ A palavra está ilegível na versão consultada no site da Biblioteca do Museu Lasar Segall.
} 


\begin{abstract}
“A banana quanto mais nova, mais nutritiva, mais rica, mais saborosa... Engorda e faz crescer!... Ora, certamente de bananas não é que está precisando o cinema brasileiro. Nem de bananas (que já tem em quantidade, 'gentilmente' doadas por indústrias de toda espécie, inimigos da indústria do celulóide...), nem de outras frutas."
\end{abstract}

Num texto publicitário apelando à erotização, o crítico chega a dizer que temos balzaquianas "belas" e "boas", "de encher a vista e provocar as glândulas gustativas." Nesse quesito, segundo ele, não ficamos nada a dever em Hollywood. Machista e com um teor vulgar, declara que "nossas potrancas cavalgam como nenhuma. São dóceis, e os cavalheiros ao vê-las, ficam "indóceis"”. Termina, convidando os produtores a realizarem um filme multi-estrelar porque "há tanta carne, tanta carne moça!". Portanto, o texto de Salvyano se presta a dois fatores, considerados uma só moeda nas revistas de fãs: realizar diatribes contra os filmes nacionais e fazer publicidade com apelo sensacionalista aos filmes. É significativo ressaltar que o exagero na erotização dos textos de Salvyano inexiste em outras matérias de Cena. Nos artigos de Cavalcanti de Paiva não era mais a simples publicidade a propulsora do sucesso dos filmes, mas sim o sex appeal.

O cronista também questionava as bases do estrelismo mundial. Era muito comum Cena listar os melhores atores de todos os tempos. Salvyano sai à frente e discute os critérios comerciais de bilheteria e do estrelismo, criados pelos estúdios na base da fotogenia, e não do talento. No início do artigo, afirma ser necessário ter um critério para escrever sobre as estrelas. Ele escolheu os atores com maior bilheteria. Fornece alguns nomes. Depois, critica sua própria lista por deixar de lado atores importantes. Alegando ser impossível enumerar os melhores atores de todos os tempos, recorre a uma lista com os de maior bilheteria. A justificativa para a escolha volta-se ao público leitor, considerando Cena Muda uma "revista de cinema essencialmente popular" ${ }^{37}$. Contudo a classificação não quer se mostrar como neutra, porque questiona abertamente o estrelismo:

\footnotetext{
"o primeiro caminho que o sujeito tem que trilhar é largar sem dó nem piedade os outros cinemas do mundo. E isto pelo simples fato de que (...) nenhum filme que não Hollywood conseguiu superar os 'records' de bilheteria da meca do cinema. O estrelismo ianque tanto no passado quanto no presente tem sido a razão principal das fabulosas rendas dos seus filmes. Comprovado isso, tratei de selecionar os SUPER-ASTROS dos dois sexos (....)."
}

\footnotetext{
${ }^{37}$ Paiva, Salvyano Cavalcanti. Ídolos das matinées. Cena Muda, v. 32, n. 01, p. 06-9, 03/01/1952.
} 
A lista com os melhores é questionada logo a seguir porque muitos atores citados são "elevados ao estrelato com as maiores mediocridades, que o mundo já conheceu", impostos "a força nos 'higiênicos', cromados e divertidos filmes americanos." Repreende, então, o estrelismo ao misturar o nome das estrelas talentosas com outros nomes presentes, apenas para censurar. Desqualifica os atributos físicos que ele mesmo elogiava em alguns textos:

\footnotetext{
"Alguns premiados da Academia posando ao lado de modestos vaqueiros, de trovadores e de gangsterns 'desalmados'. Garotas cujo mérito está no busto, nas pernas, às vezes na voz - por milagres, só por milagre...- ao lado de respeitáveis matronas da alta comédia ou da tragédia, passeando com nadadoras de piscina e patinadoras de ring, bem como moças de 'sarong'... (...) As razões nasceriam por aí sós...... Raramente, o talento, no duro. Na batata.”
}

Garante no final que provavelmente irão reclamar da lista dele, "mas, que fazer? A evidência das rendas é quem manda!", declara.

Vale assinalar que Salvyano utilizava muitos pseudônimos em Cena. Talvez muitas críticas do período com visíveis nomes falsos fossem de sua autoria. Realizamos uma busca nos textos de Salvyano escritos durante sua primeira fase na revista, entre 1949-51, apenas com seu nome. Encontramos artigos com elogios, semelhantes aos textos de apologia ao star system ${ }^{38}$. Ressaltamos apenas alguns artigos para tentar dar uma continuidade sobre a produção dele em Cena Muda.

O tom geral dos artigos de Salvyano quando se trata de amigos é o elogio, mas com restrições. Paulo Wanderley, diretor do filme a estrear Maria da Praia (1951) ${ }^{39}$, é visto como um sujeito de valor, porque estuda arte cinematográfica. Da aliança com Ruy Santos, considerado seu amigo, contém o texto uma ressalva: apesar de ser um cinegrafista de valor, ótimo "cortador", montador e o melhor fotógrafo de exteriores do Brasil, até hoje foi infeliz em filmes de longa metragem. Raramente críticos tomariam um tom tão acirrado em relação aos amigos, como fazia Salvyano.

O machismo do cronista está enraizado na maior parte de seus textos, com um tom de provocação sensacionalista. Sobre o filme citado acima, acrescenta que toda mulher bela é falsa. Nesse artigo, não há uma postura de exagero na quantidade de elogios. Ele considera as fotografias animadoras, por isso declara que aguardava com entusiasmo o filme. Contudo não antecipa seu sucesso. $\mathrm{O}$ tom de expectativa sobre a qualidade do filme vem acompanhado de elogios à capacidade dos envolvidos por

\footnotetext{
38 Consideramos os resultados numéricos reduzidos para dois anos de permanência na publicação, indicando a utilização de nomes falsos.

${ }^{39}$ Paiva, Salvyano Cavalcanti. É doce filmar na praia. Cena Muda, v. 30, n. 49, 4-5, 31, 07/12/1950.
} 
algum trabalho anterior, mesmo sem ter sido bem sucedido no todo, como no caso de Ruy Santos.

Posteriormente a seus votos de sucesso, chama o filme de "terrível abacaxi" 40. Nem sequer cita o seu "amigo" Paulo Wanderley, como tinha feito da primeira vez. Não poupa, portanto, seus amigos, quando o objetivo é analisar os filmes.

Em 1951, Salvyano Cavalcanti de Paiva publica uma série de artigos intitulada Antologia de críticos do Rio de Janeiro ${ }^{41}$. O cronista não se propõe a pensar como era feita a crítica, mas fornece informações sobre os críticos. O conceito de crítica é esmiuçado a partir da biografia de seus agentes. A crítica não é aqui entendida como recurso de uma época e de um pensamento conjunto, mas individual. A partir destas matérias, temos acesso ao universo sociológico de seus colaboradores, às classes sociais presentes, incluindo críticos conhecidos e outros nem tanto, além da descrição em terceira pessoa do próprio Salvyano. Alguns deles não tinham formação universitária, como Leon Eliachar, Adolfo Cruz, Clovis de Castro, Joaquim Menezes. A maior parte deles nasceu no nordeste. Muitos dos cronistas citados eram ou tinham sido publicistas, quatro deles foram jornalistas de Cena Muda, como Luiz Alípio de Barros (foi diretor), Pery Ribas, Celestino Silveira e Leon Eliachar.

Salvyano declara com humor seu retrato, polêmico e satírico, criando uma visão de si mesmo como indivíduo exigente, sem amigos e passional. Descende de grandes burgueses apequenados, oriundos da nobreza açucareira do nordeste. Mas declara pensar, viver e agir como proletário. Odeia a burguesia "podre" ${ }^{42}$. Compactuando para sua definição como um provocador, descreve-se como alguém sempre de uma franqueza rude, positiva. Quando gosta de alguém é sincero. Quando odeia é para toda vida.

Salvyano seria um bom exemplo para se estudar a relação entre crítica e publicidade dentre os críticos do período. Trazemos agora uma matéria de Salvyano sobre o publicista. $\mathrm{O}$ artigo ${ }^{43}$ revela muito da postura tanto do cronista, como da influência dos releases em Cena Muda. O publicista é tratado como parte do mecanismo, mas não o responsável por ele. Visão contrária a da maior parte das páginas de Cena Muda, onde a publicidade surge como a culpada de todas as invenções e

\footnotetext{
${ }^{40}$ Paiva, Salvyano Cavalcanti. Entre o documentário e a ficção. Cena Muda, v. 31, n. 28, 14, 30, $14 / 07 / 1951$.

${ }^{41}$ Os artigos ocuparam as vinte primeiras edições da revista. Paiva, Salvyano Cavalcanti. Antologia dos cronistas cariocas. Cena Muda, v. 31, n. 1-20, 1951.

${ }^{42}$ Antologia dos críticos cariocas. Cena Muda, v. 31, n. 20, p. 14; 23-4; 30, 17/05/1951.

${ }^{43}$ Paiva, Salvyano Cavalcanti. O publicista, esse condenado. Cena Muda, v. 31, n. 21-22, p. 10-11; 8, 22, 24/05/1951; 31/05/1951.
} 
aspectos negativos do cinema americano. A culpa do mau gosto dos anúncios para Salvyano é dos produtores e exibidores. A notoriedade e interesse pela profissão nos Estados Unidos e na Europa vêm do alto salário, ou do salário decente, com compensação financeira por “mentir e escandalizar”. Mas no Brasil, o salário é muito baixo, "miserável". Além disso, o profissional da área tem de obedecer a chefões que nada entendem de publicidade. É um “conformado" com a sua situação. Não pode dar sua opinião, exceto nos estúdios independentes. No Rio, a profissão não garante nem dinheiro, nem renome.

Segundo Salvyano, o publicista no Brasil deve ser bastante inteligente para fazer uma propaganda bem idiota, porque quando faz uma inteligente, desagrada ao povo e aos produtores. Ele lembra que uma base mais precária e pior faz mais sucesso. Os publicistas ganham para atender a estes pedidos. Fazem anúncios extravagantes, rotineiros, viciosos. O cronista culpa apenas o Brasil pelos textos de pior qualidade, quando a maior parte dos releases era de procedência estrangeira e utilizavam os mesmos critérios.

Apesar de o tipo de propaganda ter sido dado primeiro pelos publicistas, o público adquiriu o hábito da publicidade "estúpida" e passou a exigir cada vez mais burrice. Aceita a "mentira cretina". Cria-se, então, um círculo vicioso sem fim, com estímulo ao sexo, não ao cérebro. Salvyano descreve o trabalho do publicista como criar "a publicidade salivar, digestiva, aliás muito razoável para um cinema mais diversionista que artístico, de qualidades mais espetaculares do que estéticas." Ele se volta, então, para uma repreensão ao cinema de entretenimento, apesar de este ser o nicho editorial de Cena.

Depois, fornece acesso ao leitor dos argumentos utilizados pelos publicistas para convencer seus alvos. Quando escreve aos críticos, o agente de publicidade assegura valer a pena assistir a "determinado abacaxi" "por causa dos valores estéticos intrínsecos que nem sempre existem...”. Para conquistar o público "variado, caprichoso, instável, volátil", o criador de anúncio deve escrever frases do tipo: o drama "x é o mais bem feito até hoje", assim como a comédia y é "sem similar (...)".

Salvyano admite que muitos "comentaristas de filmes" infelizmente por interesses egoístas transformam-se em “corretores de anúncios”. Ganham por comissão de todos os lados. Mas logo a seguir, considera esses casos raros na conjuntura da época. Não há sentimento de culpa na realização do trabalho porque "para isso é que vive o publicista: propagar valores exagerando" e proteger os valores dos capitalistas, 
produtores, distribuidores e exibidores. Além de tudo, o profissional do anúncio sofre a ira "do patrão, dos críticos e do público pouco compreensivo." Quando um filme muito ruim tem bilheteria péssima, a responsabilidade recai sobre o agente de propaganda. Termina por declarar o publicista um "condenado":

"Como sofre o pobre publicista! Quebra a cabeça procurando unir o útil ao agradável no anúncio, quebra o crânio descendo até a mentalidade comum dos fãs e dos patrões, vulgarizandose, mas tendo o cuidado de não entorpecer de todo o cérebro... É obrigado a mentir barato, escreve coisas de que ele mesmo tem vergonha mais tarde; idealiza os troços mais exóticos possíveis, tudo em benefício da bilheteria do filme! O objetivo é renda!"

Uma novidade é admitir a mentira "cretina", da qual até mesmo o publicista sentirá vergonha mais tarde. Assim, o crítico de Cena entende o publicista não como o culpado pela criação material do star system, mas como vítima. Apesar de mostrar a renda como objetivo, ele exime o responsável pela produção material sobre as estrelas, por ser um mero joguete nas mãos dos produtores.

Na segunda parte do artigo, Salvyano possibilita ao fã saber a opinião dos publicistas sobre os espectadores. Todos declaram que o público nunca os decepciona, porque sempre corresponde bem às expectativas da propaganda. As declarações dadas não conferem aos leitores capacidade analítica. O estrelismo auxilia muito, quase sempre para o bem da publicidade. Sem temer entrar no assunto da relação entre estrelismo e publicidade, Salvyano traz declarações confirmando ser mais eficiente o renome da estrela para a bilheteria, do que uma campanha publicitária bem feita com uma desconhecida. Confessa também o trabalho do publicista em "forçar" o nome ou a fisionomia de um ator. Filmes considerados medíocres pela crítica e pelo público alcançaram grandes bilheterias a partir de uma publicidade discreta em conformidade com sua classe inferior. O público, segundo eles, tem duas posturas. Às vezes foge dos filmes elogiados pela crítica, ou comparece em peso para ver fitas analisadas de forma negativa pelos cronistas. Os entrevistados buscam trazer apenas exemplos nos quais a publicidade acerta a dose, deixando implícito a desqualificação da crítica pelos espectadores.

A última pergunta de Salvyano foi sobre a influência da crítica sobre os efeitos da publicidade. Tema considerado difícil de mensurar pelos entrevistados. Por isso a questão teve respostas vagas. Ou seja, não interessava aos publicistas em questão trazer os fracassos de bilheteria influenciados pela má recepção dos críticos. Quando Salvyano interrogou Zenaide Andréa sobre o tema, a reposta refletiu o tom da revista de fã 
Cinelândia na qual ela iria trabalhar depois: "Eu, hein... Para que falar em coisas sérias?...". O artigo termina em aberto no maior estilo Louella Parsons.

A idéia de destrinchar a propaganda parece uma resposta não do crítico, mas do publicista às diversas citações e reclamações na revista das invenções dos estúdios, feitas pelos publicistas. Ele mostra ao leitor sua parcela de culpa quando demonstra o interesse do espectador pelo pior tipo de propaganda.

Desta maneira, Salvyano possibilita ao fã escolher o estrelismo ou uma reflexão crítica sobre o tema. Quando verifica o aspecto negativo do star system, mostra de forma subentendida o público como receptor sem consciência da influência da publicidade, embora algumas vezes credite a ele a opção pela propaganda de baixa qualidade. Nesta dualidade entre crítica e publicidade e na incongruência de sua argumentação, encontramos a maior síntese da figura de um cronista de revista de fã. Ele vaga por dois campos distintos, mostrando nesta antinomia a maior dificuldade da publicação em ser ao mesmo tempo opinativa e geradora do star system. A seguir estudaremos este caráter paradoxal, mais presente na crítica de Cena Muda nos dois primeiros anos de nossa pesquisa: o incentivo e a diatribe como facetas de uma só moeda.

\subsubsection{2-53: Entre a diatribe, o voto de sucesso e a certeza antecipada de êxito}

Apesar da decadência na qualidade geral da crítica de 1952 para 1953, boa parte das principais características se mantém. Por esse motivo, decidimos analisar o período a partir de suas consonâncias, pontuando quando necessário as transformações sofridas. Há uma continuação de temas e preocupações nos dois anos. A principal diferença é a transformação dos votos elou expectativa de sucesso aos filmes em certezas antecipadas de êxito em 1953, sob influência crescente dos releases, tema detalhado mais à frente. Esta modificação se faz presente muito mais nos supostos espaços informativos (reportagens, notas), que são, na verdade, seções opinativas, principalmente nas colunas dedicadas ao cinema brasileiro. Tal alteração ocorre também nas seções de críticas, embora em menor escala. Tais colunas serão analisadas adiante. Apontamos novamente a falta de parâmetros e homogeneidade da revista, porque algumas vezes há a coexistência das duas posturas. 
O ponto mais importante a se enfatizar sobre o critério da crítica praticada em Cena Muda é a postura de não se negar a ser opinativa, a comentar e opinar sobre tudo, com largo destaque aos comentários sobre a situação do cinema nacional. A crítica em 1952-53 não tem medo de tomar partido, destruir egos, ou ocultar quando o crítico não assistiu ao filme, trazendo as expectativas do cronista.

Este biênio é o período em que mais se discutiu o campo cinematográfico. A revista não busca ter uma postura neutra. Fica sempre patente que se trata do pensamento de Cena, para salientar e enriquecer sua autopromoção. Cinelândia tem a pretensão de levar seus comentários como se fossem "a verdade", neutra e imparcial, recorrendo menos aos comentários inflamados. Em Cena, admite-se mais a possibilidade ao leitor de assistir ao filme brasileiro, presente nas seções de lançamentos. Em Cinelândia, os filmes brasileiros ficavam a parte, fora da coluna de lançamentos.

Apoiar o cinema brasileiro parece ser politicamente adequado para as duas revistas, assim como censurá-lo pela baixa qualidade. Em todos os períodos, Cena Muda refere-se mais à filmografia nacional do que Cinelândia. Esta última traz o material de release nas reportagens sobre as fitas brasileiras, incentiva nas colunas tais filmes, mas Cena Muda procura ainda discutir a sua situação. Coloca-se a favor do cinema brasileiro, em oposição à parcela da crítica que tinham restrições a um tipo de cinematografia brasileira, em especial às comédias de carnaval da Atlântida. Como estratégia de legitimação, Cena afirma tentar fazer convergir todos os esforços para auxiliar no desenvolvimento de nosso cinema, considerado incipiente. Na verdade, a revista se alinhava ao interesse de um determinado grupo de espectadores, também interessados por esse tipo de cinematografia. Ampliando seu público leitor. Quando declara incentivar o cinema brasileiro, cria um imaginário de dependência dessa cinematografia em relação a sua divulgação, como se também as estrelas e os diretores precisassem de auxílio. A partir desse pressuposto, Cena sugere cortes nos filmes, opina sobre o comportamento das estrelas.

Há uma grande disparidade em Cena Muda na cobertura à chanchada nos espaços da crítica e da reportagem. Geralmente as reportagens sofrem grandes influências do material de divulgação do estúdio, quando não são apenas compilações dos mesmos. Mas na maioria das vezes a cobertura da crítica é negativa no entendimento da chanchada. Em poucos casos há uma postura favorável a algumas fitas, para ser mais exata, a alguns detalhes ou cenas, como a atuação de alguns atores. A 
mesma heterogeneidade entre crítica e reportagem aparece na cobertura aos filmes da Vera Cruz. Ou seja, a disparidade presente em todos os anos não se refere apenas a uma companhia, sendo característica da forma de cobrir o cinema brasileiro.

Em 1952 e 1954 existe um questionamento e desnudamento do star system. Nos demais anos, esse aspecto existe, mas não se sobressai, devido à decadência da revista e mudanças na direção. Apesar da crítica ao estrelismo, há uma postura antagônica em relação a ele em todos os anos, porque na crítica o culto à estrela costuma ser censurado, mas nos demais espaços, os comentários engrandecem as atrizes. Às vezes o tom da repreensão se torna pesado. Envereda para comentários aos filmes norte-americanos muito ácidos, uma cobertura paradoxal em se tratando de uma revista de divulgação do star system hollywoodiano. Tal peculiaridade é um reflexo também das discussões do período e dos Congressos de Cinema, que ajudaram a analisar o papel negativo da indústria cinematográfica hollywoodiana nos países pobres. $\mathrm{Na}$ fase de maior crítica a Hollywood em 1952, grande parte das capas é destinada aos atores e atrizes brasileiros.

O foco da análise em 1952-53 é a produção americana e a brasileira, com algum destaque ao cinema europeu, principalmente nos comentários de Alberto Dines. Há, portanto, uma inversão nos padrões entre a reportagem e a crítica, onde o filme de Hollywood não teria sempre a mesma primazia. Não se fala em imitar o neo-realismo no Brasil porque o modelo a ser seguido quanto à forma é o de Hollywood.

A desaprovação ao cinema norte-americano não se dá quanto a sua linguagem, mas aos conteúdos vinculados. Como mostrou Maria Rita Galvão e Jean-Claude Bernardet, no nível da linguagem não há afirmações nacionalistas. Estas ocorrem no que é representado. Na linguagem, o cinema americano continua a ser modelo. Pode ser imitado, sem preocupação com seu cosmopolitismo ${ }^{44}$. Já no nível do representado ocorre a diferença entre os cinemas. Portanto, o representado não é modelo a se reproduzir, mas pode servir de exemplo ao nosso cinema incipiente. Para se lutar contra o cinema norte-americano se deve fazer o que ele faz.

Galvão e Bernardet lembram que as relações com esta cinematografia são antagônicas: desde a rejeição até a admiração. A postura dura em relação ao conteúdo do cinema ianque não se concretizava numa total aversão ou no impedimento de uma posição favorável a muitos dos filmes norte-americanos por parte dos cronistas. Muitos dos críticos de Cena Muda também eram fãs deste cinema, mas admiravam apenas

\footnotetext{
${ }^{44}$ Embora o cosmopolitismo das fitas brasileiras seja visto de maneira negativa nas duas revistas.
} 
determinados diretores. Alguns destes jornalistas tentavam pontuar a diferença entre os bons cineastas e os encarregados de produzir filmes de gêneros, voltados apenas à bilheteria.

Citando as observações de Paulo Emilio, José Inácio de Melo Souza mostra como o fosso entre leitores e críticos foi cavado intencionalmente ${ }^{45}$, com "um certo grau de provocativa irracionalidade", embora ambos os lados amassem o cinema americano. Para tais críticos, o cinema europeu tinha a função de aprofundar a oposição entre os dois campos de espectadores, trazendo uma via salvacionista do cinema como arte. (Souza, 1995: 206)

Embora boa parte dos críticos de Cena Muda não fizesse parte do grupo intelectualizado, nos períodos de questionamento do cinema norte americano, percebemos a mesma tentativa de provocar o leitor, censurando os filmes admirados pelos fãs, com tom irônico, ou o penalizando por suas preferências.

No aspecto informativo, vemos uma postura amadora, semelhante aos anos vinte na mesma revista, onde informações simples não eram fornecidas, como se os leitores tivessem a obrigação de tudo saber. Do ponto de vista da padronização jornalística, há uma patente despreocupação em mencionar os diretores estrangeiros, mesmo os já consagrados. Não há interesse na produção voltada ao diretor, exceto pela postura de certos críticos, como, por exemplo, Alberto Dines. Alguns cineastas são citados com bastante freqüência, tratados como personas, a partir do aproveitamento de alguns critérios da cobertura às celebridades. Trazer ao leitor a filmografia do cineasta não era uma preocupação em nenhum período porque importa o produto fílmico a analisar, característica presente em todos os anos, exceto em 1954, quando se tenta congregar observações sobre a autoria.

Há uma peculiaridade quanto à cobertura dos diretores brasileiros. Em todos os anos, eles são sempre citados. Porque lutam em prol de um cinema incipiente, são tidos como pioneiros, com alguns traços de uma constituição de personas, imitando alguns critérios do estrelismo, ao enumerar suas preferências pessoais. Quando Cena menciona os cineastas, em geral eles são sempre exaltados. Contudo se observa uma falta de parâmetros na comparação. Diretores considerados importantes como Lima Barreto, Humberto Mauro, Alberto Cavalcanti são equiparados a diretores de relativa importância na história do cinema brasileiro, como Mastrocinque, Eurides Ramos, Luiz

\footnotetext{
${ }^{45}$ Lembramos que a tese de José Inácio se refere principalmente à década de 1940.
} 
de Barros, Gianni Pons ou Alberto Pieralisi. Há uma diferença quanto à repetição destes nomes. Diretores como Cavalcanti e Lima Barreto recebem alusões constantes. Por outro lado, a autopromoção de diretores desconhecidos no meio cinematográfico, que afirmavam ter trabalhado com cineastas de renome internacional, são sempre aceitas sem questionamento. Eles são louvados nos artigos, mas no máximo em dois ou três artigos.

Existe também uma indulgência na crítica lado a lado com o esquecimento de diretores reconhecidos. O critério varia bastante, se censura Alfred Hitchcock por não fazer filmes de arte, mas se elogia Luiz de Barros, como um grande diretor, comparado a Cecil de Mille ${ }^{46}$.

Do ponto de vista dos diretores estrangeiros, os franceses e italianos do movimento neo-realismo são sempre mencionados. Há algum tipo de percepção de um cinema de autor. Por outro lado, diretores vistos como do sistema são criticados, como Cecil de Mille, por alienar as massas ${ }^{47}$. Poderíamos esmiuçar os comentários de Cena Muda sobre diversos diretores estrangeiros e principalmente brasileiros, mas sintetizamos a cobertura aos cineastas pela incongruência no enfoque para não nos alongarmos demais no tema.

Apesar do enfoque positivo aos diretores brasileiros, não é possível dizer que a postura de Cena seja sempre a favor deles, especialmente em se tratando de chanchadas. Watson Macedo, por exemplo, não é poupado. Sobre seu filme É fogo na roupa (1952), afirma-se:

"Filme de carnaval lançado na Quaresma!... Enfim, acontece de tudo no cinema brasileiro... Até a produção de 'É fogo na roupa'. Sr. Watson Macedo: o senhor estava brincando conosco, quando fez 'aquilo', não estava? Ou será que faz tão baixo juízo da mentalidade do fã de cinema brasileiro? Preferimos pensar na primeira hipótese, pois do contrário ficaríamos zangados consigo para o resto da vida...

Caso vá mesmo para a Vera Cruz, não vai brincar mais dessa maneira, não é? Eles lá podem não compreender, e muito menos o resto do mundo, que irá ver daqui por diante a produção daquela companhia." 48

O tratamento textual ao diretor é sempre transformado num tom íntimo para gerar a aproximação com o leitor. A diatribe se reveste de trocadilhos, ironia e humor com recorrência para criar intimidade com o fã. Nestes casos, a baixa qualidade dos filmes não é contextualizada, atrelando o trabalho no cinema a um divertimento, feito

\footnotetext{
46 Embora na maior parte das vezes, tanto Cecil de Mille quanto Luiz de Barros sejam censurados. Brandão, Paulo. Você é que é feliz, Lulu! Cena Muda, v. 32, n.51, p. 04-5, 19/12/1952.

${ }^{47}$ Conrado, Alberto. Meu destino é a Bíblia. Cena Muda, v. 32, n. 23, p.12-3; 28; 34, 05/06/1952.

${ }^{48}$ Por falar no cinema nacional. Cena Muda, v. 2, n. 13, p. 46, maio 1953.
} 
sem responsabilidades, devido ao caráter amador da cinematografia nativa. Os problemas seriam resolvidos caso os diretores parassem de "brincar". Fica patente neste trecho a representação sobre a superioridade do produto final da Vera Cruz em relação à Atlântida.

Os dois anos são reveladores ao mesmo tempo de uma diversidade muito grande de opiniões e de uma incongruência em relação à crítica. Dividimos em três os tipos de crítica praticada neste biênio. O primeiro calcado nos pilares do estrelismo e da adjetivação, destacando a participação da estrela. O segundo, sedimentado em critérios analíticos, tenta pontuar pontos positivos e negativos da fita. Nestes casos, a revista busca equilibrar tais aspectos, salvando o filme nos casos de algum aspecto considerado positivo. O terceiro tipo é o da diatribe contra: o filme brasileiro ou norte-americano considerado alienante, as fitas de gênero que nada acrescentam ou quando há péssima atuação dos atores. Os exemplos para esta divisão estão situados depois na análise das seções de comentário.

Quanto à estruturação textual da crítica, há uma tentativa de dividir o filme para melhor analisar, mas os critérios utilizados ainda não foram bem sintetizados como um todo na seção, muitos deles são desconsiderados, porque se envereda para o "achismo". Os artigos que se propõem a analisar cada ponto do filme são raros. Há também uma maior utilização de adjetivos na crítica.

Os comentários ao filme brasileiro têm peculiaridades. A ele se destinam tanto os votos de sucesso quanto à certeza de êxito dos filmes. A revista torce pelo sucesso do filme nacional, não do exterior. Do estrangeiro apenas se quer verificar a qualidade ou não, aproveitar seu caráter artístico ou de divertimento. Coexiste uma crítica voltada ao estrelismo e a tentativa de analisar aspectos em separado dos filmes para conferir notas. Embora para o filme nacional, entre estes tipos, a diatribe é que a mais se destaca. A censura à baixa qualidade dos filmes é apresentada como forma de garantir o progresso nossa cinematografia no futuro.

Como exemplo de diatribe, temos o comentário ao filme Pecadora Imaculata (1952), de Rafael Mancini. O jornalista coloca em dúvida a capacidade do diretor. Declara que não vai falar do filme em si porque o considera muito ruim. Acaba o artigo com um trocadinho: 
"sua ficha pessoal (de Mancini), que já é meio atrapalhada, fica mais maculada com este pecado que fomos obrigados a assistir. (...) Do filme não falamos. Recusamo-nos terminantemente. Analisamos obras, mas aquilo é um aborto!" 49

Muitas vezes a crítica vai se eximir de comentar filmes, não só os brasileiros, por considerá-los ruins. Como se a crônica supostamente voltada a um julgamento de ordem estética não merecesse se debruçar sobre fitas menores, fato comprovado no exemplo acima citado: "analisamos obras, mas aquilo é um aborto".

Quando o crítico tenta separar os filmes brasileiros em pontos negativos e positivos, busca salvar alguma parte, mesmo quando não gosta do filme no todo. Mas geralmente a empreitada não dá conta de analisar vários aspectos. Os filmes servem de pano de fundo para se discutir os meios de produção da cinematografia brasileira.

Não havia uma postura crítica firme no caso brasileiro. Quando Cena Muda antecipa o sucesso dos filmes, sem tê-los visto, o faz por serem tentativas pioneiras para o progresso da cinematografia nacional. Quando compra a visão dos estúdios, sem assistir aos filmes, o crítico deixa de cumprir sua função. Embora vez por outra, depois de o jornalista ter acesso à fita, a condenar. Neste quesito, a dependência em relação à opinião estrangeira se faz presente, como foi o caso de $O$ Cangaceiro. A falta de parâmetros da crítica neste caso tem relação com o prêmio ganho no exterior. Primeiro, a elite espera o reconhecimento dos filmes nacionais em festivais internacionais, como analisou Jean Claude Bernardet (1979). Há uma relação diferente do espectador com a procedência das fitas. Existia uma angústia para descobrir se o filme brasileiro valia ou não a pena ser visto. Faltava à elite autonomia de decisão para decidir se um filme era ou não bom. Por isso, o reconhecimento num festival internacional deixava a burguesia mais segura para opinar sobre o cinema brasileiro.

Há um número maior de textos questionando a situação do cinema brasileiro do que analisando os filmes, característica do processo pelo que passava o cinema do período, com uma tomada de consciência sobre os mecanismos de produção. A coluna com aparência de editorial denominada Conversa da semana/Comentário da semana destinou 51,11\% de seus textos em 1953 para discutir, mais do que os filmes nacionais, o ambiente de produção ${ }^{50}$.

Há também uma relação direta com o secretário de redação de cada período no tipo de crítica praticada. Cena Muda teve quatro secretários de redação diferentes em

\footnotetext{
${ }^{49}$ Telas da cidade. Cena Muda, v. 32, n. 43, p. 8-9, 24/10/1952.

${ }^{50} \mathrm{O}$ campo cinematográfico, os cine-clubes, os congressos de cinema e os festivais cinematográficos são temas recorrentes.
} 
$1952^{51}$, e mais quatro em $1953^{52}$. Para analisar as críticas em 1952 partimos da análise pautada sobre as seções de crítica. Utilizamos um critério diferente para o ano seguinte pelo seguinte motivo: em 1952 muitos críticos escrevem na revista sob a forma de pseudônimos. As seções de crítica desaparecem muito rápido. Por isso é difícil pontuar as peculiaridades textuais dos jornalistas. Porém, em 1953, as seções de crítica são escritas por um corpo constante de jornalistas citados nominalmente, tornando possível estabelecer alguns apontamentos sobre o estilo de tais críticos.

O período de maior questionamento do star system, com textos mais analíticos, e também com mais diatribes, foi sob a direção de Leon Eliachar, secretário de redação entre 1949 a março de 1952. Flora Bender (1979) considera este o melhor período de Cena Muda, denominada fase da "revista crítica". Foi o período mais lembrado pelos colaboradores. Leon Eliachar era o crítico citado por Marinho Audrá, Alfredo Palácios e Mário Civelli como um dos que recebiam dinheiro para falar bem da Maristela ${ }^{53}$. (Catani, 1983)

Depois desse período, a revista entra em crise, claramente sem foco e sem constar nenhum secretário de redação. O ano de 1952 é uma ponte para a queda do padrão editorial da revista, com exceção do primeiro semestre de 1954. Durante esta transição, a partir de março, as colunas de crítica somem, para depois voltarem nos meses seguintes, no final de junho. No período sem diretor de redação, entre março e o início de abril, os filmes são citados apenas nas novelizações ou nas fotografias. Somem também as reportagens sobre o cinema brasileiro. Há uma queda muito grande no nível geral. Não há mais editoriais. Pouco a pouco os textos sobre a situação do cinema brasileiro ressurgem, assinados por Adhemar Gonzaga.

Em abril Adhemar Gonzaga torna-se secretário. Contudo, apenas com a direção de Levy Kleiman houve melhora, comprovada também por Flora Bender. Não discordamos da divisão feita por Bender da decadência da revista, a partir de 1952, mas o critério não vale para as seções de críticas, como veremos adiante. Realmente tanto

\footnotetext{
${ }^{51}$ Foram diretores nesse ano: Leon Eliachar, Adhemar Gonzaga, Renato de Alencar e Levy Kleiman.

${ }^{52}$ Levy Kleiman de setembro de 1952 a abril de 1953, Costra Cotrim de junho a outubro de 1953, Luis Fernandes no mês de novembro e Jonald que entrou em dezembro de 1953 e saiu no final de junho de 1954. Informações existentes na tese de Flora Bender (1979).

${ }^{53}$ Parece-nos parcial provar a "compra" do crítico através dos textos escritos por Eliachar em Cena Muda porque ele elogiava todas as companhias cinematográficas, na verdade em sintonia com o tom geral da revista. Salvyano Cavalcanti de Paiva o citou como publicista na matéria O publicista, esse condenado. Segundo os três depoimentos dos dirigentes da Maristela, Eliachar pegava cheques na companhia, assim como outros críticos, incluindo até Rubem Biáfora. Afrânio Catani (1983) coloca o argumento de Civelli sob questão, exatamente pela inclusão do crítico de $O$ Estado de S. Paulo.
} 
nos critérios técnicos quanto nos de conteúdo, a revista decaia. Não houve melhora no lay-out, nem impressão em cores. A qualidade do papel piorava. Quanto ao conteúdo, observa-se uma enorme queda no nível da reportagem, incluindo também uma pobreza nas fontes jornalísticas consultadas com utilização cada vez maior de releases e uma diminuição na cobertura, principalmente do cinema brasileiro.

Depois surge uma crítica que confere cotação comercial e artística às fitas. Os artigos se voltam a dois tipos de espectadores. Os artigos explicam quando as fitas são melhores do ponto de vista artístico, mas deixam implícito que provavelmente os fãs não vão gostar. A postura aqui é diversa da de Cinelândia. Esta também exemplifica a diferença, mas se coloca ao lado dos espectadores. Em Cena Muda, a preferência do crítico anônimo envereda para aos filmes voltados à sétima arte. Nestes casos, o tom é de censura ao gosto do público. Entre as condenações aos filmes norte-americanos, Alberto Conrado ${ }^{54}$ desconsidera o filme $O$ falcão dos mares (1951), de Raoul Walsh, por não passar de um filme vulgar com muito pouco de verdade histórica, "para o gosto inadmissível das maiorias".

No período seguinte, a crítica volta-se à diatribe, sensacionalista, em tom autoritário, chamada No Tribunal da crítica. "Atenção, está aberta a sessão. Compareçam os acusados e que a opinião pública aplique as penas e confira os prêmios de acordo com a Moral, a Razão e a Justiça." 55 A ilustração mostra um juiz batendo uma palmatória numa mão. A crítica foge do modelo de orientação para o consumo e passa a ser inquiridora. Sentencia atores e diretores sem hesitar. Condena à palmatória como se ainda estivessem na escola. Não se faz uma crítica do ponto de vista estético ou sociológico. O teor do texto é sensacionalista, bombástico. Lembra muito o estilo de Salvyano Cavalcanti de Paiva, ou alguém que o quisessem imitar, embora também fosse comum esse tom na imprensa do período. Os filmes escolhidos geralmente são os "acusados" porque foram levados até o juiz. As fitas consideradas ruins não são consideradas apenas abacaxis enfeitados como se fazia no passado. Ganham bolos, ou pior, são condenadas à cadeia. Raros filmes ganham taças como prêmio. O poder de grife do nome de um crítico anônimo tenta se ver como determinador do sucesso das películas. Não se busca mais incentivar o cinema brasileiro, mas o julgar, destruir sem argumentos, assim como é feito com o cinema estrangeiro. O papel da crítica passa da orientação ao consumo para a condenação dos cineastas. Quase ninguém escapa, e a

\footnotetext{
${ }^{54}$ Conrado, Alberto. Cine crítica. Cena Muda, v. 32, n. 26, p. 6, 26/06/1952.

${ }^{55}$ Juiz Bonzê. No Tribunal da crítica. Cena Muda, v. 32, n. 28, p. 5, 11/07/1952.
} 
cadeia é o destino mais citado. Segundo o crítico Juiz Bonzê, o desenho animado de Walt Disney, Alice no país da maravilha (1951), de Clyde Geronimi e Wilfred Jackson, só pode agradar além do Mato Grosso onde não existe civilização.

A crítica paulatinamente perde espaço em meados de 1952. Aumenta a presença de textos certamente copiados de revistas estrangeiras com comentários na base do star system. O destaque recai sobre as produtoras, omitindo os nomes de diretores importantes. Ao mesmo tempo, há diatribes contra os melodramas. O tom torna-se mais panegírico. As seções A Tela em revista e A tela e a crítica em revista se convertem em resumos dos artigos publicados nos jornais. Às vezes é feito algum comentário simplificado, como por exemplo: "o filme é um melodrama de Hollywood de segunda 56 ". A base é o "achismo" do tipo "gosto ou não gosto". Por último, os artigos nestas duas seções transformam-se em sinopses. A periodicidade torna-se irregular. A maior parte dos filmes analisados são os estrangeiros. Os comentários sobre as fitas ocupam de um a dois parágrafos. Buscam pontuar alguns elementos em separado, mas sem um critério homogêneo.

O espaço das seções opinativas torna-se cada vez menor em 1953, mas a quantidade de filmes analisados é maior, com diminuição do nível de detalhamento. Para explicar as características da crítica em 1953 tomamos como critério as características textuais de cada crítico. Há uma continuidade na diatribe. A censura ao cinema brasileiro e a estratégia de incentivo convivem com a certeza do sucesso e o estrelismo nos moldes descritos. Este último tipo aumenta cada vez mais na revista. Os textos tendem a uma postura supostamente mais objetiva. Tentam enumerar os pontos positivos e negativos, um recurso para não se falar tão mal do cinema brasileiro. Alguns críticos têm uma visão coerente, como Dines, mas outros passam da diatribe ao apologético, dependendo da apreciação ou não do filme.

A maior influência do star system nas críticas ocorre sob a direção de Luis Fernandes, o então repórter de Cinelândia, responsável pelos textos mais sensacionalistas e tom mais ameno no estilo jornalístico. Todavia o jornalista ficou apenas um mês como diretor, no mês de novembro. Tentou trazer à revista um teor mais coloquial, através de gírias e lay-out mais moderno ${ }^{57}$. As mudanças significaram uma queda muito grande na qualidade. Nem sumário a revista possuía.

\footnotetext{
${ }^{56}$ A tela e a crítica em revista. Cena Muda, v. 32, n. 15, p. 30, 10/04/1952.

${ }^{57}$ O jornalista buscava um tom coloquial, quando escrevia seus elogios e quando "metia o pau", uma terminologia como esta era inimaginável nos anos anteriores. Contudo as gírias conviviam ao mesmo com
} 
São comuns os comentários julgando de modo negativo as estrelas do cinema nacional pela falta de talento. Por outro lado, a disparidade entre release e crítica é visível quando se percebe em 1953 artigos visivelmente encaminhados pelos departamentos de publicidade, antevendo os sucessos dos filmes. No período, se inicia um artigo sobre É fogo na roupa (1952) com a frase "Viva Watson Macedo!" 58 . O tom da certeza de sucesso, presente mais ainda na reportagem, se depara com condenações contundentes ao estrelismo. Contudo há também elogios à atuação dos atores. A cobertura varia de acordo com o crítico. Às vezes a revista louva o mínimo de qualidade técnica. Acredita, por exemplo, que o cinema nacional já está muito bem porque simplesmente é possível ouvir os diálogos nos filmes ${ }^{59}$.

A única coluna constante de crítica em 1953 é a Telas da cidade. O espaço foi criado por Alex Viany em 1949, voltado à análise de filmes realistas. Recriada a partir de setembro de 1952 na direção de Levy Kleiman, permanece até abril de 1953 com a entrada de Costa Cotrim como secretário de redação. O objetivo era comentar as estréias no Rio de Janeiro, com média de quatro a cinco filmes descritos em duas páginas. No período analisado, o crítico era Alberto Dines. Segundo ele ${ }^{60}$, a contratação de um garoto de 19 anos, enquanto havia tão bons críticos no mercado, denota a preocupação com a economia. A revista pagava muito pouco. Para Dines, Cena Muda tinha uma parte voltada aos "fanzocas" e a porção crítica. A dualidade entre fanzocas e crítica aparece quando o então repórter Alberto Dines comenta o sucesso da re-exibição do filme Alô, alô carnaval (1936), de Adhemar Gonzaga, por parte da platéia. Ele acaba escrevendo sobre o seu preconceito como crítico. Este o impediria de admitir gostar da fita:

"falar sobre o filme, seria entrar em choque com o brioso senhor que assina telas da cidade. Mas como repórter podemos descrever a reação do público em relação ao filme. O termo exato é n-o-t-áv-e-1!". 61

Essa frase de Dines sintetiza a dificuldade da revista nas seções de crítica como uma publicação em afirmar sua preferência por um produto cultural desprestigiado por

o linguajar antigo da revista, em frases como: "ei-la em sua nova fase", um tom totalmente diferente do de Cinelândia. Fernandes buscava se afirmar como um fã de cinema na direção da revista. Bilhete ao leitor. Cena Muda, v. 33, n.45, p. 30, 04/11/1953.

${ }^{58}$ Estréias do mundo do cinema. Cena Muda, v. 33, n. 8, p. 6, 18/02/1953.

${ }^{59}$ Brandão, Paulo. Os melhores e os piores de 1952. Cena Muda, v. 33, n. 1, p. 4, 02/01/1953.

${ }^{60} \mathrm{Cf}$ entrevista. Adamatti, 2006.

${ }^{61}$ Dines, Alberto. Oscarito e Virgínia Lane abafaram na festa de 'Alô Alô Carnaval. Cena Muda, v. 32, n. 39, p. 04-6, 26/09/1952. 
parcela da crítica, aos quais ela na maior parte do tempo procura incentivar. Dines considera a pessoa do crítico (no caso ele mesmo) como brioso, como se a postura dos leitores-espectadores fosse inferior. "Notável" para ele é apenas a recepção positiva de um filme antecessor da chanchada como Alô, alô carnaval (1936), de Adhemar Gonzaga. O espanto advém porque o público gostava de filmes norte-americanos. Assim, o crítico aprecia e estranha o interesse dos espectadores por uma fita brasileira antiga, embora como julgamento estético tal percepção não tivesse a menor importância para seus critérios. A crítica de Dines não é feita para a orientação do consumo de produtos da indústria cultural, mas é de ordem estética. Na verdade, o comentário foi uma reprovação elegante, num raro momento em que se admitiu a preferência oposta do leitor, mas sem censurá-lo de maneira explícita, como comumente era feito.

A seção Telas da Cidade é a porção intelectualizada da revista. Na média, os críticos que se dedicavam a ela no período estudado não gostavam de quase nenhum filme. A crítica se voltava a um julgamento de ordem estética, daí a dificuldade de adesão às fitas. O divertimento puro e simples nada valia. Apenas nesta coluna se utilizava o critério de separar os filmes para melhor analisar, de maneira mais qualificada.

Curiosamente, Dines gostou de Simão, o caolho (1952), de Cavalcanti. Considerou o filme "uma obra, talvez a primeira do cinema nacional" ${ }^{62}$. A idéia da primeira fita, a primeira obra é muito recorrente na revista. No geral, o cronista não gostava dos filmes brasileiros. Apesar de ter um tom de chanchada, para Dines, Cavalcanti mostrou o dia-a-dia ausente nas fitas de outros diretores nacionais. A postura dele anti-chanchada impedia sua percepção da chanchada como reveladora do dia a dia da população. Apenas neste filme, Dines conseguiu vislumbrar tal característica. Ele condena apenas o cenário, a má direção de atores e os excessos na representação da macumba. O tom geral é amistoso. Sem explicitar em detalhes quais são os pontos positivos da fita, apenas destaca o uso de cenas externas, o tom documental e o ambiente mais realista. Talvez Dines tenha gostado da fita por se tratar da assinatura de grife do diretor reconhecido mundialmente. Os filmes elogiados nas reportagens são censurados por Dines por sua porção de estrelismo ou pela falta de conteúdo. Há uma preferência clara do crítico pelos filmes europeus, incluindo também alguns filmes clássicos do cinema norte-americanos.

\footnotetext{
${ }^{62}$ Dines, Alberto. Telas da cidade. Cena Muda, v. 32, n. 46, p. 8-9, 14/11/1952.
} 
Os comentários que dividem o filme para analisar e a utilização de termos técnicos de cinema, em voga em Cena Muda no ano de 1954, já eram usados por Dines. Assim sobre o filme João Gangorra (1952), de Alberto Pieralisi, Dines questiona os planos excessivamente longos, os saltos obscuros nos planos de um "take" para o outro e uma "indesculpável e incrível descontinuidade na continuidade, coisa, aliás, de responsabilidade da (ou do) script-girl" 63 . O crítico preocupa-se em analisar ainda dos filmes: takes funcionalíssimos, valorização dos planos no shot, movimentação da câmera de acordo com o enquadramento, sintaxe do cinema silencioso ou sonoro, linguagem, fusões, cortes, ângulos, ritmos, partitura musical e aproveitamento do silêncio e de recursos visuais. Não há uma preocupação didática em explicar termos técnicos aos leitores. Levy Kleiman contou a Flora Bender que os comentários de Dines eram no estilo de Cahiers du Cinéma, quando a orientação geral da revista era de realizar comentários gerais para o grande público. Dines não teria se conformado com a recomendação da direção de escrever de maneira "menos elitista". E foi embora trabalhar na Visão. (Bender, 1979) Dines deixou a revista na mesma época em que Kleiman saiu.

Em tom um tanto agressivo aos fãs, Dines ao escrever sobre os melhores atores e atrizes de 1952, declarou:

"não se fala, proibo terminantemente alguém lembrar os montes de pernas \& caras bonitas $\&$ os... \& as ... que as revistas (inclusive 'a Cena') estampam em suas capas e que as produtoras americanas estampam em seus filmes para homens e mulheres se babarem física e mentalmente. Como não se fala aqui na carne que se compra nos açougues, como não se fala na outra que se compra em outros, não se falará aqui nas 'estrelas' e nos 'galãs",. 64

Apesar de explicitar a proibição de citar as estrelas, Dines termina por enveredar para o star system, quando elogia as mãos e olhos "divinos" de Vivian Leigh, uma concessão necessária ao público alvo da revista. Mesmo quando recorre a críticas contundentes, Dines procura congregar fatores positivos aos filmes, como o fez quando desgostou de Um lugar ao sol (1951), de George Stevens ${ }^{65}$. O desempenho dos atores salvou o filme do fracasso total e definitivo. Narra ter chegado ao meio bastante aborrecido por ser uma fita de fluência de narração, um filme de cenários. Não cita sequer o diretor. Depois considera o filme magnífico.

\footnotetext{
${ }^{63}$ Dines, Alberto. Telas da cidade. Cena Muda, v. 33, n. 4, p. 8-9, 21/01/1953.

${ }^{64}$ Dines, Alberto. Michael Redgreave e Vivien Leigh entre os dez melhores artistas de 1952. Cena Muda, v. 33, n. 2, p. 11, 09/01/1953.

${ }^{65}$ Dines, Alberto. Telas da cidade. Cena Muda, v. 33, n. 1, p. 8-9, 02/01/1953.
} 
Algumas vezes Dines recorre à diatribe, quando detesta um filme, comentário tanto para filmes brasileiros quanto estrangeiros. Sobre Eva na marinha (Ships, ahoy! $)^{66}$, declara que se os leitores soubessem inglês, veriam:

"quanta burrice, cretinice, estupidez aflora nesses filmes, como nos nativos, o mesmo dos piores abortos cinematográficos nativos, camuflado por um technicolor, com a mesma inexistência em argumentos, pieguice de armas situações, personagens caricaturados”. ${ }^{67}$

Seus sucessores conseguiram ser mais virulentos quando não gostavam de um filme. Por outro lado, Dines recorria a uma postura comum também a Cena de tentar vislumbrar alguma característica positiva dos filmes.

No mesmo período escrevia o crítico Lívio Dantas, mas os comentários ficavam longe de um julgamento estético. A seção $O$ que a tela não mostra não é exatamente uma coluna apenas de crítica porque condensa apontamentos de bastidores, filmagens e informações sobre atores. Algumas vezes Dantas realiza crítica. Nela também há uma censura ao estrelismo.

Os comentários de Lívio Dantas não têm relação direta com o diretor de redação porque ele permaneceu em 1952 e 1953 . Seu texto foi conciliador entre as direções. Analisando os dois pontos para os quais converge seu texto, descreveríamos a utilização do star system e de outro lado da diatribe, destruindo o mesmo estrelismo. O estilo textual de Dantas é a utilização de frases explosivas, bombásticas, sensacionalistas, com ironia e humor, marca registrada das diatribes, numa relação de amor e ódio aos filmes. Às vezes lembra o estilo de Salvyano Cavalcanti de Paiva. A seção possuía um nível bem mais alto de temas mais complexos do que o restante da revista.

Sucessor de Dines na seção Telas da Cidade ${ }^{68}$, Dantas aceita um pouco mais o produto cultural da indústria hollywoodiana, apesar de ter suas preferências pelo filme de arte. Contudo fitas com pretensões neo-realistas, mas sem originalidade, são condenadas porque nada acrescentam aos olhares do comentarista. A seção continua voltada também para filmes fora do circuito norte-americano. De maneira geral existe um tom negativo em relação aos melodramas, tidos como "filmes para mulher" ou "fita de amor", termos utilizados entre aspas. Algumas vezes, Dantas tem condescendência com a subliteratura e os melodramas, atento aos desejos do público. Sobre $O$ quarto

\footnotetext{
${ }^{66}$ Não conseguimos localizar o filme no site www.imdb.com. Neste consta apenas uma fita com este nome, mas de 1956.

${ }^{67}$ Dines, Alberto. Telas da cidade. Cena Muda, v, 33, n. 4, p. 8-9, 21/01/1953.

${ }^{68}$ Paulo Brandão também escrevia na seção.
} 
mandamento ${ }^{69}$ (1951), de Michel Leisen, afirma que todos os filmes deveriam ter happy end. Conclui isso a partir da constatação da beleza da atriz ${ }^{70}$. Mas isso não impede que Dantas censure várias fitas, como o fez com O Filho de Ali Babá (1952), de Kurt Neumann. A película só serve para os admiradores do casal de astros: "olhe lá para crianças" porque "Piper Laurie é de dar um bom chute na boca do estomago da gente"71.

Assim como Dines, ele utiliza termos específicos da linguagem cinematográfica, dividindo para analisar os filmes, embora a profundidade de Dantas seja menor. É recorrente a utilização da palavra "momentos de legitima arte", ou "de verdadeiro cinema", mas sem detalhar o seu significado para o leitor. Nesse sentido há uma queda no padrão da crítica. Nem sempre os diretores são mencionados. A seção de prognósticos sobre as estréias é acompanhada da possibilidade de sucesso, sem afiançar sua certeza, diferente da opção geral da revista no período. Dantas privilegia atores. Mas pode também condenar as atuações, a partir de critérios via "achismo". Existe uma atenção crescente em analisar o plano interpretativo, embora muitas vezes não se consiga ir além dos adjetivos.

Dantas tem a preocupação de orientar o público para o consumo. Aponta se vale a pena perder dinheiro e tempo com a fita. Encontramos também um tipo de crítica voltada à personalidade dos personagens, tentando situá-los na sociedade. Vê com complacência o comportamento de Don Juan como uma compensação por ter sido deserdado ${ }^{72}$. O crítico apela em alguns momentos para análises simplistas, baseadas numa psicologia banalizada. Algumas vezes os comentários jocosos são típicos de uma revista de fã, como quando afirmou com desdém que a atriz do filme Direito de Nascer (1952), de Zacarías Gomés Urquiza, além de mal caracterizada, sempre quando abraça alguém, tem o cuidado de não deixar as marcas de sua maquiagem negra ${ }^{73}$. Nestes momentos, o comentário lembra Cinelândia. Só que em Cena, o comentário serve para considerar a fita aquém do nível da novela radiofônica.

A grande diferença entre os críticos intelectualizados e as revistas de fãs é a freqüência como as opiniões mudam. Enquanto B. J. Duarte manteve-se firme na condenação às chanchadas, as revistas mudaram diversas vezes de opinião de forma concomitante. No final do ano, com Jonald como secretário de redação surge a coluna

\footnotetext{
${ }^{69} \mathrm{O}$ filme é conhecido também por Primavera do amor.

${ }^{70}$ Dantas, Lívio. Telas da Cidade. Cena Muda, v. 33, n. 8, p. 8-9, 18/02/1953.

${ }^{71}$ Dantas, Lívio. Telas da Cidade. Cena Muda, v. 33, n. 11, p. 8-9, 11/03/1953.

${ }^{72}$ Dantas, Lívio. Telas da Cidade. Cena Muda, v. 33, n. 14, p. 8-9, 01/04/1953.

${ }^{73}$ Dantas, Lívio. Telas da Cidade. Cena Muda, v. 33, n. 14, p. 8-9, 01/04/1953.
} 
Cartazes em revista. $\mathrm{O}$ estilo que Jonald impingiu à revista já estava presente logo no primeiro mês de sua supervisão, embora exista uma certa complacência com o star system, considerando vez por outra todos os atores notáveis. Características ausentes na crítica sob sua direção a partir do outro ano.

\subsubsection{4: A crítica intelectualizada e o cinema de arte}

Se nos dois anos anteriores, Cena Muda se preocupou mais em discutir a situação do cinema brasileiro do que analisar os filmes, em 1954 o quadro se altera. Devido ao panorama de crise patente das companhias paulistas, em especial à Vera Cruz, a revista deixa de debater a questão, como se não houvesse solução possível. Antes a publicação procurava discutir o campo cinematográfico para resolver as dificuldades. Pouco se avança em 1954 em termos de análise da situação do cinema brasileiro. Há apenas comentários pontuais, citando com pesar a paralisação dos estúdios.

Tal postura editorial nos primeiros meses do ano não inclui uma cobertura maior às fofocas, como poderíamos esperar, uma vez que Cena estava próxima de seu fim. Ao contrário, há um soerguimento da crítica no primeiro semestre. Os espaços opinativos delineiam uma preocupação crescente com algum tipo de atenção à análise fílmica. É interessante ressaltar que o interesse sobre o campo cinematográfico de Cena, quando se desvincula de discutir a situação do cinema brasileiro, centra-se apenas nos filmes.

O comentário de Jean-Claude Bernardet sobre o interesse maior da crítica durante a década de cinqüenta em discutir mais a situação do cinema brasileiro do que os filmes não encontram paridade mais para o ano de 1954, tomando como base essas revistas com características bem peculiares. São raras as reportagens voltadas à discussão sobre a Vera Cruz e sobre os problemas estruturais do cinema brasileiro ${ }^{74}$. Com a crise da Vera Cruz, a cobertura ao cinema nacional cai nas duas publicações,

\footnotetext{
${ }^{74}$ As duas revistas procuraram ocultar os problemas da Vera Cruz em 1953, negando a crise. No ano seguinte, quando não era mais possível deixar de debater o tema, o caso passa a ser sempre citado. Mas os comentários em Cena Muda questionam o gigantismo da empresa, a contratação por longos períodos dos atores, as grandes somas gastas com os filmes. As causas mais relevantes para o entendimento da dificuldade financeira não aparecem, tais como: a contratação da distribuidora estrangeira Columbia, o congelamento do valor dos ingressos ao filme brasileiro - em oposição à utilização do cambio oficial para a remessa de lucro dos filmes estrangeiros -, e a porcentagem de lucro da bilheteria a beneficiar apenas os exibidores e distribuidores. Para maiores detalhes sobre os motivos da crise da Vera Cruz, consultar a tese de Maria Rita Galvão (1976).
} 
mas a de Cena despenca. $\mathrm{O}$ fato se deve à crise da revista e à mudança nos parâmetros editoriais.

A mudança do ponto de vista editorial fica evidente a partir da análise do conteúdo vinculado na página três, síntese da "cara" da revista. Durante os primeiros meses de 1952, o local era dedicado à fofoca, com uma “seção de venenos", escrita pelo pseudônimo Frank. Rapidamente o box foi substituído por uma espécie de editorial. Mantido entre 1952 e 1953, era chamado de Comentários da Semana ou Conversa da Semana. Na época de maior atenção à discussão sobre o cinema brasileiro, Cena dedicava seu espaço mais importante a este tema.

A postura editorial do diretor Oswald de Oliveira (Jonald) impinge um novo padrão editorial. A página três será ocupada por uma crítica cinematográfica, acompanhada de cotação comercial e artística. À medida que o tempo avança, a cotação desaparece. A crítica praticada encaminha-se pouco a pouco para comentários sobre a atuação dos atores, com maior utilização de adjetivos. Depois da saída deste secretário de redação, edição a edição o nível decai.

A seguir, apresentaremos os parâmetros principais da crítica, destacando depois a cobertura ao I Festival Internacional de Cinema do Brasil no mesmo ano. Examinamos a cobertura ao Festival porque acreditamos que sua existência, juntamente com a direção de Jonald, tenha sido a causa de um padrão crítico diverso. A fase é muito voltada ao cinema de autor. A existência de uma filmografia clássica disponível aos jornalistas e a possibilidade de entrevistar diretores internacionais, críticos e atores de renome, criou um ambiente favorável à criação de uma revista feita realmente a partir de seu corpo de colaboradores, com menos material de release. Cena Muda mudou para cobrir o evento. Neste ano é possível falar numa homogeneidade dos critérios da crítica, constante em suas preferências. Não nos voltamos a diferenciar padrões textuais de cada jornalista porque as seções de crítica são assinadas em conjunto, embora seja possível depreender o estilo geral que parece ter sido ditado pelo diretor de redação Jonald. Os jornalistas que realizavam crítica neste período eram: Jonald, (De) Sanin, Helena Andersen, L. Botshalser, C. Maximiano.

Em termos gerais, a crítica praticada se volta à análise fílmica, mais próxima da praticada pelos críticos intelectualizados. Desmembra cenas, utiliza termos técnicos, censura no geral o cinema ianque sem qualidade estética.

Quando consideramos a crítica praticada em Cena Muda como próxima de algumas opções da crítica intelectualizada, não queremos com isso aproximar a 
qualidade do produto final das duas. Cena Muda não tinha intenção nem espaço suficiente para realizar uma crítica como a dos jornais. Seu público leitor era outro. Há uma simplificação de conteúdo devido ao universo dos leitores-fãs. Os críticos não tinham a profundidade intelectual de Paulo Emilio, Almeida Salles ou Moniz Vianna. Contudo alguns dos critérios, estrutura textual e a preferência pelo cinema de arte se aproximam das normas estabelecidas pelos críticos intelectuais.

Diferente dos anos anteriores, quando os jornalistas se colocavam em posição oposta a dos críticos intelectualizados, nesta nova fase há uma conciliação com a preferência deste grupo. No topo de qualidade, está o cinema europeu, e, às vezes, o americano. A revista realiza diversas matérias sobre os melhores filmes do ano ou do semestre, como se sua função fosse enumerar listas de fitas a assistir. Cita com freqüência os filmes do Festival que estiveram disponíveis durante todo o ano.

Há uma consistência na nomenclatura dos espaços dedicados aos comentários dos filmes. Durante o primeiro semestre do ano, a seção de crítica é chamada Cartazes em revista. Edições após a saída do diretor Oswald de Oliveira em junho ${ }^{75}$, surge a seção Filmes em revista.

A publicação compensa a falta de informações sobre fofocas, aumentando a quantidade de críticas. Estas ocupam um grande número de páginas, com média de cinco, além de outras reportagens destinadas a analisar os melhores filmes de todos os tempos, ou o cinema de alguns diretores. Houve ainda duas edições especiais dedicadas exclusivamente à cobertura do Festival, com uma média de 10 páginas de críticas e reportagens. Quando Cena busca se pautar pela crítica cinematográfica, os componentes femininos desaparecem.

Num primeiro momento, os artigos sobre cada filme são mais longos e densos. Algumas críticas chegam a ocupar uma coluna inteira ou mais. Procuram analisar vários detalhes e cenas. Depois o critério se volta a uma quantidade maior de películas, numa média de dez. A densidade dos artigos cai pouco a pouco porque os jornalistas perdem parte do fôlego em comentar tantos filmes.

Como estratégia de autopromoção, a revista afirma-se como um guia de cinema. A "única" responsável pela cobertura de todos os lançamentos de São Paulo, Rio de Janeiro, Porto Alegre, e dos principais centros do país, até mesmo nos pontos distantes

\footnotetext{
${ }^{75} \mathrm{O}$ diretor teria saído por motivo de viagem a Europa, mas é anunciado que ele mandaria textos, tentando articular junto aos distribuidores o envio de filmes de arte ao Brasil. Jonald. Aos leitores. Cena Muda, v. 34, n. 25, p. 3, 23/06/1954.
} 
do perímetro central dessas cidades. Cena declara a mudança de foco para atender aos pedidos dos leitores. Obviamente os repórteres não dão conta deste trabalho, inexistente nas direções anteriores. No começo do ano, vez por outra, os jornalistas declararam que assistiram alguns destes filmes na Argentina ou no Uruguai. A revista critica a direção anterior por não ter analisado filmes importantes do ano anterior, como se esta fosse sua nova missão. O objetivo é recomendar ou não os filmes ao leitor.

Se há raros artigos discutindo a situação do cinema brasileiro, o modelo descrito por Jean-Claude Bernardet para analisar o filme a partir de critérios em separados nessa fase realmente é exercido de maneira acurada, como não tinha sido feito antes. Os críticos nunca esquecem de pontuar muitos critérios em separado, tais como: direção (medíocre ou inteligente), roteiro, fotografia (de classe, funcional ou contrastada), trilha sonora e música, partituras, atuação dos atores, ritmo, cenário, qualidade do colorido (belo colorido ou colorido sofrível, intenso, verdadeiro, parecido com a realidade), o tipo de narração, equilíbrio entre direção e atores, articulação das seqüências, momentos de comicidade, clímax, dramalhão ou não, linguagem de semi-documentário. De todos os aspectos verificados, o diretor ocupa espaço preponderante, por ser considerado a parte mais importante.

Quando não se aprecia um filme, geralmente há mais de um destes problemas: estilização, colorido "irritante", atores "canastrões" ou personagens estereotipados, conteúdo/seqüência/clichês/chavões como lugares comuns, filme "parado", fita sem avanço entre começo e final, falta de movimentação da trama, condenação ao roteiro por "base precária" ou "mal aproveitada", esquematização da história e/ou dos personagens e artificialismo/falsidade. A revista desgosta também de tramas que podem ser de qualquer gênero (melodrama ou western) e de temas regionais, considerados inadmissíveis para as platéias brasileiras pela falta de interesse. A condenação ao sensacionalismo aparece pouco.

Uma constante nos artigos em todos os anos é a condenação aos filmes melodramáticos e os dramalhões mexicanos. Nestes momentos, a crítica se divide entre a erudição dos temas sérios, pesados, admitindo rasas vezes o melodrama para o público feminino. Sobre Jamais te esquecerei ${ }^{76}$ de Roy Becker, Erre declara não ter muito a dizer sobre o filme: "trata-se de um filme para mocinhas românticas". Condena os apreciadores do gênero ao dizer "porque Ann Blyth é abraçada e beijada por David

\footnotetext{
${ }^{76} \mathrm{O}$ filme não consta no site do imdb< http://www.imdb.com $>$
} 
Farrar, as mulheres lotaram a sessão do cinema" ${ }^{77}$. Ou seja, havia uma demanda, mas a revista se colocava contra ela.

O vocabulário comum de análise procura confirmar se a música, cenário e fotografia são funcionais. A terminologia serve tanto para a condenação quanto para o louvor. Se a música é funcional é de qualidade mediana. Caso seja "funcionalíssima" significa qualidade suprema. Quando os críticos gostam da fotografia a qualificam como contrastada. Acreditamos que a preocupação e conhecimento de Jonald sobre música tenham determinado maior atenção a este critério ${ }^{78}$. Música e fotografia nunca são esquecidos.

Os adjetivos para sintetizar a qualidade dos filmes, com notas numéricas, são: excepcional, ótimo, admirável, bom, muito bom, filme mediano, sofrível, regular, fraco, detestável, inconcebível, inqualificável ou concorrente ao pior filme do ano. Voltados ao consumo, o leitor pode ler o atributo numérico para orientar sua leitura, como se fosse possível a partir de um critério homogêneo numerar as qualidades ou defeitos dos filmes ${ }^{79}$. Na decadência da revista somem as notas de cotação entre zero a cinco. Nos raros casos de filmes "inqualificáveis", a revista se exime de comentá-los. Nem sequer apresenta sua sinopse. Adverte, então, os leitores para não perderem tempo. Não querem também desperdiçar o espaço da seção, considerando missão da crítica analisar bons filmes.

Para realizar a crítica, sempre se toma a divisão do filme clássico em três partes (apresentação/desenvolvimento/desenlace). A estratégia é muito utilizada para não elogiar nem censurar completamente. Às vezes, o crítico declara ter apreciado a primeira parte, mas não a segunda, como se o filme melhorasse apenas na terceira parte.

Existe uma preocupação da crítica em utilizar critérios correspondentes à linguagem cinematográfica. Característica ausente nos anos anteriores, com exceções dos artigos de Alberto Dines. Procuram analisar, por exemplo: câmera estática, travelling nervosos ou não, utilização de close up, tipo de plano, enquadramento

\footnotetext{
${ }^{77}$ Erre. A tela em revista. Cena Muda, v. 32, n. 17, p. 30, 24/04/1952.

${ }^{78}$ Nessa fase há uma grande cobertura a ballet, assunto de domínio e interesse de Jonald.

${ }^{79}$ B. J. Duarte atacou o estilo em voga na época de considerar os filmes a partir de cotações, consideradas por ele como uma "praxe ridícula adotada pela maioria dos que se dizem críticos de cinema". Além dos abacaxis enfeitados de Cena Muda, em utilização em décadas anteriores a de nossa pesquisa, pontuada por Flora Bender, Duarte cita: bonecos dormindo em poltronas, sentados a olhar atentos para uma tela invisível, de pé aplaudindo com frenesi, barômetros com marcações do zero ao máximo da escala (em casos especiais, o mercúrio pode fazer explodir a coluna milimetrada, sinal de ótimo filme), gatos e cães miando ou uivando, com focinho satisfeito ou torcido, poltronas vazias e números de um a cinco. (Catani, 1991: 98)
} 
("monótono" ou rápido), estética da cenografia, ritmo ("incerto" ou "ágil”), forma dos cortes (rápidos ou lentos), continuidade e forma de transição, fotografia com ou sem unidade e trabalho de laboratório deficiente. Os críticos tentam inter-relacionar estes itens para analisar a direção. Apontam até quando houve um problema durante o Festival na velocidade de uma película, causando a impressão de ter ouvido um disco de 78 rotações executado em $33^{80}$. Uma clara necessidade de mostrar aos leitores que entendem do assunto, mas sem preocupação de explicar a terminologia. Nos anos anteriores, havia uma preocupação didática em explicar termos técnicos. Tais observações não são usadas sempre, mas aparecem com uma frequiência grande nos primeiros meses do ano. A utilização parece uma mostra de erudição, mas nem sempre embasada em conteúdo correto. Certa vez houve um comentário errôneo sobre uma fusão de $O$ canto do mar (1953) de Cavalcanti, considerada uma típica "reticência" de filme nacional. Na verdade, o crítico não entendeu um flashback simples ${ }^{81}$.

Por diversas edições, Cena realiza uma retrospectiva sobre os filmes mais importantes de todos os tempos, com especial interesse sobre o cinema silencioso. $\mathrm{O}$ enfoque mostra quanto a revista nesta fase prezava seu passado, atendendo à demanda de um público leitor das décadas anteriores.

Os críticos buscam provar seu conhecimento em relação a diretores e obras famosas, diferenciando o cinema de cada autor. Até avaliam se houve plágio. Os cronistas consideram-se atentos à linguagem dos cineastas, mas nada provam. Utilizam apenas frases feitas, como conferir a René Clair um estilo próprio, simplificado a uma linguagem alegre e irônica ${ }^{82}$. Concomitante a este processo, a revista tenta depreender dos filmes vistos no Festival as características dos diretores, sem ocultar seu desconhecimento sobre obras não apresentadas no Festival. Como consequiência, cineastas de renome passam a ser citados com evidência e com nível diferente de

\footnotetext{
${ }^{80}$ Pré-estréias do Festival. Cena Muda, v. 34, n. 12, p. 28-9, 24/03/1954.

${ }^{81} \mathrm{O}$ autor do texto cita as "rememorações da mãe" depois da discussão com a filha que não encontram explicações, consideradas "reticências típicas de um filme nacional". O comentário foi indevido. A cena citada faz parte de um flashback: após ouvir os comentários da filha, de que ela ficou velha e feia, a mãe relembra seu passado, quando era bonita e esperançosa. Nesse momento, ela se dá conta do tempo que passou. Na verdade, Cavalcanti neste filme é esquemático na forma utilizada para começar um flashback. A câmera percorre o corpo do personagem na vertical até o momento em que começam as fusões, depois de um rápido congelamento. Apesar disso, o cronista teve sensibilidade para perceber um dos pontos altos do filme: as cenas documentais sobre os retirantes. Jonald; Boltshasler, L; Andersen, Helena; Maximiano. Cartazes em revista. Cena Muda, v. 34, n. 3, p. 28, 20/01/1954.

${ }^{82}$ Oliveira, Oswald. Pré-estréias. Cena Muda, v. 34, n. 2, p. 3, 13/01/1954.
} 
referência, ao contrário dos anos anteriores, quando se nivelava Lulu de Barros ${ }^{83}$ a Cecil de Mille.

José Inácio de Melo Souza (1995) aponta um interesse na crítica durante a década de quarenta pelo cinema europeu por considerá-lo um cinema artesanal, o comparando à situação de difícil competição do Brasil com os Estados Unidos. Mesmo os filmes ruins tinham para os críticos algo inexplicável que os salvava, como fotografia mais contrastada, temas reais e sociais, em oposição à falsidade do cinema americano. Postura em total desacordo com a de Cena Muda em 1950. Apesar de admirar o cinema europeu como arte, a revista aponta um esvaziamento do neo-realismo. Por vezes há uma má vontade com alguns dos lançamentos europeus. Por outro lado, há uma admiração muito grande pela história da cinematografia européia e pelo neo-realismo, assim como pelos seus diretores renomados.

Nem o renome do diretor garante a certeza do louvor. Muitas vezes filmes de cineastas consagrados são vistos de forma negativa por não acrescentarem nada de novo ou original. Há uma clara preocupação com o novo, melhor e diferente, reflexo da cultura de massa que procura sempre o original. Às vezes estes pressupostos pesam mais do que o imperativo artístico. Se um filme é bom, mas não tem nenhuma novidade em código cinematográfico ou roteiro, sua apreciação decai. Francisco, arauto de Deus (1950), de Roberto Rossellini, recebe nota um e meio ${ }^{84}$. Cena considera o argumento falho em sua verdade histórica. Apenas aceitável por ser lançado na Semana Santa. Uma fita "desinteressante, monótona e sem movimento, de um diretor irregular como Rossellini”. A reação negativa foi constatada também por Paulo Emilio Salles Gomes na Itália onde os comunistas e os católicos não gostaram do filme ${ }^{85}$. Para Paulo Emilio, os dois grupos foram injustos. A crítica de Cena Muda nada teve de original. Ao contrário, foi um reflexo da frieza com que foi recebido no mundo.

Atrelando-se ao filme europeu de qualidade, Cena Muda inicia uma campanha por algumas edições para convencer os distribuidores a mandarem filmes de qualidade artística ao Brasil. Pelas fitas disponíveis no mercado, a revista tinha concluído a decadência da produção francesa contemporânea, voltada apenas para o sex appeal. Porém, quando teve acesso à parte da produção via Festival, a considerou de ótima qualidade. Por este motivo, começou a campanha, citando filmes que gostaria de

\footnotetext{
${ }^{83}$ Embora no geral, em anos anteriores, Cena Muda tenha uma visão negativa sobre Luiz de Barros.

${ }^{84}$ Cartazes em revista. Cena Muda, v. 34, n. 16, p. 28, 21/04/1954.

${ }^{85}$ Gomes, Paulo Emilio Salles. "O escândalo Rossellini”. IN: Crítica de cinema no suplemento literário. Rio de Janeiro, Paz e Terra, 1981. v. 2.
} 
conhecer. A publicação tenta provar a existência de um mercado para filmes de arte no Brasil para justificar a empreitada. Temos aqui uma atitude diferente da crítica. Ela não se vê mais como agente responsável sobre o desenvolvimento do filme brasileiro. Quer apenas acesso a filmes para sua cultura cinematográfica. O comentário da publicação estava concatenado com a cobertura da revista Anhembi. Esta cita os comentários de uma publicação sem dar seu nome, que acreditamos se tratar de Cena Muda. O tema é semelhante: as distribuidoras mandam para o Brasil apenas as piores películas. Como exemplo, Anhembi menciona a França ${ }^{86}$.

Assim a crítica se lança numa nova meta. Provar quais são os filmes de alta qualidade "estreados à escondida do público" em cinemas de bairro que saem muito rápido de cartaz. Além de tudo, não desfrutam de destaque entre os críticos. Nasce um termo e uma seção destinada a encontrar estas fitas, chamadas de bólides (meteorito). A nomenclatura denomina as películas relegadas pelos exibidores, lançadas sem evidência no mercado, como bólides: "obras de arte são julgadas anti-comerciais, e assim, relegadas no Rio a cinemas ou de bairros ou de categoria inferior" ${ }^{87}$. A terminologia é rapidamente incorporada nas colunas dos leitores ${ }^{88}$. Nasce a seção Descobrindo os bólides. Cena Muda declara estar sempre vigilante, descobrindo filmes surpreendentes.

Quanto à estrutura da crítica, os artigos procuram dissecar cada filme a partir dos pontos positivos e negativos, quase tirando uma média matemática. Embora haja uma tendência de suposta objetividade pronta a assinalar "todas" as questões, no fundo se percebe o oposto: quando o jornalista adora ou odeia a fita. Na verdade, o recurso não busca incentivar a produção. Ao contrário, ao analisar cada parte aumenta a quantidade de provas quanto à boa ou má qualidade da película. A crítica recorre a um tom supostamente neutro, longe do tom autoritário de um juiz, como era feito nos anos anteriores. Utiliza um critério quase matemático, daí a aparência de objetividade. Fica a impressão de que tudo foi dito, todos os pontos foram mostrados e provados, como um guia completo ao consumo. O objetivo é aumentar a adesão à uma opinião e dificultar a discordância em relação às idéias do cronista.

\footnotetext{
${ }^{86}$ Marguliès, Marcos. "Cinema da França e vinho de Bordeaux". IN: Anhembi, v. 15, n. 44, p. 416-17, julho 1954.

${ }_{87}$ Cartazes em revista. Cena Muda, v. 34, n. 21, p. 28-9, 26/05/1954.

${ }^{88}$ Não iremos nos deter sobre a crítica dos leitores para não alongarmos demais o capítulo, mas há sempre uma incorporação rápida do vocabulário e preocupações da crítica praticada na revista, semelhante à divisão feita em nosso trabalho a partir de critério cronológico: preocupada com a situação do cinema brasileiro em 1952-3 ou com a análise dos filmes em 1954. Alguns artigos apresentam nível textual bem mais elevado para a média porque certamente foram escritos pelos jornalistas da revista.
} 
Como exemplo, temos a crítica ao filme Ladrão silencioso (1952) ${ }^{89}$. A revista enumera inúmeras falhas, tais como: argumento falho prejudicando o ritmo interior, história vazia e fraca, esquematização das situações gerando uma trama simples, ausência de ambiente e ritmo externo necessários a um real suspense, falta de conteúdo. $\mathrm{Na}$ banda sonora há ao mesmo tempo irritante fundo musical e "efeitos sonoros magnificamente usados". Entre os pontos positivos realça: bom cinema nas sequiências finais, com certa intensidade, fotografia de classe com os valores humanos em close up ou planos médios conferindo alguma riqueza psicológica e bons momentos de interpretação. A fita recebeu nota 2.5 , ou seja, sofrível e regular.

O mesmo critério é utilizado para o filme brasileiro. Não se recorre comumente a diatribes, mas se destrói grande parte dos aspectos com termos técnicos, para mostrar ao leitor a seriedade da crítica que não esquece nenhum ponto. Há uma nova forma de cobertura à chanchada. Os críticos conseguem censurar quase todos os pontos das comédias carnavalescas, incluindo poucos elogios. Contudo o tom geral do texto está mais próximo do que se convencionou chamar de objetividade, sem diatribes pessoais. Um cronista, por exemplo, considera tal gênero composto de tramas pueris, de precária comicidade, quando não grosseira ${ }^{90}$. O crítico mostra que quando uma chanchada se afasta da rotina e lugares comum, como Carnaval em Caxias (1953) de Paulo Wanderley, receberá elogios. Apesar de não ter apreciado o filme, na média ele avança em aspectos significativos. Depois do pequeno elogio, ele enumera os pontos negativos: o desenvolvimento cinematográfico "deficiente" e "inadequado" da fita, diálogos "enfadonhos", fotografia "descuidada", som de "má" qualidade, coreografia "insignificante".

Nenhum filme brasileiro recebe apenas elogios. O máximo de elogio ao cinema brasileiro é eleger os filmes que se destacam por poucas características positivas. Assim Jonald resume os melhores filmes brasileiros, entre eles: Sinhá Moça (1953), de Tom Payne pela fotografia, música e reconstituição histórica e Uma pulga na balança (1953), de Luciano Salce, pela decupagem ${ }^{91}$.

Raramente quando os críticos consideram um filme excelente, significa encontrar muitos aspectos positivos. Contudo, mesmo as raras películas com nota

\footnotetext{
${ }^{89} \mathrm{O}$ filme consta na revista como sendo de Bruce Humberstine, mas é de Russel Rouse. Cartazes em revista. Cena Muda, v. 34, n. 1, p. 28, 06/01/1954.

${ }^{90}$ Jonald; Boltshalser; Andersen; Maximiniano. Cartazes em revista. Cena Muda, v. 34, n. 7, p. 28-9, $17 / 02 / 1954$

${ }^{91}$ Jonald. Os melhores de 1953 no cinema brasileiro. Cena Muda, v. 34, n. 3, p. 7-8, 20/01/1954.
} 
máxima não são consideradas perfeitas pela presença de aspectos negativos ou condenáveis ${ }^{92}$. A crítica nesta fase não aprecia a grande maioria dos filmes. Consegue ver alguma falha sempre, seja na produção brasileira ou estrangeira.

Quanto à diferença entre a cobertura aos filmes brasileiros e estrangeiros, neste período não é mais possível afirmar que para o brasileiro se analisa a situação da cinematografia nacional, e para a película estrangeira, o critério seja tomá-la como uma obra de arte, como pontuou Jean Claude Bernardet sobre as características da crítica antes da década de sessenta. Na verdade, a crítica se torna democrática e desgostosa dos dois cinemas. Como numa concepção simplista de um Juízo Final filmográfico, poucos filmes se salvam por completo, mas não há o tom autoritário, como já dissemos.

O comentário de José Inácio de Melo Souza (1995) sobre a relação dos críticos com o filme brasileiro não encontra paridade quando se observa a crítica de Cena Muda em 1954. Conforme sua pesquisa, o constrangimento em condenar filmes estrangeiros sumia quando se tratava do cinema nacional. Em 1954, dá-se o contrário em Cena Muda. A filmografia norte-americana passa a ser repreendida sem ressalvas, como se a maior distância com os diretores propiciasse uma crítica destituída de pendores em atingir egos. Ao contrário, os comentários ao cinema brasileiro passam a sofrer de um certo constrangimento em censurar os cineastas brasileiros (não exatamente aos filmes), utilizando subterfúgios e complacência para não atrapalhar as fitas, talvez pela proximidade entre cronistas e diretores.

Quando o comentarista desgosta de todos os aspectos de um filme brasileiro, busca perdoar os erros do diretor, agora numa nova função presbiterial da crítica em relação aos realizadores. Para tal, relembra as qualidades do cineasta ou dos trabalhos feitos antes, mesmo sem nada provar. Os cronistas podem até censurar diversos pontos de responsabilidade do diretor, mas para poder elogiá-lo, a responsabilidade recai sob a equipe ${ }^{93}$.

\footnotetext{
${ }^{92}$ Por exemplo, Les belles de nuits (1952), de René Clair, é elogiado pela irônica linguagem do mestre do cinema. A atmosfera é diferente da usual. A música e a fotografia são consideradas funcionais, mas Jonald considera que o assunto não é novo. A sugestão de imprevisto poderia ter sido mais intensa. Há excesso em algumas cenas repetitivas sob a responsabilidade do roteiro. Oliveira, Oswald de. Pré-estréia de René Clair. Cena Muda, v. 34, n. 2, p. 3, 13/01/1954.

${ }^{93}$ Depois de censurar o filme Nem Sansão nem Dalila (1954), de Carlos Manga, por ter: desequilíbrio no roteiro, intuitivas passagens bruscas, falta de continuidade, conjunto desarticulado, falta de maior esforço da base, na mesa de trabalho e na estruturação, atores aquém de suas possibilidades, o cronista não responsabiliza o diretor, nem pela falta de boa preparação ao arcabouço. Jonald; Boltshalser; Andersen; Maximiniano. Cartazes em revista. Cena Muda, v. 34, n. 16, p. 28, 21/04/1954.
} 
No período, a crítica sofre menos a influência do release também porque não tem a preocupação com o incentivo da cinematografia nacional. Também não se incomoda em não apreciar todos os filmes. A opção de analisar supostamente "todos" os aspectos das fitas só poderia prejudicar o cinema brasileiro, porque com uma análise mais apurada em detalhes técnicos, a produção nacional não obteria sucesso, pois é vista como falha na maior parte dos pormenores técnicos. A crítica não toma outro critério para investigar os filmes brasileiros, não é mais condescendente por considerá-los fracos, como fazia antes. Não há uma postura de benevolência, desatrelando-se nas críticas a situação dos estúdios. Os artigos não precisavam recorrer a diatribes para demolir um filme. Utilizam a ironia quanto a baixa qualidade, mas de maneira sutil. Quanto aos comentários gerais sobre os filmes brasileiros, há uma condenação aos filmes cosmopolitas. A crônica prefere temas nacionais, populares para aproveitar a cultura do país. Um reflexo do discurso do período.

Os artigos se concentram mais na análise dos filmes, com menor relevo para a interpretação e comentário ${ }^{94}$. Não há contextualização histórica nas seções de crítica, nem mensagens filosóficas. Devido ao pouco espaço disponível, os críticos não recorrem às generalizações sobre a alma humana. Estas poderiam ter sido utilizadas, dado o tom moralista da publicação, como veremos adiante.

A atuação dos atores também é relevante para a estrutura textual do período. A análise não chega a ser aprofundada. Paulatinamente a crítica aumenta sua porção de estrelismo através da adjetivação. Nos melhores artigos, concentra-se na contribuição do ator ao desenvolvimento do filme. Às vezes, mesmo sem o desejar, a crítica cede ao star system, quando analisa a conciliação entre o ator e papel interpretado. A tradição de Stanislavski no teatro aparece vez por outra. Nestes casos residem os casos mais jocosos contra os atores. Para eles há um tom de diatribe. Um é acusado de "imbecilidade espantosa" e "maneirismo intragável". Não se prova nada, mas se recorre ao humor para dizer que Stewart Granger tem apenas dois recursos dramáticos: "levantar a sobrancelha e entortar a boca, em sinal de desdém" ${ }^{95}$. Entretanto o objetivo na maior parte do tempo é o de desaprovar o estrelismo, como já dissemos.

A cobertura ao cinema norte-americano pode ser resumida em três posturas. Os filmes melodramáticos ou de lágrimas são vistos de forma pejorativa em todos os anos,

\footnotetext{
${ }^{94}$ Utilizamos a divisão proposta por Ismail Xavier, a partir das aulas de Antonio Candido, dividindo a crítica cinematográfica na tríade comentário/análise/interpretação.

${ }^{95}$ Jonald; Botshalser, L; Andersen, H. Cartazes em revista. Cena Muda, v. 34, n. 5, p. 28-9, 17/02/1954.
} 
com poucas exceções. O segundo tipo é o cinema considerado de qualidade, com diretores importantes, cada vez mais mencionados em 1954. Na época de grande influência do release, Cena Muda citava diretores das massas ou da superprodução, como Cecil de Mille. Depois passa a destacar cineastas questionadores da esfera norteamericana, como Elia Kazan e Carol Reed. O terceiro tipo de filme é sempre censurado. São os filme "B", de diretores desconhecidos ou de pouca fama. Geralmente nem são objeto de artigo, só de pontos negativos em uma ou duas linhas. A nomenclatura para este último grupo utiliza um termo brasileiro, o "abacaxi”. Quando uma fita estrangeira é ruim, a terminologia utilizada para as comédias de carnaval da Atlântida é ressuscitada. Os abacaxis são universais para Cena Muda. Também a expressão (não passa de uma) “chanchada vulgar” tem conteúdo universal neste período.

Como a maior parte dos filmes avaliados em 1954 são os do Festival, analisamos de forma mais detalhada a crítica praticada no próximo subitem.

\subsubsection{A cobertura ao I Festival Internacional de Cinema do Brasil}

A cobertura ao I Festival Internacional de Cinema do Brasil ${ }^{96}$ mostra o abismo editorial que se configurava entre as duas revistas devido ao novo padrão de Cena. Como periódicos geradores do star system, esperávamos uma ampla divulgação às estrelas presentes. Contudo o foco de Cena Muda surpreendeu no diminuto noticiário ao “mundanismo do Festival". Por outro lado, o posicionamento de Cinelândia não foi tão bajulatório. A diferença entre as duas revela a diferença nos projetos editoriais. Debruçamo-nos sobre a representação do Festival para analisar de que forma as revistas de fãs transmitiram o evento ao público.

Tanto André Bazin em Cahiers du Cinéma quanto Marcos Marguliès em Anhembi acusam os grandes veículos de realizarem uma campanha de difamação contra

\footnotetext{
96 Para maiores informações sobre o Festival, consultar a dissertação de Fausto Correa Jr. (2007). O I Festival Internacional de Cinema do Brasil, realizado em São Paulo entre os dias 12 a 26 de fevereiro, fez parte dos quadros da comemoração do IV Centenário da cidade de São Paulo. O maior objetivo era colocar a população, críticos e estudiosos em contato com uma filmografia de referência. Voltado às retrospectivas da história do cinema, o Festival proporcionou ainda a compra de um acervo importante que permaneceu no país. Não havia caráter de competição ou distribuição de prêmios de acordo com o regulamento da FIAF que limitava as manifestações internacionais com caráter de competição a Cannes e Veneza. Sem poder outorgar prêmios era esperado que os produtores guardassem os melhores lançamentos para os festivais europeus. Entre as retrospectivas importantes do Festival se destacaram: a Retrospectivas sobre Stroheim, Abel Gance e Alberto Cavalcanti, o Festival do filme científico (sob a organização de B. J. Duarte), a II Retrospectiva do Cinema Brasileiro e a mostra Grandes momentos do cinema, com exibições de fitas clássicos. Havia ainda as Jornadas Nacionais onde era possível assistir a alguns dos principais filmes da produção dos países participantes.
} 
o evento. Houve na percepção de Bazin ${ }^{97}$ um problema de ligação entre a população e o evento de modo agudo. Os habitantes pensaram que por se tratar de um festival pago pelo município, a festa seria para seu uso. Na quase totalidade, a população se preocupou com a presença das vedetes e a possibilidade de conseguir autógrafos. Bazin cita uma organização paralela no Festival para satisfazer aos desejos compreensíveis da população, descentralizando a projeção dos filmes para cinemas de bairros com o deslocamento das vedetes. Ele considerou a postura da imprensa local lamentável por ter mantido o mal entendido com a população. Segundo ele, houve uma campanha da grande imprensa contra o enorme gasto ${ }^{98}$ para trazer atrizes pouco conhecidas, no lugar de estrelas.

Primeiro é necessário delinear uma visão geral do chamado "mundanismo" presente na grande imprensa. Não pretendemos aqui traçar com exatidão um quadro completo da cobertura jornalística ao Festival. Nosso objetivo não é realizar um estudo sobre o Festival, analisado por Fausto Correa Jr. (2007) e Reinaldo Cardenuto (2004). Contudo esboçar um panorama da cobertura dos demais veículos auxilia na avaliação do enfoque editorial de nosso objeto de estudo ${ }^{99}$.

Antes do Festival, os jornais explicam o que é o evento e quais serão as delegações participantes. Há especial atenção às presenças confirmadas de estrelas internacionais. A tecnologia tem também relevo no noticiário. Os jornais discutem se as salas de cinema estão equipadas para apresentar Marilyn Monroe em cinemascope. Raríssimas notícias citam a baixa expectativa para com o evento, como na matéria Festa num velório ${ }^{100}$.

Com o início do Festival, os jornais centram o noticiário sobre as estrelas presentes e ausentes. Há comentários sobre romances, festas e fofocas. Há também os artigos explicando o significado do Festival e narrando a sessão de abertura. Crescem dia a dia os artigos analisando a relevância do evento e a desorganização geral. À medida que o Festival avança, aumentam as matérias sobre os gastos e a ausência da população. O objetivo da imprensa foi em grande parte avaliar a sua validade. Depois de encerrada a festividade, o noticiário sobre os gastos e sobre o dito "fiasco" do Festival aumentam bastante. Sem ter novidade a contar, os jornais trazem condenações.

\footnotetext{
${ }^{97}$ Bazin, André. «Un festival de la culture cinematographique » IN : Cahiers du Cinéma. Paris, n. 34, v. VI, p. 23-29, abril 1954.

${ }^{98} \mathrm{O}$ Festival pagou para trazer os atores, mas nem assim muitos deles vieram.

${ }^{99}$ Realizamos uma pesquisa na Cinemateca Brasileira a partir das pastas com 920 recortes de jornais da época. Trazemos nossas conclusões desta cobertura, lembrando tratar-se de um estudo parcial.

${ }^{100}$ O Mundo. 05/01/1954. Pasta 243/15.
} 
Entre os jornais que efetuaram uma cobertura incisiva trazendo as denúncias de gastos com grande repetição há: Correio da manhã, O Mundo, O Tempo, Correio Paulista, Diário Carioca, A hora, Notícias de Hoje, O Dia. Folha da Tarde e Folha da Noite podem ser incluídas nesta lista, enquanto A Folha da Manhã, da mesma companhia, imprimia e distribuía o Boletim do Festival. Além disso, publicava um caderno especial com quatro folhas diárias sobre o evento. A TV Paulista realizou um programa chamado Maratona pró-cinema nacional ${ }^{101}$ com o objetivo de arrecadar fundos para terminar o filme Floradas na Serra (1954), de Luciano Salce. O programa chamou os atores excluídos da lista oficial de convidados. Conseguiu ainda a participação de Franco Zampari. A emissora acusou o Festival de gastar muito, quando o cinema brasileiro passava por uma grave crise.

Tanto o jornal $O$ Estado de S. Paulo quando O Globo (afiliado da mesma empresa que publicava Cinelândia) realizaram uma cobertura positiva ao Festival. Trouxeram poucos comentários negativos ao evento, sem transferir as frases de condenação ao discurso da publicação. Do material consultado na Cinemateca Brasileira, $O$ Estado de $S$. Paulo foi o único a realizar análise sobre os filmes. Os demais realizaram uma cobertura geral sobre a qualidade das fitas.

$\mathrm{Na}$ imprensa, o Festival foi assunto com grande recorrência. Houve duas principais acusações. A primeira sobre o alto preço dos ingressos que impedia a participação da população. Enfim, uma festa para a elite, não para a comemoração do IV Centenário. O mais barato era o do Cine Alecrim. Os vinte cruzeiros de entrada significavam o dobro do preço médio de um ingresso. Já no Marrocos (onde passaram os filmes de Stroheim), o valor subia para 125 cruzeiros. Alguns periódicos falam num pacote completo por dois mil cruzeiros. Lembram que enquanto os salários dos servidores públicos estariam atrasados, assim como o salário-família, se esbanjava dinheiro para trazer atrizes desconhecidas. Além de pagar diárias em hotéis de luxo, cachês, incluindo rodadas de táxi e despesas pagas para conhecer o carnaval carioca ${ }^{102}$.

A segunda acusação abordou os gastos, considerados excessivos. Segundo os jornais da época, a verba foi de vinte milhões de cruzeiros, dez do governo federal e dez do estadual. Quando o orçamento completo das comemorações do IV Centenário foi da ordem de 620 milhões. Uma Comissão Parlamentar de Inquérito foi organizada para

\footnotetext{
101 O Tempo. 17/02/1954. Pasta 250/36.

102 “Dez milhões gastos em 15 dias com um festival para a elite!”. A Hora. 16/03/1954. Pasta 259/19.
} 
apurar se houve desperdício. O deputado Mendonça Falcão pediu à imprensa que colocasse em foco o assunto para provocar mais rápido o pronunciamento da $\mathrm{CPI}{ }^{103}$.

Não queremos planificar a cobertura da imprensa. Nossa pesquisa sobre o noticiário dos jornais corrobora com os comentários de André Bazin sobre a campanha negativa feita pelos grandes veículos. Contudo, os jornais que condenam os enormes gastos apontam também em balanços os pontos positivos. Na maior parte das vezes, a imprensa traz os discursos dos deputados sobre os gastos, mas em alguns artigos incorpora a acusação. Estas se tornam parte da opinião dos veículos. Sem falar no grande espaço visual de que desfrutam estas matérias. Não é possível negar o sensacionalismo de manchetes como: Decepção Nacional ${ }^{104}$, Que se ofereceu ao povo em troca de 620 milhões? ${ }^{105}$ ou Dez milhões gastos em 15 dias com um Festival para a elite $^{106}$. Estes títulos chamam muito mais a atenção do que as manchetes sobre os pontos positivos e negativos, como: Último Balanço sobre o Festival ${ }^{107}$, Terminado o Festival, quais seus resultados? ${ }^{108}$, Encerrado o I Festival Internacional de cinema do Brasil - os bons e maus aspectos do certame ${ }^{109}$.

Os jornais citam ainda com freqüência as bebedeiras de Errol Flynn e o caso do roubo das jóias de Ninon Sevilla. Trazendo com aspas os discursos proferidos na Assembléia Legislativa, A Hora cita o discurso de Gumercindo Fleury sobre a atriz. Ele a chama de contrabandista, porque ela teria trazido vinte pulseiras e anéis iguais ${ }^{110}$. As duas revistas não fazem alarde do caso, apenas o citam.

A diferença da cobertura dos jornais diários para as revistas semanais foi grande, provavelmente devido à relação destas últimas com a propagação de um universo otimista, sob maior influência da publicidade. Tanto O Cruzeiro quanto Manchete noticiaram o evento de maneira superficial, com destaque mediano. A preocupação estava centrada sobre as estrelas internacionais presentes. A cobertura fotográfica das duas publicações trouxe flagrantes das atrizes nas festas, incluindo até imagens das estrelas dançando no Carnaval. São raros os artigos sobre os filmes. O objetivo é conseguir fotos e constatar romances. Há imagens das atrizes dançando no carnaval ou saindo da piscina de biquíni. Salvyano Cavalcanti de Paiva publica diversas fotos de

\footnotetext{
${ }^{103}$ Relatório sobre o Festival de Cinema. Folha da Noite. 06/12/1954. Pasta 241.

${ }^{104}$ O Tempo. 28/02/1954. Pasta 258/15.

105 A Hora. 09/03/1954. Pasta 258/37.

${ }^{106}$ A Hora. 16/03/1954. Pasta 259/19

${ }^{107}$ Ortiz, Carlos. Notícias de hoje. 16/03/1954. Pasta 259/18

${ }^{108}$ Correio Paulistano. 28/02/1954. Pasta 258/11.

${ }^{109}$ Correio da Manhã. 28/02/1954. Pasta 258/4

110 “Que se ofereceu ao povo em troca de 620 milhões?” 09/03/1954. Pasta 258/37.
} 
atrizes pouco conhecidas supostamente dormindo ${ }^{111}$ em seus quartos de hotel. Uma delas aparece tomando banho, embrulhada na cortina do box ${ }^{112}$. É possível ver seu busto.

Segundo Fausto Correa (2007), a relação entre o mundanismo presente e financiador da festa com o lado cultural do evento é um ponto de destaque para se estudar o suposto equilíbrio ou desequilíbrio das duas partes. O mundanismo não estava presente apenas nas revistas, mas também no Boletim do Festival. Reinaldo Cardenuto (2004) declara que numa mesma edição havia desde fotografias exaltando personalidades a textos de Paulo Emilio, preocupado em estruturar uma filmoteca. Comparando com o noticiário das revistas de fãs, podemos ir mais longe. Os boletins do Festival incitavam mais a curiosidade dos fãs sobre as estrelas do que as publicações destinadas a este nicho. Isso porque os boletins informam os nomes das estrelas presentes, as datas da chegada, os hotéis onde cada uma estará hospedada, incluindo ainda os horários das sessões de autógrafos. Esta cobertura foi feita durante o Festival. A das revistas centrou-se depois do evento, sem estímulo à participação popular. Nos curtos artigos do Boletim sobre as estrelas, não faltavam elogios às superproduções norte-americanas, com biografias elogiosas dos atores através de adjetivos. Quando se trata de atores brasileiros, o tom não é tão laudatório. Fornece os erros dos filmes brasileiros exibidos. O boletim trouxe mais imagens instantâneas das festas do que as revistas de fãs. Contudo, havia uma representação rasa do estrelismo nos boletins. O máximo eram algumas frases para conseguir se aproximar dos leitores em tom íntimo ${ }^{113}$.

Podemos sintetizar a cobertura de Cinelândia quanto ao Festival em dois itens: flagrantes das estrelas estrangeiras presentes e verificação da personalidade "verdadeira" dos atores. Ela sabia de forma empresarial qual era seu público leitor. Cena Muda parecia desconhecer este dado. Vagava para dois nichos diferentes: os fãs e os apreciadores do cinema de arte. Ambas analisam o evento depois de seu término. Cinelândia mencionou o Festival em poucas edições, mas soube agendar o tema das estrelas americanas para várias edições. Narra algumas indiscrições e detalhes de

\footnotetext{
${ }^{111}$ O que o público não viu. Manchete, n. 98, p. 36-41, 06/03/1954.

112 Guia do fã. Manchete, n. 102, p. 46, 03/04/1954.

${ }^{113}$ Um exemplo do tom íntimo presente no Boletim pode ser encontrado no do dia 11/02/1954 sobre a atriz Françoise Arnaud que não compareceria ao Festival. Escreve o repórter: "Está claro que o leitor sentir-se-á tão penalizado quanto os redatores deste boletim (...)”. Contudo não há grande apelo em termos de criação de intimidade.
} 
bastidores bem leves, geralmente "plantados". Cena Muda falou do certame em todo o primeiro semestre do ano, assim como Anhembi.

Por esta dicotomia é possível diferenciar as duas. Cinelândia como uma publicação a se reafirmar como revista de fã, destinada aos produtos culturais. Cena pretende nesta fase ser guia às obras de cunho estético. Vê com ressalvas a associação aos gêneros da indústria hollywoodiana.

$\mathrm{O}$ realce à fofoca diferencia os dois veículos. A revista da Companhia Americana evidencia sempre a inexistência de muitas fofocas sobre o Festival. Tudo teria transcorrido em perfeita harmonia, longe da expectativa dos que esperavam um "festival de orgias" feitas por milionários ${ }^{114}$. Com esta declaração, Jonald se exime de relatar o que não deseja, por ter outro enfoque editorial. Todavia para não desagradar seu público de fãs, narra alguns fatos. Cinelândia não foge do tema. Transforma mínimas ações em notícias, às vezes para poder desmentir suas próprias histórias e reativar um novo ciclo de declarações.

A jornalista Zenaide Andréa compara a estréia a uma première da capital do cinema: "a abertura foi um sonho. Mostrou-se o que é uma estréia de Hollywood" 115. Cinelândia aproxima representantes de universos díspares: fotografa Inalda de Carvalho, miss Cinelândia, conversando com Abel Gance. Assim ocorre a associação útil entre arte e estrelismo para Cinelândia. Uma imagem inclui o "maior crítico francês" André Bazin. A proximidade não gerou desejo de entrevistá-lo. Certamente Bazin não apareceu numa foto de dimensões maiores porque não foi fotografado ao lado de uma beldade. Em Cena Muda, há quase ausência de fotografias dos atores no Festival. O forte era a parte textual, opção talvez para o momento de crise da revista. Já Cinelândia conseguiu reproduzir no Festival o tipo de flagrantes fotográficos dos atores em festas, presente em suas edições apenas no noticiário estrangeiro.

Apesar do caráter publicitário de incentivar o cinema brasileiro, Cinelândia falou da falta de qualidade do Festival. Narrou detalhes da precária organização e do "fiasco" dos filmes apresentados. Todavia não enfatiza tais dificuldades. Toca no assunto apenas três vezes, sem sensacionalismo. Zenaide Andréa enumera entre os problemas: os atropelos nos vários setores do certame ligados à imprensa ${ }^{116}$ e ao

\footnotetext{
${ }^{114}$ Jonald. Doze entrevistas e muito movimento. Cena Muda, v. 34, n. 10, p. 8-9, 10/03/1954.

115 Andrea, Zenaide. O que eu vi no Festival. Cinelândia, v. 3, n. 32, p. 46-47; 52, $1^{\text {a }}$ quinz. março 1954.

${ }^{116}$ Em outro texto, Zenaide narra que teve de subir uma longa escada de difícil acesso, reservada só para jornalistas. Não havia cadeiras e mesas para os jornalistas porque os convidados ocupavam seus lugares. Sua percepção dos problemas é bastante pautada sobre aspectos concretos, como estes. Por outro lado, os
} 
público, o desalento as vésperas da inauguração, os comentários desanimados da imprensa que contagiaram os fãs dos mais longínquos locais do Brasil, a expectativa da ausência das estrelas, a falta real de astros e de romances ${ }^{117}$. A perspectiva positiva são os romances existentes a relatar. Se não há caso amoroso, o veículo inventa um. Depois, Zenaide narra de forma resumida os protestos da cinematografia brasileira ${ }^{118}$ contra os gastos excessivos com o Festival, sem compactuar com a opinião ${ }^{119}$. Cita também o desejo não concretizado de apresentar um "Festival Mirim": um evento paralelo com filmes brasileiros. A partir do auxílio conseguido para o término de Floradas na Serra (1954), de Luciano Salce, Zenaide consegue ver alguma validade no Festival. O ponto alto teria sido o contato com diretores estrangeiros, talvez possibilitando aos atores brasileiros a oportunidade de filmar no exterior. A relevância do acesso à filmografia clássica não importa para Cinelândia.

Cena Muda declarou que analisaria todos os filmes do Festival, mas concentrou seu foco sobre a produção contemporânea, apresentada nas Jornadas Nacionais. As fitas da I Retrospectiva Erich von Stroheim e da II Retrospectiva do Cinema Brasileiro não aparecem nas seções de crítica. A Retrospectiva do Cinema Brasileiro foi tema apenas de uma matéria. Já Stroheim obteve destaque um pouco maior. Cena também não cita as exposições e palestras, menciona apenas as demais mostras. A preocupação se concentrou na análise da produção da época, para orientação aos leitores dos futuros lançamentos.

A postura de Cena foi de apologia à "grande iniciativa" do Festival. Tornou-se publicista do evento como o era do cinema nacional. Talvez respondendo aos ataques da imprensa, a revista condena as acusações realizadas. Jonald declara que faltou seriedade aos colegas de imprensa para transmitir as primeiras impressões ${ }^{120}$. Os ataques visaram ao "sensacionalismo", e não o "de construir através da crítica". Sua postura é de enxergar os benefícios de um evento dessa magnitude no Brasil, lembrando a

jornalistas da imprensa diária citavam a dificuldade de conseguir credenciais e acesso aos cineastas presentes. Andréa, Zenaide. O que eu vi no Festival. Cinelândia, v. 3, n. 33, p. 46-49, 61, $2^{\circ}$ quinz. março 1954.

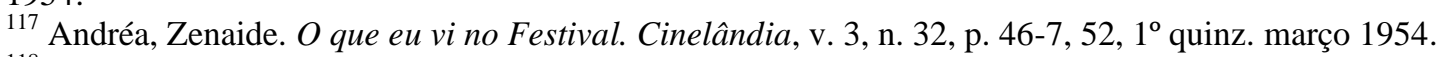

118 Há diversas matérias nos jornais comentando, por exemplo, que Tom Payne, Eliane Lage e Lima Barreto retiraram-se do Festival em protesto. Um movimento de protesto de artistas brasileiros contra o Festival de Cinema. O Globo, 20/02/1954. Pasta 253/20

119 Andréa, Zenaide. O que eu vi no Festival. Cinelândia, v. 3, n. 34, p. 44-5, 48, $1^{\circ}$ quinz. abril 1954.

${ }^{120}$ Jonald. Como foi inaugurado o Festival em São Paulo. Cena Muda, v. 34, n. 8, p. 6-9, 24/02/1954. O artigo foi publicado no Boletim do Festival em 16/02/1954 e depois em Cena Muda. Jornalistas estrangeiros e brasileiros tiveram a oportunidade de comentar suas impressões sobre o Festival no Boletim. Cena não explica que o artigo de Jonald se trata de uma compilação do mesmo texto escrito para o Boletim. 
permanência de tais filmes no país. A todo o momento, Jonald revelava os novos critérios de sua direção: a crítica como modo de construção do cinema, menor destaque ao estrelismo e ausência de indulgência ao sensacionalismo exagerado (porque o moderado continuava a ser praticado). ${ }^{121}$

A postura de Jonald foi semelhante a de Marcos Marguliès em Anhembi. Este último citava mais a riqueza em manifestações culturais ${ }^{122}$ porque era redator do Festival ${ }^{123}$. Por isso foi mais convalescente com os problemas do evento. Ambas as revista condenaram a cobertura sensacionalista da imprensa. Cena omitiu bastante as dificuldades de organização porque considerava mais importante analisar os filmes. Contudo, Jonald e Marguliès ${ }^{124}$ não negaram as imperfeições, relatadas sem lentes de aumento. A crítica de Cena se tornou maleável e complacente com os erros. Buscou ver os pontos positivos das fitas exibidas.

A baixa qualidade das fitas apresentadas nas Jornadas Nacionais parece ter sido um consenso entre os críticos estrangeiros e brasileiros. Claude Lefort ${ }^{125}$ considerou "medíocres" os melhores filmes exibidos. O "Anti-Festival" deu importância exagerada aos elementos do star system, relevando um evento que não se pretendia "sério". O quadro mundial é visto por Lefort como uma produção que "fala para nada dizer". Apenas a Homenagem a Stroheim valeu a pena. Os comentários positivos do crítico francês referem-se à possibilidade de contato do público com as obras de Stroheim, além da percepção de que a carreira dele foi encerrada pelos reis da Goldwin Mayer. Nesse único sentido, Lefort considera o Festival um sucesso.

\footnotetext{
${ }^{121}$ Sem negar a importância do star system, Jonald publica ainda em fevereiro suas impressões sobre a abertura do evento. Foi o único artigo voltado à mundanidade. Promete duas edições especiais para cobrir todas as minúcias. Descrevendo os aplausos demorados do público e o desfile de ricos trajes e a grande aglomeração, comenta que "o lado social foi brilhante". O atraso na abertura "favoreceu o mundanismo e os comentários galantes". A cobertura ao estrelismo trouxe algumas fotos das atrizes presentes, mas apenas neste artigo. Como foi inaugurado o Festival em São Paulo. Cena Muda, v. 34, n. 8, p. 6-9, $24 / 02 / 1954$

${ }^{122}$ Anhembi não analisa cada filme, mas as insere no modo de produção de cada país. Ao invés de analisar com destaque o código cinematográfico a partir de termos técnicos, como fez Cena Muda, forneceu uma dimensão dos filmes, como reflexo dos problemas pelos quais o cinema de cada país tinha passado. Marguliès, Marcos. "Primeiro Festival Internacional de Cinema do Brasil". IN Anhembi, v. 14, n. 41, p. 426-30, abril 1954.

${ }^{123}$ De acordo com Luis Carlos Bresser Pereira, ele se limitou a reclamar, dado que era impossível fazer mais que isso. (Cardenuto, 2004)

${ }^{124}$ Marguliès, Marcos. "Uma esmolinha pelo amor de Deus...”. IN Anhembi, v. 14, n. 42, p. 619-637, maio 1954.

${ }^{125}$ Lefort, Claude. «L'antefestival ». IN Alliance - Revisa de cultura franco-brasileira. São Paulo, p. 1624, maio 1954.
} 
"Medíocre" foi a mesma palavra utilizada por André Bazin na entrevista concedida à Cena Muda ${ }^{126}$. A visão negativa do crítico aparece, mas suas declarações não receberam destaque. Foi uma das versões sobre o tema, "apenas" mais um entrevistado, nivelado à opinião de starlets. Bazin teria dito também que nenhum outro festival conseguiu um programa intelectual e cultural de tão longo alcance. Foi o melhor em número de conferências, excelentes retrospectivas, ambiente intelectual e cultural.

A análise de Bazin sobre o Festival em Cahiers du Cinéma aprofunda as causas da baixa qualidade das fitas apresentadas ${ }^{127}$. Explica que o evento foi irremediavelmente deficiente nas seleções nacionais porque nenhuma nação do mundo está em condições de participar de mais de dois festivais por ano ${ }^{128}$. Os americanos e ingleses mandaram filmes apresentados no ano anterior ao Festival de Veneza e Cannes $^{129}$. Reservaram sua lista de sucessos para os grandes festivais europeus. Apenas a Itália e a França trouxeram filmes lançamentos ${ }^{130}$. Não culpa a organização do Festival pela ausência de filmes novos, mas a lógica do sistema. Apesar disso, considerou o Festival uma cópia ruim de Cannes, decepcionante em seu conteúdo.

O ponto alto para o crítico francês não foram os filmes de Stroheim em si, conhecidos pelos freqüentadores das cinematecas européias, mas a apresentação ao grande público, desconhecedor desta produção. Paulo Emilio Salles Gomes ${ }^{131}$ esclarece o grande interesse de Bazin e Lefort pela recepção dos filmes de Stroheim. Todos os críticos estrangeiros ficaram impressionados com a vitalidade das fitas apresentadas a um vasto público sem formação cultural específica.

A imprensa diária aproveitou as frases bombásticas de Stroheim como declarar não gostar nem dos filmes mal-cheirosos, nem das pessoas que trabalham em

\footnotetext{
${ }^{126}$ Doze entrevistas e muito movimento. Cena Muda, v. 34, n. 10, p. 28-9, 10/03/1954.

${ }^{127}$ Bazin, André. «Un festival de la culture cinematographique » IN : Cahiers du Cinéma. Paris, n. 34, v. VI, p. 23-29, abril 1954.

${ }^{128}$ Mais importante do que citar como causa da mediocridade dos filmes apresentados as dificuldades dos produtores de enviarem fitas a mais de dois festivais, como lembrou Bazin, foi a impossibilidade de premiação, dada às regras estabelecidas pela FIAF.

${ }^{129}$ Assim, foram vistos novamente os filmes A princesa e o plebeu (1953), de William Wyler, Audtriche em 2000 e Genevière (1953), de Henry Cornelius.

${ }^{130}$ Pão, amor e fantasia (1953) de Luigi Comencini foi apresentado pela primeira vez no Brasil, e reapresentado em segunda visão em Cannes. Também foi visto em primeira mão os filmes Masoduro (1953) de Giuseppe Bennati e Il sole negli occhi (1953), de Antonio Pietrangeli. Contudo Bazin não avaliou nenhum dos três filmes muito honrosos, apesar de considerar a seleção melhor que a atual de Cannes com Julietta (1953), de Marc Allégret, Le Guérisseur (1954) de Yves Ciampi, L'amour d'une femme (1954) de Jean Grémillon e O trigo está crescendo (1954) de Claude Autant Lara. Bazin considera estes sete filmes exibidos os dez melhores do Festival, apenas com uma surpresa agradável, o espanhol Condenados (1953), de Manuel Mur Otti.

${ }^{131}$ Gomes, Paulo Emilio Salles. "O mito, a obra e o homem". IN: Crítica de cinema no suplemento literário. Rio de Janeiro: Paz e Terra, 1981. v. 2.
} 
Hollywood. Elogiam as tiradas humorísticas dele, da qual riram bastante. Contudo, uma matéria citou seu "ar de burrice alemã, a pior burrice depois da holandesa" ${ }^{132}$. Outra questionou o título de nobreza dele e seu posto como general prussiano. O exército germânico declarou a Revue que Stroheim nem sabia colocar as medalhas de forma correta $^{133}$. Não passou de um soldado voluntário.

Não tão ingênua foi a postura de Cinelândia em relação a Stroheim. Zenaide considera a pose "carrancuda" do cineasta como parte do "violento" caráter dos personagens que o diretor traz para a vida real. Ela não entrelaça o caráter do ator com o dos papéis interpretados. Caso Stroheim fosse uma jovem e bela mulher, a transferência de personalidade com certeza seria usada por Cinelândia. A revista não menciona a suposta ascendência nobre prussiana inventada por ele. Percebe a conexão entre persona e personagem, embora não ouse entrar no tema. Prefere declarar nada ter a revelar. Paulo Emilio Salles Gomes comenta que Stroheim se conservou firme em não sorrir em público, particularmente diante dos fotógrafos: "pois a realidade maior do mito reside na sua imagem" ${ }^{134}$, faceta esta não destrinchada por Zenaide Andréa.

A postura de Jonald sobre a trajetória de Stroheim é de ressalvas pelos filmes exibidos ${ }^{135}$. Obviamente, Cena Muda nem sequer cita a falsa ascendência nobre do diretor. Sua preocupação não é a de incentivar a criação de mitos. Jonald considera impossível desmerecer as inúmeras qualidades dele como diretor, cenografista e intérprete, além da "eloqüente linguagem". As restrições não se referem à forma, mas ao conteúdo: divulgador da crueldade e morbidez, pessimismo e de acentuações de sexo, sob responsabilidade total do diretor. Lefort esclareceu que apenas uma parte do público teve condições de perceber o poder da indústria em encerrar a carreira do diretor. Jonald não teve esta acuidade devido a suas escolhas moralistas. Stroheim é retratado como um perdulário, apesar da qualidade das fitas.

Cena costumava desprezar o artificialismo e a obrigação de final feliz das fitas norte-americanas, mas quando se deparou com uma filmografia diferente, viu como

\footnotetext{
132 Maria, Antônio. A noite é grande. Diário Carioca. 04/03/1954. Pasta 258/14.

${ }^{133}$ Germânicos arrasam Stroheim. O Globo. 22/02/1954. Pasta 954/64.

${ }^{134}$ Paulo Emilio explica que a construção da persona do diretor feita pelos serviços publicitários estendeu fantasias mitológicas à personalidade do cineasta. Logo após o final da I Guerra Mundial, a Áustria ainda exercia atração sobre o imaginário, e Stroheim aparecia como um misto de aventureiro e aristocrata, muito próximo aos personagens interpretados na tela. A identificação completou-se pela publicidade. Dessa maneira, "o personagem e o homem foram reduzidos a uma unidade psicológica cujo traço dominante era a crueldade." Nessa criação, Stroheim não só contribuiu, como se conservou fiel ao mito. Gomes, Paulo Emilio Salles. "O mito, a obra e o homem”. IN: Crítica de cinema no suplemento literário. Rio de Janeiro: Paz e Terra, 1981. v. 2.

${ }^{135}$ Jonald. Retrospectiva Stroheim. Cena Muda, v. 34, n. 10, p. 16-8, 30, 10/03/1954.
} 
imperativo a existência de conteúdo otimista. Jonald não percebeu o cinema de Stroheim como irônico, realista, sem retratar a vitória do bem no final. Segundo ele, Stroheim não fez nada de bom para o espírito humano. O crítico ponderou que Stroheim estava inserido numa época de culto à forma, diferente da "tendência atual". Esta "busca, pelo menos, uma ligeira mensagem ou algo qualquer de construtivo". No futuro, a análise do conteúdo "terá maior peso nos livros de cinema", vaticina.

O "cineasta maldito", como ficou chamado, produzia filmes que abordavam numa visão muito sarcástica para o período temas como melodrama, sexo e espetáculo. Contudo, o sadismo, violência, crueldade, sordidez humana e obsessão são uma marca de fascínio dos personagens de suas fitas. Estes traços de caráter foram incorporados na criação da persona do diretor, com grande influência dos papéis interpretados por Stroheim como ator. O diretor induzia o entrelaçamento entre as duas personalidades, e Cena Muda caiu neste jogo. Não teve discernimento para separar os dois. Deixando-se influenciar pelos elementos do estrelismo menosprezados em suas seções de crítica, Jonald chega a utilizar um tom pessoal. Condena o "odioso caráter" do personagem e do diretor.

Para explicar a expulsão de Hollywood, enumera entre as razões: o exagero nas horas de duração dos filmes, a falta de síntese e os altos custos ${ }^{136}$. Adere ao padrão da indústria de cinema norte-americana e por seu sistema de produção, quando não consegue perceber o caráter de denúncia e condenação das fitas. Condenando a falta de percepção de Stroheim do "importante" caráter industrial do cinema, elogia a postura de Melvyn Le Roy. A percepção de Jonald foi uma escolha, não falta de informação. A apreciação de Stroheim nos Boletins destacava a falta de compreensão da indústria e a mutilação dos filmes. Isso sem citar o material de homenagem produzido por Paulo Emilio.

A condenação a Stroheim não foi a única. Uma incongruência na revista é tratar de modo negativo o cinema do tipo espetáculo, mas elogiar o bom divertimento, ambivalência de uma revista de fã. Devido ao conservadorismo, a revista recorre a uma divisão no binômio conteúdo x forma. Obras importantes são condenadas pela falta de final otimista, como Umberto D (1952), de Vittorio de Sica:

\footnotetext{
${ }^{136}$ Paulo Emilio acrescenta o depoimento de Stroheim dado a ele, declarando que Carl Laemmle exagerou o custo de produção do filme Foolish wives (1922) para apresentá-lo como o diretor mais caro do mundo. A propaganda aceita por Stroheim foi utilizada depois contra ele mesmo. Gomes, Paulo Emilio Salles."O mito, a obra e o homem". IN: Crítica de cinema no suplemento literário. Rio de Janeiro: Paz e Terra, 1981. v. 2.
} 
“(...) a história se fixa por demais em lamúrias. A adaptação estendeu demasiadamente os sofrimentos do professor para, afinal, deixar tudo no mesmo. Muito fácil seria sugerir um pouco de fé em lugar de expor uma tentativa do pior recurso possível: o suicídio. Qual a necessidade de entrever um caso social-psicológico se não há nada construtivo se não fica o resíduo de um breve ensinamento?" 137

Os comentários da falta de otimismo não existiam apenas numa revista de fã moralista. Paulo Emilio Salles Gomes ${ }^{138}$ narrou a não receptividade do público italiano, assim como a reação fria da crítica e reticente dos produtores. Um ministro de Estado teria aconselhado a De Sica um final com otimismo são e construtivo para Umberto $D$.

Ou seja, entre o binômio conteúdo x forma, os críticos de Cena optam pelo conteúdo. Como vimos, Maria Rita Galvão e Jean Claude Bernardet mostram como durante a década de cinqüenta pouco se falava da forma, vista como tratamento do argumento. Vale a dicotomia existente entre conteúdo brasileiro e forma do filme americana. (Galvão; Bernardet, 1981) Muitas vezes a revista procura pontuar a forma dos filmes estrangeiros, não dos brasileiros, porque estes últimos não são considerados arte.

Enquanto os jornais logo após o término do Festival, realizaram balanços para verificar sua relevância, Cena Muda demorou meses para sintetizar sua opinião. Para avaliar a pertinência dos filmes, recorreu a um critério diferente. O método não se pautou por uma percepção geral dos cronistas, mas pela análise de cada filme apresentado. Através de uma crítica matemática, a revista conferiu nota a cada uma das fitas, tirando a média. Só então observou que "apenas" treze dos oitenta filmes eram muito bons, "o mínimo que se poderia esperar de um festival. (...) Fixando o elemento qualidade, o padrão geral não foi promissor." ${ }^{139}$. Entretanto não fez a conclusão repercutir. Isso porque a falta de qualidade para Cena refere-se apenas aos filmes contemporâneos, não ao evento.

A posição da publicação é reveladora de um posicionamento que consegue separar a qualidade dos filmes da organização do Festival. Quando a revista admite a condição deficiente das fitas a partir da análise de cada película, censura e condena a baixa qualidade da produção. A responsabilidade não recai sobre a seleção do certame, mas sobre as delegações participantes. Daí a postura favorável ao evento. Uma

\footnotetext{
${ }^{137}$ Pré-estréias. Umberto D. Cena Muda, v. 34, n. 7, p. 3, 17/02/1954.

138 Gomes, Paulo Emilio Salles. "A solidão de Umberto D". IN: Crítica de cinema no suplemento literário. Rio de Janeiro, Paz e Terra, 1981. v. 2, p 124-127.

139 A crítica não gosta de alguns filmes como O Manto sagrado (1953) de Henry Koster ou Os homens preferem as loiras (1953) de Howard Hawks. Jonald; Maximiniano; Sanin. O julgamento do festival. Cena Muda, v. 34, n. 11, p. 22-3, 17/03/1954.
} 
conclusão semelhante às observações de Lefort e de André Bazin, apesar de que ambos se desapontaram com o evento. A maior diferença foi a incapacidade ou temor de Cena em tocar na impossibilidade de atribuição de prêmios. Esta desmotivou a exibição de filmes novos, lembrando que o evento visava principalmente ao acesso de uma filmografia clássica.

Quanto aos filmes brasileiros apresentados no Festival e analisados nas seções de crítica, observa-se um tom negativo em relação à qualidade, a partir do mesmo critério e termos técnicos usados para as películas estrangeiras. Apenas O Cangaceiro (1953), de Lima Barreto, foi elogiado porque já tinha sido laureado em 1953 no Festival de Cannes. Os merecedores de análise no caso brasileiro são os da Vera Cruz. A produção relativa à história do cinema nacional não é vista como digna de objeto de estudo. Apenas é lembrada em tom nostálgico.

A revista inclui a filmografia da mostra Grandes Momentos do Cinema em infindáveis e longas listas sobre os melhores filmes de todos os tempos. Contudo, quando omite sua existência, deixa de informar ao leitor sobre a possibilidade do contato com as obras. O objetivo da ocultação parece ser a possibilidade de se engrandecer frente ao público por conhecer a extensa filmografia. Com tal postura, Cena encobre o objeto maior do evento de formar o grande público. É como se a revista partisse do pressuposto que as retrospectivas se dirigem somente aos críticos e estudiosos.

A cobertura das duas revistas revela uma incongruência jornalística em não fornecer material de orientação para o público consumir o Festival. O correto seria a apresentação do evento com antecedência, mesmo sob a forma de releases ou citações de outros jornais ${ }^{140}$. De que adianta do ponto de vista jornalístico cobrir por tantas edições um evento já terminado? As revistas não demarcaram sua função principal de informar para propiciar acesso à filmografia. A resposta a essa indagação tem relação com a visão de que os festivais não são para o grande público.

Vale pensar os motivos deste enfoque. $\mathrm{O}$ acesso aos filmes do Festival permitiu algo novo em Cena: a realização da crítica antes da estréia pelo seu corpo de colaboradores e a opção de criar um guia para o consumo posterior dos leitores. Cena não trouxe a possibilidade de contato dos leitores com o Festival, mas quis servir de

\footnotetext{
${ }^{140}$ Luiz Carlos Bresser Pereira, por exemplo, em $O$ Tempo, traz aos leitores antes das sessões do Festival a recepção de alguns filmes pelo público e pela crítica, incluindo sinopses, sem esconder também suas expectativas sobre os filmes ainda não vistos.
} 
intermediária a este conhecimento, como única fonte de conhecimento via educação à distância.

Se por um lado, há maior maturidade na crítica estabelecida, analisar filmes de um festival terminado meses atrás indica também a decadência editorial da revista e as dificuldades de noticiar os fatos em curto espaço de tempo. Por outro lado, algum gasto Cena teve com o Festival porque enviou seus críticos a São Paulo para cobrir o evento, ou contratou cronistas da capital paulista. Por outro lado, um guia publicado depois do evento tem duas funções. A primeira é o acesso ao público residente fora de São Paulo. A segunda foi ser guia para os filmes da Mostra Grandes Momentos do Cinema que estiveram durante todo ano em cartaz, devido à aquisição pela Filmoteca do MAM.

O Festival foi o mote de uma alteração nos critérios da crítica. A oportunidade de assistir à filmografia clássica do cinema mundial, cobrir um evento de grandes dimensões e entrevistar diretores famosos impingiu um salto na qualidade da crítica. Num momento de decadência, a publicação tem seu último sopro de vitalidade ao realizar uma crítica bastante desatrelada do star system. A longo prazo, o Festival poderia ter promovido uma melhora na qualidade técnica da crítica, caso Cena continuasse sob a supervisão de Jonald. Contudo, no último período analisado, a crítica voltou a se atrelar ao star system. Anunciou como fator positivo o retorno à cobertura da fofoca. Foi a última fase decadente da publicação.

\subsubsection{4-55: Da crítica à atuação dos atores ao release}

Com a saída de Jonald no final do primeiro semestre, Cena Muda passa a publicar uma espécie de carta aos leitores, onde o Redator X (Costa Cotrim) ${ }^{141}$ narra as principais reportagens, fofocas e furos da revista. A imitação evidente da revista Cinelândia é adotada até a morte editorial de Cena em maio de 1955. Trata-se da decadência, centralizada na fofoca.

Como resultado, desaparece a seção de crítica nas primeiras quatro edições. Em agosto, surge a coluna Filmes em revista, escrita por Alberto Simoens Bello, presente até o penúltimo número, em abril de 1955 . Nesta fase, a crítica realça a atuação dos

\footnotetext{
${ }^{141}$ Costa Cotrim utilizava o pseudônimo Gilmar Dias. Já havia sido diretor de Cena Muda entre junho a outubro de 1953. Em abril, na penúltima edição, a revista torna-se mensal. Nos dois últimos números, volta a adotar o mecanismo de impressão em duas cores (preto/branco com magenta). A penúltima edição foi a comemorativa dos 34 anos de Cena. O editorial foi dedicado à importância da evolução técnica do cinema, quando a ela mesma não conseguia se modificar.
} 
atores, voltada em nível crescente ao star system. Depois, utiliza como critério a beleza das atrizes. Há uso demasiado de adjetivos e pontos de exclamação. Ou seja, a crítica decai ao seu nível mais baixo. O nível da revista consegue despencar mais a cada edição. As fotografias chegaram ao mais baixo nível de qualidade na impressão em duas cores (preto/branco com magenta). Depois a revista volta ao padrão preto e branco. Não há mais fofocas. Só existem informações institucionais dos estúdios, sem tratamento jornalístico informativo. A partir desta fase, o periódico fecha um contrato com a Press Cinema e Mondi Press. Afirma que tem correspondentes em Londres, Paris, Hollywood, Roma e na América do Sul. A partir deste acordo, Cena Muda consegue produzir algumas fotos de flagrantes dos atores em boites e restaurantes de Hollywood. Há algumas páginas parecidas com as de Cinelândia: coloridas e com lay-out moderno. Porém, fica mais evidente o desnível, porque o restante das folhas continuava no modelo antigo. A compra de algumas páginas de material não era suficiente para reverter o quadro de crise.

O crítico Simoens Bello não analisa os filmes a partir da divisão em três partes (apresentação/desenvolvimento/desenlace), como era feito no auge da crítica. Opta por citar apenas cenas consideradas importantes. Em alguns momentos, Bello assinala a trilha musical. Contudo, no geral, seus comentários baseiam-se no achismo para justificar a posição.

As cotações desaparecem. A coluna de crítica visa avaliar diversas películas, com comentários curtíssimos, sem exame consistente de nenhuma fita. O objetivo é dizer quando o filme "merece ser visto e sentido", ou quando não se deve perder tempo com ele. O critério de merecer ser "sentido" aponta para uma nova modificação na crítica. Ela não está mais atrelada ao filme de arte, mas ao sentimento e comoção. Há maior aceitação ao filme de gênero de qualidade mediana em prol do divertimento. Apesar da conexão com o gosto do público, Simoens Bello enumera listas com os melhores filmes citados por Jonald. Sem talento para a tarefa e dotado de piores argumentos, Bello tenta copiar os mesmos princípios da edição anterior. Ou talvez seja este o indicativo de uma preferência do cronista pelo cinema de arte, oculto em muitos dos artigos. O crítico é contraditório, defende como critério de qualidade o cinema europeu, com poucas exceções a filmes americanos, mas elogia também a filmografia oposta. Bello julga de maneira negativa o artificialismo dos filmes de Hollywood. Deixa de avaliar muitos deles por considerá-los ruins. 
Como exemplo da crítica atrelada ao estrelismo, temos o comentário ao filme Romance em Paris (1954), de Lloyd Bacon:

\begin{abstract}
“se V. é daqueles que se julga invulnerável aos encantos femininos de Jane Russell ou de qualquer outra Eva mais ou menos legal, vá ver este filme e depois me diga se não teve vontade de voltar às fraldas e choramingar... Jane dá o maior show de seus atributos físicos e eles são bem balançantes... Há muita mulher linda, muita piada interessante... e Jane, Jane, Jane, sim Jane. Quem foi que falou em cinema? Quem se lembra de linguagem cinematográfica, quem falou em montagem? Ora, pinhões, como disse o paulista quatrocentão (se fosse vivo...) Mário de Andrade, isto é outra coisa. A fita faz rir e está com a bilheteria garantida. Jane Russell dá uma aula de anatomia glamourizada, pois que a história é vivida na tela pela milionésima vez e já no início do século era usada para comover nossos avós, só que desta vez nos faz pular na cadeira com aquela 'dança' (com licença de Terpsicore) duas vezes provocante e quase amoral... Nesse momento ela só faltou oferecer amendoim..." (...) "a direção andou entregue a Lloyod Bacon, que apenas se preocupou com os 'ângulos' de Jane Russell. Bonito technicolor. Cotação aceitável." 142
\end{abstract}

Mais importante do que o cinema de qualidade nesse período é a participação da estrela. Não há grande acesso às fofocas, devido à decadência. $\mathrm{O}$ artigo acima citado ironiza a importância do código cinematográfico. Confere importância maior ao divertimento e sex appeal. Apesar da nuance de louvor, às vezes o crítico é irônico em relação ao trabalho do cineasta, como neste exemplo, quando expõe a preocupação do diretor apenas com os ângulos da estrela. Além destes comentários zombeteiros, Bello utiliza diatribes contra os atores ou diretores. Há um teor bastante humorístico, provavelmente para aumentar o interesse do público leitor. Declara sobre o filme Rose Marie (1954), de Mervyn Le Roy: “Howard Keel diz que canta e faz 'ronron'; Fernando Lamas diz que não canta, mas faz 'ronron', e 'ronron' fazem todos, até 'seu' Leão. Bert Lahr e Marjorie Main tentam fazer 'ronrom', mas não achamos graça nenhuma..." ${ }^{143}$ A diatribe vem logo a seguir, quando pondera que o diretor Merlyn Le Roy "dirigiu a fita talvez num período de depressão nervosa...” Os comentários sobre a atuação de boa ou má qualidade dos atores se convertem em artigos de cunho cômico.

O amadorismo da revista, presente em todos os anos, se acentua. Certa vez a coluna justificou logo de início que devido ao resfriado do cronista, impossibilitado de trabalhar, eles iriam utilizar críticas antigas e não publicadas de Simoens Bello. Não se avalia contratar temporariamente outro jornalista para realizar o trabalho.

Há uma modificação bastante significativa quanto à quantidade de filmes sob observação. A tentativa é de analisar todas as fitas, como se todas valessem um comentário. Afinal todas são passíveis de consumo. Um critério novo para a publicação,

\footnotetext{
${ }^{142}$ Bello, Alberto Simoens. Filmes em revista. Cena Muda, v. 34, n. 35-36, p. 68-9, dez. 1954.

${ }^{143}$ Bello, Alberto Simoens. Filmes em revista. Cena Muda, v. 34, n. 35-36, p. 68-9, dez. 1954.
} 
voltado a dar espaço crescente à produção dos estúdios. Antes os críticos costumavam citar apenas os filmes considerados dignos de apreciação ou traziam as fitas de qualidade duvidosa para censurar.

Ao lado da decadência da crítica, volta o elogio com teor de release ao cinema brasileiro nas reportagens, sem nenhuma análise sobre as cenas. Raros filmes nacionais são objeto da crítica. O nível decai mais ainda quando surge a coluna de Miryan Thereza, filha de Oscarito. Miryan declara que Matar ou correr (1954), de Carlos Manga, está "de parabéns". O motivo é simples: "na minha opinião, está admiravelmente bem feito" ${ }^{144}$. O objetivo deste artigo não era examinar o filme. Ao contrário, a cronista quer apenas provar que se a fita fosse em inglês, o público apreciaria. Afinal, até os muitos abacaxis americanos são aceitos. Para provar sua tese, envereda pelo humor:

\footnotetext{
“façamos uma experiência: procurem imaginar 'Matar ou correr' com um título mais ou menos assim: 'To Kill or to Run'. Os artistas seriam americanos e o filme feito no Texas. Sem dúvida alguma ficaria infinitamente melhor. Oscarito Cassidy falando inglês, Otelo Bodgers falando inglês e Johnnie (o nome até ajuda) cantando o sucesso do momento, 'nobody to love'. Que beleza! Grande filme, ein?"
}

Para poder indicar um filme nacional aos leitores, ela desqualifica a produção estrangeira, composta de abacaxis. Mas ao aceitar a procedência do filme como brasileira, o sentimento geral para Thereza é de estranheza. Depois ela lembra que deveria ocorrer o contrário. Afinal, o problema do cinema nacional é a "falta de hábito", principalmente em ver filmes sem legenda: "Achamos ainda uma coisa estranha, esquisita apreciar exclusivamente o trabalho dos artistas sem preocupação com as legendas." Miryam nem tenta difundir o estrelismo brasileiro. Ao contrário, lembra que o público ainda não se convenceu a assistir aos atores brasileiros na tela, apesar de já ter certo conhecimento deles. A cronista quase sintetiza o sentimento de angústia em relação à qualidade das fitas brasileiras descrito por Bernardet (1979), mas sem conseguir teorizar, permanece na superficialidade dos comentários sobre a falta de legenda ou da ausência do endeusamento das estrelas brasileiras. Seus artigos são rasos em conteúdo, superficiais. O tom da coluna procura aproximar o leitor das estrelas brasileiras recorrendo à intermediação da filha do astro. Lança mão de critérios nunca utilizados, como chamar diversas vezes Oscarito de "papai".

${ }^{144}$ Thereza, Mirhyam. Vamos conversar? Cena Muda, v. 35, n. 1, p. 9, $1^{\circ}$ quinz. jan. 1955. 
Algumas vezes, a crítica nesta etapa teme conferir apreciações negativas aos filmes brasileiros, como se não conseguisse impor sua opinião ou se decidir sobre sua qualidade. Dessa forma, Sanin, cronista da época de Jonald, certa vez traz o comentário do diretor Hermogêneo Rangel sobre a qualidade do seu filme Capricho do amor (1954). Assim, torna-se “desnecessário" ao crítico opinar:

“- se eu dissesse algo sobre o filme, o qualificasse entre os bons celulóides nacionais, alguns me achariam demasiadamente pretensioso. Se ao contrário - sinceramente não o faria dissesse, estaria mentindo a mim mesmo. Portanto, a conclusão lógica: (eu) espero a opinião do público, da crítica, de todos os que prestigiam o cinema brasileiro." 145

Dessa forma, a crítica se exime de oferecer sua opinião. Apela para a boa vontade do público, antevendo problemas ao filme. Não quer censurar. Quando evita falar bem ou mal da produção brasileira, outorga ao público o poder de decisão. Com este novo critério, não há porque continuar a existir seções de análise. Se o público tudo decide, vale apenas trazer os diversos discursos. Quando a crítica renuncia seu caráter opinativo, consolida-se sua morte editorial. Ela aceita de bom grado ser agendada ao invés de agendar. Resta apenas o release, além de poesias e contos publicados.

Procuramos resumir aqui as nuances da crítica de Cena Muda em seus diversos períodos. A participação de Cinelândia neste capítulo foi menor porque a opinião aparecia focada sob a forma da reportagem. Cinelândia não possuía seções de críticas porque queria criar um discurso de suposta objetividade. Tentava impingir uma visão de que seus jornalistas e seus leitores gostavam do mesmo cinema de "diversão". Por outro lado, Cena migrou por duas tentativas opostas. Na maior parte do tempo, tentou se adequar ao gosto do público na reportagem, mas incluía os comentários negativos às fitas nas seções de critica. A posição em relação ao cinema nacional, como mostramos, depende muito do período analisado, da seção e do crítico responsável. Nos dois primeiros anos, a crítica se dividiu entre a diatribe contra o filme brasileiro ou hollywoodiano e as discussões sobre a situação do cinema nacional. Oscilou ao mesmo tempo dos votos de sucesso à certeza de êxito, sob crescente influência do material de release. Em oposição, com a direção de Jonald e a realização do Festival de 1954, a crítica alterou seus critérios. A preferência pelo cinema de cunho estético forneceu espaço para se condenar a produção mediana de Hollywood. Porém, quando os críticos se confrontaram com uma filmografia diferente, como a de Stroheim, exigiram a

\footnotetext{
${ }^{145}$ Sanin. Dois filmes independentes e a atividade de um cine clube. Cena Muda, v. 34, n. 22, p. 27, 02/06/1954.
} 
paridade com os conteúdos escapistas dos filmes norte-americanos. Neste sentido, Cena esteve em total sintonia com o sistema de produção de Hollywood, apesar de criticá-lo no geral. Nesta fase, a revista defendia também a primazia do conteúdo sobre a forma. Devido à crise do cinema paulista que as revistas não podiam mais ocultar, os artigos sobre a situação do cinema brasileiro perdem espaço para os comentários sobre a análise fílmica simplificada. Depois do período de soerguimento da crítica com a direção de Jonald e a influência do Festival, Cena só decaiu em qualidade gráfica, vinculando apenas fofocas institucionais dos estúdios. Quanto às seções de crítica, elas voltaram-se apenas ao estrelismo. $\mathrm{Na}$ conclusão, contextualizamos parte das discussões das revistas sobre a função da crítica com as preocupações e comentários do período, trazendo, por último, um balanço das questões abordadas nesta dissertação. 


\section{Conclusão}

A fórmula, repetida a exaustão nas revistas de fãs nas reportagens, é adicionar ao sucesso o amor. Entre os ingredientes há sem exceção os caminhos ao estrelato, as dificuldades enfrentadas e vencidas sem receio, coincidência e destino, e a descoberta pelo estúdio. Finalmente as recompensas alcançadas: não só o sucesso e o dinheiro, como o bem maior a impulsionar o movimento do astro: a felicidade pessoal, principalmente a amorosa. O amor está presente em todos os textos, e deve ser o conjugal. É impossível ser feliz sozinho. As estrelas são felizes porque dada a sua beleza, talento, personalidade, o amor não lhes falta. A realização pessoal se configura na busca pelo amor. Ele é o ponto destacado da publicação, maior do que o sucesso profissional. Não se vende simplesmente o filme ou a atriz, mas a felicidade, encontrada por vias do estrelato.

Contudo esta faceta não é a única. Após a discussão sobre o teor da crítica cinematográfica nas revistas de fãs e sua relação com o estrelismo, resta discutir como ela avaliava sua função no processo. Mostramos como a crítica praticada nas revistas de fãs não pode ser planificada, apesar da influência dos releases, departamentos de publicidade e do enfoque voltado ao fã. Havia independência para condenar o mesmo cinema divulgado no restante das páginas de reportagens, mas esta repreensão tinha seus limites. O processo é complexo porque se pauta em duas vertentes. A primeira é o discurso da independência usado como estratégia de legitimação frente aos leitores, mas esta função não exclui a segunda. A crítica negativa aos filmes de baixa qualidade e o questionamento do star system existem também com finalidade diversa da simples tática comercial. As revistas de fãs não devem ser vistas como meras divulgadoras do estrelismo, mas como geradoras desses bens simbólicos. Produzem também a crença no valor do produto. Como gerador, o jornalista é agente do processo, não apenas um transmissor. E todo agente influencia o campo, tal como pontuou Pierre Bourdieu (2001). As disputas no interior de todos os campos buscam atingir o monopólio da imposição das categorias de percepção e apreciação legítimas. As lutas internas do campo fazem parte de sua constituição. As disputas são necessárias.

Há de se conferir capacidade analítica às revistas de fãs, mas sem deixar de lado suas inúmeras conexões com a publicidade, e sem lhes anular apenas pela coexistência 
desta influência. Afinal não se faz jornalismo e crítica sem a publicidade. $O$ interesse dos produtores em divulgar seus filmes não anula a autonomia do campo jornalístico da área cultural, nem a independência editorial. Os grandes veículos não são condenados por esta relação sempre presente com a propaganda, mas as revistas de fãs o foram. Todos os campos sofrem influências externas, como Pierre Bourdieu mostrou. Contudo, é o jornalístico o que possui maior influência e sanções do pólo comercial e do mercado, além do peso do índice de audiência.

Não queremos com isso negar a influência crescente da propaganda na conexão com a crítica e com as reportagens. Qual a relação do crítico quando coexiste a função de publicista? Anula-se, portanto, toda a produção por este motivo? Obviamente, não. Todavia se faz necessário pesquisar de maneira mais detida a relação da crítica com a propaganda.

A revista da Companhia Americana sofreu diversas alterações, mesmo dentro de cada direção, dificultando reconhecer uma homogeneidade em seu perfil editorial. Para Maria Rita Galvão (1981), a diversidade de opiniões de Cena era fruto de uma redação na qual os colaboradores não liam os textos de seus pares. Acreditamos que a falta de padronização nas opiniões se deva também às características da imprensa do período. Carlos Eduardo Lins da Silva mostra que o jornalismo era "personalista, polêmico, violento e missionário". Era "a pregação das verdades, das opiniões, das crenças, das simpatias dos que o faziam, dos donos dos jornais e dos grandes jornalistas". (Silva, 1990: 86) Por outro lado, a divisão na redação de Cena Muda entre colaboradores intelectualizados e publicistas provavelmente ocasionou tal posicionamento díspar em relação ao star system.

Uma das maiores defasagens presentes na crítica das revistas de fãs é a deficiência na exposição da denegação econômica, se tivermos em mente algum tipo de contribuição analítica dada ao leitor. Para pensar a postura do crítico, trazemos o artigo A tarefa do crítico ${ }^{1}$, de Siegfried Kracauer. O texto propicia a reflexão sobre a existência de algum tipo de contribuição dos críticos das revistas de fãs com o crescimento intelectivo de seus leitores.

Kracauer avaliar que os cronistas se limitam a ressaltar o máximo de detalhes correspondem ou não a seu gosto, mas o crítico não pode esgotar a tarefa diante da média da produção. Se os filmes são fracos do ponto de vista do conteúdo ou se tem por

\footnotetext{
${ }^{1}$ Über die Aufgabe des Filmkritikers. Originalmente publicado na Frankfurter Zeitung, 23/05/1932.
} 
fim a distração barata, eles adquirem um peso do ponto de vista dos significados e interesses sociais, mesmo se as produções cinematográficas medianas não exigirem julgamento enquanto obra de arte. Esta produção mediana mencionada por Kracauer equivale à maior parte dos filmes citados nas duas revistas pesquisadas. A tarefa do crítico, segundo ele, é analisar e mostrar as "intenções sociais" "bem dissimuladas" nos filmes medianos para romper com a influência das fitas onde for necessário. Contudo, as revistas pesquisadas não tinham este projeto pela relação com o estrelismo, nem se imbuíam desta missão. Poucos críticos das revistas de fãs, como Salvyano Cavalcanti de Paiva, Alberto Dines e Jonald, corroboraram com a missão do crítico descrita por Kracauer, mas apenas o fizeram parcialmente. As revistas de fãs realizavam críticas dos filmes medianos, mas mesmo no caso dos comentários negativos, faltava o intuito de desvelar as representações ideológicas ocultas, porque elas faziam parte do sistema de forma indireta. Pertenciam à imprensa, mas também representavam a continuidade dos estúdios. Quando há censura a alguns filmes hollywoodianos, as duas publicações raramente traziam a contextualização a partir da inter-relação entre os problemas do cinema brasileiro e a dificuldade de competir com o monopólio dos filmes norteamericanos. Ao menos, Cena Muda discutia com ênfase a situação do cinema brasileiro.

A crítica desviava o tema central de desvelar as representações ocultas e se imbuía do papel de agente no processo de incentivo ao cinema nacional. Conferia a si mesma uma função relacionada às discussões da época. A postura de estímulo ao cinema brasileiro presente nas duas revistas não é apenas uma estratégia de legitimação para conquistar leitores, mas tem relação com os cânones da crítica praticada em outros veículos. A metalinguagem da crítica revela qual função ela reservava a si mesma, reflexo também do pensamento do período.

Tomando o lado dos produtores, Cena costuma apresentar sempre ao leitor a dificuldade em produzir filmes brasileiros, como se quisesse convencer o público a ser menos rigoroso com o cinema nacional. Contudo, não era apenas nesta revista que se exigia mais boa vontade em relação a nossa cinematografia. Muito antes, frases do tipo "todo filme brasileiro merece ser visto", do slogan de Cinearte, criavam um "imperativo moral com tonalidade salvacionista", apontado por Galvão e Bernardet. O objetivo era convencer o público a ver os filmes como um dever patriótico, para compensar a ausência de relação de mercado entre a produção e o público. Mostrava-se, então, a situação de desvantagem, a dificuldade de competição, pedindo ao público o esforço, uma vez que os filmes nem sempre satisfaziam. (Galvão; Bernardet, 1981: 49) 
Os jornalistas e cineastas exigiam uma atitude patriótica por parte do governo e do público, nos disse Bernardet e Galvão. Contudo, quando o recurso não se mostrava efetivo no patriotismo, malhava-se o espectador. A década de cinqüenta foi marcada pelo esforço de construir uma consciência histórica. Em Cena Muda, nunca havia censura à atitude dos espectadores, pelo imperativo de não confrontar o público consumidor.

A opção irrestrita ao cinema nacional é antagônica dentro de Cena. A estratégia do incentivo ao cinema surge também na forma de diatribes contra nossa cinematografia, como se fosse necessário condenar para incentivar. A posição mostra a dificuldade de se ter um consenso sobre a produção brasileira. Enquanto isso, os críticos intelectualizados discutiam a atitude da crítica em relação ao cinema brasileiro, mas geralmente culpavam sua baixa qualidade, e não seus colegas colaboradores. A análise de Bernardet e Galvão (1981) cita o artigo de Walter da Silveira sobre o baixo nível de qualidade da crítica. Para Walter da Silveira, a mediocridade era culpa dos filmes brasileiros porque poucas fitas poderiam ser objeto de uma análise consistente. Os críticos, para Walter da Silveira, em vão esperaram alguma fita merecedora de uma análise mais profunda, aumentando mais ainda o distanciamento pelos filmes brasileiros, quando só houve obras menores.

A função da crítica como encarregada de uma suposta missão de traçar os caminhos do cinema brasileiro, como havia em Cena Muda, tornou-se um consenso durante a I Convenção Nacional de Crítica Cinematográfica, em 1960. Tanto para Walter da Silveira, quanto para os demais críticos, caberia ao cronista traçar as coordenadas para o cinema nacional. Apesar de este não ser o objetivo primeiro da crítica, as circunstâncias precárias do cinema brasileiro justificavam que ela ultrapassasse as suas funções, como dizia Almeida Salles. No seu discurso de abertura na Convenção, Almeida Salles declarou o crítico como o agente mais lúcido e isento do complexo cinematográfico, cabendo a ele traçar estes caminhos. (Galvão, Bernardet, 1981). Bernardet defende a idéia de que não cabe à critica fornecer a priori uma definição para ser seguida pelos artistas porque ela só trabalha com matérias já existentes. (Galvão; Bernardet, 1981: 191)

Os críticos de Cena Muda procuravam apontar os erros para levar o cinema brasileiro ao sucesso futuro, como se eles tivessem este poder como agentes, algo que Bernardet considerou conseqüência do procedimento da crítica de se ver como parte do processo de produção. A posição de Cena Muda seria, portanto, reflexo deste momento. 
Algum papel teve a crítica de Cena no sentido de contribuir para o envolvimento do leitor com o cinema brasileiro, mesmo em suas apreciações negativas. Se ela apenas se mostrasse como neutra ou ignorasse a cinematografia nacional, teria contribuído muito menos com as discussões presentes nas seções de crítica dos leitores. Também nos jornais, os leitores mandavam textos, surpreendendo os críticos, como mostrou José Inácio de Melo Souza (1995)

Cena Muda previa para si não apenas reconhecer o cinema brasileiro, como fazê-lo avançar. E um dos maiores inimigos neste quesito, além dos aventureiros e das companhias estrangeiras, eram os próprios colegas de profissão, imbuídos de poderes para impedir o sucesso do filme nacional. A revista pregava como função da crítica advogar a favor da nossa cinematografia. Não só os jornalistas de Cena, mas os de Cinelândia também procuravam contrapor-se aos críticos considerados intelectualizados, com uma atitude de desdém porque estes não eram condescendentes com o cinema brasileiro. $\mathrm{O}$ comentário de maior incentivo à cinematografia nacional encontra-se em Cena Muda, intitulado Avante cinema nacional. Ao condenar as diatribes publicadas na imprensa, o artigo imputa-lhes o poder de dificultar o desenvolvimento da cinematografia nacional:

\footnotetext{
"Não sabemos a troco de que, uma meia dúzia de críticos levantou uma campanha incoerente contra todo e qualquer filme nacional, seja bom, seja regular, ou seja, simplesmente um abacaxi. Eles que só concebem o cinema como arte e só arte, esquecendo-se de que a maioria dos que pagam quer se divertir, quer se emocionar, quer troca dez cruzeiros por duas horas de ilusão, não concorda com o modo de pensar da meia dúzia de rapazes que é obstinadamente contra o cinema nacional.

Avante cinema nacional, não há de ser meia dúzia de críticos que impedirá o progresso natural de uma indústria tão importante para as finanças do Brasil." 2
}

Porém, nas reportagens influenciadas pelo star system a missão da crítica era considerada outra. A repórter "Luelinha Passos" de Cena chega a afirmar que os cronistas guiam os leitores muito bem para os bons anúncios e imagens dos departamentos de publicidade. Ela entrelaça crítica com release, como se a função do comentarista fosse a de ser publicista:

"Nossa crítica cinematográfica (podem generalizar para brasileira) que tem orientado tão bem os leitores interessados em cinema com belos anúncios, bonitas notas fornecidas pelos departamentos de publicidade das empresas e que por outro lado, tem tão estupidamente prejudicado o cinema nacional com as suas atividades de frustrados e recalcados, esta crítica, pois, divorciou-se."

\footnotetext{
${ }^{2}$ Avante cinema nacional. Cena Muda, v. 33, n. 1, p. 3, 02/01/1953.
} 
$\mathrm{O}$ artigo tratava das disputas pelo poder entre os críticos da ABCC (Associação Brasileira de Cronistas Cinematográficos), sob o título de Tempestade em copo d'águaa batalha da crítica ${ }^{3}$. Passos noticia que os críticos Moniz Viana, Hugo Barcelos, Décio Vieira Otoni criaram uma nova associação porque a atual só se interessa por assuntos mundanos e cocktais. Passos inverte, então, seu próprio critério de elogiar o publicista quando condena a ABCC. Considerado o tema apenas uma "brincadeira" inventada, porque não se deve perder tempo com a influência da publicidade:

“(...) Os críticos Moniz Viana do Jockey Club, Hugo Barcelos da Cofap, Décio Vieira Otoni que já brigou também com o Cavalcanti, e que nunca se preocuparam e intentaram fazer algo coletivo, além de assinar suas unilaterais e falsamente intelectuais crônicas, estes críticos resolveram certo dia rebelar-se contra a Associação Brasileira de Cronistas Cinematográficos. Alegavam estes senhores que a ABCC presidida por Joaquim Menezes, era uma associação de corretores de anúncios, e que só se preocupava com 'cocktails' e atividades mundanas. Apoiou incompreensivelmente este movimento divisionista, o veterano crítico Salviano Cavalcanti de Paiva, que foi um dos que mais batalharam pela eleição da atual diretoria da ABCC. Nas páginas de 'Manchete' onde escreve, chegou Salviano a inventar adesões ao movimento divisionista e reacionário. Assim profetizou ele que o nosso colega Alberto Dinis e Alberto Shatovsky tinham aderido, quando estes dois críticos e cineastas são totalmente contrários a esta atitude.

A verdade é que a ABCC, é tudo o que se diz de mal dela. Devia-se até dizer mais!

Mas convenhamos, modificar desta forma, é modificar para pior.

E, em vez de preocuparem-se os nossos críticos, em estudar cinema, em aperfeiçoar-se, em lavar-se dos sentimentos de recalque e frustração, em purificar-se das taras psíquicas contra o cinema nacional, em vez disso, os nossos críticos, inventaram esta brincadeira.

Deixemos disso! Reúnam-se nas próximas assembléias das ABCC e modifiquem sua diretoria e diretrizes. Ponham gente capaz a sua testa e estará resolvido o problema.

Ponto final. Gostaram da minha 'entrée' na política? Foi tão fácil! Sabem de uma coisa confidencial? Não existe nenhuma diferença entre bisbilhotice e política. Mas não digam isto aos críticos!"

Em entrevista ${ }^{4}$, Alberto Dines desmentiu as informações da repórter. Participou do movimento, ao contrário das declarações de Luelinha. O grupo era composto pelos jornalistas que se auto-denominavam "críticos não comerciais", preocupados com os diretores, não com o star system. Eles se insurgiram contra a ABCC por conta de alguns resenhistas que trabalhavam nas empresas distribuidoras e trocavam favores, destacando os filmes uns dos outros. Dines analisa a crítica da época como um processo "devagar e gradual”. Os jornais perceberam que tinham de separar a publicidade e as críticas. "Aos poucos cresceu a consciência. Foi gota a gota, homeopatia". A crítica de cinema estava começando na época. Os cadernos culturais eram muito bons, mas deixavam o cinema de lado, na página de divertimentos. Foi preciso se acostumar a ver o cinema como arte na grande imprensa, porque antes ele era visto apenas como "show bussiness".

\footnotetext{
${ }^{3}$ Passo, Luelinha. Tempestade em copo d'água - a batalha da crítica. Cena Muda, v. 32, n. 44, p. 7; 34, 31/10/1952.

${ }^{4} \mathrm{Cf}$ entrevista. Adamatti, 2006.
} 
Não pretendemos com esta pequena digressão esgotar o tema, apenas dar uma pequena contribuição sobre o tratamento nas revistas de fãs. $O$ processo de aprimoramento da crítica cinematográfica ocorria concomitantemente com o desenvolvimento da imprensa. Por certo, as revistas de fãs auxiliavam no processo de divulgação do cinema brasileiro, mas falta tentar mensurar a partir dos itens pontuados neste trabalho o nível de eficiência destes periódicos na geração e divulgação do cinema brasileiro, via estrelismo e crítica.

Realizamos aqui um balanço da eficiência presente nestas revistas a partir do modelo norte-americano. Contudo, se tomássemos ao pé da letra a comparação com Hollywood, a conclusão seria de que as nossas estrelas eram apenas simulacros do que deveriam ser. Não vendiam capa, não eram objeto de fofocas e novelizações. As insuficiências são muitas. Primeiro, tomemos as defasagens do material de star system feito nos estúdios, para depois nos centrar sobre o mesmo tema nas revistas estudadas. A Vera Cruz, por exemplo, enviava boletins para cerca de setecentos jornais espalhados pelo país. Contudo, seus noticiários concediam maior realce primeiro à companhia e depois aos filmes. A estrela permanecia em segundo plano. Os artigos trazem as biografias das atrizes, mas procuram celebrar mais a grandeza técnica da empresa. Em termos comparativos, as matérias sobre as estrelas norte-americanas presentes em Cinelândia traziam informações sobre a personalidade das atrizes, seus romances, sofrimentos, casamentos anteriores, artigos sobre moda e dicas sentimentais. Como se não fosse o bastante, ainda relatavam os pensamentos íntimos dos astros e seus problemas. O tratamento mais eficiente dos estúdios norte-americanos advinha do esquema industrial e empresarial dos departamentos de publicidade. Em termos comparativos, o nosso ainda engatinhava.

As demais deficiências fazem parte da geração do star system brasileiro das revistas, mas também são fruto da produção dos estúdios. Primeiro não há novelização da vida amorosa, nem do sofrimento das atrizes brasileiras. A estrela brasileira não sofre de amor, não casa várias vezes. Não narra como é feliz. Por outro lado, as duas publicações tentam imitar a ampla produção de fofocas dos veículos estrangeiros, inventando fofocas de romances entre os atores dos filmes. Contudo, a estratégia não sai a contento porque existem apenas insinuações de romances, sem as novelizações citadas antes. Falta também o mecanismo de repetição das fofocas por diversas edições, para causar agendamento da informação. Além disso, os conteúdos desses boatos eram frágeis. 
Outro aspecto importante para a configuração do estrelismo do período são as matérias de conselho amoroso feitas pelas atrizes estrangeiras, presentes apenas em Cinelândia. Além disso, as atrizes abrem a casa para os leitores, mostram a decoração e narram seus problemas. Concedem a suposta intromissão na intimidade, invertendo o cânone da dependência do leitor à estrela. Novamente, a estratégia não é usada no cinema brasileiro. Nestas seções de conselho com material estrangeiro ou brasileiro, existe uma visão subjacente do papel da mulher na sociedade, presente na imprensa do período. O modelo de perfeição é a mulher submissa, voltada ao lar, e é exatamente nestes espaços que ocorrem muitos dos processos mais diretos de transferência a partir da função do duplo. Ocorre uma importante inversão nesta transferência. Apesar de que a estrela se firma como padrão de comportamento às leitoras, nas seções de conselho sentimental fica evidente o grande abismo entre as duas, porque a diva tem o it que a distingue dos mortais. Dessa forma, é impossível atingir o patamar dos olimpianos. Só resta alcançar a total realização no imaginário projetivo através da função do duplo.

Outra defasagem ocorre na composição da personalidade, das fofocas, do glamour e da erotização através da ambigüidade. Esta instiga a curiosidade dos fãs pelas informações e possibilita suscitar uma alta dose de ficção sob a credencial do jornalismo. A ambigüidade é uma das chaves para se compreender o estrelismo do período, porque a estrela não pode se mostrar por completo. Ao contrário, deve permanecer como enigma, decifrado apenas parcialmente. Porém, nas matérias sobre o cinema brasileiro, este importante ingrediente não era aproveitado como na divulgação dos filmes hollywoodianos.

$\mathrm{Na}$ cobertura ao cinema brasileiro, temas considerados tabus e as escassas transgressões comportamentais dos personagens interpretados ou das atrizes permaneciam ocultos ou dissimulados. A erotização dos atributos sexuais secundários também não era utilizada em toda sua potencialidade. A estrela é um ícone sexual, sempre mostra o corpo, mas as alterações variam de acordo com o papel interpretado e o tipo de personalidade vinculado à atriz. As mudanças são lentas e graduais, impulsionadas pelo movimento das atrizes estrangeiras. Em Cena Muda, no caso brasileiro, as desconhecidas e pin ups são erotizadas de maneira mais crua, especialmente as vedetes do teatro de revista. Cinelândia utiliza mais imagens a partir dos atributos sexuais secundários, a partir de uma "aura" de sofisticação. Nenhuma delas confere um alto apelo sensual às atrizes nas imagens e no texto devido ao conservadorismo do período. 
No caso brasileiro, o entrelaçamento entre a personalidade da atriz e o papel interpretado não era incorporado de forma contínua e eficiente. A estrela brasileira precisava ser legitimada a partir da comparação com a norte-americana. A estratégia revelava a dependência da primeira em relação à segunda. Outras vezes, as duas publicações denegavam os ídolos brasileiros. Narravam que os astros apenas se tornaram célebres após uma certa interpretação, como era feito nos boletim da Vera Cruz. Além disso, as duas revistas confessam a necessidade da publicidade via fotogenia para garantir o sucesso da nossa cinematografia. Recorriam até às diatribes contra os filmes que pretendiam divulgar. A repetição do nome da atriz por edições a fio como estratégia de agendamento das estrelas também não era completa. As revistas norte-americanas plantavam matérias meses antes do lançamento de uma estreante. No caso brasileiro, o agendamento era muito parcial. Muitas das intérpretes só apareciam no noticiário por conta do lançamento do filme ou durante sua produção.

Uma das piores deficiências do star system vinculado nas duas revistas é a dificuldade em imitar com perfeição o décor das fotografias de divulgação dos estúdios norte-americanos. As imagens revelam as dificuldades financeiras de sua produção numa composição artificial fora dos padrões de glamour que o público apreciador de Hollywood estava habituado.

Apesar das deficiências descritas, a vinculação do estrelismo brasileiro mostrava-se com algum nível de eficiência. O incentivo aos filmes brasileiros nas revistas de fãs conseguia cumprir sua fixação num tipo de agendamento na mente dos espectadores sobre a cinematografia nacional, criando alguns ídolos e aproveitando outros do rádio. $\mathrm{O}$ estrelismo nacional conseguia imitar parcialmente o star system estrangeiro, aproximando-se de seus leitores através do tom íntimo e familiar do repórter. Por certo, as formas mais eficientes de star system brasileiro eram geradas com o material de divulgação estrangeiro de Cinelândia.

$\mathrm{Na}$ média, as revistas conseguiram realizar uma propaganda eficiente dos filmes brasileiros e de suas estrelas dentro das possibilidades do período. Não deixavam de ser uma ferramenta útil da publicidade dos estúdios nacionais. No entanto, não queremos superestimar a importância das revistas de fãs neste processo, porque a propaganda ao cinema brasileiro era muito maior. Englobava outros formatos e veículos de comunicação.

Numericamente o incentivo ao cinema nacional nas páginas editoriais em Cena e Cinelândia era maior que a produção de películas. Na média, eram feitos 30 a 34 filmes 
brasileiros por ano ${ }^{5}$ nos primeiros anos da década de 1950, como mostrou Afrânio Catani (1991). Jean-Claude Bernardet (1979) cita que em 1953 foram lançados 578 filmes de longa metragem, mas apenas 34 eram brasileiros. Em 1954, o número caiu para 21 filmes nacionais ante os 490 lançados. Ou seja, ambas as revistas aumentavam muito a pequena participação quantitativa dos lançamentos brasileiros. Na verdade, o cinema nacional ocupava apenas $5 \%$ do mercado, mas possuía uma representação por volta de $20 \%$ das páginas das duas publicações. Por outro lado, Hollywood que detinha a hegemonia do mercado, com $90 \%$, ficava reduzida a uma representação nas duas revistas de $75 \%$.

Os filmes nacionais com maior realce nos dois veículos são os de superprodução do gênero melodramático com protagonista feminina. Os demais acabam por ter uma cobertura escassa. No máximo recebem duas ou três reportagens. Na avaliação do peso das seções de crítica sob o universo de escolhas dos leitores e de sua influência na construção acerca do cinema brasileiro, nossa conclusão é de um auxílio pequeno, menor do que era feito nas reportagens, porque as diatribes e comentários negativos eram bastante numerosos na média entre os anos. $\mathrm{O}$ incentivo continua a ser a um cinema considerado incipiente. Nas críticas, o critério de qualidade mínimo para a película nacional atinge um patamar muito mais exigente, por isso é menos eficiente do que o estímulo da reportagem. Na média, as diatribes pesam muito mais.

A leitura de Cinelândia revela os novos padrões do estrelismo, com maior sensacionalismo positivo via romantização e capacidade de incorporação de temas tabus da sociedade. As estrelas aumentam suas características humanas. Enfrentam problemas financeiros, erram e pedem conselhos aos leitores. As atrizes representam mais padrões comportamentais do que exemplos de perfeição. Observamos um período de transição no discurso da revista sobre a moralidade, com maior aceitação de divórcios, casamentos sucessivos e até de alguns romances extra-conjugais. Estes são mostrados de maneira positiva, especialmente no caso dos homens. Muitas transgressões comportamentais são abrandadas e tratadas como alterações comportamentais. Mesmo nos casos de condenações comportamentais, aumenta a dose de ambigüidade e diminui a reprovação, embora temas como homossexualismo e traição permaneçam ocultos. $\mathrm{O}$

\footnotetext{
${ }^{5}$ Catani (1991) cita o anuário estatístico do Brasil da FIBGE, mas lembra que a fonte não diferencia o ano de produção do ano de exibição. Em 1952, o país produziu 31 filmes, e em 1954 e 1955, 25 filmes em cada ano. Em 1951, a produção foi de 24 filmes.
} 
tom conservador se esvai cada vez mais, utilizado mais para os fins sensacionalistas e publicitários.

Cinelândia possuía um acordo com duas empresas estrangeiras de grande porte no nicho de mercado. Tinha maiores recursos tecnológicos, garantindo fotografias coloridas, paginação mais eficiente e linguagem coloquial. Uma das maiores vantagens em relação à Cena é a utilização corrente de imagens instantâneas dos atores de Hollywood. Estas fotos saciam muito mais a curiosidade dos fãs sobre a intimidade de seus ídolos.

A publicação de Roberto Marinho fazia parte do jornalismo empresarial. Estava em um patamar diferente quanto à representação das estrelas. Além da utilização dos instantâneos, outro ponto que a distingue da concorrente é a estrutura das fofocas envolvendo atores estrangeiros e a novelização da vida amorosa das divas hollywoodianas, em oposição aos rumores institucionais de Cena com suas fotos posadas e artificiais. As fofocas das atrizes dos Estados Unidos em Cinelândia são novelizações de romances supostamente não ficcionais, utilizando a linguagem do folhetim e o recurso da intimidade com o leitor. O mecanismo da fofoca pauta-se sempre pela dúvida e pelas versões da realidade.

O acesso ao material da empresa Dell não significava a ausência de releases. Ambas usavam o material de divulgação dos estúdios. Porém, Cinelândia utilizava mais as matérias de jornalistas de Hollywood. Este fator alterou toda a cobertura porque o leitor passava a ser informado sobre muitos detalhes da vida dos atores. Em Cena Muda, havia uma cobertura insuficiente e fragmentada sobre algumas estrelas, como se a revista não conseguisse dar conta de informar por completo sobre a meca do cinema.

Abordando as alterações sobre a configuração do star system, aprofundamos as razões da morte editorial de Cena Muda, não só pelo aspecto tecnológico, mas pelo entendimento dos novos cânones de representação do estrelismo e das novas demandas da imprensa do período. Não era o estrelismo exatamente que morria, como foi descrito por Edgar Morin na época, mas o exagero e artificialidade presentes em revistas como Cena Muda, que utilizava demais os releases, ou em Cinelândia com suas novelizações folhetinescas. A representação dos atores em Cena ainda estava atrelada a valores das décadas anteriores. Os departamentos de publicidade hollywoodianos mostravam as estrelas a partir de erros para humanizá-las, mas Cena não se adaptou.

Os artigos de Cena Muda eram mais artesanais na disposição das matérias e das manchetes. Os releases eram mais usados e menos cozinhados pela redação. Os 
recursos tecnológicos de Cinelândia não foram os únicos responsáveis por sua permanência no mercado. A Companhia Americana enfrentava uma crise séria, alguns a creditam à gestão de Gratuliano de Brito que não era do ramo, outros à deficiência do parque gráfico e insuficiência de se adequar aos novos valores do mercado. A cobertura de Cena até não piorou tanto nos dois primeiros anos de nossa análise, mas tinha estancado no seu padrão de décadas anteriores, enquanto as demais revistas evoluíam. Cena tinha dificuldade de realizar uma cobertura mais sensacionalista, de maior intensidade na fofoca e maior realismo nas novelizações sobre a vida amorosa das estrelas estrangeiras. Não tinha acordo contínuo com empresas jornalísticas internacionais. Faltava a capacidade editorial de moldar-se às novas demandas com velocidade, agregando um público mais jovem, e não se manter velha, nostálgica e sentimental quanto ao passado considerado áureo do cinema. Cena envelhecia não apenas na qualidade do papel e da pintura cada vez mais mal feita, mas principalmente em seus conteúdos conservadores em relação às alterações comportamentais dos astros. Grande parte da estrutura dos artigos não tinha se alterado em relação ao padrão das décadas anteriores. Enquanto isso, Cinelândia usava uma linguagem coloquial. Apesar da morte editorial, acreditamos que Cena Muda tenha sido um sucesso editorial porque foi a única revista brasileira de cinema a permanecer 34 anos no mercado. Vale lembrar também que houve uma concentração da imprensa desde os terceiros e quartos decênios do século passado. Na década de cinqüenta desapareceram numerosos jornais e revistas, mas poucos surgiram.

Talvez estas pontuações finais auxiliem no processo de entendimento da falência desse modelo das revistas de fãs, e de sua transferência para outro veículo, mais propenso a sanar o desejo do leitor em consumir a imagem e os detalhes da vida da estrela: a televisão. Cinelândia lembrava aos leitores que a entrevista com Shelley Winters feitas por seu correspondente em Hollywood, Louis Serrano, podia ser ouvida na Rádio Globo, onde ela tinha deixado um recado especial aos fãs brasileiros ${ }^{6}$. O rádio e a TV propiciavam o maior contato com o ídolo. Alguns jornalistas de Cinelândia optavam por uma narração como num diálogo ao vivo, instantâneo, linguagem próxima a do rádio e da televisão, utilizadas especialmente para atrair os leitores ao cinema brasileiro. Acreditamos que o modelo das revistas de fãs tenha migrado paulatinamente para a televisão, embora não tenha desaparecido, visto o aumento em sucessivas

\footnotetext{
${ }^{6}$ Serrano, Louis. Miss Shelley Winters. Cinelândia, v. 34, n. 41, p. 18-9; 52, 2a quinz. julho 1954.
} 
publicações ao longo de todas as décadas subseqüentes ${ }^{7}$, abrangendo o star system de outros produtos culturais, como a televisão, em especial os atores de novelas.

\footnotetext{
${ }^{7}$ Nem todas as revistas de fãs morreram na década de cinqüenta e sessenta, Photoplay continuou no mercado até os anos oitenta.
} 


\section{Bibliografia}

\section{Fontes}

\section{a) livros}

ALMEIDA, Guilherme de. Gente de cinema: I série. São Paulo: Sociedade Impressora Paulista, 1929. Assinado como “G., d'O Estado de S. Paulo'.

AUGUSTO, Sérgio. Este mundo é um pandeiro. São Paulo: Companhia das Letras, 1989.

AUMONT, J; MARIE, M. Dicionário teórico e crítico de cinema. Campinas: Papirus Editora, 2003.

AUTRAN, Arthur. Alex Viany: crítico e historiador. Rio de Janeiro: Perspectiva, 2003.

BERNARDET, Jean-Claude. Cinema Brasileiro: propostas para uma história. Rio de Janeiro: Paz e Terra, 1979.

. Cineastas e imagens do povo. São Paulo: Editora Brasiliense, 1985.

. O autor no cinema: a política dos autores; França, Brasil anos 50 e 60 .

São Paulo: Brasiliense, 1994.

BERNARDET, Jean-Claude; GALVÃO, Maria Rita. Cinema: repercussões em caixa de eco ideológica - as idéias de "nacional" e "popular" no pensamento cinematográfico brasileiro. São Paulo: Brasiliense, 1981.

BIAL, Pedro. Roberto Marinho. Rio de Janeiro, Jorge Zahar Editor, 2005.

BOURDIEU, Pierre. A influência do Jornalismo. Rio de Janeiro: Jorge Zahar Editor, 1997.

A produção da crença: contribuição para uma economia dos bens

simbólicos. São Paulo: Zouk, 2001.

Sobre a televisão. Rio de Janeiro: Jorge Zahar Editor, 1997.

BRITO, Dulce Damasceno de. Hollywood nua e crua - os bastidores da fábrica de sonhos Parte II. São Paulo: Círculo do Livro, 1992.

Lembranças de Hollywood. São Paulo: Imprensa Oficial, 2006.

BRITTOS, Valério Cruz; BOLAÑO, César Ricardo Siqueira (org). Rede Globo: 40 anos de poder e hegemonia. São Paulo, Paulus, 2005.

BROOKS, Peter. The melodramatic imagination. London: Yale University Press, 1976. BYWATER, Tim; SABCHACK, Thomas. Introduction to film criticism: major critical approaches to narrative films. Nova Iorque: Longman, 1989. 
CALIL, Carlos Augusto. A Vera Cruz e o mito do cinema industrial. São Paulo: Secretaria da Cultura, Museu da Imagem e do Som, 1987.

CAPUZZO, Heitor (coord.). O cinema segundo a crítica paulista. São Paulo: Nova Estela, 1986.

CATANI, Afrânio Mendes; SOUZA, José Inácio de Melo. A chanchada no cinema brasileiro. São Paulo: Brasiliense, 1983.

CAVALCANTI, Alberto. Filme e realidade. Rio de Janeiro: Editora Artenova, 1977.

CHAPARRO, Manuel Carlos da Conceição. Linguagem de conflitos. Coimbra: Minerva Coimbra, 2001.

Pragmática do Jornalismo: buscas práticas para uma teoria da ação jornalística. São Paulo: Summus Editorial, 1994.

CHARAUDEAU, Patrick. Discurso das mídias. São Paulo: Contexto, 2006.

DeCORDOVA, Richard. Picture personalities- the emergency of the star system in America. Chicago: University of Illinois Press, 2001.

DYER, Richard. Stars. London, British Film Institute, 1998.

EVANS, Andrew; WILSON, Glenn. Fame - the psychology of stardom. Great Britain: Vision Paperbacks, 1999.

GALVÃO, Maria Rita. Burguesia e cinema: o caso Vera Cruz. Rio de Janeiro: Civilização Brasileira/Embrafilme, 1981.

GARCIA-CANCLINI, Néstor. Consumidores e cidadãos. Rio de Janeiro: Editora UFRJ, 1995.

GIANNETTI, Louis. Understanding movies. New Jersey: Prentice Hall, 1990.

GLEDHILL, Christine (Org). Stardom: Industry of desire. Londres: Routledge, 1991.

GOMERY, Douglas. The Hollywood studio system - a history. London: British Film Institute, 2005.

GOMES, Paulo Emilio Salles. Cinema: trajetória no subdesenvolvimento. Rio de Janeiro: Paz e Terra, 1980. Publicado na revista Argumento. São Paulo, n. 1, out. 1973. Humberto Mauro, Cataguases, Cinearte. São Paulo: Editora Perspectiva, 1974.

GOMES, Paulo Emilio Salles; GONZAGA, Adhemar. Setenta anos de cinema brasileiro. Rio de Janeiro: Ed. Expressão e Cultura, 1966.

HASKELL, Molly. La femme à l'écran de Garbo à Jane Fonda. Paris: Éditions Seghers, 1977. 
HOLANDA, Heloisa Buarque de (org). Quase catálogo: estrelas do cinema mudo brasileiro (1908-1930). Rio de Janeiro: Ciec, 1991.

KAPFERER, Jean Noel. Boatos: o mais antigo mídia do mundo. Rio de Janeiro, Forense Universitária, 1993.

LAGE, Nilson. Ideologia e técnica da notícia. Petrópolis: Vozes, 1979. . Linguagem jornalística. São Paulo: Ática, 1985.

LEITE, Sidney Ferreira. Cinema brasileiro - das origens à retomada. São Paulo: Editora Fundação Perseu Abramo, 2005.

LEV, Peter. The fifties - transforming the screen 1950-59. Berkeley: University of California Press, 2003.

MARCONDES FILHO, Ciro. O capital da notícia. São Paulo: Editora Ática, 1989.

MARSHALL, P. David. Celebrity and power. London: University of Minnesota Press, 2004.

MARTINEZ ALBERTOS, José Luis. Curso general de redaccion periodistica. Barcelona: Editorial Mitre, 1983.

MARTINS, Ana Luíza. Revistas em revista: imprensa e praticas culturais em tempos de republica (1890-1922). São Paulo: Edusp, 2001.

MARY, Bertrand. La pin up- ou la fragile indifférence - Essai sur la genèse d'une imagerie délaisée. Paris, Librairie Arthème Fayard, 1983.

MCDONALD, Paul. The star system- Hollywood's production of popular identities. Great Britain, Wallflower Press, 2000.

MELO, José Marques de. A opinião no Jornalismo brasileiro. Petrópolis: Vozes, 1985. MENEGUELLO, Cristina. Poeira de estrelas. Campinas: Editora da Unicamp, 1996. MEYER, Marlyse. Folhetim, uma história. São Paulo: Companhia das Letras, 1996. MORAIS, Fernando. Chatô, o rei do Brasil. São Paulo: Companhia das letras, 1994. MORIN, Edgar. As estrelas, mito e sedução no cinema. Rio de Janeiro: José Olympio, 1989. Título original: Les stars. Paris: Éditions du Seuil, 1957.

Cultura de massas no século XX: neurose. Rio de Janeiro: Forense Universitária, 2005. Título original: L’ Esprit du temps. Editions Bernard Grasset, 1962. O cinema ou o homem imaginário. Lisboa: Moraes Editores, 1970. Título original: Le cinéma ou l'homme imaginaire: essai d'anthropologie sociologique. Paris : Minuit, 1956.

MULVEY, Laura. Cidadão Kane. Rio de Janeiro, Rocco, 1996. 
MULVEY, Laura. Death $24 x$ a second - stillness and the moving image. London: Reaktion Books, 2006.

PAIVA, Salvyano Cavalcanti de. Aspectos do cinema americano. Rio de Janeiro: Editôra Páginas, 1956.

PAIVA, Salvyano Cavalcanti de. História ilustrada dos filmes brasileiros. Rio de Janeiro: F. Alves, 1989.

PONTES, Heloisa. Destinos Mistos: os críticos do grupo Clima em São Paulo (194068). São Paulo: Cia das Letras, 1998.

POZO, Mariano del. El cine y su crítica. Pamplona: Ediciones Universidad de Navarra, 1970.

RAMOS, Fernão. História do cinema brasileiro. São Paulo: Art Editores, 1987.

RAMOS, Fernão; MIRANDA, Luis Felipe (Org.). Enciclopédia do cinema brasileiro. São Paulo: Editora do Senac, 2000.

RAMOS, José Mário Ortiz. Cinema, estado e lutas culturais (anos 50/60/70). Rio de Janeiro: Paz e Terra, 1983.

ROCHA, Glauber. Revisão do cinema brasileiro. São Paulo: Cosac \& Naify, 2003. (1963).

SALLES, Francisco Luiz de Almeida. Cinema e verdade. São Paulo: Companhia das Letras, 1988.

SENNET, Richard. O declínio do homem público - as tiranias da intimidade. São Paulo: Companhia das Letras, 1988.

SCHWARTZENBERG. Roger-Gerard. O Estado espetáculo. São Paulo/Rio de Janeiro: Difel, 1978.

SHATZ, Thomas. O gênio do sistema: a era dos estúdios em Hollywood. São Paulo: Companhia das Letras, 1991.

SILVA, Carlos Eduardo Lins da. $O$ adiantado da hora: a influência americana sobre o jornalismo brasileiro. São Paulo: Summus, 1991.

SLIDE, Anthony. International film, rádio, and television journals. London: Greenwood Press, 1985.

SODRÉ, Muniz. A comunicação do grotesco - introdução à cultura de massa brasileira. Petrópolis: Vozes, 1971.

SODRÉ, Nelson Werneck. História da imprensa no Brasil. Rio de Janeiro: Mauad, 1998.

THOMASSEAU, Jean-Marie. O melodrama. São Paulo: Perspectiva, 2005. 
VIANY, Alex. Introdução ao cinema brasileiro. Rio de Janeiro: Ministério da Educação e Cultura - Instituto Nacional do Livro, 1959.

WALKER, Alexander. Stardom. New York: Stein and Day, 1970.

WILKIE, Jane. Confessions of an ex-fans magazine writer. New York: Doubleday \& Company, 1981.

WOLF, Mauro. Teoria das comunicações de massa. São Paulo: Martins Fontes, 2005. XAVIER, Ismail. Sétima arte: um culto moderno - o idealismo estético e o cinema. São Paulo: Perspectiva, 1978.

\section{b) artigos e capítulos de livros}

BARTHES, Roland. "A estrutura do Jornalismo (fait divers)". IN: Crítica e verdade. São Paulo, Perspectiva, 1970.

BAZIN, André. «Un festival de la culture cinematographique » IN : Cahiers $d u$ Cinéma. Paris, n. 34, v. VI, p. 23-29, abril 1954.

BICALHO, Maria Fernanda Baptista. "As atrizes". IN: Centro de pesquisadores do cinema brasileiro. Cinearte. Rio de Janeiro: Cinemateca do MAM, 1991.

BUTLER, Jeremy. “The star system and Hollywood”. IN: Hell, John; Gisbon, Pámela. Film Studies. The Oxford guide. New York: Oxford University Press, 1998.

CARDENUTO FILHO, Reinaldo. Festival Internacional de cinema de 1954. São Paulo: Centro Cultural São Paulo, 2004.

ESPINAL, Luis. "Função da crítica cinematográfica". IN: Consciência crítica diante do cinema. São Paulo: Editorial Don Bosco, 1976.

FREUD, Sigmund. "Identificação". IN: Psicologia de grupo e a análise do ego. Rio de Janeiro: Imago Editora Ltda, 1976.

FREUD, Sigmund. "Identificação". IN: Psicologia das massas e análise do eu. Rio de Janeiro: Delta, 19--.

GOMES, Paulo Emilio Salles. "A solidão de Umberto D”. IN: Crítica de cinema no suplemento literário. Rio de Janeiro: Paz e Terra, 1981. v. 2.

" "Antes da Primeira Convenção". IN: Crítica de cinema no suplemento literário. Rio de Janeiro: Paz e Terra, 1981. v. 2.

"Erotismo e humanismo". IN: Crítica de cinema no suplemento literário. Rio de Janeiro: Paz e Terra, 1981. v. 2. 
. "Mitologia e verdade". IN: Crítica de cinema no suplemento literário.

Rio de Janeiro: Paz e Terra, 1981. v. 2.

"O mito, a obra e o homem". IN: Crítica de cinema no suplemento literário. Rio de Janeiro: Paz e Terra, 1981. v. 2.

GONÇALVES, Maurício Reinaldo. "O cinema de Hollywood nos anos trinta, o american way of life e a sociedade brasileira". IN: FABRIS, Mariarosaria (Org). Estudos de cinema. Porto Alegre: Editora Sulina, 2003.

HAMBURGER, Esther. "Diluindo fronteiras: a televisão e as novelas no cotidiano". IN: NOVAIS, Fernando (org.). História da vida privada no Brasil. São Paulo: Companhia das letras, 1998.

KRACAUER, Siegfried. "Sobre a tarefa do crítico de cinema". IN: Kracauer, Siegfried. Ornamento das massas. São Paulo, Cosac\&Naif. (No prelo). Título original: Über die Aufgabe des Filmkritikers. Originalmente publicado no Frankfurter Zeitung, 23/05/1932. Traduzido do francês por Adilson Inácio Mendes (La Voyage et la Danse. Figures de ville et vues de film. Saint-Denis: PUV, 1996, pp.137-139) e revisto do original alemão por Carlos Eduardo Jordão Machado.

LAVER, James. "De 1900 a 1939." A roupa e a moda. São Paulo: Companhia das Letras, 1989.

LEFORT, Claude. «L'antefestival ». IN Alliance - Revisa de cultura franco-brasileira.

São Paulo, p. 16-24, maio 1954.

LUCAS, Meize Regina de Lucena. "Ver, ler e escrever: a imprensa e a construção da imagem no cinema brasileiro na década de 1950”. IN: Revista Brasileira de História (Anpuh), v. 28, n. 55, jan./jun. 2008.

MARGULIÈS, Marcos. "Crônica amarga sobre o Festival de Cinema”. IN: Anhembi, v. 14, n. 41, p. 417-21, abril 1954.

. "Festival e suas publicações". IN: Anhembi, v. 13, n. 39, p. 616-618, fev. 1954.

"Primeiro Festival Internacional de Cinema do Brasil". IN: Anhembi, v. 14, n. 41, p. 426-30, abril 1954.

. "Primeiro Festival Internacional de Cinema do Brasil". IN: Anhembi, v. 15, n. 43, p. 193-211, junho 1954.

. “Uma esmolinha pelo amor de Deus...”. IN: Anhembi, v. 14, n. 42, p. 619637, maio 1954. 
"I Festival Internacional de Cinema do Brasil - Abertura da Retrospectiva do Cinema Brasileiro". IN: Anhembi, v. 14, n. 40, p. 212-217, março 1954.

. "I Festival Internacional de Cinema do Brasil". IN: Anhembi, v. 15, n. 44, p. 421-37, julho 1954.

. "I Festival Internacional de Cinema do Brasil". IN: Anhembi, v. 15, n. 45, p. 600-619, agosto 1954 .

MATOS, David José Lessa. “A cidade nas ondas do rádio”. IN: O espetáculo da cultura paulista - teatro e TV em São Paulo: 1949-1950. São Paulo: Códex, 2002.

MAULE, Rosanna. «Femmes et cinéma muet: nouvelles problématiques, nouvelles méthodologies ». IN: CINÉMAS (Revue d'études cinématographiques). Montreal: Université de Montreal, v. 16, n. 1.

MAYNE, Judith. "Star-gazing". IN: MAYNE, Judith. Cinema and spectatorship". London: Routledge, 1993.

MULVEY, Laura. "Cinema e sexualidade". IN: XAVIER, Ismail (org). O cinema no século. Rio de Janeiro: Imago Ed., 1996.

. "Visual and other pleasures". IN: Xavier, Ismail (org). A experiência do cinema: antologia. Rio de Janeiro: Edições Graal, Embrafilmes, 1983.

MUNIZ, Almir. “Trinta milhões de críticos de cinema”. In: Revista de Comunicação, n. 28,1992

PARANAGUA, Paulo. “A la recherche d'un star-system”. IN: Paranagua, Paulo. Le cinéma bresilien. Centre Georges Pompidou: Paris, 1987.

PEUCER, Tobias. De relationibus novellis. Leipzig: Tese (Doutorado em Periodística) Universidade de Leipzig, 1690. Tradução de Paulo da Rocha Dias. São Bernardo do Campo: PósCom-Umesp, 1999.

SILVEIRA, Walter. "Crítica e contracrítica". IN: Fronteira do cinema. Rio de Janeiro: Edição Tempo Brasileiro, 1966.

RIBEIRO, Ana Paula Goulart. "Clientelismo, corrupção e publicidade: como sobreviviam as empresas jornalísticas no Rio de Janeiro dos anos 50”. IN: BARBOSA, Marialva (org). Estudos de Jornalismo I - coletânea de textos do núcleo de pesquisas de jornalismo da Intercom. Campo Grande: Intercom, 2001.

RODRIGUES, João Carlos. A metralhadora de Salvyano. IN: Cine Imaginário, v. 4, n. 39, p. 16, fev. 1989. 
SADOUL, Georges. "O Estrelismo" IN: O cinema: sua arte, sua técnica, sua economia. Rio de Janeiro: Livraria Editora Casa do Estudante do Brasil, s/ ano.

STEINBERG, Silvia. "Cinearte, a forma de um ideal" IN: Centro de pesquisadores do cinema brasileiro. Cinearte. Rio de Janeiro: Cinemateca do MAM, 1991.

VIEIRA, João Luiz. "O marketing do desejo: Cinearte e a sua leitora” IN: Centro de pesquisadores do cinema brasileiro. Cinearte. Rio de Janeiro: Cinemateca do MAM, 1991.

VIEIRA, João Luiz. "O corpo popular, a chanchada revisada, ou a comédia carioca por excelência”. IN: Revista do Arquivo Nacional, v. 19, n. 1, jan./fev. 2003.

\section{c) periódicos pesquisados}

\section{A Cena Muda}

Boletim do I Festival Internacional de Cinema do Brasil (1954).

Cahiers du Cinéma (v. VI, 1954).

Cinelândia

Cinelândia (em espanhol) - anos trinta

Filmelândia

Hollywood romances (1955).

Manchete (1953-1954).

Modern Screen (1952-1954).

O Cruzeiro (1953-1954).

Revista Anhembi (1954)

Screen Álbum (1955).

Screen Stories (1953).

\section{d) filmografia consultada e citada no trabalho}

\section{brasileira}

A dupla do barulho (1953), de Carlos Manga

A família Lero-Lero (1953), de Alberto Pieralisi

Agulha no palheiro (1953), de Alex Viany

Amei um bicheiro (1953), de Paulo Wanderley e Jorge Ileli 
Ângela (1951), de Tom Payne

Apassionata (1952), de Fernando de Barros

Assim era a Atlântida (1975), de Carlos Manga

Aviso aos navegantes (1950), de Watson Macedo

Barnabé, tu és meu (1951), de José Carlos Burle

Caiçara (1950), de Adolfo Celi

Candinho (1953), de Abílio Pereira de Almeida

Carnaval Atlântida (1952), de José Carlos Burle

É proibido beijar (1954), de Ugo Lombardi

Esquina da ilusão (1953), de Ruggero Jacobbi

Floradas na serra (1954), de Luciano Salce

Luz apagada (1953), de Carlos Thiré

Matar ou correr (1954), de Carlos Manga

Na senda do crime (1954), de Flaminio Bollini Cerri

Nadando em dinheiro (1952), de Abílio Pereira de Almeida

Nem Sansão nem Dalila (1954), de Carlos Manga

o Cangaceiro (1953), de Lima Barreto

O canto do mar (1953), de Alberto Cavalcanti

O comprador de fazendas (1951), de Alberto Pieralisi

O homem do Sputnik (1961), de Carlos Manga

Rio quarenta graus (1955), de Nelson Pereira dos Santos

Rua sem sol (1953), de Alex Viany

Sai da Frente (1952), de Abílio Pereira de Almeida

Simão, o caolho (1952), de Alberto Cavalcanti

Sinhá Moça (1953), de Tom Payne

Terra é sempre terra (1950), de Tom Payne

Tico Tico no Fubá (1951), de Adolfo Celi

Uma pulga na balança (1953), de Luciano Salce

Veneno (1952), de Gianni Pons

Vou te contar (1958), de Alfredo Palácios 


\section{estrangeira}

A condessa descalça (1951), de Joseph Mankiewics

A embriaguez do sucesso (1957), de Alexander Mackendrick

A princesa e o plebeu (1953), de William Wyler

A tortura do silêncio (1953), de Alfred Hitchcock

A um passo da eternidade (1953), de Fred Zinneman

A viúva alegre (1952), de Curtis Bernhardt

Assim estava escrito (1952), de Vincente Minnelli

Cidadão Kane (1941), de Orson Welles

Como agarrar um milionário (1953), de Jean Negulesco

Crepúsculo dos deuses (1950), de Billy Wilder

Francisco, arauto de Deus (1950), de Roberto Rossellini

Imitação da Vida (1959), de Douglas Sirk

Janela indiscreta (1954), de Alfred Hitchcock

Lágrimas amargas (1952), de Stuart Heisler

Nasce uma estrela (1954), de George Cukor

Rebecca (1941), de Alfred Hitchcock

Stromboli (1950), de Roberto Rossellini

Um lugar ao sol (1951), de George Stevens

Uma aventura na África (1951), de John Huston

Uma rua chamada pecado (1951), de Elia Kazan

Umberto D (1952), de Vittorio de Sica

Viva Zapata (1952), de Elia Kazan

e) entrevistas

Alberto Dines 2006

\section{Bibliografia}

a) monografias 
BENDER, Flora Christina. A Scena Muda. 1979. Tese (doutorado em Teoria literária e literatura comparada) - Faculdade de Filosofia, Letras e Ciências Humanas, Universidade de São Paulo, São Paulo.

BUITONI, Dulcília Helea Schroeder. Mulher de papel, a representação da mulher na imprensa feminina. 1980. Tese (doutorado em Teoria Literária e Literatura Comparada) - Faculdade de Filosofia, Letras e Ciências Humanas, Universidade de São Paulo, São Paulo.

CATANI, Afrânio Mendes. A sombra da outra: um estudo sobre a cinematografia Maristela e o cinema industrial paulista nos anos 50. 1983. Dissertação (mestrado Faculdade de Filosofia, Letras e Ciências Humanas), Universidade de São Paulo, São Paulo.

CATANI, Afrânio Mendes. Cogumelos de uma só manhã. 1991. Tese (doutorado Faculdade de Filosofia, Letras e Ciências Humanas), Universidade de São Paulo, São Paulo.

CHAPARRO, Manuel Carlos da Conceição. Jornalismo, discurso em dois gêneros. 1997. Tese (livre docência em Ciência da Comunicação), Escola de Comunicações e Artes, Universidade de São Paulo, São Paulo.

GALVÃO, Maria Rita. Companhia Cinematográfica Vera Cruz: a fábrica de sonhos um estudo sobre a produção cinematográfica industrial paulista. 1976. Tese (doutorado FFLCH), Universidade de São Paulo, São Paulo.

MENDONÇA, Leandro José Luz Riodades de. A crítica de cinema em Moniz Vianna. São Paulo, 2001. Dissertação (mestrado na área de Comunicação e Estética do Audiovisual da USP), Escola de Comunicações e Artes, Universidade de São Paulo, São Paulo.

QUEIROZ, Eliana de Oliveira. Cena Muda como fonte para a história do cinema. 1981.

Dissertação (mestrado ECA), Escola de Comunicações e Artes, Universidade de São Paulo, São Paulo.

SOUZA, José Inácio de Melo. Carga da brigada ligeira: intelectuais e crítica cinematográfica 1941-45. 1995. Tese (Doutorado ECA), Escola de Comunicações e Artes, Universidade de São Paulo, São Paulo.

SOUZA, José Inácio de Melo. Congressos, patriotas e ilusões: subsídios para uma história dos congressos de cinema. São Paulo, 1981. 
VIEIRA, João Luiz. Foto de cena e chanchada: a eficácia do "star system" no Brasil. 1977. Dissertação (mestrado em Comunicação - Sistemas de Significação), Escola de Comunicação, Universidade Federal do Rio de Janeiro, Rio de Janeiro.

\section{b) artigos e capítulos de monografia}

CORREA JR., Fausto Douglas. "Cinemateca Brasileira, $1^{a}$ época: das luzes às chamas (1937-1957)". IN: Cinematecas e cineclubes: política e cinema no projeto da Cinemateca Brasileira (1952/1973). 2007. Dissertação, FCL de Assis, Universidade Estadual Paulista, Assis.

SILVEIRA, Walter da. "O papel vanguardista da crítica cinematográfica no Brasil". Salvador, s.d., 4 pp. Pasta D 54 da Cinemateca Brasileira.

\section{c) sites}

Site da Biblioteca do Lasar Segall < http://www.bjksdigital.museusegall.org.br>.

Site da Cinemateca Brasileira < http://www.cinemateca.gov.br> .

Site do IMDB < http://www.imdb.com>.

\section{d) bibliotecas e acervos consultados}

Arquivo do Estado de São Paulo

Biblioteca Florestan Fernandes (FFLCH-USP)

Biblioteca Maria Luisa Monteiro da Cunha (ECA-USP)

Biblioteca Nadir Gouvêa Kfouri (PUC-SP)

Cinemateca Brasileira

Museu da Imagem e do Som

Museu Lasar Segall 


\section{Iconografia}

\section{Capa}

Fada Santoro p. 3

Eliana Macedo p. 4

\section{Capítulo 1}

Imagem 1 - Catherine Hepburn p. 50

Imagem 2 - Betsy Drake p. 73

\section{Capítulo 2}

Imagem 3 - Capa de Cena Muda com Fernando Lamas e Lana Turner p. 106

Imagem 4 - Capa de Cena Muda com Tony Curtis e Janet Leigh p. 106

Imagem 5 - Anne Baxter p. 109

Imagem 6 e 7 - José Lewgoy p. 109

Imagem 8 - Mary e Emilinha p. 110

Imagem 9 - Casamento de Grande Otelo p. 111

Imagem 10 - Frank Sinatra e Ava Gardner p. 112

Imagem 11 - Cornel Wilde e Jean Wallace p. 112

Imagem 12 e 13 - Stewart Granger e Jean Simmons em Cena Muda e Cinelândia p. $114-5$

Imagem 14 e 15 - Tony Curtis e Janet Leigh em Cena Muda e Cinelândia p. 115

Imagem 16 - Eva Wilma e John Herbert p. 121

Imagem 17 - Eliane Lage e Tom Payne p. 121

Imagem 18 - Atores nos bastidores de Floradas na Serra p. 121

Imagem 19 - Piper Laurie e Rock Hudson p. 123

Imagem 20 e 21 - Grace Kelly p. 132

Imagem 22 e 23 - Eliana Macedo p. 135

Imagem 24 - Terry Moore p. 135

Imagem 25 - Miss Cinelândia Inalda de Carvalho p. 137

Imagem 26 - Cacilda Lanuzza p. 137 
Imagem 27 - Rita Hayworth p. 138

Imagem 28 - Ellen Westcott p. 138

Imagem 29 - Marisa Prado p. 139

Imagem 30 - Fada Santoro p. 139

Imagem 31 - Vera Ralston p. 141

Imagem 32 - Violeta Ferraz p. 142

Imagem 33 - Aurora Duarte p. 142

Imagem 34 e 35 - Julie Bardot p. 143

Imagem 36 e 37 - Eliane Lage nas capas de Cena Muda e Cinelândia p. 144

Imagem 38 - Aurora Duarte p. 150

Imagem 39 - Patrícia Lacerda p. 150

Imagem 40 - Cuquita Carballo p. 151

Imagem 41 - Yolanda Glacomo p. 151

Imagem 42 - Rossana Podestá na capa de Cena Muda p. 151

Imagem 43 - Silvana Pampanini p. 152

Imagem 44 - Regine p. 152

Imagem 45 - Liana Durval p. 152

Imagem 46 - Marilyn Monroe p. 153

Imagem 47 -Tônia Carrero p. 154

Imagem 48 - Kirk Douglas p. 155

Imagem 49 - Fernando Lamas p. 160

Imagem 50 - Farley Granger p. 161

Imagem 51 - Jardel Filho p. 161

Imagem 52 - Jane Russel p. 162

Imagem 53 - Mitzi Gaynor p. 162

\section{Capítulo 3}

Imagem 54 - Dalva de Oliveira p. 228 